


DE INLANDSCHE WARE HEUIPTEREN

(LAND- EN WATERWANTSEN)

BESCHREVEN EN MEERENDEELS 00K AFGEBEELD

DOOR

S. C. SNELLEN VAN VOLLENHOVEN

${ }^{4,2}$ J. U, et $\mathrm{Ph}$. nat. Doct.

MET 22 PIATEN.

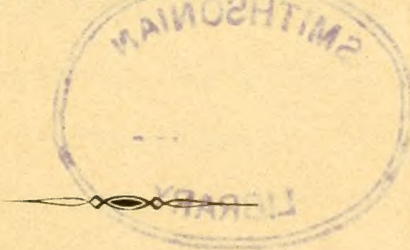

'S G R A VE N H A G E MARTINUS NIJHOFF 1878. 


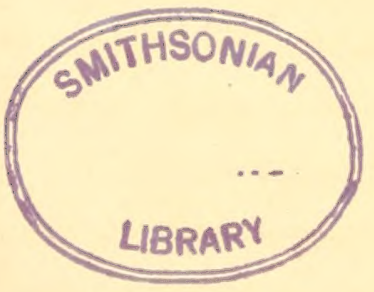

Gedrukt bij Gebr. Giunta d'Albani, 's Gravenhage. 


\section{00 R W 00 R D.}

De lezer of beschouwer van dit boek, die de eerste opstellen in het Tijdschrift roor Entomologie, waaruit het met bijvoegingen gevormd werd, niet kent, zal er zich waarschijnlijk wel over verwonderen dat de platen eene andere volgorde hebben dan de beschrijving der insecten in den text. Tot verklaring van dezen misstand diene dat de lithograaf, order ontvangen hebbende om van elke plaat 100 overcompleete afdrukken te trekken, deze genommerd heeft naar mate van de volgorde, die zij in het Tijdschrift innamen, niet vermoedende dat de familien aldaar niet in systematische volgorde zouden worden behandeld. $\mathrm{Nu}$ bij deze omwerking de systematische rangschikking wel in het oog gehouden wordt, is de rangorde der platen daarmede niet in overeenstemming.

Misschien zal een ander lezer er zich over verwonderen dat ik de Hemiptera beteroptera in niet meer geslachten verdeel, dat ik het voorbeeld niet volg van Fieber en Stål, dat ook bij Douglas and Scott, bij Puton en anderen bijval schijnt te vinden. Kort na het verschijnen der eerste afdeelingen in bet Tijdschrift is mij dit in een buitenlandsch geschrift op vrij 
hoogen toon verweten; ik was te ouderwetsch, te kortzigtig. 't Is waar, ik heb in deze omwerking het geslacht Pachymerus in meer genera moeten oplossen, maar dit was een gevolg van mijne overtuiging dienaangaande en geene concessie aan een' criticus. Naar mijne meening is alle verdeeling in geslachten, hoezeer ook op de natuurlijke karakters opgebouwd, menschelijk en willekeurig werk. De natuur geeft individuen en des noods soorten, maar geene geslachten noch ondergeslachten; die bepaalt de mensch om zich het overzigt van het geheel mogelijk te maken en dat de mensch het doet en niet de natuur, bewijs ik daaruit dat iedere schrijger over eene orde (of beschrijver eener orde of familie) naar eigen lust en zin verdeelt en rangschikt. Waren de genera in de natuur aanwezig, dan zouden de grenzen tusschen hen iedereen in het oog springen, 't geen ondertusschen niet gebeurt. Tegenwoordig schijnt hij het brevet van de meeste geleerdheid of knapheid te verkrijgen, die het meest en het fijnst verdeelt. Ik doe dan maar liever openlijk afstand van dat diploma en blijf voortleven in het geloof dat hij die te fijn verdeelt en te veel genera opstelt, de studie bemoeijelijkt en het geheugen onnoodig afmat, ja, dat mannen als Stål en Fieber door hunnen arbeid de ontwikkeling der wetenschap hebben tegengewerkt.

Ik hoop in dit werkje zoo veel geleverd te hebben als noodig is om de soorten der inlandsche land- en waterwantsen van elkander te leeren onderscheiden en aan ieder de benaming te geven, die haar toekomt. Ons rest nu het onderzoek naar de metamorphose en levenswijze, waaraan nog zoo weinig gearbeid is. Ook op dit gebied moge spoedig meer licht worden verspreid. 
Mijn welgemeende dank wordt bij dezen toegebragt aan zoo vele belangstellenden, die mij bij het bewerken van dit boek, door toezending van voorwerpen hunne zeer gewenschte hulp hebben verleend; hunne namen vindt men onder de beschrijvingen bij de opgave der vindplaatsen vermeld. Ik beveel mij aan in die hooggeschatte medewerking voor de aanstaande behandeling der Homoptera. Als het eene schip te water gelaten is, dient onmiddelijk de kiel gelegd voor een volgend.

Sept. 1878.

S. v. V. 


\section{VERKLARING DER PLATEN.}

Plaat 1, Fig. 1. Tetyra Maura L.

п2. $"$ Hottentotta F.

"3. Trigonosoma nigrolineata Rossi.

๓ 4. Podops inunctus F.

" 5. Phimodera galgulina HS.

"6. Odontoscelis fuliginosa L.

n 7. Coreomelas scarabaeoides L.

8. Asopus coernleus L.

9.9 dumosus L.

$" 10 . \quad " \quad$ luridus $\mathrm{F}$.

"11. " dumosus L.

"12. Sciocoris umbrinus Wolff.

Plaat 2, Fig. 1. Cydnus bicolor L.

$" 2 . \quad " \quad$ albomarginatus $\mathrm{F}$.

$" 3$. $"$ biguttatus L.

$" 4$ 4. flavicornis $1 \%$.

๑5. Aelia acuminata L.

"6. " Klugii Hahn.

$"$ 7. " inflexa Wolff.

"8. Tropicoris rufipes L.

" 9. Cimex lituratus Kl.

๓ 10 . $\rightarrow$ prasinus $\mathrm{L}$.

"11. " Baccarum L.

"12. " oleraceus L.

"13. Acanthosoma haemorrhoidale L.

\# 14. Membraan van Acanth. haematogaster Schr.

$" 15 . \quad n \quad n$ griseum L.

"16. Acanthosoma ferrugator L.

Plaat 3, Fig. 1. Acanthosoma clypeatum Burm.

n 2. Syromastes marginatus L.

n 3 . $n$ quadratus $\mathrm{F}$. 
Plaat 3, Fig. 4. Coreus pilicornis Burm.

5. Ceraleptus squalidus Costa.

6. Alydus calcaratus L.

7. Berytus tipularius L.

8. $n$ clavipes $\mathrm{F}$.

^9. Dekschild van Berytus Driebergensis Voll.

" 10. Berytus elegans Curt.

Plaat 4, Fig. 1. Pseudophloeus Fallenii Schill.

n2. Rhopalus Schillingii Schumm.

$n$ 3. Myrmus miriformis Fall.

n 4. Corizus crassicornis L.

$" 5$. $"$ capitatus F.

"6. $"$ pratensis Fall.

"7. " Hyoscyami L.

" 8. Pyrrhocoris apterus L.

" 9. Lygaeus equestris L.

Plaat 5, Fig. 1. Gastrodes Abietis L.

2. $\pi$ ferrugineus L.

" 3. Peritrechus rusticus Fall.

"4. " $"$ sabulosus Schill.

"5. Drymus sylvaticus F.

"6. $\quad$ varius Wolff.

" 7. Pachymerus plebejus Fall.

" 8. Ischnocoris hemipterus Schill.

" 9. Micropus decurtatus H. Sch.

" 10. Drymus agrestis Fall.

Plaat 6, Fig. 1. Pachymerus Pini L.

$\begin{array}{lrcc}n & 2 . & & \text { quadratus F. } \\ " & 3 . & n & \text { Lynceus F. } \\ " & 4 . & " & \text { marginepunctatus Wolff. } \\ " & 5 . & " & \text { pictus Schill. } \\ " & 6 . & \text { Peritrechus nubilus Fall. } \\ " & \text { 7. } & \text { Acompus rufipes Wolff. } \\ " & \text { 8. } & \text { Pachymerus contractus H. S. } \\ " & 9 . & \text { Drymus praetextatus H. Sch. } \\ " & 10 . & \text { Plinthisus bidentulus H. Sch. } \\ " & 11 . & \text { " pusillus Scholz. }\end{array}$

Plaat 7, Fig. 1. Drymus chiragra F.

$"$ 2. Heterogaster Urticae F.

3. Cymus Resedae Panz.

$\pi$ 4. $n$ Ericae Schill.

$" 5$. $"$ claviculus Fall. 
Plaat 7, Fig. 6. Cymus glandicolor Hahn.

$\begin{array}{lrrr}n & 7 . & \text { Ophthalmicus grylloides } L \text {. } \\ " & 8 . & " \text { ater F. } \\ " & 9 . & \text { Zosmenus capitatus Wolff. } \\ & 10 . & & \text { Laportei Fieb. }\end{array}$

Plaat 8, Fig. 1. Temnostethus pusillus H. S.
2. Anthocoris Nemorum L.
"3. nemoralis $\mathrm{F}$.
" 4. $"$ limbatus Fieb.
n. 5 vittatus Fieb.
6. Piezostethus galactinus Fieb.
" 7. Triphlebs minutus L.
8. Lyctocoris domestica Schill.
9. Microphysa coleoptrata Fall.
$" 10 . \quad " \quad$ pselaphoides Westw.
"11. " elegantula Bär.
12. Acanthia lectularia L.

Plaat 9, Fig. 1. Aradus depressus F.
n2. "2 leptopterus Germ.
$" \quad 3$. Aneurus laevis $\mathrm{F}$.
"4. Dictyonota crassicomis Fall.
"5. Monanthia Cardui L.
$" 6 . \quad$ Humuli $\mathrm{F}$.
7. $"$ Wolffii Fieb.
"8. $"$ 4-maculata Wolff.
"9. Monanthia nigrina Fall.
$" 10 . \quad$ parvula Fall.
" 11. " cervina Germ.

Plaat 10, Fig. 1. Monanthia carinata Panz.
"2. $n$ obscura H. Sch.
" 3. Campylosterna verna Fall.
4. Derephysia foliacea Fall.
"5. Asopus punctatus L.
6. Gonocerus Venator F.
$\pi$ 7. Peritrechus luniger Schill.
" 8 en 9. Poppen van netwantsen.

Plaat 11, Fig. 1. Monalocoris Filicis L.
, 2. Pithanus Maerkelii H. Sch.
n. Miris laevigatus L.
n4. " holsatus F.
$n$ 5. $"$ calcaratus Fall.
6. $\quad "$ erraticus L.
n. 7 ruficornis Fall. 
Plaat 11, Fig. 8. Leptoterna dolabrata L.

9. Oncognathus binotatus F.

n 10. Alloeotomus marginepunctatus H. Sch.

n 11. Lygus Fallenii Hahn.

n 12. Lopus tunicatus $\mathrm{F}$.

Plaat 12, Fig. 1. Lopus infusus H. Sch.

2. $\leadsto$ subpatellatus Voll.

3. Capsus ater L. $q$ (semiflavus).

$" 4$. $"$ capillaris F.

$" 5$. $"$ distinguendus H. Sch.

"6. Heterotoma spissicornis F.

"7. 7 magnicornis Fall.

" 8. Halticus leucocephalus L.

" 9. Camaronotus cinnamopterus Krschb.

" 10. Phytocoris Ulmi L.

$11 . \quad$ Tiliae F.

Plaat 13, Fig. 1. Halticus pallicornis F.

2. Camaronotus clavatus L.

3. Lygus Gothicus L.

4. $"$ striatus $\mathrm{L}$.

5 . striatellus $\mathrm{F}$.

6 . $"$ bipunctatus $\mathrm{F}$.

7. " Chenopodii Fall.

" $8 . \quad " \quad$ ferrugatus $\mathrm{F}$.

$" 9 . \quad$ pratensis L. var. campestris.

10 . $\rightarrow$ tripusiulatus $\mathrm{F}$.

$n$ 11. $n$ unifasciatus $\mathrm{F}$.

Plaat 14, Fig. 1. Lygus rubicundus Fall.

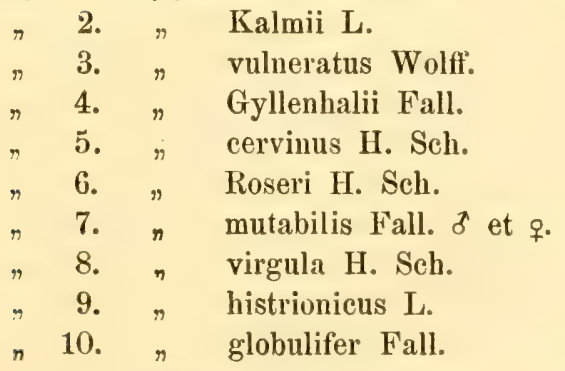

Plaat 15, Fig. 1. Lygus thoracicus Fall.

2. $r$ flavomaculatus $F$.

"3. " melanocephalus L.

4 . $"$ pilosus Hahn.

5 . $n$ Thunbergii Fall. 
Plaat 15, Fig. 6. Lygus angulatus Fall.

* 7. $\rightarrow$ contaminatus l'all.

8. $\pi$ chlorizans Fall.

9. $\rightarrow$ molliculus Fall.

Plaat 16, Fig. 1. Lygus decolor Fall.

2., nubilus H. Sch.

3. " Paykullii Fall.

4 en $4 a$. Lygus Caricis Fail. \& et o.

5. Lygus Arbustorum F.

6. varians Meyer.

7. " saltitans Fall.

8. Dicyphus errans Wolff.

" 9. $"$ pallidus H. Sch. ठ.

" $10 . n " n$ o.

Plaat 17, Fig. 1. Hebrus pusillus Fall.

» 2 ef $2 a$. Salda Zosterae F.

" 3. Salda pilosa Fall.

"4. $n$ saltatoria L.

$" 5$. $\pi$ flavipes $\mathbf{F}$.

"6. $"$ eburnea Fieb.

$" 7$. $"$ lateralis Fall.

" 8. " pulchella Curt.

"9. " geminata Cost.

, 10. " pallipes $\mathrm{F}$.

7 11. Prostemma guttula F.

Plaat 18, Fig. 1. Reduvius personatus L.

2. Harpactor pedestris Wolff:

3. Nabis brevipennis Hahn.

4. Nabis apterus F.

5. $\pi$ flavomarginatus Scholz.

6. $"$ ferus L.

7. $\pi$ brevis Scholz.

8. Ploearia vagabunda $L$.

9. $\pi \quad$ erratica Fall. (dekschild).

Plaat 19, Fig. 1. Limnobates Stagnorum L.

2. Hydrometra Paludum F.

$3 . \quad \pi \quad$ aptera Schumm.

4. $\rightarrow$ rufosentellata Latr.

5. $\pi$ odontogaster Zett. $\delta$.

6. $\rightarrow$ gibbifera Schumm.

7. $n$ lacustris $\mathrm{L}$.

8. $n$ argentata Schumm. 
Plaat 19, Fig. 9. Velia currens F.

$\rightarrow$ 10. Microvelia pygmaea Duf.

, 11. Ranatra linearis L.

Plaat 20, Fig. 1. Naucoris cimicoides L.

„2. Notonecta glauca L.

־3. Ploa minutissima F.

$\rightarrow$ 4. Sigara minutissima L.

"5. Corixa Geoffroyi Leach.

76 . Cymatia coleoptrata F.

, 7. Corixa praensta Fieb. (achterpoot).

" 8. " carinata Sahlb.

"9. " hieroglyphica Duf. (dekschild).

"10.,$\quad$ Hellensii Sahlb.

, 11. $\rightarrow$ lineolata H. Sch.

12. " Fossarum Leach (dekschild).

Plaat 21, Fig. 1. Aelia pallida Küst.

. 2. Cimex pinicola Muls.

3 . nigricornis $\mathrm{F}$.

"4. Syromastes Scapha F.

"5. Stenocephalus nugax F.

6. Atractus Dalmannii Schill.

, 7. Pseudophloeus Waltlii H. Sch.

- 8. Berytus crassipes H. Sch.

9 9. Pachymerus Rolandri L.

, 10. Drymus brunneus Sahlb.

"11. " notatus Fieb.

$12 . \%$ dilatatus H. Sch.

Plaat 22, Fig. 1. Pachymerus erraticus F.
$2 . \quad$ luscus F.

3. Plociomerus fracticollis Schill.

4. Peritrechus nebulosus Fall.

5. Pachymerus griseus Wolff.

6. Zosmenus quadratus Fieb.

7. Heterotoma unicolor Hahn.

8. Dictyonota strichnocera Fieb.

9. Monanthia vesiculifera Fieb.

$10 . \quad$ costata F.

.) 11. Agramma laetum F. 
Door een ongelukkig verzuim zijn hij het afdrukken ran blad 6 de oude nommers der platen uit het Tijdschrift niet veranderd in die der tegenwoordige volgorde: de lezer wordt dien ten gevolge rerzocht zijne andacht op de volgende verbeteringen te willen vestigen.

Op bladz, 65, 78 en 79 staat Plaat 2 . . . lees Plaat 4. Op bladz. 70, 73, 74, 76 en 77 staat Plaat 1 . lees Plaat 3. Op bladz. 74 staat Plaat 3 . . . . . . lees Plaat 21. Niog staat bladz. 139 verkeerdelijk Plaat 4. . lees Plaat 22. 
Gelijk men weet, wordt de Orde der Hemipteren niet zoo zeer door de natuur en inrigting der vlengels, als wel door die der monddeelen gekenmerkt. Deze bestaan namelijk uit een zuigtoestel, gevormd uit zes deelen, eene gootvormige naar boven als toeslaande onderlip, in welke vier borstelharen besloten zijn, die de boven- en onderkaken der kaawwende insecten vertegenwoordigen, en eindelijk eene gewoonlijk zeer smalle, wigvormige bovenlip, die den zuiger aan de bovenzijde bij den wortel sluit. Men wil, dat de mannetjes van eenige coccus-soorten geheel van monddeelen verstoken zouden zijn; bij alle overige Hemiptera is de mondtoestel naar het zoo even beschreven model gevormd.

Wat de vleugels betreft, hunne inrigting verdeelt de orde in twee groote afdeelingen; de bovenvleugels zijn namelijk zamengesteld uit tweederlei weefsel, een lederachtig en een vliezig, of wel zij bestaan geheel nit een vliezig weefsel, met luchtbuizen, zoogenaamde aderen doortrokken. De dieren der eerste afdeeling worden Heteroptera (in het gewone spraakgebruik ware Hemipteren of ook wel Wantsachtige dieren), die der tweede Homoptera genoemd. Wij zullen ons voor als nog tot de eerste bepalen en eene korte algemeene beschrijving geven der ligchaamsdeelen van de dieren, die er toe behooren. 
Ilet ligchaam is, gelijk bij alle volkomen insecten, uit drie voorname deelen gevormd, den kop, het borststuk (Ihorax) en en het achterlijf. De kop, gewoonlijk zeer diep ingedoken in de voorste opening van het borststuk, heeft nimmer eene zoo groote gemakkelijkheid van beweging als de kop der vliegen, ofsehoon bij sommige Capsinen en Reduvinen eene halsvormige verlenging van het acbterhoofd zigtbaar is. Aan den kop wor den versehillende streken onder verschillende namen onderscheiden, als schedel, voorhoofd, angezigt, wangen, keel euz. wier grenzen niet in het algemeen op te geven zijn en wier eigenlijke plaats men gemakkelijk bij analogie kan vaststellen. Boven op, aan de zijden van den kop ziet men de twee zamengestelde oogen, die dikwijls zeer groot, een enkele maal als gesteeld zijn; bijoogjes of enkelvoudige oogen (ocelli) zijn dikwijls voorhanden en dan op den schedel tusschen de groote oogen, doch meer naar achteren geplaatst.

De sprieten, gewoonlijk ter wederzijde voor aan den kop ingeplant, bestaan uit 3,4 of 5 leedjes, waarbij echter moet opgemerkt worden, dat bij de Reduvinen somtijds tusschenleedjes voorkomen, zoodat bij hen het getal der sprietleedjes vermeerdert.

De zuiger is aan het voorste gedeelte of aan de onderzijde van den kop geplaatst, zeldzaam vrij nederhangend, gewoonlijk tegen de keel en borst aangedrukt, zeer verschillend in lengte, even als de sprieten. Zijne bekleeding, de onderlip, bestaat uit drie of vier aan elkander gevoegde langwerpige leedjes, van welke het onderste volgens de meening van Burmeister de eigenlijke doch vergroeide onderlip en de overigen de vergroeide lipvoelers zouden zijn.

De thorax is uit drie deelen gevormd, I het voorborststuk, of de prothorax, in hetwelk de kop zijne anhechting vindt, 2 het middelborststuk of mesothorax en 3 het achterborststuk of metathorax. Bovendien wordt de thorax in rug, borst en zijden verdecld, doch alleen natar anleiding der rigting in betrekking tot zekere denkbeeldige as in het midden van het borststuk van den kop naar het achterlijt loopende, zonder dat 
die vier gedeelten zuiver door vaste lijnen van elkander zouden kunnen gescheiden worden, gelijk prothorax, meso- en metathorax in de werkelijkheid van elkander gescheiden zijn. Hier dient echter opgemerkt te worden dat de zijden somwijlen, b. v. bij de Capsinen, door naden of gegroefde lijnen in verschillende deelen afgedeeld zijn, zoodat tusschen de zijde en de borst van den metathorax nog een vrij breed stuk ingeschoven schijnt te zijn, in welk geval men in de zijden van midden- en achterborststuk drie deelen waarneemt, aan welken, van voren naar achteren gerekend, de namen gegeven zijn van scapulae (zijden van den mesothorax) pleurae en daaronder parapleurae (zijden van den metathorax). Voor den rug van den prothorax wordt zeer dikwijls de benaming pronotum gebezigd.

Aan dat pronotum onderscheidt men een voor- en achterrand en twee zijranden, 't geen vier hoeken makkt, doch bij sommige ware Hemipteren, met name die der eerste familie, zijn aau het pronotum zes hoeken voorhanden, angezien de achterrand zich over den middelrug uitstrekt en aldaar aan wederzijde op den rand van het schildje nog een stompen hoek vormt. De beide eerste hoeken, aan den kop gelegen, zullen wij voorhoeken, die waar de zijkanten en achterrand tot elkander komen, achterhoeken noemen, terwijl de beide overigen, die niet altijd voorkomen, achterrandshoeken moeten worden genoemd. De achterhoeken van het borststuk zijn dikwijls puntig of wel gedoornd.

Het middelborststuk is gewoonlijk gedeeltelijk onder het voorborststuk verborgen. Daar dit bedekte gedeelte in de beschrijvingen niet vermeld wordt, schijnt het mij niet noodig er een' naam aan te geven. Het meest in het oog loopende stuk van dit middelborststuk is het schildje, een driehoekig of half ellip. tisch stuk op het midden van den rug, dat bij de eerste familie bijzonder groot is, zoodat daarmede het abdomen en de vleugels gedeeltelijk bedekt worden.

Aan den mesothorax zijn de bovenvleugels ingeplant, van welken wij reeds gezegd hebben dat zij in deze afdeeling half lederachtig, half vliezig zijn. In bunnen meest ontwikkelden vorm 
bestaan zij uit vier deelen, welke bij figuu $\mathrm{A}$ op plaat 1 door de volgende letters worden angeduid.

L. of C. is het grootste stuk, genoemd het Leder of Corium.

Cl. is de Clavus of het Sluitstuk, waarvan de buitenrand tegen de zijde van het schildje aansluit.

W. is de Wigge of de Cuneus, een stuk, dat zeer dikwijls ontbreekt.

II. is de Membraan of het Vleugelvlies.

Van deze vier stukken zijn de beide eersten steeds lederachtig, het laatste altijd vliezig, terwijl de wigge dikwijls an de basis ran harder en dikker zelfstandigheid schijnt te zijn dan an de punt. Wanneer de bovenvleugels gesloten zijn, raken zij elkander alleen aan in het gedeelte van den rand tusschen $o$ en $b$ gelegen, hetwelk wij daarom den naad noemen; $b$ is voor ons de boven-nathoekpunt en o de onder-naadhoekpunt.

De ondervleugels, die aan den metathorax zijn vastgehecht, zijn steeds vliezig, op een zeer smal langiverpig lederachtig strookje na, bij soorten der eerste familien; gewoonlijk zijn zij ook geheel ongekleurd of doorschijnend.

Bij eenige soorten, gelijk bij de bedwants, ontbreken de vleugels geheel, bij anderen missen zij membraan en wigge, of zijn op eenige andere wijze slechts half ontwikkeld. Bij enkele soorten, als Velia currens, bestaat dienaangaande slechts individueel verschil, zoodat men voorwerpen met geheel ontwikkelde of half ontwikkelde vleugels en ook vleugellooze voorwerpen aantreft.

Van den metathorax is op de rugzijde gewoonlijk niets te zien, wanneer de vliegtoestel voorhanden en in rust is. Bij vele soorten wordt het midden, geheel naar de gedaante van het schildje, door twee schuin loopende groeven van het overige afgescheiden en alsdan Poslsculellum genoend. Bij het geslacht Gerris is dit deel duidelijker dan bij anderen, angezien het daar in een doorn uitloopt.

Aan de onderzijde van het borststuk zijn de pooten ingeplant; aan elk der drie deelen cen paar. Iedere poot bestaat uit 5 deelen, nam.: 1. de heup, Coxa; 2. de dijring, Truehanter; 
3. de dij, Femur; 4. de scheen, Tibia en 5. de voet, Tarsus. Deze pooten zijn zeer verschillend van vorm naar mate dat zij tot loopen, zwemmen of grijpen en vasthouden van den buit dienen moeten. Hunne tarsen hebben drie leedjes, somtijds slechts twee, of zeer zelden aan de voorpooten een leedje; het laatste lid is nagenoeg altijd met twee eenvoudige klaauwtjes gewapend. Het is noodig hier de gebruikelijke terminologie der pooten, naarmate van de plaats van aanhechting op te geven, waartegen wel eens gezondigd wordt. De 4 voorste pooten worden pedes antertores genoemd, de 4 achtersten pedes posteriores, die van het voorste paar pedes antici, die van het midden-paar pedes medii, die van het achterste par pedes postici.

Het derde ligchaamsdeel is het achterlijf of abdomen, dat uit zes ringen bestaat met een aanhangsel van 1, 2 of 3 vergroeide ringen, die tot de organen der voortteeling behooren. Het is meestal breed (sessile) aan zijne inplanting, zelden aldaar ingesnoerd (coarclatum). Elk der zes ringen draagt aan de zijden aan de buikvlakte een luchtgat (Sligma), gelijk er ook twee paar aan de borst aanwezig zijn. De organa generationis zijn verborgen; men kan echter bij de Geocorisae de mannetjes vrij gemakkelijk van de wịjfjes onderscheiden, door beschouwing van den laatsten ring van het abdomen, welke alleen bij de vrouwelijke kunne in de lengte gespleten is.

De beschrijving van den sexuelen apparatus rekenen wij overigens tot de anatomie der inwendige deelen te behooren.

De gedaantewisseling der Heteroptera is onvolkomen. De voortteeling geschiedt door eijeren, welke dikwijls een zeer sierlijken vorm hebben en waarvan het bovengedeelte als een deksel met een scharnier opgeligt wordt, gelijk reeds Martinet ${ }^{1}$ ) heeft waargenomen. Het uit het ei gekomen insect vervelt twee maal zonder buitengewone rerandering in gedaante, behalve het toenemen in grootte; men noemt het dan, ofschoon met eene onjuiste benaming, larve. Wanneer het dier voor de derde maal van huid verwisselt, komen de vleugels te voorschijn, als

1) Zie Martinet, Catechismus der Natuur, Deel III, Pl. 1. 
rudimenten aan wederzijde in eene huidachtige scheede stekende; alsdan heet men het dier nımmph. Eindelijk wisselen zij voor de vierde maal van huid en zijn dan volwassen, met vleugels voorzien en volliomen insecten of imayines. De onvolkomen dieren (larven en nymphen) hebben dikwijls dikkere sprieten met minder leedjes, en tarsen van een lid minder, terwijl hun de bijoogjes altijd ontbreken. De larven der waterwantsen ademen door stigmata, gelijk de volkomen insecten, en niet door kieuwen of kieuwvormige aanhangsels.

Vele landwantsen verspreiden, als zij aangeraakt worden, eenen meestal onaangenamen geur. Van de bedwants is dit aan iedereen bekend. Denzelfden geur vindt men bij verscheidene andere soorten, b. v. Cimex Baccarum, lituratus, Cymus Resedae, Heterogaster Urficae terug. Volgens Gorski ruikt Reduvius personalus naar muizen, stinkt Ncpa cinerea naar rottende visch, Trigonosoma lineatum naar verrotte appelen; doch er zijn ook soorten, die een' aangenamen geur verspreiden, b. v. Capsus Pastinacae en Alydus calcaralus. De Maleische naam van sommige Hemiptera op rijstvelden "Walang sangith" duidt aan dat deze mede 's menschen reukzenuwen op onaangename wijze aandoen. De geur is an zekere olieachtige vloeistof toe te schrijven, welke door klieren die in het abdomen liggen, afgeseheiden wordt en haren uitweg naar buiten vindt in twee spleten, ter wederzijde der borst in den metathorax gelegen en gewoonlijk door vrij dikke zoomen omvat. 
SYSTEMATISCHE VERDEELING EN BESCHRIJVING.

Wij hebben reeds gezien dat de Orde der Hemiptera zich in twee groote afdeelingen scheidt, naar de zamenstelling der vleugels. Dit kenmerk gaat met een ander gepaard, dat in de plaatsing of liever aanhechting van den zuiger gelegen is. De Heteroptera, wier voorvleugels uit twee weefsels zijn zamengesteld, hebben een' zuiger, die voor aan den kop of ten minste ver van de heupen der voorpooten ingeplant is; bij de Номортевл daarentegen ontspringt hij bijna nit de keel, nagenoeg tusschen de voorste heupen. De eerste afdeeling wordt dan ook door Zetterstedt die der Frontinostrin, de tweede die der Gulaerostria genoemd. De eerste omvat de ware Hemipteren of Wantsen, de tweede de Cicadellen, Bladen Plantluizen.

De afdeeling der Heteroptera wordt weder in twee sectien verdeeld naar gelang der platsing en lengte van hunne sprieten, op de volgende wijze:

1. Sprieten, gewoonlijk zoo lang als het halve ligchaam, steeds ten minste zoo lang als de kop, van $3-5$ leedjes, met de inplanting zigtbaar, of zoo die van boven niet zigtbaar is, dan steeds van 5 leedjes . . . . . . . . . $1^{\text {e }}$ Sectie.

2. Sprieten korter dan de kop, aan de onderzijde van dien ingeplant van 3 of 4 leedjes, de basis bedekt . . $2^{\text {e }}$ Sectie.

De eerste sectie noemt Burmeister die der GEocones; Amyot en Serville zeggen Geocorises, Fieber en Flor Gymnocerata, terwijl wij haar met eene Hollandsche benaming die der LANDWANTSEN zullen noemen.

De tweede sectie noemt Burmeister die der Hydrocones; Amyot en Serville zeggen Hydrocorises; Fieber en Flor Cryplocerata, terwijl wij haar de sectie der Waterwantsen zullen noemen. 
Wel is het waar dat onder de cerste sectie eenige geslachten voorkomen, wier individuen op het water loopen of rocijen, doch vooreerst zwemmen die dieren niet onder water, gelijk de waterwantsen, ten andere zijn de namen eenvoudiger en welluidender dan die van naakt- en bedektsprietigen, welke termen bovendien als slaande alleen op de basis der antennen onjuist zijn.

De Landwantsen worden in de volgende familien verdeeld:

1. (14) Zuigerscheede of onderlip van 4 , zelden 5 leedjes. Twee huidlapjes tusschen de klaauwtjes.

2. (3) Sprieteu dikwijls onder de oogen ingeplant, van 5 leedjes. Het schildje groot, ten minste half zoo lang als het achterlijf.

$1^{\mathrm{e}}$ Fam. Schildwantsen. - Sculati.

3. (2) Sprieten van 4 , zelden van 5 leedjes, vooraan of op zijde van den kop, voor de oogen ingeplant. Het schildje korter dan de helft van het achterlijf.

4. (11) Tarsen van 3 leedjes. Sprieten van 4 leedjes.

5. (8) Bijoogen aanwezig.

6. (7) Membraan met meer dan 5 langsaderen. $2^{e}$ Fam. Coreodes.

7. (6) Membraan met 5 langsaderen of minder. $4^{e}$ Fam. Lygaeodes.

8. (5) Geen bijoogen.

9. (10) Bovenvleugels zonder cuneus of membraan. $3^{\text {e }}$ Fam. Pyrrhocorides.

10. (9) Bovenvleugels met een cuncus. Membraan met tweo gesloten cellen, van waar eenige aderen uitstralen. $5^{\mathrm{e}}$ Fam. Capsini.

11. (4) Tarsen van 2 leedjes. Sprieten van 4 of 5 leedjes.

12. (13) Geen bijoogjes. In plaats van het schildje een uitsteeksel van het pronotum. Bovenvleugels glasachtig 
met een netwerk van aderen, zoodat zij eenigermate op kant gelijken. Sprieten van 4 leedjes.

$7^{\mathrm{e}}$ Fam. Netwantsen. - Tingidides.

13. (12) Ocellen aanwezig. Een onbedekt schildje. Sprieten van 5 leedjes. Bovenvleugels niet op kant gelijkend.

$9^{\mathrm{e}}$ Fam. Hebroides.

14. (1) Zuigerscheede meestal van 3 , zelden van 4 leedjes. Geene huidlapjes tusschen de klaauwtjes.

15. (22) Klaauwtjes steeds aan het einde van het laatste lid der tarsen ingeplant.

16. (17) Zuiger in eene goot tegen de keel aangedrukt. Ligchaam zeer plat. Tarsen van 2 leedjes.

$8^{\text {e }}$ Fam. Schorswantsen. - Corticicolae.

17. (16) Zuiger loshangend. Tarsen van 3 leedjes.

18. (21) Ocellen, zoo zij aanwezig zijn, geplaatst achter cene denkbeeldige lijn, van den achterrand van het eene oog tot dien van het andere getrokken.

19. (20) Voorvleugels ten minste schijnbaar met een wigge. Kop in een langwerpig vierkant of een cylinder verlengd.

$6^{\text {e }}$ Fam. Antlocorides.

20. (19) Voorvleugels zonder wigge Kop achter de oogen halsvormig nitgerekt.

11 Fam. Roofwantsen. - Reduvini.

21. (18) Ocellen digt bij elkander tusschen de oogen geplaatst. $10^{\mathrm{e}}$ Fam. Oeverwantsen - Riparii.

22. (15) Klaauwtjes zeer klein, in eene inkeeping geplaatst voór het einde van het laatste lid der tarsen.

$12^{e}$ Fam. Waterberoeijers. - Hydrodromici. 


\section{Se c t i e 1. - Landwantsea.}

\section{EERSTE FAMILIE. - SCHILDWANTSEN.}

SCUTATI.

De benaming is afgeleid van het groote schild, het meest kenmerkende ligehaamsdeel. - Het lijf dezer dieren is gewoonlijk aan de boven- en onderzijde bol, dikwijls met scherpe kanten aan de zijden; de bedekkende huid is van eene harde of vrij harde zelfstandigheid. De kop is aan de zijden voor de oogen meest scherp gerand, aan de spits door twee voren in drie lappen verdeeld, waarvan de middelste niet altijd den voorrand bereikt. De oogen ziju matig bol, soms vrij plat, bij eene soort ter zijde uitpuilend, als gesteeld; de ocellen ontbreken nooit en staan op den schedel schuin achter de oogen, elke ocel digter bij een oog dan bij hare wedergade. De sprieten zijn altijd aan de onderzijde van den kop ingeplant, meest zoo dat aan de schedelzijde slechts de tip van het eerste lid gezien kan worden; zij hestaan uit vijf leedjes, van welke het laatste gewoonlijk spoelvormig en dikker is dan de drie voorgaanden. De zuigerscheede of onderlip is uit vier leedjes zamengesteld, waarvan het tweede gewoonlijk het langste is; meestal reikt zij tot aan de heupen van het $2^{\text {e }}$ of $3^{e}$ paar.

Het voorborststuk is aan de bovenzijde gexien meer 6- dan 4 hoekig met de achterhoeken dikwijls uitstekend, of zelfs wel doornachtig. Het schildje bij de eerste geslachten bijzonder groot en aan de achterzijde afgerond; bij de volgenden iets kleiner en meer driehoekig van gedaante. De bovenvleugels hebben corium, clavus en membraan; aan het eerste onderscheidt men eene duidelijke en soms ook nog cene onduidelijke langsader; een wiggestuk ontbreekt; de membraan telt vijf of 
meer gebogene langsaderen, die dikwijls uit eenige cellen aan de basis ontspringen.

De pooten zijn alleen tot gaan ingerigt; niet tot springen, zwemmen of grijpen. Somwijlen hebben de voordijen een enkelen doorn; bij een geslacht zijn alle pooten met stekels bezet. De tarsen zijn bij een geslacht van twee, bij alle anderen van drie leedjes.

Aan de borst vindt men nu eens eene gleuf voor den zuiger, dan weder aan de midden- en achterborst een' plaatvormig uitstekenden kiel, dan weder een' kleinen kiel alleen tusschen de middenpooten. Aan den buik treft men bij sommige soorten een' doorn of uitpuilend bultje an op den tweeden ring in het midden.

Schildwantsen vindt men in bosschen, boomgaarden en moestuinen, in de duinen en op de heide. Hnn voedsel bestaat hoofdzakelijk uit plantensappen, ofschoon men enkele soorten ook aan versch gedoode insecten ziet zuigen, waarbij het echter nog niet uitgemaakt is of zij die zelf vermoord hebben. Een paar soorten zijn hoogst onaangenaam door den viezen geur en de walgelijke smaak, die zij aan de frambozen kunnen mededeelen. Een enkele verzorgt en beschermt hare jongen, zoo lang zịj larven zijn.

Verdeeling der geslachten.

1. (26) Zuiger aan de basis slank even als in het midden; zijn eerste lid in eene sleuf aan de keel geborgen.

2. (13) Schildje zeer breed, aan het einde toegerond en zoo lang als het abdomen.

3. (10) Scheenen niet met stekeltjes bezet.

4. (7) Het abdomen steekt zijdelings met een breeden rand buiten het schildje en het corium der vleugels uit.

5. (6) Voorrand van den kop eene ellips vormend; sprieten vrij kort; membraan met ongeveer 12 aderen.

Gen. 1. Tetyra F. 
6. (5) Kop driehoekig; sprieten vrij lang; membraan met 5 aderen.

Gen. 2. Trigonosoma Burm.

7. (4) Van het abdomen is an de bovenzijde nagenoeg niets te zien.

8. (9) Een doorntje voor de uitpuilende oogen, naast de sprieten; voorrand van den prothorax aan de onderzijde gewoon.

Gen. 3. Podors Lap.

9. (8) Geen doorntje voor de oogen; deze bol, maar niet uitpuilend; voorrand van den prothorax aan de onderzijde plaatvormig uitstekend.

Gen. 4. Phimodera Germ.

10. (3) Scheenen met stekeltjes bezet.

11. (12) Ligchaam behaard.

Gen. 5. Odontoscelis Lap.

12. (11) Ligchaam onbehaard.

Gen. 6. Coneomelas White.

13. (2) Schildje veel korter dan het achterlijf, van driehoekigen vorm.

14. (15) Scheenen met stekels bezet.

Gen. 8. Cyunus F.

15. (14) Scheenen zonder stekels.

16. (25) Tarsen van drie leedjes.

17. (18) Het ligchaam plat aan de bovenzijde. Rand van het abdomen aan de zijden uitstekend en scherp afgeplat.

Gen. 9. Scroconrs Fall.

18. (17) Het ligchaam aan de bovenzijde min of meer bol; rand van het abdomen niet of slechts weinig uitstekend.

19. (20) Het ligchaam langwerpig; de achterhoeken van den prothorax zeer stomp. Voorhoofd bol, aangezicht nedergebogen.

Gen. 10. Aeuin F. 
20. (19) Het ligchaam vrij breed, de achterhoeken van den prothorax dikwijls tamelijk sterk uitstekend.

21. (22) Het voorhoofd bol, de kop en de voorzijde van den thorax verticaal.

Gen. 11. Eusarcoris Hahn.

22. (21) Het voorhoofd niet bol en de kop of geheel horizontaal of nagenoeg zoo, nooit verticaal.

23. (24) Sprieten bijna zoo lang als het ligchaam, achterhoeken van den prothorax vlengelachtig verlengd en opgewipt.

Gen. 12. Tropicoris Hahn.

24. (23) Sprieten half zoo lang als het ligchaam; achterhoeken van den prothorax niet vleugelachtig verlengd en opgewipt.

Gen. 13. Cinex F.

25. (16) Tarsen van twee leedjes.

Gen. 14. Acantiosona Curt.

26. (1) Zuiger aan de basis zeer dik, los nederhangend; het eerste lid niet in eene sleuf geborgen.

Gen. 7. Asopus Burm. 


\section{Genus 1. Terya F.}

Ligchaam aan de bovenzijde eenigzins bol, aan de onderzijde platachtig; de lengte gelijk $1 \frac{1}{2}$ maal de grootste breedte. Kop eenigermate neergebogen, meer breed dan lang, met den roorrand gekromd, niet hoekig. Oogen niet zeer groot, noch ook bol. Sprieten korter dan $1 / 3$ van de ligchaamslengte; hunne inplanting verborgen onder de vooruitstekende lappen van de voorborst; lid 1 en 2 gelijk van lengte, 3 en 4 iets korter, 5 het langste en tevens dikste, aan beide rijden toegespitst. De zuiger reikt tot even voorbij de middelheupen. De prothorax meer dan 2 maal zoo breed als lang, met scherpe zijranden, afgeronde achterhoeken en een regten achterrand tusschen do buitengemeen stompe achterrandshoeken. De buitenrand van het corium blijft door het schildje onbedekt. De membraan heeft steeds meer dan 12 langsaderen. De pooten matig lang, zonder iets bijzonders. Het achterlijf met scherp uitstekenden, platten rand, zijn eerste ring half onder den metathorax verborgen, zoodat men aan wederzijde slechts 5 luchtgaten telt.

\section{Telyra Maura L.}

Plaat 1. fig. 1, $1 a$ en $1 b$.

Linn. Fn. Suec. 246, 913. - Fabr. S. Rh. 136, 36 (maura) et 38 (picta). - Panz. Fn. Germ. 112, 15. - Burm. Handb. II. p. 390. n. 3. Hahn, W. I. II. p. 44, fig. 139, 140. - Flor, Rh. Livl. I. p. 85. Douglas and Scott, Brit. Hem. I. p. 65. P1. 2, fig. 5 (Eurygaster maurus).

Lengte $9 \frac{1}{2}-11 \mathrm{~mm}$. Donker lederbruin met lichtere strepen en vlekken. Kop en borststuk aan de randen donkerder dan in het midden, over welk midden twee donkere langsstrepen loopen, door eene veel smallere lichte streep gescheiden. Schildje met twee lichte, gladde ietwat bolle vlekjes an de basis en drie vrij groote langsvlekken, warvan de middelste voor zeer smal en achter vrij breed is. De van boven rigtbare rand ven het 
acherlijf verdeeld in vierkante lichtere en donkere vlekken. Aan de onderzijde is de borst gelijk in kleur aan de bovenzijde, de buik ietwat rooder, met eene donkere streep over het midden. De sprieten geelachtig, hun laatste lid, of de beide laatsten donkergrijs of zwart; het $2^{\mathrm{e}}$ lid ietwat krom. Pooten lederbruin met zwarte stippels.

Sommige voorwerpen zijn lichter, anderen donkerder; ecn in de collectie der Vereeniging bewaard, is steenrood van kleur met zeer weinig vlekken.

Meer voorkomende dan de volgende soort. Gevonden op de Hollandsche duinen (v. Voll.), bij Utrecht (Six), bij Nijmegen (Snellen), in Julij en Augustus; bij Bergen op Zoom in Junij (Dr. Everts), bij Breda in Maart (Heylaerts) in Junij (v. Voll.), in September (Leesberg); bij Brummen in Mei (v. Voll.)

\section{Telyra Hollentotla F.}

Plaat 1, fig. 2.

Fabr. S. Rh. 136, 37 et 39 (nigra). - Hahn, W. 1. II, 4/, tab. 45, fig. 139. - Wolff, Icon. Cim. 135, tab. 13. f. 129 b. - Panz. Fn. 111, 7. - Douglas and Scott, Brit. Hem. p. 66.

Lengte $13 \mathrm{~mm}$. - In tweederlei kleur voorkomende, $1^{0}$ ledergeel; $2^{0}$ zeer donkerbruin, nagenoeg zwart; herkenbaar aan eene duidelijke kielvormige streep op het midden van het schildje.

Kop aan de zijden omzoomd, min of meer driehoekig, geheel met ingedrukte putjes bedekt, die op de middellob dikwijls zwartachtig zijn; de zoom alleen is glad. De zijlobben reiken iets verder dan de middellob. Oogen van dezelfde kleur als de kop; bijoogjes met zwarte kern. Sprieten bruinachtig geel, eind van het $4^{e}$ lid lichtbruin, het $5^{e}$ zwartachtig, behalve aan de basis die geel is. Laatste lid van den zuiger zwart. Prothorax vrij bol, gestippeld, aan de voorhoeken met ingedrukte putjes; de zijden met een' ongestippe den zoom, die veelal iets lichter van $\mathrm{klenr}$ is. Het schildje eenigzins roestkleurig aan de basis, overal gestippeld behalve op den verhev'n middenkiel, niet gezoomd. De kiel en sumtijds twee 
vlekjes aan de basis zijn lichter van kleur. Het bedekte gedeelte van het corium is glanzig pekkleurig, de uitstekende rand van het achterlijf soms iets rooder dan de grondtoon. De onderzijde van het lijf in kleur gelijk aan de bovenzijde, zoo ook de pooten. De kop en de zijden van den prothorax aldaar met zeer diepe putjes ingedrukt. Op de dijen eenige zrarte stippen; aan den rand der ringen van het achterlijf in het midden een klein zwart vlekje.

De zwarte verscheidenheid verschilt alleen in kleur.

Dit insect schijnt tamelijk zeldzaam te zijn. De heer Weijenbergh vond het in Mei te Overveen, de heer van Eyndhoven vond de zwarte varieteit (waarschijnlijk in Gelderland); de lichtbruine verscheidenheid werd bovendien bij den Haag gevangen door Dr. van Hasselt en de zwarte op Walcheren door den heer La Fontijn.

\section{Gen. 2. Trigonosona Burm.}

Ligchaam aan beide zijden bol, met scherpe zijranden, het borststuk op den rug kussenachtig verheven; de lengte gelijk $1 \frac{1}{4}$-maal de grootste breedte. Kop zeer sterk neergebogen, driehoekig, iets langer dan breed; de zijlobben veel langer dan de middellob. De oogen sterik uitpuilend; ocellen tamelijk groot en nog al digt bij de oogen geplaatst. Sprieten reikende tot aan de basis van het schildje, lid 1 kort en nog al dik, lid 2 veel slanker en bijna driemaal zoo lang, 3 iets dikker dan 2 en zoo lang als 1, 4 anderhalfmaal zoo lang als 3 en naar de spits dikker wordend; 5 bijna zoo lang als 2 en het dikste van allen. De zuiger reikt tot aan de achterheupen. De prothorax vrij bol, met scherpplatte zijranden en ronde schouders. Het schildje langwerpig, aan de basis tweemaal zoo breed als aan het einde, aldaar als afgesneden en daarna bijgerond. Het vleugelvlies vrij groot met 5 aderen, waarvan de tweede aan den top gevorkt. Pooten matig lang en forsch, de einden der scheenen en zoolen der tarsen sterk behaard. Het achterlijf als bij het vorige genus. 


\section{Trigonosoma nigrolineata Rossi. ${ }^{1}$ )}

Plaat 1, fig. 3.

Linn. S. N. I. 2. 716, 6. - Fabr. S. Rh. 135, 32. - Wolf, Cim. 1. tab. 1. fig. 1. - Stoll, Wantsen, tab. 11. fig. 9. - Panz. Fn. Germ. 1. tab. 2. - Hahn, W. I. I. 173. tab. 27. fig. 90.

Lengte bijna $1 \mathrm{~cm}$. Bloedrood, sterk gestippeld. De sprieten zwart. De kop met 2, het borststuk met 6, het schildje met 4 tamelijk breede, zwarte langsstrepen; de nitstekende rand van het achterlijf met vierkante zwarte vlekken. Het lijf aan de onderzijde met zwarte vlekken gepanterd.

Deze zeer kenbare soort behoeft geen uitvoeriger beschrijving. De diagnose van Fabricius dengt niet; men kan haar ongeveer juist vinden als men daarin de kleuren verwisselt, doch de grondtoon is rood en niet zwart; er is evenwel geen twijfcl aan of hij. heeft deze soort bedoeld.

De heer Baron van Ittersum vond eenige voorwerpen van deze soort op de heide, toen hij in Noord-Brabant kampeerde.

\section{Gen. 3. Podops Lap.}

Het ligchaam aan beide zijden vrij bol, met de zijkanten niet zeer sterk nitstekend; de kop in het midden vrij hong uitpuilend. De grootste breedte gelijk aan iets meer dan de helft der lengte. Kop weinig neergebogen, van voren toegerond met de zijkanten scherp, de middellob even lang als de zijlobben. De oogen sterk uitpuilend, bijna als of zij gesteeld zijn. Ocellen mueijelijk te onderscheiden. Sprieten kort, de vier eerste leden weinig in lengte en dikte verschillend, het vijfde tweemaal zoo lang en tweemaal zoo dik als het vierde. De zuiger reikt tot aan de basis van het abdomen. De prothorax meer dan tweemaal zoo breed als lang, met de voorhoeken in

1) Linnaeus beschreef deze soort onder den naam van Cimex lineatus, Rossi in zijne Fauna Etrusca (II. 226. 1288) onder dien van C. nigrolineatus. De eerste benaming heeft dus het regt van prioriteit en toch is het beter de tweede te gebruiken, omdat zij zeer juist het verschil annduidt tusschen deze soort en de zeer na verwante T. rubrolineata, wier grondtoon zwart is. 
platte vierkante uitsteeksels verlengd, de achterhoeken als met een haakje voorzien, de achterrandshoeken zeer stomp. Het schild groot en breed, aan het einde loegerond. Het vleugelvlies met 4 evenwijdige, doch naauwelijks zigtbare aderen. De rand van het abdomen weinig uitstekend. ${ }^{1}$ ) De ponten middelmatig van lengte en dikte, het eind der scheenen en de tarsen behaard. Het achterlijf als bij het voorgaande genus, met dit versehil dat de laatste ring niet zoo elliptisch uitgesneden en dus de daarin passende anaalplaat breeder is.

\section{Podops inunclus F.}

Plaat 1, fig. 4.

Fabr. Ent. Syst. IV. 90, 45. - Idem, S. Rh. 139, 53 et 138, 49 (Tangira). - Burm. Handb. II. p. 387, 2. - Amyot et Serv. Hémipt. 57. 1. - Wolff, Icon. Cim. 5, 5. tab. 1, fig. 5. - Schellenb. Cimic. tab. 1, f. 5 et b. - Panz. Fn. Germ. 36. f. 24. - Flor, Rh. Livl. p. 78. Douglas and Scott. Brit. Hem. p 73. Pl. 2, fig. 8.

Lengte $6 \mathrm{~mm}$. Grauw met ronde ietwat donkerder stippeltjes, terstond herkenbaar aan de uitpuilende oogen en de platte uitsteeksels aan de voorhoeken van den prothorax. De kop vrij groot, in het midden eenigzins opgeblazen, naar voren rond toeloopend, doch de middellob iets korter dan de zijlobben, die elkander niet aanraken. Voor elk oog een doornachtig uitsteeksel. De oogen zwart; ocellen moeijelijk te onderscheiden. De sprieten bijna zwart met lichte geledingen, een weinig behaard, het laatste lid vrij sterk behaard. De zuiger vuilgeel met het laatste lid bruiu. De prothorax met eene vrij diepe gleuf even voor het midden; de voorhoeken met nitsteeksels, die naar krukken van deuren zwemen; de achterhoeken haakvormig ingekeept. Het schildje aan de basis ietwat hooger, welke verhevenheid naar het midden in eene punt tocloopt, aan de basis 2 of 3 gladde, lichtgekleurde knobbeltjes. De onder-

1) De figuur op plaat $\mathbf{1}$ is slecht uitgevallen; de ranı van het achterlijf steekt te ver uit; de middellob aan den kop moest korter zijn; het schouderuitsteeksel an de regterzijde is niet krukvormig genoeg en in plaats van 1 witte vlekjes aan de basis vau het achterlijf moeten er 3 staan, 2 bij den raud en 1 in het midden. 
zijde iets donkerder dan de bovenzijde; de omgeving van het reukorgaan wratachtig en dus in miniatuur gelijkende op een rhinoceros-huid; de daarop volgende rand van den metathorax lichter van kleur. Het abdomen met eene bruingele streep aan wederzijde en met lichtkleurige knobbeltjes aan den rand, op elk seg:nent een. Pooten vuilgeel; twee ringen aan het eind der dijen, vlekken aan de onderzijde der scheenen en het laatste lid der tarsen bruin.

Gevonden bij Rotterdam in Maart (Snellen), bij den Haag. (van Vollenhoven), bij Utrecht in Junij (Six). In vrij groot aantal bij Breda in Maart, Heylaerts. Een klein exemplaar bij Arnhem, van Medenbach de Rooịj.

Gen. 4. Pinmodera Germ.

Dit geslacht heeft groote overeenkomst met het voorgaande, maar onderscheidt zich door de volgende kenmerken. De kop puilt op het voorhoofd niet uit, is zeer sterk neergebogen en door het zijdelings uitsteken der zijlobben an de spits vrij breed. De ocellen zijn duidelijk te onderscheiden. De roorhoeken van den prothorax zijn puntig, maar niet in platte vierkante uitsteeksels verlengd. Het schildje bedekt de vleugels bijna geheel, en is dus naar evenredigheid hier veel breeder dan bij het vorige genus. De membraan heeft 7 of 8 aderen. De voorrand van de voorborst steekt in eene vrij breede plaat uit, tegen welke de $k o p$ in de rust aangedrukt zit en waronder de sprieten kunnen verborgen worden. De apophysen der achterpooten eenigzins doornachtig van gedaante.

\section{Phimodera galgulina H.-Sch.}

Plaat 1, fig. 5.

Herrich-Schaeffer, Wanz. Ins. IV. p. 29. tab. 119. f. 379. - Flor, Rhynch. Livl. I. p. 82.

Lengte $6 \mathrm{~mm}$. Grijs met olijfklew en zwart getijgerd. De zeer naauweurige voorstelling up onze plaat makkt cene uit- 
voerige beschrijving overbodig. De buik is als met een zacht grijs vilt bekleed; de achterhoeken van elk segment van het achterlijf steken als kleine knobbeltjes uit. De dijen zijn geelachtig wit met fijne geslingerde zwarte dwarsstreepjes naar de knie toe, deze is geel; de scheenen zijn zwart met cen' gelen ring in het midden; de tarsen zwart met het tweedo lid iets lichter.

Deze soort schijnt bijzonder zeldzaam. Ik ving een voorwerp op het duin bij het s'cheveningsche badhuis; en misschien twintig jaren daarna heeft de heer Mr. A. F. A. Leesberg ongeveer ter zelfder plaatse in Junij een tweede aangetroffen.

\section{Genus 5. Odontoscelis Lap.}

Het lijf zeer bol an de bovenzijde, zeer weinig bol an de buikzijde, van boven greheel met korte stoppelachtige haartjes bedekt, aan den rand met langere haren. Kop breed, stomp toegerond, eenigzıns neergebogen. Oogen niet uitpuilend, nier. vormig. Sprieten vrij kort, hun $2^{\mathrm{e}}$ en $5^{\mathrm{e}}$ lid de langsten, 1 , 3 en 4 kort, aan elkander gelijk, 2 en 3 dun. De zuiger, die nog al breed is, bereikt den achterrand der middelheupen. Prothorax meer dan tweemaal zoo breed als lang, aan de zijden in eene kromme lijn verbreedend, met de achterhoeken afgerond en de achterrandshoeken naauwelijks bemerkbaar. Schild zeer breed, op een zeer smal randje na de vleugels en het achterlijf geheel bedekkend. Pooten vrij krachtig, dijen met haren, en scheenen met haren en stekels bezet.

\section{Odontoscelis fuliginosa $\mathrm{L}$.}

\section{Plaat 1, fig. 6 .}

Linn. S. N. 2. 716. 8. - Fabr. S Rh. 139, 50 et 51 (litura). Curt. Br. Ent. XV. tah. 685. - Burm. Hdb. II. 385, 3. - Hahn, W. I. II. p. 49-51. tab. 46. fig. 142, 143, 144. - Wolff, Ic. Cim. 1. 50. tab. 5. lig. 47. - I'lor, Kh. Livl. I. 152. - Douglas and Scott, Brit. Hem. 1. 60. Pl. 2), f. :3. 
Lengte 4-7 mm. In twee verseheideuheden voorkomend. De grootere zeer donker bruin met onregelmatige zwarte vlekken, eene fijne lichtgekleurde langsstreep (die soms ontbreekt) over Let midden van den rug, te beginnen met het midden van den prothorax en digt bij den zoom van het schild in een breeder langsstreepje eindigend; eindelijk an wederzijde bij de basaal. hoeken van het schild een vierkant wit of witachtig vlekje. De kleinere varieteit veel lichter van kleur, ledergeel of bruin, met den kop en het voorstuk van het borststuk donkerder en 4 zwarte langsstreepjes op het schild, 2 aan elke zijde. De sprieten zijn vaalbruin met het $1^{e}$ en laatste lid donkerder. Het geheele lijf is zeer fijn gestippeld, de onderzijde ietwat glanzig. De pooten zijn zwart of donkerbruin, de scheenen driekantig.

De groote verseheidenheid (Litura F.) werd door mij, doch zelden in de Hollandsche duinen angetroflen; de kleinere is volgens den heer Six op heigrond bij de Bildt (Utr.) in Junij geene zeldzaamheid; ook werd zij, blijkens twee voorwerpen op 's Rijks museum bewaard, door van Eyndhoven in Holland gevonden. Voorts werden lichtgekleurde voorwerpen aangetroffen in Junij bij Scheveningen (van der Wulp) en in dezelfde maand bij Noordwijk (Jhr. Dr. Everts), terwijl de var. Dorsalis F. (Zie Hahn, f. 144) door den heer Six in Junij bij Domburg werd bemagtigd.

Gen. 6. Coreomelas White. ${ }^{1}$ )

Tusschen dit genus en het vorige bestaan slechts weinig punten van verschil en het is dus meer met het $00 \mathrm{~g} 0_{i}$; de vrij talrijke exotische soorten, dat wij het ook hier opnemen. Het verschil is dit: bij Coreomelas is het geheele ligchaam glad en haarloos, het $2^{e}$ lid der sprieten is korter dan het 3 , de voorhoeken van het borststuk zijn geheel afgerond en het schild,

1) Dit geslacht werd door ons in de naamljust van Nederl. Hemipteren verkeerdelijk Thyrencorts Schranck genoemd. 
dat naar evenredigheid smaller is, laat een' rand der bovenvleugels en den zoom van het abdomen vrij.

Coreomelas scarabaeodes L.

Plaat 1, fig. 7. 1)

Linn. Fauna S. 912. - Wolff, Ic. Cim. 4. tab. 1. f. 4. - Fabr. S. Rh. 143, 70. - Hahn, W. Ins. II. p. 47. tab. 45, f. 141. - Burm. Handb. II. p. 385. 1. - Flor, Rh. Livl. I. p. 150. - Dougl. and Scott, Brit. Hem. p. 58. Pl. 2, fig. 2.

Lengte 4 mm. Glanzig gebronsd zwart van kleur, overal zeer fiju gestippeld. Membraan grijs. Sprieten, zuiger en tarsen donkerbruin of roodbruin.

Op Geum urbanm bij Driebergen, zeldzaam, Six. Bij den Haag in April, Leesberg. Bij Velp in Augustus, Ritsema. Bij Breda, Heylaerts.

\section{Gen. 7. Asopus Burm.}

Ligchaam van boven slechts weinig gewelfd, sterker aan de onderzijde. Kop van boven plat, gewoonlijk iets langer dan breed, met de zịjlobben doorgaans iets verder nitstekend dan de middellob, naar voren niet driehoekig toeloopend. Oogen vrij groot, doch niet uitpuilend; ocellen duidelijk zigtbaar, verder van elkander dan elk van het oog aan zijne zijde. Sprieten draadvormig met het laatste lid ietwat dikker en het eerste slechts even onder den zijrand van den kop uitkomend. De prothorax steeds breeder dan lang, aan de basis veel breeder dan aan den voorkant, de achterhoeken zeer verschillend in vorm. De zuiger zeer dik, los nederhangend (zie fig. 8a) met het $1^{\mathrm{e}}$ lid niet in eene sleuf der borst verborgen, de spits nimmer tot het abdomen reikend. Het schildje driehockig met eene ronde punt, die niet veel verder dan de helft van het

1) In deze figuur, welke niet betint is om de randen der deelen beter te doen uitkomen, ontbreken de fijne doorntjes aan de pooten. 
abdomen reikt. De tweede ring van het achterlijf somwijlen met een doorn gewapend. Het corium der vleugels iets langer dan het schildje; hun membraan met $6-9$ aderen. De pooten vrij lang en forseh; de voordijen soms gedoornd, alle scheenen steeds met gleuven en kanten voorzien; tarsen van drie leeijes, het $1^{e}$ zoo lang als of langer dan de beide anderen te zamen genomen.

\section{Tabel der soorten.}

1. (8) Voorste dijen ongedoornd.

2. (7) Tweede ring van het abdomen zonder stekel.

3. (4) Glanzig blaaww of blaauwgroen . . . coeruleus.

4. (3) Rood of bruin of bronskleurig.

5. (6) Bronskleurig met witte ringen om de scheenen. punctatus.

6. (5) Rood of bruin met ongeringelde scheenen . cuslos.

7. (2) Tweede ring van het abdomen met een stekel. luridus.

8. (1) Voorste dijen met een doorn voorzien.

9. (10) Achterhoeken van den prothorax afgerond . dumosus.

10. (9)

$$
" \quad " \quad \text { puntig . . bidens. }
$$

\section{Asopus coeruleus L.}

Plaat 1, fig. $8{ }^{\text {l) }}$ ) en $8 a$.

Linn. S. N. p. 722. 50. - Panz. Fn. Germ. 32. 14. - Fabr. S. Rh. 178. 119. - Gurt. Br. Ent. I. t. 20. - Burm. Handb. II. 378. no. 1. Hahn, W. Ins. II. p. 65. tab. 50. f. 154. - Wolif, Ic. Cim. p. 18. tab. 3. f. 18. - Flor, Rh. Livl. I. p. 90. - Douglas and Scott, Brit. Hem. p. 88. Pl. 3. โ. 3 .

Lengte 6-7 mm. Donker staalblaauw, met groenen en paarschen weerschijn, de laatste voornamelijk op de voorvleugels over het geheele lijf gestippeld, vrij grof aan den voorrand en in eene dwarsgleuf midden over het borststuk, eenigzins rimpelig in de zijden van het schildje. Oogen, sprieten en zuiger zivart, van de leedjes der sprieten het $1^{\mathrm{e}}$ het kleinste, dan het $3^{\mathrm{e}}, 4^{\mathrm{e}}$, $2^{e}$ en $5^{e}$, toenemende in lengte. De geledingen vau den zuiger

1) Deze figuur is wat breed uitgevallen; vooral steken de achterhoeken van het borststuk te veel nit. 
vuil wit van kleur. De membraan zwart of donkerbruin. De pooten groenachtig blaanwzwart: de voordijen zonder stekel, de achterdijen bijna tweemaal zoo lang als deze. Een tandje aan de binnenzijde der voorscheenen. De buik ongewapend.

In Friesland aangetroffen door den heer Gerlach. Bij Utrecht door den heer Verloren. In Junij bij Leyden en in het midden van Julij op tarwaren bij Brummen, v. V. In Mei op eikenloof te Strijbeek bij Breda, Heylaerts. Mede bij Breda, Leesb. Bij Arnhem, v. Medenb. de Rooij.

\section{Asopus punclatus L.}

Plaat 10 , fig. 5 .

Linn. S. N. V. p. 486, 34. - Fabr. S. Rhyng. 157, 12 - Fallèn, Hem. Suec 1, p. 25. - Burm. Handl. 1I. p. 378. - Wolf, Ic. Cim. p. 179, tab. 18, f. 173. - Hahn, W. Ins. II, p. 69, tab. 51, f. 157. Herr.-Sch. in Panzer's Fauna 113, 5. - Flor, Rh. Livl. I. p. 91. Douglas and Scott, Brit. Hem. p. 92. Pl. 3, f. 5.

Lengte $8 \mathrm{~mm}$. - Even als de voorgaande wordt deze soort gebragt tot het geslacht Zicrona der nieuweren en heeft met haar gemeen dat het $2^{e}$ en $3^{\mathrm{e}}$ lid der sprieten weinig in lengte verschillen, dat de voordijen onbedoornd zijn en de zuiger slechts tot de middenheupen reikt.

Bronskleurig bruin of zwart, boven iets donkerder dan onder, hier en daar met wit gemarmerd. Kop aan de bovenzijde plat, nagenoeg vierkant met afgeronde hoeken en nitpuilende oogen, de middellob inspringend. De sprieten iets langer dan kop en borststuk, zwart; het $2^{\mathrm{e}}$ en $3^{\mathrm{e}}$ lid gelijk van lengte, het $4^{\mathrm{e}}$ iets langer, het $5^{\text {e }}$ nog langer. Ilet borststuk gekartcld aan het begin der zijranden, met regthoekige, weinig uitpuilende achterhoeken, is vrij bol, overal sterk met vrij diepe putjes bezet, behalve op eene onregelmatig breede ivoorwitte middellijn. Het schildje groot, met paarsen gloed aan de spits, fijner gestippeld dan het borststuk en in het midden met flaanwe dwars. rimpels; er is slechts zeer weinig witte marmering op te zien. De dokschilden daarentegen hebben vrij veel wit op het corium en den zeer smallen clavus; de membraan is donker rookkleurig 
met metaalachtigen gloed. De vleugels zijn vuilwit met iets donkerder aderen. Onder de vlengels is het achterlijf groenachtig zwart. Aan de onderzijde zijn meestal eene strook over het midden van kop en thorax, steeds het midden van den buik, het eerste lid van den zuiger en een band om alle scheenen geelachtig wit; al het overige is bronsklenrig. De voorste scheenen dragen digt bij het einde een fijn stekeltje.

De heer van Medenbach de Rooij ving in de maand April bij Arnhem een mannetje van deze soort; een wijfje werd door Mr. F. Leesberg te Scheveningen gevangen, in welke maand bleef mij onbekend. Ook ving de heer La Fontijn een voor werp dezer soort op het eiland Walcheren. Op 's lijks Museum staat sedert twintig jaren een exemplaar zonder etiquette van habitat, dat door de speld en de wijze van opzetten cen' inlandschen oorsprong schịnt te verraden.

\section{Asopus dumosus $\mathrm{L}$.}

Plaat 1, fig. 9.

Linn. S. N. I. 2. 721. 46. - Fabr. S. Rh. 168. 71. - Panz. Fn. Germ. 33. f. 18. - Hahn, W. Ins. I. 101. tab. 16. f. 54 et 55. Burm. Handb. II. p. 378 .

Lengte 12 of $13 \mathrm{~mm}$. Ligt herkenbaar an de afgeronde schouders en de oranje ringen om de scheenen. Het ligchaam bijna tweemaal zoo lang als breed. Kop zwart bronskleurig, fijn gestippeld met tamelijk breede bruin- of roodgele langsstreep. Oogen donkergrauw. Sprieten zwart, de vier laatste leden schier even lang. Zuiger zwart of bruin met roodachtige bovenlip. Prothorax lederkleurig geel of met een rooden tint; de voorhelft zwarl, met randen en middenstreep van de grondkleur, de achterhelft met verspreide zwarte putjes. Schildje geheel met fijne stippels bedekt, behalve drie vlekken aan de basis, waarvan de middelste dikwijls zich tot cene streep verlengt. Bovenvleugels gestippeld als het achildje; membraan als berookt. Bovenzijde van het abdomen groenachtig zwart. Onderzijde van het lijf zwart; zijranden van het borststuk en rau 
de buik, doch aldaar smaller, geel of rood. Pooten zwart, om de scheenen een gele of roode ring, die aan de voorscheenen soms uitblijft. Voorste dijen met stekel aan de onderzijde, niet ver van de knie, voorscheenen met een scherp haakje aan de binnenzijde. De buik ongewapend.

Deze soort werd in eenige exemplaren door den heer de Graaf en mij op de duinen van Holland gevangen, door den heer Six in Junij te Driebergen en op Walcheren door den heer La Fontijn. Zij schijnt evenwel zeldzaam.

\section{Asopus luridus F.}

Plaat 1 , fig. 10.

Fabr. S. Rh. 157. 6. - Panz. Fn. G. 92. f. 9. - Wolit, lc. Cim. 130. tab. 13. f. 130. - Hahn, W. Ins. I. 97. t. 15. f. 53. - Burm. Handb. II. 379. - Flor, Rh. Livl. I. p. 95. - Douglas and Scott, Brit. Hem. p. 94. Pl. 3, fig. 6 .

Lengte 10-12 mm. Herkenbaar aan den buiksteliel en het oranje vileinde nan hel $4^{\text {e }}$ lid der sprieten. Grondkleur ledergeel, doch aan de bovenzijde met zulk eene menigte zwarte ingedrukte putjes gestippeld dat die zijde bruin schijnt, soms eene grvene bronskleur op den kop en aan de zijden van den thorax, die ook wel vaal zwart zijn. Sprieten zwart, behalve het $1^{\mathrm{e}}$ lid aan de binnenzijde eu de spitshelft van het $4^{\mathrm{e}}$ die oranjekleurig zijn, het $2^{\circ}$ tweemaal zoo lang als het $3^{\text {e }}$. Het begin der zijranden van het borststuk met witte zaagpunten voorzien, de achterhoeken breed, rond en sterk uitstekend, zeer fijn gerimpeld. Aan de basis van het schildje somwijlen 2 of 3 witte of gele vlekjes. De membraan roodkleurig met 2 bruine vlekjes, een aan den ondernaadhoek, een aan de spits. Het abdomen aan de bovenzijde glanzig koolzwart, de rand doffer zwart met oranje bandjes in het midden der ringen. De onderzijde van lijf lichtgeel met verspreide zwarte stipjes; aan wederzijde op den buik eene rij van 4 grootere stippen, 2 dergelijken aan den rand op ieder segment, eene zwarte vlek op segment 6 in het midden en 2 kleineren aan wederzijde tegen den anus. Het $2^{\mathrm{e}}$ segment draagt 
in het midden een doorntje, dat naar voren tusschen de achterheupen uitsteekt. De pooten zijn geel met zwarte stippen; het laatste lid der tarsen is zwart; de voordijen rijn ongewa pend, maar de voorscheenen hebben een haakje aan de binnenzijde.

Deze soort schijnt niet zeer zeldzaam. In Holland werd zij door mij gevonden bij Wassenaar en in Mei herhaalde malen in het Haagsehe bosch. Bij Loosduinen vond haar Dr. van Ilasselt, bij Breda Mr. Leesberg, bij Varsseveld de heer G. J. Nibbelink. In Sept. werd zij in een tuin te Driebergen gevonden (Six). De heer Albarda trof haar aan te Huisum, van Walchren in Gelderland. Een voorwerp dat ik te Brummen bemagtigde, heeft den linkerspriet uit 4 leden bestaande, waarvan het $2^{e}$ en het $4^{e}$ bijzonder lang zijn, waaruit naar mijne meening blijkt, dat het $5^{\mathrm{e}}$ voor de laatste vervelling is afgebroken.

\section{Asopus Custos F.}

Fabr. S. Rh. 157. 7. - Hahn, W. Ins. I. tab. 15. fig. 52. - Burm. Handb. II. p. 379. no. 5. - H. Schaeff. Fauna Germ. 114. f. 9- Wolfr, Ic. Cim. tab. 14. f. 131. - Flor, Rh. Livl. I. 94.

Lengte $10 \mathrm{~mm}$. Versebilt van den vorigen door het gemis van den builistekel en door de gele kleur der sprieten. Geelachtig rood of grauw, aan de bovenzijde met ontelbaar vele lichtbruine of bruine stipjes. Kop en borststuk zonder bronskleur. Oogen van de kleur van den kop. Sprieten rood of geel met een zwart ringetje om het $3^{\text {e }}$, soms ook om het $4^{e}$ lid. Zuiger rood of geel. Membraan zonder vlekken. hand van het achterlijf boven en onder met 2 zwarte vlekjes op iederen ring. Eene rij van 3 zwarte stippen aan jedere zijde van de borst en eene van 4 aan iedere zijde van den buik. De pooten schier niet gestippeld; de voordijen ongedoornd, de voorscheenen met een baakje aan de binnenzijde.

Door de heeren de Graaf en Herklots bij Wassenaar in Oct. gevonden, door mij op de Gliphoeve bij Heemstede en in Augustus op Sterkenburg bij Driebergen, door een' mijner zonen 
te Naaldwijk, door den heer Six op de heide te Dricbergen in Aug., door van Walchren en van Bemmelen te Brummen, en door Mr. W. Albarda in Angustus aan het Ginueken bij Breda.

\section{Asopus bidens L.}

Plaat 1, fig. 11.

Linn. S. N. I. 718. 23. - Fabr. S. Rh. 155. 2. - Panz. F. Germ. 26. f. 22. - Wolff, Ic. Cim. tab. 1. f. 7. - Hahn, W. Ins. I. 92. tab. 15. f. 51. - Burm. Handb. I. 379. nº. 6. - Am. et Serv. Hèm. 1. 84. Flor, Rh. Livl. I. p. 93. - Douglas and Scott, Brit. Hem. p. 96. Pl. 3. fig. 7.

Lengte 10-12 mm. Herkenbaar aan de scherp doornachig uitsteckende acherhocken van den thorax. Boven grauw of bruin met tallooze kleine stippen, onder roodachtig. Kop nog al lang, voolwaarts gestrekt met een stomp puntje tusschen oogen en sprieten. Deze lichtrood; hun $1^{\mathrm{e}}$ lid vrij kort, het $2^{\mathrm{e}}$ iets langer dan het $3^{e}$. Prothorax vrij breed; het begin van den zijiand ter wederzijde gekerfd; de achterhoeken in een scherpen, donkergekleurden doorn uitstekend, die an de achterzijde nog een tandje vertoont; achterrandshoeken met een plat, geel puntje. Het schildje dikwijls met 2 kleine gele bolle plekjes aan de basis en steeds met een' ongestippelden gelen achterrand. Vleugelvlies bruin met gelen gloed. Uitstekende rand van het abdomen met zwarte en donkerbruine vlekken afwisselend. Aan de onderzijde eenige vlekjes en de dikke zoomen van de stankspleet rood of oranje. Pooten rood met vrij bruine knieën. Voordijen met een stekel en voorscheenen met een haakje.

Bidens schijnt niet zeer zeldzaam. Ziehier de opgaaf der vindplaatsen: bij Leyden (Herklots); te Noordwijk aan zee (v. Bemmelen); in Oct. op wolwilgen te Noordwijk en Wassenaar, en in September te Katwijk op salır repens (do Graaf): bij den Haag (v. d. Wulp); bij Driebergen (Six); bij Zeist in Sept. (de Graaf); bij Haren in Groningen (de Gavere); op Walcheren (La Fontịn); bịj Arnhem den $17^{\mathrm{cn}}$ Maart, v. Med. de Rooị. 
Gen. 8. Cydnus F.

Ligchaam kort eivormig, onder en boven vrij bol. Kop gewoonlijk iets breeder dan lang, met opstaanden rand der zijlobben, die sterker uitsteken dan de middellob. Oogen slechts weinig naar boven uitpuilend. Sprieten zoo lang als de helft van het ligchaam of korter, naar de spits toe dikker; het '2e en $3^{e}$ lid verschillend van lengte, het $4^{e}$ en $5^{e}$ meestal behaard, dit iets langer dan dat. Zuiger de midden- of achterheupen aanrakend. Prothorax tweemaal, of meer dan dat, breeder dan lang, aan de zijden toeloopend en meestal gezoomd, zonder achterrandshoeken. Het schildje breed driehoekig, aan de spits toegerond, langer dan de helft van het achterlijf, welks rand van boven geheel bedekt is. Membraan breed, met $5-7$ weinig duidelijke, zich onderling door zijtakjes verbindende langsaderen, of wel zonder aderen. Pooten van matige lengte; scheenen zeer overvloedig met slekels bezet.

\section{Tabel der soorlen.}

1. (8) Kop en halsschild aan den rand onbehaard.

2. (5) Tweede lid der sprieten veel korter dan het derde.

3. (4) Zwart met witte vlekken op de deksehilden. bicolor.

4 (3) Zwart met een vuilgeel randje aan de dekschilden. . . . . . . . . albomarginalus.

5. (2) Tweede lid der sprieten nagenoeg even lang als bet derde.

6. (7) Geheel zwart . . . . . . . . morio.

7. (6) Zwart, rand van halsschild en dekschilden, benevens een vlekje op hun midden wit. bigutlalus.

8. (1) Kop en halsschild aan den rand behaard. flavicornis.

\section{Cydnus bicolor L.}

Plaat 2, fig. 1.

Linn. S. N. 722. 55. - Fabr. S. Rh. 176. 109. - Panz. Fn. Germ. 
32. ค. 11. - Wolfr, Ic. Cim. 63. tab. 7. fig. 60. - Schellenb. Cimic. tab. 1. fig. 2. - Hahn, W. I. I. pl. 31. f. 99. - Burm. Handb. II. p. 374. - Flor, Rh. Livl. I. p. 157. - Dougl. and Scott, Brit. Hem. p. 52.

Lengte 7-8 mm., breedte 5. Blinkend zryart met een' blaauwen gloed; voorste gedeelte van de halsschilds-zijiranden met een' witten zoom, eene zeer hoekige en bogtige witte vlek aan de basis van het corium, cene andere kleinere an de tip daarvan; membraan wit of vuilwit. Het geheele lijf fijn gestippeld, alleen dwars over den prothorax eene streek van

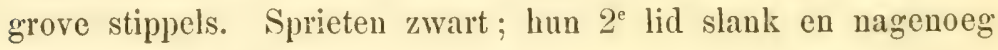
half zoo lang als het $3^{e}$. Pooten zwart met eene witte vlek of streep aan de bovenzijde der scheenen.

Eene vrij gemeene soort in het voorjaar, aangetroffen op lage planten, door de Graaf te Warmond, van der Hoeven en mij bij Leyden, door mij bij Bennebroek en door Six bij Driebergen, in Junij bij Arnhem door v. Med. de Rooij. -- Ook in Aug. aangetroffen bij Katwijk en Arnhem door de Graaf en in Nov. en Dec. bij den Haag door denzelfden. Het schijnt dus wel dat er twee generatien bestaan.

\section{Cydnus albomarginalus $\mathrm{F}$.}

Plaat 2, fig. 2.

Fabr. S. Rh. 197. 121. - Panz. Fn. Germ 33, 20, - Am. et Serv. Hém. p. 97. - Hahn, W. I. I. p. 167. tab. 26. f. 86. - Wolff, Ic. Cim. tab. 7. f. 62. - Burm. Handb. II. p. 375. n". 4. - Flor, Rh. Livl. p. 156. - Dougl. and Scolt, Brit. Hem. p. 56.

Lengte $3,5-4 \mathrm{~mm}$. Zwart met weinig glans, grof en duidelijk gestippeld, vooral dwars over het halsschild in de helft der lengte. Rand van het corium smal bruinachtign wit of geel gezoomd. Nembraan rookkleurig wit. Sprieten bruinachtig of dof zwart; hun $2^{e}$ lid zeer klein. Pooten zwart, tarsen bruin.

Op zandige gronden. Bij ter Heyde (Six), bij Scheveningen (Piaget, van Hasselt en $\mathrm{v}$ Voll.), bij Katwijk in Augustus onder walstroo (de Graaf), bij Brummen (v. Walchren). 


\section{Cydnus morio L.}

Linn. S. N. 2. 722. 51. - Fabr. S. Rh. 184, 3. - Panz. Fn. Germ. 32. f. 15. - Wolff, Ic. Cim. tab. 7. f. 64. - Hahn, W. Ins. I. p. 163. tab. 25. f. 84. - Burm. Handb. II. p. 375. no. 6. - Flor, Rh. Livl. I. p. 159. - Douglas and Scott, Brit. Hem p. 55. PI. 2. f. 1

Lengte $6-7 \mathrm{~mm}$. Zwart, niet blinkend, maar met een rettig uiterlijk, ruw en grof gestippeld, op de voorste belft van het halsschild twee ongestippelde dwarsplekken. Sprieten zoo lang als de helft van het ligchaam, zwart, met het $2^{\text {e }}$ lid rood en nagenoeg even lang als het $3^{e}$. Zuiger lichtbruin, reikende tot aan de middenheupen. Pooten zwart, tarsen licht roodachtig bruin.

Op verschillende gronden aangetroffen. Bij Loosduinen, den Haag, Leyden, Haarlem, Bennebroek, Utrecht, Brummen, Breda enz.

\section{Cydnus biguttatus L.}

Plaat 2, fig. 3.

Linn. S. N. 2. 722. 54. - Fabr. S. Rh. 178, 116. - Panz. Fn. Germ. 32, 13. - Hahn, W. I. I. 169. tab. 26. fig. 88. - Burm. Handb. II. p. 374. no. 3. - Am. et Serv. Hémipt. p. 98. 2. - Flor, Rh. Livl. I. p. 162, no. 6. - Dougl. and Scott, Brit. Hem. 1. 54.

Lengte $6 \mathrm{~mm}$. Zwart; de zijprand van halssehild en dekschilden met een vrij bol wit zoompje en eene kleine hoekige witte vlek op het midden van het corium. Dwars over het midden van het halsschild eene diepe gleuf; prothorax daar en naar de zijden zeer grof gestippeld, schildje en dekschilden fijner. Sprieten zwart, hun $3^{e}$ lid ongeveer $1 \frac{1}{2}$ maal de lengte van het tweede. Membraar berookt. Pooten zwart met bruine tarsen. Een allerfijnst wit zoompje langs den rand van het abdomen.

Deze soort is tamelijk zeldzaam. Behalve dat ik vier inlandsche voorwerpen ken, waarvan ik niet weet te bepalen, waar zij gevonden zijn, kan ik het volgende opgeven. De heer Heylaerts vond er in Januarij een onder boomschors te Breda, in Maart en Junij nog een paar aldaar; bij Arnhem werd de 
soort in Junij aangetroffen door den heer van Medenbach de Rooij en den $8^{\text {en }}$ April op den st. Pieters berg bij Maastricht door den heer Mr. A. H. Maurissen.

5. Cydnus flavicornis $\mathrm{F}$.

Plaat 2, fig. 4.

Fabr. S. Rh. 184. 2. - Panz. Fn. Germ. 33. 1. 23. - Wolfr. Ic. Cim. tab. 7. fig. 63 a. b. - Hahn, W. I. I. p. 165. tab. 25. f. 85.

Lengte bijna $4 \mathrm{~mm}$. Donkerbruin of zwart met roodbruine randen en dekschilden. Deze soort is in evenredigheid iets breeder aan den kop en het voorste gedeelte ran den prothorax dan de andere soorten. De rand van kop, thorax en voorhelft van het abdomen met roode borstelachtige haren bezet. Het lijf spaarzaam gestippeld, het sterkst dwars over den prothorax, ongeveer in de helft. Sprieten kort, rood, de twee laatste leedjes vaal zwart, behaard. Zuiger helder bruinrood. Membraan dof wit. Pooten bruinrood met roode tarsen.

Niet zeldzaam in September op de duinen. Gevonden bij Scheveningen, Wassenaar, Katwijk en de Vogelenzang. Den $20^{\text {en }}$ April ving de heer van Medenbach de Rooij bij Arnhem een voorwerp dat veel grooter is dan die van de duinen gewoonlijk zijn.

Ik veronderstel dat het deze soort is, die in Mr. E. Saunders' Synopsis of British Ilemiptera-Leteroptera ('Transact. of the Lintom. Society of London 1875) voorlsomt onder den uaam van Geolomus punclulatus Costa.

\section{Gen. 9. Scioconis Fall.}

Ligchaam plat aan de boven-, een weinig bol aan de onderzijde. Kop zeer groot en breed, toegerond driehoekig, met de middellob korter dan de zijlobben '). Oogen lamelijk groot en

1) Dit is in onze figuur niet juist uitgedrukt. 
vrij sterk uitpuilend; ocellen duidelijk, de afstand tusschen hen tweemaal grooter dan van een enkelvoudig tot een zamengesteld oog. Sprieten korter dan de helft van het ligchaam; lid 1 zeer kort, 3 iets langer dan 2, 4 en 5 aan elkaar gelijk. Zuiger tot aan de basis van het achterlijf reikend. Prothorax meer dan 2 maal zoo breed als lang, met alle hocken afgerond, en vooral de achterrandshoeken stomp; schildje breed, aan het eind toegerond, reikende tot aan den $5^{\text {en }}$ achterlijfsring. Dekschilden aan de basis vrij ver buiten het abdomen uitstekend, met het corium niet langer dan het schildje en de membraan met 4 of 5 bijna onzigtbare aderen. Pooten kort, vrij gedrongen; dijen zonder doornen, scheenen met eene menigte zeer korte stekeltjes; tarsen van drie leedjes, het middelste zeer kort. Buitenrand van het abdomen ver vitstekend buiten de membraan der vleugels.

Sciocoris umbrimus Wolff.

Plaat 1, fig. 12.

Wolf, Ic. Cim. p. 142. tab. 14. f. 136. - Fallen, Hem. I. p. 21. 1.Fabr. S. Rh. 111.8 (volgens Boheman). - Burm. Handb. II. p. 373. 5. Hahn, W. Ins. I. p. 195. tab. 31. f. 100. - Panz. Fn. Germ. 93. f.15.Flor, Rh. Livl. I. p. 111. - Am. et Serv. Hém. p. 120. - Douglas and Scott, Brit. Hem. p. 62. Pl. 2, fig. 4.

Lengte 5-6 mm. Zandkleur, dat is eenigzins roodachtig grijs. Het geheele ligchaam vrij sterk gestippeld, zoo dat er donkere langslijnen sehijnen te bestaan op kop en borststuk. Oogen vaalzwart. Sprieten geelachtig aan de basis, grauw van de spits van het $3^{\text {e }}$ lid tot den tip. Zuiger geelachtig. Buitenrand van prothorax en dekschilden zeer licht van kleur en ongestippeld. De basis van het schild wisselt af met bruine en witte vlekjes, in de lengte is het midden weinig restippeld. Membraan geheel doorschijnend. Buitenrand ran het abdomen met twee donkere vlekjes aan den rand van iederen ring, een boven, een onder. Onderzijde van den thorax met bruine vrij breede langrsstreep aan wederzijde onder den rand. Tweede segment van het achterlijf met eene zwarte dwarsstreep op het 
midden, van welker uiteinden twee langsstrepen afdalen op segment 3,4 en 5 ; het 6 e segment met eene vrij groote zwarte vlek in het midden. Voorts aan iedere zijde van den buik eene vrij breede grauwe langsstreep, in welke de gele stigmata, en aan den achterrand van elk segment een bruin vlekje. Pooten vaalgeel met bruinachtige tarsen.

Op duingronden in Junij en Julij niet zeer zeldzaam; ook bij Breda op heigrond in Maart aangetroffen door den heer Heylaerts.

Gen. 10. Aelia F.

Ligchaam vrij langwerpig, tamelijk bol aan de boven, meer nog aan de onderzijde. Kop vrịj groot, nog al - of zeer sterk naar beneden gebogen, zweemende naar dien van sommige Curculionen; de middellob veel korter dan de zijlobben. Sprieten iets korter dan de helft van het lijf, slank met de 2 laatste leden dikker; het $1^{\circ}$ lid kort, het $2^{e}$ dan eens langer dan eens korter dan het $3^{\text {e }}$, het $5^{\text {e }}$ het langste van allen. Oogen klein en best van ter zijde te zien; bijoogjes zeer ver van elkander staande. Zuiger tot aan het abdomen reikend. Prothorax tweemaal breeder dan lang, naar voren smaller toeloopend, vrij bol digt bij den achterrand, met weinig uitstekende achterhocken. De voorrand der borst an de onderzijde in twee platen verlengd, die als kragen de keel en de inplanting der sprieten kunnen beschutten. Schildje langwerpig driehoekig met afge. ronde spits, ongeveer zoo lang als $\frac{2}{3}$ val het abdomen. Corium der dekschilden zeer scheef afgesneden; membraan zoo lang als of iets langer dan het achterlijf. Pooten middelmatig; tarsen van 3 leedjes, waarvan het $2^{\mathrm{e}}$ zeer klein.

\section{Tabel der soorlen.}

Kop weinig neergebogen (fig. 5a). . . . acuminata. Kop iets meer neergebogen (fig. 6).

a. Zonder vlekjes aan de onderzijde der dijen, doch met eene zwarte langsstreep op het corium. Klugii. 
b. Met vlekjes aan de onderzijde der dijen en zonder zwarte langsstreep op het corium . pallida. Kop sterk neergebogen (fig. 7a) . . . . inflexa.

\section{Aelia acuminata $\mathrm{L}$.}

Plaat 2 , fig. 5 en $5 a$.

Linn. S. N. 2. 723, 59. - Fabr. S. Rh. 189, 6. - Panz. Fn. Germ. 32. f. 17. - Curt. Brit. Ent. XV. t. 704. - Burm. Handb. II. p. 366. no. 8. - Hahn, W. Ins. I. p. 120. tab. 19, f. 63.

Lengte 8-9 mm. Sterk gestippeld, lederkleurig geel met zwarte langsstrepen. Kop weinig neergebogen, op zijde tweemaal flaaw gegolfd. Halsschild met zeer stomp haakvormige achterhoeken. Op den kop eene gestippelde fijne gele langsstreep, beginnende bij de spits der middellob; deze zet zich ongestippeld en ietwat bol verheven voort over het midden van den prothorax tot op het schild, waar zij langzamerhand smaller wordt en eindelijk voor de spits verdwijnt. Daarnaast ter wederzijde eene zwartachtige streep, eigenlijk bestaande uit ingedrukte zwarte stippen, zijnde het breedst even voor den achterrand van het schild. Aan den zijrand van den kop ter wederzijde eene zwarte streep, die zich achter het $00 \mathrm{~g}$ naast het gele boord van het halsschild breeder wordende roortzet. Aan de hoeken van het schildje zwarte streepjes. Dekschilden met zwarte stipjes bezet, behalve de zijrand en de aderen; membraan doorschijnend met eenige bruine aderen. Drie ecrste leden der sprieten geel, de twee laatste paars-bruin; het $2^{\mathrm{e}}$ niet veel langer dan de helft van het $3^{e}$. Pooten geel met zeer fijne zwarte stipjes. Ter wederzijde van de borst vier zwarte stippen; de stigmata van het abdomen zwart.

Bij Leyden gevangen door Prof. van der Hoeven, in Limburg door Mr. A. H. Maurissen.

\section{Aelia Klugii L.}

Plaat 2, fig. 6.

Illahn, W. Ins. I. 1) 122. tab. 19. f. 64. - Küster, Stett. Ent. Zeit. XiII (1852), p. 396. $n^{n}, 5$. - Flor, Rh. Livl. I. p. 119. 
Lengte $6-8 \mathrm{~mm}$. Kleiner dan de vorige en daarvan duidelijk onderseheiden: de kop veel meer gebogen, aan den zijrand minder gegolfd, doch aan de spits als ingeknepen. De grondkleur donkerder of rooder geel, waarop vrij sterk, als lichtgeel uitkomen de middelstreep, de zoomen van het halssehild en cene scheeve streep op de dekschilden, aan de binnenzijde tegen eene zwarte streep aanliggende. Voorts is het zwart op het schild scherper en minder breed en vertoont de buik meestal zes zwartachtige vegen in de lengte.

Iets gemeener dan de vorige. Bij de Bildt op heidegrond gevangen door G. Six, bij Noordwijkerhout in Junij door de Graaf, bij den Haag door van der Wulp; an de Bildt in Julij door Dr. Everts, op den zandweg naar Wassenaar in Julij door mij.

\section{Aelia pallida Küst.}

Plaat 21, fig. 1 en $1 a$.

Küster, Stett. Entom. Zeit. XIII (1852) p. 394, taf. III, f. 4.-Flor, Rh. Lirl. 1, P. |2l.

Lengte $8 \mathrm{~mm}$. Kenmerkend roor deze soort zijn de beide vlelijes aan de ondersijde der dijen en de afwezigheid van eene zwarte langsstreep op het corium, welke laatste bij Klugii steeds anwezig is. Het geheele dier is ledergeel met donkerbruine gestippelde versieringen. Het lijf is naar gelang der lengte breeder dan bij Klugii en minder glanzig. De kop is minder sterk gebogen. Op de bovenzijde is de teekening van kop en borststuk nagenoeg dezelfde; de sprieten schijnen mij toe iets langer te zijn. Het schildje is breeder en heeft ter wederijde van de lichte middelstreep 4 langrsstrepen, uit bruine putjes bestaande, waarvan de uiterste geheel tegen den zijrand aansluit en even als de daarop naa binnen volgende zeer kort is, terwijl de beide anderen bijna reeds aan den wortel ineengevloeid, vereenigd tot an de spits doorloopen. Het corium is grof gestipueld, doch zonder teekening. Aan de onderzijde zijn de pooten met bruine stippen bespikkeld en de dijen vertonnen elk twee bruine rlekjes, nit grove stippels bestaande en schuin naast elkander geplaatst (zie fig. 1a). 
Deze soort werd door den heer de Gavere te Diever in Drente angetroffen, door den heer van Medenbach de Rooy den $16^{\text {en }}$ Sept. bij Arnhem en dour mij 15 Junij bij Velzen.

\section{Aelia inflexa Wolff.}

Plaat 2, fig. 7a.

Wolff, Ic. Cim. p. 188. tab. 18. f. 182. - IJahn, W. Ins. II. 129. tab. 69. f. 210.. - Am. et Serv. Hém. p. 134. n ${ }^{0}$ 2. - Flor, Rh. Livl. I. p. 124. - Douglas and Scott, Brit. Hem. p. 71. Pl. 2, f. 7.

Lengte 5,5-6 mm. Korter, maar vooral meer gedrongen van statuur dan de vorige. Donkerbruin met zwarte stipjes bedekt, met eenigzins lichter gekleurde dekschilden. Kop zeer krom naar beneden gebogen, bijna zwart; de insnijdingen naast de middellob zeer diep. Oogen eenigzins nitpuilend, vrij licht bruin. Sprieten bruingeel, de 2 laatste leden nagenoeg zwart; het $3^{\text {e }}$ lid iets kleiner dan het $2^{e}$. Zijranden van het borststuk zeer smal beenwit gezoomd, aan den voorhoek een zeer klein puntje. Over het midden van borststuk en schildje eene zeer smalle gele streep. Een kort geel streepje ter wederzijde an de basaalhoeken van het schild. Membraan wit met een bruinen glans. Abdomen zwart met fijnen geelachtig witten zoom. Pooten lichtrood met zwarte langsstrepen over de dijen.

Een enkel voorwerp in Junij bij den Haag (v. Voll.), een ander aldaar (Six); twee in Noord-Brabant (v. Eyndh.).

\section{Gen. 11. Eusarcoris Hahn.}

Ligchaam kort, gedrongen, breed in de schouders, boven en onder vrij bol, beneden eene denkbeeldige regte lijn loopende van den ecuen achterhoek van den thorax naar den anderen plotseling en sterk naar beneden gebogen. Kop bijna verticaal geplaatst, bol op het aangezig.t, met den middellob doorloopende en tot het einde even breed. Oogen vrij groot, ovaal, doch ocellen moeijelijk te onderscheiden. Zuiger tot de achterpooten 
reikende. Sprieten schraal en niet vecl langer dan het halve ligehaa In, de drie eerste leden slank, het $2^{e}$ iets langer dan elk der anderen, het vierde aan de basis zeer slank, doch voorbij de helft dikker dan de vorigen, aan de spits afgerond, zon lang als het tweede; het vijffle het langste van allen, spoelvormig, aan de basis zeer slank. Prothorax tusschen de schouders tivecmaal zoo breed als aan den voorrand, aldaar zeer bol en naar den achterrand weder iets afloopende. Schildje breed aan de basis, zoo lang als aldaar breed, afgerond aan het einde. Dekschilden vrij kort met geslingerden achterrand van het corium; membraan met 4 langsaderen. Buik zeer bol. Pooten matig lang en gezet.

\section{Eusarcoris perlata $\mathrm{F}$.}

Fabr. S. Rh. 187, 15. - Fall. Mon. Cim. Suec. 50, 18. - Wolf, Ic. Cim. 68, tab. 7. f. 65. - Panz. Fn. Germ. 113, 7. - Ilahn, W. Ins. 1I. p. 67. tab.51. f. 155. - Douglas and Scott, Brit. Hem. p. 76 (Acneus).

Lengte $5 \mathrm{~mm}$. Op de bovenzijde licht bruinachtig geel, zeer glanzig, grof en vrij diep bestippeld. De kop koperachtig bruin met groenen weerschijn; van de sprieten zijn de drie cerste leden geel met een bruin streepje ran onder, de beide laatsten zwart De zuiger is geel met bruine spits. Het borststuk is op bet midden ran den voorrand en op de zijranden gezoomd met cen glad verheven geel boordsel; tegen den voorrand aan ziet men twee langwerpige sterk gepuncteerde goudbruine vlekken en daarboven eenige gladde gele plooijen. Het schildje vertoont aan zijne basaalhneken twee ovale verhe. vene gladde, zeer licht gele plekken, waaraan de suortsnaam ontleend is, en bovendien op den rand van het ronde einddeel drie kleine zwarte vlekjes. De mombraan is bruinachtig, donkerderder dan het corium der deksehilden. De borst is iets donkerder bruin dan de bovenzijde en nog sterker gestippeld; de buik glanzig bronskleur in het midden en aan de zijden geel met zwarte stippels en zwarte randen der stigmata. De pooten zijn lichtgeel met zwarte stippeltjes en een onvolmaakt 
zwart bandje om de dijen; de twee laatste leden der tarsen bruinzwart.

Het eenige mij bekende inlandsche voorwerp werd door den heer Heylaerts den $2^{\text {en }}$ Mei in de omstreken van Breda op heide gevangen.

\section{Gen, 12. Tropicoris Hahn.}

Ligchaam in omtrek wapensehildvormig, tamelijk bol op het midden van den thorax en het schildje en evenzeer aan de buikzijde. Kop plat, iets langer dan breed, rond van voren met de middenlob iets korter dan de zijdelingsche lobben. Oogen vrij groot en ocellen duidelijk. Sprieten zoo lang als

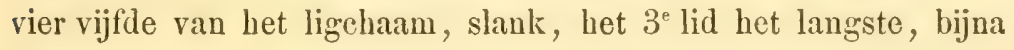
tweemaal zoo lang als het $2^{\mathrm{e}}$; zuiger reikende tot op het $3^{\text {e }}$

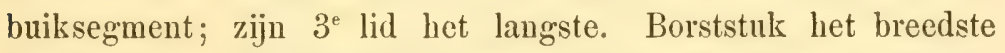
gedeelte van het ligchaam, doordien de achterhoeken vleugelvormig naar op zijde verlengd zijn; zij zijn opgewipt en eindigen in een tamelijk scherp puntje; de voorrand is S-vormig gebogen; de achterrandhoeken zijn zeer stomp en de achterrand loopt regt. Het schildje groot, reikende tot ver op het achterlijf, driehoekig met de zijde wat gebogen en de spits atgerond. De rand van het abdomen steekt op zijde buiten de dekschilden uit; deze zijn als bij het volgende geslacht. De tweede ring van den buik vertoont een naar voren gerigt doorntje of knobbeltje, 't geen soms, door de heupen bedekt, moeijelijk tc onderscheiden is. De pooten zijn lang; hunne scheenen zijn aan de buitenzijde gegleufd en hunne tarsen hebben drie leedjes.

Van dit geslacht is slechts eene soort inlandsch:

\section{Tropic. rufipes L.}

Plaat 2, fig. 8.

Linn. S. N. 2. 719. 24. - Fabr. S. Rh. 156. 5 - Wolff, Ic. Cim. tab. 1. f. 9. - Hahn, W. Ins. II, p. 54, tab. 47, f. 145. - Burm. Handb. 1I. 366, no. 7. - Am. et Serv. Hém. 1. 149. 1. - Panz. Fn. Germ. 113, f. 11. - Schellenb. Cimic. tab. 1. f. 3. - Flor, Rh. Livl. 1. 107. Douglas and Scott, Brit, Hem. 1. 98. Pl. 3. f. 8. 
Lengte $12-15 \mathrm{~mm}$., grootste breedte 9. Aan de bovenzijde roodbruin, min of meer metaalachtig, sterk gestippeld; aan de onderzijde brningeel. Kop van voren roud toeloopend; de zijlobben gebogen en de middellob naar het eind smaller uitioopend. Sprieten stank, rood; $1^{\text {e }}$ lid het kleinst, $2^{\text {e }}$ iets grooter,

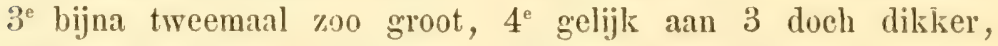
zwartachtig met roode basis, aan de inplanting met een zeer klein 1usschenvoegsel, $5^{\text {e }}$ korter dan 4, geheel zwart. Oogen bruin, nict bol uitpuilend; ocellen rood. Prothorax zeer breed met den voorhoek eenigermate gedoornd, de zijrand eerst ingebogen, min of meer gekartcld, daarna sterk naar buiten gebogen en naar boven gerigt tot aan den achterhock, die scherp puntig uitsteekt, van daar naar den achterrandshoek weder gegolfd. Spits van het schildje bijna zonder ingedrukte puntjes en dojergeel. Nembrain taankleurig met 6 langsaderen. Zuiger eerst geel, dan rood, eindelijk zwart, reikende tot op het midden van het derde segment. Aan wederzijde van de borst twee doffe bloedkleurige vlekken; in de grootste daarvan de geurspleet, die zeer klein is. De $2^{\mathrm{e}}$ ring van het achterlijf met een' stompen doorn tusschen de heupen der achterpooten nitstekende. Insnijdingen van het achterlijf, stigmata en dwarsstreepjes daaronder donkerbruin. Pooten lang, geelachtig rood met zwarte stippen.

Vrij gemeen op boomen en schuttingen. Aangetroffen in de provincien Holland (N. en Z.), Utrecht, Gelderland, Groningen, Noord-Brabant en Limburg; stellig door het geheele Rijk voorkomende.

Gen. 13. Cinex Fall.

Ligchaam aan beide zijden tamelijk bol, in rorm gelijkende op dat ran Asopus, doch van dit genus duidelijk door den slanken, gedeeltelijk in cene borstslenf verborgen zuiger verschillend. Kop aan de bovenzijde plat, vierkantig met toegeronde hoeken; van de drie lobben de middelste iets kleiner, doch de zijlobben meestal geseheiden houdende. Oogen groot 
of middelmatig; ocellen duidelijk. Sprieten zoo lang als of iets korter dan de helft van het lijf; het $2^{e}$ lid iets langer of korter dan het 3 . Zuiger ongelijk van lengte, gewoonlijk reikende tot over de achterheupen. Pruthorax somwijlen met eenigzins (bij cene soort sterk) nitstekende achterhoeken. Schildje driehoekig, voor de punt aan de zijden naar binnen gegolfd, de punt zelf afgerond. Leder der dekschilden veel verder uitstokend dan de spits van het schild; hunne membraan voorbij het achterlijf reikend met 7--9 aderen. Van dit laatste is gewoonlijk een smal randje op zijde buiten de vleugels zigtbaar. De pooten zijn vrij lang en krachtig; de tarsen hebben drie leedjes. Bij eene soort is de $2^{\text {e }}$ ring van het achterlijf gedoornd.

\section{Tabel der soorlen.}

1. (10) Kop langer dan breed of even lang als breed.

2. (3) Tweede ring van het achterlijf met een naar voren gerigten doorn. . . . . Liluralus.

3. (2) Tweede ring van het achterlijf zonder' doorn.

4. (7) Bovenzijde groen of olijfgroen.

5. (6) Zuiger reikende tot de basis van het achterlijf Prasinus.

6. (5) Zuiger reikende tot den derden ring van het achterlijf . . . . . . . Pinicola.

7. (4) Bovenzijde paarsachtig grauw of lederkleurig.

8. (9) Paarsachtig grauw. Sprieten zwart en wit geringeld . . . . . . . . Baccarum.

9. (8) Ledergeel. Sprieten zwart . . . . Nigricornis. 10. (1) Kop veel breeder dan lang . . . Oleraceus.

\section{Cimex lituratus Klug. Plaat 2, fig. 9 en $9 a$.}

Burm. Handb. II. 365. nn. 3. - Ilahn, W. Ins. II. 62. tab. 49, f. 151 (purpuripennis). - Douglas and Scoll, Brit. Hem. p. 100. Pl. 3. lig. 9 (Pieะodorus purpureipennis).

Lengte 10-12 mm. Herkenbaar aan den langen doorn tusschen de achterpooten. Aau de bovenzijde vaal olijfgroen, soms 
met rood gemeugd op borststuk en dekschilden, altijd met zwart gestippeld; onderzijde vuilgeel. Oogen lichtgroen of liehtbruin; ocellen geel. Sprieten rood; de beide laatste leedjes soms bruin; lid 2, 3, 4 bijna even lang. Zijrand van thorax en bovenvlengels met een smal geelachtig wit zoompje. De van boven zigtbare rand vau het abdomen geel of roodgeel, aan de niterste punten doornachtig. Spits van het schild gelijk van kleur met het overige. Stigmata van den buik groot, rond, zwart. Pooten geel met roode of bruingele tarsen. De doorn van het achterlijf steekt uit tot voorbij de middelheupen.

Bij Utrecht gevangen door de heeren van Hasselt en Six; bij Breda in Mei en Junij tegen ijpenstammen door Heylaerts. Op berken en brem in September en October bij Wassenaar en Noordwijk de type en de var. (met roode dekschilden) de Graaf. De fraaije verscheidenheid ook door mij gerangen in Augustus 1866 bij Wordt-Rhede in Gelderland op gaspeldoorn (Ulex: Europacus). Op dezelfde plantsoort, doch groeijende op de Meerdervoortsche duinen bij 's Gravenhage, werd Liluralus in April wedergevonden door Mr. H. W. de Graaf. Van den heer La Fontijn ontving ik uit Walcheren een fraai bauiurood exemplaar met rozenrooden zoom.

\section{Cimex prasinus $\mathrm{L}$. \\ Plaat 2, fig. 10.}

Linn. S. N. 2. 722, 49. - Fabr. S. Rh. 166, 58 et 167, 59 (dissimilis). - Panz. Fn. Germ. 33. ศ. 15. - Hahn, W. Ins. II. 1. 60. tab. 49, f. 149. - Woltf. Ic. Cim. tab. 6. f. 49 et 50. - Burm. Handb. II. 370. n'. 17 (dissimilis). - Flor, Rh. Livl. I. p. 130. - Douglas and Scott, Brit. Hem. p. 83. Pl. 3, fig. 1 (Pentatoma dissimile).

Lengte 11--13 mm. Buik ongedoornd. Van boven grasgroen, sterk gestippeld, van onderen geelachtig groen of oranjeachtig. De zijlobben krom naar elkander gebogen en elkaîr voor de middellob somtijds aanrakende. Oogen lichtgrauw of grijs; ocellen greel. Sprieten van vorm nagenoeg als bij de vorige soort, doch het $2^{e}$ lid iets langer; lid $1-3$ groenachtig geel, 
4 rood, 5 rood aan de basis, verder bruin. De sprieten zijn ingeplant op een hoekig voetstuk. Zuiger groen of groengeel, reikende tot de basis van het achterlijf. Zoom van den zijrand van thorax en dekschilden groen (Prasimus) of roodachtig geel (Dissimilis). Schildje met een zweem van geel aan de spits. Voorhoeken van den thorax soms met een fijn stekeltje, achterhoeken nooit veel uitstekend, altijd stomp toegerond. Membraan rookkleurig met 5 uit eene basaal-cel ontspringende en soms zich vertakkende aderen. Zijrand van het abdomen, van boven zigtbaar, of groen, of olijfbruin met roode randen. De middelen achterborst aan de zijden rondgevlekt; de punt van den zoom der geursplect zwart. Stigmata soms met bruine randen. Pooten groen met roode of lichtbruine tarsen; de midden- en achterdijen hebben dıkwijls aan hun' voorkant een zwart stipje even voorbij de helft.

De beide varieteiten gemeen, gevangen in Junij, Julij, Augustus te Leyden, Bleiswijk, Warmond, Sassenheim, Utrecht, Driebergen, Renkum, Oosterbeek, Rhede, Varseveld, het Ginneken en Groningen; in Augustus op wilgen te Breda.

\section{Cimex pinicola Muls.}

Plaat 21, fiğ. 2 en $2 a$.

Flor, Rhynch. Livl. I, 133 var. Longirostris en II p. 578. - Mulsant. Ann. Soc. Linn. 1852, 1. 89 ').

Lengte $11 \mathrm{~mm}$. Breeder dan de meeste naverwante soorten, bronskleurig, dadelijk herkenbaar aan de bijzondere lengte van den zuiger, die tot aan den derden ring van het abdomen reikt. De middellob van den kop is bijna even lang als de zijlobben. De sprieten zijn zwart, alleen het eerste lid heeft op de bovenzijle eene onduidelijke gele vlek. De zijranden van den prothorax zijn tot aan de schouders geel en de spits van het schildje is van dezelfde kleur. Het corium der dek-

1) Je beschrijving van Mulsant is mij onbekeud; ik neem op verzekering van Flor aan dat deze soort M.'s Pinicola is. Het is jammer dat Mulsant niet gewacht heeft met zijne beschrijving, want Flor's benaming (Longirostris) is wel zoo goed. 
schilden is taankleurig bruin, de membraan berookt met eene donkerder vlek aan den bimnenhock; de vleugels zijn zeer licht grijs met zwarte aderen en de bovenzijde van het abdomen is zwart. De buitenrand van het connexivum is met langwerpige gele vlekjes versierd. De pooten zijn vuil olijfgroen met donkerder tarsen.

Van deze merkwaardige soort ving de heer van Medenbach de Rooij bij Arnhem een vrouwelijk exemplaar; volgens Flor leeft de soort op Juniperus.

\section{Cimex Baccarum L.}

Plaat 2, fig. 11.

Linn. S. N. 2. 721. 45. - Fabr. S. Rh. 172. 92. - Panz. Fn. Germ. 33, 20. - Flor, Rh. Livl. I. p. 137. - Donglas and Scott, Brit. Hem. p. 80. - En vele andere schrijvers.

Lengte 9-11 mm. Zoo algemeen bekend, dat eene nitvoerige beschrijving overbodig is. Herkenbaar aan den ongedoornden buik, de vrij stompe schouders en de kleur, vooral die der sprieten. Bovenzijde grauw met zwarte stipjes, corium gewoonlijk paarsachtig van tint, eind van het schildje geel, zoom van het achterlijf zwart en lichtgeel geblokt. Onderzijde vaalgeel, op den buik met vrij groote zwarte stippen. Eerste lid der sprieten vaalgeel, $2^{e}, 3^{e}, 4^{e}$ zwart met vaalgele basis en spits, $5^{\text {e }}$ zwart met vaalgele basis.

Alom zeer gemeen. Lastig in moestuinen, waar men haar veel op frambozen aantreft, en liefhebster van bramen.

\section{Cimex nigricornis $\mathrm{F}$.}

Plaat 21, fig. 3.

Fabr. S. Rh. 157, 8. - Wolf, lc. Cim. p. 138. tab. 14. f. 132. Fallen, Hem. Suec. 1. p. 27, 9. - IIahn, W. Ins. II. 1. 59. P1. 48, no. 147. - Panz. Fn. Germ. 113. f. 9. - Flor, Rh. Liw\%. I. p. 138, nº. $^{\circ}$ ct $140, n^{\circ} .7$. - Douglas and Scott, Brit. Hem. 1. 78.

Lengte $15 \mathrm{~mm}$. Lederkleurig geel met bruine stippeltjes be- 
zet. De kop vrij lang nitgerekt met bijna regte zijden, welke vrij breed zwart gestippeld zijn; twee fijnere streepjes van bruine puntjes loopen van de spits over de naden der lobben naar den achterrand strijkelings langs de ocellen. Het borststuk is aan den voorrand hoekig en diep ingesneden en op de zijden tot vleugelvormige zwarte punten nitgebreid; de achterrand loopt regt, met een klein indeukje in het midden. De zwarte strepen van den kop worden op den thorax een eindje voortgezet. Het eerste lid der sprieten is geel, de overigen zijn dof zwart; het $3^{\mathrm{e}}$ is bijna de helft korter dan het $2^{\mathrm{e}}$. De zuiger is kort, geel met eene zwarte streep over de bovenzijde. Het schildje is lang nitgerekt en heeft eene lichtgele spits. De dekschilden, bekleed met de algemeene ligchaamskleur, hebben een zwart vlekje aan de basis onder den thorax; hunne membraan is bruinachtig geel met een zwart vlekje aan den binnenhoek en een bruin veegje aan de spits. Onderzijde en pooten bleek geel; de achterdijen vertoonen aan den onderkant een zwart langsstreepje.

De heer C. Ritsema Cz. ving een enkel voorwerp op Beekhuizen den $18^{\text {en }}$ Augustus.

\section{Cimex oleraceus L.}

Plaat 2, fig. 12.

Linn. S. N. 2. 722. 53. - Fabr. S. Rh. 117, 112. - Panz. Fn. Germ. 32. f. 12. - Hahn, W. Ins. I. 182. tab. 29, fig. 94. - Wolff, Ic. Cim. tab. 2, f. 16. - Burm. Handb. II. p. 368 , no. 11. - Flor, Rh. Livl. p. 147. - Douglas and Scott, Brit. Hem. p. 86 (Strachia oleracea).

Lengte 6-7 mm. Donkergroen, blaauwgroen of groenachtig: zwart aan de bovenzijde, zwart met groenen weerschijn aan de onderzijde. Fijn gestippeld op kop en dekschilden, grof op het midden van den prothorax, rimpelig op het schildje. De buitenrand der zijlobben eenigzins naar boven omgeslagen. Sprieten zwart, het $2^{e}$ lid langer dan het $3^{e}$. Zuiger zwart, reikende tot aan de middenheupen. Wit, geel of rood gekleurd zijn (evenwel niet standvastig, want er is verbazend veel verschil 
in de individuen) $1^{\circ}$ an de bovenzijde de voorrand van den kop, de voorrand van den prothorax (smal), zijne zijranden (breedi), ecne breede streep in de lengte over het midden, twee punten in de hoeken van het schildje, twee scheeve vlekken op het midden, de spits van het schildje, de zijrand van het corium aan de basis, eene vlek aan den achterrand, schuin naar het midden gebogen; $2^{\circ}$ aan de onderzijde, de plek ran inplanting der spricten, de zoom van thorax, dekschilden en abdomen, eenige vlekken aan de heupen. Voorts zijn aan de pooten de kniën en een band om de scheenen wit of geel. De membraan is wit, met eene zwarte vlek op het midden of zwart met witten zoom.

Bij eene varieteit is het abdomen wit of geel met 5 rijen zwarte vlekken en zijn de dijen wit aan de basis tot over de helft.

Op verschillende plaatsen in ons land in zekeren overvloed gevangen, als bij Haarlem en Leyden, in de duinen bij Scheveningen, bij de Bildt in April, te Driebergen in Augustus, to Zutphen, bij Brummen in Augustus, in Noord-Brabant.

De vermelde varieteit vond de heer Schubärt bij Utrecht.

\section{Gen. 14. Acanthosona Curt.}

Ligehaam van gedaante als bij het vorige genus, doch somwijlen lang gerekt, steeds vrij bol even voorbij het midden van het halsschild en van daa naar voren seheef neergedrukt. Kop plat met de middellob aan het uiteinde breeder en verder uitstekende dan de zijlobben. Oogen middelmatig, ocellen vrij groot en vrij digt bijeenstaande. Zuiger tot aan de middenheupen reikend. Sprieten zoo lang als het halve lijf, slank, voor de oogen ingeplant, zoodat het $1^{e}$ lid van boven geheel zigtbaar is. Prothorax met vrij sterk uitstekende, soms doornvormige achterhoeken, de achterrandhoeken meestal duidelijk.' Schildje driehoekig, noch breed, noch lang, derhalve eer klein te noemen, de spits in gedaante van een lancetvormig uitstecksel. Dekschilden met zeer scheeven achterrand ver voorbij het schildje 
uitstekend; membraan lang, voorbij het abdomen reikend, met 6 of 7 aderen, van welke 3 uit eene basaalcel ontspringen. Pooten lang en slank met larsen van 2 leedjes (zie fig. $13 b$ ). Voor- en middenborst mel eene verticaal uitstekende, platte of half schijfuormige liel, tegen welke van onderen ankomt een zeer lange doorn van het $2^{e}$ achterlijfs-segment.

\section{Tafel der soorlen.}

1. (4) Achterhoeken van den prothorax doornachtig uitstekend.

2. (3) De doorn stomp. Lengte des insects $14 \mathrm{~mm}$. haemorrhoidale.

3. (2) De doorn zeer puntig. Lengte d. ins. $8 \mathrm{~mm}$. ferrugalor.

4. (1) Achterhoeken van den prothorax weinig uitstekend.

5. ( 6 en 7 ) Membraan met een driehoekig bruin vlekje aan den buitenrand . . haemalogasler.

6. (5 en 7) Membraan met een zwart streepje in het midden . . . . . clypealum.

7. (5 en 6) Membraan bruin en wit gemarmerd. griseum.

\section{Acanthosoma haemorrhoidale $\mathrm{L}$.}

Plaat 2, fig. 13.

Linn. S. N. 2. 720. 35. - Fabr. S. Rh. 160. 27. - Wolf, Ic. Cim. tab. 1. f. 10. - Burm. Handb. II. 360. no. 3. - Curt. Br. Ent. I. pl. 28. - Halın, W. Ins. II. 71. tab. 52. f. 158. - Panz. Fn. Germ. 114, 12.Flor, Rh. Livl. I. p. 99. - Douglas and Scott, Brit. Hem. p. 107. PI. 4. f. 1.

Lengte 14-16 mm. Groenachtig geelbruin of bruinrood, aan de onderzijde lichter. Sprieten bruin of zwart met het eerste of de 2 voorste leden rood; lid 1 zoo lang als de kop. Deze meer of min, soms alleen voor de ocellen met zivarte stippen bezet. Zuiger geel met zwarte spits, reikt tot aan de middenheupen. Prothorax sterk met zwarte ingedrukte putjes bezet, behalve eene fijne middellangsstreep en twee knobbels achter den voorrand; de zwarte putjes hoopen zich op naar de sterk uitstekende achterhoeken toe, zoo dat deze, behalve aan den zoom van 
den zijrand, geheel zwart zien. Het schildje met minder en dus wijder uit een staande stippen; zijne spits glad. Dekschilden fijner gestippeld dam de thorax, membraan geel. Het achterlijf onder de rlengels menierood met driehoekige zwarte rlekken aan de basis. De doorn van het achterlijf aan de onderzijde (verg. fig. $13 a \ldots \alpha$ ) strekt tot an de voorste heupen en ligt op rijde tegen de borstplaat ( $\beta$ ) an. Het achterlijf is vrij scherp kielvormig; de achterhoeken van het $\sigma^{\circ}$ seginent zijn bij het wijfje nog al scherp, bij het mannetje afgerond. De pooten zijn geel of roodachtig geel met bruine tarsen.

Door de heeren de Graaf, van der Wulp, Herklots en mij in Iolland gevonden (eemmaal in December), door den heer Six bij Utrecht, door den heer Heylaerts te Breda in Junij en door wijlen den Schout-bij-nacht Ver Huell te Arnhem. De soort overwintert en wordt even als de volgende op het eerste groen van opslag van eschdoornen in het Haagsche bosch aangetroffen.

2. Acanthosoma haematogaster Schrank ${ }^{1}$ ).

Plat 2, fig. 14.

Schrank, Ins. Austr. 270, 520. - Fabr. S. Rh. 170, 84 (lituratus). II.-Sch. Fn. Germ. 115, f. 13. 14. - Wolff, Ic. Cim. tab. 2. f. 14.Burm. Handb. II. p. 360. no. 4. - Flor, Rh. Livl. 101 (dentatum de G.) - Douglas and Scott, Brit. Hem. p 104 (Ac. dentatum).

Lengte 9-10 mm. - Sterk op den rorigen gelijkend, doch veel kleiner en gewoonlijk glanziger, als gevernisd. Ḱleur olijfgeel met zwarte stippen; de achterrand van het halsschild dikwijls, de basis van het schildje (in het midden) en aan de dekschilden de beide binnenranden bloedrood. Bij een mijner voorwerpen zijn beide dekschilden geheel van die kleur. Verdere punten van onderseheid met de vorige soort zijn: $1^{\text {e }}$ lid der sprieten iets korter dan de kop lang is, kleur der sprieten olijfgeel en hruin, de achterhoeken an den prothorax weinig

1) Schrank schreef IIaemagaster, 't geen door Burmeister tot IItematogaster ver" beterd werd. 
uitstekend, niet zoo zwart. Een driekleurig roodbruin vlekje aan den buitenrand der membraan. De achterrand van het $6^{\text {e }}$ achterlijfs-segment bij het wijfje gedoornd. De doorn aan den buik reikt slechts even voorbij de middenheupen. Stigmata zwart.

Nog al vrij gemeen. Gevangen bij den Haag, Leyden, Wassenaar, Noordwijk, Heemstede, Haarlem, aan de Bildt, te Driebergen, Breda en Groningen van Maart tot September.

\section{Acanthosoma clypeatum Burm. 1)}

Plaat 3, fig. 1.

Burm. Handb. II. p. 361. no 7. - Panz. Fn. Germ 40, f. 19.

Lengte $10 \mathrm{~mm}$. Appelgroen met grijzen kop, pooten en onderzijde, de geheele binnenzijde der dekschilden vaalbruin. Het ligchaam zonder zwarte stippen. De kop lang gerekt, driehoekig met aan den tip rondgebogen zijden, langer dan het $L^{e}$ lid der sprieten. Oogen en ocellen grijs. Sprieten zeer groen, de beide laatste leden zwart aan de spits. Zuiger reikende tot aan de achterheupen, met het laatste lid zwartachtig. Achterhoeken van den prothorax niet uitstekend, afgerond, van dezen tot de achterrandsboeken een roode veeg. Schildje vrij breed aan de spits. Clavus en grootste deel van het corium vaal bruin, gedeeltelijk met donkerder stippen en met cen zwart driehoekje niet ver van de spits. Memlraan geelachtig wit me! een donkerbruin streepje nagenoeg in het midden. Pooten grijs, met groenachtige scheenen. De doorn aan den buik reikt slechts tot aan de middenheupen. De achterrand van segment 6 met een bruin stekeltje bij het wijfje.

Ik ken slechts een iudividu, een wijfje, gevangen door den heer Weijenbergh in Februarij te Overveen bij Haarlem en door hem aan de collectie der N. E. V. geschunken.

1) Ik kan niet aannemen dat Acanthosoma picta Newman (Entom Nlagazine I, 287) en Acanthosoma pictum Douglas et Scott (Brit. Hem. 105) dezelfde soort zoude zijn als de onze. Hunne beschrijvingen wijken in verschillende opzigten af; voornamelijk is die van de membraan geheel anders; zij spreken van een' donkeren dwarsband en 1 of 2 vlekken. 


\section{Acantliosoma griseum L.}

Plaat 2, fig. 15.

Linn. Fn. Suec. 248, 926. - Fabr. S. Rh. 170. 82 (Agathinus). Wolf, Ic. Cim. tab. 6, f.55. - Herr.-Sch. Fn. Germ. 114, f. 10 et 11.Burm. Ilandl. II. p. 360. no 6. - Flor, Rh. Livl. I. p. 102. - Dougl. and Scott, Brit. Hem. p. 101.

Lengte 7-8 mm. De kleinste soort, kenbaar aan de bruin gemarmerde membraan. Taankleurig geel, aan de bovenzijde grof zwart gestippeld en hier en daar rood gekleurd. $3^{e}$ on $4^{e}$ lid der sprieten rood of roodbruin, $5^{e}$ zwart. Zuiger reikend tot aan de middenheupen. Achterhoeken van den thorax vrij stomp. Schildje met eene zeer groote bruine vlek aan de basis. Bovenzijde van het abdomen glanzig zwart, de rand geel met zwarte inkervingen. Het voorborststuk aan de onderzijde mede zwart gestippeld; de anus meest rozenrood. De doorn van het $2^{e}$ achterlijfssegment vrij kort. Stigmata en uiterste hoekpuntjes der ringen van het achterlijf zwart. Pooten geel of vuil geel.

Vrij gemeen in het najaar op berken. In de tweede Naamlijst leest men dat de var. agaihimum $\mathrm{F}$. veel gemeener is dan de type griseum L.; ik moet echter verklaren dat dit geene observatie van groote waarde is, indien, gelijk ik vermoed, agathinum niets dan wijfjes bevat, die bij de wantsen veel talrijker zijn dan mannetjes. Ik weet niet of er wel ooit een vrouwelijke griseum aangetroffen is. De laatste (of type) vond de Graaf bij Doorn; de zoogenoemde varieteit werd in de duinstreken van Holland, te Driebergen, Arnhem (in Junij) en Breda gevangen. Purperroode voorwerpen ontving ik van den heer Nibbelink te Varsseveld; zij waren in Oetober gevangen.

\section{Acanthosoma ferrugator F.}

Plaat 2, figg. 16.

Falır. Ent. Syst. IV. 101, 86. - Panz. Fn. Germ. 26, f. 23 (bispina) Wolff, Ic. Cim. 8. tab. 1, f. 8. - Schellenb. p. 11. tab. 1, f. 4. - IIahn, W. Ins. II. p. 72. tab. 52, f. 159. - Burm. Handb. I. 360, no 5. Flor, Rh. Livl. p. 105.

Lengte 7-8 mm. Kenbaar aan de scherp gepunte achter- 
hoeken van het borststuk; het abdomen bovendien in vergelijking met de vorige soorten, breeder en ronder.

Roodachtig geel van kleur, overal met zwart gestippeld. Kop en voorste gedeelte van het borststuk zeer sterk naar beneden gebogen. Zwart of ten minste donkerbruin zijn: de kop behalve aan den zijrand en van onderen, het $1^{e}$ en het laatste lid der sprieten, de doornen van het borststuk, eene ruitvlek op het schildje en drie blokjes op den van boven zigtbaren rand van het abdomen. De membraan is bij eenige voorwerpen met bruin gemarmerd, bij anderen slechts met 2 bruine strepen voorzien. De pooten zijn geel zonder stippen; tarsen en uiteinden der scheenen bruinachtig.

Van deze soort ving de heer Six drie voorwerpen op blaauwbessenkruid en de heer Wttewaall een in Noord-Brabant. Bij Breda werd zij aangetroffen door de heeren Leesberg en Heylaerts, bij Arnhem in Oet. door van Medenbach de Rooij en aan de Rhedersteeg den $30^{\text {en }}$ Augustus door mij. 


\title{
TWEEDE FAMILIE. - COREODEN.
}

\author{
COREODEA.
}

Het zou zeer moeijelijk zijn eene gepaste benaming in zuiver Hollandsch voor deze familie van Landwantsen te vinden; indien de familie-naam, gelijk mij toeschijnt het geval to zijn, afgeleid is van Corcus en Coreus wederom van Kóous (eene wants), dan heeft hij eigenlijk geene sterkere betrekking tot deze dan wel tot de overige familien. Het komt mij dus het verstandigst voor den naam onvertaald, doch met een' Hollandschen uitgang te bezigen.

Tot deze familie brengen wij het geslacht Berylus, ofschoon het in zijne membraan niet meer dan 5 langsaderen bezit en dus in zeker opzigt niet volkomen aan de vereischten der in de tabel angeduide kenmerken voldoet. Doch ten eerste sluit de plaatsing der sprieten boven zekere ideale lijn, getrokken van het midden der oogen tot de punt van den clypeus, Berytus buiten de Lygacoden en doet het tot de Coreoden naderen, ten andere is de habitus zoo sterk gelijkend op dien van Myrmus Schillingii, dat het vreemd zou schijnen beiden niet nevens elkander te plaatsen. Berytus is een verbindende schakel tusschen twee familien, maar maakt onzes inziens niet eene familie op zich zelf uit, gelijk de meening is van Dr. Flor; daartoe schijnt ons het kenmerk van het aantal aderen in de membraan van te geringe waarde.

De Coreoden hebben over het algemeen een' slankeren vorm dan de Schildwantsen; humne bekleeding is wel niet zoo hard als bij dezen, maar toch harder en steviger dan die der Capsinen. Hun kop is vierkant (van boven gezien) en draagt dan de sprieten aan den voorrand, of hij is driehoekig, met de sirieten op rijde. De basis van dezen is van boven zigtbaar; 
zij zelven bestaan uit vier leedjes en zijn meestal op een voornitspringend grondstuk ingeplant, boven de denkbeeldige lijn wier rigting wij zoo even opgegeven hebben; hunne lengte en de respective lengte hunner leden zijn niet wel in eene algemeene formule te brengen. Bijj Beryfus zijn de sprieten het langst, bij Atractus het kortst; het laatste lid is dikwijls spoelvormig en dikker dan het derde. De oogen zijn over het algemeen klein en half bolvormig, de bijoogjes (bij Beryfus moeijelijk te onderscheiden) staan gewoonlijk even ver van elkander als olk afzonderlijk van het oog aan zijne zijde. De zuiger, die uit vier leedjes bestaat, reikt nimmer verder dan de basis der achterheupen; zijne leedjes verschillen onderling weinig in lengte De prothorax is an de achterzijde bij de meeste genera veel breeder dan aan den voorrand, loopt dikwijls van voren naar achteren zeer sterk naar boven en is somrijlen aan de zijden getand of gekarteld. Het schildje is driehockig of langwerpig driehoekig, middelmatig van grootte of klein. De bovenvleugels, die bij eene enkele soort onontwikkeld blijven, bestaan uit corium, clavus en membraan, doch zonder wig. In den regel ziet men in het corium 2 langsaderen, die zich aan het einde gaffelen en twee hunner gaffels in een doen loopen. De membraan heeft gewoonlijk 6, 7 of 8 aderen, waarvan eenigen zich vertakken, anderen anastomeren. De pooten uitsluitend tot gaan ingerigt, zijn gewoonlijk matig lang en krachtig, bij het geslacht Berylus zijn zij zeer lang en dun; de dijen zijn daar knodsvormig, de achterdijen bij anderen aan de onderzijde gedoornd. De tarsen hebben steeds drie leedjes, waarvan het tweede het kortste is.

De Coreoden treft men in de bosschen, op heiden en duinen aan. Ik geloof dat men vertegenwoordigers van deze familie te vergeefs op weiden en lage, moerassige landen zoeken zal. De levenswijze van het geringe aantal soorten is nog zeer weinig onderzocht, zoodat het nog niet mogelijk is op te geven of hun voedsel uitsluitend uit plantensappen bestaat. 
Analyfische tabel der geslachten.

1. (20) Laatste lid der sprieten nooit langer dan het derde.

2. (15) Ligehaam niet smal en als uitgerekt.

3. (4) Kop met eene lamel of doorntjes tusschen de spricten.

Gen. 1. Syromastes Latr.

4. (3) Kop zonder lamel of doorntjes tusschen de sprieten.

5. (12) Sprieten onbehaard of slechts met enkele haartjes.

6. (9) Tweede lid der sprieten langer dan of ongeveer gelijk aan het derde.

7. (8) Achterdijen zonder stekels.

Gen. 2. Gonocenus Latr.

8. (7) Achterdijen met stekeltjes gewapend.

Gen. 3. Ceraleptus Costa.

9. (6) Tweede lid der sprieten korter dan het derde.

10. (11) Derde lid ten minste 3 maal zoo lang als het tweede.

Gen. 5. Pseudophleus Burm.

11. (10) Derde lid nog niet 2 maal zoo lang als het tweede. Gen. 6. Atragtus Laport.

12. (5) Sprieten sterk behaard.

13. (14) Sprieten zeer dik. Prothorax stekelig.

Gen. 4. Coreus F.

14. (13) Sprieten dun. Prothorax niet stekelig.

Gen. 12. Conizus Fall.

15. (2) Ligehaam smal en als uitgerekt.

16. (17) Dijen en eerste lid der sprieten knodsvormig.

Gen. 9. Berytus F.

17. (16) Dijen en eerste lid der sprieten niet knodsvormig.

18. (19) Sprieten onbehaard.

Gen. 10. Riropalus Schill.

19. (18) Sprieten behaard.

Gen. 11. Myrmus Hahn. 
20. (1) Laatste lid der sprieten langer dan het derde.

21. (22) Achterdijen onbedoornd.

Gen. 7. Stenocepinalus Latr.

22. (21) Achterdijen aan de onderzijde gedoornd.

Gen. 8. Alydus F.

\section{Genus 1. Syromastes Latr.}

Het ligchaam zou bij dit geslacht, te rekenen van de helft van den prothorax naar achteren toe vrij wel een' langwerpigen vierhoek uitmaken, indien het achterlijf niet aan beide zijden ver buiten de dekschilden uitstak. De kop is vierkant met een verticaal plaatje of twee doorntjes tusschen de sprieten. Oogen middelmatig en weinig nitpuilend. Zuiger tot aan de middenheupen reikend met ongeveer even lange leedjes. Sprieten voor aan den kop ingeplant, onbehaard, doch korrelig en ruw; hun eerste lid iets langer dan de kop, naar de binnenzijde toe verbreed еu in het begin wat gebogen, het tweede iets langer en reel smaller, cylindrisch, het derde eveneens doch bij eene soort niet langer dan het $1^{\mathrm{e}}$, het $4^{\mathrm{e}}$ iets dikker en korter, spoelvormig. Voorborststuk naar achter sterk verbreedend en naar de hoogte opstijgend, doch van de achterhoeken naar de achterrandshoeken toe weder versmallend en zelfs weder een weinig dalend, zoodat de grootste breedte en hoogte juist tusschen de achterhoeken komt te vallen. Schildje middelmatig van grootte, plat, driehoekig met een scherp doorntje aan de spits. Dekschilden met slechts bij vergrooting zigtbare aderen, hunne buitenranden in rust parallel hebbende Membraan met eene langwerpige cel aan de basis en een vrij groot aantal (soms 13) van daar uitstralende, onregelmatig slingerende aderen, die somtijds weder in elkander loopen. Het achterlijf steekt aan beide zijden, gelijk reeds gezegd is, ver buiten de dekschilden uit. De pooten leveren niets bijzonders; tusschen de midden- en achterheupen ziet men een gleufje voor den zuiger. 
Kenmerle der soorten.

Kleur donkerbruin; lid 2 en 3 der sprieten rood; twee doorntjes tusschen de sprieten. . . . . Marginalus.

Kleur lichtbruin; lid 2 en 3 der sprieten geel; een verticaal plaatje tusschen de sprieten. . . Muadralus.

Kleur donkerbruin; lid 2 en 3 der sprieten rood; een doorntje tusschen de sprieten en twee op de zijden. . . . . . . . . . . . . Scapha.

\section{Syromastes marginatus L.}

Plaat 3 , fig. 2 en $2 a$.

Linn. Syst. nat. V. p. 485. 28. - Fabr. S. Rh. 192. 6. - Burm. Handb. II p. 315. 4. - Am. et Serv. Hém. p. 207. - Hahn, W. Ins. II. p. 102, f. 185. - Stoll, Wantsen. p. 22. tab. 5, fig. 37. - Wolff, Icon. Cim. p. 20. tab. 3, f. 20 . - Schilling, Beytr. p. 38. tab. 4, f. 1. Panz. Deutschl. Ins. 117, 11. - Douglas and Scott, Brit. Hem. p. 110. Pl 4, f. 3 .

Lengte 12 of $13 \mathrm{~mm}$. Vrij donker of graauwachtig bruin, geheel met nog donkerder fijne puntjes gekorreld, aan de onderzijde iets lichter. De kop zeer laag in vergelijking van den achterkant van den thorax, doch horizontaal vooruitgestoken en niet gebogen. Tusschen de sprieten twee naar elkander toe gerigte stekeltjes. Het $1^{\mathrm{e}}$ lid der sprieten van de kleur als de kop, het $2^{\text {e }}$ en $3^{\text {e }}$ fraai koraalrood (na den dood dikwijls onzuiver rood), het laatste zeer donk jeruin, bijna zwart, bij een mijner voorwerpen is ook het eerste lid rood, doch met een' bruinen tint. De thorax aan de zijden eenigzins gekarteld, naar achteren sterk stijgende, tussehen de afgeronde achterLoeken meer dan driemaal zoo breed als aan den hals, heeft even voor den achterrand een smal, iets verheven lijstje. De laatste ledeu van den zuiger, de scheenen en tarsen ziju bruin. rood. De dunne, buiten de vleugels uitstekende zoom van het achterlijf loopt rond zonder hoeken, en is eenigzins opgewipt. De voordijen en dikwijls ook de dijen der andere paren aan den onderkant bezet met twee rijen kleine tandjes; de achter- 
scheenen bij den man aan de spits eenigzins naar buiten gebogen. De anaalplaat van het $\delta$ is afgerond, die van het $q$ eindigt in twee weinig scherpe punten.

De mannetjes zijn aan de onderzijde en de pooten rooder dan de wijfjes. Een paar malen ving ik een insect dat ik voor de larve dezer soort houd; indien ik mij in die determinatie niet vergis, dan bezit de larve zeer zonderlinge sprieten. $\mathrm{Zij}$ zijn even lang als bij de imago, doch veel breeder; de twee eerste leden zijn driekantig en behaard; het derde lid is tot een paletje verbreed, wit aan de basis en met een verheven rigcheltje aan de onderzijde, het laatste spoelvormig.

Ik meen dat deze soort niet zeldzaam is in Utrecht en Gelderland, maar wel in Holland. Ondertusschen werd zij in April door den heer Weijenbergh in den Aerenbout bij Haarlem gevangen. De heeren Six en Schubärt vonden haar bij Utrecht, de eerstgenoemde verscheidene voorwerpen op Persicaria orientalis in een tuin te Driebergen. Door den heer van Walchren werd zij te Brummen aangetroffen, door mij bij Groesbeek, door den heer Ritsema in Julij bij Rhede en door den heer Heylaerts in Sept. bij Breda.

\section{Syromastes quadralus $\mathrm{F}$.}

Plaat 3, fig. 3.

Fabr. Ent. Syst. 4. p. 132, 20. - Idem, Syst. Rh. 199, 36. - Wolff, Ic. Cim. p. 70. tab. 7, fig. 67. - Stoll, Wantsen. pl. 5, f. 36. - Schill. Beytr. I. p. 40. 3. - Hahn, W. Ins. II, tab. 61, f. 187. - Burm. Handb. II. p. 314. no 1. - Dougl. and Scott, Brit. Hem. p. 116. Pl. 4, f. 6.

Lengte 10 of $11 \mathrm{~mm}$. Van boven lederkleurig of licht geelachtig bruin, van onder bruinachtig geel; de grondkleur is eigenlijk aan beide zijden dezelfde, doch de donkerder tint der bovenzijde wordt veroorzaakt door een ontelbaar aantal bruine korrelachtige puntjes. De kop is niet zoo zuiver vierkant en ook niet zoo laag in verhouding tot den achterkant van den thorax als bij de vorige soort, waarvan deze bovendien verschilt door het gemis van doorntjes tusschen de sprieten, die ver- 
vangen worden door een verticaal plaatje, dat tot even op den zuiger afdaalt. Het $1^{\mathrm{e}}$ lid der antennen heeft de kleur van de bovenzijde van den $k o p$, de $2^{e}$ en $3^{e}$ zijn geel en het laatste is vrij donker bruin, ietwat rossig aan de spits. De oogen zijn iets meer langwerpig dan bij de vorige soort, de bijoogjes donkerbruin met 2 gele streepjes aan de zijden die naar oogleden zweemen. De zijranden van den prothorax zijn niet gekarteld, geel; de achterhoeken steken niet bijzonder uit. De aderen op de dekschilden zijn nog al duidelijk zigtbaar; het achterlijf is aan wederzijde in een stompen hoek verbreed, zoodat het ruitvormig schijnt te zijn. De anaalplaat van den man is ovaal en het sluitstuk er van rond met eene inkeping in het midden, die van het wijfje eindigt in vier afgeronde punten. De pooten zijn van dezelfde kleur als de borst en buik; hunne scheenen zijn aan de uiteinden niet (of nagenoeg niet) gebogen. De stigmata zijn naawelijks te ontdekken; de geurspleet is klein. Aan wederzijde van de middenborst en verder op elk der zes eerste ringen van het achterlijf ziet men een pekzwart stipje.

Deze soort is niet zeldzaam; Dr. van Hasselt, de heer G. A. Six en ik, wij vonden haar meermaals in de omstreken van den Haag. Ook vond de heer de Roo van Westmaas den $12^{\text {en }}$ Augustus een mannetje bij Velp, de heer Six een exemplaar bij Utrecht en Mr. Leesberg een bij Middelburg.

\section{Syromastes Scapha F.}

Plaat 21, fig. 4.

Fabr. S. Rh. 193. 9. - Burm. Handb. II. 1. 315, nn 3. - Wolli, Ic. Cim. p. 69. tab. 7, fig. 66. - Panz. Fn. Germ. 117, f. 9. - Ilahn, W. Ins. II. p. 103. tab. 61, fig. 186. - Curtis, Brit. Ent. IV. 174. - Flor, Rhynch. Livl. I. p. 171. - Dougl. and Scott, Brit. Hem. p. 112. Pl.4. fig.4.

Lengte $11 \mathrm{~mm}$. Nootbruin met donkerbruine stippen digt bezet en daardoor zwartachtig, aan de onderzijde iets lichter. Kop vierhoekig, plat van boven, korrelig met eenige rimpels op den schedel; in de zijden en den nek licht gekleurd; een 
doorntje tusschen de basis der sprieten en twee anderen op zijde. Het eerste lid der sprieten korrelig met een fijn doorntje aan zijn' voet, boven bruin, onder rood; het $2^{e}$ anderhalf maal langer, rolrond, geheel bloedrood, het $3^{e}$ iets korter, aan de spits wat verbreed met een doornachtig nitsteeksel, tot op de helft rood, dan bruin, het $4^{\mathrm{e}}$ nog korter, spoelvormig en zwart. De zuiger reikt tot even voorbij de middenheupen. Het borststuk, aan den voorrand ingebogen met puntige voorhoeken, loopt naar achteren vrij hoog op en is op het breedste punt tweemaal breeder dan aan den hals; de zijden zijn dus zeer bogtig. De zijrand is an het lage gedeelte gekerfd. Het midden van den rug is iets lichter gekleurd. De dekschilden zijn sterk gestippeld en hebben op het corium vier witachtige onbestippelde vlekjes; hunne membraan heeft een' bronzen gloed en tusschen de aderen verhevenheden als hieroglyphisch snijwerk. Het abdomen, dat op zijde buiten de dekschilden nitsteekt, is aldaar sepia-bruin met vuilwitte vierkante vlekjes. De pooten vertoonen geen doorntjes, maar zijn sterk met bruine vlekjes getijgerd. ')

Van deze voor onze Fauna nieuwe soort werden twee exemplaren door den heer Heylaerts bij Breda gevangen, in Maart en April; het eene is zeer gaaf, het andere heeft vergroeide, abnormale sprieten.

\section{Gen.2. Gonocerus Latr.}

Dit geslacht komt in habitus met het vorige vrij wel overeen, maar onderscheidt zich daarvan terstond doordien de kop minder vierkaut en volkomen onbewapend is: De sprieten zijn vrij wel gelijk aan die van Syromasles, vooral in de breedte, buiging en korreligheid van het eerste lid; ook de overige ligchaamsdeelen toonen de grootste overeenkomst; alleen dient hier op deze punten van onderscheid gerwezen te worden. Iet

1) De na verwante Enoplops Bos A. Dohrn is eene goede zelfstandige soort, maar Cornutus van denzelfden schrijver schijnt mij toe met Sccipha in een te loopen. 
schildje eindigt niet in een scherp stekeltje; het achterlijf steekt in de zijden niet noemenswaard buiten de dekschilden uit, en de aderen der membraan zijn buitengemeen talrijk.

\section{Gonocerus Venator F.}

Plaat 10 , fig. 6.

Fabr. S. Rh. 194, 12. - Burm. Handb. II. p. 311. - Wolf, Ic. Cim. 21. tab. 3, f. 21. - Amyot et Serv. Hémipt. p. 239. - Herr. Sch. in Panz. Faun. 116, f. 15. - Douglas and Scott, Brit. Hem. p. 114. PI. 4, lig. 5.

Lengte 13 of $14 \mathrm{~mm}$. Geheel lederkleurig bruin, op de bovenzijde door eene menigte donkerbruine stippeltjes donkerder van tint dan op de buikzijde. Het ligchaam is langwerpig, van voren puntig, aan het abdomen meer ovaal. De kop is langer dan breed, het breedst achter de oogen en loopt tusschen de sprieten in een stompe punt uit. De oogen zijn rond, zijdelings geplaatst en uitpuilend. De ocellen staan achter de oogen, en elk is van het andere ongeveer zoo ver verwijderd als van bet naastbij zijnde oog. De sprieten zijn zoolang als $\frac{2}{3}$ van het ligchaam en staan op weinig verheren knobbeltjes voor de oogen; het $I^{\mathrm{e}}$ lid is zoo lang als de kop, smal aan de inplanting en terstond daarop zich naar binnen verbreedende en dus aan de bovenzijde een weinig afgeplat; het $2^{e}$ lid is rolrond, dunner en langer dan het $1^{\mathrm{e}}$; het $3^{\mathrm{e}}$, even dik doch veel korter, is rood aan de inplanting, en het $4^{e}$ weder korter, doch daarbij spoelvormig en dikker. De zuiger is geelachtig met zwarte spits en reikt tot bijna tusschen de achterheupen. Het borststuk is een trapezium met gegolfde zijlijnen en opgezwollen achterrand; naar den kop toe loopt het schuin af en op zijne grootste breedte is het meer dan tweemaal zoo breed als aan den voorrand; de achterhoeken zijn niet scherp, maar toegeronil en wippen eenigzins op. De dekschilden reiken met bunne membraan niet over den rand van het achterlijf; de aderen op het corium zijn kenbaar door dien zij ingevat zijn in rijen van ronde $z$ warte puntjes; in de membraan telt men 
11 of 12 ongekleurde, gegolfte, dikwijls gaffelvormig verdeelde aderen. De vleugels zijn rookkleurig met zeer duidelijke zwarte aderen. Het achterlijf is ovaal, op den rug zwart met roodgele vlekken op het $3^{e}$ en $4^{e}$ segment, terwijl de volgenden roodgeel zijn met zwarte vlekken; de buitenzoom, die in de rust buiten de vleugels uitsteekt, is zeer dun, ietwat opgewipt, donkerbruin met witte randen der segmenten. De pooten zijn slank, zonder doornen of nitsteeksels. De geheele olderzijde met de pooten is egaal geelachtig rood, behalve de zoomen der stigmata, die zwart zijn.

Van deze zeldzame en merkwaardige soort ving de heer van Medenbach de Rooij twee exemplaren, beide wijfjes, een in Junij bij Arnhem, het andere half October bij Oosterbeek. Ook werd een voorwerp van deze soort in Julij bij Venlo gevonden door den heer van den Brandt en een bij Houtem in Limburg, mede in Julij, door Mr. A. H. Maurissen.

\section{Gen. 3. Ceraleptus Costa.}

Dit geslacht onderscheidt zich op den eersten oogopslag van de beide vorigen doordien het den kop veel langer heeft en met stekeltjes gewapende achterdijen. De kop is eenigzins krom naar beneden gebogen, iets langer dan het borststuk en vertoont van boven gezien een trapezium welks voorrand kegelvormig is uitgerekt; zijn grootste breedte is bij de hasis der sprieten; de middellob steekt verder dan de zijlobben uit. De 4 leden der sprieten zijn ongeveer even lang, echter is het $3^{\text {e }}$ iets langer dan de overigen; het $1^{\mathrm{e}}$ lid is wat naar buiten gekromd en zeer dun aan de inplanting. De zuiger reikt tot tussehen de middenheupen. Het borststuk is kort, naar achteren oploopend, met weinig uitstekende achterhoeken en geheel rondloopende achterrandshoeken. Het schildjo tamelijk breed, driehoekig, met de spits een weinig opgewipt. De dekschilden zijn zoo lang als bet achterlijf, doch in de rust tegen elkander liggrende iets smaller, hunne membraan vertoont aan de basis 
eene korte en zeer breede cel, waaruit 8 tot 9 aderen ontspringen. De onderzijde vertoont niets bijzonders. De pooten zijn matig lang en krachtig, hunne achterdijen zijn knodsvormig en aan de onderzijde met eene rij stekeltjes gewapend.

De eenige inlandsche soort werd door mij in het Tijlschrift voor Enlomologie (Deel XII, 1869), onder het geslacht Coreus als eene nieuwe soort onder den naam van Corcus difficilis beschreven.

\section{Ceraleptus squalidus Costa.}

Plaat 3, fig. 5.

Costa, Cimic. Regn. Neap. Cent. 2. p. 13. t. 4, fig. 7. - Stein, Berl. Ent. Zeit. 1858, 1. 75, no 3 (Lividus). - Fieber, Eur. Hemipt. p. 219. Douglas and Scott, Brit. Hem. p. 127. pl. 5, fig. 1.

Lengte 1 centim. Nootkleurig of geelachtig bruin an de bovenzijde, vaalgeel van onderen. Oogen zwart, ocellen roodachtig. Op den schedel en het voorhoofd vier donkere langsstrepen, van welke de binnensten een geelachtig streepje insluiten. Het $1^{\mathrm{e}}$ lid der sprieten roodbruin, korrelig, het $2^{\mathrm{e}}$ rood, aan het einde wat behaard, het $3^{\mathrm{e}}$ zwart met roode basis, iets langer behaard, het laatste zwart met zeer weinig haren. Prothorax met twee korte donkere streepjes in het midden an den voorrand, naar achteren oploopende, doch even voor den achterrand weder plotseling dalende; zijne zijkanten tot over de helft met korte, breede, omgekromde zivarte tandjes bezet en aan den achterhoek met een geel zoompje omgeven. Dekschilden vrij grof gestippeld, vooral langs de aderen; de aanvang van den zijrand met een' gelen zoom. Membraan rookkleurig met de aderen onregelmatig afwisselend licht en donker bruin. Rand van het abdomen met zwarte stipjes op den zoom der ringen. Pooten geel met zwarte stipjes, welke vooral veelvuldig zijn op de achterdijen; spitsen der scheenen en der tarsen donker. De onderrand der achterdijen vertoont twee grootere en eenige kleinere tandjes.

Een mannelijk voorwerp van deze soort werd in Maart door den heer P. Snellen bij den Haag gevangen. De heer Heylaerts 
ving eenige exemplaren in April en Mei bij Breda en de heer La Fontijn een paar op het eiland Walcheren.

\section{Gen. 4. Coneus F.}

Dit is het geslacht waarnaar de geheele familie genaamd is, eenvoudig ondat bijna al hare soorten door Fabricius in het door hem afgezonderde en benoemde Genus Coreus geplaatst werden. Het ligehaam is gerekt eivormig met bijna evenwijdige zijden. De kop is groot, tot aan de basis der sprieten even breed blijvend, tusschen dezen in een' stompen kegel verlengd. De oogen zijjn klein, zijdelings geplaatst, de ocellen staan aan den achterrand van den kop. De sprieten, wier leedjes ongeveer even lang zijn, zijn ruw en harig; hun $1^{\mathrm{e}}$ lid is het dikst. De zuiger reikt tot an de middenheupen; haar tweede lid is het langst. De prothorax is iets breeder dan lang, heeft regtloopende met doorntjes bezette zijkanten en is aan den achterrand ietwat ingebogen. Het schildje is een gelijkzijdige driehoek, die in een scherp puntje eindigt De boven- en ondervleugels zijn wel ontwikkeld, reiken niet over het einde van het abdomen heen en laten op zijde een smal randje er van vrij; de membraan heeft aderen, die dikwijls in elkander vloeijen en aan hunne basis op eene dwarsader rusten, die niet ver van den rand van het corium af staat. De pooten zijn nog al krachtig gebouwd, vooral de achterpooten, wier dijen eenigzins gezwollen en aan de onderzijde bedoornd zijn.

\section{Coreus pilicornis Burm. (Klug.) \\ Plaat 3, fig. 4 en $4 a$.}

Burm. Handb. II. p. 309. no 2. - Wolf, Ic. Cim. p. 71. tab. 7, f. 68, Schill. Beitr. I. p. 44. tab. 4, fig. 6. - Hahn, W. Ins. II. 1. 106. f. 188. II.-Sch. id. lib. IV. p. 97. f. 441.

Lengte $9 \mathrm{~mm}$. Aan de bovenzijde licht roodbruin, aan de onderzijde bruinachtig geel. Kop en thorax zeer fijn behaard, 
de eerste met eenige langsrimpels op de bovenzijde. Sprieten dik, ruw, korrelig en vrij lang behaard. Het eerste lid donker wijnrood; het tweede en derde iets donkerder, het laatste bijna zwart met rooden tip. De zijden van den prothorax zijn met vrij groote witte doornachtige tandjes bezet, de bovenzijde eenigzins naar den kop toe afhellend, ruw met korreltjes bedekt. Het schildje en de dekschilden zijn gestippeld; de zijrand der laatsten is met microscopische haakjes bezet; de membraan is vuil wit, ietwat iriserend met flaauw roode aderen. De pooten zijn in kleur gelijk aan de bovenzijde van het lijf; alleen de uiteinden der tarsen zijn donkerder; de pooten zijn mede harig, de doorntjes aan de onderzijde van de achterdijen hebben doorschijnende tippen. Aan de onderzijde van het lijf vertoont de keel een zwarte langsstreep en het $6^{e}$ lid van het abdomen is bij het mannetje in het midden voor de genitaalplaat zoodanig ingesneden, dat de zijkanten in den vorm van groote kaken naar achteren uitsteken.

De heer van der Wulp ving op den eersten September in het duin bij 's Gravenhage een mannelijk voorwerp van deze soort, dat door hem welwillend aan de insectenverzameling der Ned. Entomologische Vereeniging werd afgestaan. Dr. Everts ving 3 exemplaren bij Noordwijk in Junij, de heer Heylaerts een in Mei bij Bergen op Zoom, de heer La Fontijn een op Walcheren en ik een bij Domburg op genoemd eiland 18 Junij en een aan de Bildt 1 Julij.

\section{Gen. 5. Pseudophloeus Burm.}

De relative lengte der leden van de antennen scheidt dit geslacht zeer scherp af van het vorige, ofschoon overigens de habitus en vorm van het ligehaam nagenoeg dezelfde zijn. Zie hier de kenmerken van het genus.

De kop is naar verhouding van het borststuk groot, vrij breed, tusschen de sprieten stomp kegelvormig uitstekend en aan wederzijde van dit middelstuk als het ware een voetstuk 
aanbiedend voor de antennen. Deze hebben het eerste lid vrij kort, ruw gekorreld, tamelijk dik, het tweede smaller en korter, het derde nog iets dunner, aan de spits een weinig gezwollen en viermaal langer dun het tweede, eindelijk het vierde langwerpig spoelvormig of liever gelijkende op een eikeltje in zijn napje, veel dikker dan het $3^{e}$. De sterk tegen de borst angedrukte zuiger ligt in eene sleuf en reikt tot aan de middenheupen. De ocellen staan iets verder van elkander af dan elke ocel van het oog aan zijne zijde. Aan den korreligen prothorax zijn de achterhoeken geheel afgerond en de zijden fijn getand. Het schildje driehoekig met een opgewipt stomp spitsje. De aderen op de dekschilden duidelijk; hunne membraan met 9 of 10 geslingerde langsaderen, welke uit eene dwarsader ontspringen, die vrij ver van den rand van het corium af staat. Het abdomen, dat op de dwarsdoorsnede driehoekig is, steekt eenigzins buiten de dekschilden uit. De pooten zijn tamelijk krachtig, niet zeer lang, de dijen naar de spits toe dikker. Het eerste lid der tarsen is zoo lang als de beide volgenden te zamen.

\section{Pseudophl. Fallenii Schill.}

Plaat 2, fig. 1.

Schilling, Beitr. I. p. 46. n ${ }^{0}$ 9. tab. 1, f. 2. - Hahn, W. Ins. II. p. 112. Pl. 64, f. 192. - Burm. Handb. II. p. 308. $\mathrm{n}^{0}$ 1. - Curt. Brit. Entom. $\mathrm{n}^{0} 500$ ? (Atractus literatus).

Lengte 7-8 mm. Rossig grauw met grijze tinten op de dekschilden en den zijrand van het abdomen. Het voorname kenmerk der soort in tegenstelling van andere niet inlandsche soorten is, dat het eerste lid der sprieten bijzonder ruw en als met stekeltjes bezet is. Het $2^{e}$ en $3^{e}$ lid is iets lichter van kleur dat het $1^{\mathrm{e}}$, het laatste is aan de basis zwart, verder zwartachtig. De oogen zijn mede zwart, even als de vrij groote ocellen. De prothorax aan den voorrand rossig, is in het midden van den achterrand zwart, aan de kanten graur, terwijl kartelige zijkanten en twee langsstrepen over het midden vuil wit zijn. Het schildje heeft een smal, verheven lijstje in het 
midden wit en het stompe spitsje zwart. Het lederachtige deel der dekschilden is met vele putjes ingeprikt, grijs; de ader naast den clavus is met zwarte blokjes versierd; de binnenzijde van de randader even zeer; de vork van de buitenste langsader, die mede twee zwarte blokjes draagt, is an de binnenzijde donker gekleurd en omvat eene bijna melkwitte vlek. De membraan vertoont aan de basis vier cellen en voorts naar den buitenrand en de spits toe, 8 zich vertakkende en soms onderling samengehechte aderen, die met zwarte stipjes en lijntjes zijn versierd. De rand van het abdomen vertoont aan de basis van iederen ring een' zwarten band en iets verder op ieder segment eene zwarte stip. De onderzijde van het lijf is iets donkerden grauw met onnoemelijk veel zwarte puntjes, hier en daar tot vlekken vereenigd. De pooten, die dezelfde kleur hebben, zijn bijzonder ruw gekorreld en op de dijen bijna stekelig.

Deze soort schijnt tamelijk zeldzaam. De heer Snellen ving een duidelijk geteekend voorwerp den $21^{\text {en }}$ Mei in de duinen, de heer van der Wulp vond er twee bij Schereningen; ik vond twee grauwere en doffere voorwerpen, een bij den Haag in Julij, het andere bij Leyden. Misschien evenwel komt zij niet zoo zelden voor, maar leeft verborgen. Schilling meldt dat zij aan de wortels van Genisla linctoria leeft, Herrich-Schaeffer noemt Sparlium scoparium.

\section{Pseudophl. Waltlii H. Sch.}

Plaat 21, fig. 7.

Herr.-Schaeff. in Panzer's Fauna Germ. 127, 6. - Idem, W. Ins. VI. p. 4, Tab. 182 D.

Lengte ongeveer $7 \mathrm{~mm}$. Van de vorige soort sterk versehillend in grootte, in kleur en door sterker doernen. Zwart, aan de buikzijde met roodbruin gevlekt. Kop met twee sterke doornen voor de oogen en 2 kleine stekeltjes aan de spits. Alle leden der sprieten doornachtig, het $3^{e}$ aan bet eind bestekeld knodsvormig. De zijpranden van den prothorax dragen sterke doornen en zijn achter het midden dieper uitgebogen dan bij de andere 
soort; voor den achterrand loopt een diepe plooi. Het schildje heeft de zijden aan de basis verdikt en een knobbeltje op de spits. De dekschilden zijn sterk gestippeld op den clavus en tusschen de aderen; de membraan is zeer donker en de op zijde uitstekende rand van het abdomen met vuilwitte streepjes geteekend. De pooten zijn donkerbruin, de dijen sterk gekorreld, de scheenen met vuilwitte bandjes geteekend; ook het eerste lid der tarsen is lichtgekleurd.

De soort werd door Waltl in Spanje ontdekt, maar is nog niet in Frankrijk en België aangetroffen. Ziedaar dan weder een zuidelijk insect in ons vaderland, en wel in Zeeland voorkomende. Kan dit anders verklaard worden dan door den invloed van den golfstroom? Het voorwerp, dat voor de beschrijving diende werd op Walcheren gevangen door den heer La Fontijn, aan wiens ijver wij de kennis van meer zeldzaamheden verschuldigd zijn.

Gen. 6. Atractus Lap.

Van het voorgaande geslacht verschilt dit nieuwe in drieërlei opzigt: ten eerste is de relative lengte der sprietleden anders, angezien lid 3 bij Atractus slechts 2 maal langer is dan 2; ten andere zijn de zijranden van den thorax niet getand, noch zelfs korrelig; ten derde onthreekt in de membraan de dwarsader digt bij de basis. Er is slechts eene soort inlandsch, namelijk:

\section{Atractus Dalmannii Schill.}

Plaat 21, fig. 6.

Schilling, Beitr. I. 41. Pl. 1, f. 1. - Hahn, W. Ins. II. p. 112, tab. 64, f. 193. - Burm. Handb. II. p. 308, no 2. - Douglas and Scott, Brit. Hem. p. 112 . tab. 4 , f. 8.

Lengte 6-7 mm. Lichter of donkerder nootbruin, aan de buikzijde iets lichter. De breede kop loopt in 3 even groote punten uit, in wier tusschenruimten do sprieten ingeplant zijn; 
van dezen is het eerste lid ovaal, van boven plat, ietwat korrelig, het $2^{\text {e }}$ slank, rolrond, iets korter, geelachtig; het $3^{\text {e }}$ tweemaal langer, geelachtig, rolrond doch uitloopende in eene verbreede zwarte knop, het $4^{e}$ korter dan 1 , dik, peervormig. De oogen puilen weinig uit. De zuiger reikt slechts tot de middenhenpen. Het borststuk is trapeziumvormig, iets breeder dan lang, met puntige voor- en ietwat stomper achterhoeken; de achterrand is aan beide zijden van het schildje lappig uitgebogen; de voorste helft van den zijrand is breed wit omzoomd. Het schildje is donker, met eene geelachtige versiering in de gedaante van een' vliegenden vogel, doch niet altijd duidelijk. Het corium der dekschilden is vrij kort, hunne membraan lang en zeer donker. De opgewipte zijrand van het abdomen is vrij breed met lichtere vlekken op de ringen. De pooten zijn gevlekt met donkere bandjes om dijen en scheenen.

De heer van der Wulp sehonk mij een inlandsch voorwerp nit de collectie door Perin bijeengebragt; later ontving ik nog twee voorwerpen, door de heeren Everts en Leesberg in Junij bij Noordwijk aangetroffen.

\section{Gen. 7. Stenocepialus Latr.}

Dit geslacht wordt daardoor gekenmerkt dat het laatste lid der sprieten langer is dan het derde, terwijl tevens de achterdijen geheel onbedoornd zijn.

Ligchaam langwerpig, vier malen langer dan hreed, voor smaller dan achter. Kop van boven gezien vrij plat, langwerpig vierkant met eene naar voren uitstekende kegelvormige spits, die aan de punt gespleten is. Zuiger reikende tot de middelherpen; zijn $3^{\text {e }}$ lid het langste. Sprieten langer dan de helft van het ligchaam; het $1^{\mathrm{e}}$ lid in het midden en an het eind verdikt, naar buiten ongebogen, bijna zoo lang als de kop; het $2^{\text {e }}$ veel dunner en $1 \frac{1}{2}$ maal zoo lang; het $3^{\text {e }}$ een weinig langer dan het $1^{\mathrm{e}}$, zoo dik als het $2^{\mathrm{e}}$; het $4^{\mathrm{e}}$ zoo lang als het $2^{\circ}$, een weinig krom gebogen, slank en aan het einde toege- 
spitst. Oogen vrij groot en bol; ocellen ver naar achter geplaatst. Thorax weinig langer dan de kop, op den rug trapeziumvormig, eenigzins bol met omgebogen achterrand. Schildje groot, driehoekig met eenigzins opgewipt spitsje. Dekschilden gewoon; hunne membraan groot met 8 langsaders ontspringende uit eene dwarsader, die tamelijk ver van den rand van het corium verwijderd is. Achterlijf breeder dan de thorax, met opstaand connexivum en sterk gewelfden buik. Pooten lang en vrij slank; hunne dijen tamelijk gezet, doch ongedoornd, achterste scheenen lang.

\section{Stenocephalus migax L.}

Plaat 21, fig. 5.

Fabr. S. Rh. 200, 42. - Wolff, lc. Cim. p. 30, tab. 3, f. 30. Schill. Beitr. 48, 11, tab. 5, f. 2. - Burm. Handb. II. 328. - Hahn, W. Ins. I. p. 22, tab. 3, f. 13. - Douglas and Scott, Brit. Hem. p. 141, tab. V, f. 6 .

Lengte $15 \mathrm{~mm}$. Slank, grauwbruin, donkerder gestippeld. Kop tweemaal langer dan breed, van de basis der sprieten af kegelvormig verlengd en in twee puntjes uitloopend; oogen bol, donkerbruin, ocellen lichter en wat roodachtig. Zuiger slank, licht gekleurd met eene donkere bovenstreep, reikende tot de middenheupen. Sprieten langer dan het halve lijf, slank, behaard; het $1^{\mathrm{e}}$ lid dikker, naar buiten krom gebogen, zwart; het $2^{e}$ lang en smal, zwart met 2 geelwitte bandjes; het $3^{e}$ veel korter, zwart met geelwitte basis; het $4^{e}$ veel langer, overal slank, gekleurd als 3. Thorax weinig langer dan de kop, op den rug trapeziumvormiy, met omgebogen achterrand. Schildje vrij groot, driehoekig met ivoorwit spitsje. Dekschilden zonder teekening; membraan bruin met iets donkerder aderen en daartusschen eene menigte bruine vlekjes; de grondader groot en ongevlekt. Rug van het abdomen bloedrood met de basis en de spits bruin; zijranden opstaand, bruin met vierkante witte vlekjes geblokt. Onderzijde bronskleurig bruin, de buik iets lichter dan de borst. Pooten lang en slank; henpen en basis 
der dijen ivoorwit; scheenen behaard, geelachtig met de beide uiteinden zwart; tarsen zwart.

Van deze nerkwaardige soort ving de Generaal Dr. van Hasselt een mannelijk individu, 23 Nov. op een' wijngaard in zijn' tuin binnen 's Gravenhage, en had de goedheid er mijne verzameling mede te verrijken.

\section{Gen. 8. Alydus F.}

Dit geslacht wordt gekenmerkt door den stomp naar beneden afgeronden kop, het lange vierde lid der sprieten en de lange knodsvormige, aan de onderzijde met stekels bezette achterdijen.

Het ligehaam is langwerpig, nagenoeg overal even breed met eenigzins uitpuilenden buik. De kop is tusschen de oogen vrij breed, naar voren driehoekig, aan de spits naar beneden gebogen. De oogen en ocellen puilen uit; de laatsten staan even ver van elkander als van de oogen. De sprieten zijn langer dan de helft van het ligchaam, slank; het $1^{\mathrm{e}}$ lid korter dan het $2^{\mathrm{e}}$, dit even lang als het $3^{\mathrm{e}}$, het $4^{\mathrm{e}}$ meer dan $1_{2}^{1}$ maal langer, iets dikker en een weinig gebogen. De zuiger reikt slechts tot de middenheupen, de 2 voorste leedjes langer dan de 2 achtersten. Het voorborststuk min of meer bol, naar achteren oploopend en breeder, met regte zijranden; achterrandshoeken in de achterhoeken opgenomen. De dekschilden smal met zeer groote membraan, in welke men tien of elf geslingerde aderen telt. De voorpooten vrij lang en stevig, de achterpooten veel langer met dikke dijen, die aan de onderzijde naar de spits toe met 4 stekeltjes bezet zijn. Het abdomen is aan de onderzijde uitpuilend, aan de bovenzijde als ingevallen met opstaande zijranden. De eerste ring is onder den metathorax verborgen, de derde veel breeder dan de overigen.

\section{Alydus calcaratus L.}

Plaat 1 , fig. 6 en $6 a$.

Linn. S. Nat. V. p. 505. 114. - Fabr. S. Rh. 251. 15. - Curt. Br. 
Ent. VIII. no 369. - Burm. Handb. II. p. 323. - Wolff, Ic. Cim. tab. 14, f. 138. - Schill. Beitr. I. p. 49, tab. 5, f. 1. - Herr. Sch. Deutschl. Ins. 121, 10. - Hahn, W. Ins. I. p. 198, f. 101. - Am. et Serv. Hém. p. 226. - Flor, Ins. Livl. I. p. 183- - Douglas and Scott, Brit. Hem. p. 143. Pl. 5, fig. 7 .

Lengte $12 \mathrm{~mm}$. Zwart, zwart behaard, op den rug van den prothorax donkergrauw, aan den buik gebronsd; tussehen de opstaande zwarte haren is het ligchaam met een zilvergrijs dons bedekt. Oogen en ocellen bruin. Drie eerste leden der antennen vuilgeel met zwarte spitsen, het laatste zwart met een stipje geel aan de basis (het schijnt uit beschrijvingen wel dat het zwart in de sprieten soms de grondkleur wordt). Uiterste spits van den kop, kopschild en twee plaatjes op zijde van de zuiger-basis geel. Zuiger vaalzwart. Dekschilden vaalbruin met donkere stippen, de aderen sterker gekleurd. Membraan rookkleurig met geslingerde aderen, ontspringende aan eene dwarsader, die vlak tegen den achterrand van het corium ligt. Rug van het abdomen met eene groote oranje vlek in het midden, de opstaande zijden vertoonen op ieder segment aan den voorrand een vuil oranje vlekje. Aan de onderzijde vlekken aan de voorborst, zoomen der heuppannen en van de stanksplect geel. Aan de pooten de heupen vaalzwart, de apoplyysen bruin, de scheenen behalve de einden en het cerste lid der tarsen aan de basis bruinachtig geel, al het overige bronskleurig zwart. - Voorwerpen uit andere landen zijn gewoonlijk donkerder van kleur.

Een vrouwelijk individu werd door den heer van Bemmelen bij Driebergen, andere voorwerpen door den heer Ritsema en mij in Augustus aan de Rhedersteeg en door den heer Leesberg bij Breda in September gevangen.

\section{Gen. 9. Berytus F.}

Een ietwat afwijkend geslacht, dat evenwel nergens beter geplaatst kan worden. Ligchaam zeer lang en smal en daardoor 
overeenkomst hebbende met Limnobales onder de waterbewoners, en Bacteria onder de Orthoptera. Kop veel langer dan breed, meestal achter de oogen in eene soort van hals uitgerekt; voorhoofd wel eens tot een verticaal plaatje vergroeid. Oogen iniddelmatig, weinig uitpuilend, ocellen zeer klein. Sprieten zeer lang en dun, bij eene soort zelfs langer dan het ligchaam. Het $1^{\mathrm{e}}$ lid het langste aan de spits kolfvormig, het $2^{\mathrm{e}}$ veel kleiner, het $2^{\mathrm{e}}$ weder langer, het laatste kort, spoelvormig, dikker dan de overigen. De zuiger reikt bij eenigen tot aan de voor-, bij anderen tot digt bij de middenheupen. De prothorax, langer dan breed, is naar achteren toe op den rug ietwat opgezet, aan de zijden kantig en draagt gervoonlijk op het midden van den rug een verheven lijstje, terwijl de zijden grof met putjes ingedrukt zijn. Het schildje is bijzonder klein, spits driehoekig. Het abdomen, veel langer dan kop en borststuk, is op den rug plat, aan den buik bol. Dekschilden zeer lang en smal, meest iets verder reikend dan het achterlijf, met korten clavus, uitgerekt corium waarin de langsaderen duidelijk uitkomen en membraan met niet meer dan 5 aderen, die niet allen altijd duidelijk zijn. Pooten zeer lang en slank met korte heupen, de dijen aan het einde knodsvormig gezwollen, de scheenen haarfijn, buitengewoon lang, de tarsen kort met vrij groote klaauwtjes; het $1^{\mathrm{e}}$ tarsaallid, in lengte gelijk an de beide overigen te zamen.

\section{Overzigt der soorten. $\left.{ }^{1}\right)$}

1. (10) Voorhoofd tusseben de sprieten in den vorm eener lamel vooruitstekend. (Verg. fig. 7a.)

2. (3) Tweede lid der sprieten grooter dan $\frac{1}{2}$ van het volgende . . . . . tipularius.

1) De synonymie is hier zeer verward. Wat $B$. clavipes $\mathbf{F}$. zij, is niet wel uit te maken, de soort door Flor aldus gennemd, schijnt te verschillen van die van Burmeister en Herrich-Schaeffer. De fig. $a$ op plat 4 van Srhellenberg is ook niet wel op eenige soort te duiden; het zou $B$. crassipes Panz. kunnen zijn indien de kleur van sprieten en dijen overeenkwam. Men zal de soorten niet wel van elkander kunnen afscheiden, tenzij men voorwerpen in copulatie vange en serien verzamele. 
3. (2) Tweede lid der sprieten korter dan $\frac{1}{4}$ van het volgende.

4. (7) Membraan ongevlekt.

5. (6) Lamel tusschen de sprieten puntig - . clavipes.

6. (5) " " " " stomper en korter . . . . . . . . . crassipes.

7. (4) Membraan gevlekt.

8. (9) Bruinachtig geel. . . . . . . cognatus.

9. (8) Okergeel . . . . . . . . Driebergensis.

10. (1) Voorhoofd zonder lamel . . . elegans.

\section{Berytus tipularius L.}

Plaat 1 , fig. 7 en $7 a$.

Linn. S. N. V. p. 506. 120. - Fabr. S. Rh. 264. 1. - Fallen, Hem. I. p. 165. 1.-Burm. Handb. II. p. 313. 1. - Hahn; W. Ins. I. p. 133. pl. 21. f. 68. - Am. et Serv. Hém. p. 233. 1. - Schill. Beitr. p. 56. tab. 7. fig. 3a. - Wolff, lcon. Cim. p. 204. tab. 20, f. 198. - Flor, Rhynch. Livl. I. p. 206. - Douglas and Scott, Brit. Hem. p. 162.

Lengte $10-10,5 \mathrm{~mm}$. Bruinachtig lichtgeel met zwarte tarsen en zwarten knop aan de sprieten. De soort onderscheidt zich van de overigen vooreerst door hare grootte, ten andere door de verhouding der lengte van de sprietleden, gevoegd bij de lamel op het voorhoofd. Deze laatste is namelijk op zijde gezien zeer merkwaardig en steekt een geheel eind vooruit, gelijk onze fig. $7 a$ aantoont. Achter de zwarte oogen is eene soort van dwarsinsnijding in den kop. De basis van het $1^{\mathrm{e}}$ lid der antennen, een ring nabij het einde daarvan en het geheele $4^{e}$ lid zijn zwart; het 2 lid is iets grooter dan de helft van het

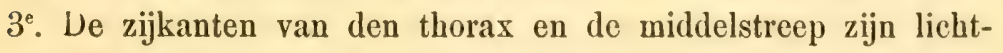
geel zonder bruinen tint; onder de zijkanten ziet men eene zwarte veeg. Op de deksehilden zijn de langsaderen zeer duidelijk te zien. Sommige voorwerpen hebben eene zwarte langsstreep aan hare buitenzijde en 4 tot 8 zwarte vlekjes op den rand van het corium en membraan; deze laatste is gewoonlijk ongevlekt doorschijnend, somwịlen een weinig bruin gevlekt. 
De uiteinden der dijen hebben eenige zwarte stippen en streepjes, de tibien-spitsen en tarsen zijn zwart. Aan de onderzijde is de kop en borst zwart met langsrijen van wit vilt; ook de laatste leedjes van den zuiger zijn zwart en de gele buik is overal, behalve in het midden, met zwarte putjes bezet.

Deze soort is in de duinen en heidestreken niet zeldzaam. Ik vond haar hij Scheveningen (in cop.) en bij Wassenaar in Augustus, alsmede in Junij bij Bennebroek op Verbascum. De heeren van Hasselt, de Graaf en Six troffen haar in de omstreken van Utrecht, bij de Bildt en Driebergen aan; de heer Heylaerts in het begin van April nabij Breda.

\section{Berylus clavipes F.}

Plaat 1 , fig. 8 en $8 a$.

Fabr. S. Rh. 165. 2 - Id. Ent. Sysi. IV. p. 192. 20. - Schill. Beitr. I. p. 56. n" 2. tab. 7, fig. $3 b .-$ Hahn, W. Ins. 1. 135. pl. 21, f. 69. Burm. Handb. II. p. 313. - Douglas and Scott, Brit, Hem. p. 154.

Lengte $6-7 \mathrm{~mm}$. Geheel rosachtig lichtbruin; alleen de uiteinden der dijen zijn donkerbruin, zwartachtig; de knods van het $1^{e}$ lid der sprieten, de spits van het $3^{e}$ en het geheele $4^{\text {e }}$ zijn zwart. Het tweede lid haalt misschien slechts $1 / 6$ der lengte van het derde. Ook bij deze soort heeft de thorax drie gele lijstjes, 2 aan de kanten, 1 in het midden, doch er is geen zwart in de zijden nog op de borst. De buik is rosser dan de rest. De uiterste tip van het corium heeft een zwart vlekje en de membraan is geheel doorzigtig en ongevlekt.

In aantal gevonden te Driebergen en bij Utrecht door den heer Six, eenmaal in Julij door mij te Heemstede.

\section{Berylus crassipes H. Sch.}

Plaat 3 , fig. 8.

Herr. Sch. Nomencl. p. 43. - Fieb. Wien. Ent. Monatschr. III. 206. Douglas and Scott, Brit. Hem. p. 156.

Lengte $6 \mathrm{~mm}$. Honiggeel met 3 witte strepen op den pro- 
thorax, sterk gelijkend op Clavipes, doch verschillend doordien de lamel tusschen de sprieten stomper en korter is; en op zijde gezien ronder; bovendien is de knods aan het eind van bet $2^{\mathrm{e}}$ lid der sprieten meer plotseling aanvangend. Deze knods, de spits van lid 3 en lid 4 zijn zwart. De aderen op het corium zijn lichter gekleurd dan de ruimte daartusschen; aan de spits van het corium ziet men een zeer flaauw bruin stipje; de membraan is niet breeder dan het corium. Het achterlijf is in het midden veel breeder dan de thorax. De dijen zijn knodsvormig, die van het voorste paar honiggreel, die van het tweede paar bruiner, die van het derde bepaald bruin. (Het zou mij niet verwonderen indien deze soort slechts eene verscheidenheid bleek te zijn van Ber. minor H. Sch.).

Een voorwerp bij Breda in Maart gevangen door den heer Heylaerts; een ander door den heer Six bij Scheveningen.

\section{Berytus cognatus Fieb.}

Fieber, Wien. Ent. Monatschr. III (1859), p. 205. - Douglas and Scott, Brit. Hem. p 153, no 3 .

Lengte $12 \mathrm{~mm}$. Bruinachtig geel of licht nootbruin met de langslijstjes van den thorax minder duidelijk, kenbaar aan het smalle corium en de breede membraan. Do vooruitstekende spits van den kop ietwat stomp en op zijde gezien opgewipt. Sprieten zeer slank en lang; de spits van het $1^{e}$ lid niet plotseling verdikt, bruin, het $2^{e}$ bijzonder kort, het $3^{e}$ met een zwart stipje aan de spits, het $4^{\mathrm{e}}$ zwart. Thorax in het midden naar beneden gebogen, middenlijstje op den rug duidelijk, maar die aan de zijden minder scherp afgescheiden en van dezelfde kleur als de thorax. Dekschilden met smal corium, dat aan den binnenzoom en tegen den clavus aan bruin is; een zwart vlekje aan de spits; membraan breeder met twee bruine strepen, waarvan de langste naar de spits verbreed. Pooten lang, gekleurd als het ligchaam met de dijen aan het eind wel dikker, maar niet eigenlijk knodsvormig.

Van deze buitengemeene soort ving de heer Heylaerts in 
April in de omstreken van Breda twee voorwerpen, waarvan het een wat sterker gekleurd is dan het andere.

\section{Berytus driebergensis Voll.}

Plaat 1 , fig. 9.

Misschien is deze nieuwe soort het mannetje van Clavipes; de heer Six en ik vingen elk een voorwerp van die sexe en bij gebreke aan frischheid der individuen kan ik niet bepalen of onder de yoorwerpen van de genoemde soort ook een mannetje schuilt; het schijnen mij allen wijfjes te ziju. De heer Six noemde deze soort, die hij ook voor onbeschreven hield, immaculatus, doch die naam komt mij minder gepast voor wegens de vlekken in de membraan.

Lengte $4 \mathrm{~mm}$. Geheel okergeel met de dekschilden iets lichter, de uiteinden der dijen en de knods van het $1^{\mathrm{e}}$ lid der sprieten iets donkerder. De kam op den kop is betrekkelijk groot; de voorhoeken van den prothorax zijn puntig. De tip

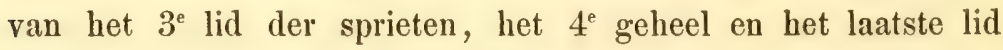
der tarsen zijn zwart. Op de membraan ziet men twee bruine langsstrepen en soms nog een vlekje. Op den buitenhoek van het corium staat een pekzwart stipje en aan de basis der aderen van de membraan fijnere stippen, die echter niet altijd duidelijk zijn.

Misschien is deze soort niets dan eene kleine bleeke verscheidenheid van $B$. minor $\mathrm{H}$. Sch., doch in allen gevalle komt zij niet overeen met de beschrijving, welke Flor van die soort geeft.

Twee voorwerpen, beide mannetjes zijn mij bekend; het eene ving de heer Six bij de Bildt in Augustus, het andere werd door mij in Julij op Sterkenburg bij Driebergen gevangen. ${ }^{1}$ )

1) Ik bezit nog een voorwerp, door den heer Six te Driebergeu gevangen, dat niet tot onze vijfde soort gebragt kan worden, maar ook niet tot een der beschreven soorten; misschien is dit wel eene var. van Minor. Het heeft door beschimmeling te veel geleden om het omstandig te beschrijven. In grootte en in evenredigheid der ligchaamsdeelen is het Driebergensis, doch het is granw van kleur; kop en uiteinden der dijen zijn donkerbruin, zoodanig ook, doch iets meer uit den roode het abdomen. De knods van het 1 e lid der sprieten, de tip van het $2 \mathrm{e}$, die van het $3^{\mathrm{e}}$ en het geheele $4 \mathrm{e}$ lid zijn zwart. Aan de spits van het corium eene zwarte vlek. De mem- 
Het ware zeer te wenschen, dat alle tot nu toe beschreven soorten uit de groep der Beryliden eens bij elkander konden gebragt worden in authentieke exemplaren, ten einde daarvan eene vergelijkende revisie te houden; want het is vrij waarschijnlijk dat er verschillende zullen moeten zamensmelten of zullen blijken niets dan verscheidenheden van vroeger beschrevenen te zijn.

\section{Beryfus elegans Curt.}

Plaat 1 , fig. 10.

Curt. Brit. Ent. IV. pl. 150. - Burm. Handb. II. p. 314. 4. (annulatus Germ.) - Douglas and Scott, Brit. Hem. p. 146 (punctipes).

Lengte $3 \mathrm{~mm}$. Onder de inlandsehe soorten dadelijk herkenbaar, ten eerste an de kleinheid, ten andere aan den pekzwarten kop. De soort is naar evenredigheid korter en meer gezet dan de drie anderen. Fraai helder geel met zwart gevlekt. De glanzig zwarte kop heeft geen vooruitstekenden kam tusschen de sprieten en den hals met oranje gevlekt. De zuiger is bijna doorschijnend. Het $1^{\mathrm{e}}$ lid der sprieten is zoo lang als kop en thorax, naauwelijks dikker an het einde, geel met zwarte ringeltjes, het $2^{\mathrm{e}}$ en $3^{\mathrm{e}}$ zijn even lang, zonder rimpels, behalve an de spits, het $4^{\mathrm{e}}$ lid is zwart met zeer fijne witte beharing. De geheele spriet is veel langer dan het lijf. Thorax gekorreld met een glanzig zwart bandje (of twee dwarsvlekken) achter den gelen voorrand; de achterhoeken knobbelig en op het knobbeltje zwart gevlekt, een fijn zwart langsstreepje in het midden bij den achterrand, die eenigzins omgebogen en wit is. De dekschilden geel doorschijnend, het corium zeer smal, bijna sabelvormig aan het eind, fijn bruin gezoomd; de membraan zeer groot, wit doorschijnend met eene rookkleurige veeg aan de spits en eene andere bij den binnenrand. Abdomen zwartachtig aan de basis. Pooten stroogeel met vele fijne zwarte

braan niet met bruine strepen, maar aan den buitemrand breed met vuilbruine stippen gezoomd. De sexe is onherkeubar. Volgens mijue anteckeningen werd ook de type Berytus minor H. Sch. door den heer Six bij den Haag gevangen, doch ik ben niet geheel zeker van de juistheid mijner determinatie. 
bandjes; knods der dijen ietwat roestkleurig; do twee laatste leden der tarsen zwart.

Van deze fraaije soort ving Dr. Piaget drie exemplaren in het duin, Augustus 1866; de heer van der Wulp zond mij een voorwerp, in Augustus op de duinen van Seheveningen gevonden, alwaar de soort later ook meermalen door den heer Six en mij aangetroffen werd.

\section{Gen. 10. Rhopalus Schill.}

Het ligchaan is bij dit geslacht mede zeer slank en uitgerekt, doch de niet knodsvormige gedaante van dijen en sprieten onderscheidt het duidelijk van het voorgaande. De kop is cylindervormig tot aan de sprieten en tusschen dezen in een stompen kegel verlengd, die door twee naden in drie parallele punten verdeeld is. De oogen en ocellen puilen tamelijk uit; de laatsten staan verder van elkander, dan elke ocel van het oog aan zijne zijde. Het $1^{\mathrm{e}}$ lid der sprieten is iets langer dan de kop, aan de basis scheef naar binnen uitgegroeid, vrij dik; het $2^{\mathrm{e}}$, langer dan het $1^{\mathrm{e}}$, wordt gaandeweg dunner, het $3^{\mathrm{e}}$ is bijna even lang, doch ietwat dunner, het $4^{\mathrm{e}}$ spoelvormig, weinig verdikt en korter dan de helft van het voorgaaude. Prothorax nagenoeg vlak, van achteren iets breeder, weinig kantig op do zijden. Schildje klein, langwerpig driehoekig. Dekschilden korter dan het achterlijf, smal; de membraan grooter dan het corium, met ongeveer 12 aderen bezet. Het achterlijf lang en smal, niet buiten de vleugels aan de zijden, maar ver naar achteren uitstekend. De zeer slanke zuiger reikt tot aan de middelheupen. Pooten lang en slank; de achterdijen dikker, doch niet knodsvormig.

\section{Rhopalus Schillingii Schill. (Schum.)}

Plaat 2, fig. 2 en $2 a$.

Schilling, Beitr. I. p. 55. 7. - Burm. Handb. II. 312. 2. - Curtis . Brit. Ent no. 297. - Herr. Sch. W. Ins. IV. p. 74. tab 131, f. 402.Douglas and Scott, Brit. Hem. p. 139. Pl. 5, fig. 5. 
Lengte 14-16 mm. Lichtgrauw of bruinachtig geel, in het leven soms groenachtig. De spits van den kop aan de tip behaard. Oogen, bijoogjes en sprieten iets donkerder dan het ligchaam. Eerste en tweede lid der laatsten met uiterst fijne haartjes bezet. Prothorax onregelmatig met fijne putjes bezaaid, een middenlijntje ietwat verheven aan de voorzijde in een dwarslijstje uitloopende; in de hoeken hierdoor gevormd twee knobbeltjes. Het schildje met een verheven langsstreepje. Dekschilden tusschen de aderen doorzigtig; membraan glasachtig met doorschijnende aderen. Abdomen aan de bovenzijde met twee donkerbruine of grijze strepen, aan de onderzijde grauw of vuil bruingeel, bij het mannetje met eene purperkleurige streep aan wederzijde; an het laatste lid ziet men bij die sexe kegelvormige uitsteeksels, bij het wijfje eene vrij breede legpijp. De onderzijde der dijen is met korte haartjes stekelig bezet; de spits der achterscheenen en de tarsen zijn gewoonlijk zwartachtig.

Van Junij tot in Augustus niet ongemeen op onze duinen en geestgronden, vooral sommige jaren in aantal aan te treffen op de aren van den helm.

Gen. 11. Mrrmus Hahn.

Dit geslacht heeft groote overeenkomst met het vorige, doch onderscheidt zich in de volgende punten. Het lijf is veel breeder in verhouding tot de lengte; de kop is iets meer breed dan lang; het $1^{\mathrm{e}}$ lid der sprieten is korter dan de kop en de dekschilden en vleugels zijn (ten minste hier te lande) altijd onuitgegroeid. Er bestaat slechts eene soort van:

Myrmus miriformis Fall.

Plaat 2, fig. 3.

Fallen, Hem. I. p. 44. 4. - Hahn, W. Ins. I. p. 82, f. 46 et 47. Schilling, Beitr. I. p. 54. pl. 6, f. 3. - Burm. Handb. II. p. 312. 1.- 
Curtis, Brit. Ent. VII. n 297 (Chorosoma microptera) ${ }^{2}$ ). - Herr. Sch. Deutschl. Ins. 121, 11 en 12. - Flor, Rhynch. Livl. I, p. 186. - Douglas and Scott, Brit. Hem. p. 137. Pl. 5, f. 4.

Lengte $8-9 \mathrm{~mm}$. Fraai papegaai-groen, soms in het gele vallend, met rozenroode verciering. Kop met zeer fijne witte haartjes bezet, achter de oogen geel gekleurd. Oogen vrij bol, roodbruin; ocellen geel, ver van elkander afstaande. Sprieten rozenrood, vrij lang grijs behaard; hun laatste lid bruin. Zuiger tot voorbij de middenheupen reikend, fraai groen doorschijnend. Prothorax breeder dan lang, plat aan de bovenzijde, met gele zijranden; op het midden eene T-vormige figutur, uit fijne bolle lijstjes bestaande. Schild vrij breed. Deksehilden niet verder reikend dan een derde van het abdomen, nagenoeg ovaal met twee rozenroode strepen aan de binnenzijde, grof gestippeld aan de buitenzijde. De membraan ontbreekt; van de vleugels zijn slechts stompjes ontwikkeld. De zijranden van het abdomen bij het wijfje zeer hoog opgezet, bij het mannetje minder; de rug van het achterlijf is bruinachtig, de buik heeft aan wederzijde eene gele langsstreep. Pooten geel, groen of roodachtig met zwarte klaawwtjes aan de tarsen.

Als de vorige in het midden van den zomer op heide- en duingrond, zoo het mij voorkomt, evenwel iets zeldzamer.

\section{Gen. 12. Corizus Fall.}

Ligchaam gezet, niet veel meer dan driemaal langer dan breed, vrij harig en gewoonlijk grof met putjes gestippeld. Kop met de oogen breeder dan lang, tusschen de sprieten in een tamelijk puntig spitsje eindigend. Oogen groot, sterk uitpuilend; ocellen wijder van elkander af staande dan elke ocel van het oog aan zijne zijde. Sprieten iets langer dan de heltt van het ligehaam; hun $1^{e}$ lid het kortst, doch tamelijk dik, 2 en 3 slank en nagenoeg even lang, 4 iets dikker, spoelvormig, langer dan 3. Zuiger tot aan de middenheupen of die van het

1) Wel beschreven, maar niet in plaat gebragt. 
laatste paar pooten reikend. Prothorax aan den achterrand veel breeder dan de lengte, aan den voorrand smaller dan de kop, met nagenoeg regte en vrij kantige zijranden, gewoonlijk met een kort lijstje in het midden, van den voorrand naar den achterrand loopende zonder dien te bereiken; digt bij den voorrand eene dwarsplooi. Schildje iets meer lang dan breed, aan de spits soms ietwat gespleten, meestal lepelvormig nitgehold. Dekschilden zoo lang als het abdomen en dit geheel bedekkend; het corium tusschen de aderen meestal dun, doorschijnend, de membraan gewoonlijk glasachtig; het aantal harer aderen ongelijk. Abdomen op de rugzijde plat met opstaande randen, aan de buikzijde kielvormig. Pooten middelmatig met tamelijk dikke dijen; $1^{\mathrm{c}}$ lid der tarsen zoo groot als, of iets grooter dan de beide anderen te zamen; klaauwtjes en kussentjes zeer groot.

\section{Tabel der soorten.}

1. (6) Corium en clavus tusschen de aderen vliezig en doorschijnend; kleur niet menierood.

2. (5) Achterdijen duidelijk dikker dan de overigen.

3. (4) Schildje van eene kleur . . . . . . crassicornis.

4. (3) Schildje aan de spits vuilwit gekleurd . . capilatus.

5. (2) Achterdijen even dik als de middelsten . - pratensis.

6. (1) Corium en clavus hoornachtig en ondoorschijnend; kleur menierood en zwart . . Hyoscyami.

\section{Corizus crassicornis $\mathrm{L}$.}

Plaat 4, fig. 4.

Linn. S. N. 2. 729, 92. - Fabr. S. Rh. 201. 46. - Fall. Hem. I. p. 41. 1. - Hahn, W. Ins. III. p. 2. pl. 73, f. 227. - Panz. D. Ins. 92. 18. - Burm. Handb. II. p. 306. no 4. - Schilling, Beitr. I. p. 50. tab. 6, f. 2. - Flor, Rh. Livl. I. p. 190. 1. - Douglas and Scott, Brit. Hem. p. 131.

Lengte 7-7,5 mm. - Roodbruin, bruin of bruingeel, kort behaard, aan de onderzijde met witte haartjes. De sprieten bruin- of geelachtig rood met het laatste lid donkerbruin, het 
$1^{\mathrm{e}}$ soms in de lengte zwart gestreept. Het sehildje aan de spits niet lichter, deze eenigzins lepelvormig. Dekschilden tusschen de aderen glasachtig, met den buiten- en achterrand van het corium dikwijls zwart bestippeld. Membraan doorschijnend. Pooten gewoonlijk zwart bestippeld, somwijlen zoo dat zij met plekken zwart zien. Rug van het achterlijf zwart, het $6^{e}$ segment, twee vlekken op het $5^{e}$ en 1 op het $4^{e}$ geel of vuilwit; zijranden van het abdomen oranje of bruingeel met zwarte blokjes. Dijen der achterpooten vrij dik.

Bij Brummen en Driebergen aangetroffen.

\section{Corizus capitatus F.}

Plaat 4, fig. 5.

Fabr. S. Rh. 201. 49. - Fall. Hem. I. p. 42. 2. - Hahn, W. Ins. III. p. 3. f. 228. - Wolff, Ic. Cim. p. 75. tab. 8, f. 72. - Panz. D. Ins. 92. f. 19. - Burm. Hb. II. 307. $\mathrm{n}^{\circ}$ 5. - Schilling, Beitr. I. p. 51. 2. Flor, Rh. Livl. I. p. 192. n 2. - Douglas and Scott, Brit. Hem. p. 133. PI. 5 , lig. 3.

Lengte 6,5-7,5. - Het verschil tusschen deze en de vorige soort is gering en bepaalt zich tot het volgende. Het lijf en vooral de kop is langer behaard. Het schildje is bruinrood met gele of vuilwitte spits, die eenigzins ingekeept is en doordien de zijranden nog al dik zijn, uit twee lamellen schijnt te bestaan. Reeds Fabricius heeft de soorten afgescheiden en alle volgende schrijvers zijn hem gevolgd; evenwel komt mij het kenmerk van verschil te subticl voor en zoude ik dus liever beide soorten ineengesmolten zien. Kweeking wit het ei alleen kan hier bepalen wat waarheid is.

Bij Wassenaar gevangen. Ook in het duin tusschen Scheveningen en den Haag angetroffen door Dr. van Hasselt en mij.

\section{Corizus pratensis Fall.}

Plaat 4, ligg. $6,6 a$ en $6 b$.

Fallen, Hem. I. p. 42. 3. - Hahn, W. Ins. III. p. 4. t. 74, f. 229. IIerr. Sch. W. Ins. VI. p. 2. - Id. D. Ins. 117. 10. (Rhop. parumpuncta- 
tus). - Schilling, Beitr. 1. p. 53. 4. - Burm. Handb. II. p. 307. 6. Flor, Rh. Livl. I. p. 195. 4. - Douglas and Scott, Brit. Hem. p. 135.

Lengte $6,5-7 \mathrm{~mm}$. - Van de beide voorgaande soorten door dunnere achterschenkels onderscheiden; even als dezen veranderlijk van kleur, geel, groenachtig of bruinachtig geel, rood en bruinrood. Kop, thorax en schildje met vrij lange grijze haartjes bezet. Sprieten geel met het $1^{e}$ en het laatste lid rood; somwijlen zijn de drie eersten met zwarte stipjes bezet. De spits van het schildje is tamelijk scherp. Dekschilden tusschen de aderen glasachtig, op de aderen met eenige zwarte stippen. Membraan en vleugels geheel doorschijnend. Abdomen op de rugzijde zwart met gele of roode zijranden, eene ovale vlek op het $4^{e}$ segment, 2 kleinere op het $5^{e}$ en twee bogtige streepjes op het zesde, alles geel of rood. De buikzijde is zwartachtig tusschen de midden- en achterheupen. De pooten gewoonlijk met uiterst fijne donkerbruine of zwarte vlekjes bezet.

De in de Naamlijst (p. 176) vermelde verscheidenheid Tigrimus Schill. onderscheidt zich door grooter aantal van zwarte stippen, die ook grooter van vorm zijn en den schedel en de basis van het schildje geheel bedekken.

Deze soort is vrij gemeen; zij werd in groot aantal door verschillende personen in de Hollandsche duinen aangetroffen; voorts bij Utrecht, aan de Bildt door Dr. van Hasselt en den heer Six, eindelijk op Walcheren door Dr. Herklots.

\section{Corizus Ilyoscyami L.}

Plaat 4 , fig. 7.

Linn. S. Nat. V. p. 496. 76. - Fabr. S. Rh. 218. 63. - Hahn, W. Ins. 1. p. 18. pl. 3, f. 10. - Wolff, 1c. Cim. 27. tab. 3, f. 27. - Panz. D. Ins. 79. 21. - Schill. Beitr. I. p. 49. tab. 5, f. 5. - Curtis, Brit. Entom. no 481 a. - Am. et Serv. Hém. p. 245. 2. - Flor, Rh. Livl. I. p. 196. - Douglas and Scott, Brit. Hem. p. 129. Pl. 5, fig. 2.

Lengte $10 \mathrm{~mm}$. - Menierood, met grijze haartjes bezet en sterk gestippeld. Sprieten en pooten zwart; oogen bruin, van ieder $00 \mathrm{~g}$ tot over de digst daarbij staande ocel eene zwarte vlek. Voorrand van den prothorax en twee groote van voren 
ingekeepte vlekken aan den achterrand zwart. Schildje zwart met roode spits. Clavus der dekschilden zwart; twee kleine vlekjes daartegen aan op het corium en eene groote dwarsvlek op het breedste punt van het corium zwart; membraan rookkleurig. Het achterlijf daaronder zwart. De borst met onregelmatige zwarte vlekken, de buik met drie langsrijen van regelmatige vlekken. Zuiger zwart.

Deze fraaije en zeer kennelijke soort is zeldzaam. De heer Six ving er eenige exemplaren van in het Driebergsche bosch; de heer Ritsema ving een voorwerp bij Beekhuizen den $18^{\text {en }}$ Augustus; de heer Heylaerts trof de soort aan bij Breda, op bloemen van Tanacetum. 


\section{DERDE FAMILIE. - PYRRHOCORIDEN.}

\section{PYRRHOCORIDEA.}

Door een enkelen representant wordt deze eigenlijk uitheemsche familie in onze Fauna vertegenwoordigd. Zij onderscheidt zich van de overigen, wier zuiger uit vier leden bestaat, wier sprieten 4 en tarsen 3 leedjes bezitten, door het gemis van bijoogjes en doordien de beide laatste leden der sprieten even dik zijn als de beide eersten. Daardoor en in vorm en habitus komen zij het naast met de Lygaeoden overeen, terwijl het gemis van ocellen hen nader bij de Capsinen brengt. Daar wij in deze familie slechts een geslacht kennen, vallen de familie. kenmerken met die van het genus te zamen.

Gen. unicum. Pyrrhoconis Fall.

Ligehaam gestrekt eivormig, boven plat, onder bol. De kop vormit van den achterrand der oogen af gerekend, of met andere woorden zoo ver zigtbaar, een gelijkzijdigen driehoek aan wederzijde bezet met een klein knobbeltje, waarop de sprieten. Deze bereiken in lengte de helft van het ligchaam en bestarn uit 4 leedjes, waarvan het $1^{\mathrm{e}}$ zoo lang als de kop tusschen de oogen breed, een weinig krom en knodsvormig is, het tweede iets langer cylindrisch, zeer weinig dikker aan het eind, het derde korter dan het $1^{e}$ en vrij dik aan het einde, het $4^{e}$ aan de tip afgerond bijna zoo lang als het $1^{e}$. De oogen zijn vrij groot en bolrond; bijoogies ontbreken. De zuiger heeft 4 leedjes en reikt tot even voorbij de middenheupen; het $1^{\mathrm{e}}$ en $2^{\mathrm{e}}$ lid schier even lang, het $3^{\text {e }}$ korter, het $4^{\text {e }}$ weder korter. De prothorax aan de rugzijde een trapeziumvormig plat schild, aan de zijden flaauwelijk ingebogen en langs die zijden als gezoomd; dwars over het midden eene gleuf en het gedeelte tusschen 
deze en een' bogtigen rimpel achter den voorrand kussenachtig verheven. Het schildje een gelijkzijdige driehoek met vrij scherpe spits. Dekschilden zonder cuneus en membraan, alzoo het abdomen niet geheel bedekkende, aan den zijrand bij de basis een weinig opgewipt. Pooten vrij lang en forsch, vooral met zware sterk uitgezette dijen; de voorheupen staan vrij ver af van de middenheupen, de voorste dijen hebben eenige tandjes aan de onderzijde. Tarsen met drie leedjes, waarvan het eerste zeer lang, het tweede zeer klein; klaauwtjes eenvoudig, daartusschen twee zuiglapjes. Aan de onderzijde het ligehaam gewelfd, met opgezette heuppannen en geene slenf aan keel of borst voor den zuiger. Het $6^{\text {e }}$ abdominaalsegment bij het mannetje regt afgesneden en de daardoor ontstaande opening bijna verticaal door de genitaal-plaat gevuld.

\section{Pyrrhocoris apterus $\mathrm{L}$.}

Plaat 4, fig. 8.

Linn. S. N. V. p. 496. 78. - Fabr. S. Rh. 227. 116. - Burm. Handb. II p. 286. 12. - Am. et Serv. Hémipt. p. 269. 1. - Curtis, Brit. Ent. X. tab. 4h5. - Hahn, W. Ins. I. p. 19, f. 11. - Stoll, Wants. p. 49. tab. 15. f. 103. - Wolff, Ic. Cim. p. 108. tab. 11, f. 102. - Flor, Rh. Livl. I. p. 212. - Douglas and Scott, Brit. Hem. p. 164. Pl 6, f. 3.

Lengte $9-10 \mathrm{~mm}$. - Zwart met eer̂? olieachtigen glans en roode versierselen. Van de laatste kleur zijn de randen van het borststuk (soms zeer breed), het corium der dekschilden behalve twee vlekken van de grondkleur op ieder (van deze beide vlekken is de bovenste klein, de onderste zeer groot, eirkelrond), de zij- en achterrand van het abdomen en de heuppannen. Dikwijls zijn ook de achterranden van meso- en metastethus rood.

Deze soort komt op sommige plaatsen in geheele scholen voor; zij is onder anderen aangetroffen op Walcheren en bij Zierikzee, bij Utrecht en Driebergen, bij Katwijk en Scheveningen. Mijj zijn geene inlandsehe voorwerpen met ontwikkelde membraan bekend, zoo als dikwijls in het zuiden van Europa en somwijlen zelfs in de omstreken van Dresden worden aangetroffen. 


\title{
VIERDE FAMILIE. - LYGAEODEN.
}

\author{
LYGAEODEA.
}

Met deze familie is het, wat de naamgeving betreft, even als met de tweede moeijelijk om eene gepaste Hollandsche benaming uit te denken. Het is mogelijk dat de naam Lygaeus, door Fabricius het eerst gebezigd en die in het Griekseh donker beteekent, afgeleid is van de kleur van eenige soorten; doch men weet dat Fabricius niet altijd even veel gaf om de beteekenis der namen die hij uitkoos, en alleen verlangde dat zij kort zouden zijn en welluidend; men mag dus aannemen dat de gedachte aan donker coloriet hier geheel op den achtergrond moet treden, zoo veel te meer voor ons, daar het geheele geslacht $C y m u s$ nict dan licht gekleurde soorten aan te wijzen heeft. Ik heb den naam Lygaeodea dus onvertaald gelaten, maar met een Hollandschen uitgang gebezigd.

De gedaante dezer dieren in het algemeen is nog al afwisselend; die der eenige soort van het geslacht Lygaeus stemt in habitus en kleur met de Pyrrhocoriden overeen; de beide geslachten, die daarop volgen gelijken eenigzins op Coreoden, het geslacht Cymus op de Capsinen, Zosmemus op de vliezige wantsen (Tingididen) en Ophthalmicus staat geheel op zich zelf. Het is dus vrij moeijelijk eene mivere schets van de eenigzins heterogene familie te geven. Wij zullen het nogtans b proeven.

De kop is zeer verschillend in breedte, doch altijd driehoekim van vorm en niet ver vooruitstekend. De oogen zijn middelmatig, behalve bij het geslacht dat er zijnen naam aan ontleert Ophlhalmicus, en staan op de zijden van het hoofd; gewoonlijk raakt hun achterrand den voorrand van den prothorax aan; de bijoogjes zijn bij alle soorten zigtbaar en staan op den schedel, elk digter bij het oog aan zijn' kant dan bij het andere 
bijoogje. De sprieten, die uit vier leedjes bestaan, zijn gewoonlijk draadvormig, somwijlen met een iets dikker eindlid; hun eerste lid is het kleinste en is ingeplant op een kort knobbeltje aan de zijde van den kop voor de oogen. Bij Zosmenus ziet men tusschen hen, voor aan den kop twee uitspringende doorntjes. De zuigerscheede bestaat uit vier leedjes, waarvan de twee middelsten in den regel de langsten zijn.

Het borststuk is meestal bijna vierkant of trapezium-vormig, op den rug gezien; het loopt van digt aan de basis naar den kop toe hellend af en heeft in het midden of even daarvoor dikwijls eene dwarsgleuf. Het schildje is altijd driehoekig en nimmer meer dan middelmatig van grootte.

De dekschilden komen in vorm met dezelfde deelen bij de vorige familie overeen. Op het leder kan men gewoonlijk twee langsaderen herkennen, waarvan de eene meest gevorkt is; ook op het sluitstuk ziet men somwijlen cene ader in de lengte. De membraan vertoont nooit meer dan 5 aderen, welke gewoonlijk niet door dwarsaderen verbonden zijn; bij het geslacht Zosmenus bestaat de membraan uit een eenigermate hoornachtig en een vliezig gedeelte, 't geen een bijzonder merkwaardige afwijking is van den gewonen regel. Bij enkele individuen van sommige soorten uit andere geslachten ontbreekt de membraan wel eens geheel of gedeeltelijk.

De pooten zijn gewoonlijk vrij lang, doch zeer verschillend in dikte; de voorpooten zijn bij verscheidene geslachten veel dikker of eenigzins dikker dan de midden- en achterpooten, meestal zijn zij in dat geval ook gedoornd. Aan de tarsen ziet men bij allen drie leedjes, waarvan het eerste meestal het langste is en het laatste met twee klaauwtjes en twee zuiglapjes gewapend; an de onderzijde is het eerste lid digt met kleine haartjes bezet. De heupen van elk paar pooten staan digt bij elkander. Op de borst ziet men nimmer eene gleuf voor den zuiger.

Aan het abdomen telt men zes segmenten en de organa generationis; deze laatsten zijn bij de verschillende genera zeer sterk op elkander gelijkend. 
Men treft de Lygaeoden op en onder planten aan; het is waarschijnlijk dat zij van de sappen uit den stengel en de laagste bladstelen leven, hoewel Burmeister verzekert dat zij Lun voedsel trekken uit de vochten van doode insecten, die zij niet zelf gedood hebben.

\section{Verdeeling der geslachten.}

1. (26) Kop zonder doorntjes of hoorntjes tusschen de oogen.

2. (25) Oogen kleiner dan een vierde gedeelte van den kop, op den schedel gezien.

3. (8) Geen drie gesloten cellen aan de basis der membraan.

4. (5) Het $4^{e}$ en $5^{e}$ buiksegment bij het wijfje duidelijk herkenbaar en met regten achterrand. Kleur grootendeels menierood.

Gen. 1. Lygaeus F.

5. (4) Het $4^{e}$ en $5^{e}$ buiksegment bij het wijfje of alleen het $5^{\text {e }}$ niet zigtbaar en onder het derde teruggetrokken. De kleur nimmer menierood.

6. (21) Eerste lid der achtertarsen langer dan 2 met 3.

7. (8) Ligchaam verbreed, buik zeer plat.

Gen. 2. Gastrodes Westw.

8. (7) Ligchaam niet in het oog vallend breed; buik eenigzins of zeer uitpuilend.

9. (10) Rug van den thorax zonder rand in de zijden overgaande.

Gen. 3. Plociomerus Say.

10. (9) Rug van den thorax door een rand of kant van de zijden afgescheiden.

11. (12) Zijden van den thorax met een platten, scherpen zoom.

Gen. 4. Pachymerus Lepel.

12. (11) Zijden van den thorax zonder platten, scherpen zoom.

13. (14) Ligchaam lineair met de zijden evenwijdig.

Gen. 7. Iscunocoris Fieb.

14. (13) Ligchaam niet lineair, in de zijden niet evenwijdig.

15. (18) Borststuk op den rug met eene dwarsgleuf. 
16. (17) Oogen niet sterk uitpuilend.

Gen. 5. Drryus Fieb.

17. (16) Oogen groot en zijdelings uitpuilend.

Gen. 9. Acompus Fieb.

18. (15) Borststuk zonder dwarsgleuf.

19. (20) Ligehaam niet plat en blinkend.

Gen. 6. Peritrechus Fieb.

20. (19) Ligchaam plat en blinkend.

Gen. 8. Plintuisus Latr.

21. (6) Eerste lid der achtertarsen korter dan 2 met 3.

22. (23) Achterrand van het borststuk naar voren ingebogen.

Gen. 10. Mrgropus Spin.

23. (22) Achterrand van het borststuk naar achter nitgebogen.

Gen. 12. Cymus Hahn.

24. (3) Drie gesloten cellen an de basis der membraan, welke niet over het achterlijf heenreikt.

Gen. 11. Heterogaster Sehill.

25. (2) Oogen zoo groot of grooter dan een vierde gedeelte van den kop, op den schedel gezien.

Gen. 13. Ophthalmigus Hahn.

26. (1). Twee hoorntjes of doorntjes voor an den kop, waarschijnlijk de zijdelingsche lappen van het aangezigt, tot uitsteeksels verlengd.

Gen. 14. Zosuenus Cast.

\section{Genus 1. Lygaeus F.}

Ligchaam langwerpig ovaal, doch de afronding vooraan door de driehoekige gedaante van den kup gewijzigd. De kleur der Europeesche soorten van dit geslacht rood en zwart; exotische soorten meest oranje. De kop driehoekig, minder lang dan breed met bolle, uitpuilende oogen; de sprieten van vier leedjes; 
het eerste slechts weinig voorbij de spits van den kop uitstekend; het tweede meer dan dubbel zoo lang; het derde korter dan 2 , langer dan 1 en het laatste iets langer dan bet $3^{\text {e. }}$. De zuiger reikt tot de midden- of achterheupen; zijn eerste lid langer dan de kop. Het borststuk veel breeder dan lang, naar voren smaller wordend, aan de vier hoeken afgerond, doch sterker nog aan de achter- dan wel aan de voorhoeken. Het schildje niet veel korter dan het halsschild lang is, puntig driehoekig. De vleugels iets langer dan het abdomen, het corium en de clavus zonder puntjes; de membraan met 5 gekromde, uit de basis voortkomende aderen. Pooten vrij lang en tamelijk dik, zonder iets bijzonders. De doorsnede van het abdomen een afgeronde ezelsrug; de spits van het achterlijf bij het wijfje als afgerond.

\section{Lygaeus equestris L.}

Plaat 4 , fig. 9.

Linn. S. Nat. V. p. 496. 77. - Fabr. S. Rh. 217. 57. - Wolff, Ic. Cim. p. 24. tab. 3, f. 24. - Schill., Beitr. I. p. 58. tab. V, f. 4.-Hahn, W. Ins. I. p. 21, fig. 12. - Burm. Handb. I1. p. 298. 3. - Panz. Fn. Germ. 79. 19. - Curtis, Brit. Ent. X. 481. - Flor, Rh. Livl. I. p. 223.

Lengte 10-11 mm. - Rugzijde rood met zwarte teekening; aan de onderzijde de kop en de geheele thorax dofzwart, het abdomen rood met zwarte vlekken. Oogen bruin, sprieten en pooten zwart.

Op den kop een helderroode vlek in ruitvorm; over den prothorax op de achterhelft een roode dwarsband, naar voren driemaal en naar achteren mede driemaal uitstekend, het breedst an de zijden; schildje dof donkergrijs met een verheven langsstreepje, dat soms rood is.

Dekschilden rood, op den clavus twee ronde zwarte vlekken en onder iedere eene bruine veeg; op het corium eene gegolfde zwarte dwarsband, die naar de zijden het breedst is. Op de zwarte membraan, die wit omzoomd is, in het midden een ronde witte schijf, daar boven een half maantje en op zijde 
een driehoekje, iets doffer wit. Buik rood met aan iedere zijde eene rij van 5 vierhoekige zwarte vlekjes en op zijde van de kielvormige verhooging twee rijen van 3 zwarte streepjes en daaronder een breede zwarte dwarsstreep. Het laatste segment en de genitalien zwart.

Eene bij ons hoogst zeldzame soort. De collectie der N. E. V. bezit een vrouwelijk ex. door den Heer Gerlach in Friesland gevangen. In Engeland schijnt deze soort niet voor te komen.

Gen.2. Gastroues Westw.

Dit geslacht, door Schilling Platygaster genoemd (welke naam echter ook in andere orden voorkomt en dus te regt in Gastrodes veranderd is) bevat de beide eerste soorten van mijn vroeger geslacht l'achymerus, waarin ik soorten bijeen voegde, die in ligehaamsbouw wel wat al te sterk verschillen, ofschoon zij toch allen overeenkomen in de kenmerken die men aldaar opgegeven vindt (zie Tijdschr. v. Ent. XIII, 1870). Gastrodes onderscheidt zich hoofdzakelijk van de overige geslachten door het zeer breede en platte ligchaam, 't geen het dier in staat stelt zijn winterkwartier tussehen de schubben der sparrenkegels te houden.

Kop klein, driehoekig, zoo lang als met de oogen breed. Sprieten een weinig langer dan het halve ligchaam, slank, van 4 leedjes, het eerste zeer klein. Borststuk met afgeronde roorhoeken van voren smal, aan de zijden eenigzins ingebogen, aan den achterrand bijna 2 maal zoo breed als voor, in het midden met eene gebogene gleuf ingedeukt. Schildje tamelijk groot, driehoekig plat. Dekschilden naar achteren verbreed; membraan groot zonder cellen. Buik ongewoon plat. Pooten vrij lang en slank, behalve de voordijen, die zeer dik zijn en aan den voorkant even voorbij het midden een fijn, scherp tandje vertoonen. 


\section{Gastrodes Abielis L.}

Plaat 5, fig. 1.

Linn. S. Nat. V. 505. 115. - Fabr. S. Rh. 256, 16. - Panz. D. Ins. 92, 22. - Schill. Beitr. I. p. 83. 2. - Flor, Rh. Livl. I. p. 233. Dougl. and Scott, Brit. Hem. I. p. 167.

Lengte $7 \mathrm{~mm}$. - Kop zwart, vrij puntig naar voren uitstekend, doch niet veel langer dan breed. Oogen bruinzwart, tamelijk uitpuilend, daarachter een zeer smal halsje. Sprieten zwart, het eerste lid roodachtig en niet of slechts even uitstekend voorbij de spits van den kop, lid 2 veel langer dan 3, 3 iets langer dan 4 . Prothorax aan de voorzijde zwart met een geel randzoompje, dan rood met bruinen tint en zwarte stippeltjes. Schildje groot, breed, zwart met eenigen glans. Dekschilden licht geelachtig bruin of lederkleurig met twee bruine vegen een op het corium tegen den clavus aan, de andere wigvormig staande op den achterrand van het corium; membraan lederkleurig met donkerder aderen, die zeer fijn zijn; een lichtgekleurd vlekje in den bovenhoek, een ander een weinig daaronder. Pooten geelachtig rood; de voordijen zeer dik met een' doorn aan de onderzijdo in het midden en eene rij tandjes aan het uiteinde onder de knie; voorste scheenen naar binnen krom gebogen. Borst dof. zwart, buik van do kleur der pooten.

Van deze soort verkreeg ik toevalliger wijze in Maart vele exemplaren op de Gliphoeve; mijn zoontje amuseerde zich met het zamelen en verkruijen van sparrenkegels in een kinderkruiwagentje; het stooten en hotsen deed de dieren hunne schuilplaatsen verlaten en het jongetje kwam zich bij mij beklagen dat zijn kruiwagen altijd onder het rijden vol werd met beesten. Abietis werd voorts door den heer van Walchren te Brummen aangetroffen.

\section{Gastrodes ferrugineus L.}

Plaat 5, fig. 2.

Linn. S. Nat. V. p. 501, 99. - Schill. Beitr. 1. p. 82. 1. tab. 7, lig. 7. - Burm. Handb. II. p. 295. - Hahn, W. Ins. III. p. 34. fig. 254. - 
Flor, Rh. Livl. I. p. 235. - Douglas and Scott, Brit. Hem. p. 168. Pl. fig. 4 .

Lengte $7 \mathrm{~mm}$. - Men kan deze soort na de vorige genoegzaam beschrijven door alleen maar de punten van verschil op te geven, welke tusschen beiden bestaan. De kleur der lichte ligchaamsdeelen is bij deze niet geelachtig rood, maar bruinachtig rood, naar kersrood trekkende. De sprieten zijn of geheel rood, of ten minste de twee middelste leden; lid 1 springt verder vooruit en lid 2 is in verhouding daarvan korter dan bij Abietis. Aan het voorste deel van het borststuk ontbreekt het geele randje aan de zijden. De dekschilden en de membraan zijn ongevlekt; de laatste is donkerder van tint.

Van deze soort welke voor jaren reeds duor den heer Gerlach in Friesland was angetroffen, ving de heer Weyenbergh in den Aerenhout bij Haarlem in Januarij eenige exemplaren en de heer Ritsema bezorgde mij eene larve, in Angustus bij Overveen gevangen. Ook werd een voorwerp in de inlandsche verzameling van Perin aangetroffen.

\section{Gen. 3. Plociomenus Say.}

Dit geslacht, eene enkele inlandsche soort bevattende, onderscheidt zich van alle andere geslachten die vroegrer tot het classieke Pachymerus geteld werden, door de bijzonderheid dat de rug van het borststuk zonder kant of hoek te vormen in de zijden overgaat; alleen bij sommige voorwerpen ziet men iets dat naar een rigeheltje gelijkt, ter plaatse waar anders de zijkant moest zijn. Het borststuk is bovendien zoo sterk ingesnoerd dat het uit twee onderscheidene deelen schijnt te bestaan. De zeer dikke voordijen hebben aan den voorkant twee langere puntige stekeltjes, het eerste even voorbij het midden, Let andere nader bij de knie, waar nog een kleiner doorntje staat; de tarsen zijn zeer lang, met het eerste lid langer dan het $2^{\mathrm{e}}$ met het $3^{\text {e }}$, zijnde het middelste zeer kort. De overige kenmerken zijn in de beschrijving der soort bevat. 
Plociomerus fracticollis Schill.

Plaat 22, fig. 3.

Schill. Beitr. I. p. 82, tab. 7, fig. 6. - Ilahn, W. Ins. I. p. 66. tal. 10, fig. 40. - Flor, Rhynch. Livl. I. p. $229, \mathrm{n}^{0}$ 2. - Douglas and Scott, Brit. Hem. p. 170. Pl. 6, fig. 5.

Lengte 5-6 mm. - Kenbaar aan de sterke insnoêring van het borststuk en de 2 bruingele vlekjes daarachter. Kop ietwat uitgerekt, zwart met fijn grijs vilt bedekt; oogen groot met grof netwerk. Sprieten langer dan de helft van het lijf, harig; $1^{\mathrm{e}}$ en $4^{\mathrm{e}}$ lid tamelijk dik, zwart; $2^{\mathrm{e}}$ en $3^{\mathrm{e}}$ slank, bruin. Zuiger geel, reikende tot bij de middenheupen. Borststuk door eene insnoering in 2 bijna even lange helften verdeeld, de eerste klokvormig zwart, de andere aan den achterrand veel breeder dan aan den voorrand, zwart met gelen achterzoom en twee bruingele vlekken in het midden. Schildje zwart met witte spits. Dekschilden geel met donkerbruine marmering, die de basis en den buitenrand vrijlaat en het donkerst is aan den binnenhoek van het corium, waar op dien donkeren grond een driehoekig geel vlekje uitkomt. Membraan rookkleurig met donkere vlammen tusschen de aderen Onderzijde zwart met den buik wat gebronsd. Pooten geelrood met de uiteinden der 4 achterste dijen bruin.

Mij zijn vier voorwerpen dezer soort bekend, twee gevangen bij Breda in het begin van Mei door den heer Heylaerts en een mede in Mei gevonden door den heer van Medenbach de Rooij in de omstreken van Arnhem. Het vierde vond de heer Leesberg in October bij den Haag.

Gen. 4. Pachymerus Lepel.

Na al hetgeen dit geslacht an de beide voorgaanden en de zes volgenden moet afstaan, blijft het slechts een elftal soorten meer bevatten, die nu evenwel meer overeenkomst in vorm en habitus aanbieden ofschoon er nog genoeg specifieke verschil. 
len overblijven, welke Fieber en zijne volgelingen er toe gebragt hebben de Europeesche soorten van het genus in meer dan 13 genera te versplinteren.

De kop is bij allen van boven gezien driehoekig, smaller dan de voorrand van den thorax, wiens voorste hoeken zijn afgerond. De sprieten zijn iets langer dan de helft van het ligchaam; uit 4 leden bestaande, waarvan het eerste altijd het kleinste en het tweede dikwijls het langste is. De zuiger reikt tot aan of even over de middenheupen. Het borststuk is altijd, soms zelfs opmerkelijk aan de zijden uitgezet in een breeden, platten zoom, en gewoonlijk door eene dwarsgleuf in twee ongelijke deelen verdeeld. Het schildje is groot, plat, driehoekig, puntig an de spits. De dekschilden zijn gewoonlijk even breed als het borststuk, zelden iets breeder; hunne membraan heeft geene cellen aan de basis, maar 5 geslingerde aderen en reikt tot even over het achterlijf; dit is eenigzins uitgezet, bol aan den buik en slechts bij een paar soorten breeder dan de dekschilden. De pooten zijn slank, vrij lang; de voordijen dik opgezwollen, met 1 groot eu soms nog een of twee kleine tandjes aan den voorrand; de achterscheenen zijn meest met stekeltjes bezet. Het eerste lid der tarsen is langer dan lid 2 en 3 vereenigd.

De soorten leven op lage heesters en kruiden.

\section{Pachymerus griseus Wolff.}

Plaat 22, fig. 5.

Wolff, Ic. Cim. p. 113. tab. 11, f. 107. - Panz. Faun. Germ 118, 7. - Fallen, Fn. Suec. 52, 8 (Pilifrons). - Fieber, Eur. Hem. p. 197, no 1 et 2 (Emblethis).

Lengte $7 \mathrm{~mm}$. - Langwerpig ovaal, vrij plat, boven lederkleurig bruingeel; onder zwart, gemakkelijk te verwisselen met Marginepunclatus Wolff. De punten van verschil tussehen beiden zijn echter tamelijk talrijk. Griscus is grooter, geler, heeft stijve borsteltjes op de spits van den kop, een' anderen omtrek van het borststuk en fijuer maar donkerder bestippeling op den 
zijrand. Ik heb vroeger beideu voor ééne soort gehouden.

Kop driehoekig met de zijranden een weinig naar binnen gegolfd, de spits toegerond en bezet met korte stijve borsteltjes; twee donkere vlekken op den schedel. Oogen bol, rond, donkerbruin; voor ieder oog een borsteltje. Sprieten iets liorler dan het halve lijf, nootgeel, sterk beborsteld, aan beide uiteinden iets donkerder. Zuiger reikende tot aan het tweede heupenpaar, aan de basis geel, verder op zwart. Borststuk aan den voorrand sterk naar biunen gebogen, aan de gebogen zijranden plat verbreed, aan den achterrand flaauwelijk naar binnen gebogen, in het midden zeer weinig bol; de voorhelft niet zoo digt gestippeld als de achterhelft; de zijianden met donkerbruine vlekjes bezaaid. Schildje groot, in de hoeken met een donker vlekje en daarvoor een lichter. Dekschilden aan den zijrand met driehoekige donkere vlekjes; hunne membraan bruinachtig met witte druppeltjes bezaaid. Rand van het abdomen met vrij groote bruine vlekken getijgerd. Pooten geel met rijen van donkere stippels; voordijen dik met 6 stekeltjes van onder; scheenen met rijen van 6 of 7 borsteltjes, tarsen aan de spits donkerder. Onderzijde zwart, met geel aan de naden van het borststuk en gele vleklien om de heuppannen; buik met rooden gloed.

Twee voorwerpen van deze nieuwe soort werden 12 Aug. op Walcheren bemachtigd door den heer La Fontijn, die er mij met zijne gerwone welwillendheid een van ten geschenke gaf.

Of deze soort de Cimex arenarius is van Linnaeus' Fauna Succica, zoo als Fieber wil, kan ik niet bepalen. Wolff's afbeelding is zeer ongelukkig, zijne beschrijving dragelijk. Hield ik vroeger Griseus en Marginepunclatus voor een, het komt mij nu nog voor dat Fieber's Plalychilus in al te minutieuse punten verschilt om er iets anders dan eene zuidelijke verscheidenheid in te erkennen.

2. Pachymerus marginepunctalus Wolff.

Plaat 6 , fig. 4 .

IVolf, Ic. Cim. p. 150. tab. 15, f. 144. - Schill. Beitr. I. p. 71 , no 11. tab. 6, f. 8. - Ilahn, W. Ins. I. p. 52. tab. 8, fig. 32. 
Lengte 4-6 mm. Geheel grijs, kenbaar bovendien aan het boven op platte en vierkante halsschild. Kop breed, doch met de oogen nog iets smaller dan de voorrand van den thorax, gestippeld. Oogen vrij groot, zwart. Sprieten iets langer dan het halve lijf, graw met eenige weinige stijve haartjes bezet; het tweede lid langer dan het derde, het vierde dikker dan de overigen en spoelvormig. De thorax plat, achter slechts weinig breeder dan voor, met de dwarsplooi duidelijk over de helft der lengte, met vele stipjes bezet, die aan de eenigzins doorschijnende zijranden tot vlekjes zijn opgehoopt; in het midden van den voor-, en evenzoo van den achterrand een klein wit drichoekje; schildje langiverpig. Dekschilden aan de buitenranden met dwarsstreepjes getijgerd, de aderen zeer fijn bruin omzoomd met stippeltjes daar tusschen. Membraan met bruine aderen en bruine vlekjes daar tusschen. Onderzijde rrij donker grijs met lichte naden; pooten grauw met gele heupen en knieen.

Door den heer Six in April aan de Bildt en in den zomer te Driebergen gevangen, bị Utreeht door Dr. van Hasselt, bij Wassenaar in April door Mr. H. W. de Graaf, door mij in Aug. bij Rozendaal en Velp in Gelderland en op de Hollandsche duinen. Somtijds bij Scheveningen en Waalsdorp gemeen onder Galium.

\section{Pachymerus Pini L.}

Plaat 6 , fig. 1 en $1 a$.

Linn. S. N. V. 500, 96. - Fabr. S. Rh. 229, 125. - Hahn, W. Ins. I. p. 38. Tab. 7, f. 25. - Schellenberg, 12. tab. 2, fig. 2. - Schill. Beytr. I. p. 64. tab. 5, fig. 3. - Wolff, Ic. Cim. 74. tab. 8, f. 71. Burm. Handb. II. p. 296. no 6. - Flor, Rh. Livl. I. p. 269. - Douglas and Scott, Hem. Brit. p. 173. Pl. VI. fig. 6.

Lengte 7-7,7 mm. Kenbaar aan zijne bijzondere grootte. Zwart, het mannetje glanzig, het wijfje dof. Kop schier zoo lang als breed, met grootte bolle oogen. Sprieten langer dan de helft van het ligchaam, zwart: lid 1 reik $\iota$ een eindje voorbij de spits van den kop; 2 , 3 en 4 van gelijke dikte, 2 en 4 
even lang, 3 iets korter. De zuiger reilkt tot an de middenheupen. Thorax aan den voorrand iets breeder, an den achterrand veel breeder dan de kop, met bol gebogen zijranden; bij het mannetje is het midden van het voorste gedeelte vrij bol verheven en zijn de zwarte zoomen eenigzins opgewipt, bij bij het wijfje is dit minder sterk uitgedrukt; de breede achterrand is of (zie fig. 1) donkergrauw met zwarte stippen en twee ovale vlekken aan de zijden, benevens een zeer smal lijntje in het midden lichter grauw, bịna geel, of wel (zie fig. $1^{a}$ ) in het midden zwart en aan iedere zijde bezet met cene onregel. matige lichtgrauwe, zwart gestippelde vlek. Het schildje is tamelijk lang, zwart. De dekschilden zijn vuil stroogeel met eene menigte zivarte puntjes, die rijen vormen om de aderen, bezaaid. Op den clavus tegen het schildje staat eene zwarte eenigzins gebogen streep en op het corium, niet ver van den binnenhoek eene zwarte fluweelachtige vlek, die uit twee vlekjes, eeu langwerpig en een eirond schijnt te zijn zamengesteld. De membraan is zwart met cen zeer fiju geel zoompje en een naauwelijks bespeurbaar vuilwit driehoekje aan den rand. Het achterlijf van het mannetje aan de onderzijde gebronsd, door eene zijdeachtige bekleeding. De pooten lang en slank, zwart, dikwijls met bruine voorscheenen; de voordijen tamelijk dik, aan de onderzijde met eene soort van gleufje en een' zeer sterken tand.

Linnaeus noemde deze soort Cimex Pini, omdat zij niet on gemeen is in streken waar jonge dennen groeijen; indien hij hare levenswijs beter gekend had, zou hïj haar waarschijnlijk Ericae genoemd hebben, want zij leeft onder de struikjes der gewone heide. In onze provincien Utrecht en Gelderland is zij niet zeldzaam; de heer G. A. Six ving haar meermalen bij Driebergen, de heeren van Walchren en van Bemmelen te Brummen, de heer de Graaf bij de Bildt in September, ik bij Hilversum, op Sterkenburg, to Rhede, te Velp en te Brummen, meest in Augustus, doch ook in Mei en October; ook werd zij bij Delft aangetroffen door Mr. Leesberg. - Merkwaardig is het dat de heeren Pollen en van Dam op Nossi-Bé bij Mada- 
gascar eene soort van $P$ achymerns vingen, die schier niet ran Pini verschilt.

\section{Pachymerus Lynceus F.}

Plaat 6 , fig. 3.

Fahr. S. Rh. 231, 137. - Herr. Sch. Fn. Germ. 118. f. 10. - Schill.

Beitr. I. p. 66 , tab. 5, f. 7. - Hahn, W. Ins. I. p. 44, tab. 8, f. $28 .-$ Flor, Rhynch. Livl. I. p. 273. - Saunders Synops p. 147. n $\mathrm{n}^{0} 3$.

Lengte 7 mm. - Tamelijk grlanzig zwart. Kop met de oogen veel breeder dan lang, doch smaller dan de voorrand van het borststuk. Sprieten geheel zwart, iets langer dan het halve lijf, lid 1 een weinig voorbij de spits van den kop uitstekend, 2 iets langer dan 3,3 en 4 bijna gelijk. Het halsschild breeder aan den achter-, dan aan den voorrand, met bol gebogen zijden; de dwarsgleuf voorbij de helft en daarachter de oppervlakte grof gestippeld. De zijranden zijn tamelijk breed lichtgeel, smal wegvloeijende naar den achterrandshoek. ${ }^{1}$ ) Schildje zwart, met twee zeer fijne naar elkander hellende gele streepjes. De dekschilden licht geel, doch zoo sterk met zwarte stipjes overdekt, dat zij daardoor donkergrauw schịnen; aan den binnenhoek ziet men op het corium eene groote, min of meer schildvormige, donkerzwarte vlek, waarin geheel tegen den achterrand, weder eene kleinere ruitvormige witte; membraan gemarmerd licht en donkergrauw met witte aderen. Zuiger tot de voorste heupen reikend, zwart. Pooten sterk en tevens lang, geheel zwart, behalve de voorscheenen, die bruinachtig geel zijn met zwarte spits. De voordijen zeer opgezwollen met een' zeer stevigen doorn en eenige fijne tandjes aan de onderzijde.

Ik ving eenige voorwerpen van deze soort in de duinen; aan een dezer steekt een etiquet, waarop te lezen staat: Wassenaar, 17 April. De overigen komen van Scheveningen en Katwijk. Ook trof ik er cenmaal een in Mei bij Bennebroek op den

1) Flor beschrijft het achterste derde gedeelte van het halsschild als geel met zwarte stipjes; zijne exemplaren waren dus bijzonder licht van tint. 
straatweg aan. Andere voorwerpen werden gevangen in het duin bij Waalsdorp (Six), bij den Haag en Loosduinen (Dr. v. Hass.); aan het Ginneken bij Breda, 3 April (Heylaerts).

\section{Pachymerus quadratus $\mathrm{F}$.}

Plaat 6, fig. 2.

Fabr. S. Rh. 232 , 141. - Schill., Beitr. I. p. 66 , tab. V, fig. 6. Herr. Sch. Fn. Germ. 118, 9. - Hahn, W. Ins. I. p. 50, tab. 8, f. 31.Saunders, Synopsis, p. 147, no 4 .

Lengte $6 \mathrm{~mm}$. - Zwart met vuilgele versierselen. Kop met de vrij sterk uitpuilende oogen even breed als de voorrand van het halsschild. Sprieten iets langer dan het halve lijf; het $1^{\mathrm{e}}$ lid naauwelijks voor den kop nitstekend, zwart met lichter spits; het $2^{e}$ rood-bruinachtig geel met zwarte spits; de beide overigen zwart; 4 kleiner dan 3. Thorax van boven bijna vierkant met bol gebogen zijkanten, vuilgeel, met eene groote vierhoekige vlek op het voorste gedeelte slechts van den voorrand afgescheiden door drie kleine gele driehoekjes; breede gele achterrand met bruine stippeltjes. Schildje zwart, iets langer dan breed. Dekschilden vuilgeel, met een' bruinen gloed overtogen behalve aan den zijrand. Aan iedere zijde van het schildje op den clavus eene zwarte streep en op het corium eene groote ruitvormige vlek, die met eene zijde op den achterrand rust. Membraan wit met bruinen eenigzins bronskleurigen gloed in het midden en lichtbruine aderen. Onderzijde van het lijf zwart, behalve de achterranden van pro-en metathorax; ook de metathorax heeft een zweem van een geel zoompje. Heupen geelbruin, dijen zwart, scheenen lichtbruin, tarsen iets donkerder. De beenen ziju slank, vooral de achterpooten; ie voordijen zeer dik met duidelijken doorn.

Dit insect schijnt bij ons zeldzaam; 's Rijks Museum bezit een door mij, in Julij op de duineu bij 's Gravenhage gevangen excmplaar. Een ander werd mede aldaar door den heer Six bemagtigd. 


\section{Pachymerus Rolandri L.}

Plaat 21, fig. 9.

Linn. S. N. 12 Ed. II, 729, 98. - Fabr. S. Rh. 230. 127. - Fallen, Hem. Succ. 60, no 20. - Wolff, lc. Cim. 119, tab. 19, f. 193. - Panz. Fauna Germ. 118, f. 3. - Douglas and Scott, Brit. Hem. p. 172.

Lengte $7 \mathrm{~mm}$. - Van gedaante als Pini en Lynceus. Boven en onder zwart, uiterst fijn gestippeld en dien ten gevolge mat, doch de kop wat glanziger. Dekschilden op corium en clavus zwart met een' bruinen gloed, de naad daartusschen geelachtig; de membraan aan de binnenzijde en het midden bedekt met eene taankleurig gele, naar buiten getande vlek; de breede zoom sepia-bruin. Sprieten, zuiger en pooten zwart.

Slechts één voorwerp is mij bekend; het werd 4 Mei in de omstreken van Arnhem gevangen door den heer van Medenbach de Rooij.

\section{Pachymerus luscus F.}

Plaat 22, fig. 2.

Fabr. S. Rh. 231, 133 - Schill. Beitr. I. p. 67. Pl. 6, f. 4. - Woll, lc. Cim. 145, tab. 14, f. 139. - Panz. Fn. Germ. 92, f. 11. - Hahn, W. Ins. I. p. 48, tab. 8, f. 30. - Douglas and Scott, Brit. Hem. p. 180. pl. 6, f. 8.

Lengte bijna $7 \mathrm{~mm}$. - Slank, aan de bovenzijde grauwgeel met zwart geteekend, aan de onderzijde zwart met zijdeachtig kort haar bekleed. Kop vrij kort, zwart met groote bruine oogen. Sprieten lang en slank; lid 1 tamelijk dik, zwart met beide niteinden geel, lid 2 zeer slank, roodgeel, lid 3 iets dikker en korter, roodgeel met de spits bruiu, 4 even lang doch iets dikker, zwart met gele basis. Halsschild geel, de voorhelft ingenomen door eene groote vierhoekige zwarte vlek, de achterhelft bruingestippeld en met twee scheeve driehoekige zwarte vlekken in de achterhoeken. Schildje groot, dof zwart, met 2 gele streepjes op het midden en de spits geel. Dekschilden grauwgeel, de clavus met rijen zwarte putjes, het corium met dergelijke rijen aan de basis, voorbij het mid- 
den zwart met eene klokvormige figuur van grauwgele kleur rustende op den buitenrand. Membraan gemarmerd met bruin, wit en geel. Pooten grauwgeel met de achterste helft der dijen en de uiterste spits der scheenen zwart; de voordijen niet bijzonder dik, hebben aan de onderzijde eene gleuf, wederzijds bezet met fijne tancljes.

Gevonden door Perin, waarschijnlijk bij Katwijk, voorts door den heer Ritsema bij Scheveningen in Julij en bij Rozendaal in Aug., alsmede door den heer Six te Scheveningen den $27^{\text {en }}$ October.

\section{Pachymerus piclus . Schill.}

Plaat 6 , fig. 5 en $5 a$.

Schill. Beitr. I. p. 79, 22, tab. 7, f. 1 et p. $80 n^{\circ} 23$. - Hahn, W. Ins. I. p. 64, tab. 10 , f. 39 et p. 139, tab. 22, f. 71. - Herr. Sch. Fn. Germ. 120, 5. - Flor, Rh. Livl. I. p. 277. - Douglas and Scott, Brit. Hem. p. 182, 1; 183, 2 et 185, 3 (Pictus, Adjunctus, Affinis).

Lengte $3,5-4,5 \mathrm{~mm}$. - Er bestaan twee verscheidenheden van deze fraaije soort, nam., met roode en met zwarte sprieten; wij houden de eerste, die het menigvuldigst voorkomt, voor den type. Zwart, thorax en dekschilden bont. De kop is een weinig smaller dan het halsschild aan den voorkant en iets breeder dan lang, doordien de oogen sterk nitpuilen. Het $1^{\text {e }}$ lid der sprieten steekt een vrij groot eind voorbij de spits van den kop; het $2^{e}$ is veel langer dan het $1^{e}$, het $3^{e}$ iets korter dan het $2^{\mathrm{e}}$, het laatste wederom iets korter en spoelvormig; in het geheel zijn de spricten veel langer dan het halve lijf. De zuiger reikt tot de middenheupen. Thorax aan den achterrand veel breeder dan lang, naar voren versmald, de zijranden met eene duidelijke golving in het midden. De kleur van de voorhelft, die slechts weinig langer is dan de achterhelft is zwart met fijne witte randen; die der achterhelft is wit met twee scheef-zakvormige lichtbruine vlekken of roodbruin met een zeer fijn wit randje; het witte zoompjo is bij de dwarsnaad vrij diep naar binnen gebogen. Selildje dofzwart 
of bruinzwart. Dekschilden licht beengeel met een' gehakkelden roodbruinen achterrand en op ieder twee scheefstaande roodbruine blokjes; membraan bruinachtig geel net bruine aderen en twee kleine bruine vlekjes aau de basis. Zeer dikwijls zijn de dekschilden onvolgroeid en nemen dan de gedaante en teekening aan van fig. $5^{\mathrm{a}}$, terwijl de membraan een bijna driehoekig lapje wordt. Pooten vrij lang, licht roodbruin, iets donkerder aan de dijen; de voordijen dikker dan de overigen met een' zeer grooten doorn en eene rij kleine tandjes; scheenen van dat paar naar binnen gebogen, vooral zeer sterk bij mannetjes. Het eerste lid der tarsen aan de achterpooten bijzonder lang.

De donkere verscheidenheid met zwarte sprieten en dijen heet bij Hahn Decoratus, die met onvolgroeide dekschilden en vlengeltjes bij Schilling Affimis. Hoe Flor er toe gekomen is om deze soort onder den naam van Podugricus F. te beschrijven, wil mij in het geheel maar niet duidelijk worden, want de diagnose van Fabricius slaat kenuelijk op een geheel ander insect.

Deze is de gemeenste soort in de groep der Pachymeriden die men des winters met nitzeven van afgevallen bladeren verkrijgt. De type werd op versehillende plaatsen van ons land door vele entomologen angetroffen, de varieteit Decoralus uitsluitend door de heeren de Haan (te Naarden?) en Six (te Driebergen in menigte).

\section{Pachymerus contractus H. Sch.}

Plaat 6 , fig. 8 .

IIerr. Schïfl. Nomencl. ent. I. p. 45. - Idem, W. Ins. IV, p. 97. tab 140, f. 440. - Douglas and Scott, Brit. Hem. p. 186, no 4.

Lengte $3 \mathrm{~mm}$. - Zwart met de helft der dekschilden licht gekleurd. Kop bijna zoo lang als met de oogen breed, achter de oogen in eene soort van halsje versmald. Oogen niet bijzonder groot. Sprieten iets langer dat het halve lijf, zwart; het $1^{e}$ lid vrij lang, een eindje voorbij de spits van den kop 
uitstekende, lid 2 langer dan 3, 3 gelijk aan 4; aan het eind zijn alle leden iets dikker. Zuiger tot het laatste heupenpar reikend, zwart. Halsschild aan den voorrand zoo breed als de kop, doch plotseling zich verwijjlend tot op de helft, dan weder eenigzins versmallend om zich daarna nog sterker te verwijden; achterhoeken afgerond. De dwarsnaad zeer diep en aan beide zijranden te dier plaatse een uiterst fijn wit zoompje. Het schildje zwart met een gleufachtig indruksel in het midden der basis en cene fijne kiel naar de spits toe. Dekschilden tot op de helft licht geelachtig bruin, dan koffijkleurig donker bruin met een driehoekje aan den rand van de lichtere kleur. Membraan grauw met bruine aderen en eene lichte dwarsvlek aan de basis. De pooten bij het mannetje vuilgeel, bij het wijfje bruin; bij beide sexen de voorste dijen zeer dik, met twee tandjes gewapend en de voorscheenen zeer krom.

Van deze op heigrond niet zeldzame soort ving de heer Six beide sexen in de omstreken van Utrecht. De heer Heylaerts vond deze soort in Maart bij Breda en de heer Gerth van Wijk op Walcheren.

\section{Pachymerus erraticus F.}

Plaat 22, fig. 1.

Fabr. S. Rh. 232, 189. - Fallen, Hem. Suec. I, p. 60, $\mathrm{n}^{0} .19$. Panz. Fn. Germ. 121, f. 3, - Schill. Beitr. I. p. 74, 15.-Flor, Rhynch, Livl. I. p. 279, no 27. - Douglas and Scott, Brit. Hem. p. 177, tab. 6, fig. 7. 1)

Lengte 5-6 mm. - Langwerpig, van boven plat, bont gekleurd, zeer kenbaar aan een half cirkelrond wit vlekje op de membraan. Kop driehoekig, schier niet gestippeld, dof zwart, oogen niet sterk uitpuilend, zivart. Sprieten slank, onbehaard, zwart, het $1^{\text {e }}$ lid wel eens rood aan de basis, de drie laatsten van gelijke lengte. Zuiger roodbruin met het $1^{\mathrm{e}}$ lid

1) De laatste schrijvers citeeren bij deze soort ook Herrich-Schaeffer's Pachymerns fenestratus (W. Ins. IV, f. 437); mijns inziens is dit evenwel eene andere soort; zelfs zou ik twijfelen of de Engelsche Erraticus wel volkomen dezelfde is als de onze. 
donker. Borststuk iets breeder dan lang met regt doorloopende zijranden; voorbij de helft is eene dwarsgroef, het daarvoor liggende gedeelte is ietwat bol en zwart, het daarachter liggende plat, gestippeld, bruingeel; naast den naad zijn de zijden wit, de achterhoeken zwart. Schildje vrij lang, weinig gestippeld, iets meer aan de basis. Dekschilden an de basis troebel licht geel, verder op geelachtig bruin, met een paar bruine veegjes naar het eind van het corium; membraan bruinzwart, aan den binnenhoek eene in aderen uitloopende gele vlek en eene helderwitte half cirkelronde vlek hangende aan de spits van het corium. Onderzijde zwart. Pooten geheel rood, de dikke voordijen met bruine knieën, een' grooten tand en eenige zeer kleine in eene rij aan de onderzijde.

Van deze fraaije soort werden voorwerpen gevonden te Utrecht (van Hass.), bij Breda in Julij (Heyl.), bij Arnhem in Sept. (v. Med. de Rooij) en op Walcheren (La Font.).

\section{Pachymerus plebejus Fall.}

Plaat 5 , fig. 7.

Fallen, Hem. I. p. 59. - Schill. Beitr. I. p. 75. tảb. VI, f. 1. (Syl-

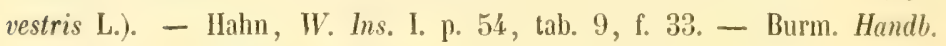
II. p. 296, no $^{\circ}$. - Flor, Rh. Livl. I, p. 249.

Lengte 6-7 mm. - Zwart met bruine dekschilden, waarop een donker streepje. Kop zoo lang als breed, dof zwart. Oogen niet bijzonder uitpuilend, roodbruin of zwart. Zuiger tot de achterheupen reikend, geelachtig bruin. Sprieten zwart met fijne grijze bekleeding en roodachtige tint aan het einde der leedjes; lid 1 vrij lang, voor de spits van den kop uitsteekend, 2,3 en 4 van gelijke grootte. Thorax dofzrvart, met grijze fijne haartjes bezet, ietwat rood aan de randen, aan den voorrand breeder dan de kop, de zijranden eerst sterk bol gebogen, dan voorbij de helft eenigzins ingedenkt, daarna weder vrij sterk uitgezet. De voorhelft eenigzins bol verheven, de achterhelft plat en met grove putjes ingedeukt; bij een voorwerp zijn beide helften door eene rij van zeer grove putjes gescheiden 
(zie fig. 7), of dit sexueel verschil is, kan ik niet zeggen, daar het voorwerp is opgeplakt; mijne overige voorwerpen zijn wijfjes. Schildje dof zwart, gestippeld, iets langer dan breed. Bovenvlengels roodbruin of donkerbruin, aan de basis soms iets lichter, met een donkerder bruin streepje in het midden. Nembraan rookkleurig bruin met iets lichter achterrand en twee vuilwitte vlekjes, het een bij de spits van het corium, het ander aan den binnenhoek van den achterrand der membraan. Pooten tamelijk lang en slank, bruin met donkere dijen en lichtere tarsen; de voorste dijen zeer dik met twee scherpe tandjes, meestal zwart, de voorste scheenen krom.

Deze soort werd door den heer Six in April aan de Bildt onder bladeren en later in het jaar ook te Driehergen aangetroffen; de heer Heylaerts trof haar 3 Maart bij Breda onder dorre bladeren an en de heer van Medenbach de Rooij den $29^{\text {en }}$ Maart bij Arnhem; de heer de Gavere zond mij een exemplaar uit de provincie Groningen. Ook trof ik haar aan in eene kleine verzameling inlandsche insecten van den heer de Haan. In de Bouwstoffen staat zij opgeteekend onder den naam van Silveslris Panz.

Gen. 5. Dryuus Fieb.

Dit geslacht onderscheidt zich van het voorgaande doordien aan de zijden van den thorax geen plat, mesachtig of vliesachtig zoompje te zien is, ten boogsten eene uitstekende rigchel; de eerste soort vormt als het ware den geleidelijken overgang. Van de eerstvolgende geslachten is het onderscheiden door eene dwarsgleuf of indieping welke even voorbij het midden over den thorax loopt, alsmede doordien het ligehaam niet te gelijk kaal, glad en blinkend is. Fieber noemt in zijn genus Drymus slechts 3 van onze soorten op en geeft dan ook andere kenmeriken aan het geslacht, doch ik meende beter te doen met den naam te behouden, dan al weder een nieurven in het systeem te brengen. Alle species tot mijn Genus Drymus be- 
hoorende hebben dikke getandc roordijen en het $1^{\circ}$ lid der achtertarsen langer dan het $2^{e}$ en $3^{e}$ vereenigd; zij zijn afgescheiden uit mijn vroeger geslacht Pachymerus.

\section{Drymus agrestis Fall.}

Plaat 5, fig. 10 z en 10 q.

Fallen, Hem. I. p. 55,12 - - Schilling, Beitr. I. p. 70 , tab. 6 , f. $6 .-$ Hahn, W. Ins. I. 25, tab. 4, f. 15. - Flor, Rh. Livl. p. 265. - Douglas and Scott, Brit. Hem. p. 192. Pl. 7, fig. 2.

Lengte $4 \mathrm{~mm}$. - Het mannetje zeer gemakkelijk te herkennen aan de roode pooten. Zwart. Kop veel brecler dau lang, met groote uitpuilende oogen, iets smaller dan de voorrand van het borststuk. Sprieten zoo lang als de helft van het ligehaam; het $1^{e}$ lid kort en slechts even voorbij de spits van den kop reikend, lid 2 vrij lang, 3 en 4 iets korter. Bij het wijfje zijn de sprieten geheel zwart, bij het mannetje het eerste lid en somwijlen de basis van het tweede oranje-rood. De zuiger reikt tot op de achterheupen en is zwart bij het $q$, terwijl bij den $\delta$ de twee eerste leedjes oranje, de laatsten bruin zijli. De thorax is bij beide geslachten zwart tot over de helft, verder bruin of grauw met vrij diepe zwarte putjes; de voorrand is bijna onzigtbaar geel gezoomd, de zijranden iets breeder. De achterrand is een weinig gegolfd. Het schildje is zwart, fijn gestippeld, iets langer aan de zijden, dan aan de basis. De dekschilden zijn bij het wijfje geel of granw, bij het mannetje geel, met eene menigte zwarte stipjes geteekend, die op den clavus in 4 rijen staan en aan den binnenhoek dikıvijls tot vlekjes ineenvloeijen. Membraan grijs, grauw of vuilbruin met witte aderen. De pooten rijn vrij kort, bij het of zwart, dikwijls met bruingele heupen en knieën, bij het $\delta$ alle pooten oranje of wel alleen de vier voorsten met de heupen en de helft der dijen van het achterste paar; gewoonlijk hebben de dijen aan het eind een bruin vlekje. De voordijen zijn bij het mannetje sterker gezwollen dan bij het wijfje en hebben aan de onderzijde eene langsglenf' en twee sterke doorntjes, 't geen 
bij het q minder sterk is anngegeven; de voorscheenen zijn vrij krom, vooral bij den man.

Men treft wel eens eene verscheidenheid van deze laatste sexe aan met schier geheel donkerbruine pooten.

Deze soort is zeer gemeen in het duin aan de wortels van verschillende planten; in Maart en April vindt men haar op zonnige dagen menigvuldig in de sporen der schelpkarren. Zij komt ook op de heidevelden voor, doch schijnt daar minder talrijk; Dr. van Hasselt vond haar bij Utrecht en de heer Heylaerts bij Breda.

\section{Drymus varius Wolff.}

Plaat 5 , fig. 6.

Wolff, Ic. Cim. p. 148, tab. 15, f. 142. - Schill. Beitr. I. p. 78, tab. 6, f. 12. - Hahn, W. Ins. I. p. 69 , tab. 10, f. 42. - Flor, Rh. Livl. I. p. 256. - Douglas and Scott, Brit. Hem. p. 195. Pl. 7, f. 3.

Lengte nog niet $3 \mathrm{~mm}$. - Kenbar aan twee gele of grauwe vlekjes op den thorax en aan de dwarsbandjes over de dekschilden. Algemeene kleur gebronsd zwart. Kop en thorax met opstaande haartjes bezet. Sprieten kort, zwart met de helft van lid 2 en 3 rood. Kop met de oogen zoo breed als de voorrand van den thorax, zeer fijn gestippeld. Halssehild desgelijks, vrij bol aan het voorste gedeelte met twee tamelijk groote, ovale geelachtig grauwe vlekjes op het laatste derde deel. Schildje met grijzen voorrand. Bovenvleugels lichter of donkerder vuil geel of bruinachtig granw met drie zwartachtige dwarsbandjes over het corium, waarvan de middelste de aanzienlijkste en naar den bimnenrand toe bruiner en meer gervolkt is. De membraan vertoont eene zwarto hoekige vlek, die breed wit omzoomd is. Onderzijde van het lijf zwart, schier niet gebronsd. Pooten gezet en krachtig, de voorste dijen zeer dik met een klein tandje van ouder; heupen en dijen zwart, schenkelringen vuil geel, scheenen rood of bruingeel met donkerder basis en spits en, voornamelijk die van het voorste paar, met stijve borsteltjes bezet; tarsen donkerbruin. 
Deze soort is in onze duinen zeer gemeen; in de eerste warme voorjaarsdagen kan men haar in menigte van individuen aantreffen in de sporen der schelpkarren, in het midden van den zomer even talrijk aan de wortels van Jasone monlana. De heer Six vond haar ook op de heidevelden in de provincie Utrecht in Junij en ik trof haar in Augustus bij Heemstede aan.

\section{Drymus sylvaticus $\mathrm{F}$. \\ Plaat 5, fig. 5 .}

Fabr. S. Rh. 229, 126. - Hahn, W. Ins. I. p. 221, tab. 36, fig. 115.Schill. Beitr. I, p. 80, tab. 7, fig. 4. - Ilerr. Sch. Fn. Germ. 120, fig. 6. - Flor, Rh. Livl. I. p. 247. - Douglas and Scott, Brit. Hem. p 196.

Lengte 4-5 mm. - Zwart met donkerbruine bovenvlengels, iets platter dan de vorige soorten en in gedaante ook eenigzins verwant aan Abietis en ferrugineus. Kop breeder dan lang, veel smaller dan de voorrand van den thorax. Sprieten zwart, langer dan de helft van het ligchaam met zeer fijne zijdeachtige haartjes dun bezet; lid 1 steekt ver voor den kop uit, 2 is het langste van allen. Thorax fijn gestippeld, in de tusschenruimten de stippen eenigzins glanzig, breeder dan lang, met de voorhoeken geheel afgerond, de dwarsnaad vrij diep en ver naar achteren geplaatst. Schildje aan de zijden iets grover met puntjes bezet dan in het midden. Dekschilden getaand bruin, somwijlen vlekkig met een paar onduidelijke donkerder en lichter streepjes, tamelijk breed nitgezet op het midden van het achterlijf; membraan rookkleurig, ietwat lichter aan de basis, dan aan de spits. Onderzijde zwart met roodbruine laatste ringen. De zuiger tot de achterheupen reikend, bruingeel. Pooten zwart met lichtbruine tarsen; de voordijen aan de binnenzijde met rooden gloed, matig opgezwollen en met een zeer klein tandje voorzien.

Sylvaticus werd door den heer Six bij Driebergen en in April op de heide achter de Bildt gevangen. De heer de Graat trof haar bij Wassenaar in October in de duinen aan, de heer Ritsema ving haar bij Leiden, de heer Heylaerts te Breda en 
de heer Gerth van Wijk op' Walcheren. In April vond ik een paar voorwerpen bij Bennebroek en in September een bij Leiden.

\section{Drymus dilatalus H. Sch.}

Plaat 21, fig. 12.

Herr.-Schaeff. W. Ins. VI, p. 33, Pl. 192, f. 591. 1) - Douglas and Scott, Brit. Hem. p. 204.

Lengte $7 \mathrm{~mm}$. - Zwart, sterk gestippeld en toch min of meer glanzig, geheel met een uiterst fiju bruinachtig zeer kort vilt bekleed, dat evenwel spoedig schijnt los te laten. Kop tamelijk kort; oogen uitpuilend zwart; zuiger en sprieten zwart, doch rossig in de geledingen; de laatsten met eenige zwarte haren bezet. Borststuk tamelijk bol en breed, naar achteren verbreed en aldaar grof gestippeld. Schildje lang gerekt en grof gestippeld. Membraan donkerbruin met lichte wolkjes aan de basis der aderen en een ander wolkje an de vlengelspits. Pooten geheel zwart, alleen iets roodbruin aan de tarsen; voorste dijen bijzonder dik met een' zeer sterken doorn onder digt bij de knie.

Vroeger heb ik deze soort verward met Sylvalicus F. 'Twee voorwerpen ontving ik van den heer Heylaerts, door hem bij Breda in Maart gevangen; twee anderen werden 19 April door den heer van Medenbach de Rooij bij Arnhem aangetroffen.

\section{Drymus brunneus Sahlb.}

Plaat 21, fig. 10.

Sahlberg, Geocor. Fenn. 57, 6. - Douglas and Scott, Brit. Hem. p. 198, Pl. 7, fig. 4.

Lengte $4-5 \mathrm{~mm}$. - Zwart met de achterhelft van het borststuk, de dekschilden en pooten roodbruin. Kop driehoekig en vrij spits, zwart, weinig glanzig. Sprieten bruinzwart, met

1) Bij deze figuur zitten de voorpooten al zeer zonderling op zijde van den prothorax aangehaakt. 
de helft van het laatste lid geel. Prothorax kort, breed met ronde voorhoeken, de achterrand breeder dan het voorste gedeelte; dit met eene dwarsrij van stippeltjes van de bruinroode, sterk gestippelde achterhelft afgescheiden. Schildje vrij breed, sterk gestippeld, zwart. Dekschilden grof gestippeld, roodbruin met de basis van den zijrand en een halfrond vlekje op het corium tegen den naad van den clavus lichter; membraan donker met een paar witte veegjes. Pooten bruinrood, soms met donkerbruine dijen, de spits der scheenen en de tarsen lichter.

De soort werd tot nog toe slechts in duinstreken waargenomen; bij Wassenar in het najaar (Perin), bij Scheveningen in April en Loosduinen in Sept. (Dr. v. Hasselt), bij den Haag in April (Dr. Everts) en in Nov. (Mr. Leesberg).

\section{Drymus nolatus Fieb.}

Plaat 21, fig. 11.

Fieber, Europ. Hemipt. p. 179, $\mathrm{n}^{0} 3$.

Lengte iets meer dan $4 \mathrm{~mm}$. - Geheel van gedaante als de voorgaande, doch roodachtig geel van kleur en kleiner. Aan den met fijne witte haartjes bezetten kop puilen de bruine oogen vrij sterk uit. Het eerste lid der sprieten is b:na zoo lang als de kop, slank, geclachtig rood met bruine spits; het $2^{e}$ is bijua de helft langer, aan de basis slanker, eveneens gekleurd; het $3^{\text {e }}$ korter dan 2 en iets dikker, is behaard, zwart met gele basis; het $4^{\mathrm{e}}$ even lang, maar spoelvormig is halfweg eerst zwart, dan geel. De zuiger is doorschijnend geel en reikt tot het $2^{\text {e }}$ paar der heupen. Het borststuk is sterk gestippeld, doch glanzig. De dekschilden zijn veel minder rood van kleur, ledergeel met bruine stipjes en een bruin, tamelijk breed streepje op den naad van clavus en corium; de membraan is donkerbruin met 2 witte in zigzag loopende streepjes. De pooten zijn geheel ledergeel; alleen het laatste lid der tarsen is bruinachtig en de klaauwtjes zijn bruin.

De heer Ritsema ving 26 Junij 1876 een enkel exemplaar dezer zeldzame soort bij Warmond. 


\section{Drymus chiragra F.}

Plaat 7 , fig. 1.

Fabr. S. Rh. 233. 144. - Burm. Handb. II. p. 294. 2. - Hahn, W. Ins. I. p. 56 , tab. 9. f. 34. - Schill. Beitr. I. p. 75 . tab. 6, f. 9. Herr. Sch. Fn. Germ. 122, 8. - Flor, Rh. Livl. I. p. 254. - Douglas and Scott, Brit. Hem. p. 203.

Lengte 5 -6 mm. - Kenbaar aan drie grauwe vlekjes op den achterrand van den thorax, die echter in onze afbeelding wat al te sterk zijn uitgedrukt. Dofzwart en geheel met opstaande, doch ijl geplaatste zwarte haartjes bezet. Kop iets smaller dan de voorrand van het halsschild. Oogen weinig uitpuilend. Sprieten iets langer dan het halve lijf, zwart behalve het tweede lid, dat rood is met zwarte spits. Lid 1 reikt even voorbij de spits van den kop, de 3 overigen ongeveer gelijk in lengte, elk bijna dubbel zoo lang als 1 . Thorax bol verheven op het voorste gedeelte, dat meer dan tweemaal zoo lang is als het achterste gedeelte, hetwelk platter is, bruinachtig van kleur en geteekend met drie kleine ronde lichtgrauwe vlekjes, staande in eene dwarsrij. Schildje grof gestippeld. Dekschilden vuil bruin met zwarte spits en 4 dof donkerbruine vlekjes aan do achterzijde tusschen de aderen. Membraan donkergrauw met een of twee lichtere vlekjes aan de basis. Pooten met de trochanters, de scheenen in het midden en de tarsen geelachtig bruin, het laatste lid evenwel donkerbruin. De voorste dijen zeer gezwollen, vooral bij het mannetje met een' stevigen tand aan de onderzijde niet ver van de knie; de voorste scheenen ietwat naar binnen gebogen.

Deze soort schijnt zeldzaam; ik ken slechts drie inlandsche voorwerpen, het eene door mij in de duinen bij den Haag gevangen, het andere door den heer Six in de omstreken van Utrecht, het derde bij Arnhem, 12 Mei door den heer van Medenbach de Rooij. 


\section{Drymus praetextanus $\mathrm{H}$. Seh.}

Plaat 6, fig. 9.

Herr. Sch. Nomenclator ent. 1, p. 45 et $79^{1}$ ). - Idem, W. Ins. IV. p. 12, tab. 113, f. 357. - Curtis, Brit. Ent. Vol. XIII, Pl. 612. Douglas and Scott, Brit. Hem. p. 205.

Lengte $4 \mathrm{~mm}$. - Vrij blinkend zwart. Kop zeer kort en breed, doch smaller dan de voorrand van den thorax; de oogen vrij sterk uitpuilend. Sprieten langer dan het halve lijf, zwart, behalve het $2^{e}$ lid, dat naar de spits bruingeel wordt; lid 1 zeer kort, 2 het langste van allen, 3 en 4 gelijk, het laatste tamelijk dik. Thorax an de eerste twee derde gedeelten zeer bol uitgezet, vervolgens na den dwarsnaad tamelijk plat, overal zeer sterk gestippeld, doch fijner naar voren toe; bij den naad zijn de zijden diep ingekeept. Schildje klein, weinig gestippeld zwart. Dekschilden vuilgeel met zwarte stippeltjes meest in rijen en met cen' breeden koffijbruinen aan de voorzijde uitgeschulpten achterzoom; membraan vaal grijs met een' witten zoom langs het corium en de helft van den binnenrand en met een vuilwit driehoekig vlekje aan de spits. De pooten zijn geheel vuil stroogeel behalve de dikke voordijen, die zwart zijn met gele knieën; de tarsen zijn ietwat bruiner dan de scheenen. De voordijen zijn met een'sterken doorn gewapend en hare scheenen zijn krom en kort.

Deze soort is zeldzaam; ik ving er een' voorwerp van in April bij den Haag.

Gen. 6. Peritreghus Fieb.

Dit geslacht wijkt in verscheidene punten van overeenkomst af van de beide vorigen doordien het borststuk, dat aan de zijden niet verbreed noch plat gozoomd is, een trapezium ver-

1) Op bl. 79 van het aangeh. werk en in den 1 ndex der $\mathbb{T}$ anz. Ins noemt Herrich-Schaeffer onze soort Praelextatus Panz. Ik vind echter bij Panzer niets dat op has betrekking heeft. 
toont met ongeveer regt doorloopende, schier niet ingebogen zijden eu geene dwarsgleuf, ten hoogste eene zeer flaawe indieping; de laatste soort vertoont dat iets meer dan de ande. ren, doch is om hare groote overeenkomst met de voorlatste nergens anders te plaatsen. De overige kenmerken van het genus komen met die van het voorgaande overeen.

\section{Peritrechus luniger Schill.}

Plaat 10 , fig. 7 .

Schilling, Beitr. p. 67, no ${ }^{0}$ 5, tab. 3, f. 1. - Panz. Fauna Germ. 121, 1. - Fieber, Eur. Hemipt. p. 184. - Douglas and Scott, Brit. Hem. p. 188. Pl. 7, fig. 1.

Lengte $5 \mathrm{~mm}$. - In gedaante en kleur zeer nabij $P$. nubilus Fall. staande en tevens gelijkende op Agrestıs Fall. De kop spits driehoekig met ingebogen zijden, dof zwart; de oogen rond en uitpuilend. De sprieten, ongeveer ter lengte van het halve ligchaam zijn grauw-zwart, het $2^{e}$ lid een weinig roestkleurig aan de basis, is iets langer dan het $3^{\mathrm{e}}$ en in lengte gelijk aan het $4^{e}$. Het borststuk heeft afgeronde voorhoeken, golvende zijden, bijna regthoekige achterhoeken en is door eene dwarsnaad in twee ongelijke deelen verdeeld, waarvan het voorste langer en dof zwart, het achterste korter en vuilgrauw is; op de zijranden ter hoogte waar deze helften aan elkander raken, springt een witte membraneuse zoom eenig. zins naar binnen.

Het schildje is groot, driehoekig, dofzwart met gele spits. De dekschilden zijn grauwachtig geel met zwarte langslijntjes, die uit stippeltjes bestaan; op het einde van het corium, naar den clavus toe, ziet men twee langwerpige zwarte vlekken, aan de spits met een geel oogje versierd. De membraan is rookkleurig, en heeft in drie zijner hoeken vrij groote zuiver witte vlekken; uit elk der beiden, die an het corium raken, verspreiden zich twee slingerende witte aderen. De vleugels zijn doorschijnend wit met dofwitte aderen. De pooten zijn zwart, bebalve de voorste knieën en scheenen tot aan de tippen; deze knieën en tippen zijn geel. 
De heer v. M. de Ruoij was zoo gelukkig van deze soort een voorwerp te vangen bij Arnhem in de maand April. Ook werd zij door ien heer Gerth van Wijk 3 Oct. in eene oranjerie te Middelburg, alsmede in April door den heer Heylaerts bị Breda gevangen.

\section{Perilrechus mubilus Fall.}

Plaat 6 , fig. 6 .

Fall. Hem. I. 54, 10. - Schill. Beitr. I. p. 68, no. 7, tah. 7, f. 2.Ilahn, W. Ins. I. p. 68. Pl. X, f. 41. - Herr. Sch. Fn. Germ. 121, 5 Flor, Rh. Livl. I. p. 246. - Douglas and Scott, Hemipt. Brit. I, p. 189.

Lengte $6 \mathrm{~mm}$. - Zwart met grijze plat nederliggende haartjes dik bezet. De driehockige kop met bruine zeer uitpuilende oogen, is aanmerkelijk breeder dan de voorrand van het halsschild. Sprieten zwart, een weinig behaard, zoo lang als het halve lijf; lid 1 springt even voorbij de spits van den kop, 2 is dubbel zoo lang, 3 en 4 gelijk, elk iets korter dan 2. Halsschild met tamelijk scherpe in het midden wat ingebogen rijkanten, aan den achterrand veel breeder dan aan den hals : met een kiein en onduidelijk geel vlekje aan den zijrand achter de weinig zigtbare dwarsplooi. Schildje vrij lang en puntig, voorbij de helft greel gevlekt en zwart gestippeld. Dekschilden geelgrauw met teekeningen van zwarte ingedrukte puntjes tusschen de aderen; op smalle plekjes vereenigen zich deze puntjes tot vlekjes. Membraan grijs, flaauw donkerder gemarmerd. Heupen zwart, dijringen rood, dijen zwart met grijze zijdeachtige beharing en roode knieën; de voordijen vrij dik met drie duidelijke tandjes. De voorscheenen rood, de middelsten half zwart, half rood, de achtersten zwart met roode tippen. Het eerste lid der voortarsen rood en alleen veel langer dan de beide and ren, die zwart zijn. De zuiger reikt tot aan de middenherpen en is zwart behalve het einde van het eerste lid, dat rood is.

Deze soort werd dour den heer Buse bij Haarlem, door den heer Heylaerts bij Breda en door den heer van der Wulp in 
Junij bij den Haag anngetroffen. Ik ving haar in Augustus te Brummen.

\title{
3. Pachymerus nebulosus Fall.
}

\author{
Plaat 22, fig. 4.
}

Fallen, Hem. Suec. I, 54, no 11. - Panz. D. Ins. I, P. 121, 7. Ilahn, W. Ins. I, p. 46. pl. 7, f. 29 (onkenbaar). - Schill. Beitr. I, p. 69, 8, tab. 6. f. 5. - Flor, Rh. Livl. I, p. 268.

Lengte $5 \mathrm{~mm}$. - Zwart met een dun grịjsachtig vilt bedekt. Kop met de zeer groote oogen breeder dan lang, oogen bruin. Sprieten langer dan de helft van het lijf, zwart; lid 1 kort, slechts even voor de kop nitstekend, lid 2 tweemaal zoo lang, 3 iets korter en 4 iets dikker en langer dan 2. Zuiger lichtbruin, reikend tot de middenheupen. Borststuk aan den achterrand bijna 2 maal breeder dan lang, met toegeronde voorhoeken en schier niet gegolfde zijpranden, die zeer eng gezoomd zijn; op dit zoompje even over het midden een wit vlekje. Voorste gedeelte van den thorax zwart, achterste geelgrauw met een zwart streepje in het midden. Schildje rrij lang, zwart met twee gele vlekjes voorbij het midden en de spits geel. Dekschilden lichtgeel met fijne zwarte aderen en rijen van zwarte puntjes, de uiterste spits van het corium zwart, alsmede eene langwerpige vlek aan den binnenhoek, in welke weder een ovaal geel vlekje met zwart oogpunt; membraan zwartachtig, aan de basis en langs de aderen wit. Buik met geelachtig vilt bekleed. Heupen en dijen zwart, de roordijen met 2 tandjes, die vrij ver van elkander afstaan, knieën en voor cheenen geel; overige scheenen en tarsen met gele bandjes.

Van deze zeldzame soort werden 3 voorwerpen in April bij Scheveningen bemagtigd door Dr. van Hasselt en mij.

\section{Perilrechus rusticus Fall.}

Plat 5, fig. 3.

Fallen, Hem. I, 64, 25. - Schilling, Beitr. I, p. 81, no 26, tab. 7, f. 5. - Hahn, W. Ins. I, 1. 43, fig. 27 en p. 223 , fig. 116. - Flor: Rh. Livl. 1, p. 241. - Douglas aud scott, Hem. Brit. p. 214, pl. 7, f.9. 
Lengte $3 \mathrm{~mm}$. - Zwart vrij digt bezet met fijne opstaande haartjes op de rugzijde. De kop nedergebogen, aan den achterrand met de oogen breeder dan de voorrand van het halsschild. De oogen vrij groot, bruin. Sprieten korter dan de helft van het lijf (iets te lang op de plaat), roodachtig bruin met het eerste lid zwart; dit is kort doch steekt toch voor de kopspits uit; lid 2 iets langer dan 3, zoo lang als 4. Zuiger roodachtig geel, tot de middenheupen reikend. Halsschild vrij digt gekorreld; op de achterhelft, die een' rooden gloed vertoont, grover dan op de voorhelft. Het schildje zeer groot, grof gekorreld en daardoor dof. Dekschilden donker kastanjebruin met grove punten, die op den clavus in rijen staan. Membraan grauw met eenige zwarte vlekjes tusschen de bogtige aderen. Pooten bruinrood, met ietwat donkerder tarsen; de voordijen zijn in geringe mate dikker dan die van het middenpaar en bij het wijfje glad, bij het mannetje naauwelijks zigtbaar getand. De voorscheenen regt.

Deze soort, die gemeen is in Augustus bij Utrecht tussehen gras, zal wel nergens zeldzaam zijn, doch zij wordt om hare geringe grootte en doffe kleur minder opgemerkt. Zie hier de mij bekende vangplaatsen: Delft op het eind van September, Dr. Everts; Scheveningsch duin $30 \mathrm{Julij}$, Six; Noordwijk in Julij, Ritsema; Utrecht in Augustus, Six; Leiden, v. Voll.; Breda in Maart, Heylaerts; Kampen in Julij en Rhedersteeg 30 Augustus (in copula) v. Voll.

\section{Peritrechus sabulosus Schill.}

Plaat 5, fig. 4.

Schill. Beitr. I, p. 81, 25. - Curtis, Brit. Ent. XIII, pl. 612. Hahn, W. Ins. I, p. 224, tab. 36, f. 117. - Flor, Rh. Liv. I, p. 243. - Douglas and Scott, Brit. Hem. p. 215.

Lengte 2,5 mm. - Zwart met fijne grijze, opstaande haarbekleeding op de rug-, en rijdeachtige bedekking op de onderzijde. Kop door de uitpuilende oogen iets breeder dan de roorrand van het halsschild, met doffen glans, fijn gestippeld. 
De sprieten iets langer dan de helft van het ligchaam, stroogeel met het laatste lid zwart of grijs; lid 1 zeer kort, 2 iets langer dan 3, 4 het dikste, spoelvormig. Zuiger roodachtig geel. Halsschild met ingedenkte zijden, aan den achterrand zoo breed als de lengte, fijn gestippeld; de achterrand zelf vuil geel. Schildje tamelijk klein, iets langer dan aan de basis breed. Bovenvleugels bruinachtig geel met rijen zwarte stippen; aan den achterrand van het corium een wigvormige bruine vlek; membraan grauw met bruine aderen. Pooten bruinachtig geel met het midden der dijen en het eerste lid der tarsen bruiu.

Deze soort werd te Driebergen gevangen door den heer Six; zij is er volgens zijne verklaring vrij gemeen op heidegrond. Andere vindplaatsen zijn: bij den Haag, Leesb.; bij Noordwijk, Weytlandt; bij Heemstede, v. Voll.; bij Arnhem, v. Med. de Rooij; op Walcheren, Gerth v. W.; bij Breda, Heyl.; aan de Rhedersteeg en te Oisterwijk, v. Voll.

\section{Gen. 7 Iscunoconis Fieb.}

In dit geslacht is het ligchaam gerekt lineair met de zijden nagenoeg aan elkander evenwijdig. De kop is driehoekig, even breed als lang, het borststuk met afgeronde voorhoeken, een weinig langer dan breed, aan den achterrand wat ingebogen; het schildje tamelijk klein, driehoekig; de dekschilden meestal onvolgroeid. Het achterlijf is voor deze familie zeer lang en heeft een naar boven omgeslagen zijrand. De voordijen zijn wel zeer dik opgezwollen, maar onbedoornd en an de onderzijde naar de punt toe zelfs van eene platte vlakte voorzien; de voorscheenen zijn krom en naar de punt toe sterk verbreed; de tarsen hebben het eerste lid in de beide voorste paren pooten zoo lang als, en in het achterpaar langer dan lid 2 en 3. Douglas en Scott noemen dit geslacht Hypmophylus, maar E. Saunders verwerpt dien naam in zijn $S_{y}$ mopsis met bijbehouding. van Ischnocoris, 't geen Smalwan/s beteekent. 
Ischnocoris hemiplerus Schill.

Plaat 5, fig. 8 .

Schill. Beitr. I. p. 77, 20. tah. 6, f. 11. - Hahn u. Herr. Sch. W. Ins. I, p. 61, f. 37 et IX, p. 210. - Flor, Rh. Livl. I, p. 261. Douglas and Scott, Bril. Hem. p. 209.

Lengte $3 \mathrm{~mm}$. - Zwart met de dekschilden vuilgeel of bruin. Kop zeer weinig breeder dan de voorrand van het halsschild, driehoekig, even breed als lang, zeer glanzig. Sprieten ongeveer van de halve lengte van het ligchaam, zwart met het $2^{e}$ lid bruinrood an de basis. Lid 1 reikt niet aan de spits van den kop, 2 en 3 zijn even lang of 2 is iets langer. Het borststuk is iets langer dan breed, aan het voorste gedeelte wat bol, met de dwarsnaad ver naar achteren geplaatst; voor die naad is het glinzig, daarachter dof, gestippeld en wel eens lichtbruin van kleur. Het schildje is an de zijde en de spits met tamelijk grove puntjes gestippeld. De dekschilden zijn bị onze inlandsche voorwerpen korter dan het balve achterlijf, geel of bruin met rijen van donkere stippen geteekend en aan het einde van eene strook witte membraan voorzien. Vleugels schijnen mij toe te ontbreken. Aan de pooten zijn de heupen, trochanters en bases der dijen bij het eene voorwerp rood, bij het andere geel; de scheenen hebben bij het laatste ook cen' vuilgelen tint.

Deze soort werd door den heer Six in September bij Driebergen en elders in de omstreken van Utrecht gevangen, bij Breda door den heer Heylaerts en op Walcheren door den heer Lafontijn; ik trof haar in Julij bij Dieren aan. 1) HerrichSchaeffer veranderde in het $y^{e}$ deel van zijne Wantsenarlige Insecten den naam, door Schilling gegeven, in dien van Pallidipennis, omdat er nu en dan voorwerpen met volkomen dekschilden aangetroffen zijn. Indien men alle onjuiste namen

1) In de laatste naamlijst van inlandsche Hemipteren, in het $3^{\mathrm{e}}$ Deel van het Tijdschr. v. Ent. staat deze soort ten onregte vermeld als Staphyliniformis Schill. 
verbeteren wilde, zou voorzeker niemand meer den weg kennen in het systeem.

NB. Pachymerus staphyliniformis Schill. (Beitr. p. 77, $\mathrm{n}^{0} .19$, tab. 3, fig. 4) is voor zoo verre mij bekend is, hier te lande nog niet gevangen, zelfs niet in Zeeland, gelijk eenmaal gemeld werd.

Gen. 8. Plintuisus Latr.

Een geslacht dat in ligchaamsvorm vrij sterk vam alle vorigen verschilt. Wel is hier ten minste bij eene soort het borststuk iets uitgerekt, maar de geheele habitus is kort en gedrongen, 't geen voornamelijk te danken is aan de bijzondere kortheid van het achterlijf en de dekschilden. De kop is kort en diep in het dekschild ingedrukt en draagt bijna geene nitsteeksels ter inplanting der voelsprieten, die merle kort zijn en dun, behalve het spoelvormige vierde lid. De oogen zijn klein en de bijoogjes ver van elkander en digter bij de oogen geplaatst. De zuiger reikt tot het $2^{\text {e }}$ heupenpaar. Het borststuk is of vierkant of iets langer dan breed, aan het voorste deel vrij bol met nedergebogen voorste hoeken; de achterrand een weinig ingebogen en de achterhoeken wat afgerond; er is geen gleuf over het midden. Schildje driehoekig, iets breeder dan lang. Dekschilden korter dan het achterlijf, aan de zijden en van achter omgebogen, meest zonder membraan. De dijen van het eerste paar pooten zijn naar onderen zeer gezwollen en aldaar voorzien van eene rij tandjes, warouler 2 die door lengte nitmunten; de voorscheenen zijn wat krom gebogen en wat verbreed aan de spits; de andere dijen rijn slechts matig dik, de midden- en achterscheenen van stekelțes voorzien; bij de achtertarsen is het $1^{c}$ lid langer dan het $2^{e}$ met het $3^{\text {e }}$. ilet doet mij leed te moeten erkennen dat mijne af beeldingen van 2 der soorten van dit geslacht de toets der critiek niet kunnen doorstaan; zij zijn slechts bij benadering gelijkend. Mij zijn drie inlandsche soorten bekenil. 
1. Plinthisus bidentulus Hers. Sch.

Plaat 6, fig. 10.

Herr. Sch. W. Ins. VI, p. 31, pl. 191, f. 588. - Douglas and Scott, Brit. Hem. p. 212.

Lengte 3,5 mm. - Zwart met eenkleurig bruine dekschilden. Kop klein, iets breeder dan lang met sterk uitpuilende oogen. Sprieten zwart, aan de basis donkerbruin, zoo lang als het halve ligehaam; lid 1 korter dan de kop, 2 iets langer dan 3, dit laatste gelijk aan 4. Thorax vrij glanzig zwart, langer dan breed, voor veel breeder dan de kop, naar achteren nog breeder nitloopend, zonder diepen naad; de achterrand schijnt kastanjebruin door. Schildje zwart, zeer klein. Dekschilden kastanjebruin, weinig naa achteren verbreed met eene witte membraan in den vorm van een smal toeloopend zoompje. Het abdomen daar achter zwart. Onderzijde schijnt zwart (mijne voorwerpen hebben zeer door schimmel geleden). Pooten fijn, met zeer dikke voordijen met twee scherpe tandjes gewapend; bij een voorwerp zijn de pooten vuil bruingeel en de dijen taankleurig, bij een ander de pooten bruin met donkerder, bijna zwarte dijen.

Door den heer Six in de omstreken van Utrecht gevangen.

\section{Plinthisus brevipennis Latr.}

Latreille, Gen. Crust et Ins. III, p. 123. - Schill. Beitr. I, p. 16, tab. 6, fig. 10. - Hahn, W. Ins. I, p. 59. tab. 9, fig. 36. - Douglas and Scott, Brit. Hem. p. 211, pl. 7, fig. 8.

Lengte 2,5-3 $\mathrm{mm}$. - Blinkend zwart met bruine sprieten en pooten. Kop breed en kort met matig groote bruine oogen. Sprieteu bruin met roode einden der leedjes, tijn behaard, zoo lang als de helft van het ligehaam; lid 1 vrij kort en iets dikker dan de anderen, lid 2 langer dan 3, 4 zoo lang als 3. Zuiger licht bruin. Thorax iels langer dan breed, achter den kop diep iugesneden, glad en glanzig tot over de helft, dan met dwarsrijen van fijne putjes bedekt. Sehildje tamelijk breed, 
fijn bestippeld, een weinig ingedeukt naar de spits toe. Dekschilden lederachtig bestippeld, glanzig met 3 rijen grover stippels langs den naad van den clavus; zij bedekken bijna het geheele achterlijf maar bebben geen membraan. De pooten hebben zwarte heupen en dijen, roodbruine knieën en scheenen met geelroode tarsen, waarvan het eerste lid donkerder is dan de beide volgenden.

De heer G. A. Six ving deze soort bij Driebergen en bij Scheveningen in Junij; de heer Heylaerts in tamelijk antal bij Breda in September.

\section{Plinthisus pusillus Schol\%.}

Plaat 6, fig. 11.

Scholz, Aufzähl. d. Schles. Land- u. Wasserwantzen, p. 41. - Fieber, Europ. Hemipt. p. 178.

Lengte $1,5 \mathrm{~mm}$. - Geheel zwart met bruine sprieten en pooten. Kop veel breeder dan lang, doch veel smaller dan de voorrand van den thorax, met matig groote bruine oogen. Sprieten roodbruin, zoo lang als de helft van het ligchaam; lid 1 zeer klein, 3 iets langer dan 2, 4 gelijk aan 2 doch iets dikker. Zuiger licht bı uin. Halsschild veel breeder dan lang, van voren rond toeloopend, naar achteren vierkant, weinig glanzig, sterk gestippeld, vooral voorbij de helft, waar vier rijen grover stippen achter elkander staan. Schildje vrij klein, glad. Dekschilden met paarsen gloed, vrij lang naar evenredigheid der lengte van het dier, grof gestippeld en daardoor een lederachtig voorkomen hebbende; vooral zijn de stippen diep ingedrukt op den clavus, waar zij in rijen staan. De membraan ontbreekt en van het achterlijf zijn, achter de dekschilden, aan de bovenzijde slechts twee ringen gedeeltelijk en een geheel te zien. Pooten licht roodbruin, de dijen donkerder; de voorste dijen zeer dik en met een tandje voorzien.

De heer Heylaerts trof ook deze soort aan in de omstreken van Breda en een voorwerp werd 17 April 1869 door mij te Wassenaar gevangen. 
Gen. 9. Acompus Latr.

Dit geslacht heeft de meeste kenmerken met Drymus gemeen, doch onderscheidt zich daarvan op den eersten blik door de zeer sterk uitpuilende oogen, waardoor de kop zelfs breeder schijnt te zijn dan hé borststuk aan den achterrand, alsmede door de meerdere dikte van het laatste lid der sprieten. De overige kenmerken vindt men in de onderstaande beschrijving onzer eenige soort opgenomen.

Acompus rufipes Wolff.

Plaat 6 , fig. 7.

Wolfr, Ic. Cim. p. 151, tab. 15, f. 145. - Schill. Beitr. 63, 3, t. 2, f. 3 (Ophthalm. Lonicerae). - Flor, Rh. Livl. I. p. 24i, 8. (Pachymerus clavatus). - Douglas and Scott, Brit. Hem. I, p. 218. pl. 8, fig. I.

Lengte $3 \mathrm{~mm}$. - Zwart, niet zeer glanzig, maar door een zijdeachtig grijs vilt bedekt. De kop met de zeer uitpuilende oogen kort en veel breeder dan de voorrand van het halsschild, sterk gestippeld. Sprieten zoo lang als het halve ligchaam; lid 1 gelijk komend met de spits van den kop, bruin; lid 2 en 3 gelijk van lengte, slank, rood; lid 4 even lang, doch dikker, spoelvormig, zwart of donkerbruin. Zuiger bruin, tot de achterheupen reikend. Borststuk bijna vierkant, zeer sterk gestippeld, vooral aan de achterzijde; de ảwarsnaad bịna niet bemerkbaar. Schildje tamelijk bol en minder sterk gestippeld dan de thorax. Dekschilden gewoonlijk niet langer dan het halve achterlijf, geel met rịen van zwarte stippeltjes en twee kaneelbruine vlekken aan het einde, waarvan de binnenste de grootste is; de membraan vormt om den achterrand een' smallen witten zoom. Achterlijf op de zijden met een duidelijk opstaanden rand. Pooten rood, behalve de heupen en het laatste lid der tarsen, die zwart zijn. De voordijen zijn wel iets dikker, doch dragen geene doorntjes.

Indien de figuur van Wolff werkelijk deze soort voorstelt, is 
zij al zeer ongelukkig uitgevallen; ik twijfelde vroeger dan ook zeer of ik mijn eenig voorwerp wel den naam Rufipes geven mogt, toen de heer Mayr mij onder den naam Acompus rufipes Wlff een voorwerp van volkomen dezelfde soort toezond, doch dat iets grooter was. Trouwens de korte besehrijving van Wolff, p. 151 past volkomen, doch is oppervlakkig. Later leerde ik de afbeelding en beschrijving van Douglas en Scott kenuen, die voortreffelijk zijn.

Een voorwerp dezer vrij zeldzame soort werd in Mei door den heer Six bij Utrecht gevangen, drie dergelijken door den heer Leesberg bij Harmelen; anderen met langer dekschilden door den heer Heylaerts bij Breda.

Gen. 10. Micropus Spin.

Met dit genus verlaten wij het oude geslacht Pachymerus, want de soort, die wij nu gaan behandelen, ofschoon vroeger door mij daartoe gerekend, wijkt in al te veel bijzonderheden af om niet eene geheel eigenaardige plaats in te nemen. Terwijl bij alle vorige geslachten de heuppannen der voorheupen in den achterrand van bet voorborststuk waren ingesneden, zijn zij hier ongeveer in het midden van het voorborststuk geplaatst. Voorts zijn alle dijen ongewapend en de voorsten schier niet dikker dan de achtersten. Eindelijk is het eerste lid der achtertarsen niet langer, maar wel een weinig korter dan de beide overigen vereenigd.

De overige kenmerken leert men uit de beschrijving onzer eenige soort kennen.

\section{Micropus decurtalus H. Seh.}

Plaat 5, fig. 9 en $9 a$.

Herr. Sch. W. Ins. IV, p. 10, tab. 113, f. 355. - Signoret, Genre

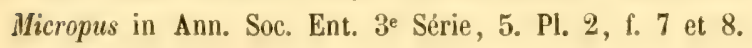

Lengte $5 \mathrm{~mm}$. - Lang en smal, gewoonlijk met onuitgegroeide vleugels en dekschilden. Kop met inbegrip der oogen 
breeder dan de voorrand van het halsschild. Oogen sterk op zijde uitpuilend; daarachter loopt de kop smaller toe in de gedaante van een' hals. Sprieten naauwelijks zoo lang als de helft van het ligchaam, vaalzwart; het $1^{\mathrm{e}}$ lid zeer kort, het $2^{\text {e }}$ bijna 3 maal zoo lang als 1 , slank doch breeder uitloopend; lid 3 iets korter doch gelijk gevormd, 4 zoo lang als 2, maar dikker en spoelvormig. Zuiger zeer dun en niet verder reikende dan tot even voorbij de voorheupen. Thorax van voren rondloopende, aan de zijden naar achteren zich verbreedende, met stompe achterhoeken en ingebogen achterrand, zwart weinig glanzig met den achterzoom bruin of geel. Het schildje gelijkzijdig driehoekig. Dekschilden in het midden wit, aan alle randen vaal geel, met bruine aderen, die somwijlen aau den achterrand nog breed met bruin omzet zijn; membraan zeer lang, van dezelfde kleur met bruine gegolfde aderen en bruingewolkt, gewoonlijk den achterrand van het lijf niet bereikende. Gewooulijk zijn de dekschilden en vleugels niet uitgegroeid en schijnen dan slechts korte schubben, als fig. $9^{\mathrm{a}}$ op onze tiende plaat. Het achterlijf is zwart, de pooten rood met het grootste gedeelte der dijen zwart. De voordijen zijn bij deze soort niet dikker dan de overigen, daar alle paren matig dik zijn.

De heer Overdijk ving deze soort bij Katwijk, de heeren de Man en La Fontijn in het duin bij Vlissingen.

Gen. 11. Heterogaster Schill.

Ligchaam langwerpig, meer dan driemaal zoo lang als breed. Kop met vrij sterk uitpuilende oogen breeder dan lang, ietwat bol, achter de oogen een weinig versmallend. Bijoogjes klein, nader bij de oogen dan bij elkander. Zuiger tot de middenheupen reikend, slank met de basis van lid 1 in een gleufje van de keel stekend. Sprieten niet langer dan een derde ge. deelte van het ligchaam, dun, uit vier leedjes gevormd, waarvan het eerste zeer klein is. Prothorax op den rug zonder dwarsnaad, naar achteren breeder nitloopend doch met afge- 
ronde hoeken. Schildje vrij groot, iets langer dan breed. Bovenvleugels uit corium, clavus en membraan bestaande; de membraan voorzien van 4 langsaderen, welke aan de basis drie gesloten cellen vormen. Pooten kort en krachtig; de voordijen schier niet dikker dan die der beide volgende paren, maar van onder digt bij de kniebuiging van een fijn, scherp tandje voorzien; het eerste lid der tarsen zoo lang als de beide volgenden te zamen. De $4^{\text {e }}$ en $5^{\text {e }}$ buiksegmenten bij de wijfjes in het

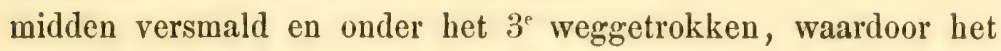
$6^{\mathrm{e}}$ in omtrek kegelvormig wordt.

\section{Heterogaster Urticae F.}

\section{Plaat 7, fig. 2.}

Fabr. S. Rh. 231, 136.- Schill. Beitr. I. p. 84, tab. 7, f. 8. - Burm. Handb. II. p. 293, 1. - Hahn, W. Ins. I. p. 73, pl. XI. - Flor, Rh. Livl. I. p. 302. - Douglas and Scott, Brit. Hem. p 222. Pl. 8, fig. 3.

Lengte 6-7 mm. - Donker bronskleurig met fijn grijs vilt bekleed. Kop met een zeer klein geelachtig vlekje in het midden van den achterrand. Eerste lid der sprieten zwart, de volgenden licht-roodachtig bruin, aan de spits donkerder en zoo dat elk volgend lid ietwat donkerder is dan het voorgaande Zuiger lichtgeel, aan de bovenzijde en aan de spits zwart. Het voorste gedeelte van den prothorax fijn, het achterste grof gestippeld; de achterrand dikwijls geel; in het midden bij sommige voorwerpen een korte gladde langskiel. Schildje eveneens voor fijn, achter grof gestippeld, dikwijls geel aan de spits. Dekschilden vuil geel met zuiver gelen buitenzoom, elk met drie of vier zwarte streepjes en geheel an de punt van het corium een zwart driehoekje; vrij zware stippeltjes aan beide zijden van al de aderen. Membraan doorschijnend wit met een rond zwart vlekje in de middelste der drie gesloten cellen. Rand van het abdomen buiten de dekschilden en membraan uitstekend, zwart en wit gevlekt in blokjes. Deze teekening van den rand ziet men ook aan de onderzijde, waar het geheele lijf zijde achtig behaard is en de wijfjes op den $6^{\text {en }}$ ring eene langwerpig 
ovale gele vlek vertoonen. Pooten zwart en geel geringeld. Het komt mij voor dat wij hier een ander ras bezitten dan onze Duitsche buren; onze exemplaren ziju bepaald bronskleurig, zelfs groen; de beschrijvingen der Duitschers spreken altijd van zwart 1). In de plaat van Hahn en de beschrijving van Flor ontbreckt het zwarte vlekje der membraan.

De soort is niet zeldzaam; men ving haar in verschillende provineien. Zij komt tamelijk veelvuldig voor te Brummen volgens wijlen den heer van Walchren, en te Katwijk onder de bladeren van Salix repens in Augustus, volgens Mr. H. W. de Graaf. Op ter Schelling werd zị door Dr. Everts, bij Breda door Heylaerts en op Walcheren door Gerth van Wijk aangetroffen.

Gen. 12. Crinus Hahn.

Ligchaam eirond of langwerpig eirond. Kop bij sommigen breed, bij anderen smal, in vergelijking van het ligchaam gewoonlijk klein. Sprieten van vier leedjes, waarvan het cerste kleiu en dik, de beide volgenden zeer slank, het laatste dikker en spoelvormig. Zuiger tot aan de achterste heupparen of zelf's daar voorbij reikend, bij twee soorten an de basis in eene gleuf van de keel gesloten. Oogen nu eens sterk uitstekend, dan weder klein en weinig verheven; bijoogjes vrij digt bij de oogen geplaatst. Prothorax altijd, van boven gezien, trapeziumrormig, doch nu eens korter dan weder langer dan breed. Schildje breed en kort, bij twee soorten zeer kort. Deksehilden schier meer vliesachtig dan lederachtig niet altijd met duidelijke langsaderen; membraan zeer groot, ver over het acherlijf heenreikend, glasachtig met moeijelijk te onderscheiden langsuderen, die geene gesluten cellen vormen. Pooten slank, voorste dijen niet dikker dan de overigen; eerste lid der tarsen an de pooten zoo lang of iets lauger dan de beide overigen te zamen. Aan het achterlijf der wijfjes zijn de drie eerste ringen regt, het

1) Ook de Engelsche van Douglas en Scott. 
vierde en vijfde segment in het midden naar boven gedrongen en vitgesneden, zoodat zij aldaar niet of slechts voor zoo ver den rand van het vierde betreft, te zien zijn, waardoor het zesde kegelvormig naar voren uitsteekt.

Geheel natuurlijk is dit geslaclıt niet; van daar dan ook dat het door sommigen, 0. a. Flor in 3 endergeslaehten worlt opgelost. Ik zeloof evenwel dat het niet noodig is dit te doen, angezion men in de sprieten, de dekschilden, de membran en het achterlijf genoeg kenmerken van vereeniging onzer vier soorten bezit.

\section{Tabel der soorlen.}

1. (2) Kop met de oogen breeder dan de helft van den achterrand van het borststuk . . . Ericae.

2. (1) Kop smaller dan de helft van dien achterrand.

3. (4) Twee donkere vlekjes op het midden der dekschilden. . . . . . . . . Ricselae.

4. (3) Geen donkere vlekjes op het midden der dekschilden.

5. (6) Achterraud van het corium zoo lang als die van den clavus . . . . . . . . claviculus.

6. (5) Achterrand van het corium langer dan die van den clavis . . . . . . . . glandicolor.

\section{Cymus Resedae Panz.}

Plaat 7 , fig. 3.

Panz. Fn. Germ 40, fig. 20. - Burm. Handl. II. p. 292. - Schill. Beitr. I, p. 89, tab. 8, f. 5. - Flor, Rh. Livl. p. 296. - Douglas and Scott, Ent. Monthly Mag. II, p. 217.

Lengte 4 mun. - Gemakkelijk herkenbaar aan de vlekjes op het midden der deksehilden. Bruinachtig rood, aan de onderzijgle iets donkerder, schier zwart. Kop driehoekig, niet breeder dan de helft van den achterrand van den prothorax, vrij sterk gestippeld; de bolle bruine oogen steken een weinig over den voorrand van het halsschild heen. Zuiger liehtrood, lang, slank, 
reikende tot voorbij het laatste paar heupen, aan de keel eenigzins in eene gleuf van den kop geborgen. Spricten zoo lang als het halve lijf; lid 1 reikt naauwelijks voorbij de spits van den kop en is zwart, 2 en 3 zijn slank en rood, met zwarte spits; 4, zoo lang als 3 , is dikker, spoelvormig en zwart. Het halssehild, ruw gestippeld, heeft twee bruine of somwijlen zwarte vlekjes aan den voomand. Het schildje is driehoekig, iets breeder dan lang, fijner gestippeld dan de thorax. Dekschilden licht rood of geelachtig rood, alleen laings de randen van den clavus en op de aderen gestippeld. De achterrand van den clavus en die van het corium bloedig rood; op de beide middenaderen ter plaatse waar zij even voorbij de helft harer lengte naar elkander toebuigen, twee roodbruine of zwarte vlekjes, die zich wel eens tot een vereenigen; twee andere roodbruine of zwarte vlekjes aan den achterrand. Membraan geheel doorschijnend met vijf langsaderen, waarvan slechts de beide binnensten de basis raken; ook deze aderen zijn doorschijnend en dus zeer moeijelijk te zien. Onderzijde van den thorax grijs met grove bruine stippen; achterrand van den metathorax vuil wit. Zesde ring van den buik bij het wijfje rood. Pooten rood met het laatste lid der tarsen zwart.

Deze soort is niet zeldzaam; ik trof haar gedurende den geheelen zomer bij Bennebroek, Heemstede, Noordwijk, Driebergen, Velp, Rhedo en Brummen aan; do heer Six vond haar in rrij groot aantal op heigrond bij Driebergen en de Bildt; de heer Snellen vond har bij Arnhem, de heer Ritsema op Middenduin bij Overveen en de heer La Fontijn op de duinen ran Walcheren. Zij sebijnt dus aan drooge gronden de roorkeur te geven en, zoo ik mij niet geheel vergis, lecft zij gaarne op berken.

\section{Cymus Ericae Sehill.}

Plaat 7, fig. 4.

Schill. Beitr. I, p. 86. tab. 7, fig. 10. - IIcrr. Sch. Fn. Germ. 135, f. 15. - Burm. Handb. II, p. 292, no 2. - Flor, Rh. Liv\%. I, 1. 292.bonglas and Scott, Hem. brit. 1. 226, PI. 8, tig. 4. 
Lengte 3-4 mm. - Grauw, abdomen zwart met cene kegelvormige gele vlek bij het wijf.je. Kop zeer breed, met do oogen veel breeder dan de helft van den achiterrand van den prothorax, zाrart gestippeld. Sprieten in lengte en gedaante als bij de voorgaande soort, nootbruin met het $1^{e}$ en $4^{e}$ lid donkerder. Zuiger matig lang, bruin; 1 e lid in eene gleuf aan de keel verborgen. Halsschild niet veel langer dan de kop, achter niet zeer veel breeder dan roor, grof gekorreld, an den hals con weinig zwart gevlekt. Sehildje icts donkerder dan het halsschild, mede grof gekor'eld. Dekselilden viil geclachtig wit, met twee langsrijen ran bruinachtige stippeltjes en driv zwarle streepjes aen den acherrand. Menbraan vuil wit, bruin bestoven tusschen de schier ouzigtbare aderen. Midden van de borst geel, randen vaal zwart. Pooten vuil licht geel of grauw, de dijen zwart gespikkeld, de beide laatste leedjes der tarsen zwartachtig.

Deze soort, die niet zeldzaam is ep lecigrond bij Driebergen en de Bildt, komt ook in de duinen voor, en wel sommige jaren in niet gering aantal. Zij werd bovendien door den heer Ver Loren te Dalfsen gevangen en door Mr. II. W. de Graaf bij Velp in Julij.

\section{Cymus claviculus Fall.}

Pliat 7, lig. כ.

Fall. Mon. Cim. Suec p. 61. - Schill. Beitr. I, p. 90, tab 8, i. 6.IIahn, W. Ins. I, p. 77, tab. 12, f. 44. - Burm. Handb. II, p. 292, no 3. - Flor, Rh. Livl. I, p. 300. - Douglas and Scott, Brit. Hem. p. 235, pl. 8 . fig. 8 .

Boven en ouder nootkleurig braingeel, alleen de borst wat grauw. Kop breeder dau lang, fijn gekorreld, iets rooder van kleur dan de thorax. Oogen rrij sterk nitpuilend, donker bruin. Sprieten korter dan het halve lijf; lid 1 zeer kort en rrij dik, 2 en 3 slank, 4 spoelvormig, dikker, vaalzwart. Zuiger tot de middenhenpen reikend, met het eerste lid niet in eene gleuf ran de kecl verborgen. Halsschild bol verheven, zoo lang als 
even voor den achterrand brecd, strof gekorreld met ecn kleis glad kieltje, voortspruitende nit het midden van den voorrand; daar nast soms aan icdere zijde cen donker dwarsstreepje. Sehildje veel breeder dan lang, fijn gekorreld. Deksehilden doorschijnend lichtbruin met eene aler langs de zijde, doch zonder anduiding van mildenaderen. be clavus breed uaar den middennad toe; achterrand van het corium iets donkerder bruin en de spits nog donkerder. Membraan gebeel doorzigtig, wit. Pooten van de kleur van het lijp.

Deze soort is volgens den heer Six gemeen in de omstreken van Utreelt, zelfs reeds vroeg in het voorjaar. Zij werd bovendien in de duinen bij Wassenaar en te Groningen gevangen. In de tweete naminlijst der inlandsche Hemipteren staat dat zij te Dalfsen gevangen is, dit is echter onjuist; het voorwerp dat met die etiquette in 's Rijks Musem beward wordt, behoort tot de roorgaande soort.

\section{Cymus glandicolor Hahn.}

Plaat 7 , fig. 6.

IIahn, W. Ins. I, p. 79, tab. 12, f. 45. - Flor, Rh. Livl. I, p. 299. - Douglas and Scott, Brit. Hem. p 236.

Deze soort is zoo na verwant aan de vorige, dat zij door Sehilling slechts voor ecne varieteit er van gehouden werd. Ondertusschen is er verschil en wel in de volgende punten:

De kop is naar verhouding smaller en sehijnt dus reel langer. De thorax is langer en loopt naar voren smaller toc. Het schildje is donkerbruin met cene licht geel verherene langsstreep in het midden. De dekschilden zijn betrekkelijk icts langer en hun achterrand kennelijk langer dan de naad tusschen corium en clavus, ook is die achterrand niet donkerder van klemr.

De heer Six meldde nij dat de soort vrij geween is in Junij op eiken te Driebergen. Ik ving haar in het Sehereningsche duin in Junij en bij Voorschoten in Julij. Ook werd zij bij Breda in April angetroffen door den heer Heylaerts. 
Gen. 13. Opitimaluicus Hahn.

Zeer gemakkelijk te onderscheiden door het korte gedrongene ligcham en de nitpuilende ongen. Kop meer dan tweemaal zoo breed als lang met verbazend groote bolle oogen, dic nar achter ver over den rand van het halssehild uitsteken. Bijoogjes moeijelijk te herkennen, vrij digt bij de oogen geplaatst. Sprieten iets korter dan het haive lijf; hun eerste lid kort, doch niet veel dikker dan de volgenden, die onder elkander schier gelijk zijn in lengte. Zuiger tot an de achterheupen reikend, zijn tweede lid korter dan het derde. Halsschild veel breeder dan lang, voor weinig smaller dan achter. Schildjo groot, driehoekig", mede breeder dau lang. Dekschilden onvolmaakt ontrikkeld, nict altijd met duidelijk afgescheiden clavus en dikwijls zonder membraan. Het abdomen van boven zigtbaar. Pooten sterk en vrij lang, zonder stekels; de roordijen ietwat dikker dan die der volgende paren; de tarsen somwijlen langer dan de helft der scheenen. Aan den buik zijn bij het wijfje de randen der 4 eerste ringen parallel, doch is de rand

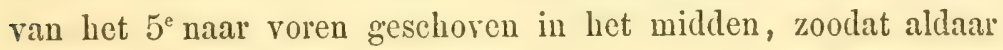
slechts een smalle zoom overblijft.

Drie soorten zijn inlandsch, die aldus van elkander onderscheiden worden:

Dekschilden zwart met witte randen . . . Grylloides.

Dekschilden geelachtig wit, naar den binnenhoek bruin . . . . . . . . Pallidipennis.

Dekschilden geheel zwart. . . . . . Aler.

1. Ophlhalmicus grylloides L.

Plitat 7 , ligg. 7 .

Limn. S. N. V, 1. 181, 13. - lialls. S. Rh. 115, 7. - Fill. Hem. I, p. 70. -- IIahn, W. Ins. I, 1. 86, tab. 1', f. 48. - Wolli, Ic. Cim. p. 4., tab. 5, f. 41 (te lang). - Schill Beitr. I, p. 62, tab. 8, f. 7.Fieber, Ent. mon. 1. 123, tab. 10, f. 7. - Flor, Rh. Livl. I, 1. 306. 
Lengte bijna $4 \mathrm{~mm}$. - Glanzig zwart met witte rersicrsels. Kop flaauw gestippeld met cen wit drichoekig vlekje aan beide zijden van de inplanting des zuigers en daarnaast naar de oogen the nog een fijn wit streepje. Oogen glanzig bruin. Sprieten zwart, met het laatste lid bruin. Halssehild grof gestippeld met aan iedere zijde een kleia ovaal ongestippeld plekje en de vier randen bruinachtig wit of geelwit. Schildje iets langer dan het halsschild, grof gestippeld met de punt geelachtig. Deksehilden kore selubbetjes zouder clavis of membraan, sterk gestippeld met al de randen breed bruinachtig of geclachtig wit gezoomd. De uiterste zijrand van het aehterlijf met een wit strecpje. Aan de onderzijde de zuiger bruin an de inplanting, gaandeweg donkerder wordend van kleur, aan iedere zijde van zijne basis weder een driehoekig vlekje even als boven. De voorrand van den thorax smal wit. Borst sterk gestippeld met de heuppannen bruinachtig wit. Pooten bruinachtig wit, iets donkerder op de dijen en aan het laatste lid der tarsen.

Dit is de beschrijving van het wijfje. Het mannetje, dat mij onbekend bleef, heeft volgeens Flor het laatste lid der sprieten geel en den achterrand van den prothorax op de bovenzijde, even als op de onderzijde zwart.

Volgens den heer Six is deze soort niet zeldzaam op heigrond bij de Bildt in Julij en Augustus; Dr. van Hasselt ving haar bij Utrecht. Ik ving drie wijfjes op de duinen bij den Ilaag in Julij en van den heer Piaget zag ik mede een zeker aantal voorwerpen aldaar gevangen.

\section{Ophulhalmicus aler F.}

P'laat 7 , fig. 8.

Fabr. S. Rh. 114, 4. - Fall. Hem. I, p. 71. - Woll, Ic. Cim. 1. 4:3, tab. 5, f. 40. - Гanz. Fn. Germ. 92, f. 20. - Ialm, W. Ins. I, 1. 88, tab. 14, fig. 49 cn 50. - Schill. Beytr. I, p. 62. - Burm. Handb. II, p. 291. - Fieb. Ent. mon. p. 121, tab. 10, f. 5. - Nor, lih. Livl. 1, p. 308.

Lengte 3-3,5 mm. - Zeer glanzig zwart met cene fijnc 
witte streep in de lengte over het midden ran het halssehild. Kop met een indruksel aan wederzijde naast het oog. Sprieters korter dan het halve lijf, zwart. Oogen donkerbruin. Halssehild grof gestippeld met twee ovale gladde plekken iets roor het midden. Schildje niet langer dan de thorax, gestippeld met eene fijne gladde langslijn. Dekschilden geheel zwart en grof gestippeld met eeu' zeer smallen, doch duidelijken clavus en eene bruine rond toeloopende membran. Zuiger bruin. Heuppannen geel; pooten licht roodbruin met donkere dijen.

De heer Six vond in Julij te Driebergen een enkel vrouwelijk exemplaar van deze soort.

\section{Ophthalmicus pallidipennis Costa.}

Costa, Monogr. deyl. Ophth. 1813. - Fieber, Ent. Alon. p. 118, Pl.10, f. 1 (Angularis). - Id. Eur. Hem. p. 176, 9.

Lengte $4 \mathrm{~mm}$. - Meer op de eerste dan op de tweede gelijkend, glanzig zwart met de basis der dekschilden vuil wit. Kop ongestippeld glad met den schedel zwart, het aangezigt en de keel licht zalmkleurig rood. Oogen glanzig, donker kastanjebruin. Sprieten zwart met een uiterst fijn wit streepje in de lengte over het derde lid. Zuiger zwart met de spits van het tweede lid geelachtig wit. Borststuk grof gestippeld met een ongestippeld dwarsrigeheltje op een derde der lengte; ook de achterrand is glad; deze is tamelijk breed, ivoorwit en ook de voorrand vertoont in het midden die kleur. Het sehildje is grof gestippeld en voorbij de helft naar de spits toe wat ezelsrugachtig. De dekschilden goed ontwikkeld met membraan, glad, glanzig met 3 rijen stippeltjes of ingedrukte putjes, gec!achtig wit, naar den binnenhoek bruin; de membraan glasachtig. Aan de onderzijde de voorrand van den thorax en de heuppannen wit; de pooten bruinachtig rood.

Deze voor onze Fauna nieuwe soort werd in twee exemplaren door den heer La Fontijn op Waleheren (bijj Vlissingen) gevangen. 
Aummerling. - In de tweede naamlijst van inlandsche Hemiptera (Tijlschr.v. Enl. III. bl. 180) staat nog opgegeven een Ophthalmicus dispar Waga, waarvan een wijfje zou gevangen zijn op Walcherer doon den heer Herklots en een mannetje bij Driebergen door den heer Six. - Dit laatste voorwerp is verdwenen maar het eerste bestaat nog in 's Rijks MIuseum, ofschoou het voor afbeelding en beschrijving niet langer is geselikt.

Ik maak bezwaar die soort hier op te nemen, omdat ik bij Fieber (Enl. Honogr. p. 121) lees dat het mannetje van deze door Waga zeer oppervlakkig beschreven en slecht afgebeelde soort, gelijk zot zijn aan dat ran 0. grylloides en het wijfje eene zeer sterke gelijkenis zou vertoonen met zijn O. Ulrichii. IIerrich-Schaeffer geeft van Dispar geene beschrijving, slechts eene diagnose en afbeelding (naar Waga?).

Ilet Zeeuwsche voorwerp bewijst ondertusschen dat er in Nederland nog cene vierde soort van Ophlhalmicus bestaat en wel hoogst waarschijulijk Ulrichii Fieb. Het dier is zwart met bruinen zuiger, roodbruine pooten en een roodbruin abdomen met zwarte dwarsstrepen. Aan den zijrand van den thorax is een fijn wit streepje onduidelijk zigthaar. De prothorax is zeer kort en de dekschilden, waaraan de membraan en de clarus niet ontwikkeld zijn, nog korter. Sprieten, pooten en abdomen zijn zoo sterk beschimmeld, dat zij alle poging tot beschrijving ontduiken.

\section{Gen. 14. Kosmenus Cast.}

Een afwijkend geslacht, dat door cenige schrijvers tot de Tingididen wordt gerekend, angezien de tarsen schijnbaar nit twee leedjes bestaan en de dekschilden vliezig zijn. Het ligeham is in omtrek elliptisch, de kop breed, doch zeer kort, tusschen de sprieten voorzien van twee, gewoonlijk naar binnen gebogen, kromme hoorntjes. Oogen klein, bijoogjes verder van elkander dan elk van het oog aan zijne zijde. Sprieten kort, niet zoo lang als de prothorax, vau vier leedjes; het ecrste vrij dik en 
kort, het tweede even lang doch iets dunner, het derde twecmaal zoo lang als het $1^{e}$, zeer dun, het laatste spoelvormig en tamelijk dik. Zuiger kort, tot het $1^{e}$ paar heupen reikend, in cene sleuf aan de kecl geborgen. Prothorax schijnbaar vicrkant, doch iets breeder dan lang en aan de achterzijde een weinig verbreed, wat opgeblazen en bultig; de zijrand eenigermate op kantwerk gelijkend. Schildje zeer klein, drichoekig. Dekschilden groot, het achterlijf volkomen bedekkend, met breeden clavus en met een cuneus, die de basis der membraan geheel bedekt (of, zoo men liever wil, met lederachtige basis der membraan). Vier langsaderen in het vliezige gedeelte, welke ver van elkander staan en niet anastomeren. Pooten vrij kort, ongedoornd; de voorste dijen ietwat dikker dan de volgenden; de tarsen van drie leedjes, doch het eerste zeer klein en onder de scheen verborgen; het derde het langste. Bij de wijfjes de 4 ecrste segmenten van het achterlijf regt, het vijfde in het midden ingesneden.

Er zijn ons slechts drie inlandsche soorten bekend, waarvan de beschrijving, volgt.

\section{Zosmenus capitatus Wolff.}

Plaat 7 , fig. 9 en $9 a$.

Wolf, Ic. Cim. p. 131, tab. 13, f. 125. - Herr. Sch. Fn. Germ. 118, f. 19 (eenigermate twijfelachtig). - Burm. Handb. II, p. 262, n. 1. IIerr. Sch. W. Ins. IX, p. 193, tab. 318, f. 983. - Fieb. Ent. Hon. p. 34, tab. 2, f. 18. - Flor, Rh. Livl. I, p. 315. - Douglas and Scott, Brit. Hem. p. 240.

Lengte $2 \mathrm{~mm}$. - Vuilgeel of lichtgrauw. Kop zwart of bruin met zwarte oogjes en gele hoorntjes, die bij het mannetje langer zijn dan het $1^{e}$ lid der sprieten en aan de basis dunner dan naar het einde en naar elkander gebogen; bij het wijfje zijn zij reel kleiner en aan de spits nog ver van elkander staande. Sprieten en pooten licht roodachtig geel. Ilalsschild aan den voorrand bleckgeel, verder op bruin of bruingrauw, met de zijkanten plat on bladachtig, elk voorzicn van ecn, 
soms twee rijen mazen; het geheele ruggeveld gekorreld, behalve twee fijne langsrigcheltjes op het midden, die noch den voor-, noch den achterrand bereiken; aan hunne buitenzijde ziet men een fijn bruin vlekje. Schildje zwart met lichte, ietwat opgewipte spits. Dekschilden als een netwerk met zeer fijne mazen, bij de basis van het corium lichtgeel, verder op grauw of grijs met de aderen zeer duidelijk. De binnenbelft der membraan als het corium, het overige vliezig, zcer licht rookkleurig. Buik aan de zijde met donkere vlekjes.

Een voorwerp werd door den heer Six in Junij te Driebergen gevangen, anderen bij Noordwijk in Julij door Jh. Dr. Everts en bij Arnhem in April door den heer van Med. de Rooij.

\section{Zosmenus Laportei Fieb.}

Plaat 7, fig. 10.

Fieb. Ent. Mon. p. 33, no. 2, tab. 2, f. 17. - Flor, Rh. Livl. I, p. 313. - Douglas and Scott, Brit. Hem. p. 230.

Lengte 2] mm. - Deze soort verschilt van de vorige in den vorm der haakjes op den kop, in de gedaante van den prothorax en in kleur. Zij is grijzer en overal met donkere vlekjes versierd. Kop bruin, somrijlen met lichten voorrand; oogen zwart, voor ieder oog een scheefstaand stekeltje; de doorntjes bij het mannetje langer dan het eerste lid der sprieten, naar elkander gebogen, grauw, bij het wijfje kleiner en met de spitsen tegen elkander aan leunend. Sprieten geelachtig grauw, het laatste lid bruinachtig. Halsschild voor niet veel smaller dan achter, aan de zijden eerst bol nitgebogen, dan met ecne golf naar binuen gebogen, daarna we der roud uitgezet. Ilet middenvak naar achteren toe vrij bultig; de voorrand is lichtgeel even als twee fijne, doch korte langsrigeheltjes; tussehen deze laatsten staan twee bruine vlekjes en aan hunue buitenzijde twee kromme bruine streepjes. Shehildje is doukerder van kleur. Dekschilden zeer licht grijs aan de basis van het corim, voor het overige gedeelte met den clavus iets donkerder en 
(vooral aan den buitenrand) bedekt met vierkante bruine vlekjes, die soms tot dwarsbandjes in een vloeijen. Basis-gedeelte van ile membraan gelijk an het corium en mede bruin gevlekt, het overige vuilwit met rosse aderen. Borst zeer grof gekorreld; pooten iicht roodachtig gecl.

De soort is niet zoo zeldzaam als de vorige, de heer G. A. Six ving haar meermalen in Mei en Julij in de omstreken van Utrecht en te Roozendaal in Gelderland; de heer Heylaerts ving haar bij Breda in April, de heeren Everts en Leesberg bij den Haag in Norember onder afgevallen bladeren; mij kwam zij voor in Mei op de Gliphoeve. Volgens Flor is zij in Liefland gemeen op soorten van Atriplex van April tut October.

\section{Zosmenus quadratus Fieb.}

Plaat 4 , fig. 6 .

lieb. Ent. Mon. p. 31, tab. 2, f. 7, 9, 11. - Douglas and Scott, Brit. Hem. p. 238. Pl. 8, fig. 9.

Lengte 3,6 mm. - Herkenbaar an de d̈rie langsrigcheltjes vooraan op den thorax. Zeer licht grauwgeel, ook de sprieten en pooten. Kop kort en breed met roodbruine oogen, voor welke een naar voren gerigt stekeltje; de middellob van het voorhoofd is vrij lang ${ }^{1}$ ) en de zijlobben krommen zich als platte hoorntjes voor dezen heen en raken elkander weder aan. Het eerste lid der sprieten is dikker dan bij de andere soorten. Het borststuk heeft 3 langsrigcheltjes op den hals en de zijranden zijn niet ingebogen. Het schildje is zeer kort, donkerbruin met een ovaal wit knobbelije op de spits. De dekschilden hebben een zeer breeden clavus, zijn vrij grof gekorreld en vertoonen aan iederen zijrand 7 of 8 bruine vlekjes; de membraan heeft de basis netachtig vliezig, daaruit ontspringen vier witte regte aderen. De pooten hebben niets bijzonders.

1) In figuur 7 op Plant II van Fieber is dit oujuist voorgesteld, beter, doch nog niet volkomen juist, in fig. 9 . 
Fieber beschrijft het corium en den clarus als gevlekt en beeldt ze ook zoo af; ik zie dit niet op mijn exemplaar behalve de randrlekjes; echter houd ik de determinatie roor juist.

Een enkel voorwerp van deze zuidelijke soort werd door den heer N. La Fontijn op Walcheren gevangen. 


\section{VIJFDE FAMILIE. -- CAPSINEN.}

Deze aan soorten uiterst rijkc familie ontleent haren naam aan het geslacht Capsus, door Fabricius het eerst onderscheiden, die celiter nog vele soorten, tot de familie behoorende, in het geslacht Lygacus liet. Van de overige familiën onderscheidt zij zich door het gemis van ocellen en doordien de membran der bovenvleugels, die bovendien als zij geheel ontwikkeld zijn, een' cuneus bezitten, gewoonlijk twee door aderen begrensile cellen vertoont, bij cene soort echter slechts eene. Voorts zou men tot de kenmerken der familie kunnen rekenen, dat de beide laatste leedjes der sprieten in den regel haarfijn zijn.

Door het overgroote antal der soorten, die zeer sterk in gedaante en habitus verschillen, wordt het geven van een algemeen beeld zeer ongemakkelijk gemaakt; men houde dus bij het lezen der volgende regels wel in het oog, dat er telkens afwijkingen van de algemeene schets voorkomen. Het lijf is nu eens kort en breed, dan weder lang nitgerekt en smal; lhet grootste aantal der Capsinen echter is eer lang en slank, dan gedrongen ran bouw. De kop is in den regel niet groot, en bepaaldelijk smaller dan de achterrand van het borststuk; meestal gaat het voorhoofd zonder boek of naad in den sehedel over. De oogen puilen gewoonlijk wat uit, somwijlen zelfs zcer sterk, en staan aan de zijden van het hoofd, zoodat zij den voorrand ran het borststuk aamraken of ten minste niet ver daarvan verwijderd zijn. Gelijk wij boven reeds zegden, de bijoogen ontbreken.

De sprieten bestaan uit vier leedjes, waaran het cerste gewoonlijk slechts matig lang en het tweede het langste is, terwijl de beide laatsten haarlun zijn. Het tweede is somwijlen ann het cinde verdikt en dus knodsvormig, bij cukele soorten 
ook wel in het geheel verbreed en plat. De sprieten zijn op het voorhoofd tussehen de oogen ingeplant. De zuiger bestaat nit vier lecdjes, ongeveer gelijk in lengte, zij reiken in den regel tot de midden- of achterpooten, zelden tot het midden van den buik, en liggen, ofschoon tegen de borst gebogen, geheel vrij, zijnde nergens in eenc sleuf gevat, tenzij vrij oppervlakkig aan het einde van het eerste lid.

Het halsschild is schier nooit langer dan breed, meestal het omgekeerde en heeft van boven gezien gewoonlijk de gedaante van een' geknotten driehoek, nu eens vrij vlak, dan weder min of meer gewelfd; zijn voorrand vertoont dikwijls een smal zoompje, zijne zijranden slechts zeer zelden; gewoonlijk is de prothorax aan de zijden toegerond. Het schildje (scutellum) is gewoonlịjk klein, driehoekig met spitse punt en dikwijls met een dwarsgleufje aan de basis. De dekschilden zijn slechts bij enkele soorten niet geheel ontwikkeld; zijn zij het wel, dan bestaan zij nit corium, clavus, cuneus en membraan. Slechts bij twee soorten, Strialus en Stria/ellus, zijn in het eerstgenoemde langsaderen te bemerken, van welke ook slechts de buitenste gegaffeld is. Op den clavus is zelden eene ader, in de lengte loopende te zien; de cuneus is driehoekig, soms langwerpig drichoekig; zijn buitenrand is gewoonlijk regt, somwijlen convex, en in dat geval bestaat er dikwijls eene insnijding aan den buitenrand tusschen het corium en den cuneus. Van de cellen in de membraan hebben wij boven reeds gesproken; wij behoeven er hier alleen bij te voegen, dat de kleinste der beiden tegen den dwars oploopenden rand van den cuneus aanligt.

De pooten zijn in lengte en dikte zeer onderscheiden, zoodat daaromtrent geen algemeen beeld te sehetsen is. Alleen zij dit gezegd, dat de midden- en achterheupen gewoonlijk digt bij elkander staan en de voorheupen op ecnigen afstand van de eerstgenoemden; voorts dat de tarsen slechts drie lecljes hebben, waarvan bij eenigen het eerste, bij rele anderen het laatste let langste is.

Ilet abdomen is meestal van boven vlak of cen weinig nit- 
gehold, van onder bol. Het bestaat bij de wijfjes uit 6 ringen, bij de mannetjes nit 7 , indien men namelijk het eerste genitaal-segment, dat rolkomen de gedaante heeft der overigen, mederekent.

Men treft de Capsinen in het gras, op lage planten en heesters aan, somivijlen op boomen; sommige soorten kan men dikwijls op schermbloemen en Compositae aantreffen. Omtrent hunne ontwikkeling en den duur van hun leven is nog weinig bekenl; vele soorten schijnen van bloemensappen te leven, anderen echter zuigen tot voedsel kleinere insecten uit.

De systematische verdeeling heeft bij deze familie met grootere moeijelijkheden te kampen, dan bij anderen. Misschien vertoont zich hier hetzelfde geval als bij de Bolstorren, dat men namelijk eens aan het verdeelen zijude, steeds door blijft verdeelen (verg. hierover Lacordaire in zijne Genera des Coléoptires), omdat men geene goed afgeronde geslachten vormen kan, daar allen $\min$ of meer in elkander overgaan. Hebben de ondere schrijvers over Hemiptera naar het oordeel van sommigen te weinig geslachten aangenomen, het is uitgemaakt reker dat Fieber er in zijne Europaeischen Ilemipteren te veel heeft opgesteld en dat het jammer is dat Douglas en Scott in hunne British Ilemiptera zijn voorbeeld, ofschoon met kleine wijziging: hebben gevolgd, waarvoor zij dan ook reels door cen hunner landgenooten eene welverdiende teregtwijzing hebben ontvangen. Na rijp beraad is het mij het best voorgekomen niet meer genera aan te nemen dan in de onderstaande tabel worden opgenoemd. Omtrent één punt heb ik mijzelven niet wel kunnen voldoen; ik had het aan soorten rijkste geslacht 't zij Capsus, 't zij l'hylocoris willen noemen, omdat de familie dan eens die der Capsinen, dan eens die der Phylocoriden betiteld wordt, doch beide namen waren aan twee zeer bekende groepen verbonden, welke ik daarvan niet dorst berooven en zoo bleef mij niets over dan den geslachtsnam Lygyus, door Hahn voor ecnigen der grootsten ingevoerd, aan deze massa toe te kennen. 
1. (2) Membraan met ééne onverdeclde cel.

Gen. 1. Movalocoris Dahlb.

2. (1) Membraan met twee tegen elkander aanshitende cellen.

3. (12) Eerste lid der achtertarsen 2 of 3 maal langer dan het tweede.

4. (5) Kop op zijde gezien bolvormig met uitpuilende oogen. Gen. 2. Pithaxus Fieb.

5. (4) Kop op zijde gezien een parallelogram met rooruitstekend voorhoofd of een langen driehoek vormende.

6. (7) Voorrand van het halssehild zonder zoom.

Gen. 3. Mrris F.

7. (6) Voorrand van het halsschild gezoomd.

8. (9) Zijden ran den prothorax scherp kantig.

Gen. 4. Leptoteria Fieb.

9. (8) Zijden van den prothorax niet kantig.

10. (11) Eerste lid der achtertarsen niet dikker dan de overigen.

Gen. 5. Oxcognathus Fieb.

11. (10). Eerste lid der achtertarsen dikker dan de orerigen. Gen. 6, Alzøoтоnus Fieb.

12. (3) Eerste lid der achtertarsen even lang als het tweede.

13. (26) De oogen raken den voorrand van het halssehild aan of nagenoeg aan.

14. (15) Het laatste lid der sprieten zoo dik als het tweede.

Gen. 7. Lorus Hahn.

15. (14) Het laatste lid der sprieten dumner dan het tweede.

16. (17) Het tweede lid der sprieten naar het cinde verdikt, knodsvormig.

Gen. 8. Capsus T.

17. (16) Het tweede lid niet kuodsvormig.

18. (19) Dat tweede lid peulvormig en an de kanten harig bij een of beide sexen.

Gen. 9. Heterotoma Latr. 
19. (18) Dat lid niet zijdelings verbreed, niet dik met hareu bezet.

20. (21) Ligchaam kort en breed, kop zeer breed en plat van voren.

Gen. 10. Halticus Hahn.

21. (20) Ligehaam niet zoo breed als lang, kop niet afgeplat van voren.

22. (23) Sprieten en achterpooten zeer lang, $1^{\text {e }}$ lid der sprieten zoo lang als kop en thorax.

Gen. 12. Pily toconis Fall.

23. (22) Sprieton en achterpooten matig lang, $1^{\mathrm{e}}$ lid der sprieten korter dan de kop met den thorax.

24. (25) Ligehaam overal even breed; achterhoofd uitgehold, veel breeder dan de voorrand van het halsschild.

Gen. 11. Camaronotus Fieb.

25. (24) Ligchaam niet overal even breed, achterrand van den kop niet over het halsschild heenreikend.

Gen. 13. Lygus Hahn.

26. (13) De oogen ver verwijderd van den voorrand van het halsschild.

Gen. 14. Dicy Prus Fieb.

\section{Genus 1. Monalocoris Dahlb.}

Ligchaam klein, ovaal; de lengte gelijk aan $1 \frac{1}{2}$ maal de grootste breedte. Kop kort, tusschen de oogen breeder dam lang, met een bol voorhoofd en de basis van den suuit uitstekend. Oogen niet zeer groot, een weinig uitpuilend, op zijde gezien ovaal. Sprieten bij het wijfje bijna zoo lang als het lijf, bij den man korter, slank; het $1^{\mathrm{e}}$ lid zoo lang als de kop, het $2^{\text {e }}$ het dubbel daarvan, het $3^{\text {e }}$ langer dan het $1^{\text {e }}$, het laatste kort en zeer fijn. Zuiger tot aan de achterheupen 
reikende. Halsschild op den rug bol, aan de zijden afloopende, met ietwat rondloopende zijden en stompe hoeken. Schildje wat bol opstaande in het midden. Deksehilden met breeden clavus en breeden zijrand, voor den cuneus ingekeept; de membraan en cuneus naar beneden gebogen, de eerste slechts met één cel. Pooten schraal en slank; het eerste lid der tarsen kort, het derde langer.

\section{Monalocoris Filicis L.}

Plaat 11 , fig. 1.

Linn. S. N. 718, 20 (1767). - Wolff, Icon. Cim. p. 46, t. 5, f. 43. Hahn, W. I. II, 86, f. 172. - Kirschb. Caps. 70, 76. - Flor, Rh. Livl. 539, no . 39. - Douglas and Scott, Brit. Hem. p. 279. Pl. X, f. 2.

Lengte $2 \mathrm{~mm}$. - Kop blinkend okergeel met wat bruin aan de basis van den zuiger, welks tip zwart is. Sprieten geel, met het eind van het $2^{e}$ lid en de beide volgenden zwart. Oogen zwart. Prothorax zwartachtig bruin, glanzig, grof gestippeld met twee kromme gleufjes achter den voorrand; achterhoeken bruingeel. Schildje van dezelfde kleur als het halsschild, fijner gestippeld. Dekschilden gewoonlijk iets lichter bruin, steeds met gelen buitenrand en gele wigge, soms met bruingelen clavus, fijner gestippeld dan de prothorax. Membraan grauw, naar den rand toe geelachtig, soms zeer bleek, met eene cel ingesloten door eene bruine of bruingele ader. Pooten lichtgeel met het laatste lid der tarsen en de klaauwtjes zwart; zeer zelden hebben de dijen voor het einde een bruin bandje.

Door mij half Julij in de gemeente Wassenaar gevangen op Polypodium filix mas, in Augustus aan de Rhedersteeg op Pteris aquilina, en te Voorst in Junij op eerstgenoemde plant. De heer Six vond haar tamelijk gemeen op varen bij de Bildt en Roozendaal, alsmede eenmaal bij Beek, de heer Ritsema te Wolfheze; Dr. Piaget ving haar aan den zoom der duinen en Jhr. Dr. Everts op ter Schelling. Waarschijnlijk komt de soort in al onze provinciën voor, maar de naverwante Mon. Pteridis Fall. is in ons vaderland nog niet ontdekt. 
Gen. 2. Pithanus Fieb.

Voornamelijk gekenmerkt door den bolvormigen kop, welks omtrek, van ter zijde gezien, van den schedel tot aan den zuiger half cirkelvormig loopt. De kop is met de sterk uitpuilende oogen veel breeder dan het halsschild, van boven ge. zien zoo lang als hij tusschen de oogen breed is. Sprieten ongeveer zoo lang als het ligchaam, met het eerste lid zeer smal aan de basis, spoedig daarop gezwollen en dik, korter dan de kop lang is; het tweede, meer dan driemaal zoo lang, een weinig krom gebogen, slank; de beide volgenden nog fijner, te zamen langer dan de twee eersten. Zuiger reikende tot aan den buik; zijn eerste lid vrij dik.

Het halsschild korter dan breed, door twee dwarsgleuven in drie deelen verdeeld, waarvan het middelste langer en boller is dan de anderen. Het schildje groot, een' gelijkzijdigen driehoek vormende. De dekschilden bij onze voorwerpen weinig ontwikkeld, niet veel langer dan de prothorax, zonder cuneus noch membraan, vierkant afgesneden bij het $q$, toegerond bij den $\delta$. Bij geheel ontwikkelde voorwerpen bezitten zij eene vrij groote membraan en eene wigge, dan reiken zij voorbij do spits van het achterlijf. Dit is in onze individuen spoelvormig met afgerond einde en scherp uitstekend connexivum of tusschenzetsel. De pooten zijn vrij lang en stevig met nog al dikke dijen en met het eerste lid der tarsen bijna 3 maal langer dan het tweede.

\section{Pithanus Maerkelii H. Sch.}

Plaat 11, fig. 2 en $2 a$.

Herr.-Schaeff. W. I. IV, p. 78, f. 406. - Flor, Rh. Livl. p. 513, no. 26. - Fieb. Eur. Hemipt. p. 239. - Douglas and Scott, Brit. Hem. p. 281 , pl. X, fig. 3 .

Lengte 4-5 mm. - Zwart, weinig glanzig. Op den schedel twee scheefstaande roode of geelroode dwarsstreepjes. Sprieten 
zwart, behalve de bovenhelft van het eerste lid, welke wit is. Zuiger roodachtig geel, zwart an de spits. Het halsschild heeft aan beide zijden nabij den voorrand een zwart knobbeltje, en op het midden een fijn, weinig verheven langsrigcheltje Het sehildje is in het midden eenigzins bol. Dekschilden in de lengte gerimpeld, zwart met breeden, geelachtig witten buitenrand; de vleugels ontbreken. Aan het zwarte achterlijf is het connexivum vuilwit. De pooten zijn steenrood, met gele heupen en apophysen en met het latste lid der tarsen bruin.

Van deze merkwaardige soort werden eenige voorwerpen in de duinen gevonden, overeenkomende met onze hierboven gegeven beschrijving, namelijk met ontontwikkelde dekschilden, door de heeren Piaget, van Hasselt, Six en v. Vollenhoven, een enkel te Domburg 18 Junij. Ook Perin heeft vroeger een dergelijk niet geheel ontwikkeld voorwerp - waarschijnlijk hij Katwijk of Wassenaar aangetroffen. Voorwerpen met geheel ontwikkelde vleugels, zoo als Herrich-Schaefier er een afbeeldt, kwamen in Nederland nog niet voor.

\section{Gen. 3. Miris F.}

Het ligehaam is langrverpig, slank, somtijds met de zijden evenwijdig. De kop is van boven gezien langer dan breed, vierkant tot de basis der sprieten, verder driehoekig, op zijde gezien een parallelogram met uitspringend voorhoofd. Somrijlen strekt zich het voorhoofd een eindje voorbij den clypeus uit; de schedel en het voorhoofd zijn gewoonlijk geheel horizontaal. De sprieten zijn voor de oogen op korte wratjes ingeplant en zoo lang als het ligchaam of iets langer; het $1^{\mathrm{e}}$ lid verbreed, harig en meestal langer dan de kop, het $2^{\text {a }}$ meest ook harig en $1 \frac{1}{2}$ of 2 maal zoo lang als het eerste; 3 en 4 te zamen genomen zijn korter dan de beide voorgaanden. De zuiger reikt tot de middenheupen of tot voorbij de achterheupen; het cerste lid is bijna altijd vrij dik. Het halsschild is boven plat, aan den voorrand zonder zoom, aan de zijden scherp, aan den 
rondgebogen achterrand breeder dan aan den voorrand, bijna altijd in het midden met een langsrigcheltje. Het schildje driehoekig, nagenoeg plat met een' dwarsuaad aan de basis onder den rand van den prothorax. De dekschilden lang en smal, met lange membraan. Ook de pooten zijn lang gerekt; het het eerste lid der tarsen is 2 tot 3 maal zoo lang als het 2 . De kleur is groen, geel of licht bruin.

Tabel der soorten.

1. (2) Achterdijen met 2 scherpe tandjes . . calcaralus.

2. (1) Achterdijen zonder tandjes.

3. (4) Buitenrand der dekschilden naar buiten gegebogen . . . . . . . . . Holsalus.

4. (3) Buitenrand der dekschilden regt.

5. (8) Achterdijen vrij dik, doch aan de spits plotseling vermagerd.

6. (7) De clypeus aan de basis door het voorhoofd bedekt. . . . . . . . virens.

7. (6) De clypeus an de basis niet door het voorhoofd bedekt. . . . . . . . . laevigatus.

8. (5) Achterdijen bijna overal van dezelfde dikte.

9. (10) Lengte slechts 6 millim. Sprieten rood . . ruficornis.

10. (9) " meer dan 6 millim. Sprieten bruingeel crralicus.

\section{Miris laevigatus L.}

Plaat 11, fig. 3 en $3 a$.

Linn. F. S. 958. - Fabr. S. Rh. 253, 2. - Ilahn, W. Ins. II, 79, f. 165 (Virens). - Herr. Sch. W. I. III, 43, f. 259. - Flor, Rh. Livl. I, p. 425. - Douglas and Scott, Brit. Hem. p. 284, pl. 10, f. 4 .

Lengte 6,5 tot $8 \mathrm{~mm}$. - Groen of bruingeel, bijna overal even breed. Kop van boven gezien onregelmatig vijfhoekig, plat met eene langsgleuf over de geheele lengle. De clypeus is aan zijne basis niet door het voorboofd bedekt. Oogen ovaal, weinig uitpuilend, grijs. Sprieten bijna zoo lang als het lig-

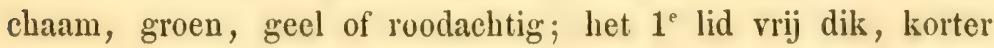


dan het halsschild, sterk behaard, groen of bruinachtig; het $2^{\text {e }}$ smaller en naar het eind toe nog smaller wordende, meer dan tweemaal zoo lang als het eerste, halverweg behaard, van het midden af naakt en roodachtig; het $3^{\text {e }}$ anderhalfmaal zoo lang als het $1^{\mathrm{e}}$, dun, rood; het $4^{\mathrm{e}}$ kleiner dan het $1^{\mathrm{e}}$, rood of bruin. De zuiger reikt tot aan de achterheupen. Het borststuk is op den rug zeer digt gekorreld met eene verheven langsstreep in het midden. Het schildje is evenzeer gekorreld. De dekschilden zijn meestal groen met bruinen clavus; de membraan is doorschijnend, zeer licht grijs, de randen der cellen bruinachtig. De achterdijen zijn met bruine vlekjes getijgerd, de tarsen dikwijls rood.

Dikwijls zijn de vrouwelijke voorwerpen geheel lichtbruin met twee donkerbruine strepen in de lengte over het borststuk.

De soort leeft als de overigen van het geslacht op duinen en heidevelden, doch ook op begroeide zandige plaatsen. Zij werd in bijna alle provincien aangetroffen.

\section{Miris virens $\mathrm{L}$.}

Linn. S. N. 502, 102. - Hahn, W. 1. II, t. 53, f. 161 (Laevigatus) en t. 71 , f. 220 (Ruficornis). - Herr.-Sch. W. I. III, p. 42, t. 85, f. 257 . - Flor, Rh. Livl. I, p. 423.

Reeds Linnaeus heeft van deze soort gezegd ,simillimus (Cimex) laevigato. Mij is zij altijd een steen des aanstoots geweest, want dan eens zag ik het verschil tusschen haar en de voorgaande wel, dan weer niet. Daarom heb ik van deze soort ook geene afbeelding gegeven en waag de veronderstelling dat de verschillen die men waarneemt, niet specifiek zijn, maar individueel. Ondertusschen daar alie schrijvers over Hemipt. Heteropt. de beide soorten onderscheiden en Fieber die zelfs in 2 geslachten heeft geplaatst, zoo meen ik wel te doen met de soort op te nemen en de punten van verschil op te geven.

Over het algemeen is de kleur meer geel dan groen, soms rood; van achter de oogen loopen dikwijls twee bruine langsstrepen tot an de hoeken van het scutellum; de kop is iets 
korter dan bij Laevigatus, de middengleuf bepaalt zich tot den schedel, maar is iets dieper. Van boven gezien ontdekt men de basis van den clypeus niet, omdat het voorhoofd dit bedekt; men ziet dus slechts een zeer klein puntje van den clypeus. De sprieten zijn iets korter, bepaaldelijk het $1^{e}$ lid. Het einde der achterdijen is nog plotselinger versmald dan bij de vorige.

Ik houd deze soort voor nog gemeener dan Laevigalus.

\section{Miris holsatus F.}

Plaat 11 , fig. 4 .

Fabr. S. Rh. 254, 4. - Burm. Handb. II, p. 265, 4. - Herr.-Schäfr. W. I. III, p. 41, t. 85, f. 256. - Flor, Rh. Livl. I, p. 427. - Douglas and Scott, Brit. Hem. p. 283.

Lengte 6-7 mm. - Kleur licht nootbruin, aan beide zijden geel. De soort van de beide vorigen te onderscheiden door meerdere breedte naar gelang der. lengte, door den gebogen loop van den buitenrand der dekschilden en door het weinig behaard zijn van het $1^{\mathrm{e}}$ lid der sprieten. De kop is slechts zoo lang als tusschen de oogen breed, bruinachtig met middengleutje tot bijna aan het eind. De basis van den clypeus is zigtbaar. De oogen zijn bruin en puilen wat meer uit dan bij de andere soorten. Sprieten korter dan het ligchaam; $1^{e}$ lid vrij dik, veel korter dan het halsschild, nootbruin, niet of ijl behaard; 2 iets meer dan tweemaal zoo lang als $1 ; 3$ en 4 te zamen iets langer dan 2. De drie laatsten zijn geel, doch 4 bruin aan de spits. De zuiger reikt tot an de middenheupen. De prothorax is aan den achterrand breeder dau hij lang is, sterk gekorreld, bruingeel, in het midden met een lichter langsrigeheltje; over beide der daardoor gevormde helften loopt eene bruine, in het midden gebogen streep. Het schildje is mede gekorreld met een bol middenstreepje. De dekschilden zijn korter dan bij de vorige soorten, in het midden breeder dan aan de beide einden, geel aan de buitenhelft, overigens geelbruin met twee bruine langsstrepen; cuneus geel, membraan vlak bij den cuneus geel, overigens vrij donker bruin. Pooten bruingeel, de achterdijen 
met bruine vlekjes, de spitsen der scheenen en tarsenleedjes roodbruin.

Deze, bij ons zoo het sehijnt zeldzame soort, werd eens door mij bij den Haag en op Staalduin, en donr den heer Heylaerts in het Liesbosch bij Breda gevonden; ook ken ik een voorwerp, door den heer Piaget an de oude plas bij Kralingen gevangen, dat ik tot deze soort meen te moeten brengen. Misschien is zij nog op vele andere plaatsen in ons land aangetroffen, maar om hare overeenkomst in kleur mot Virens, niet bemagtigd.

\section{Miris calcaratus Fall.}

Plaat 11, fig. 5.

Fall. Hem. Suec. I, p. 131, 5. - Burm. Handb. II, 265, no 2. Amyot et Serv. Hém. p. 278, 2. - Hahn, W. I. I, p. 15, t. 2, f. 8. Kirschb. Caps. p. 33, no 4.- Flor, Rh. Livl. 1, p. 421. - Douglas and Scott, Brit. Hem. p. 286, $\mathrm{n}^{0} 3$.

Lengte 6-8 $\mathrm{mm}$. - Dadelijk herkenbaar aan de kromme stekels der achterdijen. Naar gelang der lengte smaller dan de vorige; groen, bruingeel, nootkleurig of bruin. Kop matig lang, met nog al uitpuilende oogen en een zwart langsgleufje op het midden, dat nagenoeg tot het eind doorloopt. De basis van den clypeus is zigtbaar. De sprieten zijn bij den ${ }^{\delta}$ nagenoeg zoo lang als het ligchaam, bij het $q$ iets korter; lid 1 iets korter dan het halsschild, breed en sterk behaard, 2 meer dan tweemaal langer dan 1, 3 met 4 korter dan 2; de kleur is meest vuilgeel of lichtbruin; zoo 1 en 2 groen zijn, dan zijn de beide laatste leden rood. De zuiger reikt tot aan de middenheupen en is zwart aan de spits. Het halsschild is voorbij de helft tamelijk grof gekorreld, heeft een geel opstand middellijntje en dergelijke rigeheltjes voor aan de zijglen; 2 of 4 bruine strepen loopen in de lengte uver het halsschild, doch niet bij groene voorwerpen. Het gekorrelde sehildje heeft ook een licht gekleurd langsstreepje, als het bruin is. Het abdomen is van boven zwart, met groene of roode randen en 
bruinen anus. $O_{p}$ de dekschilden meest 2 bruine strepen, waarvan zich een op de membraan voortzet. De pooten zijn groen of geel, dikwijls bruin gestippeld op de dijen; de achterdijen vertoonen aan den onderkant niet verre van de spits twee kromme scherpe doorntjes, waarvan het kleinste digter bij het eind staat; de tarsen zijn rood of lichtbruin. Bij vele voorwerpen is aan de onderzijde de borst zwart en loopen er twee bruine zijdestrepen over de zijden (plcurae), en een over het midden van den buik.

Calcaralus is vrij gemeen op onze duinen en heidevelden. De heer Ritsema vond hem ook vrij gemeen in Mei op Texel, doch hij komit ook in lage streken en aan de rivieren voor. Dr. Piaget vond hem aan de Kralingsche plassen en in het Overmaassche land. Ook schijnt de soort het geheele jaar volwassen voor te komen en dus te overwinteren, want tegenover de genoemde vangst in Mei, staan andere vangsten in Junij, Julij (Groot-Zundert, v. V.), Augustus (Piaget) en het laatst van September (Oisterwijk, $\nabla$. V.).

\section{Miris erraticus L.}

\section{Plaat 11, fig. 6 en $6 a$.}

Linn. S. N. p. 731, 107. - Burm. Handb. II, 265, no 3. - Wollf, Icon. t. 16, f. 154 (Hortorum). - Ilahn, W. I. II, 78, t. 54, f. 164, 165. - Herr.-Sch. Id. op. III, p. 40. - Kirschb. Caps. 32, 1. - Flor, Rh. Livl. I, p. 431. - Douglas and Scott, Brit. Hem. p. 287.

Lengte 6-7 mm. - Groen met zwarte of donkergroene teekening op den rug, nimmer bepaald geel of bruingeel. Kop zoo lang als het halsschild, met ovale oogen, zwart met groene zijden en een dubbel lichtgroen vlekje op den schedel, of groen met 3 donkere langsstrepen. Van boven is de basis van den clypeus niet te zien, daar zij geheel door het voorhoofd bedekt wordt; op den schedel een kort ingesueden streepje. De zuiger reikt bijna tot aan de middenheupen. De sprieten zijn bij den $\delta$ langer dan het ligehaam met het $1^{\text {* }}$ lid donkerbruin, bij het q korter met het $1^{\text {e }}$ lid groen; bij beido is het vrij sterk be- 
haard; het $2^{\text {de }}$ is roodbruin, de beide volgenden zwartbruin. Het halsschild heeft een weinig uitstekend langskieltje in het midden en is groen met vier donkere langslijnen of zwart met groenachtig gele randen. Het schildje is zwart of groen met donkere strepen. De dekschilden zijn of zwart met geelgroenen buitenrand of groen met donkere strepen in de lengte. De membraan is licht- of donkergrijs gekleurd met somtijds witte, meest echter donkere aderen. Pooten groen of bruingeel, met fijne haartjes bezet, die vooral lang zijn aan de achterscheenen; achterdijen overal even dik, bij de donkere individuen met bruine vlekken en strepen, meestal naar de knie toe geheel bruin; de achterscheenen zijn geelbruin en de achtertarsen bruin. Keel, borst en buik zijn bij het mannetje zwart, bij het wijfje groen.

Deze soort is in de duinstreken in Julij en Augustus zeer gemeen, doch werd bovendien gevangen in het Overmaassche (dus op de klei) door Dr. Piaget, bij Maarsbergen door denzelfden en bij Middelburg door Dr. de Man.

\section{Miris ruficornis Fall.}

Plaat 11 , fig. 7 en $7 a$.

Fallen, Hem. I, p. 133, 8. - Herr. Sch. W. I. II, p. 119, tab. 66, f. 200 (pulchellus) en III, p. 40. - Meyer-Dür, Caps. p. 37, 6. - Flor, Rh. Livl. I. p. 435. - Douglas and Scott, Brit. Hem. p. 290, 6.

Lengte 4-6 $\mathrm{mm}$. - Kenbaar an de geringe grootte en de kleur der sprieten. Helder groen of groenachtig geel met roode sprieten. Kop korter dan het halsschild met de basis van den clypeus zigtbaar; op den schedel een kort ingesneden langsstreepje en van daar tot den clypeus een donker lijntje. De sprieten zijn ongeveer zoo lang als het ligehaam; hun $1^{\mathrm{e}}$ lid zoo lang als de kop, onbehaard, aan de basis groen. Halsschild aan beide zijden van een middenrigcheltje wat ingedeukt en daar met ietwat donkerder langistreep, soms ook nog twee donkere langsstrepen aan de zijden. Dekschilden zonder teekening met zeer langen cuneus en bleeke membraan. Onder- 
zijde van het lijf lichtgroen; pooten van dezelfde kleur met roode tarsen.

De aangehaalde afbeelding van Herrich-Schäffer vertoont het insect met roode vlekken op halsschild en clavus; een zoo fraai voorwerp heb ik nooit gezien. Scholtz verzekert dat dit eene andere soort is.

Gemeen in Julij op duinen en geestgronden; voorts nog door mij aangetroffen bij Goes in Junij, op Schothorst bij Amersfoort in Julij, op de Zundertsche heide den $21^{\text {en }}$ Julij en en aan het strand der Schelde bij Bergen-op-Zoom den $22^{\text {en }} J$ ulij.

Gen. 4. Leptoterna Fieb.

Dit geslacht verschilt van het vorige, waarvan het overigens den habitus heeft, hierin dat het borststuk aan de bovenzijde van achter. naar voren afdaalt en aan den voorrand duidelijk gezoomd is, dat het aangezigt rond naar beneden gebogen en de zuiger aan het voorste lid sterk verdikt is. Bovendien is het geheele ligchaam en met name de dijen sterk met zijdeachtige haren bedekt.

\section{Lept. dolabrala L.}

Plaat 11, fig. 8 .

Linn. S. N. V, p. 502, 103. - Fabr. S. Rh. 253, 1. - Wolll, Ic. Cim. f. 109 (slecht van omtrek) en 110. - Hahn et Herr.-Sch. W.I. II, p. 75, f. 160 et III, p. 45 , t. 86 , f. 261 et 262 . - Flor, Rh. Livl. I, p. 437. - Douglas and Scott, Brit. Hem. p. 297, Pl. 10, f. 6.

Lengte $7-8 \mathrm{~mm}$. - Langwerpig, van de schouders af bijna gelijkmatig breed, zwart met gele versieringen en vale dekschilden. Kop klein en kort met uitpuilende bruine oogen, zwart met de zoomen der oogen geel, welke zoomen op den schedel meest tweemaal zijn ingekeept; bovendien een zeer fijn geel langsstreepje op het midden van den kop. Zuiger vuilgeel, bruin an de spits, reikend tot de achterheupen. 
Sprieten zoo lang als het lijf (q), iets langer ( 8 ), harig, grauwbruin, donkerder aan de spits; lid 1 zoo lang $(\delta)$ of iets korter (o) dan het halsschild, het 2 langer dau 3 en 4 te zamen. Halssehild grijzig zwart met gele zijranden en eene gele middenstreep, die zich voorbij het midden tot eene ronde of ruitvormige vlek uitzet. Schildje vrij groot, glanzig zwart met eene oranje langsstreep in het midden; overdwars loopt eene vrij diepe gleuf. Dekschilden vaal, somtijds echter kastanjebruin met vuil- of heldergele randen, gelen cuneus en vale of zelfs rookbruine membraan, waarop de aderen in het geel of rood uitkomen. Borst zwart met twee gele rlekken; buik vuilgeel met drie zwarte langsstrepen; het laatste segment bij den man oranje met zwarte vlek. Pooten grauw of vuil bruingeel, de achterdijen met zwarte vlekjes, knieën en spitsen der scheenen zwart, zoo mede de klaauwtjes.

Bij ons komt het meest voor de var. die Ferrugata genoend wordt, welke minder sterk behaard en valer van kleur is, dan de eigenlịik zoo genoemde Dolabrala.

De soort is gemeen op duinen en geestgronden, maar komt ook op minder zanderige streken voor; b. v. te Velp (Ritsema), op de wallen van Breda (Heylaerts),

Gen. 5. Oncognathus Fieb.

Dit is het eerste der beide genera, die zich wel an de drie laatstgenoemden ansluiteu door de meerdere lengte van het eerste lid der achtertarsen, maar van Miris en Leptoterna vessehillen door de afgeronde zijden van den prothorax. De gedaante komt overigens geheel overeen met die van het geslacht Lygus Hahn. De kop is met de uitpuilende oogen breeder dan lang; van de sprieten, die de lengte van het ligchaam hebben, is het cerste lid ongeveer zoo lang als de kop, het $2^{e}$ meer dan tweemaal zoo lang. Itet halsschild is zeer smal van voren, vrij breed van achter. De zijrand der dekschilden is een weinig naar buiten gebogen. De pooten zijn lang en 
slank, vooral de achterpooten, wier dijen in het midden veel dikker zijn dan aan de niteinden en wier eerste lid der tarsen iets meer dan tweemaal langer is dan het tweede, doch niet dikiker.

\section{Oncogn. binolatus F.}

Plaat 11, fig. 9 q en $9 a$ ठ․

Fabr. S. Rh. 235, 159. - Herr.-Sch. W. I. III, p. 77, t. 98 , f. 296. Kirschb. Caps. 59, 56. - Flor, Rh. Livl. I, p. 499.

Lengte 5-6 mm. - Langwerpig, geel of groenachtig geel met zwarto vlekken. Kop glanzig, weinig gestippeld, met 2 scheve bruine vlekjes op den schedel, 2 audere voor de oogen en den clypeus zwart. Oogen uitpuilend, ovaal, met grove facetten, zwart. Sprieten slank, vuil bruingeel met de uiteinden der 3 voorste en geheel het laatste lid bruin; het $1^{\mathrm{e}}$ alleen aan de binnenzijde met eenige haartjes. Zuiger eerst geel, dan bruin, eindelijk donkerbruin, reikende tot over de achterhoupen. Het gele borststuk heeft een duidelijk afgesneden zoom aan den voorrand, is op de breede achterhelft vrij sterk gekorreld en vertoont twee langwerpig vierkante donkerbruine of zwarte vlekken, wier voorrand eene diepe groeve schijnt; in de zijden bespeurt men nog een lichtbruin vlekje. Het schildje, welks basis door eene dwarsgleuf begrensd wordt, is helderder geel met twee fijne bruine zijstrepen. De dekschilden zijn geel, op den clavus grijsachtig, op het corium met zwarte, schuin onder elkander geplaatste, doch meestal ineenvloeijende langsstrepen; de cuneus is ongevlekt geel, soms oranje. Membraan bruin of zwart, met lichtere, zelfs geelachtige aderen. Pooten van de kleur van bet lijf met bruine uiteinden der achterscheenen, die met zwarte stekeltjes bezet zijn, en met bruine tarsen. Buik soms met zwarte langsstrepen.

Gevangen bij Utrecht door den heer Six, in Augustus op Sterkenburg bij Driebergen door mij, in September mede in de provincie Utrecht op Wikkenburg door Dr. Wttewaall; voorts bij den Haag in Augustus door den heer van der Wulp en door den heer Heylaerts in Augustus bij Breda. 
Gen. 6. Alloeotomus Fieb.

Het ware kenmerk van dit geslacht bestaat in het eerste lid der achtertarsen, dat tweemaal langer en veel dikker is dan het tweede. Zonder deze bijzonderheid zou de eenige soort beter gebragt worden tot het geslacht Capsus, waarvan zij geheel den habitus heeft, tevens met het kenmerk van de knodsvormige gedaante van het tweede lid der sprieten. Zie hier $\mathrm{nu}$ een bewijs voor het gezegde, dat als men in deze familie systematisch al te scherp verdeelen wil, men genera maakt van afdwalende soorten, want kennelijk behoort deze sourt tot het Genus Capsus, doch is afgedwaald naar de groep met verlengd eerste lid der achtertarsen.

Alloeol. marginepunctalus H. Sch.

Plaat 11, fig. 10.

Herr.-Sch. W. 1. III, p. 69, lig. 284. - Fiel. Eur. Hem. p. 247 (Gothicus).

Lengte $5 \mathrm{~mm}$. - Roestgeel, dik bekleed met witte haartjes. Ligchaam langwerpig ovaal, tamelijk breed. Kop glanzig, van boven gezien driehoekig, puntig van voren, met groote, zwarte sterk uitpuilende oogen. Zuiger met donkere spits, reikt tot aan de achterheupen. Sprieten ongeveer $\frac{2}{3}$ der lengte van het lijf, het $1^{\mathrm{e}}$ lid veel korter dan de kop, niet dik, roestgeel met wat bruin aan den bovenrand en eenige haren aan de binnenzijde, het tweede bijna 4 maal zoo lang, knodsvormig, nog al sterk behaard, roestgeel, aan de spits bruin, de beide volgenden kort, fijn en bruin. Het halsschild glanzig doch grof gekorreld, naar achteren sterk verbreed met niar buiten gekromden achterrand. Schildje glanzig, bol, met 3 witte puntjes in de hoeken en aan de spits. Dekschilden ietwat doorschijnend, grof gekorreld met zwarte langsstreepjes aan den buitenrand; wigge lichtbruin met donkerbruine spits; membraan vuil- 
wit, naar de spits toe rookkleurig met duidelijke bruine aderen. Pooten geelachtig met bruine ringen aan het eind der dijen en bruine tarsen en scheenhelften.

Van deze soort is mij slechts een inlandsch voorwerp bekend, door den heer van der Wulp in Augustus in het duin bij den Haag gevangen.

Gen. 7. Lopus Hahn.

Terwijl de Capsinen in het algemeen kenbaar zijn aan de haarachtige fijnheid der beide laatste leden van de sprieten, zijn er toch drie soorten onder, bij welke de sprieten meer gelijken op sommige Lygaeoden 1) b. v. het geslacht Cymus, doordien de sprieten an het eind niet veel dunner zijn. Deze weinige soorten worden hier in het geslacht Lopus vereenigd.

Het ligehaam is meer langwerpig dan ovaal. Kop kort en driehoekig, bij eene soort wat bol op den schedel, bij de anderen meer plat. De sprieten zijn zoo lang als het ligehaam of langer; $1^{\text {e }}$ lid bij twee soorten langer dan de kop, $2^{\mathrm{e}}$ lid tweemaal zoo lang als het eerste of zelfs langer, bij ééne ietwat knodsvormig; de beide volgenden niet zoo fijn als gewoonlijk in deze familie, en in dikte weinig verschillend met het $2^{2}$. Halsschild aan den achterrand veel breeder dan aan den voorrand, van voren naar achter geleidelijk oploopend, bij eene soort met scherpe kanten, bij de anderen niet. Dekschilden vrij lang gestrekt met langen cuneus, de membraan met groote cellen. Pooten matig lang, vrij slank, alleen bij eene soort de achterdijen dik.

Ik erken gaarne dat dit geslacht in zijne zamenstelling niet door naauwkeurige morphologische overeenstemming der drie soorten uitblinkt, maar ik verkies toch de bijeenvoeging boven het afscheiden in 3 afzonderlijke geslachten.

1) Fabricius plaatste ook de eenige soort, die hem bekend was, onder de Lygaeoden. 


\section{Lopus Unnicatus F.}

Plaat 11, tig. 12.

Fabr. S. R. 233, 148. - Ahrens en Germar, Fauna Ins. Eur. fasc. 5, tab. 24 (Miris). - Hever, Caps. 40, 3 (Lopus). - Flor, Rh. Livl. I, p. 441. - Douglas and Scott, Brit. Hem. p. 338 , PI. XI, f. 2 (Pantilius).

Lengte $7 \mathrm{~mm}$. - Langwerpig, het mannetje echter meer dan het wijfje, boven bruin of bruinrood, onder geel. Kop kort, met de sterk uitpuilende grauwe oogen breeder dan lang, met een diep langsgroefje op den schedel. De dikke zuiger, die geel is met zwarte tip, bereikt naanwelijks de inplanting der niddenheupen. De sprieten zijn ietwat korter dan het lijf, bruin; het $1^{e}$ lid is langer dan de kop, van boven een weinig platgedrukt, naa binnen wat uitgebogen, sterk met zwarte stippeltjes bedekt; het $2^{\circ}$ is wat smaller, doch wordt naar het einde toe dikker en tevens donkerder van kleur, terwijl het aldaar dik met korte haartjes bekleed is; bet $3^{\mathrm{e}}$ is korter dan het eerste; half geel, half bruin; het $4^{\text {de }}$ is roodgeel en zeer kort. Het halsschild heeft een vrij dik zoompje aan den voor. rand, scherpe zijranden, die zwart afgezet zijn en stompe achterhoeken; het is van achter niet veel hooger dan van voren en overal met zwarts vlekjes bezet. Het schildje is zwart gemarmerd en vertoont aan de spits twee kleine gele vlekjes. De dekschilden hebben gele zijranden, die echter weder door fijne zwarte lijntjes omzoomd zijn; corium en clavus ziju bruin of roodbruin, zwart gemarmerd, de cuneus geel met rooden binnenrand en bruine spits; membraan geelachtig en berookt met roode cel-aderen. Aan den binnenhoek van het corium een geel vlekje. Onderzijde geel, aan wederzijde op het abdomen cene rij zwarte stipjes. Pooten geel, zwart gestippeld, de roorscheenen aan het einde bruinrood.

De heer Piaget vond deze soort in Junij aan den duinkant, de heer Heylaerts in Julij bij Breda, de heer van Medenbach de Rooij meermalen bij Aruhem zelfs in November en weder in April; ik trof haar in 't najaar bij Leyden en in het Hangsiho boseh aan en bij Heemstede in September op hazelaren, op 
welken hcester zij ook door anderen (zic Flor en Fieber) geFonden is.

\section{Lopus infusus II. Seh.}

Plaat 12, fig. 1 en $1 a$.

Herr.-Sch. W. 1. IV, p. 30, tab. 120, lig. 381. - Kirschb. Caps. Sp. 49. - Fieber, Eur. Hem. p. 249. - Donglas and Scolt, Brit. Hem. p. 331.

Lengte 7-8 mm. - Langwerpig, zeer kenbaar aan de bloederige klenr en de lange sprieten; geheel glad en onbehaard, vrij glanzig. Kop klein, rond naar beneden gebogen met een bol voorhoofd en sterk uitpuilende grauwe oogen, bruingeel of rood. De zuiger schijnt tot aan de achterheupen te reiken. Sprieten langer dan het lijf, roodgeel of rood, met het $1^{c}$ lid veel langer dan do kop, tamelijk dik, bruin aan het einde; het $2^{\text {de }}$ iets dunner, meer dan trveemaal langer dan het $1^{\text {ste }}$; het $3^{\text {de }}$ even dik, $1 \frac{1}{3}$ van de lengte van 1 , en 4 even dik of zelfs iets dikker en iets meer dan de helft der lengte van het $3^{\text {de }}$. Halsschild met een smal zocmpje aan den voorrand, veel breeder aan den achterrand, die naar achter rond uitgebogen is, geel met bruine in elkander vlocijende vlekken op de achterhelft. Schildje donkerbruin. Dekschilden op elavus en corintu roodgeel, rood naar den buitenrand en het cinde, met cen bruin dwarsbandje voor den bloedrooden cuneus; de membraan zwartachtig, met nog donkerder aderen. Pooten lang en slank, geelrood met gele voor- en middenscheenen en tarsen; alle scheenen met stekeltjes bezet, die der achterscheenen vrij lang.

Eene vrij zeldzame soort, gevonden bij Paterswolde door Dr. de Gavere, bij Driebergen door den heer Six, bij Maarsbergen in October door Dr. Piaget, in October bij Arnhem en bij Nijkerk door van Medenbach de Rooij en bij Breda uit eik geklopt door den heer Heylaerts. 


\section{Lomes subpalellatus Voll. \\ Plaat 12, fig. 2 cn $2 a$.}

A. Costa, Mémoire dans les Annales de la Soc. Ent. France, Tom. X, p. 286, Pl. VI, fig. 3 (Phytocoris flavomarginatus) ....?

Lengte iets meer dan $2 \mathrm{~mm}$. - Langrverpig', licht- of donkergrijs met gele versiersels. Kop breeder dan lang, met uitpuilende grijze of grauwe oogen, gecl op het achterhoofd, den schedel en langs de oogen, bij één voorwerp geel met twee scheve langwerpige zwarte vlekjes op den schedel. Zniger vrij dik, reikend tot de achterhenpen. Sprieten bijna zoo lang als het lijf, zwart of donkergrijs, het $1^{e}$ lid niet langer dan de kop, niet zeer dik; het $2^{\mathrm{e}}$ meer dan 2 maal zoo lang, schier even dik; het $3^{\text {e }}$ niet veel korter dan het $2^{\mathrm{e}}$ en even dik, het $4^{\text {e }}$ de helft korter en schijnbaar uit twee stukken bestaande, waarvan het voorste rolrond, het achterste daarentegen palet- of lepelvormig schijnt. Ilet halsschild niet veel langer dan het hoofd, met eenigzins ingebogen zijranden, aan den achterrand veel breeder dan aan den voorrand, grijsgelen voorrand, zijranden en middellijn, de ovalen achter den kop bijzonder duidelijk. Het schildje driehoekig met mele middellijn en 2 gele vlekken aan de basis. Dekschilden liehtgrijg met gelen zijprand en geel langs het schildje; clavus geel, membraan grijs; de anderen niet veel donkerder. Achterlijf zwart met geel connexivum. Pooten geel met grijzo strepen onder tegen de dijen, de geheele achterdijen grijs en de tarsen grijzig zwart met bijzonder groote klaauwen.

Dit insect wijkt zoo zeer van de andere Capsinen af, dat het niet wel tot de familie te brengen zou zijn, indien het niet de gesloten cellen in de membraan en wel bijoogjes bezat. Of het de Phylocoris flavomarginalus van Costa is, durf ik niet bepalen; de figum op de Plat gelijkt niet uituemend; in de beschrijving stuit ik onder anderen op het gezegde, dat de sprieten hier en daar met haren bedekt zijn en dat het $t$ licl langer is dan het $3^{e}$. Ook zegt Costa niets van het lepelvormige einde dier sprieten. Ik heb het dus noodzakelyjk geoordeeld het dier een anderen nam te geven. 
De heer Ritsema ving eerst een voorwerp in Junij op Texel, alaarna nog twee anderen, die wat kleiner en grijzer waren in Junij bij Velp.

\section{Gen. 8. Capsus $\mathrm{F}$.}

- Hot cigenlijke kenmerk van dit geslacht ligt in den knodsvorm van het tweede lid der sprieten, doch daarbij dient wel in het $00 \mathrm{~g}$ gehouden te worden dat het ecrste lid der achtertarsen even lang is als let tweede, want zonder dat zou ecue reeds behandelde soort, Allocolomus maryinepunctulus II. Sch., bepaaldelijk tot dit genus moeten behooren.

De vorm van het ligchaam is ovaal of langwerpig ovaal, 3ij eene enkele soort langwerpig en slank; deze heeft dan ook het voorhoofd bol toegerond, terwijl het bij de overigen puntig. uitsteckt. De kop is klein, de oogen vrij sterk nitpuilend, de zuiger tot de achterheupen reikend. Het 1 " lid der sprieten is langer dan de kop, het $2^{e}$ meer dan tweemaal zoo lang als het $1^{e}$, de beide laatsten zeer dun. Het halssehild heeft den gervonen vorm behalve bij het wijfje van ééne soort, bij hetwelk ook de dekschilden verkort zijn. Al het overige valt in den gervonen vorm der familie.

\section{Capsus ater L.}

Plaat 12, fig. 3.

Linn. S. N, V, p. 495, 72 et 494, 68. - Fabr. S. Rh. 241, 2; 242, 4. et $243,13$. - Hahn, W. Ins. I, p. 126, pl. 20, f. 65. - Wolf, Ic. Cim. p 32, t. 4 , f. 32 et t. 15, f. 146. - Flor, Rh. Livl. I, p. 486. Douglas and Scott, Brit. Hem. p 410, t. 14, f. 7.

Gedrongen van statum, weinig glanzig, fijn en weinig duidelijk behaard, zwart (১) of zwart met geelrooden kop en prothorax (q), soms met roode pooten. Kop kort, rrij stomp aan den eljpeus, tamelijk breed bij den man, breeder nog bij het wijfje, bij het eerste zwart, bij het andere geheel of geedecltelijk 
steenrood of roodgeel. Oogen uitpuilend, scheef ovaal, bruin of zwart. Twee voorste leedjes van den zuiger rood, de beide volgenden zwart. Sprieten iets langer dan de helft van het ligehaam; het $1^{e}$ lid niet zeer dik, zoo lang als de kop, zwart of rood; het $2^{\circ}$ steeds zwart, behaard, bij het o meest korter en meer plotseling knodsvormig dan bij den man, de beide volgenden te zamen iets korter dan 2, grijs of zwart, 3 met gele basis. Halsschild vrij kort en breed, voorbij de helft grof gekorreld. Het schildje en de dekschilden zeer fijn gestippeld, steeds zwart; voorrand tusschen corium en euncus iugekecpt; membraan rookbruin of zwart. Pooten geheel zwart, of zwart met roode vlekken of rood met bruine bandjes aan de achterknieën en de tarsen half geel, half zwart. Bij èén exemplaar in mijn bezit zijn de roorhenpen rood, is er eene roodo band over het mirtden der dijen en zijn de scheenen roodbruis met bruine spitsen.

Het wijfje met den gelen prothorax ontving van Linnacus den nam van Semiftevus, van Fabricius dien van Flavicollis, terwijl de zwarte voorwerpen met roode pooten door den laatsten Tyrannus genoemd werden.

De soort is niet ongemeen, vooral op drooge gronden, de wijfjes zijn echter vecl zeldzamer of houden zich meer schuil dan de mannen.

De var. Tyrannus werd gevonden bij Utrecht (Six), bij Toutckerke in Zeeland (de Man), bij Rotterdam (Piaget), bij Noordwịk (van Vollenhoven), bij deu Iragg en Seheveningen (verschillenden).

\section{Capsus capillaris F.}

Plaat 12, fig. 4.

Fabr. S. Rh. 244, 19; 246, 25 et 27. - Ilahn, W. Ins. I, 17, tab. 2, f. 9. - Wolf, 1c. Cim. f. 34 et 35. - Douglas and Scott, Br. Hem. 442, pl. 14, f. 8.

Lengte $8 \mathrm{~mm}$. - Grooter, maar vooral ook langwerpiger dan de voorgande, met slanker pooten; glanzig, kaal, grof 
şestippeld, roestgeel, rood of zwart. Wij zullen eerst de meest voorkomende lichtgekleurde var. (Capillaris) beschrijven. Kop) glad, ongestippeld, vrij groot, spits naar voren, met een zwart vlekje op de basis van den elypeus en met nitpuilende brnine oogen. Het $1^{e}$ lid der sprieten tamelijk dik, niet zoo lang als de kop, donkerbruin, an de binnenzijde met eenige haren bezet; het 2 aan de basis zeer smal, bruin, in het midden geel, dan knodsrormig, zwart behaard; $3^{\circ}$ en $4^{\text {e }}$ zeer dun, lichtgrijs. De zuiger reikt tot de achterheupen; $1^{\mathrm{e}}$ lid roodgeel, overigens zwart. Halsschild van voren als bij den voorgaanden, roodgeel, aan den voorrand voorbij het smalle zoompje glad, dan vrij grof gestippeld met zwarte stippels. Schildje klein met scherpe spits, weinig gestippeld, roodgeel. Dekschilden van dezelfde kleur, sterk gestippeld, behalve op den buitenrand en op den cuneus, die donkerder rood is met zwarte punt; membraan rookkleurig met witte vlek bij de spits van den cunens. Borst en buik in het midden zwart, wegsmeltend in rood naar de zijden toe. Pooten met bruine houpen, lichtere schenkelringen, zwarte dijen, wier knië̈n breed geelrood zijn, gele met donkere stekeltjes bezette seheenen en bruine of zwarte tarsen.

Bij de var. Lanicus verandert het rood op kop, borststuk en schildje geheel of gedeeltelijk in bruin of zwart, terwijl ook de dekschilden eene bruinere tint aannemen en de beide eerste leedjes der sprieten zwart worden, even als de geheele buik en borst.

De var. Tricolor, die alleen uit mannelijke voorwerpen bestaat, is nog donkerder. Ik zal tot roorbeeld een fraai voorwerp naar de kleuren beschrijven.

Kop donker oranje, met den nek, de randen der oogen en eene vrij brecde langsstreep in het midden zwart. Eerste en tweede lid der sprieten zwart, derde en vierde granwgeel. Zuiger en borststuk zwart, schildje desgelijks, doch met roode zijpranden. Dekschilden zwart met ecn' taankleurige reeg. op het corium tegen den clavus aan; de uiterste spits van het corium atu den buitenrand greel; cuncus am de basis geel, 
zerder bloedrood, voorbij te helft zwart; membraan als bij der type. Borst en buik zwart; anus vrij sterk behaard; scheef achter de middenhenpen ter wederzijde twee witte menbranen. Pooten gekleurd als boven beschreven is.

Lichtgeklenrde voorwerpen werden gevangen op brandnetels bij Utrecht (Six), bij Breda in Julij en Ang. (Heyl, en Leesberg), bij Oosterbeck in Aug. (Rits.), bij Ede in Julij, bij Leyden en $22 J_{\text {lilj }}$ bij Roozendaal in Noord-Brabant ( $v$. Voll.), bij Huyssen (v. Med. de Rooij); donkere voorwerpen bij Voorst in Julij (Wttewaall) en bij Velp in Julij (Ritsema).

\section{Capsus distinguenders $\mathrm{H}$. Sch.}

Plaat 12 , fig. 5 q en $5 a$ §.

Herr. Sch. W. Ins. IV, p. 33, pl. 121, f. 384.-Fieb. Eur. Hem. p. 262.

Lengte $6 \mathrm{~mm}$. - Deze soort verschilt van de beide voorgaanden door den bollen rorm van den kop (slecht geteekend door Herrich-Schacffer) en door het groote onderscheid tusschen beide sexen. De kop is bij den ơ eenigzins bol en naar beneden gebogen, bij het o nog veel boller, bij beiden van boven gezien veel korter dan breed, glanzig zwvart. De sprieten zijn bijna zoo lang als het lijf; hum $1^{\text {e }}$ lid schier zoo lang als de kop, dun en vuilgeel; het $2^{\mathrm{e}} \mathrm{wel}$ viermaal zoo lang, zwart, knodsvormig doch onbehaard, aan het eind bij het wijfje dikker dan bij den man; de beide volgenden grauv en dun, te zamen genomen korter dan 2. Het halssehild grijzig zwart, kort, bij den man met weinig gebogen zijranden, bij het wijfjo met twee groote ovale halsbuilen vooran, daarna ingesnoerd en aldaar met een' band van grijze haartjes bezet, verder weder nitgezet en bol. Het schildje zwvart, digt bij de basis met eene dwarsgleuf. Deksehilden bij den $\delta$ langgerekt, zwart met ecne vaalgele driehockige rlek aan de basis van het corim, zich tot halverwege de lengte van corium en cuneus nitstrekkende; de gronte cuneus is geel met zwarte spits en de groole membraan is gehecl rookbruin iriserend, zonder vlek; bij de wijf.jes zijn de delischilden afgekort en hebben bijna 
geen membraan, terwijl de cuneus zich aan het einde als een rond wit vlekje vertoont. Het achterlijf is grijsachtio zwart, bij het $q$ ook gedeeltelijk van boven zigtbaar. De pooten zijn lang en slank, zonder haren of stekels, bij den man vaal roodgeel, bij het \& bruingeel.

In de kleur bestaat er groote overeenkomst tussehen den $\delta$ van deze soort en Lygus flaromaculatus $\mathrm{F}$., doch de vorm van den kop en het ontbreken van cenig licht vlekje in de membraan zijn duidelijke onderscheidingskenmerken. Fieber, die ook nog een Globiceps flavonolatus Boh. vermeldt, welke van flavomaculatus niet gemakkelijk te onderscheiden is, komt mij voor op dit punt weinig helder te zijn. De beschrijving bij de Geer en de afbeelding (f. 235) bij Hahn toonen duidelijk aan wat Flavomaculalus F. is, doch hoe die soort door Fieber in zijn geslacht Globiceps geplaatst kan worden, terwijl do lsop volstrekt geene bolheid vertoont, is mij niet duidelijk.

Meer dan een wijfje werd door den heer Heylaerts in Sept. bij Breda gevangen, waarvan ik er een aan zijno welwillendheid te danken heb. Een enkel wijfje bemagtigde ik te Wassenaar in Aug.; Dr. Piaget ving cen' man to Wassenaar en een ander te Maarsbergen; ook de heer G. A. Six roud er een bij Utrecht (Driebergen?).

Gen. 9. Нетеrotoma Latr.

Dit genus is gekenmerkt door den vorm der sprieten, wier tweede lid bij een of wel bij beide sexen verticaal verbreed is over de geheele lengte, in den vorm van eon zaadhuls van brem, en bovendicn sterk behard. Voor de overige ligehanmsdeclen vallen de suorten, die er toe behooren, in de algemeene beschrijving der Capsinen.

1. Helerol. spissicomis $\mathrm{F}$. Plaat 12, fig. 6 en $6 a$.

Fabr. S. Rh. 246, 28. - Panz. Fn. Germ 2, f. 15. - Schellenb. Cim。 
Helv. 1. 3, figg. 4. - Burm. Handl. 1I, p. 276, $\mathrm{n}^{\circ}$. 1. - Doughs and Scott, Hem. Brit. p. 435, Pl. 14, lig. 4. (Merioptera).

Lengte $5 \mathrm{~mm}$. - Gerekt ovaal, vrij glanzig zwart, met fijne witte haartjes bekleed. Kop niet zoo lang als breed, vijfhoekig, spits aan den elypeus, met lichtbruine nitpuilende vrij groote oogen. Zuiger reikende tot de achterheupen, groen of geel. Eerste lid der sprieten zoo lang als de liop, tamelijk dik bchalve aan de basis, met zwarte haren vrij digt bekleed; het $2^{\circ}$ van gedaante als boven beschreven, blinkend zwart (of roodbruin, zelfs rood volgens Fabr.), evenzeer behaard, doch niet op de platie zijwlakken, driemaal langer dan het $1^{\circ}$; het derde korter dan het $1^{e}$, zwart met witte basis, en liet vierde nog iets korter, even zoo gekleurd; de beide laatsten zeer dun. Het halsschild slechts weinig verbreed naar achter, vlak op den rug, zonder zoom noch gleuve. Schildje middelmatig met cen flaauw dwarsgleufje, niet ver van de basis. Dekschilden eenkleurig, met donkere membraan, waarop dikwijls een wit vlekje bespeurd wordt onder de spits van den cuneus. Borst en buils glanzig metaalzwart. Pooten slank, alleen de achterdijen tamelijk breed; groen of geel met zwarte tippen der tarsen, somwijlen met bruine achterdijen.

Spissicornis, die op elzenstruiken en brandnetelen schijnt to leven, is niet zeldzaam in ons vaderland en werd in de meeste provinciën gevangen.

\section{Ileterot. magnicornis Fall.}

Plaat 12 , fig. 7.

Fallen, Cim. Succ. 99, n. 7. - Iahn, W. Ins. I, p. 130, tab. 20, f. 67. - Neyer, Caps. p. 62, no 29 , tab. 2, fig. 4. - Flor, Rh. Livl. I, p. 575. - Douglas and Scott, Brit. Hem. p. 435 , Pl. 14, f. 4.

Lengte 2,3-2,7 mm. - Breeder oval dan de vorige, zwart, dik met zilvergrijze haartjes of schubbetjes bekleed, dic zece ligt afbreken en verloren gaan. Kop klein, voorover gebogen, ran boven gezien veel breeder dan lang, met scherpen achterrand en roodbrume nitpuilende oogen. Spricten veel kister 
dan liet lijf, de beide eerste leedjes zwart (het $1^{\circ}$ naar evenredigheid minder dik dan bij de voorgaande soort), de beide laatsten wit en haarrormig. Bij den man is - volgens Flor het $2^{\mathrm{e}}$ lid niet over de geheele lengte verbreed, gelijk bij hot wijfje. Halsschild kort, zoompje aan den voorrand, achter tweemaal breeder dan de lengte bedraagt. Dekschilden somtijds bruinachtig; membraan zwart, doch iriserend, met fijne witte aderen en een klein wit vlekje aan de spits van den cuneus. Pooten aan heup en dij zwart of donkergrijs, aan knie en scheenen grauw; de achterscheenen met vrij lange stekeltjes, die uit zwarte stipjes ontspringen; tarsen aan de basis grauw, verderop zwart.

De heer Six vond deze soort niet zelden onder sparren (Pinus Abies) bij Utrecht; ik trof haar aan bij Leyden, Rotterdam, en te Brummen in Augustus.

\section{Helerotoma Mali Mey. D.}

Meijer, Stett. Ent. Zeit. 1841, p. 87. - Id. Verжeichn. Caps. p. 63, no 30 , taf. 2, f. 5 .

Lengte bijna $4 \mathrm{~mm}$. - Zwart, met de dekschilden roodbruinachtig zwart, geheel met grijze of goudglanzige haartjes dik bezet. Om de groote overeenkomst met Magnicornis Fall. zal het wel voldoende zijn op het onderscheid tusschen beide soorten te wijzen. Mali is grooter, de thorax is boller, do membraan is donkerder; het $1^{\mathrm{e}}$ lid der sprieten is naar evenredigheid dikker; de knieën en scheenen zijn licht roodbruin en de stekeltjes der achterpooten ontspringen niet uit zwarto puntjes.

De heer G. A. Six ving twee voorwerpen bij Driebergen, ik een bij Leyden en een gepaard paar op Staalduin in Aug. Ook werd de soort bij Breda angetroffen door den heer Heylaerts.

\section{IIcleroloma unicolor Hahn.}

Plaat 22, fig. 7.

Ilahn, W. Ins. II, p. 94, Pl. 59, f. 179. - Kirschb. Capsinen 8i, 111. - Douglas and Scott, Brit. Hem. p. 432 
Lengte $4 \mathrm{~mm}$. - Geheel zwart, het manuetje volgens de genoemde Engelsche auteurs slanker en zonder merkelijke rerdikking van het $2^{\mathrm{e}}$ lid der sprieten. Bij ons werden alleen voorwerpen gevangen, ovaal van gedaante met knodsachtig en behaard $2^{\mathrm{e}}$ lid der sprieten; dezen zouden volgens Hahn f zijn, volgens Douglas q. De kop is vrij breed, het borststuk kort, de dekschilden aan den buitenrand voor den cumeus ingekeept, de membraan donker doch iriseerend. De pooten zijn maiig dik, de scheenen met 2 rijen stekeltjes bezet.

Deze soort werd reeds als inlandsch opgegeven in mijne naamlijst in de Bouwstoffen, in het $5^{\mathrm{c}}$ stuk (Tijdscher. v. Eint.) heb it haar echter overgeslagen. Zij is volgens den heer Six gemeen op heigrond bij Driebergen en de Bildt in Junij. Bij Brtumen werd zij gevonden door den heer van Walchren en door mij in Aug. in de omstreken van Rozendaal in Gelderland.

NB. In de tweede Naamlijst van inlandsche IIemiplera volgt op dezo soort Crinicornis Klug, naar Burmeister's Handbuch gedetermineerd. Een enkel voorwerp was door den heer G. A. Six bij Utrecht gevangen, sedert is het door beschimmeling verloren gegaan. Het komt mij voor dat het ecne verscheidenheid van Magnicornis moet gerweest zijn, met gouden schubbetjes in plaats van zilveren.

Gen. 10. Halticus Hahn.

Het ligehaam is kort en zeer gedrongen. Do kop is rerticaal, zeer breed op den seherlel met nagenoeg plat aangezigt; de rand tusschen het voor- en achterhoofd is scherp en het achterhoofd tegen het borststuk anngedrongen. De zuiger is dik en vrij kort; het 1 lid is voornamelijk breed. De sprieten zijn bij 2 soorten korter dan de helit van het ligehatim, dun; lid 1 bijzonder kort, 2 twee en een half maal zoo ling, ; jets langer dan 1 en 4 nog korter; bij de derde soort (die ik deswegens bijna tot een afzouderlijk geslacht gebragt had) zoo lang als het lijf en zeer dun, met het 2 lid viermaal langer 
dan het $1^{\mathrm{e}}$ en de beide laatsten te zamen gelijk in lengte met het tweele. Het halsschild is van boven gezien trapeziumvormig, vrij bol met scherpe zijranden. Sehildje kort en breed. Dekschilden desgelijks, bij den cuneus hoekig naar beneden gerigt. Pooten gezet en-stevig met fijne tarsen; de achterdijen bij ééne soort sterk verdikt; bij allen de achterscheenen aan wederzijde met stekeltjes bezet.

Hahn heeft eigenlijk dit geslacht opgesteld voor soorten met dunne en lange sprieten en zeer dikke achterdijen, en de beide cerste soorten, die wij nu zullen besehrijven vormen bij Fieber het geslacht Stiphrosoma; doch ik heb gemeend beter te doen met de drio soorten bijeen te voegen en een ouden naam aan te nemen, daar de overeenkomst tusschen de soorten van Hahn's genus en de beide eersten zoo bijzonder groot is.

\section{Halt. leucocephalus L.}

Plaat 12 , fig. 8.

Linn. Fn. Suec. 940. - Fabr. S. Rh. 237, 173. - Fanz. Fn. Germ. 92, f. 12. - Hahn, W. Ins. II, p. 88, tab. 57, f. 174. - Fall. Hem. I, p. 111. - Flor, Rh. Livl. I, p. 558. - Douglas and Scott, Brit. Hem. p. 21, f. 2.

Lengte 3-4 mm. - Het geheele lijf uiterst fijn behaard. Kop roodachtig geel of bleek oranje, glanzig, niterst fijn gestippeld met zwarte ronde oogen en zwarten clypeus. Het $1^{\circ}$ lid der sprieten van dezelfde kleur, het tweede aan de benedenhelft geelachtig, verder zwart of wel geheel zwart, geliji de beide volgenden. Zuiger eerst roodgeel, dan vuilgeel, aan do spits zwart. Thorax, schildje en dekschilden blaauwzwart, grof gekorreld; de membraan zeer donker rookkleurig, bijna zoo donker als de elytra. Aan de korte, dikke pooten zijn de voorste heupen en dijen roodachtig geel, de voorste scheenen lichtgecl; de midden- en achterheupen en dijen bruinrood, hunne scheenen vuilgeel; alle tarsen zwart. De buik is paarszwart met roode inkervingen der ringen.

Deze rrij zeldzame soort werd eenmaal in vrij groot aantal 
in Mei bij Breda angetroffen door den heer Ileylaerts en voorts in Junij gevangen bij Wolfheze door den heer Ritsema.

\section{Halt. luridus Fall.}

Fall. Hem. I, p. 112, 69. - Herr. Sch. W. I. III, p. 87, tab. 101, fig. 312 (slecht). - Flor, Rh Livl. I, p. 559.

Lengte bijna $4 \mathrm{~mm}$. - Men zou deze soort voor cene roode varieteit der vorige kunnen houden, zoo niet het $1^{\text {" lid der }}$ sprieten zwart was en iets korter dan bij Lencocephalus. De algemeene kleur is steenrood; de kop is tamelijk glanzig en duidelijk, min of meer wollig, wit behaard, met kleine orale zwarte oogen en een zwarten veeg op den clypeus; do zuiger is roodbruin met zwarte spits. De korte sprieten rijn geheel zwart, behalve de uiterste tip van het $1^{e}$ lid, die wit is. Het halssehild is mede vrij dik wit behaard en vertoont op het cenig exemplaar in mijn bezit twee bruine langsstreepjes, beginnende vlak achter de oogen en slechts tot het midden doorloopende. De dekschilden zijn zeer fijn gestippeld en vertoonen van het midden tot het eind van het corium een bruinen langsveeg; de membraan is rookkleurig met lichtbruine cellen en aderen. Het achterlijf is bruinrood, glanzig, donkerder op den rug, aan den buik sterk behaard. De pooten zijn rood, met lichtere scheenen en zwarte tarsen.

I. lurius werd door den heer G. A. Six eens of tweemaal in de provincie Utrecht gevangen, en den $23^{\text {ten }}$ Junij op de duinen bij Scheveningen; alsmede bij Velzen in Junij door Jhr. Dr. Everts.

\section{IIalt. pallicornis $\mathrm{F}$.}

Plaat 13 , fig. 1.

Fabr. S. R. 115, 6. - Woln, Ic. Cim. 1. 128, tab. 13, f. 122. IIahn, W. I. p. 114, fig. 61 en III, p. 34, tab. 8k, figg. 25̌. - Burm. Handb. II, 1. 278, 2. - Hlor, Rh. Livl. I, 583. - Douglas and Scott, Brit. Ilem. p. 479.

Leugte $2 \mathrm{~mm}$. - Deze soort onderseheidt zich van de beide 
rorigen door langere en fijnere sprieten en door dikkere achterdijen, overeenkomende met die van het geslacht IInllica onder de kevers. Het geheele lijf is glanzig, bijna metaalachtig zwart. De kop, het schildje en de dekschilden zijn vrij grof gestippeld, het halssehild met fijne dwarssehrapjes gegroefd. De sprieten, die iets langer zijn dan het lijf, hebben eene zwavelgele kleur. Buik en heupen ziju zwart, ook de 4 voorste dijen aan de basis en de achterdijen tot digt bij de knie; cindelijk is ook het laatste lid der tarsen zwart; al het overige aan de pooten is zwavelgeel.

Volgens Hahn springt deze soort zeer behendig. De heer G. A. Six is de eenige, die haar in ons vaderland waargenomen heeft. Hij trof een vrouwelijk exemplaar den $1^{\text {sten }}$ Junij bij Beek aan, in het oude kwartier van Nijmegen.

\section{Gen. 11. Camaromotus Fieber.}

Ook bij dit genus is het achterhoofd uitgehold, gelijk bij het vorige en sluit de rand van den schedel op het borststuk, dit als omvattende, doch het lijf is niet kort en breed, maar meer cylindrisch en $2 \frac{1}{2}$ maal langer dan het breed is. De kop is als bij het vorige verticaal geplaatst, doch niet zoo groot naar gelang van het ligehaam. De oogen zijn naar achter sterk nitpuilend. De sprieten zijn langer dan de helft van het lijf; hun eerste lid rrij dun, is niet veel langer dan de kop nitsteekt, van boven gezien; het $2^{\mathrm{e}}$ is rijkelijk driemaal zoo lang en min of meer knodsvormig; de beide laatsten zijn dun en te zamen niet zoo lang als het $2^{\circ}$. Het halsschild is kort, bultig, niet sterk naar achter verbreed, eenigermate scherp van zijranden. Het sehildje is bol aan de voorzijde en brengt zoodoende bij tot de bultigheid van den prothorax. De dekschilden zijn tamelijk lang gestrekt en humue zijjranden bijna evenwijdig; bij alle soorten zijn zij met zilverwitte dwarsstreepjes voorzien, die uit fijne haartjes of schubbetjes zamengesteld ziju. De pooten zijn lang en de dijen over de gehecle lengte gelijkmatio verticaal verbreed. 


\section{Cam. cinnamopterus Kirschb.}

Plaat 12 , fig. 9.

Kirschb. Caps. p. 72, 81; p. 116 et p. 135. - Flor, Rh. Livl. I, p. 572. - Douglas and Scott, Brit. Hem. p. 358, pl. 11, f. 8 .

Lengte 3,6-3,9 $\mathrm{mm}$. - Kop en prothorax zwart, zonder bronskleur; dekschilden gewoonlijk bruingeel. De rugzijjle nagenoeg kaal. De oogen puilen zeer sterk uit en zijn eenigzins naar achteren gekeerd. De sprieten staan aan de inplanting wijd uiteen; hun eerste lid is roodgeel, het $2^{\mathrm{e}}$ tot de helft van dezelfle kleur, verder donkerbruin, het $3^{\text {e }}$ zwart met witte basis, het $4^{\mathrm{e}}$ wit met bruine spits. De vorm van het halsschild schijnt mij toe te verschillen naar de individuen; bij eenigen is het zeer breed aan de schouders, bij anderen minder. Het schildje is zwart en heeft even voor de spits een klein vlekje, bestaande nit zilveren schubbetjes, die echter ligtelijk loslaten. De dekschilden zijn bruinachtig geel, aan het einde donkerder met nog donkerder cuneus en vrij donker rookkleurige membraan. Op $\frac{1}{3}$ van de implanting af staat een tamelijk breed schnin streepje van sneeuwwitte schubbetjes, dat bijna tegen den clavus aankomt, op $\frac{2}{3}$ weder een ander, smaller doch langer, zoodat men het een dwarsbandje noemen kan; dit loopt. door over den clavus. In den binnenhoek van de wigge staat nog een vlekje van witte schubbetjes en in de membraan, tegen den euneus aan, een gebogen wit streepje. De pooten zijn bruinachtig roodgeel met donkerder achterscheenen.

De heer Ileylaerts bezit een voorwerp, dat de dekschilden over het geheel donkerbruin heeft; daarbij zijn ook de achterdijen van die kleur.

Deze soort werd door den heer Heylacrts in Mei en Junij in zija' tuin te Breda op een morellenboom aangetroffen. Dr. Piaget ving haar bij Maarsbergen in Junij en de heer Six bij Driebergen, onder andere voorwerpen ook een met roesibruine dekschilden; voorts werd de soort bij Loosduinen angetroffen door Dr. van Hasselt en op Walcheren een zeer donker ex. door den heer La Fontijn. 


\section{Cam. clavalus L.}

Plaat 13, fig. 2.

Linn. S. N. V, 501, 97. - Fabr. S. R. 212, 7 (C. bifasciatus). Kirschb. Caps. p. 72, 80. - Flor, Rh. Livl. I, p. 569, n $\mathrm{n}^{0}$ 59. - Douglas and Scott, Brit. Hem. p. 360.

Lengte 3,7-4 mm. - Deze soort, tot welke ik in mijne naamlijst alle inlandsche voorwerpen bragt, verschilt van de vorige in den metaalglans van kop en borststuk en in het niet op den clavus doorloopen van het $2^{\mathrm{e}}$ dwarsbandje der dekschilden. Er bestaat nog eene derde soort, die door Herrich-Schaeffer afgebeeld is (W. I. III, p. 47, pl. 87, f. $264^{1}$ ) en sterk op Clarahus gelijkt; deze is echter kleiner en donkerder en voor zooverre mij bekend is, nog niet in ons land aangetroffen.

Kop en borststuk bronskleurig, somtijds bijna groen; de oogen springen nict zoo sterk naar achteren als bij de voorgaande soort. De sprieten zijn over het geheel genomen donkerler van kleur; hun laatste lid is niet wit, maar bruin met witte basis. Volgens de schrijvers moeten bij gehecl zuivere voorwerpen zwarte haartjes op den rug van den thorax worden waargenomen. Het hronskleurige schildje vertoont voor de spits zcer onduidelijk een plekje van zilvergrijze haren. De dekschilden zijn minder geel, donkerder bruin dan bij de vorige; hun elavus is geheel donkerbruin; het $1^{\circ}$ dwarsstreepje staat op dezelfde plaats, doch is minder breed; het $2^{\circ}$ dwarsbandje loopt lot aan den clarus en het daardoor ontbrekende stukje staat op den clarus cen tamelijk eind hooger. De cuneus vertoont het witte vlekje en de membraan het streepje, als bij de andere soort. De pooten zijn iu het geheel donkerder, vooral zijn de achterdijen in het midden bijna zwart.

Deze soort ving de heer van Medenbach de Rooij bij Arnhem in Augustus en de heer Ritsema bij Velp in Julij.

1) Niet 267, gelijk Nlor zegt en de hem copiecrendo Douglas en Scott. 
Gen. 12. Pirtocoris Fall.

Dit geslacht laat zich uit de anderen gemakkelijk onderscheiden door de bijzonder lange en dumne sprieten en zcer lange achterpooten. Het ligcham is langwerpig of aitgerekt ovaal met de zijden der dekschilden bijna over de scheele lengte evenwijdig. De kop is gewoonlijk een weinig nedergebogen, driehoekig, met de oogen zoo breed als hij lang is. De oogen zijn zeer groot en uitpuilend, van boven gezicn aan den buiteskant cirkelrond, op zijde gezien eivormig. De sprieten zịjn langer dan het ligehaam, zeer fijn; alleen het $1^{e}$ lid, dat gewoonlijk zoo lang is als de kop met het borststuk, is dikker dan de anderen; het $2^{\mathrm{c}}$ is zoo lang of iets langer dan 3 en 4 te zamen, het laatste is het kortste. De zuiger reilit een eind voorbij de achterheupen. IIct borststuk is van achteren toegerond en naar voren veel smaller wordend, tamelijk plat, doch naar voren afhellend en niet scherpkantig ann de zijden, met twee dwarsplooijen voor het midden. Ilet schildje middelmatig van grootte, driehoekig met eene vrij spitse punt. Dekschilden bij een paar soorten zeer smal en lang, bij allen van eene zeer ontwikkelde membraan voorzien. De vier voorste pooten zijn slank en tamelijk lang, doch de achterpooten he!ben zeer lange en tevens ran de zijde gezien zeer dikke dijen, en scheenen die bijzonder slank en langer dan deze zijn.

Het geslacht is zeer natuurlijk, dosh de soorten hebben zoo vele punten van overeenkomst, dat zij moeijelijk te onderseheiden zijn. IIare wooiplaats zijn boomen en heesters; men zegt dat zij door middel der lango achterpoten springen, ik hels dit echter niet gezien en twijfel er aan, oudat zij zoo gemakkelijk tot vliegen overgaan.

Tabel der soorten.

a. rood, geel en bruin gekleurd. . . . . . b. "1. srijs of sroenachtion gekleurd. 
$b$. roodgeel met roode strepen, op het schildje eene gele langsstreep; lengte $6 \mathrm{~mm}$. . . . IImi.

$b b$. bruin met lichtere vlekken gemarmerd, op het schildje geen gele langsstreep, lengte $8 \mathrm{~mm}$. . Divergens.

c. thorax gelijk van kleur, grijs of bruin met witten achterrand . . . . . . . . . Populi.

$c c$. thorax geel of groen in de zijden ingevat door zwarte langsstrepen . . . . . . . Tiliae.

\section{Phytoc. Ulmi L.}

Plaat 12, fig. 10.

Linn. Faun. Suec. 964. - Fabr. S. Rh. 256, 17. - Hahn, W. Ins. III, p. 9, fig. 234. - Neyer, Ent. Zeit. Stett. 1811, p. 88. - Douglas and Scott, Brit. Hem p. $313, \mathrm{n}^{\circ} 7$.

Lengte 4-6 mm. Grondkleur geel of oranje-achtig, ook wel lichtbruin. Kop niet zeer ver uitstekend, geel met twee roode langsstrepen of rood met drie gele. Het $1^{\text {e }}$ lid der sprieten bruinrood met witte stipjes en eene geelachtige langsvlek aan de buitenzijde; de binnenzijde vertoont eenige vrij lange witte haartjes; het $2^{e}$ lid is roodachtig geel met witte basis, waarop bij sommige voorwerpen een bruin bandje volgt; de beide volgende leden lichtgeel. De oogen puilen sterk uit en zijn bruinzwart van kleur. De zuiger is rood, doch naar de spits toe bruin. Het borststuk is op den rug of geheel geel met 2 of 4 roode langsstrepen of voor de voorhelft zoo gekleurd en voor de achterhelft roodbruin met een smal wit zoompje. Het roode schildje draagt eene gele middellijn en twee onregelmatige gele vlekjes daarneven. De dekschilden zijn roodbruin met eenige onregelmatige vlekken in de lengte van gele en nootbruine kleur en eene gele ruitvormige vlek boven den bloedrooden, aan de spits purperbruinen cuneus; de membraan is meest grijs met witte vlekjes, soms zeer licht gekleurd. Kop, thorax en dekschilden zijn bij onbeschadigde voorwerpen met sneeuwwitte haartjes vrij digt bezet. De onderzijde is donkerder van kleur, soms wijurood met gele vlekjes. De 
pooten hebben de heupen met de basis der dijen licht gekleurd, de voordijen geel met bruinroode stippen en vlekken, de middelsten desgelijks, de achtersten bruin of bruinrood met 2 of 3 schuine gele halve bandjes. De voor- en middenscheenen zijn lichtgeel met de spits breed bruin en 1 of 2 bruine bandjes; de achtersten zijn wit, met een' breeden bruinen band voor het midden. Van de tarsen zijn de twee voorste leedjes geel, het laatste met de klaauwtjes zwart.

Deze soort, die niet ongemeen is, werd zoo dikwijls met de volgende verwisseld, dat ik sommige schrijvers niet heb durven aanhalen, b. v. Flor en Fieber. Het komt mij voor dat de punten van verschil nog niet bij iedereen zoo overtuigend vaststaan, dat er niet dikwijls verkeerd zou worden gedetermineerd. Zijn het werkelijk twee soorten?

Ulmi werd hier te lande veelvuldig angetroffen, als bij Arnhem in Aug. (de Gr.), bij Velp (v. Med. de R.), bij Leyden (H. en v. V.), bij Utrecht (Six, Ver Loren, v. Hasselt), bij Wolfheze (Piaget), aan de Rhedersteeg in Aug. (H. Alb. en v. V.), bij den Haag (v. V.), bij Domburg (de Man).

\section{Phyloc. divergens Meyer.}

Mever, Ent. Zeit. Stett. 1841, p. 88. - Idem, Rhynch. d. Schw. p. 44, tab. 1, f. 1. - Douglas and Scott, Brit. Hem. p. 311, no 6. - Misschien ook: Wolff, Ic. Cim. 155, tab. XV, f. 149 (Miris longicornis).

Lengte 6-8 mm. - Ik geloof dat ik hier volstaan kan met het onderscheid tusschen deze soort en de vorige op te geven. Vooreerst is zij, nam. Divergens, gewoonlijk iets langer, in de tweede plaats donkerder van kleur, in den regel roodbruin met onduidelijke bruine versieringen; voornamelijk is de kop altijd donkerder; het schildje heeft geene gele middellijn en geene gevlekte teekening; de achterscheenen zijn minder donker. Maar dit alles zou nog slechts eene kleurverseheidenheid aanduiden en geen regt geven om van Divergens eene bijzondere soort te maken; het eigenlijk kenmerkende verschil is dan ook dat het eerste lid der sprieten bij deze naar even- 
redigheid langer is dan bij $U l m i$, en dat het achterlijf bij $D i v$. overal even breed is en bij Ulmi in het midden uitgezet en naar achter smal toeloopend.

Ik meen het eerste kenmerk, dat der sprieten, voldoende waargenomen te hebben, doch omtrent het tweede behoef ik wel niet te bewijzen, dat het bij gedroogde voorwerpen alle waarde verliest, aangezien het achterlijf dikwijls onder het opdroogen sterk in vorm verandert.

Indien het waar is dat Wolff bij de beschrijving en afbeelding van zijne Miris longicornis deze soort van Phytocoris heeft voor zich gehad, dan zal de naam Divergens wegens het regt vail prioriteit voor Longicornis moeten plaats maken.

Divergens werd door mij bij Hattem, door Ritsema bij Oosterbeek, en door Snellen bij Rotterdam gevangen.

\section{Phytoc. Populi L.}

Linn. S. N. V, p. 503, 109. - Fabr. S. Rh. 237, 171. - Fall. Hem. I, p. 84, no 16. - Schellenb. Cimic. t. 3, f. 3. - Burm. Handb. II, 268, no 9. - Flor, Rh. Livl. II, p. 594, no 3.

Lengte $6 \mathrm{~mm}$. - Grijs of graw gemarmerd. Kop kort en naar onder gebogen. Oogen donkerbruin, zeer bol uitpuilend. Sprieten zeer lang en slank, bruin en wit; het $1^{\text {e lid langer }}$ dan kop en thorax (op den rug gezien), wit, boven op met cene fijne bruine streep, die voorbij de helft eens afgebroken is en onder met eene zeer smalle bruine lijn, aan de binnenzijle bezet met witte borsteltjes; lid 2 heeft $1 \frac{1}{3}$ van de lengte van 1 en is bruin met witte basis en een onduidelijk wit bandje voorbij de helft; 3 iets langer dan de helft van 2, bruin met witte basis; 4 korter dan 3 en lichter van kleur. Zniger vuilwit met bruine spits. Thorax $1_{\frac{3}{3}}^{2}$ zoo breed als lang; aan den achterrand bijna tweemaal zoo breed ais aan den hals; voor vuilwit, doch spoedig grauwbruin wordend en donkerder naar achter, evenwel geheel an het eind met een wit zoompje dat in het midden wat naar voren springt. Schildje zwart aan de basis, verder roodachtig wit met 2 bruine langsstreepjes, 
die voor de spits van elkander afwijken. Dekschilden vuilwit met bruin gemarmerd; eene niet altijd duidelijke ruitvormige vlek aan de spits van het corium; cuneus bruin met witte spikkels; membraan in kleur weinig verschillend van het mid. dengedeelte van het corium. Pooten bruin en wit gewolkt; voorscheenen altijd met 2 donkere banden en donkere spits, middelscheenen met 3 donkere banden, wit aan de spits; achterdijen geelwit met 2 schuine bruine banden voorbij de helft; achterscheenen eerst zwart met een wit bandje, dan wit met een zwart bandje. Alle tarsen zwart.

Lichtere voorwerpen hebben grijs al wat hier bruin of zwart is genoemd, ja! men treft exemplaren aan bijna zonder teekening.

Deze soort is voorzeker de gemeenste van dit geslacht in ons land. Zij werd in alle provinciën wargenomen behalve Groningen en Drenthe, doch zal voorzeker ook daar wel voorkomen.

\section{Phytocoris Tiliae F.}

Plaat 12, fig. 11.

Fabr. S. Rh. 237, 169. - Fall. Hem. Suec. I, p. 85, 17. - Neyer, Rh. d. Schw. t. 7, f. 1. - Flor, Rh. Livl. II, p. 599. - Douglas and Scott, Brit. Hem. p. 303, pl. X, f. 8.

Lengte 5 -6 $\mathrm{mm}$. - Herkenbaar aan den lichten prothorax met zwarte zijranden. Geel of groenachtig geel met sterk geteekende zwarte of zeer donkere bruine vlekken. Kop sterk naar beneden gebogen, geel, soms met groene tint. Oogen niet bijzonder bol, zwart. Sprieten langer dan het lijf; $1^{\mathrm{e}}$ lid zwart met eenige witte stippen, $2^{\text {e } z w a r t ~ a a n ~ d e ~ b a s i s ~ e n ~ e v e n ~}$ voorbij het midden met een' witten band, $3^{e}$ zwart met witte basis, $4^{\mathrm{e}}$ iets minder donker. De lengteverhouding als bij de vorige soort, doch de borsteltjes donker. Prothorax geel of groenachtig geel met 2 zwarte puntjes an den achterrand en de zijde bedekt met eene zwarte langsstreep, die naar achteren toe gevorkt is; somtijds is zij ongevorkt, maar dan ziet men 4 punten aan den achterrand in plaats van 2. Schildje van de kleur van den thorax met twee fijne puntjes in de voorhoeken 
en 2 zwarte streepjes scheef op de zijden, digt bij de spits. Dekschilden geel of groen, verschillend van teekening; bij fraaije exemplaren met 2 zwarte stippen op den clavus, op het corium een dwarsband op $\frac{1}{3}$ der lengte, daarvoor 1 en daarachter 2 stippen aan den rand; van den laatsten eene schuine lijn naar den achterhoek, verbonden aan een ander lijntje voor de membraan; eindelijk een driehoekig vlekje aan den rand voor den cunens; deze heldergeel met zwarte spits. Membraan met eene dubbele zwarte vlek onder den cuneus en nog 2 grijze aan den rand. Ook het bovenste deel der groote cel is berookt grijs en de ader tusschen beide cellen is zeer donker. De pooten zijn gekleurd als bij de vorige soort.

Men treft voorwerpen aan, zoo licht van kleur dat de normale teekening niet altijd gemakkelijk te herkennen is. Meijer Diir verklaarde deze soort slechts voor eene verscheidenheid der vorige.

Zij werd in de maanden Julij, Aug. en Sept. gevangen bij Beek, Velp, Arnhem, Oosterbeek, Utrecht, den Haag, Breda en Middelburg.

Gen. 13. Lrgus Hahn.

Ziehier nu het an soorten rijkste geslacht der Capsinen, waarvan de algemeene beschrijving geheel moet overeenkomen met die der familie, vereenigd met de ontkenningen der kenmerken van de 12 voorgaanden en van het veertiende. In plaats van dat algemeene beeld van het groote aantal soorten in dit geslacht vervat hier te schetsen, 't geen den lezer' voorzeker al even weinig zou voldoen als het mij aangenaam zou wezen het neder te schrijven, meen ik te mogen verwijzen naar de analytische tabel der genera, voorkomende op bladzijde 144 on 145.

Ik laat hierachter wel eene tabel der soorten volgeu, doch geheel afwijkende van de geleerde en diepzinnige tabellen, waarop men zich sedert de laatste 15 jaren in entomologische 
werken toelegt. In terenstelling derrvan heb ik verkozen eene ware pons asinorum te geven, eenigzins naar het voorbeeld van de analyti che tabel van Herrich-Schäffer, hoofdzakelijk gegrond op de ver. chillen in grootte en kleur; volkomen overtuigd zijnde dat men met zoodanige tabel eerder te rezt komt dan met eene die op het min of meer bol uitpuilende der wangen, of den afstand tusschen de voor- en middenheupen verwijst. Het geheele doel van het leveren van zulk eene tabel moet toch niet wezen geleerdheid uit te kramen, maar den lezer op de kortste wijze tot de kennis te brengen van den naam der soort die hij voor zich heeft.

\section{Tabel der soorten.}

A. Grootere soorten van 6 millimeter en daar boven.

$a$. Met duidelijke langsaderen op het corium.

b. met geheel gelen cuneus . . . . . . . . . . striatus.

bb. cuneus geel met zwarte spits. . . . . . . . . striatellus.

aa. Met onduidelijke langsaderen of zonder

c. zwart.

d. met rood schildje . . . . . . . . . . Gothicus.

dd. met zwart schildje. . . . . . . . . . seticormis.

$d d d$. met hartvormige hooggele vlek op het schildje . . cordiger. cc. groen.

e. zonder vlekken op de dekschilden . . . . . . . bipunctatus.

ee. met grauwe vlekjes op de dekschilden . . . . . Chenopodii.

eee. met roode vlekken op de dekschilden . . . . . . ferrugatus.

$\Lambda \mathrm{A}$ Kleinere soorten van 6 millimeter lengte tot $2 \mathrm{~mm}$.

B. Ovale, wier lengte tot de breedte staat ongeveer als 2 tot 1 .

f. Bij beide sexen sprieten en scheenen regt.

1. Dekschilden grauw of nootgeel.

$\times$ scl :ldje zwart met drie roode vlekjes. . . . Fallenii.

$\times \times$ " nootbruin met 3 gele vlekjes. . . punctulatus.

$\times \times \times$ "geel met of zonder 2 bruine streepjes. pratensis.

2. Dekschilden rood . . . . . . . . . . rubicundus.

3. " zwart met geel gevlekt.

o. cuneus hooggeel met zwarte basis en spits . . . tripustulatus.

oo. " rood . . . . . . . . . .unifasciatus.

000. " groenachtig geel met de benedenhelft zwart Kalmii.

4. Dekschilden zwart zonder gele versiering

+ met lichtbruinen buitenrand en bruinrooden cuneus. Gyllenhalii.

++ met zwarten cuneus . . . . . . . . . mutabilis.

5. Dekschilden geel met rooden cuneus ...... vulneratius,

6. " tanig bruin met donkere membraan . Pinastri. 
7. Dekschilden groen met ongevlekte membraan. - . Pastinacae.

8 " doorschijnend zeer licht bruin, met bloedroode spits van den cuneus . . . . cervinus.

9. - grauwgeel met eene driehoekige donkere vlek. Roseri.

$f f$. Bij $\delta$ het $2^{e}$ en $3^{\mathrm{e}}$ lid der sprieten en de voorscheenen krom. thoracicus.

BB. Langwerpige, wier lengte meer dan 2 maal de grootste breedte is.

$\alpha$. Het borststuk in den vorm van een halsje verdnnd.

$\S$ cuneus zwavelgeel, met roode spits . . . . . . virgula.

$\$ \oint$. geel of bijna wit, met fijue zwarte spits . . histrionicus.

\$\$ " bruin als de dekschilden... . . . globulifer.

$u \alpha$. Het borststuk niet in den vorm van een halsje verdund.

$>$ Achterscheenen zonder rijen zwarte stippeltjes.

I. Dekschilden rood, borststuk groen. . . . . . . rufipennis.

II. " en borststuk geelachtig rood . . . . rubricatus.

III. " hooggeel.

* Kop zwart . . . . . . . . . . . . . melanocephalus.

** Kol geel . . . . . . . . . . . . . . . aurantiacus.

IV. Dekschilden zwart.

* Gele vlekken op de zwarte dekschilden . . . . flavonotatus.

** Dekschilden geheel zwart.

† Scheenen zwart . . . . . . . . . . pilosus.

t† Scheenen roodbruin. . . . . . . . tibialis.

V. Dekschilden groen of groengeel of grijsgroen.

. B Borststuk korter dan het schildje, membraan met groene vlekken .......... chlorizans.

\% Borststuk langer dan het schildje.

¿ $1^{\mathrm{e}}$ en $2^{\mathrm{e}}$ lid der sprieten zwart aan de basis . angulatus.

¿d $1^{\mathrm{e}}$ lid geheel zwart . . . . . . . nubilus.

ఏढं $1^{\mathrm{e}}$ en $2^{\mathrm{e}}$ lid der sprieten niet zwart aan de basis.

$\beta$. tarsen geheel zwart of bruin.

0 zuiver groen of geelachtig, membraan met

groene aderen . . . . . . . pabulinus.

oo grijsachtig groen, membraan donker met witte aderen......... molliculus

$\beta \beta$. tarsen niet geheel zwart.

$\gamma$. thorax en dekschilden wit behaard, de laatsten ook aan den rand. . . . nassatus.

$\gamma \gamma$. thorax en dekschilden niet te gelijk wit behaard, de laatsten in allen gevalle niet aan den rand.

i. kop met scherpen achterrand, borststuk dwars gerimpeld . . . . . . rugicollis.

ii. kop zonder scherpen achterrand.

c. membraan ongevlekt.

† dekschilden met witte vlekjes als bezaaid . . . . . . flavosparsus.

t† dekschilden zonder witte vlekjes.

$\$$ kop zeer breed, achterdijen zeer dik, corium en cuneus van dezelfde kleur . . . . . Tanaceti. 
\$ kop niet zeer breed, achterdijen niet zeer dik, corium groen, cuneus geel . . . . Ericetorum.

$k k$. membiaan gevlekt.

l. membraan grauw met 3 bruine vlekken . . . . . . . contaminatus.

ll. membraan zwart met gegolfd wit dwarsbandje ...... Paykullii.

VI. Dekschilden vaal.

$\times$ zonder bruine strepen op het borststuk. . . decolor.

$\times \times \operatorname{met} 2$ " " ". . . albidis.

VII. Dekschilden bruin.

$+1^{\mathrm{e}}$ en $2^{\mathrm{e}}$ lid der sprieten zwart, $3^{\mathrm{e}}$ wit, $4^{\mathrm{e}}$ bruin. Caricis.

++ alle leden ". vaalwit. . . . . Coryli.

VIII. Dekschilden bruin of vuilgeel met witte of gele langsstrepen. Thunbergii.

IX. Dekschilden aan de basaalhelft vaal, het overige donker-

bruin, schildje rood gevlekt. . . . . . . Bohemanni.

Achterscheenen met rijen zwarte stippels.

1. Zwart met het $1^{\mathrm{e}}$ lid der sprieten zwart . . . pulicarius.

2. Donkerbruin met de 2 eerste leden der sprieten zwart. Arbustorum.

3. Donker- of lichtbruin met witte sprieten . . . . variabilis.

4. Grauwgeel met de 2 eerste leden der sprieten zwart . brinnipennis.

5. Geel met witte sprieten. . . . . . . . . varians

6. Groen met groenachtig gele sprieten, $\mathbf{1}^{\mathrm{e}}$ lid met zwarte

bandjes . . . . . . . . . . . . viridulus.

7. Vaalrood met lichtroode sprieten. . . . . . rosens.

AAA. Kleinste soort, beneden 2 millim. lengte.

Dekschilden zwart en grijs gevlekt, zonder membraan . . saltitans.

\section{Lygus striatus L.}

Plaat 13, fig. 4. 1)

Linn. S. N. (Ed. 13) 730, 105. - Fabr. S. Rh. 255, 15. - Hahn, W. I. II, p. 134, f. 219. - Panz. F. Germ. 93, 22. - Woln, Ic. Cim. p. 37, tab. 4, f. 37. - Flor, Rh. Livl. I, p. 490. - Douglas and Scott, Brit. Hem. p. 320 .

Lengte 10 of $11 \mathrm{~mm}$. - Lang en smal, zoo goed als onbehaard. De kop aan de oogen (met deze) iets breeder dan lang, stomp driehoekig, zwart met een naanwelijks onderscheidbaar geel stipje op den schedel tegen den rand ran elk der oogen. Deze rond, bol, bruinzwart. Sprieten bijna zoo lang als het lijf; $1^{\text {e }}$ lid veel langer dan de kop, slank, rood

1) De twee gele streepjes op het schildje zijn in deze figuur door den graveur geheel over het hoofd gezien 
met zwarten top; $2^{\text {e }} 1_{2}^{\frac{1}{2}}$ maal zoo lang, zwart, slank, dikker wordende naar het einde; $3^{\mathrm{e}}$ iets langer dan het $1^{\mathrm{e}}$, slank, wit aan de basis, daarna vaalzwart; $4^{e}$ kort en grijs. Borststuk aan den voorrand niet zoo breed als de kop met de oogen, naar achteren tweemaal breeder wordend, zoo lang als in het midden breed, met stompe achterhoeken, zwart met een ruitvormig geel vlekje in het midden, met versmeltende randen. Schildje vrij groot, driehoekig, zwart met 2 gele streepjes aan de zijden naar de spits toe, die zij niet bereiken. Dekschilden met hoogliggende langsaderen, geel met zwarten zoom, bruinen clavus en daartusschen 5 zwartachtige langsstrepen; boven den oranje-gelen cuneus een driehoekig zwart vlekje. Membraan zeer donker met gele aderen en een wit vlekje tegen de spits van den cuneus. Buikzijde zwart. Pooten fraai rood met de dijen, trochanters, basis en uiteinde der scheenen en de tarsen zwart.

Van deze zeldzame soort ving de heer Ritsema te Velp in Junij 2 voorwerpen; vroeger had ik er een te Brummen gevangen den $28^{\text {sten }}$ Mei.

\section{Lygus striatellus F.}

Plaat 13 , fig. 5.

Fabr. S. Rh. 236, 164. - Fall. Hem. I, p. 84, 15. - Panz. Fn Germ. 93, 17. - Hahn, W. I. II, p. 133, f. 218. - Wolff, Ic. Cim. p. 156, tab. 15, f. 150. - Flor, Rh. Livl. I, p. 492. - Douglas and Scott, Brit. Hem. p. 318.

Lengte 6 of $7 \mathrm{~mm}$. - Korter en naar evenredigheid breeder dan de voorgaande, aan de bovenzijde geel met bruine versicring, aan de buikzijde zwart met gele vlekken. Kop van boven gezien meer dan 2 maal zoo breed als lang met uitpuilende zwarte oogen, doch van voren gezien langer, dus sterk vaar beneden gebogen, geel met een zwart en 2 scheve bruine langsstreepjes op het aangezigt. Sprieten zoo lang als $\frac{2}{3}$ van het ligchaam, slank; $1^{\mathrm{e}}$ en $2^{\mathrm{e}}$ lid geel met de tippen donker, $3^{\text {e }}$ en $4^{e}$ lid grauwzwart. Borststuk vrij kort en zeer breed 
van achteren, aldaar in het midden ingebogen, geel met den nitersten voor- en achterrand wit, vier langwerpige zwarte vlekjes voor het midden en een vrij hreeden, doch in het midden afgebroken zwarten dwarsband tegen den witten zoom aan; deze band is in enkele voorwerpen ook wel smal. Schildje geel met zwarte basis, die echter meest onder den prothorax verborgen blijft. Dekschilden sterk gelijkende op die van Striatus, doch minder donker, grondkleur geel; langsstrepen en vlekjes bruin; cuneus geel met zwarte spits. Membraan rookkleurig met ronde lichtere vlekken en gele aderen. Onderzijde bruinachtig zwart met bruingele streep en daaronder twee ronde vlekken aan wederzijde op den buik. De zuiger geel met het eerste lid zwart. Pooten geel met roodachtige dijen en zwarte achtertarsen. De voorwerpen verschillen nog al in teekening en in intensiteit van kleur.

Deze soort is vrij wat gemeener dan de vorige en komt in Mei en Junij voor. In de beide provinciën Holland werd zij aangetroffen door de heeren van der Hoeven (Leyden), l'iaget (duinen), de Graaf (Haagsche straatweg), van Hasselt (Haag), v. Vollenhoven (Haarlem, Haag), Ritzema Bos (Ameland); in Utrecht door de heeren Six en van Bemmelen (Driebergen), Ver Loren (Amersfoort); in Gelderland door den heer v. Medenbach de Rooij (Arnhem); en in Zeeland en Noord-Brabant door mij (Domburg en het Ginneken).

\section{Lygus Gothicus L.}

Plaat 13, fig. 3.

Linn. S. N. 13 ed. 726, 73. - Fabr. S. Rh. 244, 20, - Fall. Hem. 1, p. 117, 4. - Panz. Fn. Germ. 92, 15. - Wolff, Ic. Cim. p. 33, tab. 4, f. 33. - Hahn, W. Ins. I, p. 12, f. 5. - Flor, Rh. Livt. I, 1. 479.

Lengte 5,5 of $6 \mathrm{~mm}$. - Langwerpig ovaal, van voren ietwat hockig, zwart met ijle, tamelijk lange zwarte beharing. Kop bijna verticaal staande, daardoor van boven gezien zeer breed en kort, weinig glanzig zwart met twee scheve gele vlekjes op den schedel. Oogen bol uitstekend, donkerbruin. 
Zuiger glanzig zwart, reikend tot even voorbij de middelhenpen. Sprieten langer dan de helft van het ligchaam, zwart, het $2^{e}$ lid slechts weinig langer dan 2 maal het $1^{\mathrm{e}}$, de beide laatsten te zamen korter dan het $2^{\text {e, }}$, de beide eersten met cenige tamelijk lange haartjes bezet. Borststuk aan den voorrand vrịj breed, naar achteren een weinig oploopend, aan den achterrand minder dan twreemaal zoo breed als voor; zwart, op het midden der zijkanten een oranje vlekje. Schildje aan den voorrand zwart, van achteren bedekt met eene ruitvormige geelachtig roode vlek. Dekschilden zwart met eene vrij brecde gele rand. streep, die echter een eindje boven den cuneus ophoudt. Deze geelachtig rood met de niterste spits en den binnenhoek zwart. Membraan roetkleurig. Onderzijde zwart met eenige gele vlekken op borst en buik. Pooten zwart met bruine scheenen.

Op 's Rijks Museum te Leyden wordt een voorwerp bewaard, dat volgens de etiquette door Dr. W. de Haan in Holland zou gevonden zijn.

\section{Lygus selicornis F.}

Fabr. S. Rh. 244, 18. - Fall. Hem. I, 1. 88, $\mathrm{n}^{0} 23$ (Lateralis). Wolff, Ic. Cim. p. 117, tab. 12, f. 111 (Tibialis), p. 158, tab. 16, f. 152. - Hahn, W. I. I, p. 220 , f. 114. - Flor, Rh. Livl. I, p. 503.

Lengte 6 tot $8 \mathrm{~mm}$. - Langwerpig ovaal, zoo goed als onbehaard, behalve op dekschilden en buik; zwart, kop en borststuk glanzig, dekschilden mat. Kop bijna verticaal, van boven gezien zeer kort en breed; oogen tamelijk nitpuilend, van ter zijde gezien niervormig, donkerbruin. Sprieten iets korter dan het ligchaam, lid 1 en 2 zwart, 3 en 4 bruin, de laatsten niet bijzonder dun. De zwarte zuiger reikt tot $\varepsilon$ ?n de achterheupen. Borststuk van voren tamelijk smal, naar achter oploopend en aldaar bijna 3 maal zoo breed als voor, met naar buiten gebogen achterrand, zwart met fijnen witten zoom voor en achter, die van den achterrand in het midden puntig naar voren uitstekend. Schildje zivart, met fijne gele haartjes bezet. Dekschilden donkerbruin, tamelijk dik met gele haartjes 
bezet, met een onzuiver begrensden witten veeg onder den zwarten buitenrand; cuneus roodachtig in het bruin, membraan iets lichter bruin dan het corium, aderen donker. Onderzijde zwrart met de randen der geurklieren geel. Pooten lang en slank, zwart met de apophysen en scheenen vuilgeel, deze laatsten met 2 rijen fijne, doch zeer duidelijke stekels.

Deze soort werd hier te lande gevonden door den heer Mr. H. W. de Graaf in Julij bij Noordwijk en door den heer Heylaerts in de omstreken van Breda, in het midden derzelfde maand.

\section{Lygus bipunclatus F.}

Plaat 13, fig. 6.

Fabr. S. Rh. 235, 158. - Fall. Hem. I, p. 78, 2. - Herr.-Sch. W. I. III, p. 79, pl. 98 , f. 298 (te bont). - Kirschb. Rh. Wiesb. p. 59. Flor, Rh. Livl. I, p. 498. - Douglas and Scott, Brit. Hem. p. 319.

Lengte 7 tot $8 \mathrm{~mm}$. - Langwerpig ovaal, aan de schouders let breedst, groen, groenachtig geel of roodachtig geel, vau boven met niterst fijne zwvarte en gele, van onder alleen met gele haartjes bezet. Kop bijna verticaal, ran boven gezien echter stomp driehoekig met grauwgroene, van ter zijde gezien niervormige oogen. Zuiger geel, aan de spits bruin, reikend tot de achterheupen. Sprieten bijna zoo lang als het lijf; het $1^{\text {e }}$ lid matig dik, groen; het $2^{\text {e }} 2 \frac{1}{2}$ maal zoo lang als 1 , aan de spits niet verdikt, geel laugzamerband naar het bruine trekkend, 3 en 4 te zamen zoo lang als 2, bruinachtig rood. Borststuk aan den hals iets minder breed dan de helft van de grootste breedte, en $1 \frac{1}{2}$ zoo lang als de breedte van den duidelịjk afgezonderden voorzoom, met zeer nitgebogen achterrand en naar achteren sterk oploopend. In het midden 2 kleine ronde, zwarte vlekjes, die echter dikwijls wegblijven. De dekschilden hebben, voornamelijk bij het mannetje, somwijlen een rooden gloed op clavus en corium. Membraan grauw met gele aderen. Abdomen onder de dekschilden zwart met gele of groeue randen. Pooten groen, of groenachtig of bruinachtig 
geel, met bruine scheenspitsen en tarsen; de achterdijen vrij dik, soms met rijen zwarte puntjes, de achterscheenen met 2 rijen zwarte stekeltjes.

Deze soort is in het geheele land gemeen en overal zeer veelvuldig in de duinen op wilde kool of mosterd: zij komt van Junij tot in October voor.

\section{Lygus Chenopodii Fall.}

Plaat 13, fig. 7.

Fall. Hem. Suec. 77, 1. - Wolff, Ic. Cim. p. 36, tab. 4, f. 36. Hahn, W. Ins. I, p. 202, tab. 33, f. 103 (Binotatus). - Flor, Rh. Livl. I, p. 501. - Douglas and Scott, Brit. Hem. p. 325.

Lengte 6 tot 7,5 mm. - Gelijkende op de vorige soort, doch grauwer van kleur en onderscheiden door de teekening op het schildje en door de inplanting der sprieten. Langwerpig ovaal, grauwgroen met grijze of zelfs witte beharing. Kop bol op het voorhoofd, iets minder naar beneden gebogen dan de vorige. Sprieten tegen de oogen aan ingeplant (bij Binotatus niet zoo digt tegen den oogrand aan), veel donkerder van kleur dan bij den voorgaanden. Op den schedel dikwijls 2 bruine streepjes. Zuiger lichtgroen met bruine spits en donkergroen einde van het $1^{e}$ lid, reikt tot aan de middenheupen. Borststuk iets korter dan bij de voorg. soort en minder oploopend naar achter, bruinachtig groen, glanzig, soms met 2 kleine donkere vlekjes op de achterhelft. Schildje met 2 van elkander afgebogen kleine bruine streepjes, die echter ook wel eens ontbreken, vooral bij het wijfje. Op de dekschilden is de buitenrand van het corium onder den zeer smallen zwarten zoom, en tevens de cuneus iets lichter en glanziger van kleur, dan het overige; het corium naar de spits toe donkerder, soms in langsstrepen. Membraan iets donkerder grauw dan de dekschilden met vuilgele aderen, die aan het cind der kleine cel een bruin verdikt punt vertoonen. Abdomen aan de bovenzijde zwart met grauwgroene randen. Pooten groen met geelachtige heupen; de dijen met rijen bruine stipjes besprenkeld, 
de scheenen met zwarte stekeltjes en het laatste lid der tarsen zwart.

Volgens den heer Piaget is deze soort vrij gemeen in de duinen. De heer de Graaf ving haar in Aug. te Katwijk op Eryngium marilimum, ik zelf bij Scheveningen $22 \mathrm{Julij}$; doch ik ving haar bovendien in Aug. te Naaldwijk, waar geene duinen zijn en 22 Julij aan het strand der Schelde bij Bergenop-Zoom. Ook ving de heer van Medenbach de Rooij haar bij Huissen in Aug.

7. Lygus ferrugatus $\mathrm{F}$.

Plaat 13 , fig. 8.

Fabr. S. Rh. 236, 163. - Fall. Hem. Suec. I, p. 86, 19. - Ilahn, W. Ins. I, p. 204, tab. 33, f. 104. - Flor, Rh. Livl. I, p. 496. Douglas and Scott, Brit. Hem. p. 32T.

Lengte 7-8 $\mathrm{mm}$. Langwerpig eirond, doch iets breeder dan de vorige soorten, groenachtig geel of grauwgroen, met zeer fijne en korte zwarte beharing. Kop van ter zijde gezien bolrond, naar beneden gebogen, van boven gezien stomp driehoekig, met 2 zwarte vlekjes op den sehedel en den achterrand van den kop zwart. Oogen matig groot, bol, bruin. Sprieten zoo lang als het ligchaam; het $1^{e}$ lid vrij dik, grauwgroen; het $2^{e}$ rood met bruine basis, niet dikker wordende naar het einde; 3 en 4 te zameu langer dan 2, zwart. Zuiger aan de basis groen, in het midden bruingeel, aan de spits zwart. Borststuk van gedaante als bij Bipunclafus, doch iets breeder van voren, grauwgroen met twee breede, doch onduidelijke roode langsstrepen. Schildje met gele basis onder den prothorax en soms met eene bruine langsstreep over het midden Dekschilden met eene kaneelroode groote vlek op den clavus en twee zulke langsstrepen in wigvorm op het corium. Membraan grauw met lichtere aderen; de cellen iets donkerder dan de grond. Pooten groen met bruine einden der achterdijen; de scheenspitsen en tarsen zwartbruin.

Beschreven naar een voorwerp door den heer Maurissen 26 
Julij '74 bij Bunde in Limburg gevangen. De soort werd bovendien aangetroffen aan de Bildt en te Driebergen door den heer Six, terwijl do heer van Medenbach de Rooij bij Arnhem in Julij twee voorwerpen ving.

\section{Lygus cordiger Hahn.}

Hahn, Wanะ. Ins. II, p. 85, PI. 56, fig. 171. - Fieber, Die Eur. Hemipt. p. 264.

Lengte $6 \mathrm{~mm}$. - Ovaal, tamelijk breed, grof gekorreld, zwart met doojergele versiering. Kop kort en breed driehoekig, vrij spits aan de basis van den zuiger, glanzig zwart met een smal geel dwarsstreepje op den schedel. Oogen sterk uitpuilend, bruin, volgens Herich-Schaeffer in het leven rood. Sprieten niet langer dan de helft der ligehaamslengte, zwart, het $2^{\text {e lid }}$ min of meer verdikt naar het einde, de beide volgenden hirrfijn. Borststuk grof gestippeld, glanzig, zwart, aan den achterrand scherp omlijst. Schildje driehoekig, glad, zeer glanzig, doojergeel met eene zwarte vlek aan den voorrand, die zich soms naar achteren tot bijna aan den achterrand uitstrekt. Dekschilden aan de binnenhelft zwart, aan de buitenhelft doojergeel; cuneus meer oranjegeel met zwarte spits. Membraan roodkleurig met lichtere wolken aan de basis. Achterlijf boven en onder zwart. Heupen en dijen zwart, de laatsten met 1 of 2 gele bandjes voor de knie; scheenen geel met de basis en spits, alsmede een bandje in het midden zwart; tarsen grauw met het laatste lid en de klaauwtjes zwart.

Een voorwerp in de omstreken van Breda in het gras bij brem in Julij (Heylaerts); twee voorwerpen in Julij bij Arnhem (v. Med. de Rooij); een in Julij te Oosterbeek (Dr. v. Hasselt).

\section{Lygus Fallenii Hahn.}

Plaat 11, fig. 11.

Hahn, Wan\%. Ins. II, p. 89. Pl. 57, fig. 175. - Kirschb. Rh. Wiesb. p. 67.

Lengte $4 \mathrm{~mm}$. - Ovaal, tamelijk breed, bruin met lichtere 
dekschilden. Kop van boven gezien breed driehoekig, zwart op den schedel met 2 van daar tusschen de oogen afdalende vlekken. Oogen uitpuilend en bruin. Sprieten korter dan het halve ligehaam, donkerbruin, met de basis van lid 1 rood. $O p$ het schildje drie lichtgekleurde vlekken, twee in de zijhoeken, 1 aan de spits. Dekschilden lederkleurig, bijna doorschijnend, glanzig, gestippeld met 1 zwart vlekje in het midden en 2 aan den achterrand van het corium, de spits van den cuneus mede zwart. Membraan doorschijnend met lichtbruine aderen. Pooten lichtbruin met roodbruine ringen op de dijen; eene breede donkere ring om de scheenen, de scheenspitsen en het $3^{\text {e }}$ lid der tarsen donkerbruin.

Een voorwerp werd 29 Junij in de Hollandsche duinen gevangen door Dr. Piaget.

\section{Lygus punctulatus Fall.}

Fall. Hem. Suec. 95, 36. - Meyer, Rh.d. Schweiz, p. 103, taf. IV, fig. 2.

Lengte $4 \mathrm{~mm}$. - Vrij breed ovaal, als de vorige, glanzig, kaal, gestippeld, lichter of donkerder nootbruin. Kop van boven gezien breed, kort met eene vooruitstekende punt. Oogen sterk uitpuilend, donkerbruin. Sprieten zoo lang als het halve ligchaam, geel, naar de spits donkerder. Borststuk naar achteren sterk oploopend, bol, aan den achterrand, die in bet midden regt loopt, tweemaal zoo breed als aan den hals; de twee verhevenheden achter den voorrand zijn soms van achter donkerbruin gezoomd. Het schildje heeft 3 gele vlekken in do hoeken of bet is door 3 gele lijntjes, die van de hoeken af naar een punt voor het midden toeloopen, in drie donkerder veldjes verdeeld. Dekschilden sterk gestippeld, doch bijna doorschijnend, met '2 donkere plekken, een naar het einde van het corium, de andere in het midden; deze teekening verdwijnt dikwijls. Een dwarsbandje op de spits van den cuneus donkerbruin. Membraan geelachtig met de buitenader der groote cel donkerbruin. Cuneus en membraan sterk naar beneden gebogen. Pooten bruinachtig geel; een zwart bandje om de achterdijen, 
midden- en achterscheenen met 2 donkere bandjes en het laatste lid der tarsen donkerbruin.

Deze zeldzame soort komt zeer vroeg en zeer laat in het jaar voor en overwintert waarschijnlijk. De heer van Medenbach de Rooij ving bij Arnhem 4 exemplaren in April en November; doch hij trof de soort ook bij Huissen in Julij aan.

\section{Lygus pralensis $\mathrm{L}$.}

Plaat 13, fig. 9, de var. Campestris.

Linn. S. N. 13 ed. 728,86 et 87. - Fabr. S. Rh. 234 , 154 et 155 Fall. Hem. 90, 28 et 91, 29. - Panz. Fn. Germ. 93, 19. - Halın. W. Ins. I, p. 217 et 218 , tab. 35, fig. 112 et 113 . - Flor, Rh. Livl. I, p. 517. - Douglas and Scott, Brit. Hem. p. 463, 7 (Campestris), p. 464, 8 (Pratensis).

De autoriteit van Linnaeus en Fabricius schijut vele entomologen genoopt te hebben de gladde en de harige voorwerpen dezer soort als twee afzonderlijke species te beschouwen; doch Burmeister, Meyer en vooral Flor (zie zijne lange noot op bladz. 520) bebben voldoende bewezen dat men hier slechts met eene soort in twee verscheidenheden, die in elkander loopən, te doen heeft. Zonderling is het dan ook, dat Douglas en Scott hen weder van elkander scheiden, doch dit feit is waarschijnlijk te verklaren uit de overweldigende lust die de Engelschen drijft om hunne fauna met soorten te verrijken, waarvan ook vroegere werken in ruime mate getuigen. Tot Pralensis wordt ook nog door Flor gebragt Capsus gemellatus H. Sch. (Wanz. Ins. III, p. 81, fig. 301).

Lengte 4,5-5,5 mm. - Ovaal, bijna glad of wel met korte haartjes bezet, glanzig, op het borststuk gestippeld, geel of groenachtig geel of grauw. Kop vrij sterk naar beneden gebogen, van boven gezien tweemaal breeder dan lang, driehoekig met ronde uitpuilende bruine oogen, die van ter zijde gezien ovaal zijn. Sprieten iets langer dan de helft van het ligchaam, fijn, het $1^{\mathrm{e}}$ lid iets dikker; groen, geel of roudachtig; het $2^{*}$ geel of roodachtig met donkerbruine spits, die iets dikker is 
dan de rest, 3 en $t^{p}$ te zamen langer dan 2, haarfijn, zwart. Zuiger groen of lichtbruin, reikend tot de achterheupen. Borststuk van achteren tweemaal zoo breed als voor, sterk bol naar achteren oploopend, doch aan den achterrand weder naar beneden gehogen, glanziger dan de rest van het lijf; het hoogere gedeelte is gewoonlijk het donkerst gekleurd. Schildje minder sterk gestippeld dan het borststuk, bijna glad; het basaalgedeelte (onder den rand van den prothorax) donker gekleurd, van war dikwijls in het midden op het onbedekte gedeelte 2 donkere streepjes naar beneden dalen. Dekschilden minder glanzig dan het borststuk, 't zij ongevlekt, 't zij met 2 vlekjes aan het eind van het corium, 't zij bovendien met donkere langsstrepen. Pooten niet zeer lang, noch zeer slank, met 2 of 3 bandjes om de einden der dijen.

De gladdere lichtgekleurde voorwerpen zijn de ware Pratensis, de meer behaarde, sterker gekleurde en vooral gevlekte voorwerpen behooren tot Campestris; rele voorwerpen zijn even goed tot de eene als tot de andere verscheidenheid te brengen. De verscheidenheid Gemellatus Herr.-Sch. is eenmaal in Julij bij Groningen aangetroffen door Dr. de Gavere. Pratensis behoort tot de zeer gemeene soorten en is, zoo ik wel heb, in al onze provinciën gevangen.

Van den heer Mr. Leesberg te 's Gravenhage ontving ik een voorwerp dat, in April in de omstreken dier stad gevangen, zich door een buitengewoon coloriet onderscheidt. Het is iets kleiner dan de normale grootte, niterst fijn en kort van beharing en heeft in de bestippeling en vorm niets buitengemeens. Misschien zijn de sprieten iets korter dan bij de anderen, doch dan toch in allen gevalle maar weinig. De algemeene kleur is helder groen als die van $L$. bipunctalus zonder tot het gele of grauwe over te hellen. De kop vertoont een bruin streepje op het voorhoofd en een op den clypeus; de oogen zijn zeer licht roodbruin. Het borststuk is naar den achterrand toe wat gebruind en vertoont achter den voorrand twee sepiabruine halve maantjes. De clavus der dekschilden is olijfbruin, even als cene ruitvormige vlek op het eind van het corimm 
tegen de wigge aan. De membraan is berookt geelachtig met lichtere aderen. Buik en pooten zijn fraai groen, de achterdijen met bruine ringeltjes.

Ik kan dit voorwerp voor niets anders houden dan voor voor eene prachtig gekleurde verscheidenheid van Pratensis.

\section{Lygus rubicundus Fall.}

Plaat 14, fig. 1.

Fall, Hem. I, p. 92, 30. - Flor, Rh. Livl. I, p. $53 \%$.

Lengte 4-4,5 mm. - Ovaal, van gedaante als de voorgaande, doch geelrood of rood van kleur en kleiner. Kop sterk neergedrukt, bijna verticaal, glanzig met 2 putjes up den schedel. Zuiger roodachtig geel met bruine spits, reikend tot over de middenheupen. Sprieten iets korter dan de helft van het lijf, met de 2 eerste leedjes en de basis van het $3^{\mathrm{e}}$ roodgeel, het overige bruin. Borststuk niet veel langer dan de breedte van den voorrand, van achter bijna 2 maal zoo breed als lang, in het midden van den achterrand ingebogen, vrị bol kussenvormig, glanzig, doch sterk bestippeld, behalve de 2 halsbultjes, die glad blijven. Halsschild fijner bestippeld, even als de dekschilden; deze met korte lichtgrijze haartjes bezet. Cuneus iets lichter van kleur, doch met fijne bloedroode spits. Membraan berookt met fijne roode cel-aderen; een fijn bruin dwarsstreepje onder de spits der groote ader en een hoornvormig wolkje aan den buitenrand. Buik en pooten lichter van kleur dan de bovenzijde. Dijen met donkere bandjes voor de knie.

Het komt mij voor dat deze soort bij de sehrijvers met andere roode, doch langwerpiger soorten verward is; zelfs stemt de beschrijping bij Flor niet volkomen met mijne voorwerpen overeen.

Volgens mijne aanteekeningen werd deze soort gevonden: bij Utrecht door Dr. van Hasselt, bij Driebergen door den heer Six, bij Arnhem in October door den heer van Hedenbach de looij, in de omstreken van Breda door den heer 
Heylaerts en door mij in de maand April op de Gliphoeve onder Heemstede.

\section{Lygus Iripustulatus F}

Plaat 13 , fig. 10.

Fabr. S. Rh. 239, 182. - Fall. Hem. Suec. I, p. 96, 38. - Hahn, W. Ins. I, p. 213, pl. 34, f. 110 (Pastinacae) et 111. - Burm. Handl. II, p. 273, 25. - Flor, Rh. Livl. I, p. 515. - Douglas and Scott, Brit. Hem. p. 450.

Lengte $4 \mathrm{~mm}$. - Ovaal, glanzig, met putjes bestippeld, zwart met oranjekleurige teekening. Kop geel met bruine vlekjes voor de oogen en bij den zuiger, bol van voren, bijna verticaal staande, van boven gezien tweemaal zoo breed als lang. Oogen uitpuilend, bruin. Zuiger geel, donkerbruin aan het einde, tot de achterheupen reikend. Sprieten ver over de helft van het ligchaam reikend, slank; het $1^{\mathrm{e}}$ lid geel met een zwart langsstreepje aan de binuenzijde en een zwart bandje vool de spits, het $2^{\text {e }}$ eerst zwart, dan bruin, dan geel, dan weder zwart, het $3^{\mathrm{e}}$ bruin met gele basis en het $4^{\mathrm{e}}$ geheel bruin. Borststuk vrij breed van voren, $1 \frac{1}{2}$ maal zoo lang en op het breedst 2 maal zoo breed als an den hals, met den achterrand rondgebogen, zonder indruksel, van voren greel, van achteren zwart of wel met 4 zwarte vlekken; in het $1^{\mathrm{e}}$ geval het geel in het midden met eene wigvormige vlek inspringende en 2 zwarte vlekken op het geel achter de halsbuilen. Schildje geel of oranje met zwarte basis, die onder den rand van het halsschild verborgen is. Dekschilden zwart met 2 gele vlekken aan den rand, die soms vrij diep naar bimnen doorloopen; cuneus oranje of geel aan de basis en de spits zwart. Menbraan zeer donker met gele aderen en bovendien 2 gele of witte vlekjes, 1 rond in het midden, 1 hoornvormig aan den rand. Borst geel met zwarte vlekken, buik glanzig zwart met gele randvlekken. Pooten geel, dijen met 2 of 3 zwarto banden, scheenen met 1 bandje.

$\mathrm{Er}^{\mathrm{r}}$ is veel versehil in donkerder of lichter teekening. Bij de 
var. P'ustinacae van Hahn loopt de middenband op de dekschilden door en is er een geel vlekje op de spits van den clavus.

Bij Groningen en Diever in Julij gevangen door Dr. de Gavere, bij den Haag en Leyden door mij, bij den Haag in Februarij en Maart door Mr. Leesberg, bij Utrecht door den heer Six, bij Breda in menigte door den heer Heylaerts, bij Huissen door den heer v. Medenbach de Rooij met de var. welke ook gevonden is bij den Haag door den heer van der Wulp.

\section{Lygus Kalmii L. ${ }^{1}$ )}

Plat 14, fig. 2.

Limı. Fn. Suec. 948. - Fabr. S. Rh. 243, 10 (Flavovarius). - Fall. Hem. Suec. I, 93, 34. - Ilahn, W. Ins. I, 1. 211, pl. 34, f. 109 (Flavovarius). - Schellenberg, Cim. tab. 3, tab. 3, f. 2 en $c$ (te hoog geel). - Flor, Rh. Livl. I, p. 521. - Douglas and Scott, Brit. Hem p. 452.

Weder eene soort met twee namen, een voor de licht-, een voor de donkergekleurden; ofschoon Fieber hen als twee soorten gescheiden heeft, hebben nogtans de Engelsche auteurs hen weder vereenigd, 't geen zeer opmerkelijk is.

Lengte $4 \mathrm{~mm}$. - Ietwat langwerpig ovaal, donkerbruin of zwart met geel of geelachtig groen versierd. Kop sterk naar beneden gebogen, glanzig geel met 2 zwate langsstreepjes of donkerbruin met 3 gele streepjes, die zich op den schedel tot eene vlek vereenigen. Oogen uitpuilend, lichtbruin. Sprieten iets langer dan de helft van het lijf; $1^{\mathrm{e}}$ lid geel met zwarten band aan de spits, de 3 volgenden bruin; lid 2 is $2 \frac{1}{2}$ maal langer dan lid 1 en naar de spits toe iets dikker wordend. Zuiger geel met zwart uiteinde. Borststuk naar achteren oploopend en vrij bol, fijn gestippeld, op het breedste punt 2 maal zoo breed als lang, aan den achterrand, die rond nitgebogen is, flaauwelijk ingedenkt in het midden, zwart met smallen gelen voor- en achterrand en een geel langsstreepje in

1) Linnaeus zou zich wel gewacht hebben ooit Kalmi (met cen i), te schrijven, gelijk men leest hij Fieber, Douglas en helaas! ook bij Flor. 
het midden. De var. Flavovariu. heeft 3 gele vlekjes op het midden, of het borststuk in het midden geheel geelgroen. Schildje glad, glanzig, geheel geel, of met een driehoekig of halfrond zwart vlekje in het midden van de basis. Dekschilden (Kalmii) zwart of bruin, met eene langwerpige geelgroene vlek aan de basis van het corium en met de bovenhelft van den cuneus geel; of wel (Flavovarius) groenachtig geel met de bovenhelft van den clavus, een' dwarsband aan het eind van het corium en de benedenhelft van den cuneus bruin. Menbraan lichter of donker wolkig berookt, met de groote ader geel. Ondersijde zwart met 2 zeer breede gele langsstrepen over den buik. Pooten geel, de achterdijen met 2 bruine bandjes voor de knie, de achterscheenen en tarsen aan de achterhelft bruin.

Gemeen op verschillende schermbloemen, voornamelijk beerenklaauw (Heracleum sphondylium), en in de meeste provincrën aangetroffen.

\section{Lygus l'astinacae Fall.}

Fall. Hem. 94. 35. - Flor, Rh. Livl. 1, p. 523, n" 30. - Douglas and Scott, Brit. Hem. 1. 455, pl. 15, f. 4.

Zoo sterk gelijkend op de roorgaande, dat men haar voor dezelfde zou bouden, indien niet de oogen minder uitpuilend waren en vooral niet aan den binnenrand ingebogen, terwijl Kalmii de oogen vrịj sterk ingebogen heeft. Ook is er cenig rerschil in kleur gelijk blijken zal uit de volgende beschrijving.

Lengte $4 \mathrm{~mm}$. -- Groen met bruine teekening, membraan ongevlek. Kop olijfbruin, glanzig met een zwart dwarsstrepje in den nek en donkerbruine oogen. Sprieten van dezelfde

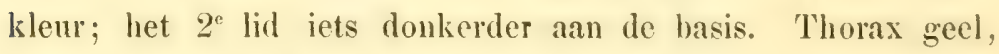
glanzig, tamelijk grof gestippeld, met bruinen achterrand der halsknobbeltjes. Schildje zwavelgeel of appelgroen. Dekschilden groen met een' bruinen gloed op den clavus en aan het eind van het corium; euneus lichtgroen met donkerder randen. Membraan wit, doorsehijnend met zeer licht bruine aderen. 
Underzijde vuil groenachtig geel met de borst bruinachtig; ; ecne zwarte vlek op het midden van den laatsten buikring en twee kleinere aan de zijden daarran. Pooten groenachtig geel met de scheenen lichtgroen en het laatste lid der tarsen zwart.

Deze soort werd gevangen $13 \mathrm{Junij}$ in het Overmaassche bij Rotterdam door Dr. Piaget, in Jilij op Staalduin door den heer van der Wulp, in dezelfde maand door den heer Heylaerts in de omstreken van Breda en in Mei bij Utrecht door den heer G. A. Six.

\section{Lygus unifascialus $\mathrm{F}$.}

Plaat 13, fig. 11.

Fabr. S. Rh. 243, 9. - Fall. Hem. 1, 1. 86, 21 (Semiflavus). Wollf, lc. Cim. p. 154, tab. 15, fig. 148 (Semiflavus). - Ilahn, W. Ins 1, p. 208, tab. 34, fig. 107 (Semiflavus) II, P. 85, tab. 56, fig. 169 (Lateralis) et 170 (Marginatus). - Flor, Rh. Livl. I, p. 54. - Douglas and Scott, Brit. Hem. p. 467, pl. 15, f. 6.

Eene in kleur nog al varie̊rende soort, die echter daarom nog geene drie afzonderlijke namen verdiende, zoo als Hahm aan de kleurverscheidenheden toediende.

Lengte bijna $5 \mathrm{~mm}$. - Z Zwart met goudgele en grijze haartjes bezet, ovaal, de mannetjes iets langwerpiger dan de wijfjes. Kop sterk naar beneden gebogen en niet zeer bol, daardoor van boven gezien zeer kort en breed, zwart met twee gele vlekjes tegen de oogen aan op den schedel. Oogen licht bruinrood, sterk uitpuilend, grof van facetten. Sprieten zoo lang als van het ligchaam; het $1^{\mathrm{e}}$ lid betrekkelijk kort, vaalrood, het $2^{e}$ driemaal langer, ran dezelfde kleur met bruine spits,

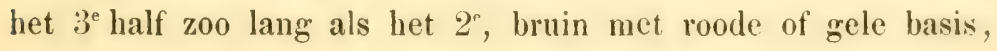
het $4^{e}$ zwart. Zuiger bruinrood, reikend tot de middenheupen. Borststuk naar achteren oploopend, kort en breed, met smallen gelen zoom aan den achterrand. Schildje of geheel zwart, of meer of min geel aan de spits, soms over de helft. I)eksehilden geel met zwarten clavus en op het corium 2 tegen elkander an liggende ovale zwarte vlekken, die den buiteurand en den 
cuneus niet raken, maar wel den achterrand; deze vlekken breiden zich soms zoo zeer uit, dat er weinig van de grondkleur meer overblijft (var. laleralis en marginatus); cuneus rood met een zwart vlekje aan den buitenrand. Liembraan rookkleurig, de zwarte cellen omzoomd met gele aderen. Voorpooten rood, middenpooten roodbruin, achterpooten bruin met gele basis der dijen.

Eene niet bijzonder zeldzame soort, gevangen bij Utrecht door Dr. van Hasselt en den heer Six, op Walcheren door den heer Gerlach, te Katwijk door den heer de Graaf, te Wassenaar en Scheveningen in Julij door mị. De var. Lateralis werd te Katwijk op walstroo angetroffen door den heer de Graaf en bij Amersfoort door den heer Six.

\section{Lygus vulneralus Wolff.}

Plast 14, fig. 3.

Panz. Fn. Germ. (Wolff) 100, 22. - Fall. Hem. Suec. p. 87, 22. (Dalmanni), - IIahn, W. Ins. I, p. 210, pl. 34, fig. 108 (Dalmanni). Flor, Rh. Livl. I, p. 549 (eodem nom.).

Lengte 3 tot $4 \mathrm{~mm}$ - Zeer na aan de voorgaande verwant. Ovaal, het wijfje iets breeder dan de man, grauw of groenachtig geel, met goudgele of zilverachtige haartjes bekleed. Kop verticaal, zeer weinig bol, daardoor van boven gezien breed en kort; oogen overmatig uitpuilend, grijs. Zuiger aan de spits bruin. Sprieten ongeveer ${ }_{4}$ der lengte van het ligchaam, roodachtig geel met de uiteinden der leedjes bruin; het laatsto geheel bruin. Lid 2 is $\frac{1}{3}$ langer dan de beide volgenden te zamen, bij den $\&$ zoo dik als het $1^{e}$ lid en overal van gelijke dikte, bij het $q$ aan de basis dunner dan aan de spits. Borststuk met 4 zwarte vlekjes, 2 aan den roorkant achter den witten zoom (zij blijven wel eens weg, doch verlengen zich ook wel tot 2 langsstreepjes en in het laatste geval is op den kop mede eene zwarte langsstreep te zien) en 2 aan de schouders. Schildje geel met zwarte basis of zwart met eene hartvormige gele vlek aan de spits. Dekschilden met zoer fijnen 
zwarten buitenrand en soms met 2 wigvormige vlekken op het het corium. Cuneus bloedrood met een fijn zwart streepje aan den buitenrand. Membraan lichter of donkerder grijs met gele aderen. Pooten grauwgroen of vuilgeel, de dijen aan de onderzijde met rijen van bruine stipjes, achterdijen met $1 \frac{1}{2}$ bruin bandje aan de knie; laatste lid der tarsen zwart. Het achterlijf op den rug zwart met grauwgele randen.

Zeer gemeen op de duinen van half Junij tot in Augustus. Ook op Ameland gevonden door den heer Ritzema Bos.

\section{Lygus Gyllenhalii Fall.}

Plaat 14, fig. 4.

Fall. Hem. S. 97, 40. - Herr.-Sch. W. Ins. III, p. 86, pl. 101, f. 310. - Flor, Rh. Livl. I, p. 546 partim. - Douglas and Scott, Brit. Hem. 1. 416, pl. 15, f. 1 .

Lengte 3-4 mm. - Breed ovaal, zwart met grijze haartjes dik bekleed. Kop sterk gebogen, weinig bol, van boven gezien vijfhoekig. Oogen van ter zijde gezien nagenoeg niervormig, uitpuilend, grof van facetten, bruin. Sprieten niet langer dan de helft van het ligchaam, geelachtig wit met een bruin vlekje aan de binnenzijde van het $1^{e}$ lid; het $4^{e}$ en de spits van het $3^{\text {e }}$ bruinachtig. Borststuk hoog oploopend en bol gewelfd, eene zeer lichte indeuking in het midden van den rond uitgebogen achterrand; deze rand aan wederzijde met cen fijn witachtig zoumpje. Schildje kort en breed, overdwars gekrast, aan de spits sterk behaard. Dekschilden met een vlekje aan de basis, den zeer smallen zoom van den buitenrand, den achterhoek van het corium en den cuneus steemrood; deze laatste is aan den voorrand door eene diepe inkeeping van het corium afgescheiden. Membraan zwart met witte aderen en een wit vlekje onder de spits van den cuneus. Onderzijde zwart, vlekkig behaard. Pooten geelachtig met bruine gedcelten; de heupen en dijringen zwart, de dijen met bruine bandjes, de tarsen vuilwit met zwarte spits en zwarte klaauwtjes.

Eene zeer na verwante soort, Holosericeus Hahn (W.Ins. I, 
1. 27, tig. 17) wordt door Flor met deze vermengd; zij onderscheidt zich echter van fryllenhalii door meerdere grootte, betrekkelijk langere sprieten en geelachtig witte scheenen en werd bij ons nog niet aangetroffen. Merkwaardig en kenschetsend voor zijne methode is het dat Fieber beide soorten in twee verschillende genera plaatst. Het is wel de moeite waard het zoogenaamde verschil bij Fieber, p 271 na te lezen.

Van Gyllenhalii vond ik een voorwerp in de duinen bij scheveningen op den $22^{\text {sten }}$ Julij 1874, en Dr. van Hasselt een bij Loosduinen.

\section{Lygus Pinastri Fall.}

Fall. Hem. S, I, p. 112, 68. - Hahn, W. Ins. 11, P. 87, lab. 57, f. 173. - Flor, Rh. Livl. I, p. 536.

Lengte $4 \mathrm{~mm}$. - Langwerpig ovaal, bruin met donkere hararjes bezet, vooral op de dekschilden. Kop bijna verticaal en toch van boven gezien breed driehoekig, glanzig, getaand geel met een bruin langsstreepje in het midden. Oogen bol, sterk uitpuilend, donkerbruin. Sprieten zoo lang als 3 van het ligchaam, slank; het $1^{\mathrm{e}}$ lid bruingeel met 2 bruine smalle bandjes, lid 2 geel, 3 geelbruin, 4 donkerbruin. Zuiger bruin, tot aan de achterheupen reikend. Borststuk op de breedste plaats tweemaal zoo breed als lang, met de voorhoeken geheel afgerond, bol knssenvormig, grof gestippeld, zeer glanzig zwart met in het zwart wegsmeltende geelbruine zijden; de smalle voorrand wit, ook de achterrand naauwelijks zigtbaar wit gezoomd. Sichildje iets fijner gestippeld, glanzig zwart. Dekschilden tijn gestippeld, lichter of donkerder bruiu, naar het eind toe bijna zwart; cuneus bruin met donkere spits. Membraan taankleurig berookt. Pooten taankleurig geel, op de dijen en scheenen met bruine bandjes bezet; de heupen, apophysen en het eind der tarsen donkerbruin.

De mannetjes zijn donkerder van kleur dan de wijfjes. De figuur van Hahn is echter veel te donker, te zwart.

Deze soort werd door mij in Julij op de duinen van scheveningen gevangen. 
20. Lygus cervinus H. Sch.

Plaat 14, fig. 5.

Herr. Sch. W. Ins. IV, p. 57 , H. 199, f. 617. - Meyer, Schw. Rh. 1. $103, n^{n} 91$.

Lengte $4 \mathrm{~mm}$. - Bruinachtig geel, glanzig, langwerpig ovaal. Kop verticaal, weinig bol, met niervormige donkerbruine oogen. Sprieten langer dan de helft van het ligchaam,

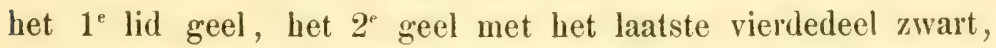
lid 3 en 4 zwart. Zuiger geel met zwarte spits, reikend tot voorbij de achterheupen. Borststuk grof gestippeld, doch zeer glanzig, met donkere onbepaalde vlekjes, de achterhoeken bruiner. Schildje iets fujner gestippeld (ik kan er de 2 donkere langsstreepjes niet op terugvinden, die er volgens Herr:Schaeffer en Meyer op te zien zijn). Dekschilden doorscbijnend, hoornachtig, met een zeer fijn zwart zoompje aan het begin van den buitenrand, met een klein rood langsstreepje boven en een bruin dwarsstreepje bezijden den cuneus; deze mede boornachtig met een fijn bloedkleurig randje aan de spits. Membraan met 3 donkere wolkjes, waarvan 1 in de groote cel en 1 tegen de spits van den cuneus. Onderzijde en pooten geel, achterdijen rood gekleurd.

Een voorwerp, zoo bont gekleurd als de angehaalde figuur heb ik nooit gezien; toch noemt Meyer die at beelding "sebr getreu". Onze inlandsche voorwerpen schijnen dus bleeker van tint, dan sommige Zwitserschen.

Gevangen door den heer de Gavere bij Groningen, door den heer Six in Nov, bij den Haag (?) en door mij in Maart bij Haarlem.

\section{Lygus Roseri H. Sch.}

Plaat 14 , fig. 6.

Herr.-Sch. W. Ins. IV, p. 78, pl. 132, f. 40\%. - Meyer, Schw. Rh. 1. 105, 94. - Flor, Rh Livl. J, p. 560, $\mathrm{n}^{\circ} 53$.

Van deze soort, die volgens de beschrijvingeu een zwart 
borststuk moet hebben, ken ik hier te lande slechts eene verseheidenheid met licht gekleurd borststuk.

Lengte 3,5 mm. - Vrij breed ovaal, bijna onbehaard, glanzig. Kop verticaal, zeer weinig bol uitstekend, van boven gezien breed driehoekig, donkerbruin met den schedel en 2 scheve strepen langs de oogen geelachtig rood. Oosen weinig uitpuilend, brnin. Sprieten korter dan de helft van het ligchaam, matig slank; de 2 voorste leedjes geel, de spits van het $2^{\text {e }}$ met 3 en 4 zwart. Borststuk breed en kort, fijn gestippeld met eene golvende vrij diepe dwarsoleut achter de gewone halsknobbels; rood- of onk wel groenachtig geel, aan den voorkant donkerder, bijna bruin. Het schildje van dezelfde kleur en even zoo gestippeld. Dekschilden onduidelijk bestippeld, licht of grauwachtig geel met een' donkeren langsveeg in het midden. Cuneus iets rooder; membraan rookkleurig. Onderzijde zwart met eene roode vlek op den buik. Pooten rood met bruine heupen en bruine basis der dijen; de scheenen geel met zwarte doorntjes in 2 rijen, tarsen geel met zwarte spitsen.

Dit insect is uitsluitend door den heer Six in Julij bij Utrecht gevonden.

\section{Lygus mulabilis Fall.}

Plaat 14, fig. 7 of et q.

Fall. Hem. S. I, p. 118, 5. - Hahn, W. Ins. II, p. 95, بl. 59, f. 180 § , III, p. 11, pl. 76 , f. 236 q (Saltator). - Curt. Brit. Ent. XV, tal). 693 (Hirtus). - Mejer, Schw. Rh. p. 58, no 23 et 112 no 106 (Saltutor). - Flor, Rh. Livl. I, p. 567. - Douglas and Scott, Bril. Hem. p. 431, pl. 11, f. 2.

Eene soort, waarvan het wijfje, om de rerkorte dekschilden, van Hahn een' anderen naam hecft ontrangen, of schoon Fallen's opgave ontrent die sexe hem bekend was. Even als in Zweden, zijn de wijfjes met volkomen dekschilden en rleugels hier zeer zeldzaam of ontbreken misschien geheel.

Lengte 4-5 mm. - Zwart, dik met schubachtige, goudgele haartjes bezet, die echter ligt loslaten. Ilet mannetjo langwerpig ovaal, het wijfje peervormig. Kop scherp drie- 
hoekig, aan het achterhoofd als afgesneden en tegen het borststuk gedrukt, met vrij lange zwarte haartjes aan de basis van den zuiger, die tot aan de middenheupen reikt. Oogen uitpuilend, bruinzwart. Sprieten bij den man iets langer dan de belft van het ligehaam, zwart, onbehaard, het $1^{\text {P }}$ lid dikker, het $2^{\circ}$ an de spits schier niet dikker dan in het milden, het $3^{\mathrm{e}}$ slechts weinig langer dan het $1^{\mathrm{e}}$. Sprieten bij het wijfje nagenoeg zoo lang als het ligehaam, zuvart, harig; lid 1 iets langer en dunner dan bij den man, 2 knodsvormig en dik behaard, 3 zeer slank en $2 \frac{1}{2}$ maal langer dan 1 , met 4 vederachtig behaard. Halsschild bij het $q$ korter en breeder dan bij den man, bij haar is de voorrand zoo breed als het halsschild in het midden lang is. Dekschilden bij hem voluitgegroeid met donkere membraan, met lichtere aderen, bij hatr zonder cuneus noch membraan, maar aan het eind wat toegeknepen. Pooten vrij lang en zwart met afstaande haren, meest met donker roodbruine scheenen; vooral bij het wijfje zijn de achterdijen lang en tevens grof.

Beide sexen werden in de omstreken van Breda angetroffen door den heer Heylaerts. Een \& werd door den heer Ritsema in Junị bij Velp gevangen, en een q op Walchoren door den heer Gerth van Wijk. Waarsehijnlijk heb ik wel meer mannetjes ter determinatie in handen grehad, doch bij den twijfel omtrent den naam, daar er meer geheel zwarte soorten rijn, dienaangaande geene anteekening gehouden. Een enkel bevindt zich in mijne verzameling met het etiquette Hollanl. Of het wijfje springt, gelijk de naam Sallator aanduidt, is mij niet gebleken. Door den knodsvorm van het $2^{\text {e }}$ lid $d \in \mathrm{r}^{\mathrm{r}}$ sprieten nadert dit wijfje tot de soorten van het geslacht Capsus, 't geen al wederom aantoont dat de genera in deze familie geene zuivere, vast afgebakende grenzen hebben.

\section{Lugus virgula Herr. Sch.}

Plaat 14, fig. 8.

Herr. Sch. Wanz. Ins. III, p. 51, pl. 88, fig. 268. - Douglas and Scott, Brit. Hem. p. 373, pl. 12, f. 10. 
Lengte $4 \mathrm{~mm}$. - Smal, langwerping, het borststuk eenigrzins in den vorm van een halsje verdund, onbehaard, weinig. glanzig, geel met roode versieringen en zwarten kop. Kop van boven gezien breed vierkant met een uitstekend puntje, van voren gezien met de oogen hartvormig, zwart met 2 driehoekige gele vlekjes in den nek. Oogen groot, donkerbruin.

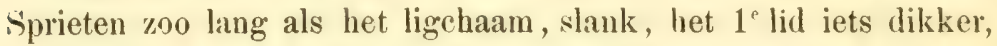
aan de binnenzijde bij de basis krom ingebogen, eerst rood,

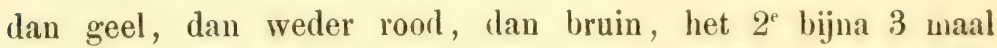
zoo lang, zwart met de uiterste basis en het tipje van de spits wit, lid 3 wit met zwarte basis, lid 4 wit. Zuiger geel met bruine spits, tot aan de achterheupen reikend. Halsschild iets langer dan van voren breed, aan de zijden ingebogen met vrịj scherpe achterhoeken, de voorhelft rood met een' witten voorzoom, de achterhelft wit of lichtgrijs. Schuldje vrij groot, de voorbelft bloedrood of oranje; de achterhelft fraai geel. Dekschilden doorschijnend, als hooruachtig, met een smal zwart lijntje op voor en achterrand; cuneus zeer langwerpig, helder. geel met bloedroode punt. Membraan bijna wit, met de aderen dikwijls fijn rood. Pooten zeer lang en slank, geel, de achterscheenen met gele stekeltjes; alleen de klaawtjes bruin.

Deze zeer fraaije soort, die overigens in Europa zeldzaam schijnt te wezen, werd op verschillende plaatsen in Nederland gevangen. Zie hier de opgaaf: bij Leeuvarden (Albarda), bij Arubem in Aug. (de Graaf), op Beekhuizen in Aug. (v. Voll.), bij Utrecht met eene verscheidenheid in Junij en Sept. (Six), bij Driebergen (v. Voll.), bij Wassenaar (v. Bemmelen en v. Voll.), bij Leyden en Heemstede (v. Voll.), bij Middelburg (Gerth v. Wijk).

24. Lygus histrionicus L.

Plaat 14, fig. 9.

Linn. S. N. V, p. 499, 89. - Fabr. S. Rh. 247, 31 (Agilis). - Fall. Hem. Suec. 1, p. 120. - Hahn, W. Ins. II, p. 98, pl. 60, f. 182. Wolff, Ic. Cim. p 153, tab. 15, f. 147. - Neyer, Schw. Kh. 1. 90, 
но. 75. - Flor, Rh. Livl. I, 1. 475. - Douglas and Scott, Brit. Hem. p $368, \mathrm{pl} .12$, f. 3.

Leugte 4 tot $1,6 \mathrm{~mm}$. - Smal, langwerpig, het borststuk eenigzins in den vorm van een halsje verdund, onbehaard, glanzig, zwart met bonte versiering. Kop van boven gezien breed en kort, aan de voorzijde rond uitstekend, zonder punt, van voren gezien driehoekig;, geheel glanzig zwart; het voorhoofd bol. Oogen niet zeer bol uitstekend, zwart. Sprieten zoo lang als het ligehaam, slank; lid 1 zoo lang als het halsschild, rood of oranje, aan de uiterste basis wit, staande op een zwart knopje; lid 2 meer dan 2 maal zoo lang, Haauwelijk dikker wordend naar de spits, zwart; lid 3 zoo lang als 1 doch haardun, zwart; lid 4 zeer kort, aan de spits wat platgedrukt en bruingeel. Zuiger geel met bruine spits, reikend tot aan de achterheupen. Borststuk met fijnen witten voorzoom, het halsachtige glanzig zwarte voorste deel horizontaal, het overige bol naar boven oploopend, geel of oranje met 2 groote zwarte vlekken aan den voorrand. Schildje vrij bol, helder geel met de eenig\%ins opgezette basis blinkend zwart. Dekschilden lang en smal, aan de basis donkerbruin, verder op rood, kaneelkleurig of geel, soms met eene witte of gele vlek op het corium, digt bij de basis, en eene donkere dwarsstreep tegen den cuneus aan; deze hoog- of lichtgeel met de uiterste punt zwart. Membraan donker met eene witte vlek onder den cuneus en een gedeelte der aderen geel. Buik bij de mannetjes zwart, bij de wijfjes zwart met gele vlekken. Pooten lang en slank, geel met de dijen roodachtig en het laatste lid der tarsen bruin.

Histrionicus is niet zeldzaam en werd gevangen van Mei tot in Augustus, op de duinen, voorts te Bennebroek, Heemstede, Driebergen, bij Renkum, Velp en Breda. Volgens de schrijvers komt deze wants voornamelijk op berken voor, volgens den heer Heylaerts op eiken. 
25. Lygus globulifer Fall.

Plaat 14 , fig. 10.

Fall. Hem. I, p. 121, 18. - Flor, Rh. Livl. I, p. 512. - Misschien ook, doch zecr onzeker Hahn, W. Ins. IH, 1.53, tab. 88, f. 271 (Alienus).

Lengte $3-3,5 \mathrm{~mm} .-$ Ook bij deze soort schijnt eenigermate tusschen kep en borststuk een halsje te bestaan, welke schijn alleen daaraan toe te schrịven is, dat de bolle oogen niet tegen den voorrand van het halsschild ansluiten. Langwerpig ovaal, niet glanzig behalve op kop en halsknobbels. Kop van boven gezien breed vierkant, sterk naar beneden gebogen, zoodat van voren beschouwd zelfs het achterhoofd te zien is, glanzig zwart, met 2 lichte vlekjes op den schedel tegen den rand der oogen. Deze sterk uitpuilend, dcnkerbruin. Sprieten kort en niet zeer slank, het $1^{\text {e }}$ lid zwart met de basis en een zeer smal bandje om de spits wit, de overigen zivart; bet $2^{e}$ zeer flaauw knodsrormig, iets langer dan de beide volgenden te zamen. Zuiger loogreel met bruine spits, tot de middelheupen reikend. Borststuk iets langer dan aan den voorrand breed, niet breed uit- maar naar achteren sterk oploopend, in drio deelen verdeeld; het eerste is de vrij dikke, licht gekleurde voorrand, het $2^{\text {e }}$ een schier geheel zwart gekleurde band, waarin zich zeer bol uitpuilend, glanzig en glad de gitzwarte halsknobbels verbeffen; het $3^{e}$ is zeer grof gekorreld, bol, grauwgeel en loopt tot den achterrand, die in het midden ingehogen is. Schildje even grof gekorreld en van dezelfde kleur. Dekschilden fijner gestippeld, iets lichter ran kleur, doorsehijnend; cuneus ongestippeld, overigens gelijk aan de dekschilden. Membraan licht met grauwgele aderen. Pooten matig lang, groenachtig geel, de dijen met zeer vele zwarte stippels in rijen, de basis der scheenen sums met een zwart vlekje aan den binnenkant; de stekeltjes grijs; uiteinde der scheenen en laatste lid der tarsen zwart.

In Mei en weder in Sept. en Oct aan te treffen; overwintert waarschijnlijk. Gevonden in zeker aantal voorwerpen bij Heemstede en bij den Haag, in cen eukel exemplaar ook bij Val- 
kenburg en an de Bildt (Utrecht). Het is deze soort, die in de eerste naamlijst als Alienus H. S. voorkomt.

\section{Lygus thoracicus Fall.}

Plaat 15, fig. 1.

Fallen, Hem. S. I, p. 111, 66. - Germar, Fauna Germ. 13, f. 19. Curtis, Brit. Ent. XV, 709 (Harpocera Burmeisteri). - Heyer, Schw. Rh. p. 98, pl. 5, f. 3 (₹ Curvipes), p. 102 , pl. 6, f. 5 (क Thoracicus). Douglas and Scott, Brit. Hem. p. 469, pl. 15, f. 3 .

Lengte 5-6 $\mathrm{mm}$. - In het mannelijke geslacht zeer gemakkelijk te herkennen aan den zonderlingen vorm van het $2^{\mathrm{c}}$ lid der sprieten (zie de afbeelding). Langwerpig ovaal, zeer kort en dun behaard, glanzig, licht- of donkerbruin. Kop bijna verticaal en toch van boven gezien breed driehoekig, zwart met eene lichtgele middenstreep en bij de wijfjes ook nog met twee gebogen dergelijke zijstrepen; de clypeus rood. Oogen uitpuilend, roodbruin of zwart. Sprieten bij o valgeel, harig; het $1^{\mathrm{e}}$ lid regt, een weinig dikker aan de spits, het $2^{\mathrm{e}}$ naar buiten omgebogen, aan de spits naar onder knobbelig verbreed en zeer harig; lid 3 krom naar buiten gebogen, tweemaal zoo lang als 2 , en lid 4 kort en dun, regt. Sprieten bij $q$ : lid 1 regt, onbehaard, bruin met fijne, witte spits, lid 2 fijn harig, regt, geel met bruine knobbeltjes bezet, slechts weinig dikker aan de bruine spits, lid 3 ietwat krom gebogen, bruin met een fijn wit bandje, niet ver van de basis, 4 als bij den man, doch bruin. Zuiger geel met zwarte spits, zeer kort, reikt naauwelijks tot aan de middenheupen. Borststuk sterk naar achteren oploopend en daar zeer bol, schier $1 \frac{1}{2}$ maal zoo lang als aan den voorrand breed, vrij grof gestippeld, aan den achterrand ingebogen, zwart of donker roodbruin met gele mididenstreep bij den man, bruingeel met 2 zwarte plekken die de halsknobbeltjes bedekken, en eene fijne gele middenstreep bij het 'wịfje. Schildje an de basis donkerbruin, naar de spits lichtbruin of rood, met gele middenstreep. Dekschilden nootkleurig, vrij doorschijnend, met eene donkere vlek aan het 
einde van het corium; cuneus donkerbruin met nootkleurige of vuilwitte basis. Membraan lichtgrijs met een donker vlekje an de spits en bruine vlekken om de bruine aderen. Onderzijde geel met roodachtigen buik en eene zivarte langsstreep op de borst. Pooten geel met roode dijen, de achterdijen bij den man donkerbruin; voorscheenen bij hem aan het eind krom naar beneden gebogen, achterscheenen bij beiden met 2 rijen zwarte stekeltjes voorzien, die uit ronde zwarte stipjes komen. Al de tarsenleedjes wit aan de basis, overigens bruin.

Deze fraaije soort was eenmaal bij Bennebroek en is sommige jaren bij den Haag in Mei gemeen. Bij Utrecht is zij zeldzamer volgens den heer Six. Van Medenbach de Rooij vond haar in 't laatst van Mei bij Arnhem. De mannetjes worden in aantal verre overtroffen door de wijfjes.

\section{Lygus rufipennis Fall.}

Fall. Hem. I, 1. 92, 31. - Herr.-Sch. W. Ins. VI, p. 50, pl. 197, fig. 610. - Flor, Rh. Livl. I, p. 489. - Douglas and Scott, Brit. Hem. p. 478, pl. 15, f. 8 .

Lengte 4,5 mm. - Zeer langwerpig van vorm, weinig glanzig, zeer fijn wit behaard, lichtgroen met hel schildje en de delischilden geelrood. Kop groot, van boven gezien driehoekig met de voorzijden rond gebogen; oogen zeer bol uitpuilend, grijs. Zniger lichtgroen, aan de spits bruin, tot voorbij de achterheupen op den buik reikend. Sprieten slank, langer dan $\frac{2}{3}$ van het lijf, lid 1 lichtgroen, 2 en 3 geel, 4 lichtgrijs. Borststuk kort en zeer breed, weinig oploopend naar achteren, lichtgroen. Schildje een gelijkbeenige driehoek, geelachtig rood. Dekschilden aan de basis van dezelfde klenr, naar het eind van het corium iets rooder. Membraan doorschijnend met een rooden gloed en fijne roode aderen. Pooten lichtgroen met roodachtige achtertarsen.

Van deze zeldzame soort ken ik slechts 2 inlandsche voorwerpen; het eene werd in Julij bij Zeist gevangen door den heer Mr. H. W. de Graat, het andere bij Velzen in Junij door Dr. E. Piaget. 


\section{Lygus rubricatus Fall.}

Fall. Hem. S. p. 100, 45. - Hahn, W. Ins. I, p 156, pl. 24, f. 80. Flor, Rh. Livl. I, p. 526.

Lengte 4-4,5 mm. - Zeer langwerpig, weinig glanzig, op de dekschilden zeer fijn zijdeachtig wit behaard, licht geelachtig rood. Kop van boven gezien breed driehoekig, van voren vijfhoekig met scheefstaande oogen, vrij glanzig, rood an de basis van den zuiger. Oogen sterk naar de zijden uitpuilend, bruinzwart. Sprieten iets korter dan het ligchaam, slank, lichtgeel, de beide laatste leedjes bruinachtig. Zuiger zeer lang, geel met donkere spits. Halsschild kort, voor vrij smal, achter zeer breed, kussenvormig gewelfd, fijn bestippeld. Schildje driehoekig klein, uiterst fijn bestippeld; de zijhoeken iets rooder. Dekschilden ietwat hoornachtig met den buitenraud iets rooder dan het midden; cuneus geler met de uiterste spits bloedrood. Membraan grijsachtig, iriserend, met een donker vlekje aan den buitenrand; de aderen wit. Pooten vrij lang en slank, lichtgeel met de dikkere achterdijen naar de spits bloedrood; de stekelljes iler achlerscheenen wit en het laatste lid der tarsen bruin.

Deze soort, niet te verwisselen met de roodgekleurde verscheidenheid van Variabilis Fall., die met zwarte stekeltjes aan de achterseheenen bezit, werd in Julij bij Noordwijk angetroffen lloor den heer de Graaf, bij Breda door den heer Heylaerts en meer dan eens bij Driebergen door den heer Six.

\section{Lygus flavomaculatus F. ${ }^{1}$ )}

Plaat 15, fig. 2.

Fabr. S. Rh. 247, 30. - De Geer, Mem. (Vert. v. Goeze) III, p. 194 (Flavoquadrimaculatus). - Burm. Handb. II, 267, 3.- Panz. D. Ins. 92,

1) Er bestaat voor mij geen twijfel of Boheman heeft zich vergist in bet duiden der soort door Fabricius en de Geer bedoeld. Van daar de verwarring die hij in 't leven geroepen heeft door dexe zelfde soort Flavonotatis te noemen en den naam Flavomaculatus toe te passen op eene schier eveneens gekleurde soort, die echter om haren dikken kop in het geslacht Globiceps Latr. past. Flor, Fieber en Douglas and 
16. - Wolff, Ic. Cim. p. 114, tab. 11, f. 108. - Hahn, W. Ins. III, p. 10, pl. 76, f. 235 (volgens Herr. Schaefter niet zuiver van gelijkenis). Flor, Rh. Livl. I, p. 467. - Douglas and Scott, Brit. Hem. p. 366 , 1). 12, f. 1 .

Lengte $5 \mathrm{~mm}$. - Langwerpig, tamelijk smal, niet zeer glanzig zwart. Kop van boven gezien breed driehoekig, ran voren gezien vijfhoekig, glanzig; oogen sterk uitpuilend, bruinzwart. Sprieten ter lengte van $\frac{3}{4}$ van het lijf, slank, aan de spits niet veel smaller dan aan het $2^{e}$ lid. Lid 1 langer dan de kop, roodgeel met zwarte basis en fijn zwart bandje aan de spits, 2 langer dan 3 met 4 te zamen, een weinig verdikt naar het einde, even als 3 en 4 zivart. Zuiger aan basis en spits zwart, in het midden bruinrood, reikend tot de midden. heupen. Halsschild iets langer dan aan den voorrand breed, met den achterrand ietwat concaaf, door eene plooi in twee deelen gedeeld; het $1^{\mathrm{e}}$ met evenwijdige zijranden, bezet met

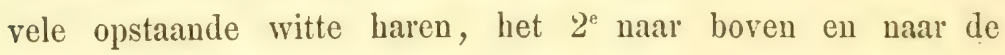
zijden verbreed, minder met haren bezet. Van boven bezien schijnen dus de zijranden hoekig ingebogen. Schildje driehoekig met eene dwarsgleuf achter den voorrand. Dekschilden zwart; eene langwerpig driehoekige gele vlek an de basis van het corium, door een zeer fijn zwart lijntje afgescheiden van den gelen zoom des buitenrands; cuneus zwart, doch met een geel dwarsbandje aan de basis en de uiterste spits weder geel. Membraan zeer donker met een wit dwarsvlekje tegen de spits van den cuneus en daaraan grenzende witte ader; het overige gedeelte der aderen zrvart. Pooten geel met de achterhelft der dijen roodachtig en soms met een bruinen veeg aan de binnenzijde daarvan in het midden; spits der achterscheenen en laatste lid der tarsen bruin.

In Mei en Junij is deze soort op sommige gronden niet

Scott zijn hem in zijne opvatting gevolgd Evenwel blijf ik bij het gevoelen dat Fabricius onze soort, als de algenneenste, bedoeld heeft en dat de Geer ook geeue andere kende; hịj zon toch anders wel den vreomden vorm van kop en borststuk vermeld hebben. Overigens heeft de nieuwe Flavomaculatus een gezwollen kop, eeu vooraan ingeregen onbehnard halsschild en past in het geslacht Globiceps Latreille, doch onze inlandsche Flavonotatus past er niet in, ofschoon Fieber hem er in plantst. 
zeldzaam. Zij werd gevonden in het Liesbosch bij Breda (Heylaerts), bij den Haag naar de zijde van Scheveningen (van der Wulp, van Hasselt, de Graaf, van Voll.), aan de Oude Plas bij Rotterdam (Piaget), op eiken bij Driebergen (Six) en bij Heemstede en Bennebroek (van Vollenhoven).

\section{Lygus melanocephahus L.}

Plaat 15, fig. 3.

Linn. S. N. 13 ed. 728, 88. - Fabr. S. Rh. 254, 8 (Pallens). - Fall. Hem. S. I, p. 89, 26 (Revestitus). - Hahn, W. Ins. I, p. 155, tab. 24, f. 79. - Flor, Rh. Livl. I, p. 621. - Douglas and Scott, Hem. Brit. p. 355, pl. 11 , fig. 7 .

Lengte $4 \mathrm{~mm}$. - Langwerpig, slank, kop en lijf zwart, halsschild, schildje en dekschilden bleek oranje, met korte witte haartjes bezet. Kop klein, van boven gezien driehoekig, glad en glanzig. Sprieten zoo lang of of zelfs iets langer $\delta$ dan het lijf, slank, zeer licht geel, aan de inplanting met een sinal zwart bandje. Oogen groot, hol, zcer donker bruin, bijna zwart. Zuiger geel met bruine spits en zwarte basis, een eind voorbij de achterheupen reikend. Halsschild niet langer dan aan den voorrand breed, aan den regt loopenden achterrand tweemaal breeder met scherpe achterhoeken. Schildje driehoekig met eene dwarsgleuf, die de basis afsnijdt. Dekschilden smal, de puntige cuneus met het corium ineensmeltend. Menbraan licht berookt met eene donkere vlek aan de buitenzijde en lichtgele aderen. Pooten lang, slank met tamelijk dikke dijen, geel met witte scheenen, die met lichtgrijze stekeltjes bezet zijn; tarsen wit met het laatste lid en de klaauwtjes bruin.

Deze soort is tamelijk gemeen op eiken te Driebergen (Six); zij werd bovendien in de duinen van Holland aangetroffen (van Hasselt, Piaget en Six), bij Arnhem in Junij (Snellen), bij Oosterbeek in dezelfde maand (v. Hasselt) en in het Valkenberg te Breda (Heylaerts). 


\section{Lygus aurantiacus Voll.}

Lengte $4,5 \mathrm{~mm}$. - In gedaante geheel gelijk aan den voorgaanden, doch verschillend in kleur en ietwat gtooter. Het geheele dier is oranje-achtig geel, alleen bet uiteinde van het achterlijf is eenigermate bruin. Van een zwart bandje aan de basis van het $1^{\mathrm{e}}$ lid der sprieten is zoo goed als niets te zien. De oogen alleen zijn zwart. De pooten zijn in allen opzigte gelijk aan die van den vorigen.

Het spreekt van zelf dat er twijfel rijst of het eenige mij bekende voorwerp, door mij zelven voor vele jaren in Holland gevangen (op de etiquette staat niet nader aangeduid waar en ik kan het mij nu niet meer herinneren), niet maar eene verscheidenheid van Melanocephalus zou wezen. Ik vind het zeer moeijelijk dit punt bij absentie van alle overgangen tusschen beiden te beslissen en oordeel het meer geraden voorloopig aan mijn insect de regten van zelfstandige soort toe te kenuen.

\section{Lygus Coryli L.}

Linn. S. N. 13 ed. 733, 121. - Fabr. S. Rh. 234, 50 (Lygaeus!) Fall. Hem. Suce. I, p. 90, 27. - Hahn, W.Ins. I, p. 26, tab. 4, f. 16. Flor, Rh. Livl. I, p. 620. - Douglas and Scott, Brit. Hem. p. 356.

Lengte $4 \mathrm{~mm}$. - Volkomen in gedaante overeenstemmend met Melanocephalus, zoo dat het zonderling is dat Linnaeus hem in eene andere rubriek en Fabricius zelfs tot een ander genus brengt. Het moge volstaan de verschillen aan te geven. De sprieten zijn iets korter, het eind van het $2^{\mathrm{e}}$ lid soms lichtbruin; de zuiger is merkelijk korter en reikt slechts tot aan de achterheupen; de dijen der pooten zijn na het midden tot aan de knie meer bruin- dan wel roodachtig; eindelijk borstschild, schildje en dekschilden zijn zwart met een olijfbruinen gloed en de membraan is donker bruingrauw met een wit vlekje onder den cuneus.

De heer van der Wulp trof deze soort in Junij in het llaagsche bosch aan, de heer Heylaerts in Aug. in het Valkenberg 
te Breda, de heer Gerth van Wijk op Walcheren en de beer van Medenbach de Rooij in het midden van Junij te Huissen Ik zelf heb haar nimmer gevangen, 't geen tot bewijs mag strekken voor hare zeldzaamheid.

\section{Lygus pilosus Hahn.}

Plaat 15 , fig. 4.

Halın, W. Ins. II, p. 96, tab. 59, f. 181. - Hlor, Rh. Livl. I, p. 564 .

Lengte $5 \mathrm{~mm}$. - De man zeer langwerpig (doch met kort borststuk), het wijfje waarschijnlijk meer gedrongen van statuur. Geheel glanzig zwart, harig. Kop van boven gezien veel breeder dan lang, bij frissche voorwerpen even als de thorax met grijze schubbetjes bedekt. Oogen sterk uitpuilend. Sprieten langer dan de helft van het lijf, met het 2 lid vrij dik, vooral naar het einde, bijna 3 maal langer dan het $\mathrm{l}^{\mathrm{e}}$; alle leedjes met fijne haartjes pluimachtig bezet. Borststuk slechts $1_{2}^{1}$ maal langer dan de kop en naar achteren niet sterk verbreed, met ietwat krullende haren bezet. Schildje minder behaard, doch de basis der deksehilden weder zeer harig. Deze, wanneer zij open staan, pekbruin doorschijnend; cuneus iets donkerder. Membraan zeer lang, slechts weinig lichter dan de dekschilden, doch iriserend. Pooten lang en slank, sterk behaard; de achterscheenen bijzonder lang. Een bij den Haag gevangen vıorwerp heeft bruine voorscheenen.

De synonymie van deze soort is onduidelijk. Volgens Fieber is Pilosus Hahn gelijk aan Mulabilis Fall., die wij boven blz. 94 behandeld hebben en welke veel minder langwerpig, veel meer ovaal van omtrek is. Ook de Engelschen schijnen van hetzeltde gevoelen te zijn als Fieber, doch Meyer Diir maakt er 2 soorten van.

Pilosus werd in het mannelijke geslacht door den heer Six bij Driebergen en ook in Augustus bij den Haag aangetroffen. Ook ik vond een paar voorwerpen van die sexe in ZuidHolland. 


\section{Lygus tibialis Hahn.}

Hahn, W. Ins. I, p. 128, tab. 20 , f. 66.

Lengte $5 \mathrm{~mm}$. - Tussehen deze en de voorgaande soort zie ik geen ander verschil in de mannelijke sexe dan dat de scheenen der 4 voorste pooten van de basis tot digt aan de spits roodbruin zijn en de achterseheenen in het midden ook een' rooden gloed vertoonen, waarbij nog gevoegd moet worden dat de kop en de thorax niet met schubbetjes bezet zijn, 't geen echter misschien aan de oudheid van het voorwerp toegeschreven moet worden. De wijfjes der beide soorten bieden mogelijk meer verschil aan, doch die sexe is mij nog onbekend gebleven in natura.

De heer Six ving het mannetje dezer soort bij Driebergen, ook de heer Piaget bezit inlandsche voorwerpen, in het duin aangetroffen.

\section{Lygus Thunbergii Fall.}

Plaat 15, fig. 5.

Fall. Hem. Suec. 105, 56. - Hahn, W. Ins. I, p. 144, pl. 22, f 73 (Lopus Hieracii). - Meyer, Rh. d. Schw. p. 81, 59. - Flor, Rh. Livl. I, p. 608. - Dougl. and Scott, Brit. Hem. p. 396, tab. 13 , f. 3.

Lengte 3-4 mm. - Langwerpig ovaal, vuil graurgeel of groenachtig bruin met uiterst fijne zwarte haartjes bezet. Kop tamelijk bol, sterk gebogen, van boven gezien zeer breed driehoekig; twee witte of geelachtige vlekken, de eene achter op den schedel, de andere voor op het aangezigt; ook do binnenzoom der oogen van die kleur. Oogen zeer bol en ver uitstekende, donkerbruin. Sprieten zon lang als de helft van het lijf, tamelijk dik, fijn behaard, groenachtig geel; lid 2 iets korter dan de beide volgenden te zamen genomen. Zuiger bruin, aan de basis groenachtig geel; hij reikt tot het $3^{\text {e }}$ segment van het abdomen. Borststuk tweemaal breeder dan lang, naar voren afhellend, even voor het midden met eene dwarsgleuf en daarvoor 2 zwart gekleurde builen; de voorrand en 
eene langsstreep over het midden groenachtig geel, zoo ook 2 ovale dwarsvlekjes op den achterrand. Schildje geel met zwarte basis. Dekschilden met 2 schuinloopende licht gekleurde soms witte strepen, die beiden digt bij den schouder aanvangen, een op het corium, de andere tegen den clavus aan; cunens graur, met de basis en uiterste spits witachtig. Membraan donker berookt met vuilwitte aderen en een dergelijk vlekje onder de spits van den cuneus. Pooten vrij kort, grauw met zwarte haartjes bekleed; scheenen met zwarte stekeltjes, laatste lid der tarsen bruin. Buik dikwijls met 5 zwarte dwarsstreepjes.

Deze soort is volgens den heer Six gemeen op blocmen van Hieracium pilosella bij Driebergen. Ook bij Breda werd zij aangetroffen door den heer Heylaerts. Op de duinen, waar het havikskruid zoo gemeen is, schijnt zij te ontbreken.

\section{Lygus Bohemanni Fall.}

Fall. Hem. Suec. I, p. 106, 58 (Bohemanni) et p. 107,60 (Ruficollis) Herr.-Sch. W. Ins. IV, p. 79, pl. 132, f. 408, 409 (Furcatus). - Flor, Rh. Livl I, p. 625.

Lengte ruim $3 \mathrm{~mm}$. - Van dezelfde gedaante als de vorige en daarop wel eenigzins gelijkend, zwart of roodbruiu. Kop van boven gezien breed driehoekig, tamelijk naar beneden gebogen, bij den man zwart met eene gele streep op het achterhoofd en twee langs den binnenrand der oogen, bij het wijfje geel met eene bruinroode vlek op het midden van het voorhoofd. Oogen bol en donkerbruin. Sprieten iets langer dan de helft van het lijf, bij o donkerbruin, bij o geelgrauw; het $1^{\text {e }}$ lid aan de spits wit. Zuiger bruinachtig geel met bruine spits, reikt tot de achterheupen. Halsschild van gedaante als bij den vorigen, bij den man zwart met lichte langsstreep, bij het wijfje geelachtig rood, lichter naar den voorrand. Schildje bij den man zwart, soms met 2 gele vlekjes aan de basis, bij het wijfje bruin met lichte langsstreep in het midden. Dekschilden aan de basis licht gekleurd, naar het einde donker gevlekt met lichtere langsstrepen, tamelijk verschillende bij de 
individuen. Cuneus witachtig met zwarte spits. Membraan berookt. Pooten grauw of vuilwit; bij den man alle dijen donkerbruin, bij het wijfje alleen de achterdijen bruin gevlekt. Buik bij of zwart, bij of roodbruinachtig geel.

Deze soort is niet zeldzaam in Junij en Julij in de duinstreken op Salix repens; zij werd bij Scheveningen door de heeren de Graaf en Six aangetroffen, bij Overveen door den heer Ritsema en bij Wassenaar door mij zelven. Ook ontdekte en ving haar de heer Heylaerts in de omstreken van Breda.

\section{Lygus rugicollis Fall.}

Fall. Hem. Suec. I, p. 79, 6. - Herr. Sch. W. Ins. III, p. 80 , pl. 98, f. 299. - Flor, Rh. Livl. I, p. 537.

Lengte 5 of $5,5 \mathrm{~mm}$. -- Zeer langwerpig, papegaaigroen, na den dood op kop, borststuk en den zoom der dekschilden geel, bijna zonder glans en onbehaard. Kop kort en breed, weinig vooruitstekend, met scherp afgesneden achterrand. Oogen tamelijk klein, grijs of zwartachtig. Sprieten ter lengte van van het ligchaam, slank, groenachtig geel; het $1^{e}$ lid somtijds zwart aan de basis, de laatsten naar het bruine trekkend. Zuiger lichtgroen, aan de spits zwart, reikend tot de middenheupen. Borststuk vrij breed en kort, aan den voorrand breeder dan de helft van den achterrand, weinig oploopend, met eene gegolfde gleuf voor het midden; het gedeelte daarvoor bultig en nog al glanzig, het gedeelte daarachter dof en in de dwarste fijn gestreept. Schildje met eene regte gleuf niet ver van de basis en daarachter ook fijn dwarsgestreept. Dekschilden en cunens groen; membraan ongekleurd met groene aderen en eene hoornvlek in de groote cel. Pooten lang en slank, groen of geel; het laatste lid der tarsen bruin.

Deze soort werd in Junij door Dr. Piaget bij Rotterdam (Jaffa) grevangen, vourts door den heer Kitsema den $2^{\text {den }}$ Junij op ter Schelling, in Junij in het Bloemendaalsche bosch en in Aug. bij Leyden, eindelijk door mij in Julij bij den Haag. 
38. Lygus angulalus Fall.

Plaat 15, fig. 6.

Fall. Hem. Suec. I, p. 80, 8. - Herr. Sch. W. Ins. III, p. 75, pl. 97, f. 292. - Flor, Rh. Livl. I, p. 477. - Douglas and Scott, Brit. Hem. p. 347 , pl. 11 , f. 4.

Lengte 4-5 mm. - Lang en smal, hoekig aan de schouders, weinig behaard, loog- of zeegroen (na den dood zijn dikwijls kop, schildje en pooten geel). Kop van boven gezien bijna vijfhoekig, met scherp vooruitstekende punt, bol, glanzig, zonder scherpen rand aan het achterhoofd. Oogen vrij groot en bol, grauw of grijs. Sprieten iets langer dan hel lijf, zeer slank; het $1^{\mathrm{e}}$ lid veel langer dan de kop, groenachtig geel, aan de basis zwart en met een zwart bandje voor de witte spits, an de binnenzijde met 2 of 3 zwarte borstelhaartjes; lid 2 zwart aan de basis, voorts grauwgeel, 3 desgelijks doch langzamerhand naar het bruine trekkend, 4 bruin. De groene zuiger reikt tot de achterheupen. Borststuk eenigzins klokvormig mel opgewipte zwarte achterhoelien. Schildje met eene dwarsgleuf voor het midden. Cuneus gelijk van kleur met de dekschilden. Membraan een weinig berookt, iriserend, de aderen lichtgroen; een hoornvlekje in de groote cel en een donker veegje onder de spits van den cuneus. Pooten slank, groen; een zwart vlekje aan de basis der achterscheenen, die met grijze stekeltjes bezet en aan de spits bruin zijn; achtertarsen donkerbruin.

Deze soort is vrij gemeen en in de meeste provinciën gevangen; zij wordt in de maanden Julij en Aug. aangetroffen. Een Friesch voorwerp, gevangen door Mr. H. Albarda in Aug. te Leeuwarden, heeft aan de onderzijde van het $1^{\text {e }}$ lid der sprieten een doorloopend zwart streepje en mist het zwart op de schouders, waardoor een overgang verkregen worlt tot Lygus striicornis Kirschbaum. 
39. Lygus contaminatus Fall.

Plaat 15, fig. 7.

Fall. Hem. Suec. I, p. 79, 5. - Hahn, W. Ins. I, p. 151, pl. 23, f. 76. - Meyer, Rh. d. Schw. p. 45, no 1. - Flor, Rh. Livl. I, p. 528. - Douglas and Scott, Brit. Hem. p. 461.

Lengte 5 of $5,5 \mathrm{~mm}$. - Langwerpig ovaal, niet zoo slank als de voorgaande, geelgroen of groengeel, uiterst fijn wit behaard. Kop bijna verticaal en dus van boven gezien naatwelijks driehoekig, weinig bol, glad en glanzig met scherpen achterrand. Oogen nitpuilend, eenigzins naar achter gebogen, grijs. Sprieten iets korter dan hel ligchaam, slank, bruinachtig geel; het laatste derde van lid 2 met 3 en 4 bruin. Borststuk vrij bol, niet zeer lang, maar naar achter sterk oploopend, sterk gestippeld met den achterrand naar buiten uitgebogen en bijna geen dwarsgleuf voor het midden. Schildje voorbij de helft eenigermate dwars gerimpeld. Deksebilden fijner gestippeld dan het borststuk met eene halfronde bruine vlek op hel midden van den achterrand van het corium; cuneus ongestippeld en geler. Membraan bruinachtig betint met gele aderen; eene donkere vlek binnen de cellen aan hare spits en twee anderen aan den buitenrand. Pooten groenachtig geel, de dijen aan de spits soms met bruine ringen; de achterscheenen met bruine stekeltjes; het laatste lid der tarsen zwart, even als de spits van den zuiger.

Flor noemt deze soort eene verscheidenheid van Limbatus Fallen, welke meening echter Fieber niet aanneemt. Limbafus is hier te lande nog niet aangetroffen.

Deze zeldzame soort werd in Junij bij Zeist door Mr. II. W. de Graaf gevangen, in de omstreken van Utrecht door Dr, van Ilasselt en den $24^{\text {sten }}$ Junij in de duinen door Dr. Piaget. De heer van der Wulp ving te Empe op 't cind van Julij een exemplaar bijna zonder bruine vlek en met hooggele pooten.

\section{Lygus pabulinus L.}

Linn. S. N. II, p. 727, 83. - Fabr. S. Rh. $254,5$. - Hahn, W. Ins. 
I, p. 148, t. 23, f. 74. - Meyer, Rh.Schw. p. 48, no 7 , tab. 1, f. 3.

Lengte 5,5 mm. - Langwerpig ovaal, bleekgroen (na den dood vuilgeel) met witte haartjes bezet, herkenbaar aan de zwarle larsen. Kop sterk neergebogen, niet zeer bol, van boven gezien breed driehoekig, zonder scherpen achterrand. Oogen op zijde gezien niervormig, zwart. Sprieten ietwat langer dan het ligchaam, slank, groen of groenachtig geel; het laatste derde deel van lid 2 met 3 en 4 bruin. Zniger groen met zwarte spits, tot de achterheupen reikend. Borststuk aan den achterrand bijna $1 \frac{1}{2}$ maal breeder dan de lengte, naar achteren oploopend, zeer bol, flauw bestippeld. Corium met de dekschilden van eene kleur; membraan berookt met groene aderen. Pooten groen met zivarte tarsen.

Deze soort werd eenmaal in menigte door den heer de Graaf in Julij op distels bij Katwijk gevonden; een enkel exemplaar vond de heer van der Wulp in Julij bij den Haag. Ook vond de heer Six haar bij Utrecht en de heer van Medenbach de Rooij bij Arnhem, eindelijk de heer Ritzema Bos op helmplanten op Ameland.

\section{Lyqus nassalus $\mathrm{F}$.}

Fabr. S. Rh. 236, 167. - Fall. Hem. Suec. I, p. 80, 7. - Ilahn, W. Ins. I, p. 149, pl. 23, f. 75 (Icterocephalus) et p. 153, pl. 24, f. $78 .-$ Flor, Rh. Livl. I, p. 618. - Kirschb Caps. p. 78. - Douglas and Scott, Brit. Hem. p. 337, pl. 11, f. 3.

Lengte 5, כ́ mm. - Zeer sterk gelijkend op de vorige soort, doch daarvan onderscheiden door de duidelijke witte beharing langs den rand der dekschilden en de lichtere kleur der tarsen. $\mathrm{Na}$ den dood zijn gewoonlijk de kop, de voorhelft van het borststuk en de zoom der dekschilden met de pooten stroogeel, welke deelen in het leven lichtgroen zijn. De achterrand van den kop is ietwat scherp en verheft zich als een zoompje. Oogen niet aan de binnenzijde ingebogen, zwart. Sprieten korter dan het ligehaam, bruinachtig geel, voorbij de helft 
bruin. Borststuk sterk wit behaard, gelijk mede het schildje en de dekschilden. Membraan naauwelijks berookt, met groene aderen. Pooten groen of geel; de scheenen met witte doorntjes; alleen het laatsle lid der tarsen bruin of zwart.

Bij Driebergen door den heer Six en op Walcheren door den heer Gerth van Wijk gevangen; zeldzaam.

\section{Lygus chlorizans Fall.}

Plaat 15 , fig. 8.

Fall. Hem. Suec. I, p. 82, 10. - Panz. Fn. Germ. 18, 21. - Hever, Rh. d. Schw. p. 76, tab. 4, f. 4. - Flor, Rh. Livl. I, p. 551.Douglas and Scott, Brit. Hem p. 383, pl. 12, f. 7.

Lengte $4 \mathrm{~mm}$. - Zeer langwerpig, plat van boven, herkenbaar aan het bijzonder liorle borststuk; groenachtig geel of lichtgroen, met uiterst fijne witte haartjes bekleed. Kop van boven gezien vijfhoekig, achter de naar voren gerigte grijze oogen nog eenigzins in den vorm van een dikken nek nitgezet. Sprieten zoo lang als het ligehaam, slank, geel; het $1^{\mathrm{e}}$ lid met een zwart streepje aan de onderzijde, het $2^{\circ}$ met smalle zwarte basis. Zuiger met zwarte spits, reikt voorbij de achterheupen. Borststuk korter dan het schildje, aan den achterrand ingebogen en naar achteren oploopend, met vrịj scherpe zijkanten. Sehildje groot, sterker gekleurd dan het borststuk, met eene dwarsplooi voor het midden. Dekschilden dun en doorschijnend met groote groene vlekken bezaaid; de buitenzijde en spits van het doorschijnende corium helder groen. Membraan wit, iriserend met eene groote groene vlek over het benedengedeelte der cellen. Pooten lang en dun, geel met gele stekeltjes.

Van deze zeldzame soort ving de heer Gerth van Wijk exemplaren bij Middelburg.

\section{Lygus flavosparsus Sahlb.}

Kirschb. Rh. Wiesb. 89, 120. - Flor, Rh. Livl. I, p. 582.

Lengte 2,7 mm. - Langwerpig, licht appelgroen met korte 
zwarte en witte haartjes bezet. Kop breed driehoekig met uitpuilende grijze oogen. Sprieten der lengte van het ligehaam, geel, het $1^{\mathrm{e}}$ en laatste lid bruinachtig. Borststuk 2 maal zoo breed als lang, naar achteren oploopend, met eene bogtige gleuf voor het midden; het gedeelte daarachter met witte vlekjes bezet. Senildje met eene dergelijke, doch regte greuf voor het midden. Dekschilden met deu cuneus, eveu als de thoraxhelft met witte vlekjes besprenkeld, die zeer dik wit behard zijn. Membraan doorschijnend met groene vlekken over de cellen. Pooten lang en slank met witte doorntjes; het laatste lid der tarsen bruin.

Van deze soort is mij een voorwerp bekend, door Dr. Piaget den $23^{\text {sen }}$ Junij 1869 in den tuin der Rotterdamsche Diergaarde gevangen. Volgens Flor leeft zij op Atriplex en Chenopodium.

\section{Lygus molliculus Fall.}

Plaat 15, fig. 9.

Fall. Hem. Suec. I, p. 82, 12. - Herr. Sch. W. Ins. IV, p. 32, pl. 191, f. 589. - Flor, Rh. Livl. I, p. 611 ?

Lengte bijna $\left.6 \mathrm{~mm} .{ }^{1}\right)$ - Langwerpig, grijsachtig groen met zwarte haartjes vrij dik bekleed. Kop klein, scherp driehoekig, glad, helder groen. Oogen sterk uitpuilend, grof van facetten, grijs. Sprieten over de helft van het ligehaam reikend, vrij grof, grauwgeel, naar de spits donkerder, het $2^{e}$ lid zeer kort doch dik behaard, aan de spits bruin. Zuiger groen met bruine punt, reikt tot de achterheupen. Borststuk vrij kort en aan den achterrand zeer breed, sterk oploopend en sterk behaard. Schildje met eene regte dwarsgleuf voor het midden, groen. Dekschilden grijzer van tint, met 2 lichtere langsstrepen, de voorrand van corium en cuneus fijn zwart; de beharing daar dikker. Membraan donker grauw met witte aderen en 2 lichte vlekjes, een in het midden, het andere van daar naar den

1) Flor geeft slechts $4 \mathrm{~mm}$. op, doch noemt ook de beharing wit, zoodat het twijfelachtig is of hij wel dezelfde soort beschreven heeit. 
buitenrand loopend. Onderzijde groen, schier onbehaard. Pooten grijsachtig groen, lang, met donkere tarsen en de achterhelft der achterdijen grauw.

De heer Six vond deze soort vrij gemeen op heideplanten bij Driebergen. Flor zegt dat zij op Tanacenum voorkomt, 't geen het vormoeden versterkt dat hij eene andere soort voor' zich had.

\section{Lygus Tanaceli Fall.}

Fall. Hem. Suec. I, p. 83, 13. - Germ. Faun. Germ. 16, f 15. - Herr. Sch. W. Ins. III, p. 85, pl. 101, f. 309. - Flor, Rh. Livl. I, p. 610.Douglas and Scott, Brit. Hem. p. 394.

Lengte $4 \mathrm{~mm}$. - Langwerpig, grasgroen of geel, met zwarte haartjes dun bezet. Kop vrij groot en breed, tamelijk bol, niet zeer gebogen, glad. Oogen bol, uitpuilend, grijs. Sprieten bijna zoo lang als het lijf, slank, graurgeel, naar het einde bruiner wordend, lid 2 onbehaard. Borststuk kort en breed, met den achterrand regt en eene dwarsgleuf voor het midden. Schildje met eene vrij diepe dergelijke dwarsgleuf en glad voorbij het midden. Dekschilden alleen aan de basis sterk behaard, verder de beharing bijna microscopisch; de cuneus steeds helder geel. Membraan donker gekleurd met sterke regenboogkleuren, naar de spits toe lichter, hare aderen geel. Pooten geel, met fijne zwarte hartjes en zwarte stekeltjes; het laatste lid der tarsen bruin of zwart.

De heer G. A. Six ving vele voorwerpen dezer soort, die bepaald geel waren en iets langer ùan $4 \mathrm{~mm}$., bij de Bildt op T'anacelum, ik ving een groen voorwerp, dat kleiner was, den $30^{\text {sten }}$ Augustus aan de Rhedersteeg. Zou dit laatste ook misschien tot eene andere soort behooren?

\section{Lygus decolor Fall.}

Plaat 16, fig. 1.

Fall. Hem. Suec. I, p. 123, 16. - Hahn, W. Ins. I, p. 10, pl. 1, f. 4 (?) - Meyer, Rh. d. Schw. p. 86, no 68. - Flor, Rh. Livl. I, p. 555. - Douglas and Scott, Brit. Hem. p. 393, pl. 13, f. 2. 
Lengte 3,5 mm. - Langwerpig, vuil grauwgeel en grijs, met zeer fijne zilverkleurige haartjes spaarzaam bekleed. Kop van boven gezien vijfhoekig, weinig neergebogen, tamelijk groot, onbehaard, grauwgeel met bolle grijze oogen. Sprieten iets korter dan het ligehaan, niet zeer slank, eer grof te noemen, grauwgeel met fijne zivarte bandjes aan het eind van lid 1 en 2. Borststuk kort en breed met afgeronde achterhoeken en den achterrand gegolfd; niet ver van den voorrand eene gegolfde divarsgleuf; het daarvoor liggend gedeelte eenigzins knobbelig en geel, het daarachter liggend gelijkmatig oploopend en grijs. Schildje groot, driehoekig, wet eene dwarsgleuf, die in het midden afgebroken is, voor het midden; het voorste deel iets geler dan het achterste. Dekschilden grijs met eene flaawe gele tint helderder aan den buitenrand, ietwat doorschijnend, vooral op den cuneus. Membraan doorschijnend grijs. Pooten grauwachtig geel, slank, met de uiterste spits der scheenen en de tarsen donkerbruin.

Twee voorwerpen dezer soort ving de heer Six in Julij te Driebergen; ook Dr. Piaget bemagtigde er eenige exemplaren van te Maarsbergen.

\section{Lygus albidus Hahn.}

Hahn, W. Ins. II, p. 77, tab. 53, f. 162. - Fieber, Hem. Eur. p. 318.

Lengte $5 \mathrm{~mm}$. - Langwerpig, vrij plat, schier onbehaard. Kop vrij lang vooruitstekend, weinig neergebogen, vaal met 2 bruine streepjes van de spits af langs den binnenrand der oogen tot in den nek loopend. Sprieten vaalwit, voorbij de helft bruin, langer dan de helft van het ligehaam, het $1^{\mathrm{c}}$ lid langer dan de kop. Oogen vrij klein, doch bol uitstekend, zwart. Zuiger met de 3 laatste leden bruin. Borststuk breed van voren, $1_{2}^{\frac{1}{2}}$ maal langer dan aldaar breed, weinig oploopend, vaal met twee naar achter uit elkander loopende smalle bruine strepen langs de zijden. Schildje groot en vaal. Dekschilden vaal met het middengedeelte min of meer bruin betint; cuneus wit, membraan doorschijnend met eene bruine randvlek. Pooten 
tamelijk dik, vaal. Onderzijde bij den man roodachtig op den buik, bruin op de borst, bij het wijfje geheel wit.

Deze soort ving de heer Heylaerts in Julij in het Liesbosch bij Breda, en ik in Julij aan den duinkant bij 's Gravenhage.

\section{Lygus nubilus H. Sch.}

Plaat 16, lig. 2.

Herr. Sch. in Panzer's Fauna Germ. 135, 9. - Meyer, Rhynch.d. Schw. p. 89, 73. - Douglas and Scott, Brit. Hem. p. 382, pl. 12 , f. 6.

Lengte 2,5 mm. - Langwerpig, smal, bijna onzigtbaar geel behaard, geelachtig groen, na den dood hooggeel. Kop vrij lang, aan den voorkant stomp toegerond, met de oogen eenigzins van den voorrand van het borststuk verwijderd; deze klein en weinig uitpuilend, bruin. Daarachter een klein en zeer fijn zwart streepje in den nek. Sprieten ver over de helft van het lijf heen strekkend, niet zeer slank, geel met het eerste lid zwart. Borststuk $1 \frac{1}{2}$ maal langer dan de kop, met den achterrand eenigzins ingebogen: eene gegolfde dwarsgleuf voor het midden. Schildje vrij groot, bijna zoo lang als het borststuk. Dekschilden van gelijke kleur met den cuneus; membraan doorschijnend met een gegolfd rookkleurig dwarsstreepje; de aderen bruinachtig. Pooten slank en geheel groengeel.

Deze zeldzame soort werd tot nog toe uitsluitend in de onstreken van Utrecht aangetroffen, door den heer Six.

\section{Lygus Ericetorum Fall.}

Fall. Hem. Suec. 1, 1. 105, 55. - Kirschb. Caps. p. 90. 122. - Flor, Rh. Livl. I, p. 587.

Lengte bijna $5 \mathrm{~mm}$. - Langwerpig ovaal, groen, na den dood geelachtig wordende, zwart hehaard. Kop niet zeer groot, sterk voorover gebogen, breed met vooruitstekenden clypeus. Oogen zeer bol, bruin. Sprieten veel langer dan de helft van het lijf, slank, geel, met de 2 laatste leden bruin, het $1^{\circ}$ korter dan de kop. Zuiger geel met bruine spits, voorbij de achter- 
heupen reikend. Borststuk kort en breed, met eene dwarsgleuf voor het midden. Schildje tamelijk klein. Dekschilden groen mel gelen cuneus en berookte membraan. Pooten lang en slank, bruinachtig groen, met fijne zwarte stekeltjes aan de dijen, wier uiteinden bruin zijn; tarsen bruingrauw met het laatste lid zwart.

Ik twijfel aan de zuiverheid der bestemming van deze soort, aangezien het eenige voorwerp waarnaar de beschrijving genomen is, niet in allen deele stemt met Flor's beschrijving, tamelijk goed met Fallen's korte beschrijving van Prasimus en grooter is niet alleen dan de opgave van Flor, maar ook dan voorwerpen van Ericelorum uit Zwitserland, bestemd door MeyerDiir. Het genoemde voorwerp, door den heer Six bij Utrecht gevangen, staat in de Eerste naamlijst vermeld onder den naam Prasinus Hahn (rerg. zijne figuur 233), doch deze opgaaf is in het vervolg dier lijst veranderd in Evicetorum Fall. (zie bl. 75) op grond van het verschil in kleur tusschen dekschilden en chneus. Op dienzelfden grond ben ik nu bij die meening gebleven, doch mag niet nalaten te doen opmerken dat:

10. de kop volgens Flor grooter moet zijn;

$2^{0}$. de sprieten langer;

3". het schildje met de basis door de dwarsgleuf niet ver van het midden afgescheiden, 't geen bij dit voorwerp niet het geval is, daar de dwarsgleuf bijna onder den achterrand van het borststuk staat.

\section{Lygus Paykullii ${ }^{1}$ ) Fall.}

Plaat 16 , fig. 3.

Fall. Hem. Suec. I, p. $106,57$. - Herr. Sch. Nomencl. p. 50 (Haculipennis). - Meyer, Rhynch. d. Schw. p. 81, tab. V, f. 1. - Dougl. and Scott, Brit. Hem. p. 388.

Lengte 3 nm. - Langwerpig, vrij glanzig, geélachtig groen, met zwarte haartjes bezet, die bij zeer gave, pas vervelde

1) Deze naam wordt door Fieber willekeurig veranderd in Paykuli en zal dus helaas! wel zoo verminkt tot de nakomelingschap overgaan. 
exemplaren in bundeltjes bijeen staan en dus vlekjes vormen. Kop zoo lang als breed, van boven gezien vijfhoekig, tamelijk spits toeloopend. Oogen vrij klein, doch sterk uitpuilend, grijs of zwart, bij gedroogde voorwerpen soms wit. Sprieten 3 der lengte van het lijf, niet zeer slank, groen, naar de spits toe bruinachtig; het einde van lid 1 en de basis van lid 2 donkerder, soms zwart. Borststuk aan den achterrand $1 \frac{1}{2}$ maal zoo breed als de lengte bedraagt, met een dwarsgleufje digt bij den voorrand, zeer weing naar achteren oploopend, in het midden groener dan aan de randen. Schildje tamelijk klein, met eene gebogen dwarsgleuf voor het midden en dikwijls met een donkergroen langsstreepje over het midden. Dekschilden lichter en glanziger dan het borststuk; cuneus met een lichteren naad afgescheiden van het corium, doch van dezelfde kleur. Membraan grijs of zwart met witte aderen en een wit dwarsbandje, dat zich naar den buitenrand toe in twee armen verdeelt, die an den buitenrand een langwerpig donker zwart vlekje omvatten. Pooten olijfgroen, niet behaard en zonder stekeltjes; de achterkniën en de spitsen der tarsen donkerder.

In Junij en Julij vindt men deze soort op de duinen; op de strandreep is zij op Scheveningen op bepaalde plekken zeer gemeen. Men vindt haar in aantal op Ononis repens.

\section{Lygus Caricis Fall.}

Plaat 16 , fig. 4 en $4 a$.

Foll. Hem. Suec. I, p. 123, 15. - Hahn, W. Ins. II, p. 100, tab.60, f. 184. - Flor, Rh. Livl. I, p. 623. - Meyer, Rh. d. Schw. p. 112, 105 \& (Ruffirons).

Lengte $4 \mathrm{~mm}$. - Langwerpig, onbehaard, glanzig zwart. Kop van boven gezien vijfhoekig, de spits aan den clypeus zeer weinig gebogen, zeer glanzig. Oogen zeer groot en bol uitpuilend, roodbruin. Sprieten bijna de lengte van het ligehaam halende, met de 2 eerste leedjes vrij grof, donker zwart; de beide volgende wit of geelachtig, slank, het $2^{e}$ lid meer dan 3 maal langer dan het eerste. Zuiger vaal met het $1^{\text {c }}$ lid dik 
en blinkend zwart. Borststuk van voren veel smaller dan de kop met de oogen, met ingebogen zijden naar achteren breed uitloopend en met den achterrand mede ingebogen, zoodat de zijhoeken vrij sterk uitpuilen, glanzig zwart. Schildje zwart met eene dwarsgleuf voor het midden. Dekschilden veel langer dan het achterlijf, bruin, aan de basis met zwarten zijrand, met den cuneus bleek aan het bovengedeelte en daaronder eene inkeeping in den rand voor de membraan. Deze donker berookt met eene posthoornvormige lichte vlek langs den buitenrand. Pooten lang en slank, bruingeelachtig met witte heupen en apophysen.

Zoodanig zijn de mannetjes, waarvan er eenigen in Nederland gevangen zijn; de wijfjes die zich tot heden aan onze onderzoekingen hebben weten te onttrekken, zijn volgens de beschrijvingen der aangehaalde schrijvers zeer verschillend. Haar kop is veel grooter en bruinrood van kleur, hare sprieten roodgeel of helder geel, haar borststuk aan den achterrand smaller en hare dekschilden half zoo lang, zonder clavus, cuneus en membraan, zwart; terwijl de vleugels ontbreken.

Mannetjes kwamen voor bij den Haag in Julij en October.

\section{Lygus pulicarius Fall.}

Fall. Hem. S. I, p. 113, 71. - Burm. Handb. II, 277. - Hahn, W. Ins I, p. 117, t. 18, f. 6z. - Flor, Rh. Livl. I, p. 600. - Meyer, Rh. d. Schw. p. 110, no. 102, - Douglas and Scott, Brit. Hem. p. 427, pl. 14, f. 1 .

Lengte 2,7 mm. - Langwerpig ovaal, zwart met matten glans, uiterst fijn witachtig behaard. Kop sterk neergebogen met scherpen schedelrand. Sprieten iets korter dan het lijf, slank; het $1^{\text {e }}$ lid zwart, het $2^{e}$ zwart met gele spits of bruinachtig geel, 3 en 4 geel. Borststuk tweemaal breeder dan lang, weinig bol en naauwelijks naar achteren oploopend, niet sterk versmald naar den voorrand; zonder gleuf in of voor het midden. Dekschilden goed ontwikkeld met bijna even zwarte membraan. Pooten met dikke achterdijen, kort, zwart of bruin 
aan heupen en dijen; kniën, scheenen en 2 voorste tarsenleedjes geel; de scheenen met zwarte vlekken in langsrijen en op ieder vlekje een zwart stekeltje. Laatste lid der tarsen zivart.

Deze soot, welke door middel van hare dikke achterdijen springen kan, werd door den heer G. A. Six in tamelijke hoeveelheid op heigrond bij de Bildt (Utrecht) aangetroffen; in 1875 en 77 vond hij ook voorwerpen bij den Haag.

\section{Lygus Arbustorum F.}

Plaat 16 , fig. 5 .

Fabr. S. R. 238, 174. - Fall. Hem. S. I, p. 104, 52. - Hahn, W. Ins. II, p. 138, pl. 72, f. 225. - Herr. Sch. id. op. III, p. 80, pl. 99, f. 300. - Flor, Rh Livl. I, p. 602. - Douglas and Scott, Brit. Hem. p. 402, pl. 13, f. 5 .

Lengte 3,5 mm. - Langwerpig, zeer donker bruin, retachtig glanzig, met fijne zwarte haartjes schraal bezet. Kop klein, scherp driehoekig, een weinig bol, bepaald zwart. Zuiger slank, bruin, tot de achterhenpen reikend. Sprieten 3 der lengte van het ligehaam lang, slank, het $1^{\mathrm{e}}$ en $2^{\mathrm{e}}$ lid zwart, de beide anderen vuilgeel. Oogen rond, zeer bol uitstekende, in 't leven rood, na den dood bruin. Borststuk kort, van voren vrij smal, naar achteren sterk verbreed, weinig oploopend met een gegolfd dwarsgleufje voor het midden, donker pekbruin. Schildje met eene regte dwarsgleuf voor het midden, donker pekbruin. Dekschilıen gewoonlijk lichter van tint, somwijlen met metaalglans; membraan bijna van dezelfde tint met een driehoekig zuiver wit vlekje onder de spits van den cuneus. Pooten lang en slank, doch met vrịj breede, zijdelings platte achterdijen, grauwgeel; de dijen zijn aan de basis of aan de bovenzijde \%wart; de scheenen hebben smalle zwarte bandjes of grove stippels, waaruit zwarte stekeltjes oprijzen; de tarsen zijn grauwgeel met zwarte einden, de achtertarsen soms geheel zwart.

Van deze soort werden voorwerpen gevangen door de heeren Piaget (Velzen in Junij) en Six (Driebergen). 


\section{Lygus brunnipennis Meyer.}

Meyer, Rh. d. Schw. p. 66, pl. 3, f. 3.

Lengte bijna $4 \mathrm{~mm}$. - Gedaante geheel gelijk aan Arbusto$\mathrm{rum}$, doch verschillend in kleur on niet dieu vetachtigen glans vertoonend, ook bepaaldelijk langer. De kop is zwart met een geel vlekje op den schedel. Sprieten en zuiger als bij Arbustorum. Borststuk, schildje en dekschilden geheel onbehaard, vuil bruin- of grauwgeel met den cuneus okergeel, de membraan donker met een driehoekig wit vlekje. De pooten veel lichter geel dan bij de vorige soort, doch met dezelfde zwarte versierselen.

De tijd zal leeren of $n^{0}$. 5:3 en 54 bijeen behooren; voor als nog scheid ik hen liever als twee zelfstandige soorten af, ofschoon mijn gevoelen meer rust op empirischen dan wel wetenschappelịken grond. Brumnipennis is overigens ten onzent veel algemeener dan de vorige soort, en werd gevangen aan de Plassen bij Rotterdam door den heer Snellen, te Jaffa bij Rotterdam door Dr. Piaget, bij Utrecht door den heer Six, bij Naaldwijk in Aug. door mij, en bij 's Gravenhage in Julij en Aug. door den heer van der Wulp en anderen. Het is deze soort, die in de Naamlijst vermeld staat als Betuleti Fall.

\section{Lygus variabilis Fall.}

Fall. Hem. S. 1, p. 98, 43. - Hahn, W. Ins. II, p. 137, tab. 72, f. 224. - Neyer, Rh. d. Schw. p. 68, no 38, tab. 3, f. 4. - Flor, $R h$. Livl. I, p. 592.

Lengte omstreeks $3 \mathrm{~mm}$. - Langwerpig, kop en thorax zwart met fijne goudgele haartjes bezet, die ligt afvallen, dekschilden licht of donkerbruin. Kop klein, driehoekig, sterk neergebogen, bol op het voorhoofd. Oogen bol, doch niet zeer groot, bruin. Sprieten langer dan de helft van het lijf, vuilwit, het $2^{e}$ lid zoo lang als 3 met 4 , soms an de onderzijde naar het midden bruinachtig. Zuiger haarfijn, geel met bruine spits, reikend tot de achterheupen. Borststuk bijna 
dubbel zoo breed als lang, sterk gebogen, nog al convex, glanzig onder de goudgele haartjes. Schildje met een flaauw dwarsgleufje achter den voorrand, zwart of donkerbruin. Dekschilden licht of donkerbruin, ook wel aan de basis licht, naar achter donker; de cuneus door een licht streepje van het corium afgescheiden, zijne randen met purperen tint; membraan donker met een driehoekig wit vlekje onder de spits van den cuneus, een ander in de groote cel en een gebogen veegje daaronder. Pooten vrij krachtig, met dikke achterdijen, doch de scheenen zeer slank; heupen zwart of bruin, dijen zwart, of bruin of rood, scheenen wit met zwarte spits en zwarte vlekjes, waaruit zwarte stekeltjes oprijzen. Tarsen wit met de uiterste spits en de klaauwtjes zwart.

Mr. H. W. de Graaf trof deze soort in Julij bij Zeist aan; ook werd zij door den beer Six niet zelden bij Driebergen op bloemen gevonden. Dr. Piaget zag haar in groote menigte aan de Oude plas bij Rotterdam, de heer Ritsema ving haar in Junij bij Velp en de heer Heylaerts noemt haar gemeen in het Valkenberg te Breda. Ik ving haar in Junij bij den Haag.

\section{Lygus varians Meyer (H. Sch.). \\ Plaat 16 , fig. 6 .}

Herr. Sch. W. Ins. VI, p. 45, pl. 195, f. 603 . - Meyer, Rh. $d$. Scliw. p. $69, \mathrm{n}^{0} 39$.

Lengte bijna $4 \mathrm{~mm}$. - Gelijk aan den vorigen, doch iets slanker en grooter, steeds geel gekleurd, soms zeer licht. De beharing is wit. Even als bij de vorige soort is er een licht dwarsbandje voor den cumeus, doch deze is bruinachtig oranje. De sprieten zijn wit, naar het einde eenigzins donker; de pooten zijn geel met witte scheenen en tarsen; de scheenen hebben de zwarte stekeltjes nit de zwarte stipjes ontspringende, even als bij Variabilis.

In hoeverre dit eene afzonderlijke en goede soort is, zullen latere onderzoekingen moeten uitmaken. Flor kende haar niet en Fieber neemt haar niet op in zijne Europeesche Hemiptera. 
Bij Utrecht gevonden door den heer Six; door mij in Junij bij den Haag.

57. Lygus viridulus Fall.

Fall. Hem. Suec. I, p. 105, 54. - Hahn, W. Ins. II, p. 136, pl. 72, f. 221. - Meyer, Rh. d. Schw. p. 77, no 51. - Flor, Rh. Livl. I, p. 595. - Douglas and Scott, Brit. Hem. p. 401.

Lengte bijna $3 \mathrm{~mm}$. - Langwerpig groen of groengeel (na den dood meestal geel), met de bovenzijde fijn en schraal zwart behaard. Kop klein, driehoekig, vrij sterk neergebogen en bul. Oogen rond, bol, grijs. Sprieten ter lengte van $\frac{2}{3}$ van het ligchaam, slank, lichtgroen of geel; het $1^{\text {e }}$ lid met 2 smalle zwarte bandjes, het $2^{e}$ aan basis en spits bruin. Borststuk kort en breed, vrij convex, glanzig met een zeer flaauw gegolfd dwarsgleufje. Schildje vrij groot, met eene regte dwarsgleuf voor de basis. Dekschilden lang; corium en cuneus als aaneengesmolten. Membraan rookkleurig, iriserend, met onduidelijke geelachtige aderen, een licht vlekje onder de spits van den cuneus en daaraan hangend een fijn donkergrijs streepje; nog een ander donker streepje langs de gebogen ader der groote cel. Pooten groen of geel, de dijen en scheenen met zwarte stippeltjes en de laatsten mede met zwarte stekeltjes; tarsen bruinachtig, het laatste lid zwart met lange klaauwtjes.

Door den heer Six bij Utrecht en ook door mij op het eind van Junij aldaar gevangen, door Dr. Piaget, in Julij bij Wassenaar, door den heer Six in Junij bij den Haag en door mij in Augustus bij Gennep. Ik vermoed dat deze soort is de Chrysanthemi van Herrich-Schaeffer's Nomenclator.

\section{Lygus roseus $\mathrm{F}$.}

Fabr. S. Rh. 238, 178. - Fall. Hem. Suce. I, p. 101, 47. - Herr. Sch. W. Ins. III, p. 71, t. 96, f. 287. - Flor, Rh. Livl. I, p. 591.

Lengte $3 \mathrm{~mm}$. - Langwerpig ovaal, geel of vaalrood, met witte haartjes bekleed. Kop tamelijk groot, driehoekig, sterk neergebogen. Oogen rond, zeer uitpuilend, donkerbruin of 
zwart. Sprieten slank, licht rood of geel, aan het eind bruin. Borststuk aan den achterrand tweemaal breeder dan lang, voor ook tamelijk l,reed, met een gegolfd dwarsgroefje voor het inidden. Schildje donkerder naar de spits dan aan de basis. Dekschilden mede naar achteren iets donkerder, met den cuneus van dezelfde kleur als het einde van het corium, doch aan zijne basis daarvan afgescheiden door een lichter dwarsbandje. Membraan eenigzins bewolkt, vooral donkerder in de cellen, daarentegen doorschijnend licht tegen den cuneus aan Pooten matig lang, doch stevig, de achterdijen plat en breed, de achterscheenen lang; zij zijn roodachtig geel van kleur, de dijen soms donkerder, de scheenen met rijen zwarte stippeitjes, waaruit zwarte stekeltjes voortkomen, de tarsen zwart aan de spits.

Deze soort en hare varieteit Signulipes (zie Herr. Seh. Nomenclator p. 49) werd door den heer Six bij Driebergen angetroflen in Junij; ook de heer Piaget vond eenige exemplaren.

\section{Lygus sallitans Fall.}

Plaat 16 , fig. 7.

Fall. Hem. Suec. p. 114, 72. - Burm. Handb. II, p. 278, no 5. (Saltians). - Flor, Rh. Livl. I, p. 603. - Douglas and Scott, Brit. Hem. p. 428. 1)

Lengte 2 mm. - Kort, breed en gedrongen van vorm, in het klein wel wat gelijkende op het wijfje van Mutabilis, met korte dekschilden zonder membraan. De kop is zeer breed driehoekig, stomp toegerond van voren, glanzig zwart, met een gebogen grauw dwarsbandje op het achterhoofd. Oogen groot, rond, uitpuilend, bruin. Sprieten ter lengte van het halve ligchaam, niet zeer slank (vooral zijn de beide laatste leedjes dik naar gelang van 't geen wij bij de laatste soorten zagen), zwart, aan het einde grijjsachtig. Zuiger bruin, reikend

(I De afbeelding bij Douglas and Scott durf ik niet aanhalen, daar zij op mijne exemplaren niet gelijkt. De beschrijving bij Fieber (Eur. Hem. p. 311) is in de allerhoogste mate onduidelijk. 
tot do achterhempen. Borststuk schier niet langer dan de kop en zelfs aan den achterrand niet breeder dan deze met de oogen, van voren naar achteren zeer weinig verbreed, zonder knobbeltjes of dwarsgleuf, glanzig zwart, doch naar achteren bestippeld. Schildje zwart met een' bruinen gloed, tamelijk klein. Dekschilden bij onze voorwerpen zeer kort, zonder af. gescheiden clavus, zonder membraan en eigenlijk ook zonder cuneus, doch aldaar naar beneden gebogen; hun achterrand is rond. Zij zijn in het midden bruinachtig zwart, met een bruinen gloed, aan de basis breed, aan den buitenrand smal lichtgrijs; ter plaatse waar men de cuneus veriacht, staat in dit grijs een rond zwart vlekje. Achterlijf glanzig zwart. Pooten met zeer dikke en breede achterdijen, tot aan de knie bruinzwart, verder vuil bruinachtig geel, de scheenen met zwarte stekeltjes, de tarsen met het laatste lid en de klaauwtjes zwart.

Van deze merkwaardige soort ving de heer C. Ritsema Cz. op het eiland Vlieland den $31^{\text {sten }}$ Mei 1873 drie exemplaren op zandgrond. Gelijk de naam aanduidt en de dikke achterdijen doen vermoeden, maken deze dieren kleine sprongretjes, als zij verontrust worden.

\section{Gen. 14. Dicrphus Fieb.}

I)it geslacht is voornamelijk gekenmerkt door de lengte van den kop achter de ougen. De kop is sterk gebogen, hijna hoekig, zoodat het aangezigt verticaal staat en de schedel horizontaal; van boven gezien is het gedeelte achter de oogen, de hals als ik het zoo noemen mag, langer dan het voorste gedeelte. De sprieten zijn niet bijzonder lang, doch slank, het $1^{e}$ lid korter dan de kop, het tweede $2 \frac{1}{2}$ maal langer dan liet eerste. Het borststuk is vrij lang en smal en wordt door eene groef in twee deelen verdeeld, waarvan het eerste 
twee kleine knobbeltjes draagt, waarvoor nog een smal ringetje gezien wordt. De dekschilden zeer lang en vliezig met lange membraan; zij zijn echter niet altijd volkomen ontwikkeld. Achterlijf vrij lang en slank. Pooten zeer lang en mager, zelfs aan de achterdijen.

De naam van dit genus, beteekenende dubbel bogchel, is al zeer zonderling gekozen en weinig eigenaardig, want men moet van eene goede loupe voorzien zijn om iets van de twee knobbeltjes, die met de bogehels bedoeld worden, te kunnen waarnemen.

Er zijn slechts 2 soorten bekend, die gemakkelijk van elkander onderscheiden worden, door het kenmerk dat bij de eene (Errans) de cuneus aan zijne basis en spits drie zwarte vlekjes vertoont, bij de andere (Pallidus) niet.

\section{Dic. errans Wolff.}

Plaat 16 , fig. 8.

Wolff, lc. Cim. p. 161, tab. 16, f.155. - Fall. Hem. Suec. I, 125, 19 (Collaris). - Hahn, W. Ins. Il, p. 121, tab. 66, fig. 203. - Flor, Rh. Livl. I, p. 483. - Douglas and Scott, Brit. Hem. p. 379, tab. 12, f. 4.

Lengte $5 \mathrm{~mm}$. - Lang, gerekt, zeer spaarzaam behaard, zwart aan kop en onderzijde, grijs of lichtgranw aan de bovenzijde. Kopl smal, doch tamelijk lang, glanzig zwart met 2 witte strepen langs de oogen, of wel grauw met diezelfde witte strepen en voorts het naar beneden gebogen aangezigt, een V-vormig teeken tusschen de oogen en twee langsstrepen in de zijden van den hals zwart. Oogen bol nitstaande, naar beneden eivormig verlengd, donkerbruin. Zuiger schier niet tegen de keel en borst aangebogen, zeer licht grauw, tot voorbij de achterheupen reikend. Sprieten ${ }_{4}^{3}$ der lengte van het lijf bedragend, slank, uiterst fijn behaard; het $1^{\mathrm{c}}$ lid veel korter dan de kop, bruin met zwarte basis en witte spits; $2^{\mathrm{e}}$ lid aan basis

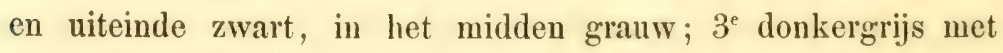
witte basis, 4 grijis. Bịj sommige voorwerpen zijn de sprieten in het geheel donkerder. Borststuk van vorm als in de be- 
schrijving van het genus is opgegeven, doch met den achterrand sterk naar voren ingehogen, onder glanzig zwart, boven geheel grauw of wel zwart met eene grauwgele langsstreep in het midden. Schildje donkergrijs of lichtgrauw met eene regte dwarsgleuf even voor het midden. Dekschilden doorschijnend, vliezig met den clavus minder doorschijnend, grauw; het corium met rijen van licht- of donkerbruine stipjes, waaruit korte haartjes ontspringen, aan het einde tegen den cuneus aan een donkerbruin, bijna zwart vlekje en een dergelijk krom streepje. Cuneus doorschijnend, vliezig met de uiterste spits zwart. Membraan iriserend, zeer weinig berookt, met een donkerder vlekje onder de cellen, wier aderen vrij dik en bruin zijn. Vlengels bij mijne exemplaren volgroeid (Flor zegt: rudimentair). Achterlijf boven en beneden zwart, alleen aan de spits grauwachtig. Pooten uit den grauwen wit, de dijen bezaaid met zwarte stipjes, de scheenen harig en bovendien bezet met eenige weinige zwarte stekeltjes; het laatste lid der tarsen bruin en de lange klaauwtjes zwart.

De heer Piaget ving eenige exemplaren in Junij bij Velzen; ik ving de soort in September en October bij den Haag.

\section{Dic. pallidus H. Sch.}

Plaat 16 , fig. 9 ठ en 10 ㅇ. 1)

Herr. Scl. W. Ins. III, p. 51, tab. 88, f. 269. - Meyer, Rh.d. Schw. p. $84, n^{\circ} 64$. - Douglas and Scott, Brit. Hem. p. 380.

Lengte 3,5-5 mm. - Het mannetje is in vorm en gedaante geheel gelijk aan den vorigen, doch verschilt zeer in kleur; het wijfje heeft niet-ontwikkelde dekschilden en geene vleugels.

Man gelijk aan den vorigen met dit versehil. Het ligehaam is boven en onder licht grauwachtig geel. Geen wit op den kop langs de oogen; op het voorhoofd eene wigvormige bruine

1) Bij de figuur van het vrouwelijke voorwerp ontbreekt de aanduiding der lengtc, even als ook bij figuur 7 het geval is. Men zij zoo goed deze onachtzaamheid te verschoonen. 
vlek en twee zwarte in de zijden van den nek. Sprieten licht gekleurd, het $1^{e}$ lid met een zeer breed rood bandje. Geen zwart aan het borststuk, alleen in de zijden een paar bruine vlekjes. Schildje ros. Dekschilden geheel rliezig zonder bruine of zwarte stippen, vlekken of streepjes; membraan met grauwe aderen. Pooten als bij den voorgaanden.

Wijfje kortei, zwakker van bouw en meer groenachtig van kleur. De kop met sprieten, oogen en zuiger als bij den man. Het borststuk is an het achtergedeelte meer naar boven gebogen, min of meer gebogeheld, zeer glanzig, aan den achterrand groen. Schildje groen. Dekschilden kort, het achterlijf naauwelijks bedekkend, alleen met aanduiding van cuneus en membraan; zij hebben geene stippen, noch vlekken, maar vele naar achter gebogen grijze haartjes. Achterlijf groen, met de spits en de scheeden der genitaliëu bruingeel. Pooten iets groener dan bij den man, de stipjes op de dijen onduidelijk; de achterscheenen schijnen mij toe nog langer te zijn dan bij de andere sexe.

In Junij en Julij zijn voorwerpen van beiderlei kunne op zandgronden bij Driebergen en 's Gravenhage gevangen doo: den heer G. A. Six en door mij. Ook wurd een ex. met verkorte dekschilden, dus waarschijnlijk een wijfje, door wijlen Dr. J. Wttewaall in Julij bij Voorst aangetroffen. 


\title{
ZESDE FAMILIE. -- ANTHOCORIDEN.
}

\author{
ANTHOCORIDEA.
}

De Hollandsche vertaling van den Griekschen naam dezer familie levert ons het woord Bloemenwants, doch deze komt mij voor ten opzigte der Anthocoriden vrij wat minder gepast en bruikbaar te zijn dan voor de Capsinen, wier ware plaats van oponthoud bloemen zijn. Ik stel dus voor den naam onveranderd te laten, even als wij zulks voor de Coreoden gedaan hebben.

Onze familie der Anthocoriden is zamengesteld uit die, welke Fieber noemt: Anthocoridae, Acanthiadae en Micropliysa, en komt derhalve overeen met de gelijknamige van Flor en die van Amyot et Serville met bijvoeging van het geslacht Acanthia. Dit laatste kan men rekenen dat ons, ten spijt van de overgroote menigte der voorwerpen, die in Europa roorkomen, nog onvoldoende bekend is, omdat bij allen de hemelytra en vleugels onontwikkeld blijven, ten gevolge waarvan het zeer moeijelijk is te bepalen of geheel ontwikkelde individuen ook ocellen zouden bezitten.

In den regel zijn de wantsen dezer zesde familie kleine en teedere dieren, en schijnbaar op een' lagen trap van ontwikkeling staande, daar de vlengels en dekschilden dikwijls half ontwikkeld zijn. De kop is tamelijk lang, regt vouruit gestoken en vertoont meestal tusschen de oogen een stomp, snuitachtig uitsteeksel, dat zoo lang is als, of langer dan het eerste lid der sprieten. Dikwijls schijnt de kop op een tamelijk lang halsje te staan. De oogen zijn klein, aan de zijden van den kop geplaatst; de ocellen zijn bij goed ontwikkelde voorwerpen aanwezig, doch zeer klein; zij staan achter de oogen op den schedel en zijn van elkander meestal verder verwijderd, dan 
elk hijoog afzonderlijk van het naastbij zijnde zamengestelde oog. De sprieten staan aan de zijden van den kop op een klein wratje voor de oogen, zijn nimmer langer dan het ligehaam en hebben vier leedjes, waarvan het tweede het langste is en de beide laatsten gewoonlijk niet dunner zijn dan dit. De zuiger heeft drie leedjes (bij Micropliysa duidelijk vier), waarvan het tweede het langste is. Bij de ware Anthocoriden is hij lang, regt naar achteren uitgestoken en reikt tot aan de achterheupen, doch bij Microphysa is hij, ten minste bij de wijfjes gebogen en gekromd, even als bij de Reduvien; bij Acanthia ziet men een spoor van eene gleuf aan de keel, waarin een gedeelte van den zuiger zou kunnen geborgen worden. De prothorax is aan de voorzijde niet veel breeder dan de kop, doch loopt naar achteren breeder uit en heeft gewoonlijk op den rug nog eene dwarsinsnijding in het midden. Het schildje is driehoekig, niet langer dan de kop. De dekschilden bestaan, wanneer zij geheel ontwikkeld zijn, 't geen dikwijls het geval niet is, uit corium, clavus, cuneus en membraan; wel heeft de al te scherp onderscheidene Fieber, die ook de wetenschap met een verbazend groot aantal genera heeft bemoeijelijkt, ons medegedeeld dat de cuneus bij deze familie slechts schijnbaar bestond en dat in de dekschilden der Anthocoriden een zeer bijzonder stuk, door hem Embolium genoemd 1), aanwezig is, doch microscopisch onderzoek heeft mij geleerd dat de vleugels bij Anthocoris volkomen gevormd zijn als bij Capsus, met uitzondering van de cellen in de membraan en dat het zoogenaamde tusschenzetsel of embolium niets anders is dan de costa, die hier wat dikker is dan bij de Phytocoriden. In de nembraan zijn vier afzonderlijke plooijen, die men wel eens voor aderen kan aanzien of er is aan de basis in het midden eene soort van kleine, weinig scherp begrensde cel aanwezig, van welke twee adcren naar de rigting van den buicenrand loopen.

Het achterlijf heeft bij het mannetje zeven ringen, bij het

1) "Halbdecken mit Eimbolium, hiedurch scheinbar ein Cuneus gebildet. "Dr. F. X. Hieber, Die europäischen Hemiptera, Heteroptera p. 24. 
wijfje zes met eene nitrekbare legbuis. De pooten zijn meest slank en dun, doch ook wel korter en dik; de dijen van het voorste paar zijn niet dikker dan die der beide achterste paren, met uitzondering van een geslacht. De tarsen hebben dirie, doch bij Microphysa slechts twee leedjes.

In strijd met de beteekenis van den naam Anthocoriden treft men de leden dezer wantsenfamilie zelden op bloemen aan, maar daarentegen in opgerolde en verdorde bladeren, op sommige vruchten, tegen boomstammen en onder schors, in mos en verdroogde zaadhulsen, de welbekende weegluis in duiventillen en menschelijke woningen. Allen schijnen van vruchtensappen of dierlijke vochten te leven, doch langen tijd zonder nadeel voedsel te kunnen ontbeeren; Microphysa en hare verwanten werden wel in mierennesten aangetroffen.

Analytische tabel der ges'achten

1 (14). Voorrand van het borststuk niet half cirkelvormig ingesneden.

2 (3). Zuiger gebogen en los hangend, van 4 leedjes.

Gen. 7. Migropuysa Westw.

3 (2). Zuiger regt, onder naar de borst reikend, van 3 leedjes.

4 (7). Schijnbaar een halsje tusschen kop. en borststuk.

5 (6). Zuiger tot aan het laatste paar pooten reikend.

Gen. 1. Temostetnus Fieb.

6 (5). Zuiger tot even over de voorste heupen reikend.

Gen. 2. Anthoconis Fall.

7 (4). Geen halsje tussehen kop- en borststuk.

8 (9). De beide latste leden der sprieten dun- en harvormig. Gen. 6. Lyctocoris Hahn.

9 (8). De beide laatste leden der sprieten weinig dunner dan de beide vorigen.

10 (13). Voorste dijen gezwollen, het eind der voorste selueenen verdikt. 
11 (12). Ligehaam tamelijk breed; zuiger veel langer dan de kop. Gen. 3. Piezostetius Fieb.

12 (11). Ligehaam driemaal langer dan breed; zuiger naauwelijks langer dan de kop.

Gen. 5. Xrlocomis L. Duf.

13 (10). Alle pooten ongeveer even dik.

Gen. 4. Triphlers Fieb.

14 (1). Voorrand van het borststuk half cirkelvormig ingesneden.

Gen. 8. Agantula F.

Gen. 1. Temiostetaus Fieb.

Dit geslacht geeft geheel de uiterlijke gedaante van Au/hocoris terug, zoodat wij daaruaar verwijzen; het verschilt door den langeren zuiger, die tot aan het midden van den metathorax reikt. Het eerste lid van dien zuiger is ongeveer zoo lang als een derde deel van het tweede. De prothorax is aan den achterrand tweemaal zoo breed, als zijne lengte bedraagt. Het $4^{e}$ lid der sprieten is een weinig korter dan het derde.

Temnost. pusillus H. S.

Plaat 8 , fig. 1.

Herr. Sch. Nomencl. p. 60. - Idem, I'ans. Ins. IX, fig. 977. Fieber, Eur. Hemint. 1. 136. -- Douglas and Scott, Brit. Hem p. 493.

Lengte 2,5 mm. - Zwart met zwarte sprieten. De prothorax aan de achterbelft met fijne dwarsrimpeltjes. De dekschilden bruin met zwarten cuneus en rookkleurige membraan; even voorbij de inplanting cen smal wit dwarsvlekje, drie rondachtige witte vlekjes in een driehoek op de membraan. Ilenpen 
en dijen donkerbruin, selıeenen lichtbruin, iets donkerder aan de beide einden, tarsen van kleur als de spits der scheenen.

Slechts vier inlandsche voorwerpen zijn mij bekend, het eene gevangen door den heer Six bij Utrecht, het andere door mij in de maand Junij bij Leyden, voorts een van Breda (Heylaerts) en een uit de omstreken van Arnhem (v. Voll.)

Gen. 2. Axtrioconis Fall.

Het ligchaam is langwerpig, naar voren toegespitst, naar achteren afgerond. De kop is viij groot met uitpuilende oogen en een kegelvormig nitsteeksel tusschen de sprieten, dat zoo lang is of iets langer dan hun eerste lid. Even achter, doch ook min of meer tusschen de oogen staan de kleine, doch wel te onderscheiden ocellen. De zuiger reikt slechts tot tegen de middelborst aan en niet er over heen; zijn eerste lid is zeer kort. De sprieten zijn draadvornig en nimmer langer dan de helft van het ligchaam; de leedjes zijn ongeveer even dik, het tweede is aan de basis dunner dan aan het eind. Het $1^{\text {e }}$ lid der sprieten reikt tot de spits van den kop; bet $2^{\circ}$ is dubbel zoo lang, 3 iets korter dan 2, en 4 gelijk aan 3. De prothorax vertoont eerst een soort van halsje, zet dan plotseling uit en is aan den achterrand meer dan tweemaal breeder dan aan den voorrand; hij loopt naar achteren ietwat op en is aan den achterrand sterk ingebogen; de voorrandshoeken zijn afgerond, daarentegen zijn die aan den achterrand zeer scherp; de oppervlakte is bijna altijd in dwarse rigting gestreept, doch uiterst fijn. Het schillje is breed driehoekig, door eene dwars. lijn in twee deelen verdeeld, warran het voorste bol, het achterste plat is. De platte dekschilden reiken tot ver over het achterlijf, de membraan is bijzonder lang. De pooten zijn slank en vertooneu niets bijzonders, de dijen zijn iets dikker dan de scheenen en nagenoeg allen even gezet. 
1. Anthocoris Nemorum L.

Plaat 8 , fig. 2.

Limn. Fauna Suec. 953. - Fabr. Syst. Rh. 116, 17 (Salda sylvestris). - Fall. Hemipt. Suec. 66, 1. - Wolli, Ic. Cim. p. IX, lig. 8\%. - Burm. Handb. II, p. 288. - IIahn, W. Ins. I, pl. 17, fig. 56. - Amyot et Serv. Hemipt. p. 263. - Flor, Rh. Livl. I, p. 651. - Douglas and Scott, Brit. Hem. p. 495, pl. 16 , fig. 6 .

Lengte $3-4 \mathrm{~mm}$. - Glanzig zwart met microseopische witte haartjes dun bekleed. Oogen en zuiger bruinachtig zwart. Sprieten iets korter dan de halve lengte van het ligchaan, met het $1^{\text {e }}$ lid zwart, het $2^{\text {e }}$ peenrood met zwarte spits, het $3^{\mathrm{e}}$ half

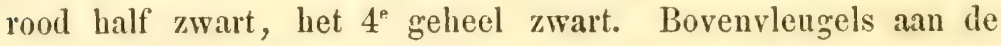
basis en den clavus, mitsgaders het cind van het corium en den cuneus geelbruin, het midden van bet corium vuilwit, eene vlek, die bet eind van den clavus bedekt, zwart, twee vlekken aan het eind van het corium en de spits van den cuneus zwart; de membraan is wit, doch de tip is zwart en deze laatste kleur zet zich op de helft der lengte van de membraan tot eene tweede grijze vlek uit. In de membraan zijn somwijlen 2, somwijlen 3 aderen te herkennen. Pooten roodgeel, de achterdijen hebben dikwijls een bruin bandje voor de spits.

Deze soort is zeer gemeen in verschillende provincien en wordt dikwijls reeds vroegtijdig in het voorjaar gezien; z:j schijnt onder boomschors en planten te overwinteren en wordt mede in versehrompelde bladeren en drooge zaadhulzen aange. troften. In kleur verschillen de individuen sterk van elkander en het komt mij roor dat Anth. pralensis F., die door Fabricius, Hahn en Fieber voor eene bijzondere soort wordt gehouden, slechts cene varieteit van deze is; het cenige soortkenmerk toch zou - behalve de kleur - dit zijn, dat bij P'ralensis het schildje wat korter is dan bij Nemorum.

\section{Anth. nemoralis F.}

P'aat 8 , lig. 3.

Fabr. Syst. Rh. 116, 15 et 239, 181 (Lygnens austriacus). - Fall. 
Hem. Suec. 67, 2. - Iahn, Wans. Ins. I, p. 108, iab. 17, fig. 58. Burm. Handb. II, p. 289, 2. - Flor, Rh. Livl. I, p. 650, 4. - Douglus and Scott, Hem. Brit. p. 496.

Lengte $3-3,5 \mathrm{~mm}$. - Van de vorige soort onderseheidt zich deze doordien zij in den regel icts kleiner is, door korter en gezetter sprieten en door eene andere punctering van het borststuk; dit latste kenmerk is echter naar mijne bevinding nict standrastig, zoodat ik er volkomen vrede mede zou hebben, indien de soort als verscheidenheid bij de vorige werd angesloten.

Uit den bruinen zwart, met microscopische haartjes. De sprieten korter dan de helft, ja niet meer dan $\frac{1}{3}$ van het ligehaam, zwart met roodgele basis van het tweede lid, bij enkele individuen geheel zwart. Borststuk op de achterhelft meer gestippeld, dan wel met dwarsstreepjes gerimpeld, zwart. Schildje als bij Nemorum. Dekschilden bruin of donkerbruin met een donkerder vlek, die het eind van den clavus en een gedcelte van het corium bedekt; de spits van den driehoek, gevormd door de anneengesloten clavi der beide vleugels is gewoonlijk lichtbruin of geel; de wigge is donkerbruin met lichteren buitenrand. De membraan is aan de basis doorschijnend wit tot voorbij de helft, daarna donkergrijs; op het witte gedeclte staan 2 of $3 \mathrm{~min}$ of meer zamenhangende langsstreepjes, grijs of zwart van kleur. De pooten zijn geelrood met een bruin tintje; aan de bovenzijde zijn de dijen altijd bruin, soms de pooten geheel en al.

Het is angenomen dat de beschrijvingen van Fabricius deze soort bedoelen; waarschijnlijk bleek dit uit zijne nagelaten verzameling; anderzins zou men mocite hebben om het van Nemoralis 116, 15 te gelooven. Voor luet onderscheid tusschen beide Fabricische soorten zie men Fieber na, dic Europacischen Ilemiptera, p. 13 .

Onuitgekleurde, pas vervelde exemplaren zijn fraai rood, in plaats van zwart.

De soort is weinig minder gemeen dan de voorgaande. Zij werd gevangen: bij Leyden door de Graaf, Herklots, Ritsema 
en mij zelven; bij Noordwijk door Ritsema; bij Heemstede door mij; bij Utrecht door van Hasselt en Six, bij Driebergen door Six; bij Arnhem door van Medenbach de Rooij; bij Beek door Six. De tijd van voorkomen was van Mei tot September, doch waarschijnlijk overwinteren de individuen en zijn dus van Scptember tot Mei ook wel op te sporen of reeds werkelijk gevangen, zonder dat daarvan aanteekening gehouden is.

\section{Anth. Limbatus Fieb.}

Plaat 8 , fig. 4 .

Fieber in Weilenweber's Beiträge, p. 110, 13, 1. 2, f. 9. - Herr. Sch. Wans. Ins. IX, p. 225, pl. 316, f. 975.

Lengte $3 \mathrm{~mm}$. - Iets kleiner dan Nemorum, doch naar evenredigheid langer van kop en hals, en zoo 't schijnt, smaller aan de vleugel-inplanting. De algemeene kleur van het ligchaam is zwart; roestkleurig geel zijn de benedenhelft van het tweede en derde lid der sprieten, de achterhelft van den thorax en de pooten geheel. De dekschilden zijn lichtgeel, iets donkerder aan de punt van den clavns en op den cuneus. De membraan is wit met een donker rlekje aan den binnenhoek, een dwars wolkje in het midden en eene grootere vlek an de spits. De zwarte zuiger reikt tot even voorbij het eerste henpenpaar.

Deze soort werd door den heer Drechsler in Junij bij Valkenburg, door den heer van Medenbach de Rooij bij Arnhem 22 April, door den heer Heylaerts bij Breda en door den heer La Fontijn op Walcheren aangetroffen.

De heer Scholy, ontdekker der soort, hield haar voor eene verscheidenheid van Nemorum L. Herrich-Sehiaffer is van andere meening en ik sluit mij hij zijn gevoelen aan, roornamelijk omdat het achterste gedeelte van den prothorax geheel glad is zonder putjes of rimpels en het geheele dier mij onbehaard voorkomt. Exemplaren uit Zwitserland, die op 's Rijks Museum bewaard worden, leeren mij dat de soort in dezen opzigte varieert: het geel op het $3^{e}$ lid der sprieten is meer of min uitgestrekt; de pooten hebben wel cens bruinachtige of bruine 
dijen; het rookkleurige vlekje ann den binnenlıok der membraan ontbreckt wel eens.

\title{
4. Inthocoris villatus Fieb.
}

\author{
Plaat 8 , fig. 5. 1)
}

Fiehrer in Ireitenweber's Beitrüge, P. 108, t. 2, fig. 6. - Idem, Europ. Hemipteren, p. 136. - Herr. Scl.. Wans. Ins. IX, p. 230 (bicuspis).

Lengte 2,5 mm. - Zwart, niet zeer glanzig, met microseosche haartjes bezet. Oogen roodbruin. Sprieten niet langer dan de helft van het ligehaam, donkerbruin met lichte haatjes bezet, het $2^{\mathrm{e}}$ lid $2 \frac{1}{2}$ maal langer dan het eerste, het $3^{\mathrm{e}}$ iets langer dan de helft van het voorgaande, het $4^{e}$ iets korter dan 3. Het halsje van den prothorax zeer kort; dwarsgroef vrij sterk naar voren staande, het veld daarachter dwars gerimpeld. Schildje met eene dwarsgroef in het midden; het voorste gedeelte bol, het achterste plat. Dekschilden gelijkvormig kastanjebruin, alleen wat donkerder aan de spits van den cuneus, zeer duidelijk gestippeld en daardoor bijna chagrijnachtig. Nembraan rookkleurig met een wit vlekje onder de spits der wigge en vier witte langsaderen. De lichtbruine zuiger rcikt tot aan de inplanting der middenpooten. De buik is pekbruin en de anus rood. De pooten zijn geelachtig roodbruin, met de basis der dijen en de laatste tarsen donkerder.

Van deze soort ving de heer Six een voorwerp te Driebergen, de heer Ritsema een te Velp in Julij en ik een bij Leyden in het laatst van October.

NB. Anllocoris pralensis F. (op bl. 245 vermeld), die hoogstwaarschijnlijk hier te lande wel voorkomt, is voor zoo ver mij bekend is, nog niet gevonden; de suort leeft bij mieren colonien op den ratelaar, Populus dilatuta.

1) De spricten dezer figuur ziju veel te lang 
Gen. 3. Piezostethus Fieb.

Bij dit en de nu volgende geslachten is de voorrand van het borststuk niet sehijnbaar in een halsje verlengd, met andere woorden, niet nitgerekt. Het geheele ligehaam vormt een korter ovaal; de kop is bol op den schedel en eenigzins naar voren nedergebogen; de oogen puilen niet bijzonder uit; de suuit strekt zich cen eind voorbij de voorste heupen nit. De sprieten hebben de lengte van het halve ligchaam; hunne beide eerste leden zijn matig gezet en naakt, de beide rolgenden slank en met afstaande haren bezet; lid 1 is zeer kort, 2 bijna viermaal zoo lang, 3 en 4 elk afzonderlijk bijna gelijk in lengte aan twee derde deelen van 2. Het borststuk heeft stompe voorhoeken, rondgebogen zijkanten, vrij scherpe achterhoeken en is bol aan de voorhelft, plat en met rimpels gegroefd op de achterhelft. Dekschilden en vleugels zijn kort en steken slechts een weinig voorbij den anus uit. De buik is gekield. De pooten bebben dikke dijen en de spits der voorpooten is verbreed.

Piezost, gaiactimus Fieb.

Plaat 8 , fig. 6.

Fieber, in Weitenw. Beiträge, p. 107, 7. - Herr. Sch. Wanz. Ins. IX. fig. 971 (albipennis, het ondersehrift heeft ten onregte X. ater). - Fieber, Europ. Hemipt. p. 139. - Douglas and Scott, Brit. Hem. p. 500, pl.17, f. 2.

Lengte 2,5 mm. - Glanzig zwart; kop en thorax met enkcle opstaande haartjes bezet. Sprieten zwart. Zuiger bruingrauw, aan de basis donkerder. Dekschilden licht ledergeel zouder teekening, alleen zijn de buiten- en achterrand van den cuneus bruin-zwart omzoomd; de membraan en de vleugels zijn zuiver doorschijnend wit en iriserend. Aan de behaarde pooten zijn de heupen en dijen pekbruin, de scheenen en tarsen bruinachtig geel. De legboor der wijfjes steekt wat nit en is lichthruin. 
Van dit insect ving ik twee exemplaren in Augustus bij Leyden en de heer Six een bij Rijzenburg in Junij.

Gen. 4. Tripuleps Fieb.

Als het voorgaande vertoont nok dit geslacht geen halsje tusschen kop en prothorax, of om juister te spreken, is hier de voorrand van het borststuk niet tot een halsje verengd en nitgerekt. Het groote versehil tusschen dit geslacht en het rorige is daarin gelegen dat hier de achterrand van het borststuk vrij sterk naar voren ingebogen is en de pooten niet zijn verdikt, gelijk daar. De sprieten der mannetjes zijn hier bovendien zamengesteld uit zcor breede en gedrongen lcedjes, 't geen bij Piezoslelhus het geval niet schijnt te zijn.

\section{Triphl. mimulus L.}

Plaat 8 , fig. 7 .

Linn. Faun. Suec. 911. - Fallen, Cim. Succ. p. 73, 22. - Idem, Hem. Suec. p. 68 (Anth. Fruticum). - Iahn, Wanะ. Ins. I, p. 110 , fig. 60. - Zett. Ins. Lapp. p. 266, no. 9. - Flor, Rh. Livl. I, p. 266, 9. Fieb. Eur. Hem. p. 141. - Iouglas and Scott, Brit. Hem. p. 504, pl. 17, fig. 3.

Lengte ten hoogste $2 \mathrm{~mm}$. - De vorm is een ovaal, waaraan de kop is vastgehecht, de Kleur bruinachtig zwart. De kop heeft breede uitpuilende roodbruine oogen en een niet zeer lang uitsteeksel; de sprieten zijn veel korter dan het halve ligehaam, bij het wijfje vrij slank, geclachtig bruin, behalve het $1^{e}$ lid en de basis van het latste, die donker zịn; bij het mannetje korter en dikker met de bide eerste leedjes geel, het derde donkerbruin, het laatste roodbruin. De zuiger is roodbruin en reikt slechts tot de voorste heupen. Het borststuk is zeer kort, halvemaanvornig, aan den achterrand zeer breed, en diep ingebogen; een dwarsgroef verdeelt het in twee ongelijke deelen, waaran het voorste dwars gerimpeld en het 
achterste gestippeld is. Het schildje heeft voor een rerheven lijstje en is vervolgens ingedeukt. De deksehilden zijn bij het q driemaal zoo lang als het schildje, zeer duidelijk, bijna ruw met bolle puntjes bezet, vuil olijfkleurig bruingecl of bruin, met donkerder cuneus en vuil-witte membraan; bij den z zijn zij korter en zeer licht geel. De pooten zijn nootkleurig geel met bruine dijen.

In kleur van sprieten, dekschilden en membraan verschillen de individnen dezer soort nog al sterk; Fieber geeft 5 kleurverscheidenheden op.

De soort werd binnen Nederland gevangen bij Bennebrock in Aug. (v. V.), bij Driebergen in Sept. (Six), bij Utrecht in $\Lambda$ pril en Mei (van Hasselt en Six), bij Arnhem in April (v. MI. de Rooij), bij Breda (Heylaerts), bij Helpman in Groningen (de Gavere).

Van den heer Six ontving ik uit Driebergen een mannetje dat zcer donker gekleurd is, bijzonder dikke zwarte sprieten heeft, waarvan het eindlid rood is, zwarte of ten minste donkere pooten bezit en op de achterhelft van den thorax dwarsrimpeltjes heeft en niet zoo chagrijnachtig is als anderen. Ik zou wel geneigd zijn dit voorwerp tot Triphebs niger WIf. (1)sscurus Hahn 59) te brengen, maar het is niet zuiver genoeg om er eene beschrijving van te maken.

\section{Gen. 5. Xrzoconis L. Duf.}

Het ligchaam dezer diertjes is plat en langwerpig, meer dan drie mal langer dan breed, met de zijden bijua over de geheele lengte evenivijdig. De kop is snuitvormig verlengd. De sprieten zijn korter dan de helft der ligchaamslengte en slank, doch aan de spits niet zoo haarachtig dun als bị Lyctocoris; het $2^{e}$ lid is ietwat knodsachtig en bijna driemaal langer dan het $1^{\text {e}} ; 3$ en 4 te zamen zoo lang als 1 en 2. Zuiger maar weinig langer dan de kop; zijn 2e lid zeer lang. Thorax zeer kort en plat, met eene langsgleuf in het midden. Dekschilden lang 
en smal met groote membraan, welke 4 aderen rertoont, die niet tot den rand doorloopen. De dijen van het $1^{\mathrm{e}}$ en $3^{3}$ paar pooten verbreed, die van het laatstgenoemde bovendien vrij lang.

\section{Xytoconis ater L. Duf.}

Leon Dufour, Ann. Soc. Ent. II, 106, pl. 6 B, fig. 3. - Flor, Rh. Liv\%. I, p. $667, n^{\circ} 1$.

Lengte $2 \mathrm{~mm}$. - Geheel glanzig zivart of donkerbruin, behalve het tweede lid sprieten dat tot over de helft geel is en de membraan, die ten minste aan de basis witachtig is. Ook zijn de voorscheenen geelachtig naar de spits. Ilet schildje is aan de basis ingedeukt.

Een zeer fraai voorwerp werd in de maand Maart bij Breda onder de schors van Larix aangetroffen door den hecr Heylaerts; twee voorwerpen werden in April bij den Ilaig gevangen door den heer Carric̀re.

Gen. 6. Lycrocunis Hahn.

Ligchaam ovaal, vrij plat aan de bovenzijde, voorbij de lijn van den cuneus nedergebogen. Kop in den vorm van een' afgeknotten kegel met sterk uitpuilende oogen. Sprieten korter dan de helft van het lijf met de twee laatste leden zeer fijn, met afstaande haartjes bezet. Zuiger reikende tot aan de voorste heupen, de 2 eerste lcedjes gelijk van lengte, het $3^{e}$ korter, het $4^{\mathrm{e}}$ nog korter. De prothorax van voren toegerond, van achteren ingebogen en aldaar zoo brecd als het dubbel der lengte. Schildje breed driehoekig. Dekschilden met de membraan tweemaal zoo lang als breed, op de helft dwars geplooid en naar beneden gebogen; de cuneus bijna zoo groot van oppervlakte als het corium. De pooten viij lang en de dijen dik; dat de voorste dijen zooveel dikker zonden zijn dan de achtersten, gelijk Fieber wil, kan ik niet toegeven. 
Lyctocoris domestica Schill.

Plaat 8 , figg. 8 .

Schill. in Isis 1831, p. 738 . - Hahn, Wans. Ins. III, p. 20, pl. 79, ligr. 243. - Flor, Rh. Livt. 1, 1. 665. - Fieb. Eur. Hemipt. 139. Herr. Sch. Nomenclator, p. 60 (Anth. bicuspis). - Douglas and Scott, Brit. Hem. p. 499 , pl. 17, f. 1.

Lengte 4-4,5 mm. - Roodbruin, ongelijk van tint, microscopisch behaard. Kop glad en glanzig, aan de spits bepaaldelijk rood. Eerste lid der sprieten een weinig voorbij den kop uitstekende, bruinachtig geel, het tweede dubbel zoo lang, zeer fiju aan de basis en gaandeweg dikker wordende, bruin; 3 en 4 slank, behaard, bruinachtig geel. Zuiger licht bruingeel. Prothorax weinig gewelfd, flaauw dwars gestreept, nootbruin met rooden achterrand. Schildje voor bol en weinig gestippeld, achter ingedenkt en met fijne dwarskiasjes, donkerbruin of zwart. Dekschilden rnil nootgeel, soms met donkerder tint tegen het eind van den clarus en der costa, en steeds met bruinen cuneus; membraan doorschijnend wit met een bruin tintje. Pooten bruinachtig geel, de scheenen aan de binnenzijde met zwarte haartjes.

Volgens Fieber varieert deze soort sterk in kleur; een mijner voorwerpen is zeer donker en heeft het geheele borststuk met den achterrand zwart.

Mij zijn als inlandsche voorwerpen bekend: een in September te Groningen gevangen door Dr. de Gavere, een door den heer Sncllen te Rotterdam binnen 's huis gevonden, een door mij den $6^{\text {aen }}$ Junij bij Staalduin, drie door Dr. Piaget aan het huis Ter Heide en bij Wassenaar in October, anderen bij den Haar en op het eiland Walcheren aangetroffen, op welk eiland de soort niet zeldzaam schijnt te zijn. De heer G. A. Six meldt mij dat ook hij een voorwerp dezer soort in ons land gerangen heeft. 
Gen. 7. Micropiysa Westw.

Zeer kleine dieren, welke bij of in de mierennesten en onder mos leven; naar voren zijn zij puntig toegespitst, van achteren breed en afgerond. De kop is driehoekig en naar voren in eene stompe spits verlengd; de zamengestelde oogen zijn bol en tamelijk uitpuilend; op zijde van elk van hen ziet men een microscopisch klein putje, waarin echter geen ocel te ontdekken is. De zuiger is of kort en dik, of iets langer en slanker; doch steeds van 4 leedjes, waarvan het eerste zeer klein is; steeds hangt hij los, dat is an de basis niet naar de keel gebogen. De sprieten zijn zoo lang als de helft van het ligchaam, slank, kort behaard, en bestaan nit 4 leedjes; het $1^{\mathrm{e}}$ is kort en vrij dik, de overigen zijn langer, van gelijke lengte en dikte. Het borststuk is kort en breed, door eene dwarsgleuf in twee deelen rerdeeld. Het schildje is driehoekig. De pooten zijn slank, hunne tarsen hebben niet meer dan 2 leedjes. De dekschilden (bij het mannetje gelijk an die der overige Anthocoriden) zijn bij het wijfje of breed en kort, aan den achterrand als afyesneden en niet meer dan de helft van het achterlịf bedekkende, of wel zij zijn bolrond, lederachtig, geheel van één gehalte, zonder cuneus of membraan en gelijk aan die van Coleoptera, of wel zij ontbreken geheel. Dit verschil, en dat in de rigting van den zuiger, die bij eene soort krom gebogen, bịj eene andere eenmaal hoekig gebogen en verder regt is, heeft aanleiding gegeven tot het vormen van nieuwe genera, als Myrmedobia Bärenspr., Idiotropus Fieb. en Zyg!onolus Fieb., die wij niet zullen aannemen, omdat ons tot heden slechts drie soorten van Microphysa en wel eene daarvan alleen in het vrouwelijk geslacht bekend zijn geworden. Tot narigt moge echter dienen dat onze eerste soort volgens Birrensprung en Fieber tot Myrmedubia behoort, de anderen rolgens Fieber tot Zygonolus en dat het geslacht Microphysa bij laatstgenoemden schrijver geheel wegvalt. 
1. Microphysa coleoptrala Fall.

Plaat 8, figg. 9.

Fallen, Mon. Cim. Suec., p. 31, no 7. - Mirkel in Germar's Zeilsckr., V, p. 262. - Germar, Faun. Ins. Eur. 24, tab. 19. - Von Bärensprung, in Berl. entom. Zeitschr. I, p. 163. - Douglas and Scott, Brit. Hem. p 484, pl. 16, fig. 1 of et to.

Lengte 1,5 mm. - (Wijfje.) Gedrongen, peervormig, op den rug bol en aldaar geheel met korte geelachtige haartjes bekleed. Het geheele ligchaam, behalve de dekschilden, helder rood. De oogen zwart. De sprieten aan de basis licht gekleurd, aan de spitshelft grauw. De zuiger is aan de inplanting rood, verder bruingeel. De pooten zijn geel. De dekschilden, die zeer bol zijn en het geheele abdomen omvatten, zijn of bruinachtig of paarsachtig zwart; somwijlen is de naad en de buitenrand roodachtig gekleurd, somwijlen echter is de naad niet alleen in kleur niet verschillend, maar ook zelfs niet wel te zien en schijnen de dekschilden aneengegroeid. Of er vleugrels zijn is mij onbekend; ik vermoed dat zij ontbreken.

Naar de bestaande beschrijvingen te oordeelen, vertoonen nitlandsche roorwerpen minder rood, dan de onzen en is daar bepaaldelijk de buik bruin.

(Man). Langer dan het wijfje, met lange dekschilden, waaraan een vrij groote membraan. Lijf zwart met roode oogen, pekbruine zuiger en pooten. De dekschilden aan den buitenrand doorschijnend met donker bruinen cuuens en daaronder in de membraan een wit half-maantje.

De heer Six rond achtervolgens drie of meer voorwerpen op zandgrond te Driebergen, en beide sexen bij den Haag. In Denemarken, Saksen en l'ruissen werd de soort bij mierennesten waargenomen, meer bepaaldelijk nesten van Formica rufa.

2. ilicroph. pselaphoides Westw.

Plaat 8, figg. 10 en $10 \alpha$.

Westwood, Ann. Soc. ent. de Fr. III, p. 612, tab. 6, lig. 3. - Burm. Ilandbuch II, 287. - Herr. Sch. Wanz. his. IX, p. 186, fig. 970 (q), 
p. 219 en 228, fig. 974 (子). - Flor, Rhynch. Livl. 1; p. 661. Douglas and Scott, Brit. Hem. p. 487, pl. 16, fig. 3 z en $q$.

Van deze soort bestaan eenige inlandsche vrouwelijke individuen in de verzamelingen. De heer Six zeide mij dat hij eens in Junij bij Utrecht een exemplaar gevangen heeft van Anthocoris truncalulus (H. Sch. 974), welk wantsje gehouden wordt vorr het mannetje van de onderhavige soort. Ik heb dit voorwerp bij hem gezien, loch vond het te zeer vergaan voor eene beschrijving; het scheen mij toe geheel met Herrich-Schaeffer's afbeelding overeen te komen. Volgens Flor is dit mannetje slank, smal, zwart of donkerbruin, met den zuiger en de pooten van de knieën af bruinachtig geel, met grauwe dekschilden die een' rooden cuneus en eene berookte membraan hebben; ook bezit volgens hem het mannetje bijoogen. Of de copula bij deze soort ooit is waargenomen, bleef mij onbekend en $i k$ weet niet op wiens verzekering dit mannetje aan dit wijfje gehuwd is.

Het wijfje heeft dekschilden, doch verkort en slechts tot an de helft van het achterlijf reikend. Kop vuilruod met zwarte spits en zwarte oogen. Leden der sprieten overal van gelijke dikte, het $1^{\mathrm{e}}$ zwart, het 2 e rood, de beide overigen bruinrood. De zuiger veel langer dan bij de vorige soort, zwart. De thorax of bloedrood of bruinachtig paars met rooden roorrand, breed en in het miuden diep gegroefd. Het schildje klein, rood of paars. De dekschilden of wijnkleurig paars en aan den achterrand scheef afgesneden, of geheel vliezig en bijna doorschijnend wit en dan aan den achterrand min of meer afgerond. Vlengels schijnen te ontbreken. Het achterlijf breeder dan lang en vrij plat, van kleur bloedrood of dof zwart. De pooten licht bruinachtig geel met roode of wel met donkerbruine dijen, an welke echter de knieën lichtgekleurd zijn. Het roodgekleurde dezer beide wijfjes is dat, hetgeen in mijne eerste lijst en in die geschreven met de heeren de Graaf en Six onder den naam van Sanguinea roorkomt (Zie fig. 10).

Van deze soort rond de heer Six eenige vrouwelijke roorwerjen bij Utrecht op mierennesten. Het voorwerp dat ik 
vroeger $M$. sanguinea noemde, werd voor vele jaren door mij in mijn' tuin te Leyden op het verdroogde zaa lhuis eener sierplant aangetroffen.

3. Micr. elegantula Bär.

Plaat 8 , fig. 11.

Bärensprung, Berl. Ent. Zeit. II (1858) p. 191, t. 2, fig. : (ठ) . Douglas and Scott, Brit. Hem. p. 488, pl. 16, fig. 2 o et q.

Lengte bijna $2 \mathrm{~mm}$. - Het mannetje gelijkt wel op dat der voorgaande soort, doch is smaller, heeft langer kop en is vooral herkenbaar aan den bloedrooden cuneus der de!sschilden en aan de lichtgele scheenen. Het wijfje is rleugelloos. Het diertje is zeer glanzig, licht oranje van kleur met een zwart achterlijf. De kop is voorbij de oogen eenigermate tot een halsje uitgerekt en smaller dan bij de voorgaanden. Zuiger, sprieten en pooten zijn van dezelfde gedaante en kleur, maar de thorax is lang en smal, eenigzins bultig op den prothorax voor de dwarsnaad en op het schildje, aan welks zijden men twee zeer kleine driehoekige vliesjes ziet, die de plaats der dekschilden bekleeden. Het achterlijf is dwars ovaal en dus veel breeder dan lang, bol kussenvormig en schijnt uit vijf ringen te bestaan; aan de inplanting is bet ietwat rossig.

Of deze soort werkelijk zeldzaam is, blijft vooralsnog onuitgemaakt; volgens de aangehaalde Engelsche schrijvers, die beide sexen dikwijls in copula aantroffen, is de soort in de omstreken van Londen sommige jaren gemeen tegen boomstammen en oude palen. Bij ons is dit wel niet waargenomen, maar kan toch evenzeer het geval wezen. Tot heden zijn, zoo ver mij bekend is, in Nederland slechts een man en een wijfje gevangen, hij door den heer G. A. Six bij Utrecht, zij in Julij ann de Vuursche door mij, zoo ik mij wel herinner op cen der granietblokken voor het logement. 
Gen. 8. Acantuin F.

Dit geslacht verschilt voorzeker veel in uitwendigen vorm van de ware Anthocoriden, maar de breede Microphysen vormen een geleidelijken overgang. Ook hier ontbreken de ocellen, even als bij de laatstgenoemden (o), zoodat het meest kenmerkende versehil in den uitgesneden voorrand van het borststuk hestaat.

Het ligchaam is ovaal en vrij plat, op de bovenzijde zeer fijn behaard. De kop veel breeder dan lang, met een vierkant nitsteeksel tusschen de sprieten, is tot bijna tegen de oogen in het borststuk ingeduwd. Dezen zijn wel uitpuilend, doch niet groot. De sprieten zijn niet langer dan $\frac{1}{3}$ van het ligchaam en slank; hun $1^{\mathrm{e}}$ lid is kort en gezet, het $2^{\mathrm{e}}$ cylindervormig, driemaal zoo lang als het voorgaande, aan de binnenzijde behaard; het $3^{\text {e }}$ zeer slank, in lengte gelijk aan 3 , en 4 even slank, doch korter. De zuiger is zeer kort, reikt maar even tot de voorste heupen en bestaat uit drie leedjes, waarvan het laatste kort en priemvormig is. Het borststuk is van voren diep ingesneden om den kop te ontvangen, aan de zijden sterk gerond en aldaar met borstelharen bezet, aan den achterrand regt; het is wel driemaal zoo breed als lang. Het schildje is driehoekig, kort, dubbel zoo breed als lang. Dekschilden in den vorm van korte, breede platen of lappen. Metathorax van boven duidelijk zigtbaar en schijnende de eerste ring van het achterlijf te zijn. Abdomen veel breeder dan het borststuk, uit zeven ringen bestaande waarvan de beide laatsten sterk behaard zijn. Pooten vrij lang en stevig. De voorste heupen raken elkander aan, doch die der beide andere paren zijn door platte borstplaten van elkander afgescheiden. De dijen zijn zijdelings eenigzins zamengedrukt; de tarsen bestaan uit drio leerjes. 


\section{Acanthia lectularia L.}

Plaat 8 , fig. 12.

Linn. Syst. nat. V, p. 477, 1. - Fabr. S. Rhyny. 112, 1. - Burm. Handb. II, p. 253. - Curtis, Brit. Ent. XII, tab. 569. - Hahn, Wanz. Ins. III, p. 17, f. 212. - Schellenb. Cim. Helv. 21, tab. 6, f. 1. Wolff, Icon. Cim. 127, tab. 13, f. 121. - Flor, Rh. Livl. I, p. 673. Douglas and Scott, Brit. Hem. p. 510, pl. 17, fig. 7.

Lengte 4-6 mm. - Bruinrood met gele 2 laatste leden der sprieten, scheenen en tarsen. Alle haartjes op het lijf rood of geel. De kop zwak gestippeld, het borststuk iets sterker, de dekschilden zeer ruw, het achterlijf weder fijner en digter.

In vele huizen aan te treffen en hier en daar gemeen. In een' hollen omgewaaiden lindeboom in de Maliebaan te Utrecht werden zij eens bij honderden angetroffen; deze leefden er waarschijulijk van drekstoffen of van de jongen der vledermuizen. De heer J. Wttewaall zond mij eens eene doos vol weegluizen nit een' duiventoren, die er duizenden beherbergde. Deze waren iets kleiner en breeder dan die uit de bedsteden, doch overigens vond ik er geen verschil tussehen. Zij zonden tot de soort Columbaria Jenyns moeten behooren, wier soortskenmerken nog aan niemand duidelijk zijn geworden ${ }^{1}$ ). Gevleugelde individuen zijn, voor zoover mij bekend is, in ons raderland nog niet aangetroffen.

1) Zie ondertusschen de kenmerken opgegeven in de Annals of Natural History, vol. III en daaruit overgenomen bij Douglas and Scott. Ook zijn zij duidelijk uiteengezet door $\mathbf{E}$. Saunders in zijue Synopsis of British Hemiptera-Heteroptera in de "Transactions of the Entom. Society of London" 1876, p. 621. Desniettemin moet ik verklaren dat ik geen soortgelijk verschil zie tusschen weegluizeu uit duiventorens en uit kazernen. 


\title{
ZEVENDE FAMILIE. - - SCHORSWAN'TSEN.
}

\author{
CORTIGICOLAE.
}

De wantsen dezer zevende familie zijn kleine, zeer platte dieren, welke de volgende kenmerken vertoonen. De kop is plat, tusschen de sprieten in een uitsteeksel verlengd, dat in lengte het eerste lid der sprieten overtreft, en aan beide zijden voor de oogen met een doorntje gewapend. De sprieten hebben vier leedjes en zijn veel korter dan het halve ligchaam. De oogen zijn middelmatig en de bijoogjes ontbreken. De zuiger bestaat uit drie leedjes, is kort en in de rust liggende in een gleuf aan de onderzijde van den kop. Borststuk veel breeder dan lang, met de zijden rond gebogen. Het schildje groot en breed, driehoekig of aan de spits toegerond. Dekschilden bij een geslacht korter dan het achterlijf en bestaande uit coritum, clavus, en membraan, in het andere geslacht zoo lang als het achterlijf en bijna geheel vliezig zonder duidelijke afdeeling. Achterlijf plat en breed, uit 6 segmenten bestaande in beide sexen. Pooten kort en tamelijk slank; tarsen van twee leedjes, waarvan het laatste het langste is.

In deze familie treffen wij slechts 2 inlandsche geslachten met 3 soorten aan. De punten van verschil tusschen de genera zijn menigvuldig; het zij voor het spoedig onderkennen voldoende bier op te merken dat bij Aradus het tweede lid der sprieten langer is dan elk der overigen afzonderlijk en bij Aneurus het vierde alleen zoo lang als de drie anderen te zamen.

\section{Gen. 1. Aradus F.}

Het ligchaam langtverpig ovat on plat, de opperhuid sehier overal ruw. De kop rij kort, doch met een lang uitstecksel tusschen de sprieten, breed tusschen do oogen, voor welko 
twee spitse doorntjes staan. De oogen rond, niet groot, maar sterk naar de zijden uitpuilende. De sprieten zijn weinig langer dan de kop met de oogen breed is; zij bestaan uit vier leedjes, wier inplantingssteel niterst fijn, en wier tweede lid bet langst is; de spits ran het $4^{e}$ of laatste lid is kegelvormig, schijnbaar in het overige gedeelte van dat lid ingestoken en met zilverwitte haartjes bekleed. De zuiger is middelmatig van dikte en reikt bij de eene soort tot an de middenheupen, bij de andere daarover heen; onder den kop is hij in eene gleuf ingesloten, welke zich van daar over de borst uitstrekt en op het abrlomen nog als tijne lijn zigtbaar is. Het borststuk veel breeder dan lang, met de voorhoeken schuin vooruitstekend en de zijpranden liervormig toegerond; over den rug loopen vier verhevene langslijnen, waarvan de buitensten korter zijn dan de binnensten. Schildje gelijkzijdig driehoekig met opgeheven zijranden en spits. Dekschilden iets korter dan het achterlijf, welks zijden zij onbedekt laten, behalve aan de basis waar zij over de zijranden heen reiken; de cuneus ontbreekt, doch clavus, corium en membraan zijn voorhanden, zelfs is de laatste vrij groot. Zij heeft vier langsaderen, die door kleine dwarsaderen tot eene soort van netwerk verbonden zijn. Er zijn vleugels anwezig, wanneer de dekschilden geheel uitgegroeid zịn, 'tgeen echter niet bij alle rnorwerpen het geval is. Wanneer zij onvolkomen uitgegroeid zijn, ontbreken hun de clavus en de membraan. De pooten rijn niet lang, maar ook niet gezet; de voorheupen zijn alleen maar door den gleuf van deu zuiger van elkander gescheiden, doch de midden en achterpooten staan zeer wijd van cen. Het achterlijf is zeer breed, bijna cirkelrormig, het zesde segment is aan het einde door eene spleet ingekeept.

In vergelijking met Duitschland en vooral met de Russische Oostzee-provincien bezitten wij zeer weinig soorten van dit geslacht, ran welke onevenredigheid naar mijne meening de ooraak moet gezocht worden daarin, dat de Aradi gewoonlijk huizen onder de schors van doode of stervende boomen, die men bij ons slechts zelden in de bosschen aantreft. 
Aradus depressus F.

Plaat 9, fig. 1.

Fabr. Syst. Rh. 119, 10. - Fallèn, Hemipt. I, 138, 7. - Schellenb. Das Gest. p. 19, tab. 5, f. 2. - Wolf, Icon. Cimic., p. 129, tab. 13, f. 123. - Amyot et Serv. Hémipt. 309. - Herr.-Sch. Wanz. Ins. V, p. 93, fig. 542 (onnaawkeurig). - Flor, Rh. Livl. I, p. 391.-Douglas and Scott, Brit. Hem. 1). 271, pl. 9, f. 9.

Lengte 5-6 mm. - Roodbruin of zwart met een steenrood achterlijf. De kop is tot aan de spits van het uitsteeksel zoo lang, als bij met de oogen breed is, het nitsteeksel is tweemaal zoo lang als het breed is; de doornen boven de inplanting der sprieten zijn breed en reiken bijna tot hun eerste lid. De antennen zijn donkerbruin, behalve de zilverachtige spits van het $4^{e}$ lid; het $1^{e}$ is klein, bijna vierkant, het $2^{e}$ is wel driemaal zoo lang, aan de basis smaller dan aan de spits, die eenigzins bol twegerond is, het $3^{\mathrm{e}}$ is iets korter en iets breeder, en nitgehold aan de spits; het $4^{e}$ is iets kleiner dan het derde. De zuiger reikt slechts tot aan de heupen van het voorste paar. Het borststuk is eerst geheel plat, daarna even voor de helft gewelfd; zwart of bruin in het midden, met de zijden voor de voorhelft wit, voor de achterhelft rood of bruinrood; de vier langskielen uit grauwe korrels bestaande; de zijden van even voorbij de helft roodachtig ingekerfd. Het schildje zwart, in de dwarste gevoord, met grauve korrelige zijranden en spits. De dekschilden steken eerst in ronde bogt met hun aan den zoom gekartelden zijrand breed over het abdomen uit, doch zijn vervolgens naar binnen gebogen en smaller dan dit. Corium en clavus zijn wit, met bruine vlekken, nam. een aan de inplanting, den buitenrand en het laatste eind der aderen. De membraan is wit aan de basis en rerder rookkleurig met een wit aderen-netwerk. Het abdomen is rood met geelachtige vlekken, bruine randen en stippeltjes; het zesde segment draagt op den rand zijner lobben twee witte vlekken, elk ingesloten door twee bruinen. De pooten zijn vuilwit of zeer licht grauw, met bruinachtige knieën en bruinachtige bandjes over het midden der dijen en scheenen. 
De heeren Dr. van Hasselt en Six vonden deze soort in de omstreken van Utrecht, laatstgenoemde in IEei; de heer Snellen te Wolfheze in Aug. en bij den Haag in Mei. In Mei werd zij ook door Mr. H. W. de Graaf in Wassenaar gevonden en in onbekenden tijd onder denneschors bij Breda. Door mij werd zij bij 's Gravenhage in Junij en bij Amersfoort mede in Junij angetroffen, voorts in April en Mei op de Gliphoeve en in Augustus bij Leyden. $Z_{i j}$ is dus waarschijnlijk door het grootste gedeelte van ons land verspreid.

\section{Aradus leptopterus Germ.}

Plaat 9, fig. 2.

Germ. Fauna Ins. Eur. 17, tab. 8. - Herr. Sch. Wanz. Ins. V, P. 91, tab. 175, fig. 539. - Flor, Rhynch. Livl. I, p. 394. - Fieber, die Eur. Hemipt. p. 111. - Panz. Fauna Germ. 100, 20 (Cinnamomeus).

Lengte $5 \mathrm{~mm}$. - Geelachtig, bruinachtig of rooskleurig rood. De kop heeft geheel den vorm als die der vorige soort; alleen is op het midden van het voorhoofd een glad wapenschildvormig plaatje te zien tusschen twee scheve groefjes, Sprieten zoo lang als de kop en gevormd als bij de vorige, met dit verschil dat het $4^{e}$ lid 't geen bruin is, terwijl de overigen rood zijn, zoo lang is als het 3 . De zuiger die voorbij de helft donkerbruin wordt, reikt tot aan de heupen van het laatste paar. De oogen zijn zwart. Het borststuk is niet gewelfd aan zijn achterhelft; het voorste gedeelte is ietwat wrattig en donkerder van kleur; de langsribbeltjes zijn alleen op de achterhelft te zien. Dekschilden somtijds slechts weinig ontwikkeld; zijn zij het wel, dan reiken zij tot het anaalsegment en zijn (q) slechts weinig smaller dan het achterlijf, zij zijn eenkleurig met het burststuk; de membraan is aan de basis wit, verder grijs met wit omzoomde aderen. Het achterlijf is op het midden van den rug rooder dan an de zijden; aan de buik met ovale nootbruine vlekken op bruingeel getijgerd. De pooten zijn roodbruin.

Van deze soort ving de heer Six een onvolgroeid voorwerp 
in September onder denneschors bij Driebergen en een dergelijk den $1^{\text {en }}$ Junij te Beek bij Nijmegen. Met volgroeide dekschilden vond de heer Snellen cen voorwerp in het laatst van Augustus bij Wolfheze, mijn zoon Corn. een in Augustus bij 's Gravenhage, ik zelf een in Augustus op Sterkenburg en een mede in Augustus in het park van Soestdijk. Gevleugelde en ongevleugelde vonrwerpen trof de heer Heylaerts in Dec. in de omstreken van Breda onder afgevallen dennermaalden aan. De heer de Han ving eenige voorwerpen in Augustus en September bij Middelburg, doch ik vind niet aangeteekend of zij nitgewassen dekschilden hadden. Al deze voorwerpen schijnen wijfjes te zijn.

Gen. 2. Aneunus Curt.

Ligchaam langwerpig ovaal en bijzonder plat. Kop niet zeer groot, vierkant met een vooruitstekend snuitvormig deel, dat in de voorzijde als een wig ingeslagen schijnt. Oogen klein, in den rand van het hoofd geplaatst; voor hen een scherp doorntje. Sprieten bepaaldelijk langer dan de kop, hun eerste lid dikker dan de overigen; het $2^{\mathrm{e}}$ iets kleiner dan het $1^{\mathrm{e}}$, het $3^{\mathrm{e}}$ iets langer, en het $4^{\mathrm{e}}$ zoo lang als de beide vorigen te zamen. De zuiger is zeer kort en wordt onder tegen de keel in eene gleuf opgenomen. Het borststuk vrij breed, plat, zonder verhevenheden of groeven, aan de zijden naar achteren een weinig gebogen en verbreed. Het schildje is groot, breed, aan den achterrand rond uitstaande. Dekschilden geheel vliezig behalve een klein lederachtig driehoekig grondstuk, koiter dan het achterlijf en in de rust ook de zijden daarvan niet bedekkende; daaronder vleugeltjes die maar half zoo lang zijn. Het achterlijf groot, uit zes breede ringen bestaande. Pooten kort met eenigermate gezwollen dijen; tarsen kort en fijn. 


\section{Aneurus laevis F.}

Plaat 9 , fig. 3 en $3 a$.

Fabr. Syst. Rh. 119, 12. - Fallèn, Hemipt. I, p. 140, 10. - Curtis, Brit. Ent. II, pl. 86. - Burm. Handb. II, p. 253, 1. - Herr. Sch. Wan\% Ins. IX, p. 141, pl. 310, fig. 951. - Amyot et Serv. Hemipt. p. 307. - Flor, Rhynch. Livl. I, p. 397. - Douglas and Scott, Brit. Hem. p. 268 , pl. 9, fig. 8.

Lengte $4 \mathrm{~mm}$. - Roodbruin. - Bruinachtig rood zijn het uitsteeksel van den kop, de sprieten, de achterzoom van het borststuk en de rugzijde van het abdomen. De dekschilden zijn bruin aan het lederachtige grondstuk en van daar tot de spits geelachtig, met dien verstande dat het geel naar de spits toe verbleekt. Pooten van de kleur van het ligehaam zonder bandjes, zeer fijn korrelig.

Van deze zeldzame soort ving ik in Junij een mannelijk exemplaar op het landgoed de Becle bij Voorst; sedert werd zij ook door den heer Heylaerts bij Breda gevangen. 


\title{
ACHTSTE FAMILIE. - NETWANTSEN.
}

\author{
TINGIDIDEA.
}

Tot deze familie behooren niet dan kleine dieren, gemakkelijk daaraan herkenbaar dat hunne bovenvleugels glasachtig zijn en bezet met een op kant- of netwerk gelijkend aderbeloop. Een Hollandsche naam is, voor zoo verre mij bekend is, voor deze familie niet algemeen angenomen en men heeft te kiezen tusschen netwantsen, netwerkwantsen in kantuantsen, doch daar de beide laatste benamingen eenigzins dubbelziunig zijn, heb ik de eerste verkozen.

Het ligchaam is gewoonlijk ovaal van ontrek, somwijlen echter bijna cirkelvormig, of ook wel langgerekt met tamelijk evenwijdige zijden. De kop is eer klein dan groot en op den schedel veelal met stekeltjes bezet. De oogen zijn klein, meest bolrond; bijoogjes ontbreken. De sprieten staan aan de zijden van den kop voor de oogen, of op het voorhoofd tusschen de oogen, en zijn in den regel veel korter dan het ligehaam; zij bestaan uit vier leedjes, waarvan het $3^{e}$ steeds het langste en het laatste gewoonlijk spoclvormig is. De zuiger schijnt uit vier leedjes te bestaan, doch is volgens de onderzoekingen van Flor werkelijk uit vijf leedjes zamengesteld, daar bij het levende dier tusschen het $2^{\text {e }}$ en $3^{\text {e }}$ lid nog een klein leedje zigtbaar is; hij strekt zich nimmer verder uit dan tot de basis van het abdomen en is aan de onderzijde van den kop ingesloten tusschen twee uit netwerk bestaande regt op staande vrij hooge plaatjes, welke bij de nieuwere schrijvers over Hemiptera den naam van Bucculue ontvangen hebben. De prothorax is gewoonlijk niet zeer bol verheven, heeft an den voorrand dikwijls een' doorigtigen met netwerk bedekten blaas- 
vormigen kap, en drie verheven rigehels daarachter, die in de lengte doorloopen; hij is an het achtergedeelte in een' langen stekel met netwerk verlengt, die het schildje en tevens den clavus der dekschilden verbergt; zijne zijranden zijn dikwijls bladvormig in netwerk verbreed. De voorvleugels of dekschilden, aan welke de membraan dikwijls ontbreekt, zijn vliezig en door de aderen tot een, nu eens fijn, dan weder grof netwerk vervormd en hebben slechts een' zeer rudimentairen of zelfs in het geheel geen clavus. Fieber, die aan deze dekschilden een bijzonderen naam (Sagenae) toekent, onderscheidt vier velden in hunne oppervlakte, het randveld, het zijdeveld, het middenveld en het eindveld; dit laatste is kennelijk de membraan, doch die nu aan de binnenzijle, dan weder ook aan de buitenzijde den vleugel omgeeft en alsdan een is met het randveld. De voorwerpen bij wie de vleugels ontbreken, hebben tevens slecht ontwikkelde dekschilden, welke niet meer den waren typus der Hemipter-voorvleugels terug geven, tenzij zeer gewijzigd; de vier velden, die Fieber onderscheidt, zijn in de meeste gevallen bovendien niet door randen of grootere aderen van elkander afgescheiden, zoodat het zoo goed als ondoenbaar wordt daarmede een waar denkbeeld van een Tingidide-dekschild te geven. De vleugels zijn nu eens wel ontwikkeld, doch zeer klein, dan weder in het geheel niet aanwezig; daarnaar schijnt zich de gedaante der dekschilden te wijzigen (zie daarover Flor, l. c. p. 319 en vooral de noot op pag. 329). De pooten zijn vrij dun en matig lang; hunne tarsen bestaan slechts nit twee leedjes, waarvan het laatste twee klaauwljes en daartusschen twee zeer kleine zuiglapjes draagt. Het abdomen vertoont niets bijzonders.

Netwantsen treft men op verschillende planten aan, welker sappen haar tot voedsel verstrekken. Hare levenswijze en gedaantewisseling is nog zeer weinig onderzocht; de laatste schijnt mij toe zeer merkwaardig te moeten zijn, to oorleelen naar de zonderlinge gedaanten van een paar insecten, die ik voor poppen van netwantsen meen te moeten houden en die ik op de derde bij dit opstel behoorende plaat afgebeeld heb. 
Verdeeling der geslachten.

Het geslacht Tingis, ofsehoon hoogst waarschijnlijk wel in Nederland voorkomende, is nog niet als inlandsch bekend geworden. Het geslacht Orlhoslcira Fieb. opgenomen in de "Tweelo Naamlijst van Inlandsche Hemiptera, blz. 188" wordt hier weder met IIonanthia vereenigd, omdat het voorname punt van onderscheid gebleken is te zijn een gebrek aan ontwikkeling (zie de boven aangehaalde noot van Flor).

1 (8). Dekschilden door naden of rigchels in dric duidelijke velden afgescheiden.

2 (7). Het middenveld der dekschilden vlak en door een hoogen rigehel van het zijdeveld afgescheiden; netwerk der dekschilden fijn.

3 (4). Het middenveld loopt met eene bogt door het geheele dekschild tot aan de spits; het borststuk is aan den voorrand uitgesneden.

Gen. 3. Camprlostina Fieb.

4 (3). Het middenveld is door een of twee hoogere aderen van het randveld aan de spits afgescheiden. Voorrand van het borststuk blaas- of kapvormig.

5 (6). Sprieten kort en dik, aan de beide laatste leden sterk

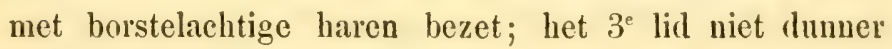
dan de overigen.

Gen. 1. Dictyonota Curt.

6 (5). Sprieten slank, nagenoeg onbehaard, tenzij aan het laatsto lid; het $3^{e}$ dunner dan de overigen.

Gen. 2. Monantuin St. Farg.

7 (2). Het middenveld met het zijdeveld dakvormig en blazig verheven; netwerk der dekschilden zeer grof.

Gen. 4. Derepursia Spin.

8 (1). Deksehilden niet in 3 duidelijke velden verdecld.

Gen. 5. Agrama Westw. 
Gen. 1. Dictyonota Curt.

Ligehaam langwerpig ovaal en tamelijk plat. Kop stomp driehoekig met 2 fijne stekeltjes op het voorhoofd voor de oogen, die vrij klein en rond zijn. Sprieten korter dan kop en thorax lang zijn, van vier leedjes, allen even dik; lid 1 cylindrisch en iets langer dan 2 , 't welk napvormig is; deze beiden in eene soort en onbebaard; 3 driemaal zoolang als de twee eersten te zamen, rolrond en even als 4, dat de helft kleiner en spoelvormig is, borstelachtig met haren bezet. Op zijde aan de basis der sprieten een doorntje. Zuiger reikend tot tusschen het derde heupenpaar. Borststuk met eene kleine blaasvormige kap boven den nek, met de beide zijranden bladvormig in netwerk verbreed en met drie laugsrigehels over het midden van den rug. Vleugels aanwezig; dekschilden over elkander slaande, met een aan het eind afgesloten, scheef lancetvormig middenveld en vrij groote netwerk-cellen aan den rand. Pooten vrij lang en slank.

\section{Dyclyon. crassicornis Fall.}

Plaat 9 , fig. 4 en $4 a$.

Curt. Brit. Ent. IV, p. 154. - Fallèn, Hemipt. I, p. 147, 10. Herr. Scbaeff. W. Ins. IV, p. 74, tab. 129, B. - Zelt. Ins. Lapp. 1. 269, $n^{\circ}$ 5. - Flor, Rhynch. Livl. I, p. 358. - Fieber, Ent, Monogr. 1. 92, tab. 7, f. 42-47. - Douglas and Scolt, Brit. Hem. 1. 255 , pl. 9, f. 5.

Lengte $3 \mathrm{~mm}$. - Zwart met het abdomen roodbruin en alle netwerk lichtgrauw met bruine aderen. Na de algemeene beschrijving der gedaante zoo even gegeven, zal het niet noodig zijn daarover lang uit te weiden; alleen nog maar dit. De drie langsrigehels op den rug zijn vrij hoog en staan loodregt op het vlak; de beide zijdelingschen zijn een weinig gekromd en hebben 7 of 8 vierkante celletjes; de middelste, die over de halskap doorloopt, heeft er 10. De zijranden van het borststuk steken naar voren met afgeronde hoeken uit, hebben 3 
rijen van mazen en zijn een weinig naar boven opgewipt. Op de dekschilden zijn de rigchels om het middenveld mede vrij hoog, zoodat dit komvormig is uitgediept; het heeft 4 langsrijen van mazen, zeer onregelmatig; het zijdeveld zalst schuin naar het randveld toe en er bestaat geen rigehel tusschen deze beiden; het laatste heeft voor en achter twee rijen celletjes, in het midden slechts eene. Aan de pooten zijn de heupen vuilgeel, de dijen en tarsen vrij donker bruin en de scheenen lichtbruin of vuilgeel.

De heer Six vond deze soort meermalen tusschen gras bij Utrecht en Driebergen. Zijne voorwerpen werden door ons eerst gedetermineerd als Eryfhrophthalma Germ., daarna als Pilicormis H. Sch., nu eindelijk na kennisneming van de geheele literatuur over het genus ontwijfelbaar als Crassicornis Fall. Bij Gorkum werden 5 exemplaren dezer soort angetroffen en voor mij opgevangen door Jhr. Dr. Everts. Bij de af beelding van Herrich Schaeffer is er geene beschrijving gegeven en de af beelding zelve is veel te slecht om er een insect naar te bestemmen; ja, zelfs komt het mij twijfelachtig voor of er wel eene soort $D$. pilicornis in werkelijkheid bestaat.

\section{Dictyon. strichnocera Fieb.}

\section{Plaat 22, fig. 8.}

Fieber, Ent. Monogr, p. 95, no 3, taf. 8, f. 1-7. - Donglas and Scolt, Brit. Hem. p. 256.

Lengte $3, \overline{\mathrm{mm}} \mathrm{m}$. - Ik meen te kunnen volstaan met de punten van onderscheid op te geven tusschen deze soort en de voorgaande. Strichnocera heeft de sprieten met korter haren bezet, die naawwer aansluiten; ook zijn de beide eerste leedjes op dezelfde wijze behaard als het derde en even dik, zoodat zij daarmede een geheel schijnen uit te maken. De zijranden van het borststuk loopen ronder toe, zonder hoeken, en hun netwerk bestaat slechts uit 2 rijen mazen, niet uit 3 of 4 . Het borststuk is op den rug iets bultiger. De dekschilden zijn wel even lang, maar hun corium is korter en dus de vorm 
der membraan anders; hun netwerk is grover en de zijrand is naar achteren breeder.

Een enkel inlandsch voorwerp is mij bekend, door den heer A. vau den Brandt te Venlo gevangen.

\section{Gen. 2. Monantmia St. Farg. et Serv.}

Ik voeg in dit geslacht de Orthostiren en Monanthien bijeen, om liervoren reeds opgegeven berveegreden. Dien ten gevolge moet de algemeene beschrijving van het genus aldus luiden:

De kop is breed, min of meer vierhoekig en op het voorhoofd met doorntjes gewapend. De oogen zijn middelmatig, bij eene enkele soort zeer gront, steeds bolrond. De sprieten zijn iets korter dan de helft van het ligchaam; de 2 eerste leedjes zijn zeer kort, het derde veel langer, doch tevens veel smaller, het $4^{\text {e }}$ weder dikker en spoelvormig, gewoonlijk behaard. Aan de inplanting der sprieten is een kort, somtijds echter zeer puntig stekeltje bemerkbaar. De zuiger ligt tussehen 2 hoog opstaande netplaten en reikt tot op de borst. Omtrent het borststuk valt wegens de soortgelijke verschillen niet veel meer te zeggen dan 't geen reeds in de beschrijving der familie gezegd is. De dekschilden zijn niet altijd geheel ontwikkeld, maar reiken toch altijd over den anus heen; zijn zij niet geheel ontwikkeld, dan hebben zij eene andere gedaante en gelijken in omtrek op die der kerers; hun naad loopt dan regt tot het einde door en zij slaan dus ook niet over elkander heen. De vleugels ontbreken meer dan dat zij voorhanden zijn. De pooten zijn slank, middelmatig van lengte.

\section{Overzigt der soorten.}

1 (16). De dekschilden slatn met de membraan over elkande1 heen.

2 (3). Sprieten kort en bijna overal even dik.

Sp. 1. Cosiala F. 
3 (2). Sprieten betrekkelijk lang en slank; hun derde lid dunner dan de overigen.

4 (5). Het ligchaam (met de membraan) is meer dan dricmaal langer dan breed. De kleur bruin.

Sp. 6. Quadrimaculala Wolff.

5 (4). Het ligchaam is 2 of $2 \frac{1}{2}$ maal langer dan breed. De kleur grijs of grauw.

6 (13). De dekschilden zijn met zwarte vlekjes versierd.

7 (10). De rug van den thorax is grijs.

8 (9). Beide eerste leedjes der sprieten zwart.

Sp. 2. Cardui L.

9 (8). Beide eerste leedjes der sprieten rood.

Sp. 3. Humuli F.

10 (7). De rug van den thorax is, ten minste op het midden, zwart.

11 (12). Geen blaasachtige verhevenheden op de dekschilden. Sp. 4. Wol/fi Fieb.

12 (11). Vier blaasachtige verhevenheden op de deksehilden.

Sp. 5. Vesiculifera Fieb.

13 (6). Dekschilden ongevlekt.

14 (15). De buitenrand van bet middenveld der deksehilden is weinig gebogen.

Sp. 7. Nigrina Fall.

15 (14). De buitenrand van het middenveld is sterk S-vormig gekromd.

Sp. 8. Parvula Fall.

16 (1). De dekschilden slaan met de membraan niet over elkander heen; hun naad loopt regt door tot aan de spits.

17 (18). Geheel zwarte sprieten.

Sp. 10. Carinala Panz.

18 (17). Niet geheel zwarte sprieten. 
19 (20). Rosachtig met twee driehoekige zwarte vlekken op den rug.

Sp. 9. Cervina Germ.

20 (19). Grauw zonder driehoekige zwarte vlekken.

Sp. 11. Obscura H. Sch.

A. Soorten bij welke de dekschilden over elkander slaan.

1. Monanthia costata F.

Plaat 22, fig. 10.

Fabrr. S. Rh. 152, 2. - Fall. Hem. Suec. 143, 1, - Herr. Sch. W. Ins. IV, p. 55, pl. 123 , f. 390 . - Flor, Rh. Livl. I, p. 347. - Douglas and Scott, Brit. Hem. p. 248.

Lengte 3-4 mm. - Langwerpig ovaal, voor en achter vrij spits, het borststuk bijna zonder bladachtigen zoom, geelachtig grauw. Kop klein met 2 naar elkander gebogen doorntjes tusschen de sprieten. Oogen donkerbruin. Sprieten kort en vrij dik, bruinachtig rood met het eindlid zwart. Halsschild urnvormig, van achteren in een' langen processus puntig toeloopend; de nek bedekt met eene gele, naar achter toegeronde kap, waarachter de kleur zeer donker is, ja bijna zwart; de drie langskielen zijn grof en loopen evenwijdig; de opstaande zoom van netwerk is bijzonder smal. De zoom der dekschilden daarentegen is zeer breed en bestaat uit drie vrij regelmatige rijen mazen. Onderzijde bruin. Pooten tamelijk kort en dik, roodachtig geel met het laatste tarsenlid zwart.

Bij Arnhem in April, van Med. de Rooij; bij Middelburg in Junij, Leesb.; bij Breda in Mei en Junij, Heylaerts en Leesberg.

\section{Monanthia Cardui L.}

Plaat 9 , fig. 5 .

Linnaets, Syst. nat. V, p. 483, 21. - Fabr. S. Rhyng. 125, 3. Burm. Hundb. II, p. 260, - Fallen, Hemipt. I, P. 143, 2. - Panz. D. 
Fauna 3, n० 24. - Fieb. Ent. Mon. P, 61, 3, tab. 5, f. 1-8. - Flor, Rh. Livl. I, p. 345. - Douglas and Scott, Brit. Hem. p. 251.

Lengte $3,5 \mathrm{~mm}$. - Ovaal, vrij plat, zwart, op de bovenzijde zeer licht grauw of grijs. Kop klein, wit met een driehoekig grijs vlekje op den schedel en donkergrijze wangen. Sprieten kort, slechts een vierde van de lengte des ligehaams; de twee eerste leedjes zivart, het derde vrij dili, rood, het vierde zwart, als een ovaal knopje aan het eind van het $3^{\text {e }}$ hangend, iets dikker en van de helft zijner lengte. Oogen bolrond, zwart. Op den schedel twee witte nedergebogen en vooruitstekende doorntjes en daarachter nog een onduidelijk derde. De zuiger reikt tot over de middelheupen. Het borststuk op het verhoogde gedeelte groenachtig grauw, met drie paralelle langsrigchels, die schier aan den voorrand beginnen en waarvan de middelste over de kap (halsblaas) en tot aan het eind van het schildbedekkend nitsteeksel loopt, terwijl de zijdelingschen slechts even op dat nitsteeksel doorloopen; het borststuk zelf is gekorreld, op vele plekken langs de randen der rigchels zijn de korrels zwart, voornamelijk is dit het geval aan het einde van den middenrigehel. De randen, die een weinig opgewipt zijn, bestaan uit een netwerk van zeer fijne mazen, waarvan die aan de uiterste zijranden zwart zijn. De dekschilden hebben een bijna langwerpig ruitrormig, doch aan de buitenzijde toegerond middenveld, eene zeer gionte membraan van zeer fijne mazen, een zeer smal verlengd zijdeveld en een vrij breed, niet opstaand randveld. De plaatsing der zwarte vlekjes zie men in de figuur na. De borst is zwart met lichtgrijze randen der onderdeelen, de buik ongevlekt zwart, de pooten geelrood met bruine of zwarte dijen.

Deze dieren leven tusschen de schubben der distelkoppen en onder de distelbladeren. De heer Six vond ze in tamelijk grooten getale op die planten in de omstreken van Utrecht; de heer de Graaf in Maart onder dorre bladeren te Wassenaar; de heer Ritsema bragt ze in het laatst van Mei van zijn uitstapje naar Texel mede en ik ving ze in Julij bij Middelburg eu Rotterdam. Sedert werden zij weder in Junij bij Huissen 
door van Medenbach de Roo:j en op Walcheren door den heer Gerth van Wijk aangetroffen.

\section{Monanthia Humuli F.}

Plati 9, fig. 6.

Fabr. Syst. Rh. 126, 7. - Burm. Handb. II, p. 261, 5. (M. convergens). - Herr. Sch. Wanz. Ins. IV, p. 15, pl. 114, f. 361 (twijfelachtig). Fieber, Ent. Mon. p. 84, tab. 7, f. 17 en 18. - Flor, Rhynch. Livl. I, p. 355. - Douglas and Scott, Brit. Hem. p. 244.

Lengte 3 of $3,5 \mathrm{~mm}$. - Gelijkt wel op den vorigen, doch is terstond te onderscbeiden door den zwarten kop en de beide roode eerste leedjes der sprieten. De kleur van thorax en dekschilden is meer uit den bruingelen. De kop is geheel zwart, behalve de witte bucculae, waar tusschen de zuiger ligt, en schier onbedoornd. De zuiger strekt zich tot tusschen de middenheupen uit. De sprieten zijn langer en slanker dan bij de vorige soort, rood behalve het bijna peervormige laatste lid; het $3^{\mathrm{e}}$ is zeer slank en 3 maal langer dan de beide eersten te zamen. De randen van het halsschild zijn naar beneden omgeslagen, de kap is klein, bruinachtig groengrauw met witte streep op het midden, die het begin van den middenrigchel is, welke tot het eind van den processus doorloopt; de zijderigchels ontspringen digt bij elkander, aciter de kap, en loopen van daar beneden tot het begin van het uitsteeksel, zoodanig dat de grond, dien zijn insluiten, een' gothischen boog vormt. De zijranden zijn overal even breed en als met glinsterende korreltjes bezet. De dekschilden hebben cen breeder zijdeveld, dan bij de vorige; zij loopen op $\frac{2}{3}$ der lengte met eene bogt aan de zijrand in en zijn van daar af een kantwerk met vrij grove, vierhoekige of bijna ronde mazen. Behalve vier zwarte vlekjes, twee op het midden van den buitenrand van het middenveld en twee aan zijne spits, ziet men een aantal zwarte aderen in het randveld, waarvan de binnenrigehel mede grootendeels zwart is. De heupen zijn bruin, de pooten peenrood met bẹt laatste lid der tarsen zwart. 
Deze soort is door verschillende personen op verscheiden plaatsen aangetroffen, waarvan de lijst volgt. De schrijvers beweeren dat zij op vergeet-mij-niet (Myosolis) leeft, 't geen bewaarheid is doordien de heer Groll haar bij Haarlem op eene soort van dat plantengeslacht waargenomen heeft. - Bij Utrecht in Mei, Six; bij Rotterdam, Snellen; in het Overmaassche land, Piaget; bij Rijnsburg in Augustus en op de Gliphoeve in Mei en Augustus aan eenen slootkant, v. Vollenhoven. Zonderling is het dat de heer Ritsema ze te Leyden in Maart in nesten van zangrogels aantrof.

\section{Monanthia Wolffii Fieb.}

Plaat 9 , fig. 7.

Fieber, Ent. Monogr. p. 86, $\mathrm{I}^{0} 30$, pl. 7, f. 22-24. - Wolff, Icon. Cim. p. 130 , t. 13 , f. $124 a b$ (Ac. Echii). - Herr. Sch. Wanz. Ins. IV, p. 14, tab. 114, f. 360 (Echii). - Flor, Rh. Livl. I, p. 352.

Lengte 3 of $3,5 \mathrm{~mm}$. - Gelijkt op de beide vorigen, doch is terstond te onderscheiden door den zwarten rug met grijze randen van den thorax.

De geheele kop is zwart en heeft geen doorntjes. De sprieten zijn weder vrij lang en slank, als bij de laatste soort, doch hunne beide eerste leedjes zijn zwart, het $3^{\mathrm{e}}$ rood, aan de spits iet of wat knodsvormig, het $4^{e}$ zwart, spoelvormig. Rug van den thorax grof gekorreld, zwart, de rigchels vuilwit, de middelste doorloopend, de zijdelingschen eerst digt bij het nitsteeksel beginnend. De halskap breed maar kort, lichtgrauw even als de gezwollen zijranden en de processus. Dekschilden grauw; het middenveld iets lichter met twee zwarte plekken op de plaatsen als bij de vorige soort, doch grooter en duidelijker; de membraan bestaat uit grove mazen; haar zoom en het geheele randveld uit nog iets grover mazen met afwisselend grauwe en zwarte aderen, 't geen zeer sierlijk staat. Heupen en dijen zijn zwart; de scheenen en het $1^{e}$ lid der tarsen zijn rood, het $2^{\mathrm{e}}$ zwart.

Alleen op het duin werd deze soort angetroffen, de heeren 
Piaget en Everts vingen er voorwerpen van bij Velzen in Junị, de heer Ritsema in Maart op Middelduin bij Overreen; de heer Groll bij Haarlem op Echium; desgelijks de heer Six bij Wassenaar.

\section{Mon. vesiculifera Ficb.}

Plat 22, fig. 9.

Fieber, Entom. Monogr. p. 87, no 31, pl. 7, f. 25, 96. - Herr.-Schanf. W. Ins. IV, p. 15 , tab. 144, f. 362 (I. costata).

Lengte $3 \mathrm{~mm}$. - Kenbaar aan de 4 blaasachtige verherenheden op de dekschilden. Geclachtig wit en zwart gemengd, breed ovaal, naar voren een weinig uitgerekt. Kop zwart, ruw, met 2 kleine stekeltjes op het voorhoofd; voor de ronde, roodbruine oogen een wit streepje. Sprieten zeer dun en tamelijk lang; lid 1 en 2 licht zalmrood, 3 geel, 4 zwart, van onder halfweg geel. Borststuk midden op zwart, aan de zijkanten gemarmerd, de 3 langsrigehels wit. Dekschilden zeer breed met tamelijk fijn netwerk, dat echter aan den buitenrand grover mazen heeft. De buitenste der beide kielen vertoont twee zwarte blazen; de mazen in het midden van den zijrand en aan den achterrand zijn zwart, de overigen geelachtig wit. De onderzijle is zwart met opstaande witte randen van de borstgleuf, waarin de zuiger ligt. De pooten zijn zeer licht geel.

Deze soort werd voor het eerst bij ons waargenomen door den heer Snellen, die imagines en larven bij elkander aantrof in de omstreken van Rotterdam. Later vond de heer Heylaerts haar ook bij Breda, en Dr. Everts bij 's Gravenhage.

\section{Mon. quadrimaculata Wolff.}

Plaat 9, fig. 8 en $8 a$.

Wolf, Icon. Cim. p. 132, tab. 13, f.127. - Fallén, Hemipt. 144, 4.Herrich-Schaeffer, Wan₹. Ins. IV, p. 58, tab. 125, fig. A. - Fieber, Ent. Mon. p. 81, tab. 7, f. 1-3. - Donglas and Scott, Brit. Hem. p. 247.

Lengte $3 \mathrm{~mm}$. - Duidelijk van de drie vorigeu onderseheiden door donkerbruine kleur en zeer ver uitstekende membraau. 
Het ligchaam schijnt langer te zijn dan tweemaal zijn breedte, doch dit is aan de verlengde dekschilden toe to schrijven. De kleur van de borenzijde is donker roodbruin, die van de onderzijde is lichter, geler. De sprieten en pooten en vier doorntjes op het voorhoofd zijn rood, alleen het $t^{\circ}$ leedje der eerstgenoemden is zwart; hun derde lid is zeer lang en slank, 4 maal zoo lang als de twee eersten te zamen. De kap is klein en heeft in profiel gezien eene flaauwe inkeeping achter den rand; daarachter verheft zich het borststuk bultig; de drie rigehels loopen evenwijdig, digt bijeen en geheel door. Het borststuk is tamelijk fijn gekorreld; het middenveld der dekschilden even zoo fijn van mazen; het zijdeveld is zeer smal en moeijelijk van het randreld te onderscheiden; dit laatste heeft voor 2 rijen grove doorsehijnende mazen, achter een; ongeveer op de helft is eene langwerpig vierkante plek, waar de mazen reel digter bijeen staan en die dus niet doorschijnend is, maar bruin; de membraan of het eindveld heeft mazen die ietwat grover zijn, dan die van het middenveld.

Mijne beschrijving en afbeelding komen niet geheel overeen met die der aangehaalde schrijvers; het schijnt dat mijne voorwerpen tot eene zeer donkere verscheidenheid behooren. I I ving mijne voorwerpen in groot aantal, op de Gliphoeve in Augustus, te Leyden in mijnen tuin in het rroege voor- en late najaar, steeds op perenboomen. Ook de heer Six zond mij een exemplaar uit Utrecht, aldaar in Mei gevonden. - In de naamlijst staat deze soort onder den naam van Dumetorum $\mathrm{H}$. Sch. opgeteekend; het zou mij niet verbazen indien deze laatste slechts eene kleinere, sterker gevlekte varieteit ware. $\left.{ }^{1}\right)$

\section{Monanthia nigrina Fall.}

Plaat 9, fig. 9 en $9 a$.

Fallen, Hem. Suec. I, p. 145, 5. - Herr. Sch. Wanะ. Ins. IV, p. 52,

1) Zie overigens over Dumetorum het werk van Fieber, p. 82 , fig. 4-fi cn Brit. Hemipt. van Douglas and Scott, p. 246. Indien er werkelijk twce soorten bestaan, kan ik bepaaldelijk verzekeren dat zij in grooten getale door elkunder gemengd op denzelfden boom voorkomen. 
62, tab. 125, f. 5 cu IX, p. 156. - Zett. Ins. Lapp. p. 269, 3.-Flor, Khynch. Livl. 1, 1. 334. - Misschien ook Panzer, F. Germ. 118, 16.

Lengte $2 \mathrm{~mm}$. - Deze en de volgende soort, die zeer sterk op elkander gelijken, onderscheiden zich van de vorigen door eene ongevlekte grauwe kleur en rooral door de relaticf groote mazen hunner dekschilden.

Ovaal, donkergrauw. De kop kort en rrij breed met twee vooruitstekende doorntjes op den schedel en cen kegelachtig wratje voor de oogen. De sprieten niet langer dan een derde der lengte van het ligehaam, slank; de beide cerste leedjes bruingrauw, kort, het derde dun, rood, aan de basis iets dikker, meer dan 3 maal zoo lang als de beide vorigen te zamen, het vierde kort, spoelvormig, zwart. De zuiger reikt tot aan het middenpaar der beupen. Borststuk in het midden bol, sterk met putjes ingedeukt; de halskap steekt ver naar voren, de rigchels bestaan uit kantwerk met eene rij vierhoekige mazen; de zijrigchels zijn naar elkander gebogen; de breede zijranden, wat opgewipt naar de kanten hebben voor drie rijen mazen, achter slechts twee. De dekschilden steken aan de zijden en van achter een geheel eind over het abdomen heen; hun middenveld is zeer langwerpig en de buitenrigehel er van weinig gebogen; het zijdeveld is tweemaal breeder dan het randveld en naar beneden gerigt; het randveld heeft aan de schouders twce rijen mazen, verder op maar ecn. Pooten grauwgeel, het laatste lid der tarsen zwartachtig.

Volgens Flor en Fallèn zou de kleur van het lijf zwart zijn, 't geen ook aanduiding geeft van den naamsoorsprong. De heer Six trof deze soort nict zelden aan in Julij te Utrecht; ik vond haar in Augustus te Heemstede.

\section{Monanthia parvula Fall.}

Plaat 9, fig. 10 en $10 a$.

Fallen, Hem. Suec. I, p. 145, 6. - Flor, Rhynch. Livl. 1, 1. 3335.Misschien ook Panzer, Fn. Germ. 118, 23 (testacea) en Fieb. Ent. Mon. 1. 62, tab. 5, 1. 19-22 (11. Echinopsis). 
Lengte 1,5 mm. - Zeer sterk gelijkend op de vorige en slechts bij vergelijking te onderscheiden. Zij is kleiner en vooral korier. De kleur is dezelfde. De kop is aan de onderzijde door de bucculae rond en nict opgewipt, hoekig in profiel; de doorntjes op den schedel zijn korter. De sprieten zijn veel donkerder van kleur, meer bruin dan rood. De thorax is naar voren eigenlijk smaller dan bij Nigrina, doch de breedte der zijranden doet dit weinig in het oog loopen; ook is de kap iets langer. Het grootste verschil bestaat in de dekschilden, wier middenveld an den buitenrigebel S-vormig gebogen is, welke bogt ook eigen is aan het geheele zijdeveld. Zij hebben bovendien veel grover mazen dan Nigrina, vooral op de membraan.

Het blijft echter altijd twijfelachtig of dit wel eene zelfstandige soort is en niet eer eene verscheidenheid. De meeste beschrijvingen en figuren kunnen ons niet helpen in de oplossing van dit vraagstuk; zij zijn te onvolledig en te slecht. Monanthia testacea $\mathrm{H}$. Sch. van de naamlijst is deze zelfde soort.

Zij werd in Angustus aan de Bildt door den heer Six aangetroffen en in hetzelfde jaargetijde door mij op de Gliphoeve.

B. Soorten bij welke de dekschilden niet over elkander staan.

\section{Monanthia cervina Germ.}

Plaat 9, fig. 11 en $11 a$.

Germar, Fauna Ins. Eur. 18, f. 22. - Herr. Sch. Wans. Ins. IV, p. 26, pl. 118, f. 375. - Fieber, Ent. Mon. p. 48, no 2, pl. 4, fig. $1-3$. - Flor, Rh. Livl. I, p. 341. - Douglas and Scott, Brit. Hem. p. 262, pl. 9 , fig. 7 .

Lengte 2,כ $\mathrm{mm}$. - Tamelijk breed ovaal; geclachtig grauw met de aderen van het netwerk slechts weinig donkerder. De kop bruin, kort, met 2 divergerende lange stekels en voor ieder oog een korter doorntje. De sprieten zijn rood, behalve de spits van het $3^{\text {e }}$ lid en het geheele vierde, welks top met zilverwitte haartjes dik bezet is; ook is het eerste lid donkerder dan de overigen; in het geheel ziju de sprieten in lengte 


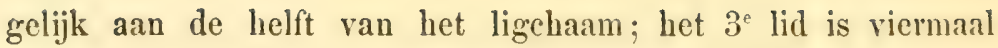
zoo lang als het 4 . De oogen zijn groot en rood met bruinen tint. De thorax is kort en breed, de kap bruin met naanwe mazen, de langsrigehel daarachter hoog en uit ecne rij van 5 vierhoekige mazen bestaande; de beide zijdelingsche rigchels divergeren naar achteren; de zijranden breed, naar achteren slechts weinig versmald, een weinig opgewipt, nit 3 onregelmatige rijen mazen bestaande; de processus zeer weinig nitstekende. De dekschilden met hooge rigehels en vrij groote ronde mazen, sluiten niet aan het begin der naad. Het middenveld en de daartussehen gelegen randen zijn vlak, het zijdeveld dat breeder is dan het randveld, loopt schuin naar beneden en het randveld wipt op. De rigehel tussehen midden-en zijdeveld loopt S-vormig, doch is oni zoo te spreken slordig en kinderachtig geteekend. Het randveld heeft slechts 2 rijen mazen. Geheel aan de spits slaan de dekschilden voor een bitter klein geleelte toch wel over elkander, doch men bespeurt het niet zonder goede loupe. De pooten zijn slank en geheel lichtgeel.

Cerrina is eens of twecmaal bij Driebergen gevangen door d in heer Six.

\section{Monanthia carinala Panz.}

Plaat 10, fig. 1 en $1 a$.

Panzer, Fanna Germ. 99, 20. - Fieber, Ent. Mon. 11. 52, 11 4, lir. 10. - Misschien ook Herr. Sch. Wanz. Ins. IV, p. 21, tab. 118, lig. 373 (II. pusilla Fall.).

Lengte 2 mm. - Dadelijk bericenbaar aan den zwarten kop en de geheel zwarte sprieten. De thorax en deksehilden zijn grauw van kleur, het achterlijf zwart, de vorm icts mecr rond dan bij de vorige. De doorntjes op den kop zijn hier kleiner, de halskap is duidelijk te onderscheiden, daarachter is de thorax ingedenkt en donker gekleurd. De zijranden van den thorax zijn zeer weinig opgewipt en naar voren zuirer afgerond, de zijrigehels loopen een weinig krom naar binnen. De deksehilden rormen met elkander cen zeer breed, bijna cirkelvormig 
ovaal, hun middenveld is veel smaller dan bij Cervina en veel gelijkmatiger van breedte, hun zijdeveld is breeder, doch daarentegen het randveld smaller en het bestaat slechts uit eene rij mazen. De pooten hebben roodachtig zwarte heupen en dijen, met roode scheenen en tarsen.

Het is deze soort, die wij in onze naamlijst ten onregte Orlhostcira macropthalma Fieber genoemd hebben; deze, ofschoon zeer na aan Carinala verwant, heeft een langwerpiger vorm en zoo het schijnt, minder zuiver zwarten kop en sprieten. Eeliter, ik herhaal het, valt over de validiteit der soorten van het geslacht Monaulhia niet te oordeclen, dan nadat men die soorten uit de larve zal hebben opgekweekt.

Volgens den heer G. A. Six is Carinala in Julij bij Driebergen niet zeldzaam.

\section{Monanthia obscura H. Sch.} Plaat 10, fig. 2.

IIerr. Schaefi. Wans. Ins. IV, p. 23. - Fieber, Ent. Monogr. 1. 54, 110 17, tab. 4, fig. 22-25. - Douglas and Scott, Brit. Hem. p. 263.

Lengte $1 \mathrm{~mm}$. - De kleinste van allen en daaraan wel te herkennen, daarenboven duidelijk ondersebeiden van de voorgaande door hare rosse sprieten. Het gehecle dier is grauw, behalve de buik die somtijds roodbruin is, de oogen die rood zijn, de sprieten en pooten. De kop is kort en zijne doorntjes weinig nitstekend, zijne kleur is uit den rossen grauw. De sprieten zijn korter dan de halse lengte van het ligehaam, rosachtig geel, behalve het laatste lid, dat donker zwart is; ook is het eerste somwijlen iets donkerder dan het $2^{\text {c }}$; het $3^{\text {e }}$ is bijzonder dun. Het borststuk is zeer kort en de halskap naar evenredigheid bijzonder groot; de eirenlijke schijf is donkergrauw, de rigchels, die zeer licht van kleur zijn, loopen daarover divergerend naar achter, de zijranden steken niet sterk naar voren uit, doch zijn toch stomphoekig en niet rond. De processus is van den thorax door cene diepe naad duidelijk afgescheiden, breed drichoekig en nit netwerk zamengesteld. 
De dekschilden zijn langwerpiger dan bij de vorige en vooral is de uiterste spits nitgerekt; het middenveld is iets breeder, daarentegen het zijdeveld, ten minste naar achteren toe smaller; het randveld is smal en bestaat slechts uit eene rij mazen, behalve aan de uiterste voorlap. De pooten zijn geheel grauwachtig geel, behalve het laatste lid der tarsen dat zwart is.

Deze soort werd in September door mij bij Heemstede gevangen en bij Utrecht en Driebergen door den heer Six, door ons beiden bij den Haag, in Junij door mij bij Velzen en in April door den heer Heylaerts bij Breda. Ook bezit 's Rijks Museum een voorwerp vroeger door den heer de Haan in Holland aangetroffen.

Gen. 3. Caypylostira Fieb.

Langwerpig ovaal en in het algemeen sterk op vele soorten van het vorige geslacht gelijkende en daarmede overeenkomende in den vorm der sprieten en pooten en van den zuiger, alsmede in het bezitten van drie langsrigchels op den thorax, doch verschillend in de volgende opzigten. Aan het borststuk ontbreekt de halskap en de voorrand is naar achteren hol, in plaats van naar voren bol te zijn; het middenveld der dekschilden loopt zonder afscheiding door tot aan de spits, waar zij in het rand. veld overgaat; zoodat de vleugel uit niet meer dan 3 velden schijnt te bestaan, een smal randveld aan den voorrand, een ietwat breeder zijdeveld, daarmede evenwijdig, en een derde veld, dat uit middenveld en eindveld zamengesteld is.

Slechts eene soort van dit geslacht is in Nederland waargenomen.

Camp. verna Fall.

Plaat 10 , fig. 3.

Fallèn, Hem. Suec. p. 147, 9. - Herr. Sch. Wans. lns. IV, p. 6.', tab. 127, fig. 398. - Fieb. Ent. Mon. p. 45, tab, 3, f. 38, - Douglas and Scott, Brit, Hem. p. 258. 
Lengte naauwelijks $2 \mathrm{~mm}$. - Bruin met het abdomen geelachtig en de deksehilden met den zijrand van het borststuk doorschijnend; langwerpig ovaal. De bruine kop is driehoekig op den schedel ongedoornd, met twee stompe nitsteeksels tusschen de sprieten en de oogen voorzien; bucculae naar achter breeder dan naar voren. Oogen rond en zwart, matig groot. Zuiger tot midden tussehen het tweede paar der heupen reikend. Sprieten zoo lang als kop en thorax, matig dik, bruinrood met het laatste lid donkerder; het $1^{e}$ lid is klein, het $2^{e}$ iets grooter en dikker, door een uiterst fijn steeltje met het vorige verbonden, het $3^{\text {e }}$ smaller dan 2 doch vijf maal zoo lang, aan de spits ietwat verbreed, het $4^{\mathrm{e}}$ peervormig, $2 \frac{1}{2}$ maal korter dan 3. IIet eigenlijke borststuk (zonder den doorschijnenden zijrand) aan den voorrand smaller dau de kop, daarna echter vansvormig verbreed; de voorrand een weinig gezwollen en op die hoogte verbonden aan de 3 langsrigchels, die nagenoeg paralel loopen; de achterrand is wel rond nitgebogen, maar cen processus ontbreckt; de zijranden bestaan nit twee rijen onregelmatige mazen. De dekschilden zijn aan de inplanting smal, verbreeden zich dan gaande weg en nemen voorbij $\frac{2}{3}$ der lengte weder in breedte af; aan de apex zijn zij afgerond; ter plaatse waar het schildje wezen moest, laten zij eene driehoekige ruimte van het abdomen onbedekt, die in mijn voorwerp met witte haren bekleed schijnt. De beide velden aan den voorrand hebben veel fijner mazen dan het overige gedeelte. Of er vleugels anwezig zijn is mij onbekend. De pooten zijn slank, bruingeel.

De af beelding van Herrich-Schaeffer, aan welks juistheid Fieber twijfelt, is vrij goed van teekening, doch zeer slecht en slordig van coloriet.

Van deze soort zijn er een of twee exemplaren gevangen bij Utrecht in Augustus door den heer Six.

\section{Gen. 4. Derephisia Spin.}

De kop is klein en tusschen de oogen met twee scherpe 
stekeltjes gewapend. De oogen zijn matig van grootte, bolrond. De zuiger reikt tot voorbij het laatste paar pooten. De sprieten staan tusschen de oogen in, zijn iets langer dan de helft van het ligchaam, lebben een knobbeltje aan hunne basis en bestaan nit rier leedjes, waarvan de beide laatsten behaard zijn. Het borststuk is eigenlijk breed vaasvormig, doch zijn omtrek verkrijgt eene geheel andere gedaante door den halskap, de zijranden en den processus; de eerste is zeer groot en steekt een geheel eind over den kop heen; in profiel gelijkt hij op de kap van een cabriolet (zie fig. $4^{a}$ ); de zijranden zijn naar voren tot even voorbij den kop uitstekend, aan de zijden vrị sterk opgewipt en naar achteren versmald en toegerond. De processus is vrij lang en puntig, en bestaat uit netwerk; de drie rigchels zijn dun en hoog, vooral de middelste. De dekschilden bestaan, even als de zijranden van het borststuk, uit netwerk van zeer groote mazen; hun midden- cn zijdeveld zijn dakvormig tegen elkander opgerigt en het randveld is een weinig opgewipt; naar het einde toe is het middenveld niet gesloten. De pooten zijn matig lang en zecr slank.

\section{Derephysia foliacea Fall.}

Plaat 10 , fig. 4 en $4 a$.

Fallèn, Hem. Suec. 1, p. 149, 12. - Herr. Schaeff. Deutsch. Ins. 118 , 18. - Idem, Wanะ. Ins, IV, p. 70, tab. 129 D. et 130 M. N. - Fieber, Ent. Mon. P. 99, tab. 8, ศ. 23-27. - Hor, Rhynch. Livl. 1. 36. Douglas and Scott, Brit. Hem p. 25\%, pl. 9, fig. 4.

Lengte 2,5 of $3 \mathrm{~mm}$. - Kop en thoraxrug zwart, borst bruin en abdomen ruil geel. De sprieten zijn donkerbruin met het eindlid zwart; de twee eerste leedjes te zamen zijn zoo lang als de kop, het derde is wel viermaal zoo lang als deze beiden, zeer gelijkmatig van dikte en iets rooder van kleur, met tamelijk lange fijne zwarte haartjes bekleed; het $4^{\circ}$ is pecrormig, zoo lang als de beide eersten te zamen, aan de basis rood, verder zwart en mede behaard. Het netwerk van kap, zijranden en dekschilden is iriserend wit met bruinachtig 
grauwe aderen; de mazen zijn veel grooter dan bij eenige andere inlandsehe soort. De vleugeltjes zijn zuiver wit, zeer sterk iriserend met flaauw gekleurde aderen. Aan de bruine borst ziet men grijze randen en grauwe vlekken. De zuiger en pooten zijn vuil bruinachtig geel, even als het abdomen.

Volgens den heer Six is deze soort niet zeldzaam op drooge gronden tusschen het schrale gras bij Utrecht en Driebergen; de heer Perin heeft haar bij Leiden gevangen. Op eenige wandelingen in gezelschap met den heer Six in den nazomer vonden wij Der. foliacea niet zeldzaam op ecne bepaalde plek van het begroeide binnenduin van Waalsdorp.

\section{Gen. 5. Agramia Westw.}

Dit geslacht, door Laporte Piesma genoemd, rersehilt ran al de overigen in de familie der Netwantsen doordien het borststuk aan den voorrand den doorzigtigen met netwerk bedekten blaasvormigen kap mist en tevens zijne zijranden ook niet bladachtig verbreed en met netwerk bedekt zijn. In alle overige opzigten past dit genus volkomen in de familie.

\section{Agramma laelum Fall.}

Plaat 22, fig. 11.

Fallen, Hem. Suec. I, 151, 15. - Burm. Handb. 111, 257, 1. - Germar, Faun. Ins. Eur. 10, 14. - Herr. Sch. W. Ins. IV, p. 49, pl. 122, f. 388. - Flor, Rh. Livl. I, p. 324. - Douglas and Scott, Brit. Hem. p. 242, pl. 9 , f. 1.

Lengte $2 \mathrm{~mm}$. - Zwart, met den voorrand van het halsschild wit, den processus en de dekschilden zeer licht grauw. Kop rond, zeer weinig gestippeld; ongen groot, doch vrij plat, zwart. Sprieten zwart, niet veel langer dan $1 \frac{1}{2}$ maal de lengte van den kop, tamelijk dik en naar buiten gekromd. Borststuk zwart, grof gestippeld, met den voorrand op den rug naar achteren ingebogen, de zijranden met eene zeer geringe golving 
voor het midden, de achterhoeken afgerond en de breedte aldaar slechts anderhalf maal die van den voorrand. Een wit zoompje langs den voorrand, kort daarachter eene dwarsgroef; de processus iets neergedrukt, licht geelachtig grauw. Dekschilden langer dan het achterlijf, van kleur als de processus, uit eene soort van netwerk bestaande, even als hun zoom, die zeer smal is; de membraan is van het corium door geen zoom of rigchel afgescheiden. Pooten kort en vrij dik, rood met zwarte klaauwtjes.

Deze soort is, waar zij voorkumt, in grooten getale vereenigd aan te treffen. Zij werd gevonden bij den Haag door den heer Six, in het midden van April door den heer Heylaerts bij Breda en in Junij bij Noordwijk door Dr. Everts. 
NEGENDE FAMILIE. - HEBROIDEN.

\author{
HEBROIDES.
}

Deze familie is, even als de derde, hier te lande slechts vertegenwoordigd door eene soort, zoodat de familie- en geslachts-kenmerken zamenvallen. Eene inlandsche benaming bestaat voor haar niet, angezien de eenige soort hoogst zelden voorkomt en dus tot heden voor de oogen van het groote publiek verborgen bleef. De ware plaatsing der familie is bovendien eenigzins moeijelijk, daar zij naar hare levenswijs groote verwantschap toont met de volgende familie der Oeverwantsen en zelfs met de geslachten Velia en IIydroessa onder de Waterwantsen, doch in ligchaamsgedaante en vooral in den vorm van den zuiger en de tarsen overeenkomst toont met de Netwantsen.

Het ligchaam is vrij breed en ineengedrongen, hard van bekleeding. De kop is middelmatig groot, van boven gezien hijna vijfhoekig, op zijde gezien driehoekig met gebogen voorrand. De oogen staan op de zijden van den kop en zijn klein, ovaal en grof van facetten; daartusschen, verder van elkander dan elk van het oog aan zijne zijde, twce ocellen. De sprieten staan meer naar voren dan de oogen, elke op een kleine verhevenheid en bestaan uit vijf leedjes, waarvan echter de beide voorlaatsten aan de basis nog eene afsnoering hebben, zoodat er schijnbaar 7 leedjes aanwezig zijn. Het eerste lid is het langste en dikste, de drie middelsten zijn slanker, echter 2 dikker dan $3 ; 5$ is dikker dan 2 en spoelvormig. De zuiger bestaat uit 4 leedjes, waarvan het eerste het langste en geheel in eene gleuf aan de keel verborgen is.

De prothorax is grof en breed, doch niet bijzonder lang, in 
het midden der zijden ingedeukt en aan den bollen achterrand meer dan tweemaal zoo lang als aan den voorrand. Het schildje is klein, korter dan zijne basis lang is; in het midden is een fijn dwarsgleufje en de punt is meer stomp dan spits. De dekschilden bezitten clavus, corium en membraan, doch de eerste en laatste zijn van dezelfde, van aderen ontbloote lederachtige zelfstandigheid, terwijl het corium hoornachtig is; de dekschilden zijn aan het eind zeer breed naar gelang hunner lengte en bedekken het abdomen geheel; de vleugels hebben eene drichoekige cel aan de basis en eene van daar uitloopende ader. Het abdomen is aan de bovenzijde plat, an de buikzijde toegerond, doch in het midden weder eenigzins afgeplat. De genitaalsegmenten zijn slechts van onderen zigtbaar.

De pooten zijn matig lang, wat gebogen; hunne tarsen hebben twee leedjes, doch het eerste daarvan is bijzonder klein; het tweede draagt 2 klaanwtjes en twee zuiglapjes.

\section{Genus Hebrus Curt.}

Kenmerken hierboven opgegeven.

\section{Hebrus pusillus Fall.}

Plaat 17, fig. $1,1 a, 1 b$.

Fallèn, Mon. Cim. 71, 19. - Germ. Faun. Ins. Europ. 15, pl. 11. Westw. Ann. d. l. Soc. Ent. III, p. 652, pl. 6, f. 6. - Flor, Rhynch. Livl. I, p. 374. - Douglas and Scott, Brit. Hem p. 266, pl. 19, f. 4.

Lengte 2 millim. - Zwart, aan de onderzijde met grijze haartjes bezet. Kop aan de voorkant witachtig, om den zuiger heen ros; zuiger zelf bruinachtig geel. Oogen bruin. Sprieten zwart, doch de basis van het $1^{e}$ lid en het $2^{e}$ bijna geheel bruingeel. De achterrand van het borststuk bruin. Corium donker zwart met een wit streepje in het midden aan de basis; clavus aan de basis sneeuwwit; membraan bruinachtig met 3 witte vlekjes, 2 aan de zijden en een aan de spits. Pooten vuilgeel met de spits der tarsen zwart. 


\section{9}

Dit diertje leeft in slooten en waterpoelen op krous. De heer A. G. Six ving er eenige exemplaren van bij Driebergen en Periu eenigen in April in slooten bij Leyden. Waarschijnlijk is het in ons land niet zeldzaam en maar alleen door zijne kleinheid an het $00 \mathrm{~g}$ van andere entomologen ontsuapt. 


\section{TIENDE FAMILIE - OEVERIVANTSEN.}

RIPARII.

Dat de naam der familie van het oponthoud der Oeverwantsen aan de oevers van beekjes, moerassen en poelen afgeleid is zal wel niet behoeven gezegd te worden. Zij schijnen voornamelijk in menigte voor te komen bij plassen van zeewater op de eilanden en in of bij brak water aan de rivieroevers.

Hun ligebaam is eivormig, korter of langer, van boven zeer flaauw gewelfd, van onder veel sterker. Hun kop is van boven gezien min of meer driehoekig, met een zeer kort halsje en met bijzonder groote bolle, uitpuilende oogen en 2 kleine digt bijeen staande bijoogjes daartusschen op het voorhoofd. De sprieten staan voor de oogen, ter zijde onder den voorrand van den kop, zijn korter dan het ligchaam en bestaan uit 4 leedjes, waarvan het tweede, dunner en langer dan de overigen, die meestal onderling van gelijke lengte zijn, gewoonlijk een weinig gekromd is. De zuiger is lang en dun, geheel onbedekt, doch naar de zijde van den buik uitgestrekt; hij bestaat uit drie leedjes, waarvan het eerste zeer kort en het tweede veel langer is dan het derde.

Het horststuk is aan den achterrand altijd veel breeder dan aan den voorrand en heeft gewoonlijk rond gebogen zijden, terwijl de achterrand diep naar voren ingedeukt is; er zijn twee dwarsgleuven, een aan den voorrand, de tweede in het midden; tusschen deze beiden ziet men wel eens twee knobbeltjes. Het schildje is groot, gewoonlijk veel langer dan de prothorax. De dekschilden bestaan uit duidelijke clavus, corium en membraan, en bedekken steeds het geheele achterlijf. Op het corium ziet men dikwijls 2 of 3 verhevene aderen; de mem- 
braan onderscheidt zich van die van andere wantsen doordien hare 5 of 4 langsaderen voor den rand in elkander loopen, zoodat er 6 of 5 gesloten cellen en eene randcel ontstaan. Somtijds blijven de vleugels onontwikkeld en in dat geval zijn ook de verdeelingen der dekschilden onduidelijk. De pooten zijn tot loopen, niet tot zwemmen geschikt, vrij lang en slank; hunne beupen staan bij paren tegen elkander aan, hunne dijen zijn gewoonlijk onderling van gelijke dikte, hunne scheenen met stekeltjes bezet. De tarsen zijn vrij lang en zeer dun, uit 3 leedjes bestaande, waarvan het eerste zeer kort is; de klaauwtjes zijn lang en fijn, weinig gebogen.

\section{Genus Salda F.}

De kenmerken van dit eenige inlandsche geslacht worden, als ook die der familie zijnde, hierboven vermeld.

Tafel der soorten.

1 (16). Zijden van den prothorax bol uitgebogen.

2 (9). Rand van den prothorax zwart.

3 (4). Corium geheel zwart.

$$
\text { Sp. 2. Flavipes F. }
$$

4 (3). Corium zwart met witte vlekjes of wit met zwarte.

5 (6). De witte vlekjes alleen aan den achterrand van het corium. Lengte $7 \mathrm{~mm}$.

Sp. 1. Zosterae F.

6 (5). De witte vlekjes ook op het midden.

7 (8). De witte vlekjes op het midden oogvormig.

Sp. 3. Sallatoria L.

8 (7). Eene vrij groote vlek voor en op het midden bandvormig.

$$
\text { Sp. 4. Pallipes F. }
$$


9 (2). Rand van den prothorax wit of geelwit.

10 (11). Dekschilden harig.

Sp. 5. Pilosa Fall.

11 (10). Dekschilden kaal of slechts met een paar haartjes aan den rand.

12 (13). Corium wit met een bruin vlekje aan den buitenrand.

Sp. 6. Eburnea Fieb.

13 (12). Corium zwart met witten zijrand.

14 (15). Het wit aan den buitenrand een ongetande strook.

Sp. 7. Lateralis Fall.

15 (14) Het wit getand naar binnen inspringend.

Sp. 8. Pulchella Curt.

16 (1). Zijden van den prothorax hol ingebogen.

17 (18). Twee laatste sprietleden verbreed.

Sp. 9. Geminata Cost.

18 (17). Twee laatste sprietleden niet verbreed.

Sp. 10. Cincla H. Sch.

\section{Salda Zosterae F.}

Plaat 17, fig. 2 en $2 a$.

Fabr. S. Rh. 113, 1. - Burm. Handb. II, 216, no 1. - Herr.-Sch. W. Ins. VI, t. 194, f. 599. - Flor, Rh. Livl. 701, $\mathrm{n}^{0} 2 b$.

Lengte bijna $7 \mathrm{~mm}$. - Ovaal, zwart, kaal, schijnbnar olieachtig en dus met een' zeer matten glans. Clypeus en bovenlip bruinachtig geel. Oogen slechts matig uitpuilend, bruin. Sprieten lauger dan de helft van het ligchaam; de beide cerste leedjes bruingeel, de beide laatsten zwart, allen niterst fijn behaard. De zijden van den prothorax zijn bol naar buiten gebogen; hun zoom is een weinig opgewipt en zwart; de achterrand loopt in het midden krom naar voren. Schild lang nitgerekt driehoekig met 2 scheeve indruksels, waardoor de basaalhocken uitpuilen. Dekschilden langer dan het achterlijf, 
een weinig gewelfl, hun zijprand opgewipt; de beide middenaderen van het corium naderen op het midden tot elkander en tusschen hen is aldaar eene wratrormige verdikking. $O p$ den achterrand van het corium naar den naad toe zict men flaauwelijk ter wederzijde twee wigvormige lichtbruine vlekjes. Membraan lichtbruin met den buitenrand, de langsaderen en eene rij langwerpige vlekken tusschen de aderen donkerbruin. Pooten lichtbruin en vrij lang; de basis der heupen zwart; onderkant der voordijen zwart; spitsen en scheenen der tarsen donkerbruin. Haren en stekeltjes aan de scheenen zwart.

In mijne naamlijst staat dat deze soort bij Utrecht gevangen werd; ik kan dit nu niet meer verifieeren, maar betwijfel de juistheid mijner toenmalige determinatie. Zeker is het dat Zosterae in het begin van Junij door den heer Ritsema op Vlieland en ter Schelling en in Julij door mij op de schorren aan den oever der Schelde gevangen is; de heer Heylaerts zond mij ter determinatie een voorwerp, door hem in Junij bij waterpoelen op de Galdersche heido aangetroffen; ook ving Mr. Leesberg een exemplaar in Junij in de omstreken van den Haag. Het voorwerp van den Schelde-oever is eene verscheidenheid met 4 gele rlekjes onder elkander tusschen de beide middenaderen van het corium.

\section{Salda flavipes F.}

Plaat 17 , fig. 5 .

Falbr. S. Rh. 114, 3. - Fieber, Eur. Hemilt. 1. 147, 14.-- Misschien Flor, Rh. Livl. I, p. 710 Morio.

Lengte $5 \mathrm{~mm}$. - Deze soort gelijkt in vorm sterk op de voorgaande, doch verschilt $1^{0}$ in grootte, $2^{0}$ in kleur en $3^{0}$ daarin, dat de kop en de prothorax met een zeer fijn vilt van zilverachtige haartjes bedekt zijn. Het zal overigens voldoende zijn de punten van verschil in kleur aan te geven.

De beide voorste lecljes der sprieten zijn lichter van kleur, de beide laatsten schijnen mij toe langer behaard. Prothorax en schildje hebben een' bruinen gloed. De dekschilden ver- 
toonen geene witte vlekjes op het corium. De membraan is dof zwart met eenigermate glanzige zwarte aderen, eene lichtere spits en twee zeer kleine bruinachtig witte stipjes tegen de eerste ader van buiten af. De pooten zijn veel lichter geel; de basis der heupen, de spits der scheenen en het laatste tarsenlid zijn zwart.

Het zou kunnen wezen dat deze soort niets dan eene verscheidenheid der vorige ware, gelijk Flor en na hem Douglas en Scott schijnen te meenen; Fieher daarentegen deelt die meening niet.

Een voorwerp in mijn bezit werd door den heer Heylaerts in Mei aan de Schelde bij Bergen op Zoom bemagtigd.

\section{Salda sallatoria L.}

Plaat 17, fig. 4.

Linn. S. N. El. 13, 729, 93. - Fabr. S. Rh. 115, 13. - Fall. Hem. Suec. I, p. 73, 3. - Burm Handb. II, p. 216, no 3. - Am. Serv. Hém. 1. 405, no 2. - Hahn, W. Ins. II, t. 55, f. 167. - Panz. D. Ins. II, 92, 13. - Wolf, Ic. Cim. p. 77, t. 8, f. 74. - Flor, Rh. Livl. 713. Douglas and Scott, Brit. Hem. p. 522.

Lengte 3--4 mm. - Dof zwart, met microseopische haartjes bedekt, ovaal. Kop minder breed dan bij de vorige soorten; sprrieten korter dan de belft van het ligchaam; hun eerste lid aan de binnenzijde geelbriin, aan de buitenzijde zwart; de overigen zwart. Borststuk met rond gebogen zịjden en diep naar voren ingebogen achterrand. Schildje met een' dwarsnaad over het midden. Dekschilden zwart met eenige witte vlekjes; bij fraai geteekende voorwerpen staat een langwerpig vlekje op den clavus even voorbij het midden; op het midden van het corium scheef naast elkander twee oogvormige rlekken met zwarte pupillen, daarmaast een witte rlek aan den rand, en eindelijk aan de spits een langwerpig bijna vierhoekig vlekje. De membraan is geelachtig wit met grijsbruinen rand en bruive aderen; tusschen deze eene rij bruine streepjes en aan den rand een zwart vlekje. Somtijds echter is van al deze versie- 
ringen niet veel te zien. Pooten bruingeel of bruin; lunne dijen aan den onderrand zwart en dikwijls aan de achterzijde bezet net zwarte stippen; de basis en spits der schcenen zwartachtig, zoo als ook het laatste lid der tarsen of ten minste de spits er van.

Deze soort, die in geheel Europa voorkomt, is ook bij ons tamelijk gemeen en boudt zich op in vochtige lage streken, aan den kant van poelen en waterplassen. Zij werd gevonden in het Haagsche bosch, an den oever van de voormalige Haarlemmermeer, bij Heemstede, op ter Schelling, bij Utrecht en Driebergen, bij Roozendaal in Gelderland, in Friesland, bij Breda, bij Bergen op Zoom en op Walcheren.

\section{Salda pallipes $\mathrm{F}$.}

Plaat 17 , fig. 10.

Fabr: S. Rh. 115, 12. - Fallen, Hem. Suec. 1, 1. 73, no 4. Hlahn, W. Ins. II, p. 82, pl. 55, f. 166. - Herr. Sch. W. Ins. VI, p. 43, pl. 194, t. 600 (onjuist). - Flor, Rh. Livl. I, p. 715. - Douglas and Scott, Brit. Hem. p. 518.

Lengte 3,5 mm. - Deze soort schijnt in teekening op de dekschilden zeer te varieeren; het eenige mij bekende inlandsche voorwerp is als volgt:

Ovaal, zwart, met microscopische haartjes bekleed, waardoor een rijdeachtige glans ontstaat. De kop zeer breed, met een uiterst fijn geel streepje tusschen de bruine oogen; clypeus en eerste lid der sprieten van onder geel. Sprieten overigens zwart, korter dan het halve ligchaam. Halsschild aan de zijden bol uitgebogen, aan den achterrand veel minder ingebogen dan bij de rorige soort. Het schildje schijnt eene flaauwe dwarse indrukking te hebben in het midden. De dekschilden zijn zwart met geelwitte versiering; van de laatste kleur zijn op elk dekschild een klein driehoekig vlekje an de punt ran den clarus, cen rrij brecde, boven en onder getande dwarsband op liet corium voor het midden, daasorder zes langwerpige vlekjes, waarvan het meest in het oog vallende tegen den buitenrand; 
de membraan aan den binnenhoek zwart met 2 witte vlekjes, verder greelwit met zwarte aderen en daartusschen langwerpige zwarte vlekjes; aan den rand naar de spits van het corium toe een zwart vlekje tusschen 2 witten, en het overige van den buitenrand berookt. Pooten geel; de dijen met eene zwarte streep van onderen, de scheenen met eene zeer fijue zwarte streep aan den buitenkant en met de spits zwart; de 2 voorste leden der tarsen wit, het laatste zwart.

Dit voorwerp werd den $1^{\text {en }}$ September door Dr. Piaget in het duin, waarschijnlijk bij 's Gravenhage, gevangen.

\section{Salda pilosa Fall.}

Plaat 17 , fig. 3.

Fall , Mon. Cim. 29, 3. - Id. Hem. Suec. 74, 5. - Burm. Handh. II, 216, n². 2. Germ. Faun. Germ. 10, 15, - Douglas and Scott, Brit. Hem. p, 518 .

Lengte 4-5 mm. - Deze soort laat zich van de overige inlandschen dadelijk onderscheiden doordien zij niet alleen met zeer fijne nederliggende gele haartjes bekleed is, maar ook aan de bovenzijde met verspreid staande langere opstaande zwarte haren. Zij is zeer breed en gedrongen van vorm, vooral breed voorbij het midden en ook wat boller dan anderen. Haar kleur is licht geclachtig bruin of geel, doch er is verschil in kleur bij de individuen. $O_{p}$ het midden van den kop staat een zwart, hoekig vlekje, waarin de ocellen. De oogen zijn bruin. De beide eerste leden der spricten zijn geel, de beide overigen zwart, bezet met enkele zwarte haartjes. De zuiger is geel met bruine spits.

De prothorax is aan den voorrand vrij breed en de rijilen zijn zeer weinig nitgebogen, zoodat er duidelijke voorhoeken ontstaan; de achterrand is vrij sterk naar voren ingebogen; alle randen zijn geel of bruingeel, het middenveld is zwart of donkergrijs. Het sehildje is vaal grauwbruin en vertoont in het midden een' dwarsnaad. De dekschilden hebben den clavus vaal yrauwbruin met gele spits, het corium geel of bruin met 
de basis zwart en eene zwarte hoekige of halfronde vlek voor de spits. De membraan heeft roestkleurige aderen en daartusschen dikwijls lichtbrnine streepjes. De pooten zijn geel met rijen bruine stippen op de dijen, die borendien dikwijls aan de onderzijde eene donkere langsstreep vertoonen; de spits der scheenen is zwartachtig even als het laatste lid der tarsen, de scheenen hebben zwarte stekeltjes en roestbruine haren.

Van deze zeer kennelijke soort werden verseheidene voorwerpen gevangen in Mei op de schorren der Schelde bij Bergen op Zoom door den heer Heylaerts, in Junij op ter Schelling door den heer Ritsema en op Walcheren door den heer Gerth van Wijk.

\section{Salda eburnea Fieb.}

Plaat 17 , fig. 6 en 6 i $a$.

Fieber, Europ. Hemipt. p. 144, no. 3.

Lengte $3 \mathrm{~mm}$. - Gedrongen van gedaante, kort en breed, kaal. Kop breed met zeer uitpuilende oogen, glanzig zwart op den schedel, grijs op het aangezigt en verder naar den zuiger toe wit. Oogen en ocellen bruin. Sprieten kort, schicr onbehaard, vuil geel, met een zwart langsstreepje onder tegen

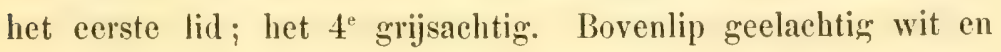
zuiger zwart. Prothorax zeer kort en zeer breed met rond nitgebogen zijden en diep ingebogen achterrand; aan den hals een dwarsgleufje en over het midden een ander, daartusschen twee glanzige knobbels; de zijden breed lichtgeel, het overige zwart. Schildje tamelijk groot, zwart met eene dwarsglenf over het midden; het voorste gedeelte zijileachtig, het andere meer als verlakt blinkend. Deksehilden geheel geel, onk de membraan, alleen een bruin of zwart vlekje aan den buitenrand voorbij het midden, en cen zecr klein even zoo gekleurd stipje aan de spits. De aderen der membraan zijn weinig zigtbaar. Onderzijile glanzig zwart met gele zoomen en gelen anus. Ponten geel of wit, met een haartijn zwart streepje onder de dijen, 
cen zeer smal zwart bandje aan de spits der scheenen en het laatste lid der tarsen aan de punt van dezelfde kleur.

Twee voorwerpen werden door den heer Ritsema den $2^{\text {en }}$ Junij Junij 1872 op ter Schelling gevangen; de heer Gerth van Wijk trof de soort aan op Walcheren.

\section{Salda lateralis Fall.}

Plaat 17 , fig. 7.

Fall. Mon. Cim. 30, 4. - Id. Hem. Suec. 74, 6. - Fieber, Europ. Hem. p. 144, no. 2. - Dougl. and Scott, Brit. Hem. p. 519.

Lengte 3,5-4 mm. - Langwerpig ovaal met de grootste breedte voorbij het midden, glanzig zwart met microscopische haartjes bezet en met gele versiering. Kop met de oogen en den zuiger als bij de vorige soort. Sprieten bijna zoo lang als de helft van het ligchaam, geelachtig wit op de bovenzijde van lid 1 en op het geheele tweede lid; het overige zwart. Prothorax als bij de vorige, doch het wit der zijden vrij wat minder nitgestrekt. Schildje groot, glanzig zwart; ik bespeur aan mijn exemplaar geene dwarsgleuf, slechts eene vrij breede verdieping. Dekschilden glanzig zwart met eene langwerpige gele, aan beide uiteinden spitse streep aan den buitenrand tot even voorbij het midden; de spits vertnont eene ovale gele vlek, die zich na cen klein bruin vlekje ingesloten te hebben op de membraan voortzet. Het overige deel der membraan bruinachtig geel met vrij onduidelijke aderen en cen bruin vlekje aan de spits. Pooten lichtgeel met zwarte langsstreepjes op de dijen, boven en onder; aan de scheenen zijı de basis en de spits, even als de tijne stekeltjes bruin, aan de tarsen de basis van bet eerste lid en de spits van het laatste.

Ook deze soort werd (met eene rerscheidenheid) op ter Schelling aangetroffen door den heer Ritsema. De heer Heylaerts ving eenige exemplaren in Mei bij Bergen op Zoom aan den oever der Schelde. 


\section{Salda pulchella Curt.}

Plaat 17 , fig. 8 .

Curtis, Brit. Ent. XII. PI. 548. - Fieber, Eur. Hem. p. 144, no. 4.Herr.-Sch. W. Ins. IX, P. 131, tab. 308, f. 947. - Douglas and Scott, Brit. Hem. p. 520 , pl. 17, f. 9.

Lengte $3 \mathrm{~mm}$. - In gedaante overeenstemmend met $S$. eburnea. Kop breed, zwart, grijs bestoven met wit benedengedeelte en witte borenlip. Oogen bruin, ocellen zwart. Sprieten bijna zoo lang als de helft van het ligchaam, fijn behaard; $1^{\mathrm{e}}$ lid licht geel met een bruin streepje aan den onderkant, $2^{\mathrm{e}}$ licht bruin of vuil geel, de laatsten donkerbruin. Zuiger bruin met gele basis. Halsschild naar voren glanzig zwart, naar den achterkant bruinachtig dof zwart, met de zijden bedekt door een' witten zoom, voor smal, achter tamelijk breed. Schildje bruinachtig zwart met grijze beharing, korter en breeder dan bij Lateralis. Dekschilden bruinachtig zwart met grijze beharing; de uiterste basis en spits van den clavus zijn geelwit; van dezelfde kleur is eene wigvormige vlek an den voorrand; strekkende van den schouder tot over de belft van het corium en zijode ecns ingekcept aan haren achterrand; de spits is wit gekleurd door eene driehoekige liggende vlek, onder welke op de vuilwitte membraan een bruin veegje te zien is; de aderen der membraan en nog een paar vlekjes daartusschen zijn bruin. De onderijide is zwart, op de borst met cenige witte vlekken. De pooten zijn geel, met streepjes en stippen als bij de voorgaande soort.

Eeu enkel exemplaar dezer soort ving de heer Ritsema 2 Junij op ter Schelling; de heer Heylaerts trof een paar roorwerpen aan in Mei op de schorren bij Bergen op Zoom.

\section{Salda geminala Cost. \\ Plaat 17, fig. 9.}

Fieber, Europ. Hem. 1. 147. 1)

Lengte $3 \mathrm{~mm}$. of iets meer. - Deze soort verschilt van al

1) Costa's beschrijving dezer soort bleef mij oubekend; ik moest mij behelpen met Fieber's korte opgaaf, waarin it bovendien nog fouten vermoed. 
de voorgaanden door de gedaante van het halsschild, 't geen aan de zijjden ingebogen is, zoodat de randlijn coneaaf en niet convex is; bovendien is er groot verschil in de gedaante der sprieten, waarvan de beide laatste leden sterk verdikt zijn.

Het geheele ligchaam op de rugzijde met opstaande zwarte haren bedekt. Kop van boven gezien breed en kort, naar beneden onder de oogen echter smal en vrij sterk verlengd, overal, ook op de bovenlip, glanzig zwart. Oogen zeer sterk nitpuilend, donkerbruin. Zuiger licht bruin. Sprieten korter dan het halve lijf, vrij forsch van bouw voor dit genus: $1^{\mathrm{e}}$ lid zwart tot op de helft, dan geel, $2^{\mathrm{e}}$ geel met zwarte basis, $3^{\circ}$ bijna zoo lang als 2 , doch dikker, spoelvormig, zwart met zwarte beharing, $4^{\mathrm{e}}$ gelijk aan 3 doch iets puntiger aan de spits. Thorax aan den voorrand weinig breeder dan het halsje van den knp en aan den naar voren ingebogen achterrand slechts weinig breeder dan de kop met de oogen, op het midden met 2 dwarsglenven voorzien, knobbelig aan den hals en op de schouders, glanzig zwart. Schildje kort, breed, driehoekig, zonder dwarsgleuf, glanzig zwart. Dekschilden zwart met gelen zoom, die zeer flaanw begint, op de helft van het corium vrij breed is, daarop plotseling hoekig smaller wordt en zich aan de spits wederom wat verbreedt. Daartegen aan staan twee kleine ronde vlekjes, het bovenste greel, het onderste, bijna tegen de menbraan aan, wit. Bovendien is er een zeer klein wit vlekje aan de spits van den clarus. De membraan is bruinachtig geel met bruine aderen, tusschen welke de membraan in het midden donkerder is; de zoom is grijs berookt. Pooten roodachtig geel met een weinig bruin op de kniën en aan de spits der scheenen en der tarsen.

Twee voorwerpen $\delta$ en q werden 25 Julij bij IIilversum gevangen door den heer C. Ritsema $\mathrm{Cz}$.

\section{Salda cincta H. Sch.}

Herr.-Sch. Wanz. Ins. VI, 40, pl. 194, f. 598. - Fieb. Eur. Hem. p. 148.

Lengte $3 \mathrm{~mm}$. - Twee voorwerpen heb ik voor mij, onder- 
ling niet geheel gelijk, van eene soort, na verwant aan de voorgaande, doch met onverdikte sprieten, welke noch geheel passen op de beschrijving van Cincla H. Sch., noch op die van Eleganfula Fall., doch het meest gelijken op de eerstgenoemde.

Kop als bij Geminala, doch iets meer vooruitstekend, bovenlip zwart, zuiger bruingeel. Sprieten tamelijk kort en vrij slank, gekleurd als bij de vorige. Thorax en schildje als bij Geminala. Dekschilden dofzwart met gelen zoom, die bij het eene voorwerp vrij regelmatig doorloopt tot de spits, bij het andere meer golvend en voor de spits eenmaal afgebroken. Membraan bij het eerste lichtbruin met donkerder aderen, bij het tweede lichtgeel met 2 bruine rlekjes an den rand. Pooten als bij de vorige soort.

Het eene, vrij goed bewaarde werd in Mei door Perin bij Rijnsburg aangetroflen; het andere, minder van gehalte, werd voor jaren door den heer Six bij Driebergen gevangen. Het eerste zou, indien de sprieten meer verbreed waren, voor een wijfje van Geminala kunnen doorgaan.

In het algemeen komt het mij voor dat de Europeesche soorten van dit geslacht niet zuiver van elkander zijn afgescheiden en dat bij kennisneming van gebeele serien, eenigen zullen blijken uiterste einden te zijn van eene doorloopende serie. 


\section{ZEVENDE FAMILIE. - - ROOFWANTSEN.}

\section{REDUVINI.}

Roofwantsen zullen wij de insecten dezer familie betitelen, omdat zij voor zooverre waargenomen is, andere levende insecten grijpen en uitzuigen; een onder hen, de oudst bekende, doet zelfs het menschdom in dat opzigt voordeel door als verklaarde vijand der bedwantsen, hun overgroot aantal eenigermate te verminderen.

De ware kenmerken der familie bestaan hierin: $1^{0}$ dat de zuiger onbedekt en loshangend is, $2^{0}$ dat de ocellen stann achter eene denkbeeldige lijn getrokken dwars over den kop, zoo dat zij de achterranden der oogen anraakt, $3^{0}$ dat de kop achter de oogen halsvormig is uitgerekt, $4^{0}$ dat de tarsen uit 3 leedjes bestaan, $5^{0}$ dat de voordijen dikker zijn dan de achterdijen.

Kop gewoonlijk klein naar gelang van het ligchaam; aangezigt nitgerekt voorbij de zijdelingsche inplanting der sprieten; achter de oogen en ocellen een halsje, soms tamelijk lang en door eene dwarsgleuf van den schedel afgezonderd. Oogen bol, uitpuilend met vrij grove facetten. Ocellen, gelijk boven gezegd is, nimmer tusschen, altijd achter de oogen. Sprieten zijdelings voor de oogen op een knobbeltje ingeplant, slank en vrij lang, soms zweepvormig van vier leedjes, waartusschen echter dikwijls zeer kleine leedjes ingevoegd zijn, doch zoo dat een zoodanig leedje eigenlijk altijd als afgezette basis bij het volgende groote lid behoort. Zuiger loshangend, bij de meeste geslachten kort, gezet en slechts van 3 leedjes, bij een enkel lang en slank van 4 leedjes. Prothorax aan den voorrand meest zeer smal, naar achteren vrij regelmatig verbreed, door twee dwars- 
gleuven in drie deelen verdeeld, waarvan het roorste gewoonlijk zeer kort is. Schildje klein, driehoekig, soms vrij puntig aan de spits. Achterlijf van zes duidelijke ringen, met de huid aan de zijden zeer dikwijls opgewipt. Vleugels dikwijls slechts half ontwikkeld; indien zij volledig uitgegroeid zijn, bestaan zij uit clavus, corium (zonder cuneus of embolium) en membraan, de laatste dikwijls met vele langsaderen. De pooten zijn middelmatig van lengte, bij een genus zeer slank en lang; de voordijen zijn altijd dikker dan de achterdijen en de voorpooten in 't geheel tot grijpen en vasthouden ingerigt; de tarsen bestaan uit drie leedjes, waarvan het eerste zeer klein is en het laatste van 2 klaauwtjes voorzien.

\section{Tafel der geslachten.}

1 (6). Zuiger van drie leedjes, kort en vrij dik.

2 (5). Voorheupen gewoon. De voorpooten dienen tot gaan en grijpen. Ocellen aanwezig.

3 (4). Sprieten zeer dun en zweeprormig.

Genus 2. Reduvius F.

4 (3). Sprieten niet bijzonder dun, draadvormig.

Gen. 3. Harpagtor Lap.

5 (2). Voorheupen zeer dun en lang; de voorpooten dienen niet tot gaan, maar slechts tot grijpen. Ocellen ontbreken.

Gen. 5. Ploearia Scop.

6 (1). Zuiger van vier leedjes.

7 (8). Zuiger en voorpooten kort en dik, prothorax aan den voorkant bol.

Gen. 1. Prostemua Lap.

8 (7). Zuiger slank, tot voorbij de voorheupen reikend; prothorax niet bol aan den voorkant. Voorpooten vrij lang. Gen. 4. Nabis Latr. 
Gen. 1. Prosteman Lap.

Dit genus dient wel vooraan te komen omdat hier het halsje nog zeer onduidelijk is en de ocellen min of meer tusschen de oogen zijn geplaatst, zoodat het geslacht nog niet in allen oprigte voldoet aan de kenmerken der familie. Niettemin is l'rostemma een Reduvide en wel even zeker als l'locariu, dat door andere karakters weder eenigzins van den typus der familie afwijkt. De eerstgegeven naam Prostemma werd door Laporte gekozen, omdat hij ten onregte meende dat de ocellen, stemmata, voor de oogen staan; Léon Dufour, die de onjuistheid daarvan inzag, veranderde den naam in Postemma (post stemma), maar Amyot, die geen hybridisch gevormden naam wilde aannemen, veranderde dit weder in Mletastemma van meta en stemma; doch, ofsehoon nu de benaming etymologisch zuiver is, beteckent zij niets, want zij.gceft geen karakter van het genus, maar alleen een der kenmerken der familie aan. Geene verbetering vindende in de verandering, keer ik dus weder tot Prosiomma terug.

Kop tamelijk lang, bol, krom naar beneden gebogen, van een uiterst smal halsje voorzien. Oogen uitpuilend en ovaal; ocellen zeer duidelijk, tegen den hals aan staande, doch niet geheel achter de oogen. Spricten harig, slank van 4 leedjes, waarvan echter het $2^{e}$ aan de basis in een condylus is afge snoerd, ten gevolge waarvan verschillende schrijvers 5 leedjes tellen. Het $1^{e}$ lid is kort en reikt niet voorbij de spits van den kop; het $2^{e}$ is driemaal zoo lang, naar de spits verdikt en daar zeer harig, het $3^{e}$ is iets korter en mede van langere haren voorzien, het $4^{\mathrm{e}} \mathrm{nog}$ korter met eene soort van dons bedekt. Zuiger van 4 leedjes, waarvan het $1^{c}$ zoo kort en ringvormig, dat het door Curtis bij de spits van den kop werd gerekend; het $2^{\mathrm{e}}$ iets langer, minder dik, doch naar het eind toe zich uitzettend, het $3^{\text {e }}$ nog langer kegelvormig, het $4^{e}$ zeer kort en harig. 
Prothorax aan de voorzijde bol en bijna bultig op den rug, in de zijden voorbij het midden een weinig ingedeukt, daarop weder sterk nitgezet. Schildje vrij breed en kort, volstrekt niet spits aan het einde. Dekschilden zeer breed, in beide bekende inlandsche voorwerpen kort, zonder clavus en aan den achterrand flaauwelijk ingebogen met eene uiterst korte membraan zonder aderen. Het abdomen veel langer en veel breeder dan kop en thorax te zamen, boven weinig, onder zeer bol, met scherpe, opgewipte zijranden; de laatste ring wat ingetrokken. Pooten krachtig, vooral de voorpooten (zie plat 17, fig, $11^{2}$ ) wier dikke heupen aan de onderzijde voorbij het midden met eene dubbele rij fijne stekeltjes bezet zijn; hunne scheenen, naar de spits sterk verbreed, hebben aan de onderzijde van de basis tot over het midden mede eene rij stekeltjes. De tarsenklaauwtjes vrij lang.

\section{Prostemma gullula $\mathrm{F}$.}

Plaat 17 , fig. 11.

Fabr. S. R. 281, 70. - Laporte, Hèm, 12, no 13. - Curtis, Brit. Ent. XV, pl. 684. - Léon Duf. Ann. Soc. Ent. de France III, p. 350, pl. 5, f. 8. - Hahn, W. Ins. II, p. 28, t. 41, f. 130. - Douglas and Scott, Brit. Hem. p. 546 , pl. 18 , f. 6.

Lengte $8 \mathrm{~mm}$. - Kop en thorax blinkend zwart, met vrij lange opstaande haren bedekt. Oogen donkerbruin. Sprieten aan de onderste leden roodgeel, de laatsten zwart. Zuiger zwart aan de basis, met de beide laatste leden geelachtig. De thorax op den bollen rug eenigzins metaalachtig van glans. Schildje zwart met roodgele zijhoeken. Het corium der korte dekschilden oranje met haren van dezelfde kleur bezet; de membraan vuilwit met een bruin vlekje. Achterlijf zwart met metaalglans, vooral op het midden; de ringen fijn gestippeld met gladde zoomen; de voorlaatste ring sterk behaard. Pooten oranjerood met de heupen donkerbruin, de uiteinden der scheenen en het laatste lid der tarsen bruin; de haren licht- en de stekeltjes der voorste dijen en scheenen donkerbruin. 
'Twee roorwerpen dezer merkwaardige en fraaije soort zijn mij als inlandsch bekend geworden. Zij werden op Walcheren gevangen door den heer N. La Fontijn, die de bijzondere welwillendheid had beiden voor mijne verzameling af te staan.

\section{Geu. 2. Revuvius F.}

In vroegeren tijd omvatte dit geslacht de geheele familie, tegenwoordig slechts een zeer gering getal soorten. Onder de inlandsche genera kenmerkt het zich dow den korten zuiger van 3 leedjes, door niet uitsluitend tot grijpen geschikte voorpooten en door den vorm der sprieten; in de inlandsche fauna bevat het slechts eene soort.

Bouw krachtig; van het ligehaam rijn alle deelen behalve dekschilden en vleugels, met zijdeachtige haren dun bekleed. Kop van langer hals voorzien dan het voorgaande genus; deze hals is van den schedel afgescheiden door eene dwarsgleuf; de kop draagt op zijn hoogste punt de groote bijoogen. Oogen groot, uitpuilend, aan de onderzijde van den kop elkander bijna aanrakend, uit grove facetten bestaande. Sprieten digt voor en tegen de oogen aan ingeplant, zoo lang als de halve lengte van het ligchaam, van vier leedjes en zweepvormig; $1^{\text {e }}$ lid 200 lang als de kop, in het midden wat spoelvormig uitgezet, tusschen 1 en 2 een condylus-leedje, 2 minder dik dan 1 maar tweemaal langer, 3 en 4 iets korter maar bijna haarvormig, waardoor de geheele spriet op eene zweep gelijkt. Zuiger van 3 leedjes, vrij dik, de voorheupen anurakend. Prothorax aan den uitgebogen achterrand breeder dan in het midden lang, voor smal; zijn eerste helft (na het smalle voorzoompje) in het midden door eene langsgleuf verdeeld en zijne tweede helft door drie zulke gleuven, waarvan de middelste het diejst gaat. Schildje vrij groot, spits driehoekig met opstaande lijstjes voor de zijranden en daartusschen ingedrukt; de spits doornachtig opgewipt (zie pl. 18, fig. $1^{\mathrm{a}}$ ). Dekschilden met smallen clavus en groote, aan den buitenrand bijna leder- 
achtige membraan met drie aderen; welke door haar kronkelen twee gesloten cellen vormen. Pooten vrij lang; de voorheupen kegelvormig, hunne dijen niet bijzonder sterk verdikt, hunne scheenen en die van het tweede paar van onderen aan de spits van eene holle, behaarde zool voorzien, die an het einde in een krom uitsteeksel uilloopt. Achterlijf anderhalfmaal zoo lang als de thorax met den kop, weinig breeder dan de borst, boven eenigzins hol, onder vrij bol, aan de bovenzijde van den latsten ring sterker behaard dan op andere punten.

\section{Reduvius personatus L.}

Plaat 18 , fig. 1 en $1 a$.

Linn. S. N. ed. 724, 64. - Fabr. S. Rh. 267, 7. - De Geer, Mémoires (vert. Goeze) III, p. 185, tab. 15, f. 1-9. - Panzer, Faun. Germ. 88, f. 2 Z. - Hahn, W. Ins. II, p. 17, pl. 39, f. 125. - Wolff, Ic. Cim. p. 79 , tab. 8, f. 76. - Flor, Rh. Livl. I, p. 679. - Douglas and Scott, Brit. Hem. p. 544, pl. 18, f. 3 et $3 a, b, c$.

Lengte 15 of $16 \mathrm{~mm}$. - Grauwbruin of donkerbruin met zijdeachtige lichtbruine haren bekleed, voornamelijk op de pouten. De basis van het eerste lid der sprieten geel; de spits van den kop met de bovenlip geelachtig bruin, de basis der scheenen geelachtig wit; het verdient vermelding dat dit laatste wel bij alle inlandsche voorwerpen plaats grijpt, terwijl een tweede voorwerp nit mijne verzameling dit kenteeken mist, welk exemplaar echtel een Spanjaard is.

Voor ongeveer 40 jaren vond ik eens op een' zoldertrap cene larve van deze soort; zij kwam volkomen overeen met de beschrijving bij de Geer en had zich geheel met stof en zandkorrels bedekt. Om deze bekleeding gaf Linnaeus aan de soort den naam van Personatus (vermomde). De volwassen insecten zijn nachtdieren, die op roof uitgaande des avonds wel door de openstaande vensters komen binnenvliegen. Men zegt dat zij bedwantsen tot roedsel gebruiken, waarschijnlijk echter ook nog vele andere insecten. Met zekerheid kan ik meedeelen dat hun steek bijzonder pijnlijk is.

De soort werd angetroffen te Leyden, Warmond, Wocrden, 
's Gravenhage, Driebergen, Brummen en Middelburg, meestal bimnen 's huis. Zij schijnt echter niet zeer gemeen.

Gen. 3. Hanpacton Lap.

Van het vorige onderscheidt zich dit genus hoofdzakelijk door den vorm der sprieten, wier beide laatste leden niet zoo uitermate fijn zijn en meer overeenkomen met de beide roorgaanden; overigens stemt het met het voorgaande in het aantal leedjes des zuigers overeen.

Kop klein, doch van een' vrij langen hals voorzien. Zuiger van 3 leedjes, dik; het $2^{\text {e }}$ lid in lengte gelijk aan het eerste of iets langer. Oogen zeer bol uitpuilend. Sprieten zoo lang als de helft van het ligehaam, of iets langer, slank, van 4 leedjes; bij de eene slank, van 4 leedjes; bij de eene soort een tusschenleedje aan de basis ran het $1^{\mathrm{e}}$, bij de andere aan de basis van het $3^{\text {e }}$ lid ; het $2^{\text {e }}$ lid steeds het langste.

Borststuk aan de voorzijde hoekig en smal, aan de achterzijde bij de eene soort zeer breed, bij de andere minder; over het midden door eene dwarsgleuf in 2 deelen verdeeld. Schildje klein, puntig opgewipt. Dekschilden bij de eene soort (Pedestris) gewoonlijk niet ontwikkeld, bij de andere wel ontwikkeld en in de rust over elkander gevouwen, veel smaller dan het abdomen, met groote membraan, waarin vier aderen, ran welke de 3 buitensten 2 gesloten cellen vormen. Achterlijf langer dan kop en boiststuk, en in het midden $1 \frac{1}{2}$ maal breeder dan het laatste, aan de zijden opgewipt, dus hol op den rug, doch bootvormig als men het op rijde beziet. Pooten matig dik en lang, met de voordijen niet bijzonder gezwollen.

De beide inlandsche soorten van dit genus zijn, vooral aan de pooten met opstaande haren bezet; zij zijn door de kleur gemakkelijk van elkander te onderscheiden, daar de eene geheel grijs en zwart is (Pelestris); terwijl de andere aan abdomen en pooten eene bloedroode kleur vertoont (Anmululus). 


\section{Harp. pelestris Wolff.}

P'aut 18, fig. 2 en $2 a$.

Wolfi, Icon. Cim. 1. 205, tab. 20, f. 199 (Ped"stris). - Burm. Handb. II, 230, 3. - Curtis, Brit. Ent. X, pl. 453 (Coranus subapterus). IIahn, W. Ins. II, p. 25, t. 41, f. 129. - Flor, Rhynch. Livl. I, p.681 (Subapterus). - Douglas and Scott, Brit. Hem. p. 541, pl. 18, f. 2.

Lengte ongeveer $10 \mathrm{~mm}$. - Grijs met zwarte en gele vlekjes, met grijze zijdeachtige opstaande haren bezet, zelden met nitgegrocide dekschilden en vleugels. Kop met een' vrij langen, naar achteren kegelrormig versmalden hals. Zuiger aan de basis grijs, naar de spits zwart en glanzig. Oogen uitpuilend, donker bruin of zwart. Sprieten donker bruingrauw, aan de cerste leden harig; voor het $2^{\mathrm{e}}$ lid, dat het langste is, een klein tusschenleedje. Borststuk achter niet zeer veel breeder dan voor, bij de gevleugelden iets meer. Schildje klein, opgewipt. Van daar naar voren tot op het midden van den kop een smal lichtgrijs streepje. Dekschilden als zij onontwikkeld blijven, riltig grijs met zeer korte scheeve bruine membraan; ontwikkeld, tot aan den anus reikend, minder viltig, bruiner, met zeer groote bruine membraan. Midden van het abdomen op den rug, met gladde, glanzige vierkante plekken, de opgewipte zijjen geblokt ruilgeel en zwart, de buik in het midden glanzig bruin, met ruil gele vlekken daartegen aan. De zeer harige pooten zijn geringeld vuilgeel en zwart, de dijen gegolfd knobbelig.

Deze soort is op enkele plaatsen gemeen, bijv, in het dennenbosch te Driebergen onder heideplanten en in de duinen tusschen den Haag en Scheveningen. Men vindt haar volwassen in het najaar. Behalve op de genoende plekken werd zij aangetroffen bij Katwijk (de Graaf), Noordwijk (v. Bemmelen), Utrecht en Brummen (v. V.), Breda (Ileylaerts) en Domburg (de Man). Voor het overige is zij over geheel Europa rerspreid.

Een gevleugeld inlandsch exemplaar ving o. a. Perin. 


\section{Harpactor ammulatus L.}

Linn. S. N. 与̌ ed. p. 495, 71. - Fall. Mon. Cim. 120, 2. - Fabr. S. Rh. 271, 24. - Panz. Faun. Germ. 88, f. 23. - Wollf, Ic. Cim. p. 81, tab. 8, f. 78. - Hahn, W. Ins. II, p. 22, tab. 40, f. 128. - Flor, Rh. Livl. I, p. 683.

Lengte $12 \mathrm{~mm} .-\mathrm{Z}$ wart met bloedroode versierselen, geheel met zachte opstaande zwarte haren bezet. Sprieten zwart, langer dan bij de voorgaande soort; een tusschenzetsel aan de

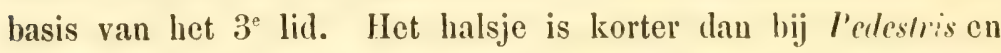
aan den voorkant meer gezwollen. Het halsschild heeft uitstaunde puntjes op zijile van den voorrand en is aan den achterrand tweemaal zoo breed als tusschen die puntjes. Dekschilden altijd volgroeid en de zwarte membraan zcer groot. De spits van het schildje nict opgewipt. De opgewipte zijden van het abdomen bloedrood en zwart geblokt. Pooten zwart, behalve het grootste gedeelte der scheenen en twee breede ringen om de voor- en achtcrdijen, die blcedrood zijn.

Van deze fraaije soort zijn door den heer Heylaerts eenige voorwerpen angetroffen in het Ulvenhoutsche bosch bij Breda.

\section{Gen. 4. Nabis Latr.}

Dit geslacht heeft even als het eerste den zuiger van vier leedjes, doch wat de gedaante betreft, sluit het zich reel nader bij het voorgaande aan.

De gedaante van het ligchaam zonder den kop is langwerpig ovaal, voor een groot deel met evenwijdige zijden. De kop is vrij lang, zonder de oogen smal, met ecn voor deze familie zeer kort halsje, dat bovendien dikwijls onder den voorrand van het balsschild terurgetrokken wordt. De oogen zijn zeer sterk uitpuilend, de bijoogjes digt bij elkander geplaatst, niet zoo zeer achter dan wel tusselien de oogen. Sprieten ter wederzijde op een knobbeltje ingeplant halverwege tussehen de oogen en de spits van den kop, zeer slank draadvormig; lid 
1 de helft zoo lang als 2 , dit iets langer dan 3 en 4 weinig langer dan 1, ja zelfs ook wel iets korter. Zuniger lang en dun, voorbij de voorste heupen reikend, van 4 leedjes, waarvan het $1^{e}$ zecr kort is en het $2^{e}$ het langste. Borststuk op den rug gezien, van den vorm van een' afgeknotten kegel met afgeronde achterhoeken, aan den achterrand tweemaal zoo breed als voor, soms iets langer dan breed, met 2 dikwijls zeer onduidelijke dwarsgleuven, waarvan de vorrste vlak bij den hals, de $2^{e}$ iets voorbij het midden ligt. Schildje klein, brecd drichoekig. Dekschilden soms zeer kort, dikwijls met de membraan de spits van het abdomen niet bereikend; zijn zij onrolgroeid, dan zijn de 3 deelen dikwijls niet van elkander te onderscheiden; zijn zij volkomen, dan is de clavus naar achteren breed, dan vindt men 2 middennerven op het corium en 4 op de membraan, die zich naar den rand vergaffelen.

Achterlijf op den rug plat met opstaande randen, aan de onderzijde kielvormig. Pooten vrij lang; hunne henpen zwaar, bij paren digt bijeen staande; dijen van het voorste paar zeer dik, dic ran het $2^{\mathrm{e}}$ iets dunner, maar even lang; die van het $3^{e}$ langer en smaller; scheenen der beide voorste paren forsch, verbreed naar het eind en aldaar van onder van een viltig zooltje voorzien; achterscheenen langer en smaller. Tarsen met een zeer klein eerste lid; het $2^{\mathrm{e}}$ aan de achterpooten even lang als het $3^{e}$; klaauwtjes lang, slank, ongetand en weinig gekromd.

Tabel der soorten.

1 (3). Kleu bruinachtig rood; dekschilden en membraan meestal bruin gemarmerd; beiden zelden goed ontwikkeld.

2 (4). Grootte $1 \mathrm{~cm}$. Kop van boven gezien tweemaal zoo lang als breed.

Sp. 1. N. brevipennis Hahn.

4 (2). Grootte $7 \mathrm{~mm}$. Kop van boven gezien anderhalfimaal zoo lang als breed.

Sp. 2. N. aplerus F. 
3 (1). Kleur geel, grauw of granwrood; dekschilden niet gemarmerd; membraan meestal met donkerder adcren.

5 (6). De membraan der dekschilden reikt over het ligchaam heen.

$$
\text { Sp. 4. N. ferus L. }
$$

6 (5). De membraan reikt niet tot an den anus.

7 (8). Grooter, donkergranw met gelen rand.

Sp. 3. N. flavomarginalus Scholz.

8 (7). Kleiner, niet donkergrauw, de deksehilden zeer verkort. 9 (10). Kleur geel of grijsachtig.

Sp. 5. N. brevis Scholz.

10 (9). Kleur rood uit den grauwen.

Sp. 6. N. dorsalis Duf.

\section{Nabis mevipennis Hahn.}

Platat 18, fig. 3 en $3 a$.

Hahn, Wanz. Ins. III, p. 32, pl. 83, f. 253. - Flor, Rh. Livl. I, 1. 69\%. - Douglas and Scott, Brit. Hem. p. 549.

Lengte ongeveer $1 \mathrm{~cm}$. - Kenbaar aan de grootte. Van gedaante fleschvormig, van kleur rood of roodbruin, met bedekking van grijs vilt. Kop cylinderrormig met tocgeronde spits, 2 maal zoo lang als tusschen de oogen breed; het bijna alijgd zigtbare achterste gedeelte van het halsje glanzig zwart. Voor de bijoogjes een zeer flaauw en fijn dwarsglenfje, dat gebogen achter de oogen loopt. Oogen rond, uitpuilend, donkerbruin. Zniger dun, lang, glanzig roodbruin. Sprieten nog al ver voor de oogen ingeplant, zeer slank, op 3 der lengte van het ligchaam, geelbruin met een donker bandje aan de basis van lid 1, een ander even voor de spits van dat lid en een derde even voor de spits van lid 2. Prothorax met weinig ingedcukte zijden, die zeer rond nar beneden loopen, aan den achterrand naauwelijks 2 maal breeder dan an den voorrand; de achterrand dikwijls donker gemarmerd, het middengedeclte aan de zijden dikwijls donker gevlekt. Schildje gelijkzijdig, dof zwvart, 
soms met (door dikke beharing) lichtere zijden. De dekschilden reiken gewoonlijk niet tot op het midden van het abdomen en hebben geene aderen, maar wel eene scheef aangehechte korte membraan. 1) Hunne kleur is bruinrood of roodgratuw met donkerder marmering, de membraan is grauw, iets lichter naar den zoom. Achterlijf veel langer en tevens veel breeder dan kop en borststuk, met opgewipte zijden, die aan den rand cen oranje vlekje vertounen aan de basis der ringen 2 tot 6. $\mathrm{Na}$ den $6^{\text {en }}$ ring is het ligehaam plotseling toegespitst. De pooten zijn roodgrauw met vele donkere dwarsbanden, die cehter in het midden van dijen en scheenen niet bij alle voorwerpen te zien zijn.

Nahis brevipennis werd gevangen binnen Leyden in den hortus tegen hagedoorn in Augustus (de Graaf), bij Hecmstede in September, in het Haagsche bosch en de Seheveningsche boschjes, mitsgaders aan de Rhedersteeg in den herfst (v. Voll.) en bij Breda (Leesberg). Mij zijn slechts wijfjes bekend en ik zie dat Flor in hetzelfde geval verkeerde. Douglas en Seott schijnen gelnkkiger te zijn geweest.

\section{Nabis aplerus F.}

Plaat 18, fig. 4.

Fabr. S. R. 281, 72. - Hahn, W. Ins. I, p. 35, tab. VI, f. 21. Wollf, Ic. Cim. p. 201 , tab. 20, f. 200 (nymf). - Fieber, Eur. Hem. p. 160 (Subapterus de Geer). - Doughs and Scot, Brit. Hem P. 550.

Fieber haalt bij deze soort de beschrijiving en plaat van Richuius subaplerus bij de Geer an Némoires (Duitsche vert.) III, p. 189 , pl. 15 , f. 10 , doch stellig ten onregte. Vooreerst toont de vergroote afbeelding van den kop (fig. 11) reeds aan dat hier Ilarpactor pedestris bedoeld is, maar ten overvloede

1) In November 1877 vond ik op eene rastering in de Scheveningsche boschjes een volkomen uitgegroeid vrouvelijk voorwerp, met lange dekschilden en vleugels. Het corium reikte tot aan het 5 de abdominaal-segrnent en vertoonde eene duidelijke middenader die voorbij het midlen gevorkt was; de membraan was niet veel korter dan het corium en bezet met eene menigte moeijelijk met het oog te volgen langsaderen, lie voor den rand met vorkjes in elkander liepen. Zij was bezaaid met bruine vlekjes. 
leert ons de text dat de zuiger kort en dik is, 't geen op geen Nabis past. Of de fig. 200 van Wolff, die eene nymf voorstelt, hier juist geciteerd is, zal latere $\mathrm{k} w e e k i n g$ moeten leeren.

Lengte nog niet ten volle $7 \mathrm{~mm}$. Het zal voldoende zijn bij de groote gelijkenis met de vorige soort het verschil tussehen beide kenbaar te maken. Aplerus is kleiner, heeft lichter kleur op kop en thorax en langer dekschilden, die tot over de helft van het abdomen reiken. Voorts is het abdomen op de rugzijde donkerder, bijna zwart, en het oranje vlekje op den zesden ring is veel grooter naar rato en niet scherp begrensd. Eiudelijk heeft de prothorax aan wederzijde eene donkerbruine of zwarte vlek.

De suort werd met en zonder membraan aan de deksehilden in April en Mei in het Liesbosch bij Breda angetroffen door den heer Heylaerts; de Man ving er eene 27 April bij Middelburg en Ritsema schonk mij eene nymf door hem in Augustus bij Rozendaal gevangen.

\section{Nabis flavomarginalus Scholz.}

Plaat 18, fig. 5.

Scholz, Aufzihl. 1) no ? p. ? - Fieb. Eur. Hemipt. p. 161.

Lengte $9 \mathrm{~mm}$. - Van gedaante een langwerpig ovaal, dat naar voren kegelvormig is toegespitst, van boven vrij plat, van onder kielvormig verheven, donker grijs of grauw met gele randen. Kop van den voorrand der oogen tot de spits even lang als van den voorrand der oogen nar het halsschild, boren zwart met 2 gele strepen tegen de oogen aan en eenige gele vlekjes voor en tusschen de inplanting der sprieten. Deze weinig langer dan de helft van het ligchaam, lichtgrauw, bruin aan het einde met een donker bandje aan de spits van het 2 r lid. Ongen bruin. Zuiger glanzig licht bruin met gele basis. Keel even als de voorborst licht geel. Borststuk op den rug

1) Dit opstel bleef mij oubekend; het komt voor in de Arbcilen der Schlesische, Gesellschaft fior Kultur, 1846. 
grauw met drie breede donkere langsstrepen; de zijden licht onzuiver geel. Schildje zwart met gele zijden. Dekschilden bruingranw met de helft van den buitenrand geel gezoomd; de membraan zeer groot, van dezelfde grauwe kleur doch met lichtere vlekken tusschen de aderen. Het achterlijf op zijde buiten de dekschilden nitstekend en ook iets langer, zwart, doch de opstaande zijrand vuilgeel. Onderrijde an den rand breed geel, dan bruin en glanzig, in het midden echter met eene rij van ronde gele vlekken. Alle heupen geel met zwarte basis; de 4 roorpooten zeer forsch gebouwd, gecl; hunne dijen met donkere dwarsstrepen getijgerd. Achterpooten langer en slanker, geel; de uiteinden der dijen en de spits der scheenen en der tarsenleedjes zivart.

De korte beschrijving bij Fieber stemt niet geheel met deze overeen, doch is op verscheidene punten onduidelijk. De gelijknamige soort bij Flor schijnt eene andere.

De soort werd gevangen bij Leyden in September door Perin, op Walcheren door den heer La Fontyn, bij Loosduinen door Generaal Dr. van Hasselt, in Sept. bij Rotterdam door den heer Snellen en 10 October door mij bij Scheveningen. Ook werd eene nymf dezer soort bij Loosduinen aangetroffen.

\section{Nabis ferus L.}

Plaat 18 , fig. 6.

Linn. S. N. ed. 13, 731, 108. - Fabr. S Rh. 255, 11 ен 12. Fall. Hem. Suec. I, 183, 9. - Wolf , Ic. Cim. p. 159, tab. 16, ґ. 153. - Burm. Handb. II, p. 242, 1. - Hahn, W. Ins. III, p. 31, pl. 83, f. 252. - Flor, Rh. Livl. I, p. 698. - Douglas and Scott, Brit. Hem. p. 555 .

Lengte $6-7 \mathrm{~mm}$. - Licht geel met een bruinen of grauwen glans, veel smaller dan de vorige naar gelang der lengte. Kop klein, niet sterk nitstekend voor de oogen, met eene tamelijk breede zwarte langslijn in het midden en een vlekje achter ieder oog. Sprieten iets langer dan de helft van het ligchaam, vuil lichtgeel; het $1^{e}$ lid, ofschoon zeer dun, toch dikker dan 
de overigen, een weinig naar beneden gekromd; 2 en 3 met bruine bandjes om de spits. Borststuk smal van voren en van achter $2 \frac{1}{2}$ maal zoo breed en aldaar boller dan bij de rorige, met cene naar achteren smaller wordende zwarte middellijn; van den hals tot den $2^{\text {en }}$ dwarsnaad ter wederzijde bij den zijkant aanduiding van nog eene dergelijke lijn. Schillje zwart met 2 gele vlekjes in de hoeken. Dekschilden geheel rolgroeid, reikende tot cen geheel eind over de spits ran het abdomen. Clavus naar den naad toe verbreed; corium met bolle aderen en 3 zwarte vlekjes onder elkander, waarvan het laatste op den rand van corium en membraan staat. Membraan cen weinig grijzer dan het corium, met lichtbruine aderen. Abdomen op den rug zwart met breelen gelen zoom, aan de onderzijde helder geel met eene zecr smalle langslijn in het midden en twee iets breedere aan de zijden (Deze teekening is soms onduidelijk). Pooten vaalgeel met eenige donkere puntjes en strecpjes op de vier voorste dijen.

De soort varieert wel in donkerder grijze of grauwe tint en met bruine membraan.

Zij is vrij algemeen verspreid over het geheele land op drooge gronden en komt in grooten getale voor op de heide en de duinen. Ik heb indertijd te Heemstede waargenomen dat zij in het najaar zeer belust is op frambozen, 't geen nict wegneemt dat hare eigenlijke spijze dierlijk voedsel zal wezeı.

De beide nu volgende soorten zullen missehien later blijken niet anders te zijn dan verseheidenheden van Ferus.

\section{Nabis brevis Schol\%.}

Plaat 18 , fig. 7.

Scholz, Arbeiten, Aufz nn? - Fieber, Eur. Hemipt. 1) 160.

Lengte $6 \mathrm{~mm}$. - In het algemeen meer geteckend dan de vorige, maar vooral van korter dekschilden roorzien en, misschien ten gevolge daarvan, slanker in de schouders. De algemeene kleur is een koud geelwit, min of meer grijsachtig. Kop, sprieten, zuiger, oogen als bịj de vorige. Ilet midden- 
gedeelte van het borststuk is met zeer tijne zwarte slingerstreepjes fraai beteekend, - en van daar uit loopen 5 of 7 donkere streepjes naar achteren, van welke die in 't midden de duidelijkste is. Dekschilden niet geheel uitgegroeid, met vrij sterk verhevene aderen en een zeker aantal zwarte vlekjes, gewoonlijk zeven op elk, soms minder, soms ook tot streepjes in een vloeijend. In de vrij korte meubraan zijn veel minder aderen en die somtijds niet eenmaal anastomeeren. De pooten zijn vrij sterk met rijen zwarte stippeltjes bezet en schijnen daardoor donkerder dan bij Ferus.

Brevis werd in Mei bij Utrecht gevangen (Piaget); in het voorjaar onder dorre bladeren bij Breda (Heylaerts); bij den Haag, Scheveningen en Noordwijk in Aug. (v. Voll.)

\section{Nabis dorsalis Duf.}

L. Dufour, Recherch. 62, 1, tab. 5, f. 55. - Am. et Serv. Hémipt. p. 332, 4. - Scholz, Aufzähl. no ? (Ericetorum). - Fieber, Eur. Hem. p. 160. - Flor, Rh. Livl. I, p. 690 tn II, 618. - Douglas and Scott, Brit. Hem. p. 552 .

Fieber en Scholz noemen dezen Nabis: Ericelorum, welke naam stellig karakteristieker is dan die van Dorsalis, die niets beteekent ten minste om het onderscheid met Ferus te doen uitkomen; doch de naam van Léon Dufour is ouder. Zijne beschrijving bleef mij onbekend, doch die van Amyot et Serville, naar de zijne vervaardigd, slaat uitmuntend op onze voorwerpen.

Lengte 5-6 mm. - Kleur glanzig bruinrood, met donkere langsstreep over kop en thorax. Iets slanker dan Ferus en vooral minder behaard; overigens daarop in allen deele gelijkende, behalve in de lengte der deksehilden, die slechts weinig over het midden van het abdomen heen reiken. Hunne aderen zijn vrij hoog oppuilend, op het corium is eene rij van 4 zwarte vlekjes te zien; de membraan is zeer kort en telt minder aderen dan bij Ferus.

Van deze soort werden eenige voorwerpen zeer laat in het 
jaar onder heideplanten en op gras in den omtrek van Breda en met name in het Liesboseh gevangen door den heer Heylaerts.

\section{Gen. 5. Ploearia Scop.}

Van Scopoli ontving dit genus den naam van Plocaria (eigenlijk schreef hij Ploiaria) tusschen 1785 en 88 ; Fabricius gaf er in 1794 den naam van Gerris aan. De eerste benaming is dus de ondste, doch, al ware zij dit niet, dan zou toch mijns inziens de tweede naam vermeden mueten worden, omdat Gerris ook gebruikt is om het geslacht aan te duiden dat wij met Fabricius en anderen Hydromelra noemen; zoo ontgaan wij alle verwarring.

Het is van de vorigen zeer gemakkelijk te onderscheiden door de bijzonder lange voorheupen en de bestemming der voorpooten, kennelijk niet voor den gang, maar alleen voor het grijpen en vasthouden eener prooi. De beide insecten, die tot dit afwijkende geslacht bebooren, gebruiken dan ook in het gaan de lange sprieten als voorpooten, waarop zij werkelijk steunen, terwijl het ligchaam overigens tusschen de vier achterpooten, wier knieën ver boven den rug uitkomen, hangt te schommelen.

Ligchaam zeer smal; kop en borststuk slechts een vijfde gedeelte der geheele lengte uitmakende. Kop $\frac{1}{3}$ korter dan het borststuk met een bol opgezetten hals, die door eene dwarsgleuf van den eigenlijken kop afgescheiden is. Geen bijoogies; oogen sterk uitpuilend met grove facetten; daarvoor de dikke grondknobbels der sprieten en geen uitsteeksel daartusschen. Zuiger kort en dik, tot tusschen de voorheupen reikend, van 3 leedjes. Sprieten zeer dun, haarvormig, langer dan het ligchaam, met een tusschenleedje aan de basis van lid 1 ; de beide laatste leedjes te zamen slechts half zoo lang als het tweede, 3 driemaal langer dan 4. Borststuk slechts weinig breeder achter dan aan den hals en iets langer dan breed. Schildje viij groot, doch door eene gleuf in 2 deelen verdeeld, waarvan het voorste veel hooger ligt dan het andere en boven- 
dien van een opgewipt stekeltje voorzien, zoodat dit voorste dcel het geheele schildje schijnt uit te maken.

Dekschilden iets langer dan het achterlijf en dit geheel bedekkend; zij zijn zeer smal aan de basis en verbreeden zich bijzonder sterk voorbij het midden; de membraan neemt er het grootste gedeelte van in. Deze heeft even voor de binnenzijde eene lange ader, van waar kleine dwarsaderen uitgaan naar eene andere ader in het midden. Achterlijf van onder kielvormig met opgewipten dunnen zijrand. Voorpooten met zeer lange heupen, des niettegenstaande echter in het geheel niet veel langer dan de dijen der achterpooten. Voordijen vrij dik, midden- en achterdijen zeer dun en bijzonder lang, even als hunne seheenen; tarsen daarentegen kort.

Door bunne gedaante en het bangen tusschen de pooten doen deze insecten aan sommige soorten van muggen (b. v. Limnobia) of wel aan het geslacht Berylus denken. Zij worden meest in tuinhuisjes en dergelijken aangetroffen. Flor verzekert dat zij snel vliegen. Inlandsch zijn twee soorten, eene grootere en eene kleinere.

\section{Ploearia vagabunda $\mathrm{L}$.}

Plaat 18 , fig. 8 en $8 a$.

Linn. S. N. Ed. 13, p. 732, 119. - Fabr. S. Rh. 262, 9. - De Geer, Mémoires vert. III, 212, 41, tab. 17, f. 1-7. - Wolf, Ic. Cim. p. 203 , tab. 20 , f. 197 . - Schellenb. Cim. Helv, p. 24, tab. 8, f. 1 $a-d .-$ H. Sch. W. Ins. IX, p. 117, tab. 305, f 941. - Flor, Rh. Livl. I, p. 689. - Douglas and Scott, Brit. Hem. p. 536, pl. 18, fig. 1.

Lengte $7 \mathrm{~mm}$. -- Kop grauw, aan de spits en achter de zwarte oogen bruin. Zuiger geelachtig wit met 4 donkere bandjes. Sprieten, $1^{\text {e }}$ lid en benedenhelft van het $2^{e}$ wit met fijne zwarte bandjes, het overige van het $2^{\mathrm{e}}$ met 3 wit, 4 grijjs. Borststuk lichtgrauw met eenige bruine schrapjes op de voorhelft. Schildje an den voorrand lichtgrauw met eene witte spits, het overige zwartachtig. Achterlijf bruin met eene roodachtige streep aan wederzijde. Dekschilden gemarmerd grijs met witte aderen; 2 bruine vlekjes aan den buitenrand, waar- 
van de achterste grooter en donkerder, begrenzen een belder wit langsstreepje; spits der membraan lichtbruin bewolkt met 4 witte vlekjes an den rand. Voorpooten met tamelijk lange haren behard; alle pooten geelaehtig wit; voordijen naar de spits toe met 3 vrij breede bruine bandjes, voorscheenen desgelijks, maar de bandjes flaauwer. Vier achterpooten met tal van fijne zwarte bandjes.

Ik heb eenmaal deze soort gevangen op de Gliphoere bij Bennebroek, zoo ik mij wel herinner in cen grotwerk, op klimop; Prof. J. van der Hoeven ving er een in een tuinbuisje bij Leyden; de heer F. J. M. Heylaerts Jr. zond mij ter determinatie een voorwerp door hem in zijn' tuin binnen Breda aangetroffen; voorts zag ik nog een exemplaar door den heer de Gavere te Groningen gevangen, en twee voorwerpen die de heer Schepman in October te Rhoon aantrof, kruipende op stammetjes van hazelaren. In Enge'and is de soort plaatselijk gemeen op klimop; het is dus rreemd dat men haar hier te lande, waar zoo veel klimop wast, zoo zelden antreft.

\section{Plocaria erratica Fall.}

\section{Plaat 18 , fị̣, 9.}

Falı. Mon. Cim. 117, 6. - Id. Hem. Suec. 164, 2。 - Herr. Sch. W. Ins. IX, 118. - Burm. Handl. II, p. 224. - Douglas and Scott, Brit. Hem. p. 536.

Lengte $5 \mathrm{~mm}$. - Deze soort, veel kleiner dan de voorgaande, is bovendien herkenbaar aan de volgende kenteekens; de voorpooten zijn onbehaard; de kleur is iets donkerder; de spits der membraan is bepaald bruin, met fijne witte aderen, de zijrand van het achterlijf is geblokt, zwart en wit, en de bandjes om de achterpooten zijn iets breeder.

Deze soort is niet zeldzaam. Zij werd aangetroffen: bij Rotterdam (Gijsberti Hod.), bij den Haag (de Graaf, v. Hass., v. d. Wulp), bij Leyden (van Voll.), bij Utrecht (Six) en bij Breda (Heylaerts). Zij komt voor van Mei tot in October, in huizen en tuinhuizen. 


\section{TWAALFDE FAMILIE - WATERBEROEIJERS.}

HYDRODROMICI.

De vertaling van den Griekschen naam zou eigenlijk in het Hollandsch luiden op het waler loopers, doch daargelaten dat dit moeijelijk tot een woord zamen te vatten is, loopt eigenlijk slechts eene soort uit de familie over lhet water (Limnobates Slagnorum), terwijl de overigen op het water drijvende, zich met hunne pooten roeijende voortbewegen.

De familie onderscheidt zich van alle vorigen door de in. planting der klaaurtjes, die zeer klein zijnde, geplaatst zijn in eene inkeeping voor de spits van het laatste lid der tarsen. Hierop maakt nu wel het geslacht limnobates eene uitzondering, doch wat de overige karakters betreft, behoort het kennelijk tot deze groep, zijnde eene overgangsvorm tusschen de evenzeer lang uitgerekte Ploearien en het geslacht IIydromelra dat de hoofdstam is in deze familie.

Gedaante meestal lang uitgerekt, zelden klein en gedrougen, onderzijde van het ligehaam steeds met zijdeachtige, zeer digte, als metaal blinkende beharing bedekt, die het water niet tot het ligchaam laat doordringen. Kop gewoonlijk klein. Oogen steeds bol en uitpuilend. Bijoogjes ontbreken of zijn moeijelijk te zien. Sprieten van 4 leedjes, aan de zijden van den kop, voor de oogen ingeplant. Zuiger los, doch tegen de borst aangedrukt van 3 of 4 leedjes, waarvan het middelste of voorlaatste verreweg het grootst. De prothorax strekt zich met een uitsteeksel, den zoogenaamden processus, over den mesothorax en het schildje heen. De dekschilden en vleugels ontbreken dikwijls; wanneer de eersten aauwezig zijn, zijn zij van basis tot spits van eene en dezelfde lederachtige hoedanig- 
heid, doch van krachtige alleren voorzien, die echter weinig cellen vormen. Het abdomen levert geene bijzondere kenmerken op. De ponten zijn zeer verschillend gevormd; die ran Limnobales zijn looppooten (de dieren loopen op) het water), die der andere geslachten zijn roeipooten of grijppooten met dien verstande dat het voorste paar gebruikt wordt om de prooi te grijpen en te houden, terwijl de beide andere paren tot roeijen dienen, zijnde hier het middelste paar altijd langer. De beweging is bij het $1^{e}$ paar verticaal, bij de beide anderen horizontaal. De tarsen hebben 2 of 3 leedjes; over de inplanting der klaauwtjes in het laatste is reeds gesproken.

Men ziet deze dieren hetzij aan den oever van stilstaande wateren loopen en zich tusschen kroos en andere waterplanten bewegen, hetzij op stroomeude beekjes in grooten getale roeijend zich tegen den stroom opwerken en met elkander spelen. Hun roeijen is niet gelijkmatig, maar geschiedt hij schokken. Hun voedsel bestaat in kleinere insecten.

De familie telt slechts 4 geslachten, die zeer gemakkelijk in schema te brengen zijn.

Tabel der geslachten.

1 (2). Kop langer dan de prothorax; voorpooten tot gaan geschikt. Gen. 1. Limnobates Burm.

2 (1). Kop korter dan de prothorax; voorpooten niet tot gaan geschikt.

3 (4). Borststuk langer dan breed.

Gen. 2. Hydrometra F.

4 (3). Borststuk zoo lang als breed of breeder dan lang.

5 (6). Het $1^{\mathrm{e}}$ lid der sprieten het langste. Tarsen van 3 leedjes.

Gen. 3. Velia Latr.

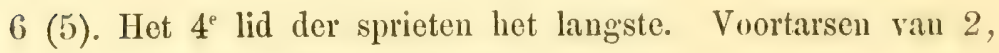
achtertarsen van 3 leedjes.

Gen. 4. Microvelia Westw. 
Gen. 1. Limponates Burm.

Een geslacht van bijzondere gedaante. Ligchaam slank. Kop langer dan het borststuk, bijna cylindervormig, doch in het midden dunner dan aan de beide einden; het gedeelte voor de oogen veel langer dan dat er achter. Oogen middelmatig, uitpuilend, cirkelrond. Zuiger zeer slank, zoo lang als de kop, van 3 leedjes, de beide uitersten ongeveer even kort. Sprieten zijdelings bijna op het eind van den kop ingeplant, hun grondlid iets dikker dan de 3 haarvormige volgenden; het $3^{\circ}$ langer dan 2 en 4 vereenigd. Thorax tweemaal zoo dik als de kop, prothorax zeer kort, mesothorax korter dan de metathorax. Vleugels en dekschilden zelden ontwikkeld; zijn zij het, dan reiken zij bijna tot de spits van het achterlijf; deksebilden lederachtig met 2 langsaderen en bij de spits 2 scheeve dwarsaderen; vleugels met 2 langs- en eene dwarsader. Achterlijf bij de mannen zeer slank, bij de wijfjes in het midden uitgezet met opstaanden rand, bij beiden iets korter dan kop en thorax te zamen genomen. Pooten zeer slank en vrij lang, allen, ouk die van het voorste paar, tot gaan ingerigt; de heupen staan vrij ver van elkander en zijn tamelijk dik; dijen en scheenen zijn zeer dun, tarsen vau drie leedjes, met 2 klaauwtjes an de spits, niet in eene inkeeping onder de spits.

\section{Limnobales Slagnorum L.}

Plaat 19 , fig. 1 en $1 a$.

Linnaeus, S. N. ed. 13, 732, 118. - Fabr. S. Rh. 258, 6. - Fals. Mon. Cim. 116, 4. - Curtis, Brit. Ent. 1, pl. 32. - Burm. Handb. II, 211.-Herr.-Sch. W. Ins. IX, p. 118, tab. 304, f. 938, 939.-Douglas and Scott, Brit. Hem. p. 576, pl. 19, f. 7.

Lengte ongeveer $1 \mathrm{~cm}$. - Zwart of zeer donker bruin. Zuiger pekbruin. Eerste leden der sprieten aan de basis roodachtig. Somtijds drie zeer fijne zilverachtige langslijntjes op het borststuk. Als de vlengels aanwezig zijn, draagt de thorax 
op de achterhelft an de zijden twee kleine ronde, gladde bultjes. Dekschilden bruin met vuil okerbruine vlekjes tusschen de aderen. Het onbedekte abdomen vertoont soms goudglanzige bestuiving op de zijden van den rug. De pooten zijn roodbruin, doch worden donkerder van het midden der scheenen naar het eind.

Men vindt deze dieren aan den oever van slooten en poelen; zij loopen er langzaam over het kroos en zelfs over het water, en zijn misschien ook nachtdieren. De meeste voorwerpen, die men aantreft, zelfs laat in den herfst, hebben geene uitgegroeide dekschilden en vleugels.

Gen. 2. Hyprometra F.

Dit en de beide volgende geslachten bevatten insecten, die op het water roeijen, niet loopen als Limnobates, noch ook onder water zwemmen, gelijk de waterwantsen. IIydrometra onderscheidt zich van de beide anderen door dat het borststuk langer dan breed is, volgens andere schrijvers ook doordien alle tarsen uit niet meer dan 2 leedjes bestaan; dit kenmerk is echter niet gaaf aan te nemen, daar het microscoop bij sommigen een derde leedje doet ontdekken. De benaming werd door Fabricius gegeven, Latreille noemde hen Gerris, een' naam later mede door Fabricius gebruikt, doch ook gegeven an het vroeger beschrevene geslacht Plocaria en daarom maar liever geheel te verwerpen, vooral daar er een betere en misschicn ook oudere bestaat.

Ligchaam langwerpig, min of meer spoelvormig, an de onderzijde geheel met zijdeglanzig vilt bekleed, dat goud- of zilverstof nabootst. Kop vrij klein, tot aan de oogen in den prothorax verzonken, voor de oogen in eene stompe punt uitgestrekt op wier zijden ter halver lengte van de spits de sprieten op knobbeltjes zijn ingeplant. Oogen groot, bolrond, aan den binnenkant een weinig ingesneden. Bijoogjes zeer klein en meest onder beharing verborgen. Sprieten met 4 leedjes van 
ongelijke lengte, ten hoogste zoo lang als de kop met den thorax; tusschen lid 2 en 3 gewoonlijk een tusschenzetsel. Zuiger kort, kegelvormig, los hangend, van 3 leedjes, waarvan het middelste verreweg het langste. Prothorax aan deu hals van een dwarsgleufje en daarachter van een paar bultjes voorzien, in de zijden naar achteren toe verbreed en over den mesothorax nitgestrekt met cen rondloopend nitstecksel (Processus), dat de plaats van een niet aanwozig schildje inneemt, maar niet den geheelen mesothorax bedekt. Dekschilden on vleugels zịn bịj enkele soorten niet, bij anderen wel ontwikkeld; in dit laatsto geval zijn zij zoo lang als of iets korter dan het achterlijf en tusschen de opgewipte zijranden daarvan in de rust plat op het abdomen nedergelegd; de dekschilden vertoonen geene afscheiding in clavus, corium en membraan, en bezitten drie langsaderen, waarvan de beide voorsten gegaffeld zijn en onderling door een smal dwarsadertje verbonden. Abdomen op den rug vlak, aan den buik bol, met scherpe, eenigzins opgewipte zijpranden, onder welke eene fijne vrij diepe langsstreep loopt. Het zesde segment eindigt aan beide zijden in eene punt, die bij een paar soorten als een werkelijke doorn naar achter uitsteekt. Na dit zesde hebben de wijfjes nog 2, maar de mannetjes nog 3 korte genitaal-segmenten. De voorpooten zijn zeer ver van de overigen af ingeplant, gezet en vrij kort; hunne beweging is nagenoeg verticaal, terwijl die der vier anderen horizontaal is; dezen zijn veel langer, vooral de middenpooten. De vier achterheupen ziet men op zijde nitsteken, als men de dieren op den ruy beschouwt. Dijen en scheenen der achterpooten zeer slank, tarsen vrij lang en slank van twee leedjes; hunne klaawwtjes aan de onderzijde voor het einde ingeplant.

Tabel der soorten.

1 (4). Eerste lid der sprieten duidelijk langer dan 2 met 3. Achterlijfshoeken als doornen uitstekend. 
2 (3). Zijrand van het abdomen geel. Eerste tarsenlid der achterpooten bijna 2 maal langer dan het tweede.

Sp. 1. H. Paludum F.

3 (2). Zijrand met het abdomen eenkleurig. Dekschiiden en vleugels ontbreken meest. Eerste tarsenlid der achterpooten slechts $1 \frac{1}{2}$ maal zoo lang als het tweede.

Sp. 2. H. aptera Schumm.

4 (1). Eerste lid der sprieten korter dan 2 met 3.

5 (6). Doornen van het $6^{\text {e }}$ segment lang en kegelvormig. Sp. 3. H. rufoscutellata Latr.

6 (5). Uitsteeksels van het $6^{e}$ segment kort, breed en plat.

7 (8). Zesde segment bij ${ }^{7}$ aan den buik met 2 naar voren gerigte haakjes. Eerste bij of dwars ingedrukt.

Sp. 4. H. odontogaster Zett.

8 (7). Zesde segment bij के zonder haakjes. Eerste bij 우 met een' kiel.

9 (10). Thoraxrug naar het eind roestgeel.

Sp. 5. H. thoracica Schumm.

10 (9). Thoraxrug geheel zwart of donkerbruin.

11 (14). Grooter dan 7 millim.

12 (13). Buik zwart met eene smalle roestgele middenstreep.

Sp. 6. H. gibbifera Schumm.

13 (12). Buik bij q geel met 2 breede zwarte zijstrepen. Sp. 7. H. lacustris L.

14 (11). Gewoonlijk kleiner dan 7 millimeter, zwart met zilverstreepjes.

Sp. 8. H. argentala Schumm.

\section{Hydrometra Paludum F.}

Plaat 19, fig. $2 a$ en $2 b$.

Fabr. S. Rh. 258, 3.- Schumm. Ploteres, 29, t. 4, f. 5 et 4-13.Burm. Handb. II, 210, 1, - II. Sch. W. Ins. IX, p. 67 et 70, t. 300 , f. 926, - Flor, Rh. Livl. 1, p. 732, - Douglas and Scott, Brit. Hem. p. 559. 
Lengte 14-15 mm. - Donkerbruin, op de bovenzijde hier en daar met goudgele haartjes bezet, onderzijde loodgrijs met zilverglans. Kop van onder zilverwit, welke kleur in den hals loodregt tegen het bruin aanligt. Oogen, bijoogen, zuiger en sprieten zwart; van deze laatsten is lid 1 bijna zoo lang als de 3 volgeuden te zamen, 3 korter dan 2, en ook dan 4. Voorborststuk met een klein stekeltje aan wederzijde van voren, en in het midden aldaar een kort geel streepje; middengedeelte naar achter wat verbreed en aan de achterhoeken in een knobbeltje nitloopend; over het midden, dat bol oprijst, een fijn rigcheltje; processus bol met platten rand, waarop een geel bandje. Aan de zijden der borstringen een zeer zwart streepje op den zilverglanzigen grond. Dekschilden zeer donker bruin met goudgele beharing aan de basis. Pooten zwart; heupen der achterpooten met hunne pannen geel. Midden- en achterdijen eveu lang; middenscheenen ongeveer zoo lang als de achterscheenen met hunnen tarsus; ecrste tarsenlid der middelpooten meer dan 3 maal, dat der achterpooten slechts 2 maal zoo lang als het daarop volgende lid. Achterlijf in het midden met een flaanw kieltje, in iedere zijde met eene rij van 5 zilverwitte vlekjes op den achterrand der 5 voorste segmenten; zijdestrepen vuil oranje. Stekels van het $6^{\text {e }}$ segment bij het $\delta$ zoo laug als, bij het $q$ langer dan de genitaalsegmenten.

In de tweede naamlijst staat dat deze sourt in Holland in een exemplaar door den heer van Bemmelen gevangen werd; het bedoelde voorwerp bleek echter tot II, aptera Schumm. te behooren; doch op 's Rijks Museum voor natuurlijke geschicdenis te Leyden staan drie voorwerpen van $H$. Paludum met het etiquet "Calkoen, Holland". (Calkoen was een handelaar in naturalien te Amsterdam, omstreeks 1820).

\section{Hydrometra aptera Schumm.}

Plaat 19 , fig. 3 en $3 a$.

Schumm. Plot. 34, 3, tab. 4, f. 4 en 20-24. - L. Duf. Recherch. 
p. 69, tab. 5, f. 59 (Canalium). - Flor, Rh. Livl. 1, p. 731 1) -

Douglas and Scott, Brit. Hem. p. 560 .

Lengte 13-17 mm. - Mij zijn geene andere dan ougevleugelde voorwerpen als inlandsch bekend. De soort versehilt van de voorgaande in de volgende opzigten. Zij wordt grooter in de vrouwelijke sexe, vertoont minder zilverglans op de onderzijde en heeft veel korter stekels aan het $6^{\circ}$ segment.

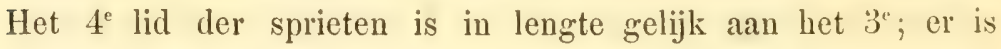
geen stekeltje aan de zijden van den prothorax, geen strecpjes in het midden, geen geel bandje aan den processus, geen oranje zijdestrepen aan het achterlijf. Op de borst zict men 2 divergeerende langsvlekken; daarachter volgt eene zalmklenrige vlek tusschen de middenpooten. Middelscheenen iets langer dan de achterscheenen met hunnen tarsus. Eerste tarsenlid der achterpooten slechts $1_{2}^{1}$ maal langer dan het tweedc.

Deze sourt komt hier te lande veel meer voor dan Paiuhtum: zij werd gevangen bij den Haag (v. d. Wulp), bij Warmond (v. Bemm.), op Sterkenburg bij Driebergen in Aug. (v. Voll.), bij Hattem (Piaget), onder Wolf heze in Aug. (de Graal), bij Nijmegen (van Bemm.), bij Breda in Mei (Heylaerts.)

\section{Hydrometra rufoscutellata Latr.}

Plaat 19 , fig. 4 en $4 a$.

Latr. Gen. Cr. et Ins. III, p. 134. - Cuvier, Rène An. pl. 92, 1. Ј.Schumm. Plot. p. 32, t. 3, f. 1 et 2 , tab. 4, f. 1, 2, 14-19. - Herr. Sch. W. Ins. IX, p. 62, t 300 , f. 924 et t. 299, f. $g h$ i. - Flor, Rh. Livl. I, p. 736.

Lengte $15 \mathrm{~mm}$. - Iets kleiner dan de vorige, er op gelijkend, doch slanker en vooral lichter van kleur. Kop van boren zwart, aan de zijden en van onder glanzig als geelachtig zilver. Zuiger slank, grijs. Sprieten langer dan bij de andere soorten,

1) Ik haal de Geer's Cimex Najas niet aan, omdat het mij voorkomt dat bcschrijving en afbeelding eer op 11 . lacustris slaat; evenmin citeer ik Schellenberg's Aquarizs Paludum, oundat ook daar de soort niet te bepalen is. 
langer dan kop en borststuk, roestbruin met zwarte einden der leedjes; lid 1 aan de basis wat naar binnen gebogen, $1 \frac{1}{4}$ maal zoo lang als $2 ; 3$ korter dan, 4 gelijk aan 2 , het vierde soms zwart. Oogen groot, glanzig zwart. Voorborststuk op den rug zwart met een roestkleurig middenstreepje, middenborststuk roestkleurig met zwarte zijden vooral naar voren toe, processus geheel roestkleur. Aan de zijden van den thorax eene zwarte langsstreep en daaronder de zwarte borst met zilverwit behaard. Dekschilden en vleugels ontwikkeld; de eersten roodbruin met donkerder aderen, bezet met gele haartjes. Pooten rosbruin met donkerder tarsen. Eerste tarsenlid der middenpooten 4-5 maal, dat der achterpooten 2-maal zoo lang als het volgende lid. Buik met fijne middenrigehel. Doorntjes van het $6^{\text {e }}$ segment vrij lang en stekelig, bruinachtig geel, bij het wijfje zoo lang als de genitaalsegmenten, bij het mannetje veel korter.

Deze soort werd in Holland aangetroffen door den heer van Bemmelen, bij Wassenaar in het voorjaar door den heer de Graaf en in de omstreken van Breda door den heer Heylaerts. Ik vond haar vroeger in overvloed in Junij en Julij op den vijver van de Gliphoeve onder Heemstede en bij Sterkenburg.

\section{Hydrometra odonlogasler Zett.}

Plaat 19 , fig. 5 .

Zetterstedt, Fauna Lap. 506, 3. - Schumm. Plot. p. 36, tab. 3, f. 8-10. - Herr.-Sch. Wanz. Ins. IX, p. 73, t. 301, f. 931. - Flor, Rh. Livl. I, p. 738.

Lengte $7, \check{\partial}-8,5 \mathrm{~mm}$. - Zeer sterk gelijkend op Lacustris (de gemeenste soort), doch in de mannelijke sexe daarvan duidelijk te onderscheiden door de kleine buikhaakjes aan segment 6 , in de vrouwelijke moeijelijker door een' dwarsen indruk in het eerste genitaalsegment.

Zwart, door de beharing op den rug bruin; buikzijde loodgrijs met zilverwitten weerschijn. Sprieten bijua tot de middelheupen reikend, zwart; lid 1 nagenoeg als $2+3,3$ het kortste 
der vier. Een streepje op den prothorax en de zijden van den thorax geelachtig. Een flaauw langsrigcheltje op den processus. De zijden der borst vertoonen in bepaalden stand eerst een looden, dan een kopergelen gloed, door een smal bruin streepje van elkander afgescheiden. Dekschilden zwart met blaawen glans en bruine aderen. Pooten geelachtig bruin; voordijen zwart met gele basis of geel met zwarte streep aan de buiten zijde. Eerste lid der tarsen aan de middenpooten 3 maal langer dan het tweede.

Zoomen van het achterlijf bleek rood; zesde segment bij den man diep ingesneden met 2 korte naar voren gebogen haakjes. Bij het wijfje is het eerste genitaalsegment dwars ingedeukt.

Deze zeer zeldzame soort werd tot nog toe alleen gevangen door den heer Mr. H. W. de Graaf en wel bij Wassenaar in het eerste voorjaar onder dorre bladeren en in April op de slooten aldaar.

\section{Ilydrometra thoracica Schumm.}

Schumm. Ploteres, p. 46. - Herr. Sch. W. I. IX, p. 71, pl. 301, f. 928 en pl. 299, Z aa, bb. - Flor, Rh. Livl. I, p. 739. - Dougl. and scott, Brit. Hem. p. 562 .

Lengte 10-11. - Deze soort is met geene andere te verwarren als men let op grootte en kleur.

Zwart of donkerbruin met een streepje op den prothorax, de achterhelft van den mesothorax met den processus roodbruin en de zijranden van het achterlijf geel. De sprieten ziju zeer kort en reiken slechts tot de helft van den mesothorax, zij zijn roodachtig lichtbruin met zwarte spitsen. De randen van den processus en de dekschilden zijn donkerbruin. De onderzijde is zilverglanzig met een geel streepje op de rijden van den mesothorax. Pooten aan de heupen geel, verder geelbruin en aan de tarsen zwart. Eerste lid der middeltarsen slechts 2 maal langer dan het tweede. Spitsen van het $6^{\circ}$ segment plat en vrij breed, roodachtig geel even als de genitaalsegmenten. 
Eene vrịj gemeene soort, gevonden bij Wassenaar, Leyden, den Haag, Haarlem, Breda, Middelburg en Koudekerke, meestal in het voorjaar.

\section{IIydromelra gibbifera Schumm.}

Plaat 19, fig. 6.

Schumm. Plot. p. 41, tab. 3, fig. 5-7. - Herr.-Sch. W. Ins. IX, p. 72, tab. 301, f. 929 - Douglas and Scott, Brit. Hem. p. 564, pl. 19, f. 1.

Lengte 8-- $10 \mathrm{~mm}$. - Kenbaar aan het roode bultje op het midden van de buikzijde van den mesothorax, overigens sterk gelijkende op Lacustris.

Ligchaam van den gewonen vorm, boven zeer donker bruin, onder zwart met loodglans. Kop gewoou gevormd. Sprieten kort, slechts tot an de middenheupen reikend, zwart; $1^{\text {e lid }}$ gelijk aan $2+3$, latste langer dan 3 . Over den rug eene middenrigchel, die aan den prothorax roodachtig betint is. Zijden van den thorax voor de inplanting der vleugels vrij sterk bultig; juist daaronder in de zijden een kort geel streepje. Dekschilden bruin. Zijrand van het abdomen roodgeel; hoeken van segment 6 van boven bijna onzigtbaar. Voorpooten aan houpen, apophysen en basis der dijen zeer licht geelrood, dijen verder zwart, scheenen lichtbruin met hunwe uiteinden en tarsen donker. De vier overige pooten aan de basis geelrood, naar het eind toe bruin. Onderzijde van het lijf zwart; bij den man op het midden van den metathorax een oranje knobbel; van daar eene smalle gele middelstreep naar den anus; zijranden, achterzoom en genitaalsegmenten geel. Bij het wijtje ontbreekt de knobbel, doch schijnt aldaar eene hoekige gele vlek aanwezig.

Ik ken slechts een inlandsch voorwerp dezer soort; het is een mannetje, door mij in Julij op een der slooten bij Schothorst ten noorden van Amersfoort gevangen. 


\section{Hydrometra lacustris $\mathrm{L}$.}

Plaat 19 , fig. 7.

Linn. S. N. 13 ed. 732, 117. - Schumm. Plot. p. 43. 7, pl. 3, f. 11.Burm. Handb. II, p. 210, n 2. - Herr.-Sch. W. Ins. IX, p. 68 en 73, pl. 301 , f. 930 en pl. 299, f. T-V. - Flor, Rh. Livl. I, p. 742. Dougl. and Scott, Brit. Hem. p. 566.

Lengte 8-9 mm. - De meest gewone soort, op den rug zwart, door fijne goudgele beharing bruin, aan den buik zilverglanzig en loodgrijs, in de zijden bij het wijfje koperglanzig. Een streepje op het midden vau den prothorax, een veegje onder tegen de zijranden van den mesothorax en de zoomen van het achterlijf met de genitaalsegmenten geel. De middelkiel over den thorax is vrij sterk opgezet en vooral op den processus ietwat kamvormig. De sprieten zijn als bij de vorige soort, ook de dekschilden. Het gele zoompie van het achterlijf is weder door een zeer smal zwart randje omgeren. De pooten zijn bruinachtig geel aan de basis, lang donker wordend, zoodat de tarsen bijna zwart zijn; de rooldijen hebben op de bovenzijde eene zivarte langsstreep. Eerste tarsenlid der middenpooten bijna 4 maal, dat der achterpooten tweemaal zoo lang als het daarop volgende lid. Aan de onderzijde loopt over de borst eerst een middenglenfje, dat echter reeds ter hoogte van de middenheupen in een rigcheltje verandert en als zoodanig ver over het midden van het abdomen heenloopt. Bij den man is het achterlijf eenvoudig zwart of donkergrijs met gele rijranden en achterrand, ook de rand van het $1^{e}$ genitaalsegment en het geheele tweede zijn geel; bij het wijfje is het achterlijf meestal bruingeel met 3 zwarte langsstrepen, een over het midden, de anderen langs de zijden.

Men treft deze soort in zeer vele slonten en stilstaande wateren van ons land aan. De heer Mr. H. W. de Graaf ving onder de anderen ook volwassen voorwerpen met verkorte dekschilden. 


\section{Hydrometra argentata Schumm.}

Plaat 19 , fig. 8.

Schumm. Ploteres, p. 49, 9. - Herr. Sch. W. Ins. IX, p. 68 en 74, pl. 301, f. 932. - Flor, Rh. Livl. I, p. 740. - Dougl. and Scott, Brit. Hem. p, 568.

Lengte $78 \mathrm{~mm}$. - De kleinste soort, bovendien herkenbaar aan eenige in eene bepaalde lichtrigting glinsterende streepjes op den thorax. Bovenzijde donkerbruin, onderzijde zwart met loodgrijze of kopergele spiegeling. Gedaante als bij de vorige. Sprieten zwart, lid $1=2+3$, deze beiden aan elkander gelijk, lid 4 iets langer. Over den thorax loopt een langsrigeheltje dat op den prothorax vuil oranje is gekleurd. De zilverglans, die bij zekere rigting van het licht gezien wordt is of op dit rigcheltje of op het midden van den processus of wel op de zijden daarvan. Dekschilden soms maar half uitgegroeid, zwart met een blaawwen weerschijn. Zoom van het achterlijf zwart, doch in het midden met een zeer fijn oranje streepje geteekend. Pooten van boven gezien bruin, van onder bruingeel, de heupen zeer licht gekleurd. Voorheupen met een donker vlekje. Achterscheenen met hunne tarsen bijna korter dan de middenscheenen alleen. Eerste tarsenlid der middelpooten 3 maal, dat der achterpooten slechts $1 \frac{1}{2}$ maal langer dan het daarop volgende. Aan den buik geene lichte strepen of vlekken, behalve de randzoom, die geel is.

Ik ken van deze soort slechts twee vindplaatsen, de omstreken van Breda (Heylaerts, Leesberg) en duinslooten om 's Gravenhage (van der Wulp in Julij).

Gen. 3. Velia Latr.

Ligchaam vrij gedrongen, naar gelang der lengte breeder dan bij het voorgaande geslacht. Kop even als daar, tot aan de oogen in den prothorax gedoken, breeder dan lang, bol op het voorhoofd eu dan regt naar beneden gebogen. Zuiger van 
3 leedjes tot aan de middenheupen reikend. Oogen rond en bol; bijoogjes ontlureken. Sprieten op een knobbeltje onder de oogen, bij de basis van den zuiger ingeplant, van 4 leedjes; het eerste langer en ook iets dikker dan elk der overigen afzonderlijk, de 3 anderen ongeveer gelijk van lengte. Borststuk voor breeder dan de kop met de oogen, op $\frac{2}{3}$ der lengte zeer breed, gewelfd en met een' korten processus, die echter bij gevleugelde individuen wat langer is. Meestal zijn er geene dekschilden, noch vleugels; waar zij voorkomen, zijn zij iets korter dan het achterlijf en liggen in de rust op elkander tusschen de opstaande zijdeu. Deze zijn scherp en bij ongevlengelden op den rug vrij digt bijeengebragt, aan het einde vormen zij driehoekige opstaande lappen; van ouder is het achterlijf zeer buikig gewelfd; het is niet veel langer dan kop en thorax. Het $6^{\text {e }}$ segment is langer dan de overigen en van achteren loodregt afgesneden. Pooten tamelijk lang en dik, de voorpooten niet veel korter dan de anderen en meer naar buiten gekeerd dan bij IIydrometra: humne heuppannen staan vrij digt bij die der middelpooten. De heupen der laatsten staan zeer wijd uiteen. Achterdijen van den man sterk gezwollen en van 2 grootere tanden, tusschen welke eene rij kleinere, voorzien. Middelscheenen aan den binnenkant met vrij lange haren bekleed. Tarsen van 3 leedjes, waarvan het $1^{\mathrm{e}}$ zeer kort is, het $2^{e}$ aan de voorpooten korter, doch aan de achterpooten langer dan het 3 . Klaauwtjes vrij lang en tamelijk ver van de spits des tarsen ingeplant.

\section{Velia currens $\mathrm{F}$.}

Plaat 19, fig. 9.

Fabr. S. Rh. 259, 12. - Fall. Hem. I, 160, 2. - Burm. Handb. II, p. 212. - Curtis, Brit. Ent. I, tab. 2. - Wolff, lc. Cim. p. 201, tab. 20, f. 195. - Schumm. Plot. p. 19, tab. 1, f. 8 et 2, f. 1, 2. - Herr. Sch. W. Ins. IX, p. 76. - Flor, Rh. Livl. I, p. 746. - Douglas and Scott, Hem. Brit. p. 571, pl. 19, f. 2.

Lengte $6-8 \mathrm{~mm}$. (de gevleugelden langer). Zwart, door de 
digte beharing chocolaadbruin, het achterlijf van onder en de opstaande zijden peenrood. Sprieten en oogen zwart, zuiger glanzig bruin. Op den prothorax staan twee vrij groote driehoekige zilverglanzige vlekken en de streek daartusschen is min of meer helder rood. Het abdomen zwart, zonder bruine haarbekleeding, doch aan wederzijde כ̌ zilverglanzige vlekken in eene langsrij. De roodgele opstaande randen zwart ingekerfd. Het laatste buiksegment geelachtig, de genitaalsegmenten bruin. Pooten boven donkerbruin, onder bruinrood.

Bij de gevlengelde individuen zijn de deksehilden zwart met vier doorzigtige vlekjes, waarvan 2 digt bijeenstaan aan de basis, een op het midden en het $4^{e}$ digt voor den achterrand. De gevleugelde voorwerpen zijn zeldzaam.

Men heeft deze soort aangetroffen in de provincien ZuidHolland, Utrecht, Gelderland en Noord-Brabant; als bij Katwijk (Perin), Wassenaar (de Gr., v. V.), Warmond (de Graaf), Woerden (id.), bij Zeist (v. V., de Gr.), Driebergen (v. Bemm., Six), Wolfheze (Piaget), Doorweerth (de Gr.), den Keijenberg nabij Renkum (v. V.) en Breda (Heyl.). Waarschijnlijk komt zij ook in andere provincien voor; zij houdt zich liefst op stroomend of zachtvlietend water op.

\section{Gen. 4. Microvelia Westrv.}

Wij hadden dit geslacht in onze vroegere naamlijst IIydroessa genoemd naar Burmeister, doch de benaming Microvelia dagteekent van een jaar vroeger.

Het grootste verschil tusschen beiden ligt in de sprieten on tarsen, daargelaten de relatieve meerdere breedte. Het ligchaam is slechts 2 maal zoo lang als breed en dus zeer gezet, van de schouders af naar achteren slechts weinig smaller wordend. Kop kort, van het achterhoofd tot den zuiger spheroidaal naar beneủen gebogen, met uitpuilende oogen en zonder bijoogjes. Zuiger iets voorbij de voorheupen reikend, van 3 leedjes, waarvan het $1^{\mathrm{e}}$ kort, het $2^{e}$ anderhalf maal langer dan 3 . 
Sprieten even voor de oogen ingeplant, zoo lang als de voorscheen met haren tars, van 4 leedjes, waarvan 2 het kortste, 4 het langste; twee tusschenleedjes aan de basis van 2 en 3. Thorax breed en bol, met ingedrukte zijden voor de dekschildbasis, een indruksel over het midden en den processus ietwat puntig toeloopend. Dekschilden en vlengels zoo lang als het achterlijf; de aderen op de eersten vormen 3 gesloten cellen. Pooten ongeveer als bij Velia, doch die van het middelste paar niet veel langer dan de achterpooten en de trochanters langer dan daar. Tarsen der voorpooten van 2 , die der overige pooten van 3 leedjes.

\section{Microvelia pygmaea Duf.}

Plaat 19, fig. 10.

Léon Dufour, Ann. Soc. Ent. de Fr. III, p. 115, tab. 6 B, f. 1. Westw. ibid. III, 647. - Burm. Handb. II, 213. - Curtis, Brit. Ent. XV, tab, 681. - Flor, Rh. Livl. I, p. 749. - Douglas and Scott, Brit. Hem. p. 574, pl. 19, f. 3.

Lengte 1,7 mm. - Fluweelachtig olijfbruin; randen der oogen en onderzijde bekleed met zilverachtig vilt. Kop met een flaauw middelrigcheltje. Sprieten zwart met het eerste lid rood aan de basis. Over den prothorax aan den hals een smal rood bandje, in het midden afgebroken en in weerschijn zilverachtig. Abdomen dof zwart, doch met cen paar glanzige veegjes aan de basis. Dekschilden zwart met eenige doorzigtige vlekjes tusschen de aderen; de meesten zijn langwwerpig, doch het grootste is rond en staat het digst bij de spits. Pooten zwart met roode heupen, trochanters en basis der dijen.

Tot nog toe werd deze soort in ons land uitsluitend gevangen door den heer G. A. Six bij Driebergen in September. 
Sectie 2 .

WATERWA NTSE N.

HYDROCORES.

Deze tweede afdeeling der Ilemiptera heteroptera wordt door de schrijvers met versehillende benamingen bestempeld. Burmeister noemt de dieren daartoe behoorende /lydrocores, Amyot en Serville Hydrocorises, Flor en Fieber Cryptocerata.

De insecten die er toe behooren, leven allen in het water, 't zij zij daarin zwemmen of op den bodem rondloopen; echter rliegen zij ook wel uit het water op en vindt men hen dan toevallig op den grond rondspringen ter plaatse waar zij niet behooren en waar zij slechts gekomen zijn, doordien bun de kracht ontbrak om verder door te vliegen of doordien zij zich door het zintuig van het gezigt lieten bedriegen (b. v. wanneer zij het glas der broeibakken voor water aanzien). Ofschoon nu eenige Geocores op hat water of aan den oever van het water leven en dus door toeval een enkele maal onder het water kunnen geraken, blijven deze waterwantsen de eenige Hemiptera die onder water hun verblijf houden.

In den ligehaamsbouw hebben zij tevens een doorslaand kenmerk ter afscheiding van de landwantsen in hunne sprieten, die korter zijn dan de kop en aan de onderzijde van dien zijn ingeplant, hebbende altijd de basis of het grondlid bedekt. Men kan daar als algemeene kenmerken nog bijroegen: de bijoogjes ontbreken bij allen; de sprieten hebben slechts 3 of 4 leedjes; de dekschilden bestaan uit drie declen, coıium, clarus en membraan; de voorpooten zijn altijd geschikt om eene provi vast te houden. Overigens echter is de ligchaamsgedaante 7.00 
verschillend (ofschoon het antal soorten in betrekking tot de vorige afdeeling zeer gering is), dat het onmogelijk is een algemeen beeld der Hydrocores te geven.

Zij worden op natuurlijke wijze in vier familien verdeeld volgens dit schema:

1 (6). Zuiger uitwendig zigtbaar, uit leedjes zamengesteld.

2 (5). Voorkeupen op het midden of aan den roorrand der voorborst ingeplant.

3 (4). Sprieten van 3 leedjes, warvan het tweede een zijdelingsch uitsteeksel vertoont. Eene uitstaande buis aan het achterlijf.

$1^{\text {e }}$ Fam. Nepina.

4 (3). Sprieten van 4 leedjes, zonder uitsteeksels. Geene uitnitstaande buis aan het achterlijf.

$2^{\text {e }}$ Fam. Naucoridea.

5 (2). Voorheupen tegen den. achterrand der voorborst ingeplant. Eenvoudige sprieten van 4 leedjes.

$3^{\text {e }}$ Fam. Notonectidea.

6 (1). Zuiger onder de bovenlip verborgen, van een leedje.

$4^{\text {e }}$ Fam. Corixidea.

EERSTE FAUILIE. - WATERSCORPIOENEN.

NEPINA.

Het komt mij gepaster voor met deze niet zwemmende familio den aanvang te maken, dan wel, gelijk gewoonlijk geschiedt met de Naucoridea. Dat de waterscorpioenen hunnen naam verkregen naar zekere overeenkomst in gedaante met de ware scorpioenen, is ligt te gissen; die overeenkomst is echter slechts schịjnbaar.

Bij de twee geslachten, die hier te lande tot deze familie behooren, is de gedaante versehillend, zijnde of plat oval of lang cylindrisch. De punten warin beide geslachten overeenstemmen, zijn de volgenden: Kop klein met bolle oogen. 
Sprieten zeer kort van 3 leedjes, onder de oogen ingeplant, het tweede lid met een uitsteeksel aan de bovenzijde. Zniger kort, priemvormig van 3 leedjes. Dekschilden en vleugels ontwikkeld, de eersten uit clavus, corium en membraan bestaande. Buik eenigzins gekield. Voorpooten tot grijpen geschikt, zonder klaauwtjes, achterpooten niet tot zwemmen ingerigt, met twee klaauwtjes aan den tars. De spits van het achterlijf draagt twee nitgeholde lange platen, die tegen elkander sluiten en zoo eene holle buis vormen.

Over deze buis is eenig verschil van inzigt bij de geleerden, waarover men kan naslaan Flor, Rhynch. Livlands p. 760 vlg. Naar mijne meening moet men het meest geloof hechten aan hetgeen Léon Dufour en Burmeister op grond van zostomische onderzoekingen voor waar verklaren. De buis is dan een adembalings-toestel, die het dier vergunt te ademen ook wanneer het in het slijk bedolven ligt.

Want de dieren dezer familie leven in het slijk der slooten en poelen, en kruipen over dag tusschen de wortels der waterplanten rond. Des nachts en in de schemering vliegen zij dikwijls uit het water en zelfs in de allereerste fraaije voorjaarsdagen ook wel midden op den dag (even als vele waterkevers), waardoor het geschiedt dat men hen wel eens op landwegen antreft, waar zij echter eene zeer onbeholpen figuur maken.

Er zijn in deze familie slechts twee geslachten inheemsch waarvan de eene Nepa van de andere Ranalra verschilt doordien het ligchaam van boven zeer plat is en de voorheupen veel korter zijn dan de voordijen.

Gen. 1. Nepa L.

Ligeliaam zeer plat, oraal, aan den roorkant als afgesneden en voorbij het midden het breedst. Kop klein, plat vooruitstekend, tot aan de oogen in het halsschild gedoken, in het midden met een langsrigeheltje. Oogen rrij groot, grof van netwerk, naar boven uitpuilend. Sprieten in de rust achter de 
ongen verborgen, van 3 leedjes, waarvan het $1^{\text {e }}$ het kleinste en bijna kogelvormig, het $2^{e}$ veel langer en met een doornvormig uitsteeksel, waaronder het $3^{\text {e }}$ dat lang en priemvormig is. Zuiger naar beneden gebogen, kort, van 3 leedjes; het $1^{e}$ smal, aan de inplanting eng, aan den rand breed, het $2^{\mathrm{e}}$ langer en versmallend naar het einde, het $3^{e}$ korter dan dik, priemvormig.

Prothorax breed vierhoekig, met scherpe randen, de voorrand diep klaverbladvormig ingesueden om den kop op te nemen; de rugvlakte ongelijk, hobbelig. Schildje groot, driehoekig met scherpe punt naar achteren en de zijranden ietwat gegolfd. Dekschilden het geheele achterlijf bedekkend, het corium met 2 langsaderen en daartusschen eenige fijne, geslingerde dwarsadertjes; membraan bijna van dezelfde lederachtige zelfstandigheid als het corium met vele adertjes en vliezigen zoom. Buik met eene kiel in het midden over de lengte. Pooten wijd uiteen ingeplant; heupen der voorpooten dik, lunne apophysen zijdelings nitgebogen, hunne dijen scheef daarop ingeplant, naar beneden zeer sterk uitgezet en aldaar van eene gleuf voorzien, warin de zeisvormige scheen kan geborgen worden; tars der voorpooten van een lid, zonder klaauw. De 4 overige pooten, gewone looppooten, zijn langer en smaller, hunne heupen zijn kort, hunne dijen aan de onderzijde kantig, doch zonder gleuf, hunne scbeenen regt, hunne tarsen van 1 lid en met 2 lange klaawwen voorzien.

\section{Nepa cinerea L.}

Linn. S. N. $13^{e}$ ed. 714, 5. - Fabr. S. Rh. 107, 8. - Panz. Faun. Germ. 95, 14. - Schellenberg, Cim. Helv. p. 32, tab. 14, f. 1. - Rösel v. Rosenh. Ins. Bel. III, p. 133, tab. 22. - Voll. Gelede Dieren, p. 284, tab. XIX, f. 9. - Flor, Rh. Livl. I, p. 76\%.

Lengte 17-21 mm. - Algemeen bekend onder den dirazen naam van waterscorpioen. Grịs of aschkleurig grauw, soms bruin, met de bovenzijde van het achterlijf vermiljoen rood, bij den man roor en achter \%wart gevlekt. Ook de basis der 
vleugels is rood, en hunne voorste aderen. De adembuis is geelachtig en somtijds $1 \mathrm{em}$. lang. Bj enkele voorwerpen ziet men lichtere en donkerder ringen om de dijen; de scheenen der 4 achterpooten zijn aan de binnenzijde met eene franje van vrij lange zachte haren bezet.

Deze soort van insecten, waarvan de ontwikkeling en levenswijze omstandig door Rösel von Rosenhoff besehreven is, schijnt door geheel Europa, behalve het hooge noorden voor te komen. Bij ons werd zij in de provineien Zuid. en Noord-Holland, Zeeland, Utrecht, Gelderland, Noord-Brabant en Friesland waargenomen en zal in de 4 overigen wel niet ontbreken. Het is wel te betreuren dat er van de fauna onzer Noord-Oostelijke grenzen nog zoo weinig bekend is.

Gen. 2. Ranatra F。

Dit geslacht onderscheidt zich van het voorgaande bij den den eersten opslag van het oog door het lange cylindrische ligchaam en de nitgerekte voorste heupen.

Lijf ongeveer 7 of 8 maal langer dan breed. Kop bijzonder klein, horizontaal geplaatst met twee sterk uitpuilende oogen, onder welke de zeer korte sprieten verborgen zijn. Deze (zie fig. 11a) van 3 leedjes, het $1^{\mathrm{e}}$ cylindervormig, het $2^{\mathrm{e}}$ bijna drichoekig, met eene punt naar beneden uitstekend, het $3^{\text {e }}$ ongeveer boonvormig. Zuiger icts langer dan de helft van den kop, vrij slank, van 3 leedjes, waarvan het middelste iets langer dan de beide anderen. Thorax bijna vijfmaal langer dan de kop, rond in de zijden, voor scheef afgesneden, achter op den rug diep ingekerfd voor het schildje, voorbij het midden breeder wordend en ook van onderen wat uitgezet aan de voorheupen. Schildje van voren puntig, naar achteren wapenschildvormig. Dekschilden smal en lang, doch niet het geheele achterlijf bedekkenl. Buik sterk in de lengte gekield. Pooten zeer lang en slauk; voorpooten (zic pl.9, fig. 11b) bijna onder den kop ingeplant, hunne heupen langer dan de helft van de 
dijen, apophysen sterk naar boven opgewipt; dijen even voorbij de helft beneden van cen tandje voorzien, daarna een wcinig krom naar boven loopend en aan de onderzijle gegleufd, de rand der gleuf met eene rij korte borsteltjes bezet; voorscheenen en tarsen een sikkelvormig geheel uitmakend zonder klaawwtje. Achtertarsen van een lid met 2 uiteenstaande dunne klaauwen.

\section{Ranatra linearis $\mathrm{L}$.}

Plaat 19, fig. 11, $11 a$ en 116 .

Linn. S. N. ed. 13, 714, 7. - Fabr. S. Rh. 109, 2. - Fall Hem. Suec. I, p. 169. - Panz. Fn. 95, 15. - Curt. Brit. Ent. VI, t. 281.Riösel, Ins. Bel. III, p. 141, tab 23. - Hahn, W. Ins. II, p. 30, tab. 42, 1. 131. - Flor, Rh. Livl. I, d. 765. - Douglas and Scott, Brit. Hem pl. 20 , f. 2.

Lengte $30-36 \mathrm{~mm}$. Adembuis $30 \mathrm{~mm}$. - Licht grauw of lederkleurig, het borststuk aan de onderzijde met zwarte rlekken in de lengte, aan de zijden naar achteren geelachtig. Van deze laatste kleur zijn ook de zijranden van den buik en de adembuis; de rug van het abdomen is menierood.

Dit insect, ofschoon door geheel Europa verbreid, schijnt hier te lande zeldzaner dan het voorgaande. Exemplaren werden gevangen bij Bleiswijk en Voorschoten (v. V.), bij Leyden (Herklots en v. V.), bij Noordwijk (de Gr.), bij Overveen (Rits.) en bij Driebergen (Six).

\section{TWEEDE FAMILIE - NAUCORIDEN.}

NAUGORIDEA.

De eenige inlandsche soort van waterwantsen, welke tot deze familie gebragt kan worden, heeft tot heden geene bijzondere Hollandsche benaming ontvangen. 
Volgens onze tabel der familien verschilt deze tweede van de ecrste door het gemis van eene ademhalingsbuis en in den vorm der sprieten; er zijn echter nog meer punten van verschil. Ligehaam breed, ovaal, een weinig gewelfd. Kop kort en zeer breed, van voren afgerond; aangezigt verticaal. Oogen groot, van boven gezien min of meer driehoekig. Sprieten kort en vrij dik, van 4 leedjes zonder uitsteeksels. Zuiger breed, kort van 3 leedjes, waarvan het $2^{e}$ veel langer dan het $1^{e}$, en het derde kegelvormig en kort.

Thorax vierhoekig met toegeronde zijden, veel breeder dan lang, van voren echter iets smaller dan van achter, met naar voren verlengde voorhoeken. Schildje groot, breed driehoekig met gegolfde zijden. Dekschilden met clavus, coriun en membraan, de laatste zonder aderen. Vleugels breed. Abdomen breed met platten zijrand en eene kiel op het midden van den buik; luchtgaten klein. Pooten vrij kort en gezet; de voorpooten zeer ver naar voren ingeplant, met dikke heupen en zeer gezwollen dijen, die aan de onderzijde eene gleuf vertoonen, waarin de fijne, gebogen scheen en tars als een knipmes geborgen kunnen worden; de tars is onbewegrelijk en heeft geen' klaauw. De vier andere pooten hebben minder dikke dijen, scheenen die aan de binnenzijde sterk gedoornd zijn en beweegbare tarsen van twee leedjes, waarvan het laatste aan het eind twee lange klaauwtjes draagt.

$\mathrm{Er}$ is slechts een geslacht in deze familie.

Gen. Naucorts Geoffr.

Bij de opgegeven karakterschets der familie dient hier generisch nog vermeld te worden: dat het voorhoofd twee kromme rijtjes van fijne jutjes vertoont, dat de achterrand van het borststuk iets gewelld is en van het voorste gedeelte afgescheiden door eene dwarsrij van ondiepe putjes, dat clavus en corium beide cene lengteader bezitten en de membraan van dezelfde lederachtige Loedanigheid is als deze beiden, dat de 
achterrand van ieder buiksegment aan de zijden doornachtig uitsteekt en dat de achtertarsen aan de binnenzijde met lange zwemharen bezet zijn.

De Naucoriden zwemmen en vliegen zeer goed, doch loopen slecht op het drooge, waarop zij soms toevallig in hunne vlugt nederkomen. De steek $m$ et hunnen zuiger is zeer pijnverwekkend, doch de pijn verdwijnt binnen korten tijd.

\section{Naucoris cimicoides L.}

Plaat 20, fig. 1.

Limn. S. N. 13 ed. 714,6 - Fabr. S. Rh. 110, 1. - Panz. Fn. Germ. 95, 16. - Schellenb. Cim. Helv. p. 30, tab. 12. - Burm. Handb. II, p. 193. - Flor, Rh. Livl. I, 753. - Rösel, Ins. Belust. III, bl. 173, t. 28. - Douglas and Scott, Brit. Hem. p. 580, pl. 19, f. 6. - v. Voll. Gel. dieren v. Ned. bl. 284, pl. 19, f. 10.

Lengte 12-15 mm. - Groenachtig of bruinachtig geel met lichtere randen en onderzijde. Kop, thorax en pooten zeer glanzig; schildje en dekschilden met de membraan olijfbruin, dof. Oogen glanzig bruinzwart. Op het midden van den thorax ecn licht vlekje tusschen twee grootere donkere. Zijdoorntjes aan de ringen van het achterlijf van boven bruin; zoom van het achterlijf lang behaard. Kanten der gleuf aan de dijen met zeer korte geelwitte borsteltjes digt bezet. Tarsen groen, stekeltjes der dijen bruin, klaauwtjes bruinrood.

Deze waterwantsen zijn hier te lande vrij gemeen en werden in bijna al onze provincien aangetroffen. Men ziet hen dikwijls aan de oppervlakte van bet water hangen met den anus naar boven; zij hernieuwen dan den voorraad lucht onder hunne dekschilden en aan den buik. 


\section{DERDE FAMILIE - ONDERSTBOVENZWEYMERS.}

\section{NOTONECTIUEA.}

Het ware kenmerk dezer familie ligt in de wijze van zwemmen, namelijk op den rug; men kan er echter morphologisch bijvoegen dat de voorheupen veel verder naar achter zijn ingeplant dan bij de beide vorige familien, dat de sprieten uit 4 leedjes zamengesteld zijn, dat er geene ademhalingsbuis aan het achterlijf is en dat de groote zuiger voor het bloote $00 \mathrm{~g}$ steeds zeer duidelijk te zien is.

Ligchaam langwerpig spoelvormig of ovaal, van boven gewelfd, van onder niet. Kop kort verticaal met groote oogen. Sprieten zeer kort van 4 leedjes, waarvan of 2 en 3, of alleen 3 langer zijn dan 1 en 4 . Zuiger van 4 of 3 leedjes, langer dan de voordijen, priemvormig. Thorax breeder dan lang, tusschen de schouders het breedst. Schildje groot. Dekschilden met clavus en corium en 't zij met in de rust in de lengte geplooide membraan, 't zij zonder. Pooten vrij lang, vooral die van het laatste paar, die geheel tot zwemmen zijn ingerigt en daartoe aan de binnenzijde behaard zijn; de voortarsen dragen stceds 2 klaauwtjes, de achtertarsen in een geslacht geslacht wel, in het andere niet.

Hier te lande telt de familie twee geslachten, die aldus kunnen onderkend worden :

Achtertarsen zonder klaauwtjes, ligchaam bijna driemaal zoo lang als breed. . . . . . . Nolonccla.

Achtertarsen met klaauwtjes, ligchaam anderhalf maal zoo lang als breed. . . . . . . I'loa.

\section{Gen. 1. Notosecta L.}

Ligehaam bijna spoelvormig, boven gewelfd, onder plat, niet hooger dan breed. Kop van boven gezien kort, verticaal ge- 
plaatst. Aan de wangen is een stuk door een' gebogen naad afgescheiden, dat teugel (Lora) genoemd wordt. Oogen zeer groot, bol driehoekig, met grove facetten. Sprieten kort van vier leedjes, 1 knobbelvormig, 2 vrij dik, subcylindervormig, even voorbij de basis het dikst, 3 smaller maar even lang, aan de buitenzijde met eene rij van (7?) geknopte haartjes bezet, 4 zeer kort en dun. Zuiger reikend tot aan het metasternum, van 4 leedjes; 1 kort en breed, bedekt door de breed driehoekige bovenlip, 2 iets korter dan het voorgaande, 3 zoo lang als 1 en 2 te zamen, naar de punt versmallend, 4 kort priemrormig.

Thorax tweemaal zoo breed als lang, van boven gezien zeshoekig, de voorrand iets enger dan de kop met de oogen. Schildje groot, driehoekig met uitgerekte spits. Dekschilden het geheele abdomen bedekkend, bestaan uit clavus, corium en membraan; het corium is fluweelig behaard met dikken voorrand, de membraan is in de rust door eene overlangsplooi dakvormig in twee neêrgebogen deelen verdeeld, hare basis is van dezelfde hoedanigheid als het corium; aderen ontbreken; aan het eind van de langsplooi is de membraan ingesneden. Vleugels zeer breed met 3 langsaderen en 1 dwarsader. Achterlijf sterk behaard aan den rand en vooral aan de spits. Pooten tamelijk lang, achterpooten bepaaldelijk zeer lang. Voor- en middenheupen zeer groot, in gleuven aan de borst geborgen; hunne apophysen steken een eind naar achter uit en zijn zeer groot, bunne dijen iets korter dan de scheenen, naar beneden uitgezet, zijdelings zamengedrukt; de middendijen (zic pl. 10 , f. 2a) met twee tandjes onder aan naar de knie toe; hunne tarsen van 2 leedjes, waarvan het achterste vrij klein met twee smalle lange klaauwtjes. Heupen der achterpooten zijdelings weggedrukt, opdat de dijen daarover heen zouden kunnen glijden, 't geen de Notonecten in staat stelt hunne achterpooten bijna geheel naar voren te brengen. Dijen dier pooten niet zoo gezet als de anderen maar langer, van onder bezet met twee digte rijen van zeer korte stekeltjes. Scheenen en tarsen dier pooten aan de binnenzijde met lange zwemharen 
bezet; tarsen van 2 leedijes, aan de spits zonder klaanwtjes.

De insecten van dit geslacht zwemmen uitmuntend, vliegen des nachts, een enkele maal ook wel op den dag en zijn zeer roofuchtig. Loopen kunnen zij niet en trachten dus door springen het water weder te bereiken, wanneer zij er toevallig ziju uitgekomen.

\section{Nolonecta glanca L.}

Plaat 20 , fig. 2 en $2 a$.

Liun. S. N. $13^{\mathrm{e}}$ ed. 712, 1. - Fabr. S. Rh. 102, 1, 2 et :3. Panz. Fn. Germ. 3, f. 20. - Rösel, Ins. Bel. III, pl. 27. - De Geer, Mem. vertal. v. Goeze, D. III, p. 250 rlgg. pl. 18, f. 16-28. - Burm. Handb. II, 190. - Fieber, Rhynchotogr. p. 49, 3. - Flor, Rh. Livl. I, p. 772. - Douglas and Scott, Brit. Hem. p. 587, pl. 20 , f. 4.

Lengte $15 \mathrm{~mm}$. - Zwart met den kop en het voorborststuk vuilwit; beide zijn glanzig, glad en onbehaard; de groote oogen zijn zeer glanzig bruin. Onder het achterste gedeelte van den prothorax schijnt dikivijls het schildje door, dat fluweelachtig zwart is. De dekschilden zijn of vuilgeel of lichtbruin, zelfs bij eene varieteit bijna zwart met witte basaalvlekken. Bij de minst geteekende voorwerpen ziet men alleen onder den voorrand eene rij van vierhoekige donkerbruine vlekken; sterk geteekenden hebben de dekschilden geheel met donkerbruin getijgerd. Steeds zijn zij met zeer korte neêrliggende haartjes bezet en daardoor dof en wat fluweelachtig. De pooten zijn geel of bruinachtig; hunne haren en klaauwtjes bruin.

De bedoelde donkere varieteit, Furcala F., heeft de dekschilden roetkleurig met lichtere membraan en met twee vuilgele langwerpige rlekken aan de basis, waarvan de grootste op den clavus, de andere daar tegen aan op het corium. Wat ik van Marmorea F., Lutea Miill. en Maculata der Engelschen denken moet, weet ik niet; zijn het soorten, zijn het verscheidenheden? Versehillen zij van Glauca in iets anders dan grootte en kleur? Zoo reel is zeker dat ik hicr te lande nooit 
cenig voorwerp gezien heb, dat met zekerheid tot cene der genoemde soorten te brengen was.

N. glauca is zeer algemeen verspreid en schier in iedere sloot aan te treffen. Furcufa werd door den heer van Medenbach de Rooij bij Nijkerk, door mij in Zuid-Holland gevangen.

\section{Gen. 2. PloA Leach. ${ }^{1}$ )}

Het zal wel voldoende rijn de punten van verschil tusschen dit genus en het voorgaande op te geven. Het ligehaam is kort en breed, doch nog hooger dan breed; de kop is sterk naar beneden gebogen en met de oogen breeder dan de thorax. De dekschilden zijn geheel lederachtig, zonder membraan. Aan de achterpooten zijn de zwembaren veel korter en hebben de tarsen twee vrij lange klaauwtjes.

\section{Ploa minutissima $\mathrm{F}$.}

Plaat 20, fig. 3 en $3 a$.

Fabr. S. Rh. 104, 10. - Leach, Trans. Lin. Soc. XII, 14, 1.-Burm. Handb. II, 189. - Panz. Fn. Germ. 2, 14. - Amyot et Serv. Hém. 419, 1. -- Fieb. Ent. Monogr. 17, pl. 1, f. 27-35. - Douglas and Scott, Brit. Hem. 1. 591 , pl. 20, f. 3 et 21, f. 8.

Lengte $2 \mathrm{~mm}$. - Granw-wit of geelachtig. Op het angezigt eeue vrij lange bruine langsstreep. Zuiger vuilbruin. Oogen zwart. Thorax en dekschilden sterk gestippeld, schildje daarentegen glad en bruinachtig. De dekschilden zijn of van achter alleen in de putjes donker gestippeld, of wel zij vertoonen nog twee vlekjes in het midden van het corium. Borst en buik zwart. Dijen aan de basis donker gekleurd.

De soortnaam Minutissima was eigeulijk door Linnaeus aan cene andere waterwants toegekend (de volgeude soort); maar Fabricius duidde dit verkeerd en nam onze soort voor de

1) Leach schreef Plea, doch Stephens heeft dit naar de e:genaardighcid van het Grieksch in Ploa verbeterd. 
Minutissima aan. Naar regt van prioriteit moest dus, indien zij niet in twee genera, zelfs in twee verschillende familien waren ingedeeld, de nu beschrevene soort haren naam verliezen.

Ploa mimulissima zal waarseaijnlijk wel in alle provincien voorkomen; ik kan echter slechts de volgende vindplaatsen opnoemen: bij Leyden (van der Hoeven); aldaar en bij Heemstede onder kroos in April gemeen (v. Voll.); gemeen in slooten bij Utrecht (Six); bij Breda (Heylaerts); op Walcheren (La Fontijn en Gerth van Wijk).

\section{VIERDE FAMILIE - DUIKERWANTSEN.}

CORIXIDEA.

De laatste der familien van Waterwantsen onderscheidt zich voornamelijk door den zuiger, die uit een leedje bestaande onder de bovenlip verborgen blijft. De Hollandsche benaming is door mij ontleend aan de gewoonte, die deze insecten hebben om, even aan de oppervlakte van het water gekomen om hunnen voorraad lucht te ververschen, plotseling als eene pijl uit een boog naar den bodem te duiken.

Ligchaam langwerpig aan beide zijden afgerond, of ovaal (Sigara), op den rug slechts weinig gewelfd. Kop van boven gezien half cirkelvormig, van voren lang uitgerekt en aan den zuiger naar achter gekromd; angezigt gewoonlijk zonder afscheiding van het roorhoofd, bij een geslacht door een vrij scherpen kant afgescheiden. Oogen groot, drieboekig. Sprieten van 4 of 3 leedjes. Bovenlip breed en plat, gespleten om de borstels van den zuiger doorgang te rerleenen; zuiger korter dan deze, van een lid. Pruthorax een weinig bol gebogen, aan den roorrand smaller dan de kop met lie oogen, naar 
achter in eene punt verlengd, die gewoonlijk het schildje bedekt. Schildje, wauneer het onbedekt is, klein driehoekig. Dekschilden en vleugels ontwikkeld; de eersten over het abdomen reikend, bestaan uit clavus, corium en eene van het corium slechts door eene plooi gescheiden, nagenoeg gelijkvormige membraan, die in de rigting van den naad geplooid is, doch geene aderen vertoont. Vlengels doorsehijnend vliezig en zeer dun. De borst zijdelings in lappen verdeeld, doch niet bij de schier onzigtbare voorborst, die een uitsteeksel tusschen de voorheupen vertoont; ook tusschen de achterheupen ontspringt een puntig uitsteeksel, dat Xyphus genoemd wordt.

Het eerste paar der pooten is tot vasthouden van den buit ingerigt; daar zijn de dijen gezet, de scheenen kort en dik, en de tarsen omgevormd tot eene soort van schepper, snoeimesvormig gebogen en aan de binnenzijde hol, aan de kanten met borstels bezet, doch aan de spits zonder klaauwen; dit deel heet Pala en verschilt vrij sterk in vorm bij de sexen. Het $2^{e}$ paar pooten is het langste en dunste; zijne tars bestaat uit een enkel cylindervormig lid met 2 zeer lange dunne klaauwen. Met deze middelpooten houden de Duikerwantsen zich onder water aan planten en stengels rast. De achterpooten zijn ware roeipooten, tamelijk breed en plat aan dij, scheen en tars; de scheen is bijna even lang als de dij, maar de tars, die uit 2 leedjes bestaat is veel langer en even als de scheen aan de binnenzijde met lange haren bezet. Het tweede lid is gewoonlijk slechts een derde zoo lang als het eerste en eindigt in een klaauwtje.

Achterlijf van zes ringen en een genitaalssegment, dat bij het mannetje daarin van het wijfje verschilt dat de daarin anwezige spleet of regts of links van het midden afwijkt, terwijl zij bij wijfje in het midden staat.

De levenswijze is vrij gelijk aan die der Onderstbovenzwenk mers; ook de dieren dezer familie zijn geweldige roovers, en zwemmen en vliegen goed. Zij hangen echter meer met het achterlijf aan de oppervlakte van het water, mar bij de minste stoornis duiken zij als een bliksemschicht naar onder. 
In het eerste voorjaar vliegen zij veel bij avondschemering.

Men treft in deze familie drie geslachten aan, waarvan de verdeeling door de volgende tabel duidelijk gemaakt wordt.

Tabel der geslachten.

1 (2). Schildje zigtbaar; sprieten van 3 leedjes.

Gen. 1. Sigara F.

2 (1). Schildje onder den processus verborgen; sprieten vierledig.

3 (4). Tars der voorpooten scheppervormig, zonder klaauwtjes. Voorhoofd zonder kant in het aangezigt overgaand.

Gen. 2. Conrxa Geoffr.

4 (3). Tars der voorpooten cylindervormig, bij den man met eene krachtige klaauw. Voorhoofd bij het wijfje door een kantje van het aangezigt afgescheiden.

Gen. 3. Суматіa Flor.

Gen. 1. Sigara F.

Ligchaam ovaal van omtrek, vrij plat van boven. Kop ran boven gezien halvemaanvormig, met de driehoekige oogen iets breeder dan het borststuk, van voren gezien naar beneden puntig en naar achter gebogen; geen plooi noch lijstje tusschen schedel en aangezigt. Bovenlip met eene dwarsplooi, onder haar de korte zuiger onzigtbaar. Sprieten (Pl. 10, f. 4a) zeer kort van 3 leedjes, het derde, dat het langste is, in het midden naar eene zijde verbreed. Prothorax zeer kort met de voor- en achterranden uitgebogen. Sehildje zigtbaar; doch klein, driehoekig. Dekschilden en vleugels ontwikkeld, een weinig langer dan het abdomen; clavus breed; corium zonder naad of plooi in de membraan overgaande. Pooten als in de kenmerken der familie opgegeven is. 


\section{Sigara minutissima L.}

\section{(Minula F.)}

Plat 20, fig. 4 en $4 a$.

Linn. S. N. $13^{\mathrm{e}}$ ed. 712, 3. - Fabr. S. Rh. 105, 6。 - Fallèn, Hem. Suec. 1, P. 179. - Burm. Handb. II, P. 188. - Ilerr.-Sch. W. Ins. IX, p. 46 , ‥ 295 , f. 907 . - Fieb. Ent. Mon. p. 13, tab. 1, f. 11-19. 1) - Flor, Rh. Livl. I, p. 803. - Douglas and Scott, p. 616, pl. 20, f. 6.

Lengte $2 \mathrm{~mm}$. - Grauwgeel en bruinachtig. Kop geelachtig wit, meestal met eene bruine langsstreep op het midden van het angezigt, soms met twee fijnere daarnevens aan wederzijde. Prothorax uiterst kort met eene bruine, in het midden afgebroken dwarsstreep. Schildje grauwgeel. Dekschilden rlekkig; clavus aan den bovenrand en den naad graurgeel, het overige vlekkig bruin; corium met 6 onbepaalde bruine vlekjes; membraan zeer kort, grauw aan den rand doorschijnend. Onderzijde en pooten vuilgeel, bijna wit, haren der achterpooten bruin.

Het is mij niet bekend dat dit insect door iemand anders hier te lande gevangen is dan door Perin; hij ving het bij Leyden in Mei en Junij. Door de welwillendheid van den heer van der Wulp kwam ik in het bezit van 3 exemplaren uit die vangst.

Gen. 2. Corixa Geoffr.

Het rijkste aan soorten der drie geslachten, van het vorige verschillend door het verborgen zijn van het schildje onder den processus van den prothorax, van het volgende onder anderen doordien de schedel zonder kant of rigehel in het voorhoofd en dit in het aangezigt overgaat. De algemeene beschrijving der familie is overigens geheel op dit geslacht toepasselijk, indien men de volgende nadere besehrijving der sprieten en voorpooten in het $00 \mathrm{~g}$ wil houden.

1) De voorstelling van het overslaan der membraan van den linkervlengel is vecl te sterk uitgedrulit; teu minste bij onze vorrwerpen is het naawrelijks te bespeuren. 
De sprieten van Corixa (onder de oogen verborgen) bestaan uit 4 leedjes, waarvan 1 en 2 kort en cylindervormig zijn, het derde langer, eenigzins knods- of wel spoelvormig en het vierde kort en priemvormig. Het eerste paar pooten is het kortste der drie en vrij krachtig; de heupen zijn langwerpig, iets korter dan de dijen; deze gezet, zamengedrukt cylindrisch; scheenen zeer kort en ietwat knodsvormig; tarsen van een lid, scheppervormig (I'ala), zeer verschillend in vorm bij de mannetjes der verschillende soorten en daarom tegenwoordig als onderscheidingskenmerk gebruikt, ofschoon daarbij een onvermijdelijk vereischte is dat men daartoe voorwerpen bezitte, zoodanig opgezet dat zij de Pala zeer duidelijk vertoonen, 't geen gewoonlijk niet het geval is.

De prothorax en dekschilden zijn zeer dikwijls door niterst fijne streepjes in de lengte als met de naald gekrast; in de volgende tabel en beschrijvingen zal ik om dat aan te toonen alleen het woord gekrast gebruiken; de Duitschers zeggen daarvoor "rastrirt", de Engelschen "rastrated".

\section{Tabel der soorten.}

1 (2). Borststuk en dekschilden niet gekrast. Lengte $13 \mathrm{~mm}$.

Geoffroyi.

2 (1). Borststuk en soms ook de dekschilden gekrast; lengte beneden $10 \mathrm{~mm}$.

3 (4). Achtertarsen met eene zwarte vlek. . . Praeusia.

4 (3). $\quad$ ongevlekt.

5 (10). Het corium niet gekrast.

6 (7). Borststuk bleek geel met zeer smalle zwarte dwarslijntjes . . . . . . . . . Hieroglyphica.

7 (6). Gele en zwarte banden op den thorax al even breed.

8 (9). Een zeer kort langwerpig knobbeltje aan den voorrand van het borststuk . . . . Slálii.

9 (8). Een bijna doorloopend langsrigcheltje over het borststuk . . . . . . . . Carinata.

10. (5). Het corium even zeer als clavus en prothorax gekrast. 
11 (14). Corium en clavus met gegolfde, doch meestal doorloopende streepjes.

12 (13). Borststuk met 4 lichte dwarsstreepjes en een in de lengte. . . . . . . . . . Mellensii.

13 (12). Borststuk zonder licht lengtestreepje . . Regularis.

14 (11). Corium met afgebroken en soms zeer verwarde streepjes.

15 (16). Thorax en dekschilden geel met fijne zwarte streepjes. . . . . . . . . . Lincolata.

16 (15). Thorax en dekschilden bruin met gele streepjes.

17 (20). Borststuk met 8 of 9 gele streepjes.

18 (19). Geul aan den rand der dekschilden geel. . Striata.

19 (18). " $"$ ",$\quad$ bruinachtig zwart. . . . . . . . . . . Fallenii.

20 (17). Borststuk slechts met 6 of 7 gele streepjes.

21 (22). Grooter, achterrand van het borststuk scherp geel afgezet . . . . . . . . Mosta.

22 (21). Kleiner, achterrand van het borststuk bruin. Fossamm.

\section{Corixa Geoffroyi Leach.}

Plaat 20 , fig. 5 en $5 a$.

Leach, Trans. Lin. Soc. XII, 17, 7 - Burm. Handb. II, p 186, 1.Amyot et Serv. Hém. p. 447. - Fieb. Spec. Cor. 14, 1, tab. 1, f. 1. Herr.-Sch. W. Ins. IX, p. 62, tab. 296, f. 914. - Rösel, Ins. Bel. III, tab. 29, f. $a, b, c .-$ Flor, Rh. Livl. I, p. 786. - Douglas and Scott, Brit. Hem. p. 593 , pl. 20 , f. 5.

Lengte 13-14 mm. - Kenbaar aan zijne grootte en de gladheid van den thorax. Kop, borst en pooten geel, borst en buik met bruine vlekken, r'ug van het achterlijf zwart. Borststuk en dekschilden glad zonder krassen, het eerste bruin met 16 of meer, aan den rand in eene vloeijende zeer fijne gele dwarsstrepen. Dekschilden bruin met een bezaaisel van gele vlekjes en gekriewelde korte slingertjes; de geul aan den voorrand greel; de membraan niet van het corium afgescheiden; de zoom harer linkerzijde vliezig. 1)

1) Den vorm der palae in de verschillende soorten en ook bij de sexen verschillend zal ik niet opgeven, omdat ik bij gebrek aan hèt noodige aantal exemplaren zelf geene studie gemaakt heb; men vergelijke het aangehanlde werk van Fieber. 
Deze soort schijnt niet zeer zeldzaam. De heer Mr. H. W. de Graaf voud haar bij Leyden in April in slooten (ook door mij aldaar gevonden) en in October in de duinen van Wassenaar in eene waterput, alsmede bij den Haag. De heer Six trof haar vroeg in het voorjaar bij Driebergen en de Bildt in slooten aan. De heer van Medenbach de Rooij ving haar in October bij Arnhem en Nijkerk, de heer Gerth van Wijk op Walcheren.

\section{Corixa praeusta Fieb.}

Plaat 20 , fig. 7.

Fieber, Spec. Cor. p. 28, 80, tab. 1, 17, f. 1-18. - Flor, Rh. Livl. I, p. 787 , no 2.

Lengte $8 \mathrm{~mm}$. Kop, buik en pooten lichtgeel, borst met groote zwarte vlekken. Borststuk geel met 8 fijne zwarte dwarslijntjes, die den zijrand niet bereiken. Dekschilden bruin met vele geslingerde gele bandjes op clavus en corium, en de membraan dik bezaaid met korte gele slangetjes. Aan de onderzijde van den achtertars is het laalste derde ran het voorste lid zwarl; de zwemharen op zijde van die vlek zijn mede zwart.

Tot nog toe alleen bij Maastricht gevonden door den heer Mr. A. M. Maurissen.

\section{Corixa carinata Sahlb.}

Plaat 20 , fig. 8.

Sahlb. Not. Fenn. p. 12, no 4. - Fieb. Spec. Cor. no 47, tab. 2, f. 24. - Herr.-Sch. W. Ins. IX, p. 56, tab. 296, f. 913.

Lengte $8 \mathrm{~mm}$. - Kop en onderzijde geel met zwartbruine vlekken achter de voor- en achterheupen. Borststuk en clavus wel gekrast, doch het corium niet of slechts flaauwelijk. $O p$ het borststuk een bijna tot het eind toe doorloopend langsrigchelije in het midden. Borststuk bruin met 9 (10?) smalle gele bandjes, die wel eens gevorkt in een loopen. Clavus bruin met 17 gele dwarslijntjes, waarvan de zes eersten regt; 
corium van dezelfde kleur met iets meer gegolfde, doch niet afgebroken gele divarslijntjes. Nembraan zeer donker met flaauwelijk aangeduide slingerbandjes. Haren der achtertarsen donkerbruin.

Door Perin in Zuid-Holland (bij Leyden?) en door den heer van Bemmelen bij Wassenaar gevonden; in menigte door den heer Heylaerts bij Breda gevangen.

\section{Corixa Stâlii Fieb.}

E. Saunders, Synopsis in Transact. Ent. Soc. of London 1876, p. 648, $n^{\circ} 12$.

Lengte $7 \mathrm{~mm}$. - Borststuk en clavus wel, corium niet gekrast. Kop en onderzijde geel; op de eerste buikringen een paar bruine vlekjes. Borststuk alleen met een langsknobbeltje aan den voorrand, bruin met 7 of 8 gele dwarsstreepjes, die aan den buitenrand in een loopen. Dekschilden bruin met afgebroken geslingerde gele bandjes, die vrij smal zijn en atleen iets breeder aan de basis van den clavus. Membraan bruin met geslingerde streepjes en vlekjes, meest allen klein, doch op elkaar gedrongen tegen den zoom. Randgeul bruingrauw. Haren der achterpooten bruin.

Ik kan voor de juistheid der determinatie niet instaan, vooreerst om het onvolledige der beschrijving door Saunders (in Fieber's Europ. Ilemipteren is de soort niet opgegeven), ten andere omdat ik maar een enkel voorwerp ken. Dit werd door Mr. H. W. de Graaf bij Woerden gevangen.

\section{Corixa hieroglyphica Duf.}

Plaat 20, fig. 9.

Léon Dufour, Hem. 86, 2, fig. 85, 87. - IIerr.-Sch. W. Ins. IX, p. 59, pl. 297, f. 921. - Fieb. Spec. Cor. p. 22, 1. 1, f. 20.

Lengte $6 \mathrm{~mm}$. - Kop geel met den sehedel vuil bestoven, zelfs min of meer met eene donkere langsstreep. Prothorax vrij donker bruin met $8-10$ onduidelijke lichtere dwarsstrepen; 
deze en de clavus wel, corium niet gekrast. Dekschilden een weinig minder donker bruin met 3 dikkere dwarsbandjes aan den grond van den clavus en overigens met een menigte korte afgebroken gele slangetjes, die op het corium min of meer duidelijk 4 langsrijen vormen. Membraan van het corium afgescheiden door eene gele streep, donker, vooral bijna zwart aan den zoom, doch geteekend even als het corium. Borst en buik bruin met gele zijden; ook de zoomen der ringen van het abdomen zijn geel met grijze zwemharen.

Deze soort werd door Mr. H. W. de Graaf in October bij Wassenaar gevonden, door mij bij den Haag in Augustus, door Dr. Weyenbergh bị Haarlem en door den heer La Fontijn op Walcheren.

\section{Corixa Hellensii Sahlb.}

Plaat 20, fig. 10.

Sahll. Not. Fenn. p. 11, 3. - Herr.-Sch. W. Ins. IX, p. 54, pl, 295 , f. 909 .

Lengte $5 \mathrm{~mm}$. - Kop geler dan bij de vorige soorten met een okerkleurig langsstreepje op het voorhoofd. Onderzijde en pooten geel, doch de basis van den buik zwartachtig. Borststuk, clavus en corium gekrast, even als bij alle volgende soorten. Borststuk zeer kort, bruin met 4 flaauwgele doorloopende dwarslijnen en het begin van eene gele middellijn. Clavus donkerbruin, zeer duidelijli en helder geel gezoomd, met 10 onduidelijke, regle dwarslijntjes; corium even donker en mede geel gezoomd, doch met geslingerde en deels afgebroken lijntjes; membraan zeer douker, vooral aan den zoom, in het midden met korte gekronkelde gele slangetjes. Klaauwen der middelpooten bijzonder lang; zwemharen bruin.

Een enkel voorwerp bij Breda, door den heer Heylaerts gevangen. 


\section{Corixa regularis $\mathrm{H}$. Sch.}

Herr.-Sch. W. Ins. IX, p. 57, pl. 295, f. 910. - Misschien ook Fieber, Spec. Cor. $\mathrm{n}^{0} 25$, t. 2 , f. 4 en Eur. Hem. p. 94 (G. Linnéi Fieb.).

Lengte 6- $8 \mathrm{~mm}$. - Kop lichtgeel, bijna wit, achterrand van den schedel zwartachtig. Onderzijde lichtgeel met bruine vlekken achter de heupen, soms ook op de achterheupen. Borststuk bruin met gelen achterrand en zes smalle gele dwarsbanden. Dekschilden van dezelfde kleur met zeer smalle bijna allen doorloopende dwarsstreepjes, waarvan die op de voorhelft van den clavus regt en de overigen wat geslingerd zijn; membraan donkerder dan het corium, met onduidelijke gekriewelde lichte slangetjes. Randgenl lichtgrauw. Pooten geel, zwemharen bruin.

Ik zie eigenlijk geen verschil tusschen Regularis H. Sch. en Linnéi Fieb. dan misschien de grootte, doch ik begrijp evenmin waarom Fieber Linnéi schrijft en niet Linnai, gelijk ieder verstandig mensch doen zou.

De soort werd aangetroffen: in Holland door Dr. de Haan, Dr. Herklots en door Perin; bij Leyden door Prof. J. van der Hoeven; bij Driebergen in Sept. door den heer Six en bij Woerden in Maart door Mr. H. W. de Graaf.

\section{Corixa lineolata Herr. Sch.}

Plaat 20, fig. 11.

Herr. Sch. W. Ins. IX, p. 55, pl. 295, f. 911. - Misschien ook Fieb. Spec. Cor. $\mathrm{n}^{0} 40$, t. 2, f. 18 (Nigrolineata) en Dougl. and Scott, Brit. Hem. p. $605, \mathrm{n}^{\circ} 12$.

Lengte $6 \mathrm{~mm}$. - Gemakkelijk daaraan te herkennen, dat de donkere streepjes smaller zijn dan de gelen. Kop geel met een vuilen, zwartachtigen schedel. Onderzijde bruinzwart, met gele vlekken in de zijden van de borst. Borststuk geel met ongeveer 9, niet tot den rand doorloopende en vooral niet evenwijdige fijne zwarte lijntjes. Dekschilden mede geel met fijne zwarte dwarsstreepjes, die op de voorhelft van den clavus 
evenwijdig zijn, doch verder en op het corium onregelmatiger worden en dikwijls aan eene van boide zijden zijn gegaffeld. IIembraan geel met donkere marmering, die aau den zoom eene soort van borduursel vormt. Pooten geel, zwemharen zeer licht bruin.

De beschrijving van Nigrolincata bij Fieber past niet best; cerder nog komt die van zijne Parallela met onze voorwerpen overeen, doch deze soort is tweemaal grooter en stamt uit den Griekschen Archipel.

Lineolata werd bij Wassenaar in het duinwater gevonden door Mr. H. W. de Graaf. Ook bezit ik voorwerpen van Perin, waarschijnlijk wel ter zelfder plaatse gevangen.

\section{Corixa striala L. (Fieb.)}

Fieber, Spec. Cor. no 33, tab. 2, f. 4. - Id. Eur. Hem. p. 97 Herr. Sch. W. Ins. IX, p. 58, tab. 297, f. 918 (Basalis) - Ik moet muj van meer citaten ontlouden, daar ik er geen vind, die volkomen passen.

Lengte $7 \mathrm{~mm}$. - Kop en onderzijde met de pooten geheel geel (z), buik met 3 of 4 bruinachtige banden (q). Borststuk bruin, met 7,8 of 9 gele dwarsbandjes en smallen gelen achterrand. Basis van den clavus geel met ongeveer 7 bruine dwarsstreepjes, het overige deel bruin met afgebroken gele streepjes; corium bruin met eene menigte niet doorloopende, gegolfle of gekrinkelde gele vlekjes; randgeul geel, aan het eind ietwat grauw. Nembraan van het corium afgescheiden door een zwart streepje onder een geel, bruin met fijnen zwarten zoom en vele hieroglyphische gele slingertjes. Achterpooten met eene donkere streep op de buitenzijde.

Door Dr. Herklots in Zuid-Holland gevonden, door den heer de Graaf bij Woerden, bij Driebergen in April door den heer Six, bij Nijkerk door den heer van Medenbach de Rooij, op Walcheren door den heer La Fontịn en in Limburg door den heer Mr. Maurissen. 


\section{Corixa Fallenii Fieb.}

Fieber, Spec. Cor. no 34, t. 2, f. 12. - Id. Eur. Hem. p. 97.

Lengte bijna $7 \mathrm{~mm}$. - Verschilt van de vorige alleen in deze punten. De onderzijde is bruin met groote gele vlekken in de zijden en gelen rand van het achterlijf. De gele achterrand van het borststuk is zeer onduidelijk. Op de basis van den clavus is het geel minder verbreid. De geul langs de dekschilden is donkerbruin, aan het einde bijna zwart. De membraan is van het corium wel door een geel lijntje afgescheiden, maar het zwarte daaronder ontbreekt.

Een enkel voorwerp werd door Mr. H. W. de Graaf den $21^{\text {en }}$ October in eene duinbeek bij Wassenaar aangetroffen.

\section{Corixa moesta Fieb.}

Fieber, Spec. Cor. no 39, tal). 2, fo 17. - Id. Eur. Hem. 1. 98.

Lengte 7,5 mm. - Kop en borst geel; onder de voorheupen zwarte vlekken, de achterheupen bruinachtig, de drie eerste ringen van het achterlijf bruin met gele zoomen. Borststuk bruin met 6 doorloopende gele dwarsstreepjes en gelen achterrand. Clavus bruin met ongeveer 16 gele dwarsstreepjes, warvan de 6 eersten regt en doorloopend; corium bruin met donkergrauwe randgeul en vele gegolfde en soms afgebroken gele dwarslijntjes. Membraan bruin met gele hieroglyphische slangetjes, meest naar de randen toe; eene zwarte veeg onder de spits van het corium langs den buitenrand. Kwemharen der achterpooten bruin.

Een voorwerp in Maart bij Woerden gevangen door Mr. H. W. de Graaf.

\section{Corixa Fossarum Leach.}

Plaat 20, fig. 12.

Herr.-Sch. W. Ins. IX , p. 55, pl. 295, f. 908. - Flor', Rh. Livl. I, p. 795. - Fieb. Spec. Cor. p. 32, no. 37, tab. 2, f. 15. 
Lengte $6 \mathrm{~mm}$. - Kop geel met roestkleurige tint op den schedel en aan de bovenlip. Borst donkerbruin met gele vlekken aan den rand; buik geel aan den rand en in het midden bruin. Borststuk bruin met 6 tamelijk breede, nagenoeg evenwijdige dwarsbandjes; achterrand niet geel gekleurd. Clavus met fijnen gelen zoom, bruin met ongeveer 16 gele dwarsbanden, waarvan de vijf voorsten iets breeder en gelijker dan de anderen, de laatsten afgebroken en verward; corium met donkergrauwe randgeul, bruin met gele dwarslijntjes, die zeer onregelmatig staan en als in 3 langsrijen onder elkander gesteld zijn. Membraan van het corium afgescheiden door eene gele streep, waaronder eene zwarte, bruin met zeer fijne gele slangetjes en puntjes; de rand zwartachtig. Pooten roestgeel, zwemharen bruin.

Van deze soort ving de heer Six een voorwerp bij Utrecht en de heer Heylaerts eenigen bij Breda.

Ik mag niet instaan voor de zekerheid dezer determinatien der soorten van het geslacht Corixa, dat ook voor anderen een struikelblok is geweest. Werden de waterwantsen door entomologen meer verzameld, het zou mij misschien mogelijk worden tot meer duidelijkheid te geraken, vooral ook door het onderzoek der palae en vergelijking daarvan met de afbeeldingen van Fieber.

\section{Gen. 3. Cymatia Flor.}

Dit laatste genus der Heteroptera onderscheidt zich van het voorgaande voornamelijk door den vorm van de tarsen aan de voorpooten en ten tweede door het profiel van het aangezigt. Kop met de oogen breeder dan het borststuk. Sprieten als bij Corixa. Schedel vlak vooruitstekend, langer dan het borststuk, aan wederzijde met eene fijne ingedrukte langsstreep. Aangezigt van den schedel afgescheiden door een' scherpen kant, en bij den man bovendien ietwat hol. Clypeus glad. Borststuk glad, zonder krassen in de lengte, noch streepjes in de breedte. 
Eerste lid der tarsen aan de achterpooten niet veel meer dan tweemaal zoo lang als het tweede. Tars der voorpooten cylindervormig, doch een weinig dunner naar de spits toe, aan de basis van gelijke dikte met de scheen, die driemaal korter is, en van dezelve slechts door eene kringvormige insnijding gescheiden; aan zijne onderzijde zeer lange borstels in 2 rijen.

\section{Cymatia coleoptrata. F.}

Plaat 20, fig. 6.

Fabr. S. Rh. 105, 4. - Fall. Hem. Succ. I, p. 185, 7. - Panz. Faun. Germ. 50, 24. - Burm. Handb. II, p. 188, no 4. - Amyot et Serv. Hem. p. 448, no 3. - Ilerr. Sch. W. Ins. IX, p. 53, pl. 297, f. 915. - Flor. Rh. Livl. I, p. 800. - Dougl. and Scott, Brit. Hem. p. 614.

Lengte 3-4 mm. - Kop, onderzijde en pooten geel, bovenlip met hare omgeving roestkleurig, achterrand van den schedel zwartachtig. Oogen zeer groot, zwart. Borststuk veel kortor dan de kop van boven gezien, olijfbruin, glanzig. Deksehilden zeer glanzig en ongestippeld, icts langer dan het achterlijf; clavus olijfbruin met gelen voorrand en naad; corium geel met 2 breede olijfbruine langsstrepen tegen elkander aan; membraan donkerbruin, zeer klein, doch aan het linker dekschild iets breeder. Randgenl geel, doch op de zoomen aan wederzijde eene fijne zwarte lijn, waarvan de buitenste tot aan de membraan doorloopt. De vleugels ontbreken. Middelpooten met donkere knieën en zwarte spitsen van scheen en tars. Achterscheenen dikwijls bruin gekleurd; zwemharen bruinzwart.

In Holland aangetroffen door Dr. de Haan en mij; gemeen in de omstreken van Utrecht volgens den heer Six. In April bij Nootdorp en in den zomer bij Breda gevangen door den heer Mr.Leesberg; in October in de oinstreken van Maastricht door den heer Mr. Maurissen. 


\section{2-43. Lygus angustus H. Sch.}

Herrich-Schaeff. Nomencl. p. 49. - Meyer, Rh. d. Schwei , p. 56, no. 19, tab. II, fig. 3. - Fieh. Eur. Hem. p. 288.

Lengte bijna $4 \mathrm{~mm}$. - Geheel geel met donkerbruine oogen. Kop breed driehoekig, glanzig, aan de spits roodachtig. Oogen hol, uitpuilend. Zuiger fijn, geel, reikend tot de middenheu-

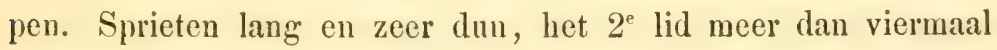
langer dan het eerste, een weinig bruin aan de spits. Borststuk met witte microscopische haartjes bedekt. Dekschilden bijna doorschijnend, zeer licht geel; hunne membraan groot, glashelder en sterk iriseerend; spits van het corium en aderen der membraan flaauwelijk groenachtig. Achterlijf geel met groene tint. Pooten van de kleur van het ligehaam, behalve het laatste tarsenlid, dat bruin is. Klaauwtjes donkerbruin.

Door den heer Six in Junij bij den Haag gevangen. 



\section{B L A D W IJ Z E R.}

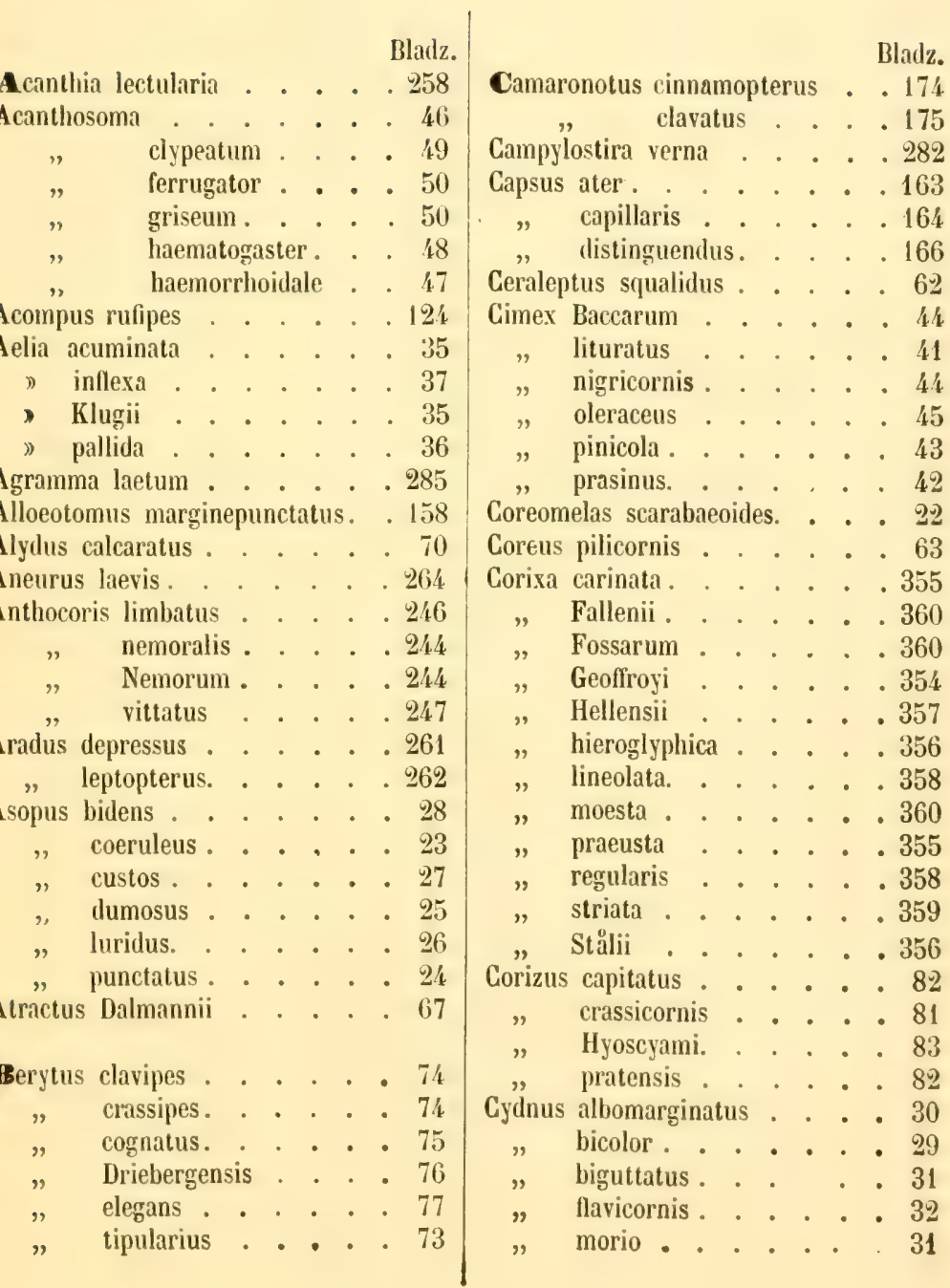




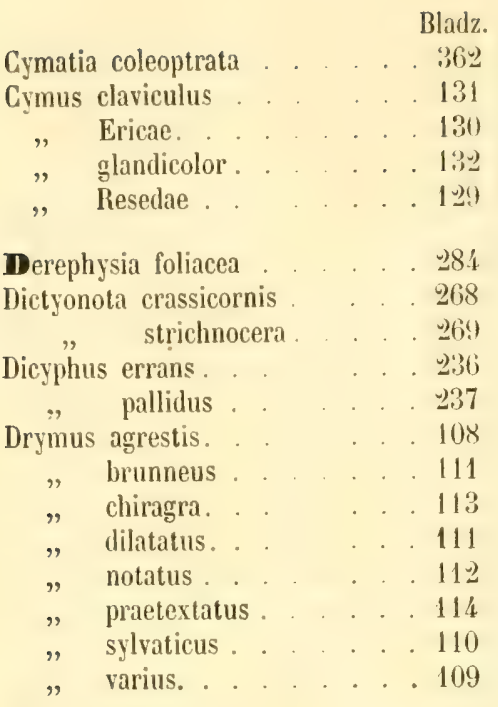

Eusarcoris perlata. . . . . 38

Castrodes Abietis....... 93 ferrugineus . . . 93

Gerris zie Hydrometra.

Gonocerus venator. . . . . 60

Iralticus leucocephalus. . . 171

"luridus. . . . . 172

$"$ pallicornis . . . 172

Harpactor annulatus . . . . 310 pedestris . . . 309

Hebrus pusillus . . . . . . . 288

Heterogaster Urticae. . . . . 127

Ileterotoma magnicornis. . . 168

"Mali . . . . 169

" spissicornis.... 167

" unicolor.... 169

Hydroessa zie Microvelia.

Hydrometra aptera. . . . . 327

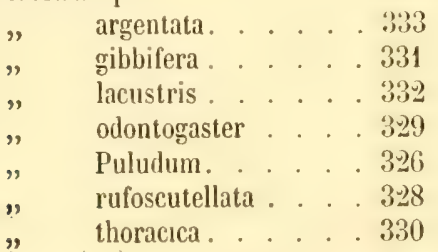

Ischnocoris hemipterus. . . 120

Leptoterna dolabrata. . . . 155
Lopus infusus. . . . . 161

162

160

Lyctocoris domestica . . . . . .
Lygaeus equestris

Lygus albidus . . . . . . 205

angulatus. . . . 219

Arbustorum. . . . .

aurantiacus . . . 214

bipunctatus. . . 188

Bohemanni . . . 217

brunnipennis . . . 231

campestria . . . . 193

Caracis . . . . 228

cervinus . . . . 203

Chenopodii . . . . 189

chlorizans . . . . 222

contaminatus . . . . 220

cordiger . . . 191

Coryli . . . . 214

decolor. . . . 224

Ericetorum _ . . 226

Fallenii . . . 191

ferrugatus . . . . 190

flavomaculatus. . . . . 11

flavosparsus. . . . . . 222

globulifer. . . . . . 208

Gothicus . . 186

Gyllenhalii . . . 201

histrionicus. . . . 206

Kalmii. . . . . 197

melanocephalus . . . 213

molliculus . . . . . . 223

mutabilis. . . . . 204

nassatus . . . . 221

nubilus. . . . . . 226

pabulinus . . . . 220

Pastinacae . . . 198

Paykullii. . . . . . . 27

pilosus. . . . . . 215

Pinastri .... 202

pratensis . . . . . 193

pulicarius. . . . . . 229

punctulatus. . . . . 192

Roseri...... 203

roseus . . . . . 233

rubicundus . . . . 195

rubricatus . . . . . 211

rufipennis . . . . 210 


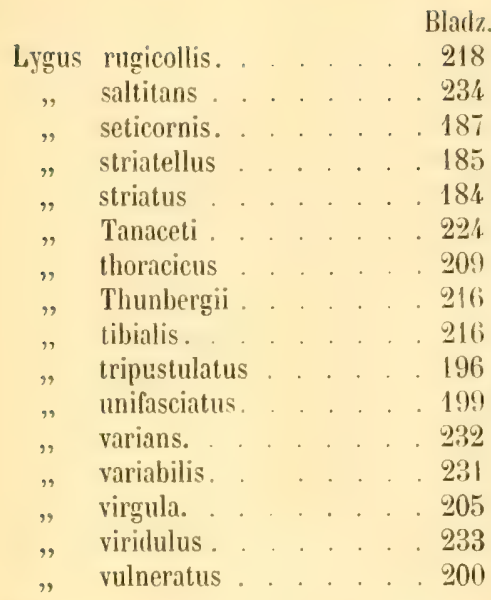

Metastemma zie Prostemma.

Microphysa coleoptrata . . . 251 " elegantula . . . 256 $"$ pselaphoistes. . . 254

Micropus decurtatus . . . . 125

Microvelia pygmaea. . . . . . 336

Miris calcaratus . . . . . . 152

,. erraticus. . . . . 153

", holsatus. . . . . . 151

$"$ laevigatus . . . . . . 149

"ruficornis .... 154

"virens. . 150

Monalncoris Filicis . . 146

Monanthir Cardui . . 272

\begin{tabular}{|c|c|}
\hline "' & carinala. \\
\hline " & costata. \\
\hline$"$ & cervina . \\
\hline$\therefore$ & limmmit. \\
\hline " & nigrina . \\
\hline$n$ & obseura. \\
\hline$"$ & parvula . . . \\
\hline " & quadrimaculata . \\
\hline & vesiculifera . \\
\hline
\end{tabular}

Myrmedobia zie Microphysa.

Myrmus miriformis . . . 79

Nabis apterus.

Naucoris cimicoides . . . . 344

Nepa cinerea _ . . . 340

Notonecta filuıca . . . . . . 347

(Odontoscelis fuliginosa . . . . 20

Ophthalmicus ater. . . 134

" grylloides. . . 133

pallidipennis. . . 135

Orthostira sie Honanthia.

Pachymerus contractus. . . 104

,$\quad$ erraticus . . 105

" griseus . . . . 96

,$\quad$ luscus .... 102

„ Lynceus. . . . 100

" marginepunctatus . 97

" pictus . . . 103

" Pini . . . . . 98

$"$ plebejus. . . 106

" quadratus ... 101

" Rolandri. ... 102

Pentatoma zie Cimex.

Peritrechus luniger. . . . . 115

$"$ nebulosus . . . 117

" nubilus .... 116

" rusticus . . . 117

" sabulosus .... 118

Phimodera galgulina. . . . . 19

Phytocoris divergens . . . . . 178

" Populi . . . 179

"Tiliae. . . . 180

"Ulmi $\quad$. . . . 177

Piezostetlus galactinus . . . 248

Pithanus Maerkelii. . . . . 147

Platygaster zic Gastrodes.

Plinthisus bidentulus. . . . 122

"brevipennis ... 122

" pusillus. . . . 123

Ploa minutissima $\quad . \quad . \quad 348$

Ploearia erratica . . . . . . 320

" vaģabunda. . . . . 319

Podops inunctus. . . . . 18

Prostemma guttula . . . . . . 305

Pseudophloeus Fallenii . . . . 65

$313 \quad$ \# Waltlii. . . . 66

" lorevipennis . . . . . 312 Pyrrhocoris apterus . . . . 86

$"$ brevis . . . . . . 316

"dorsalis. . . . . . 317

$"$ ferus. . . . . . 31:

" flavomarginatus. . . . 31'

IRanatra linearis . . . . 342

Reduvius personatus. . . . 307

Rhopalus Schillingii .... 78 


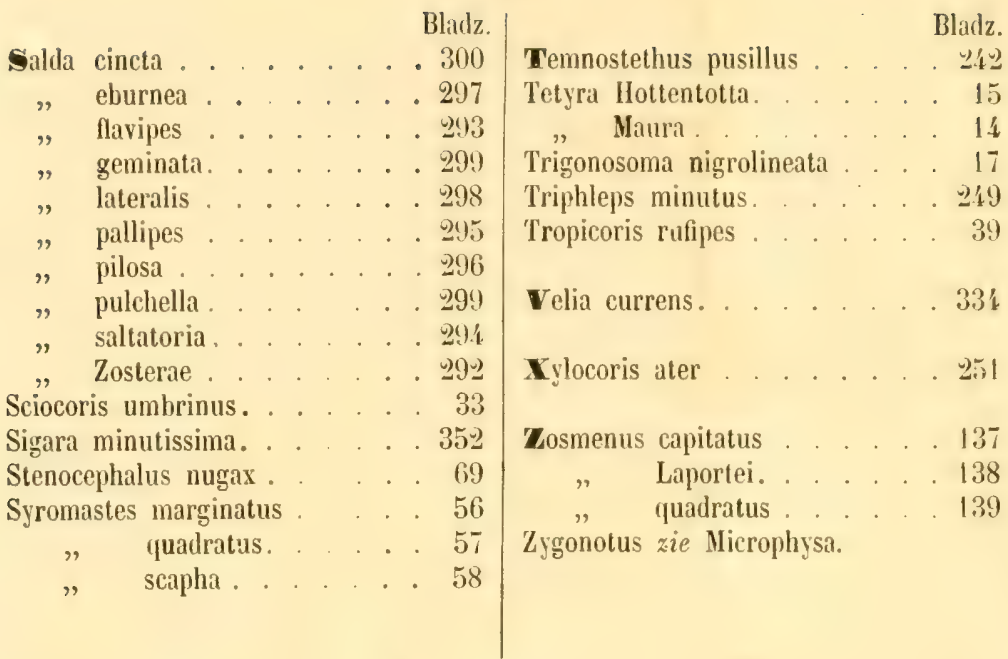



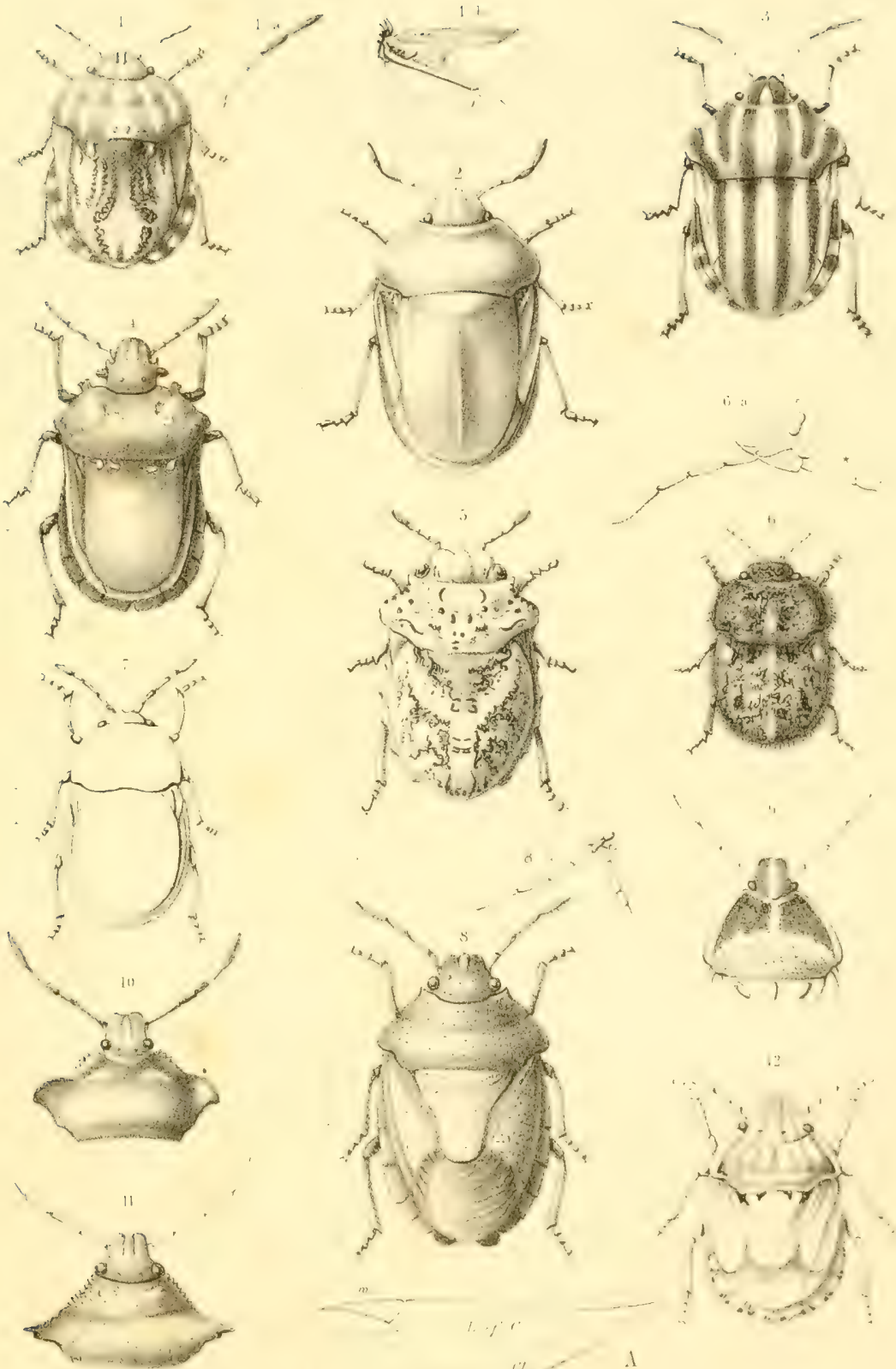


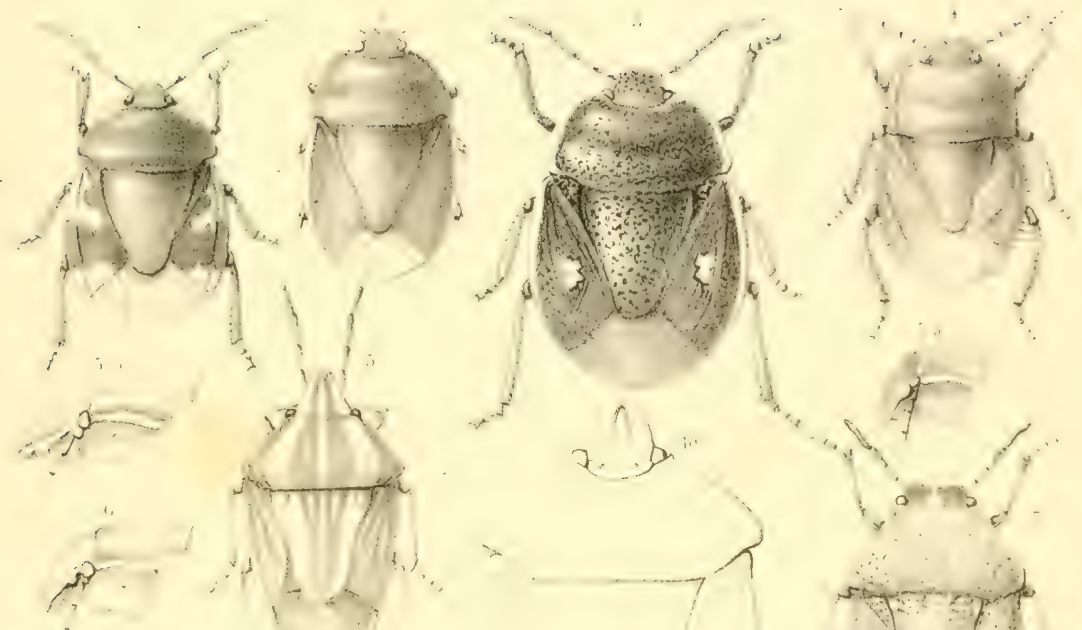

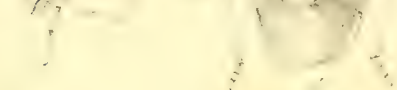
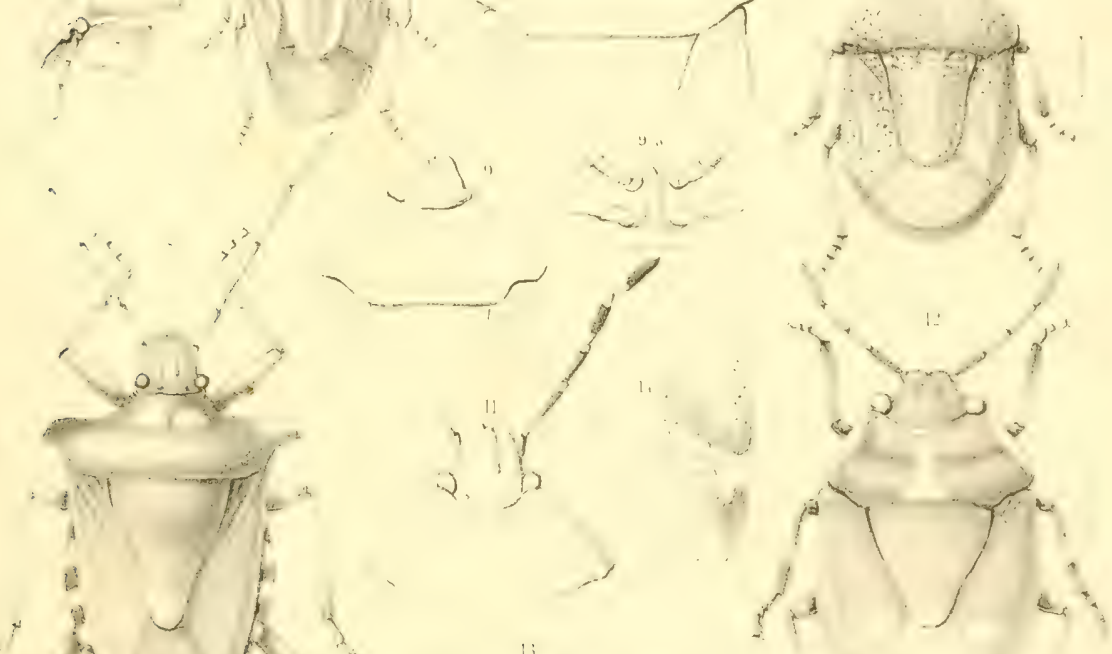

$13 k$
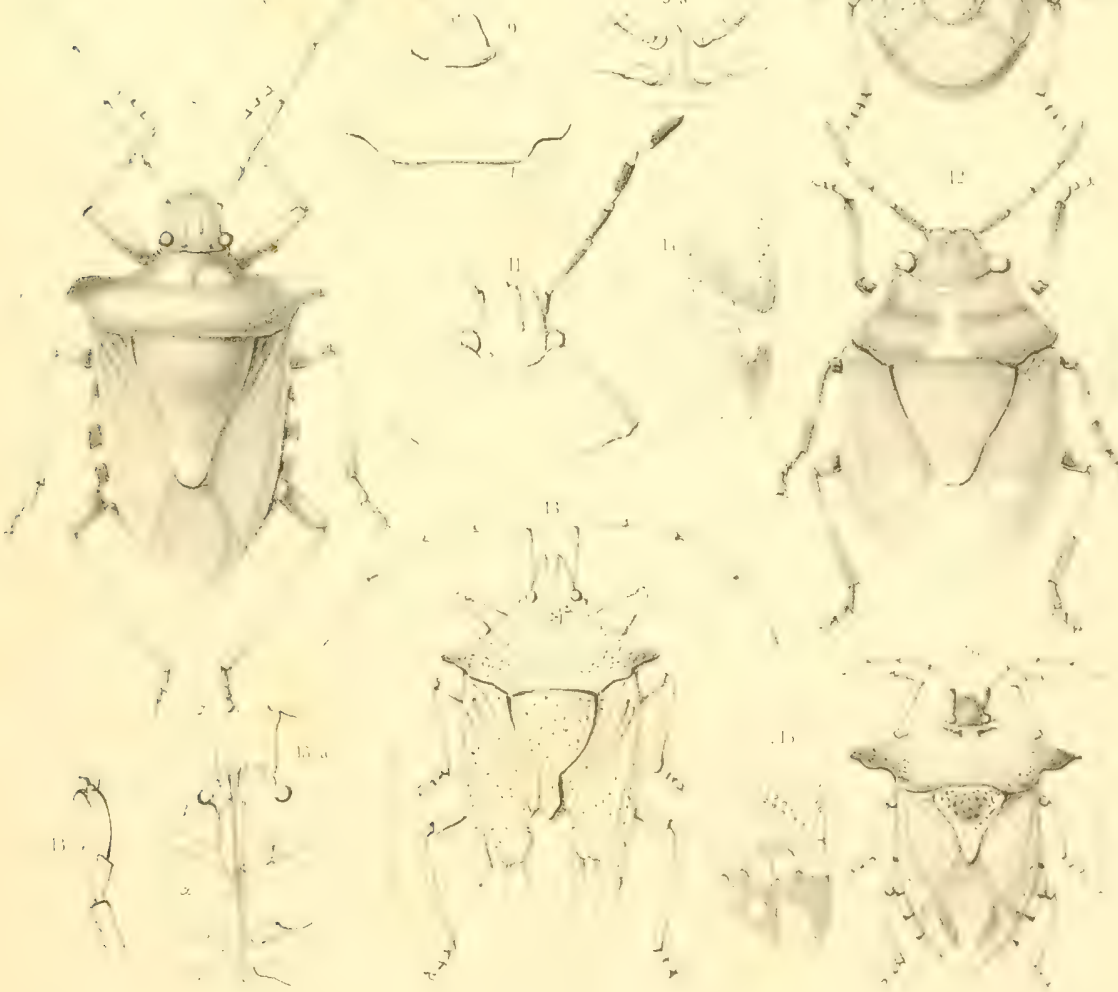

Inlandsche Hemiptera. 



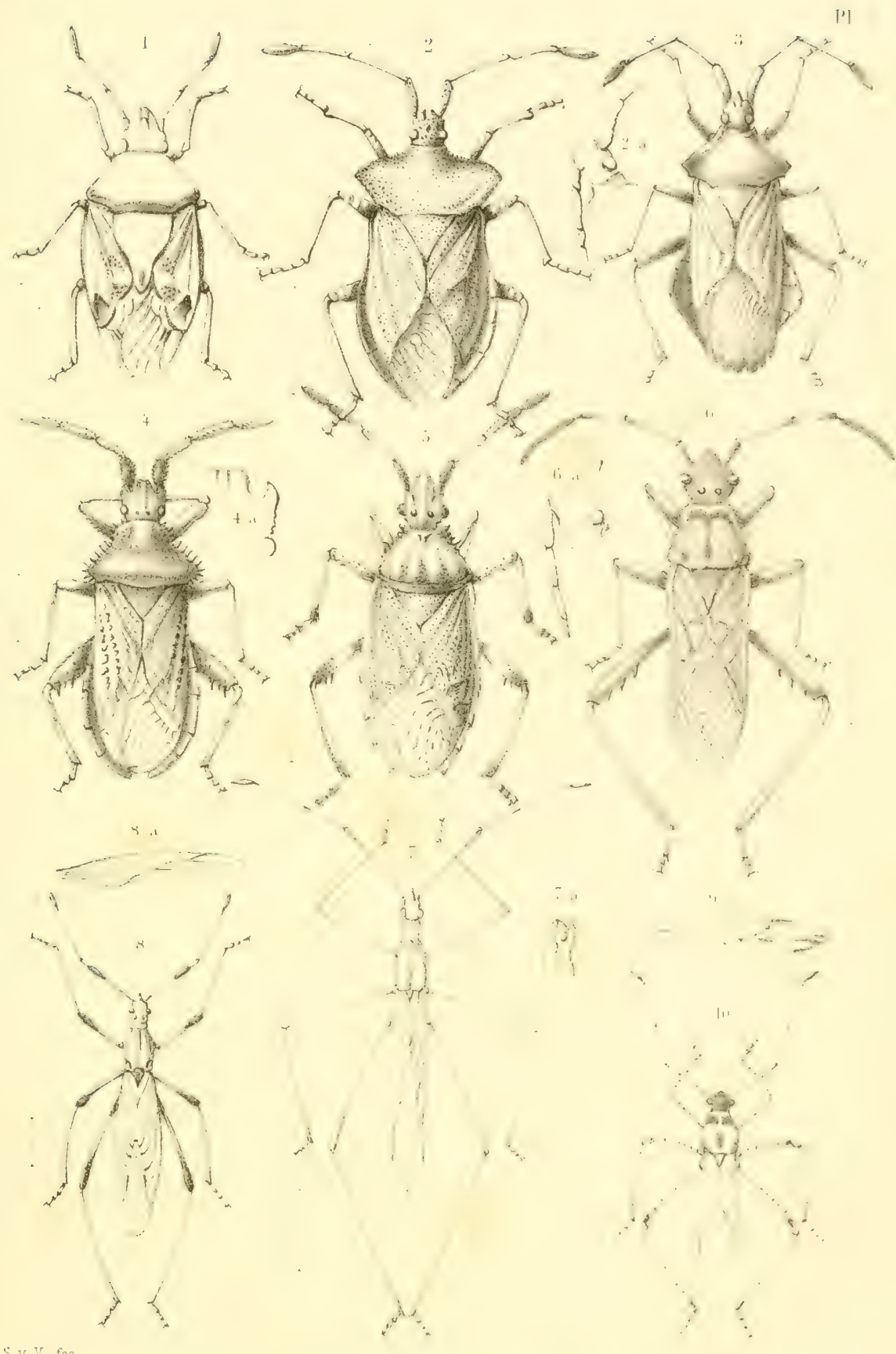

3. Inlandsche Hemiptera 



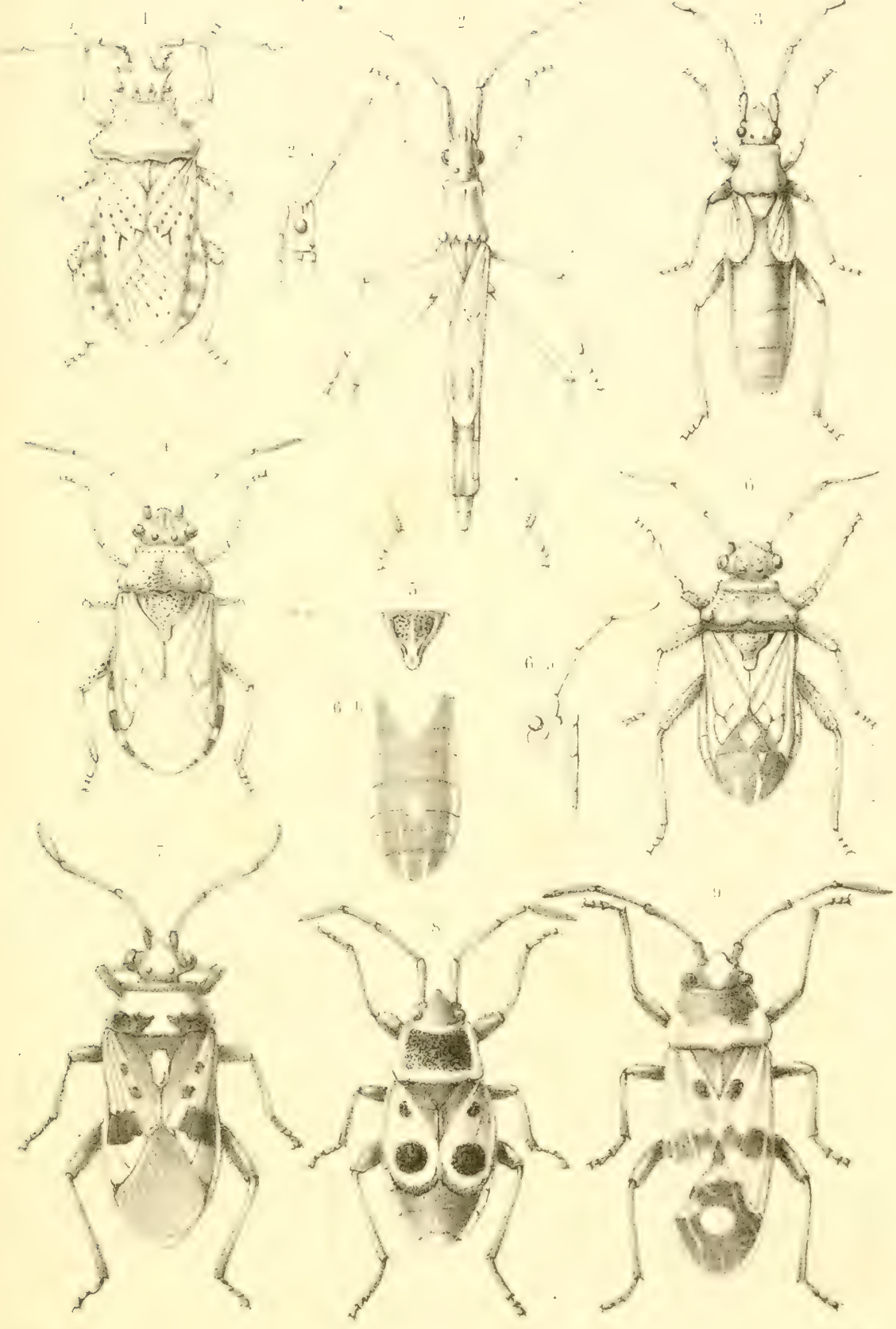

4 Inlandsche Hemptera 


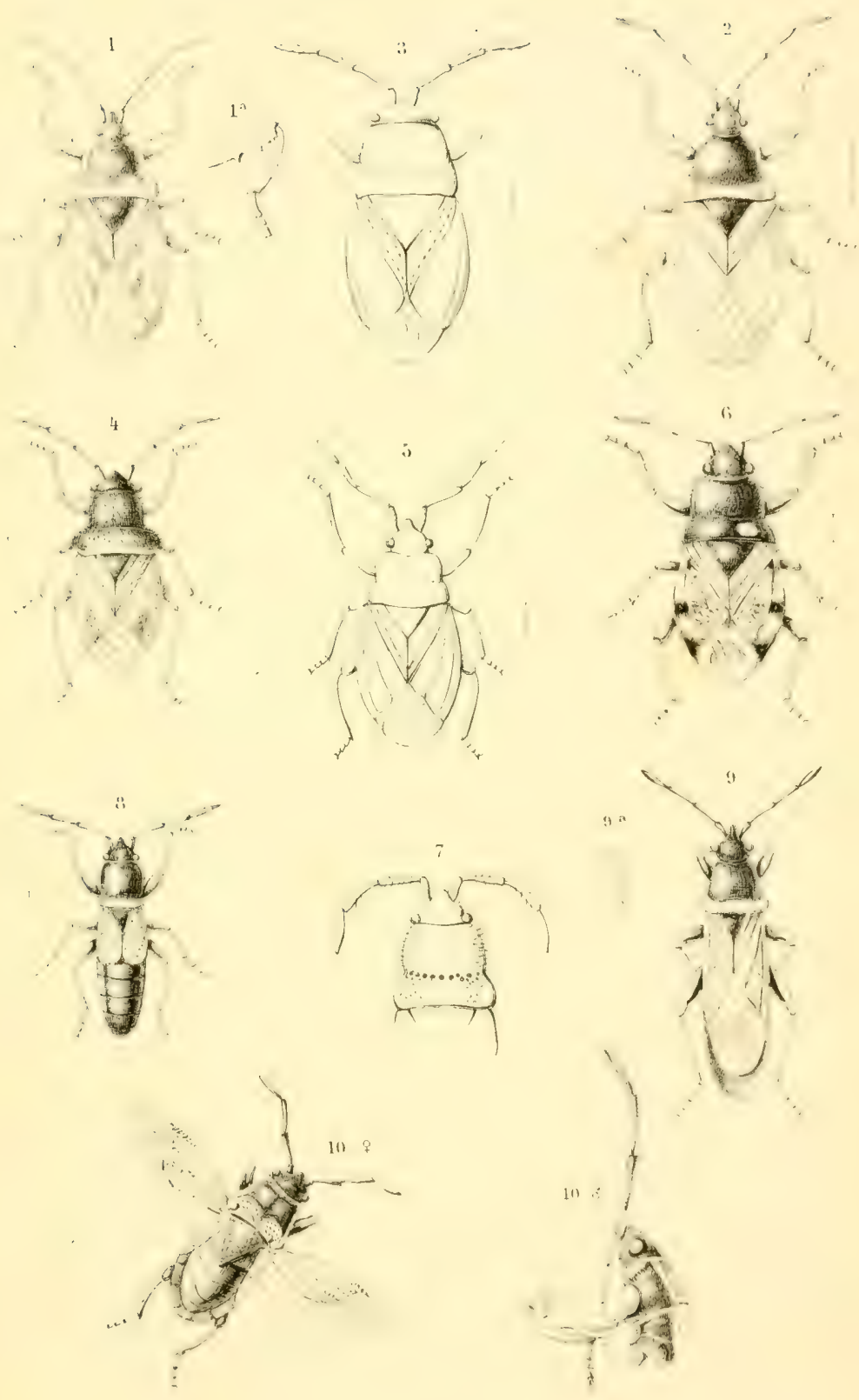

Inlandsche Hemiptera 

Pl $\mathrm{Yl}$

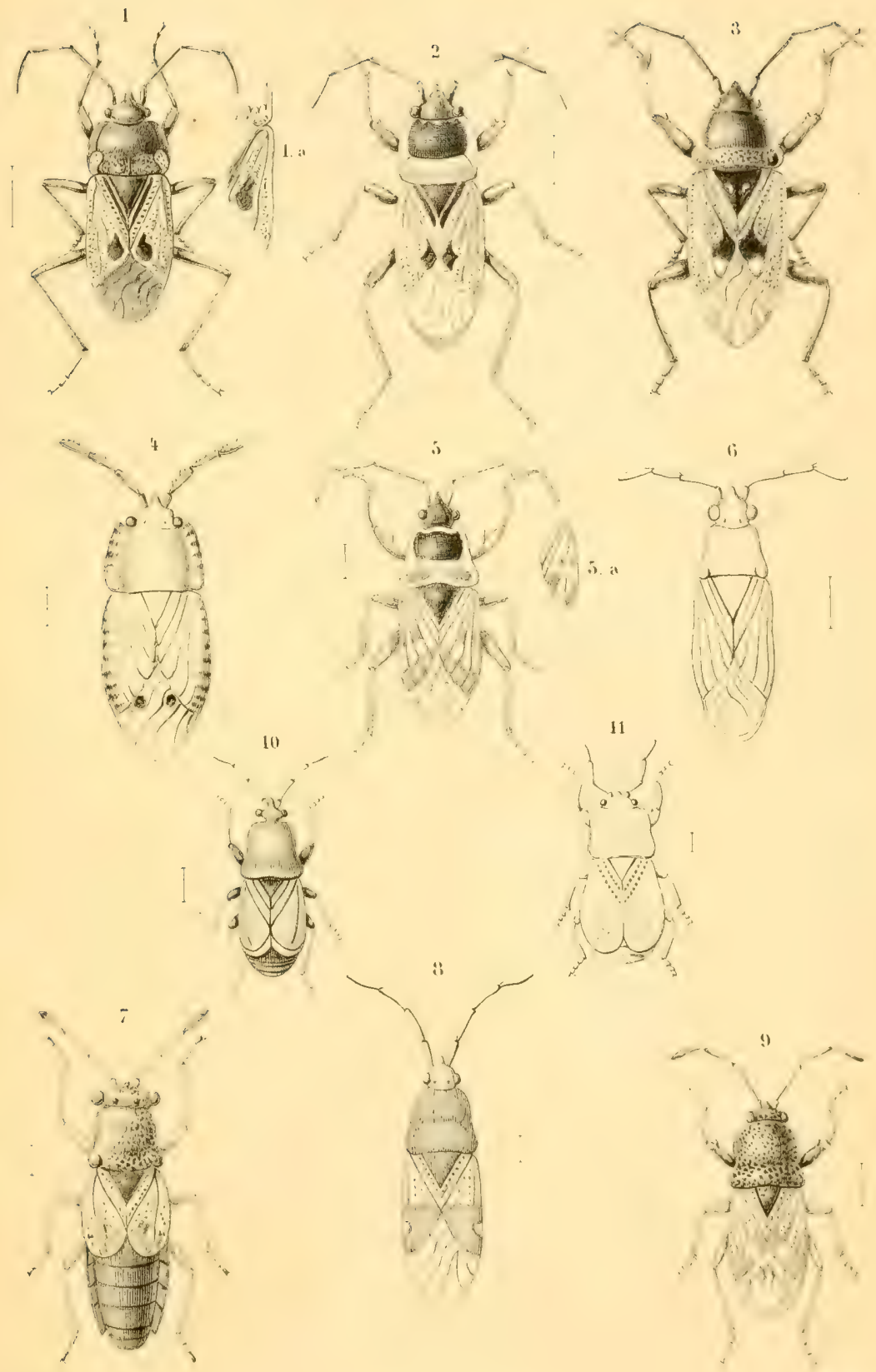

Inlandsche Hemiptera. 

P'I VII.
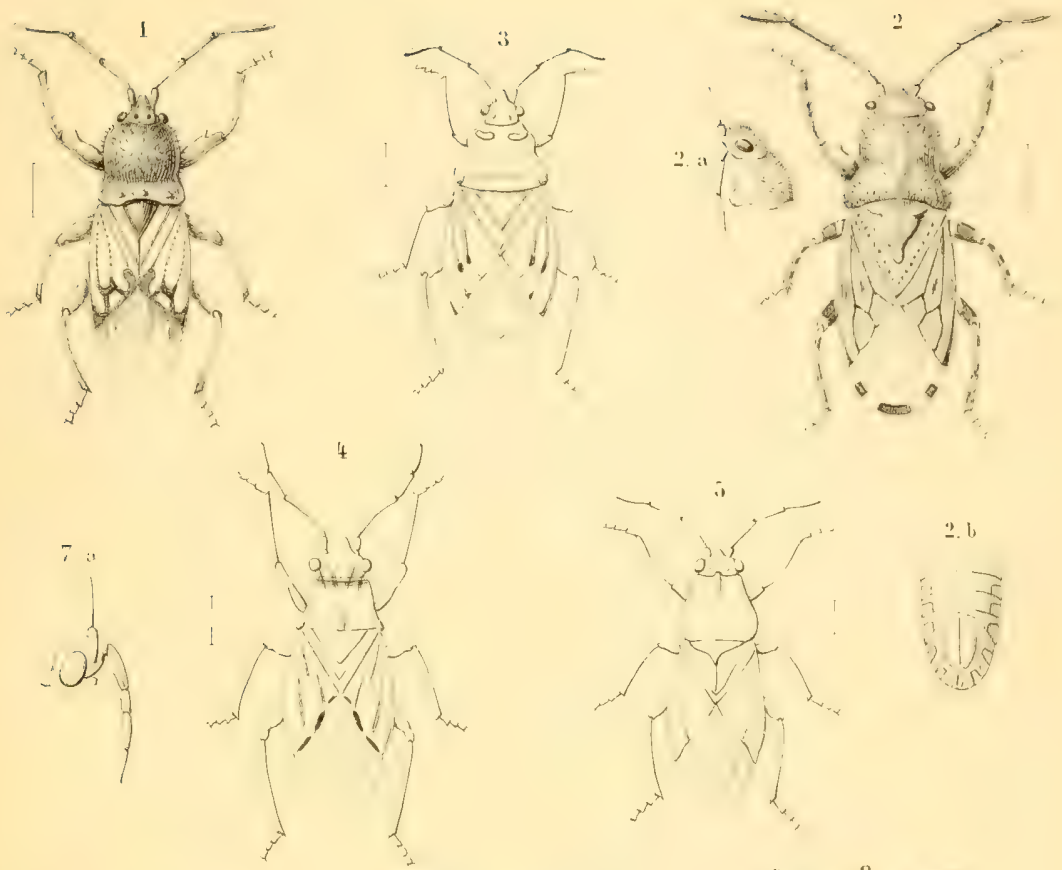

2. $b$
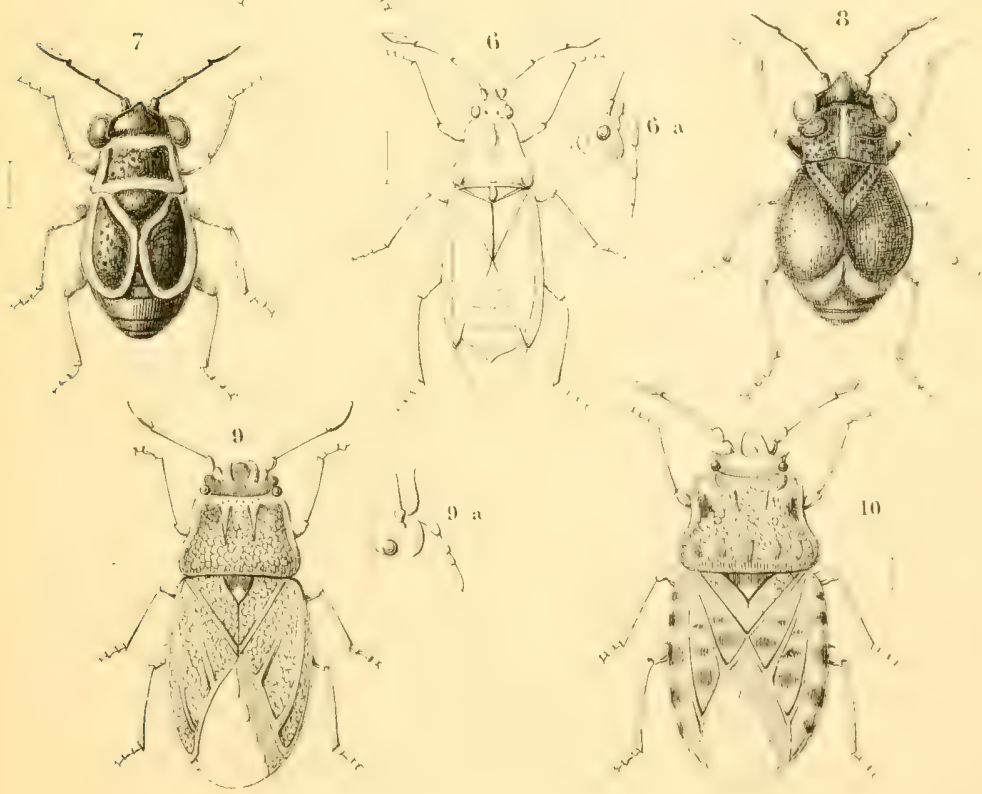

Inlandsche Hemiptera. 


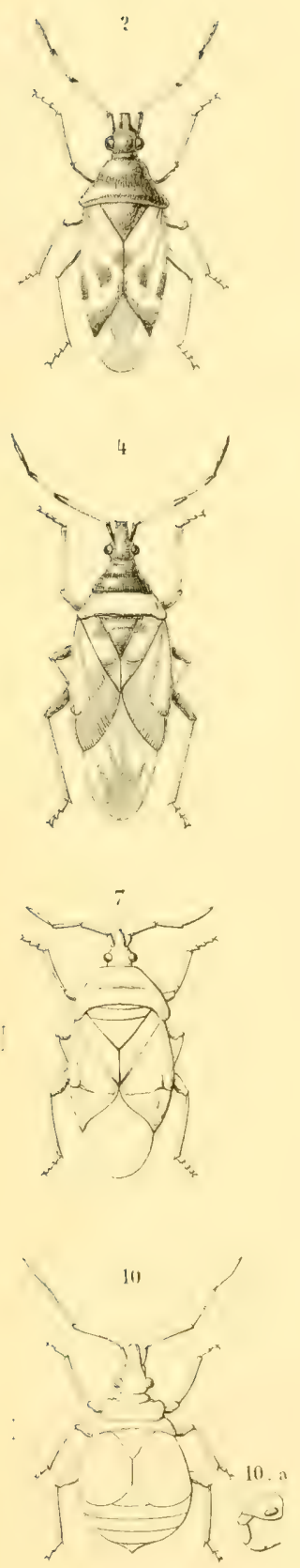
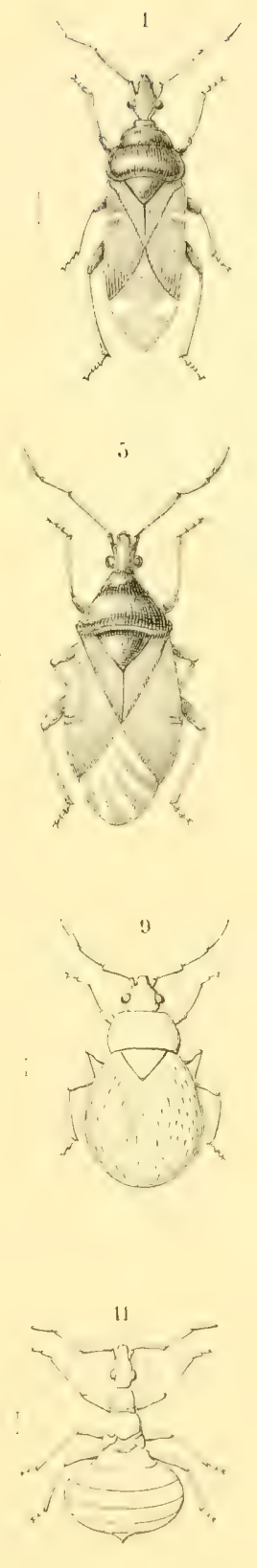

Inlandsche Hemiptera.
I'I. IIII.
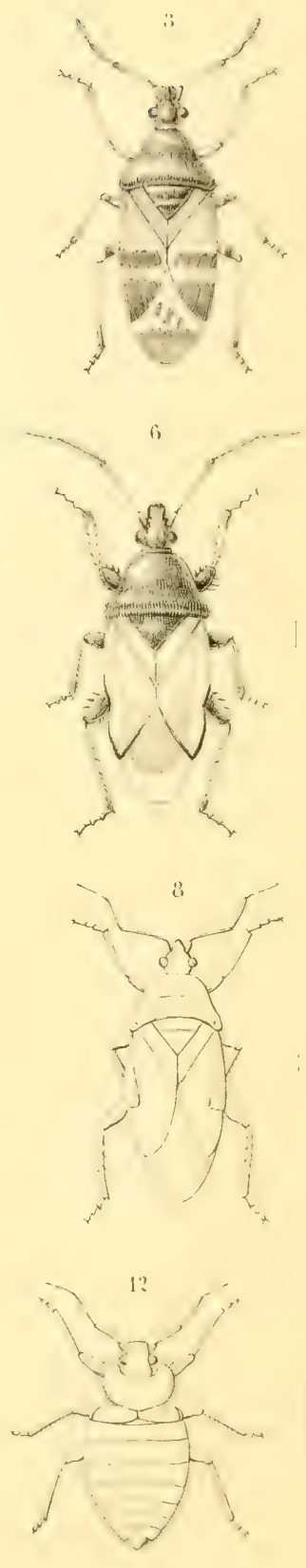

PL. IX.
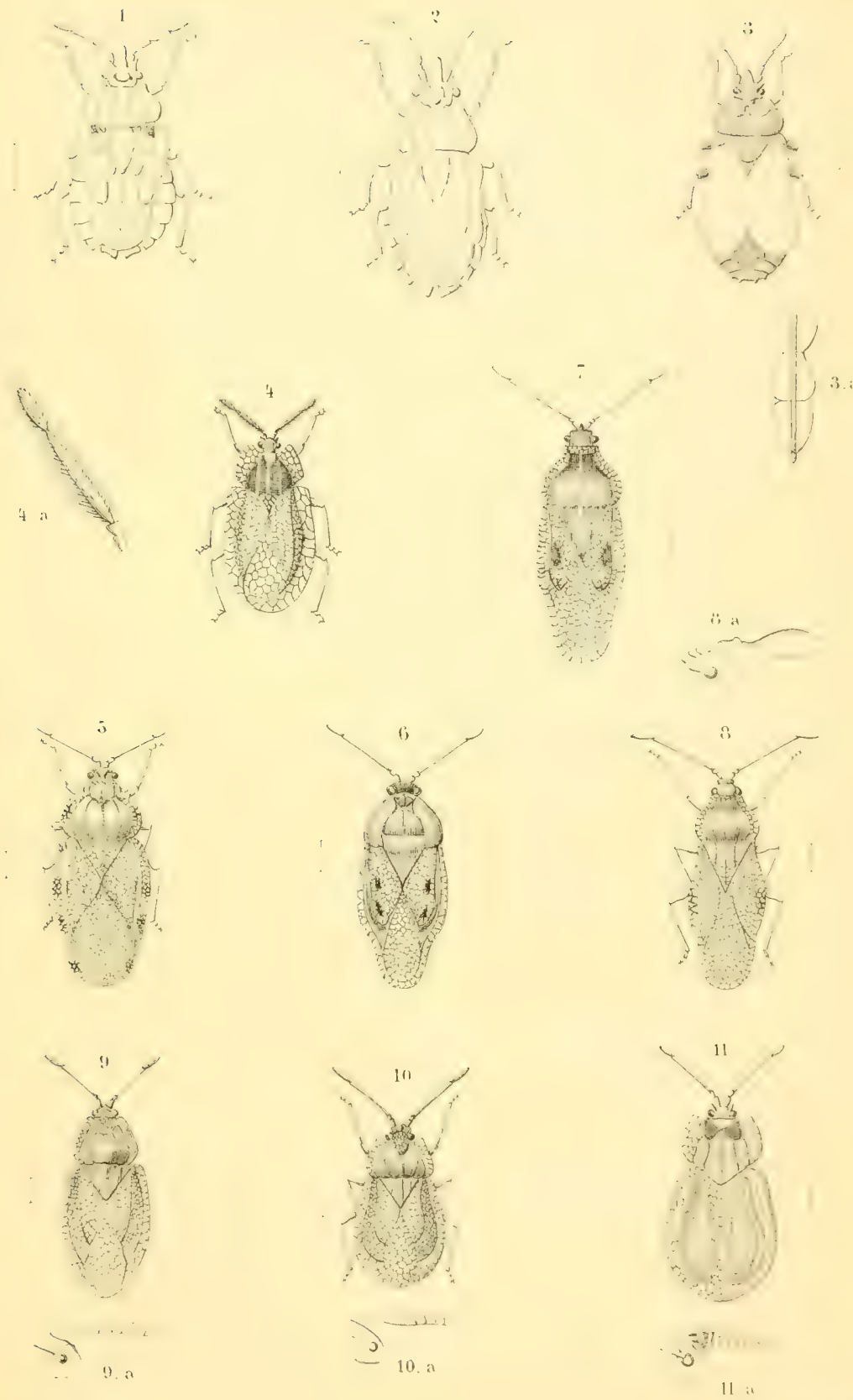

Inlandsche Ifemiptera. 

PL X
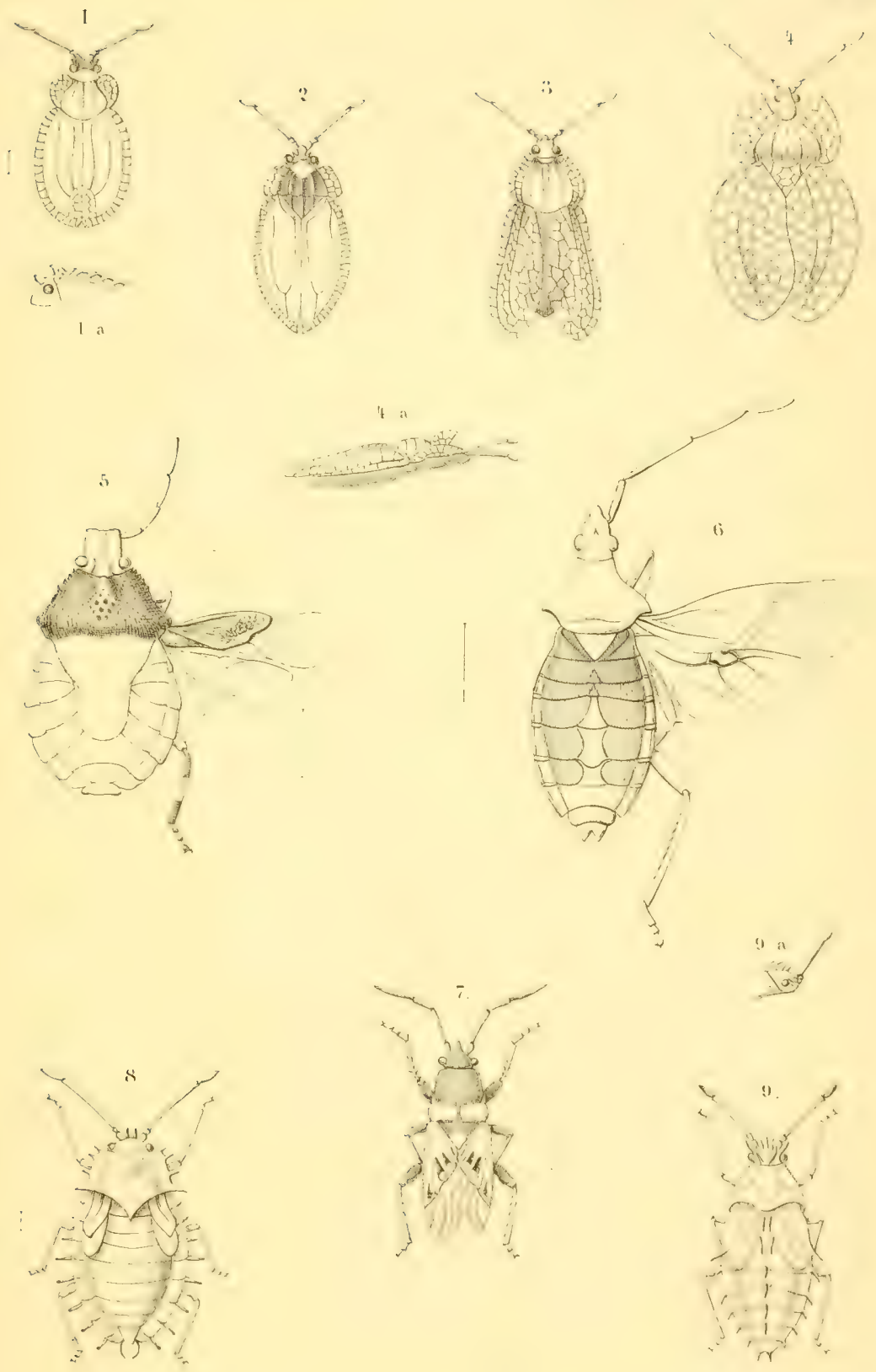

Inlandsche Hemiptera 

I'L. XI

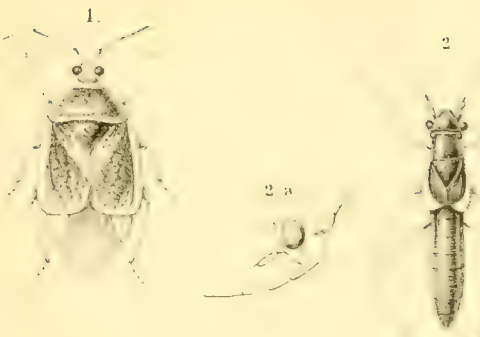

3)
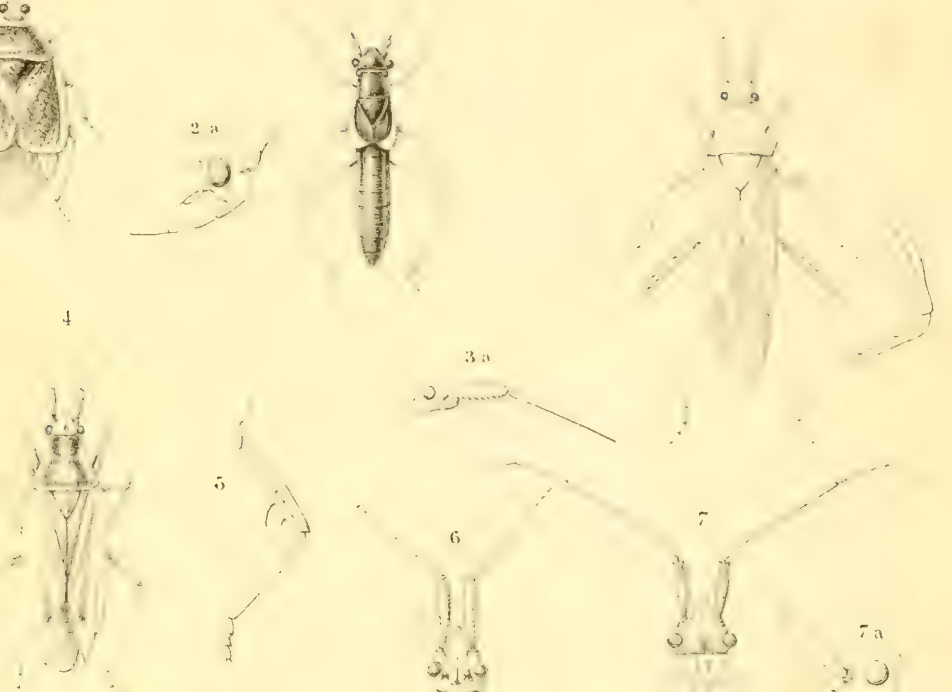

8
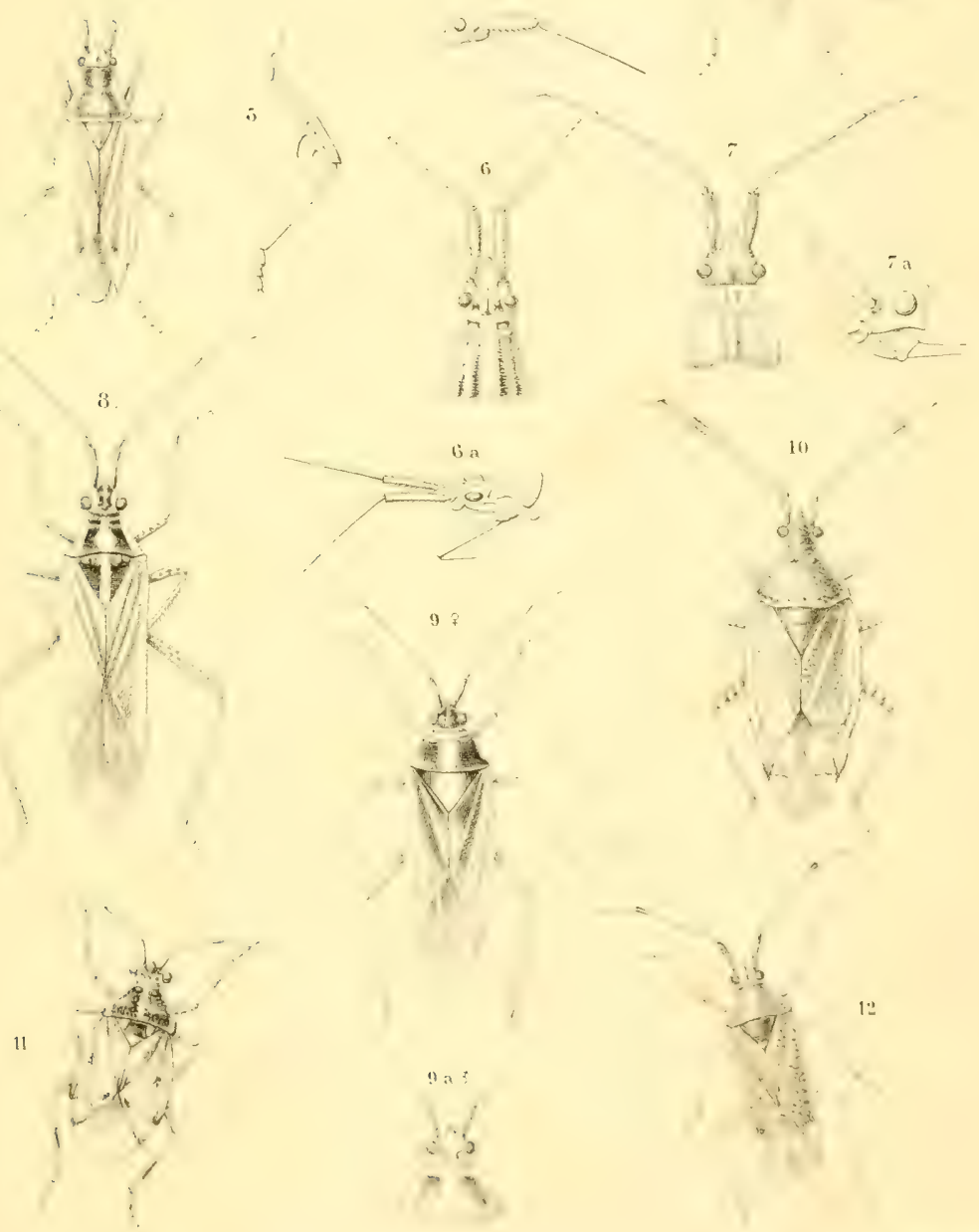

Intundsche Ilemipteria 



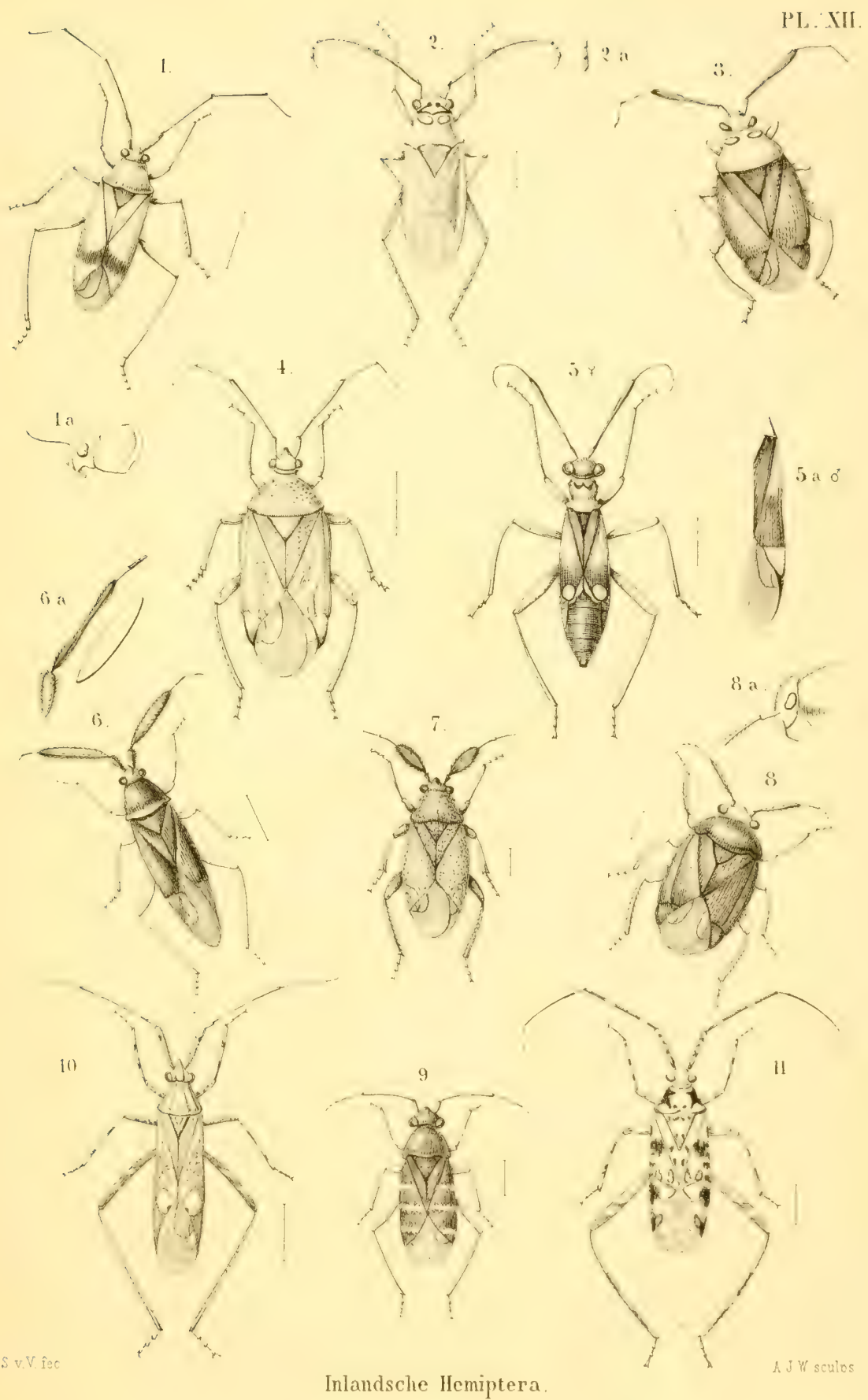



I'L. XIII

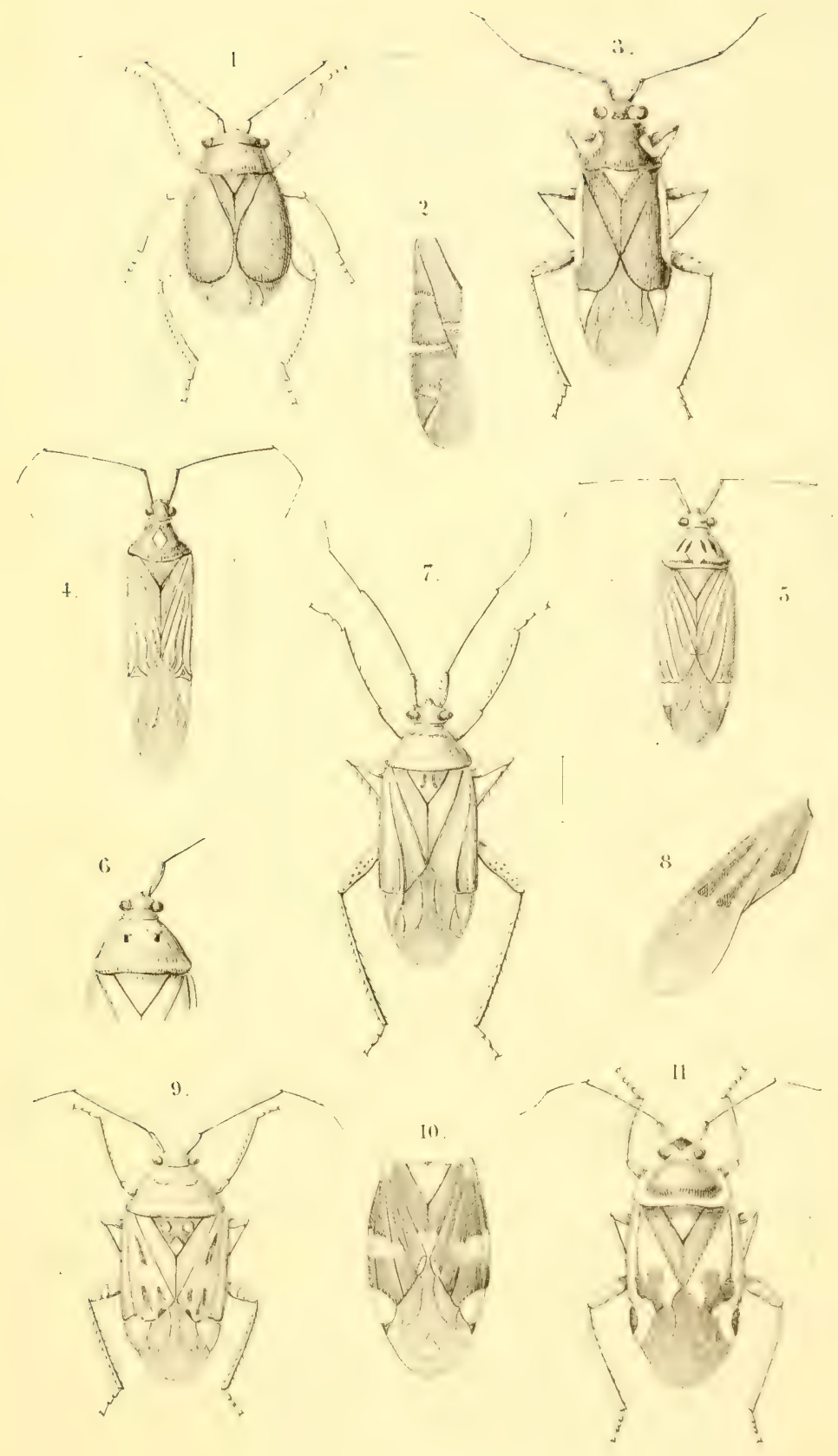



I'I. XTV.
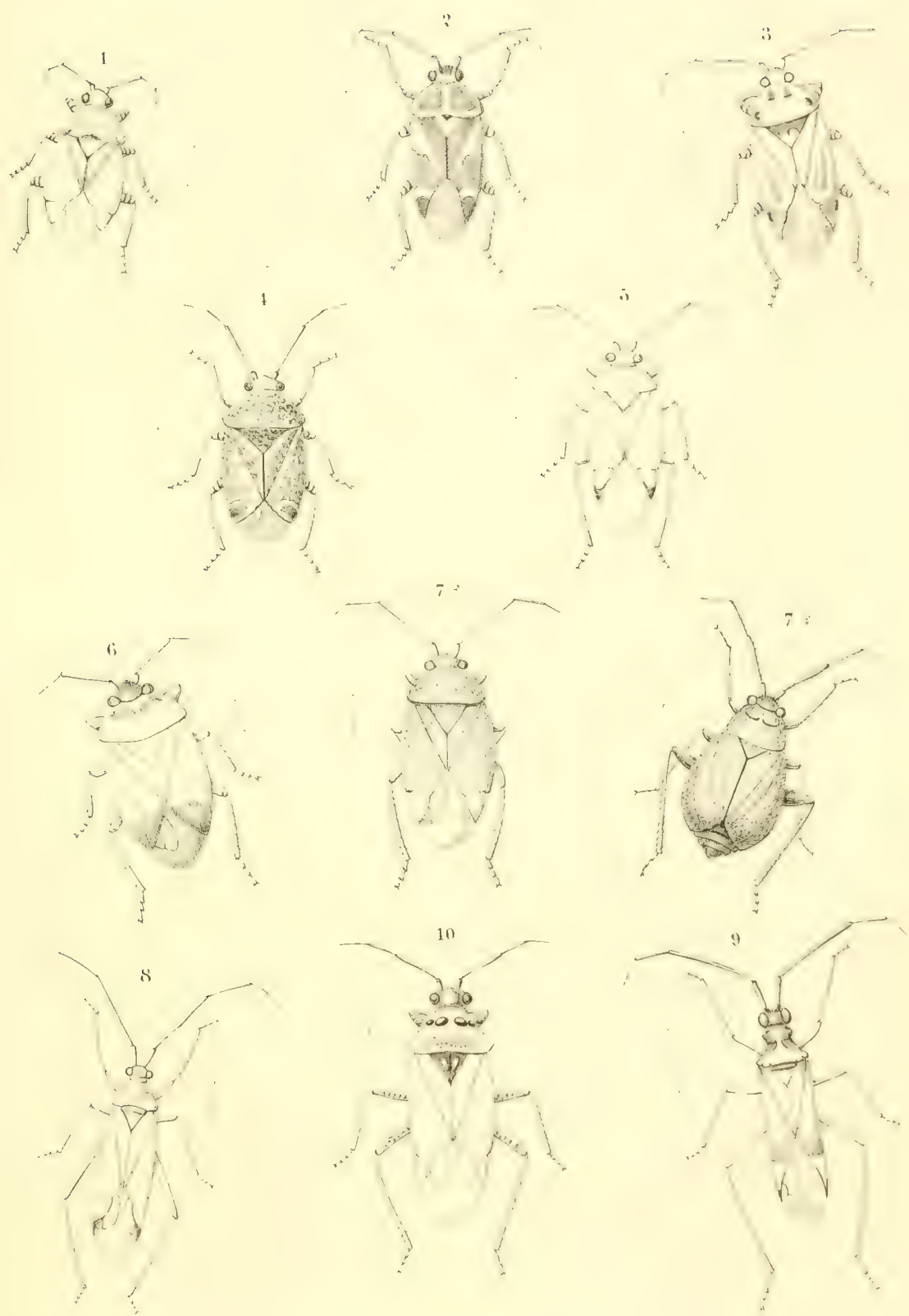

PL. IT:
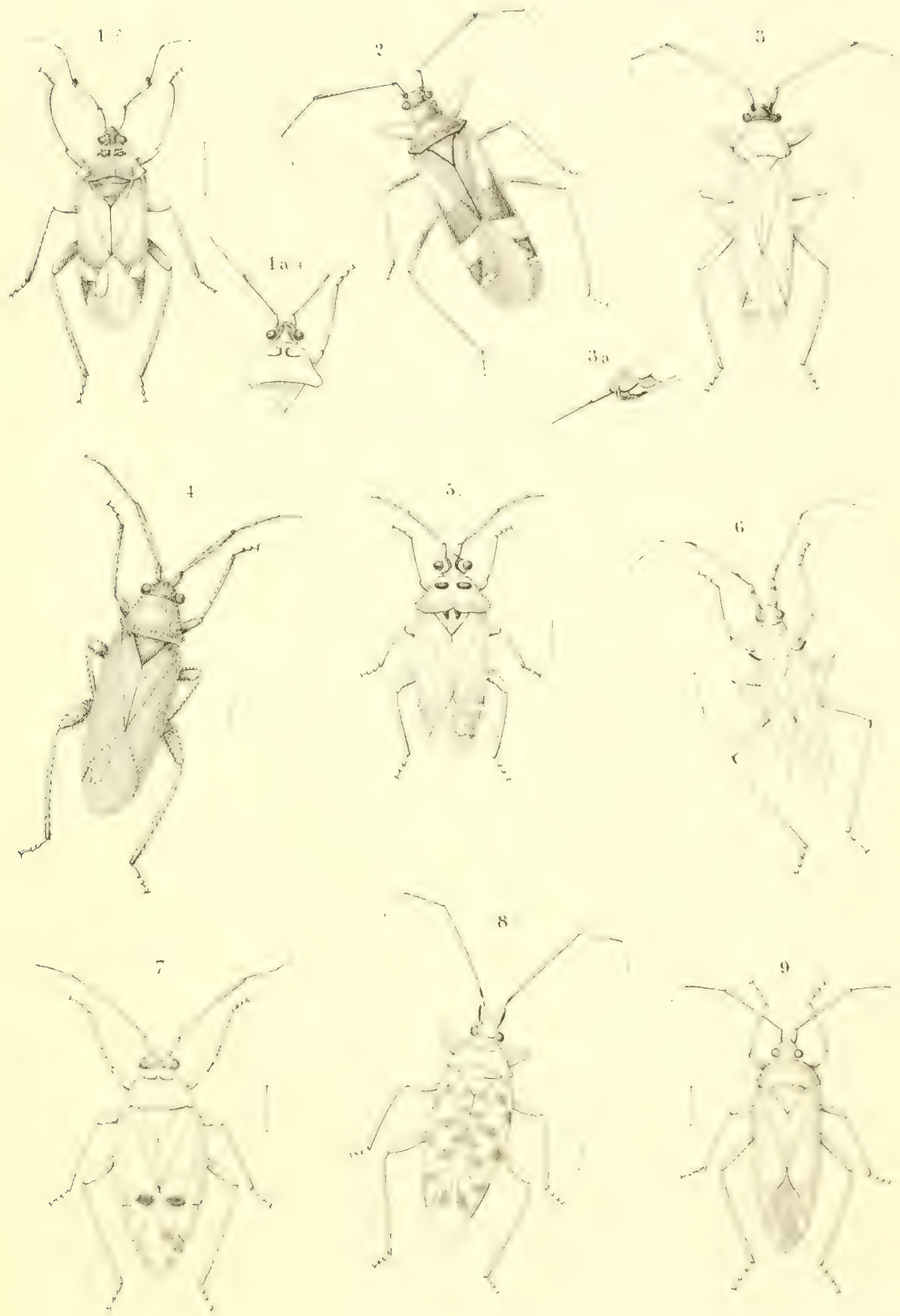



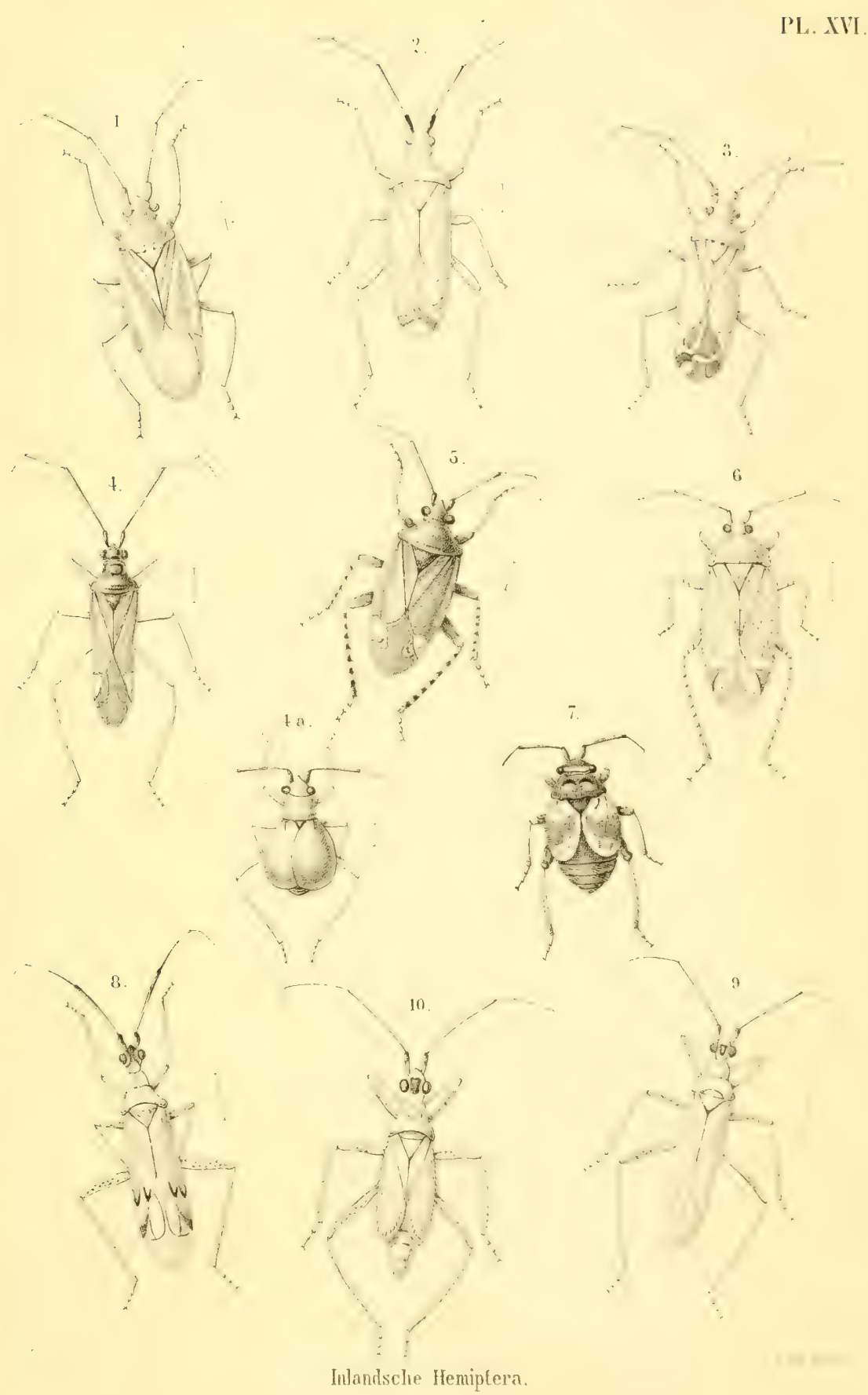



PI. XTII.

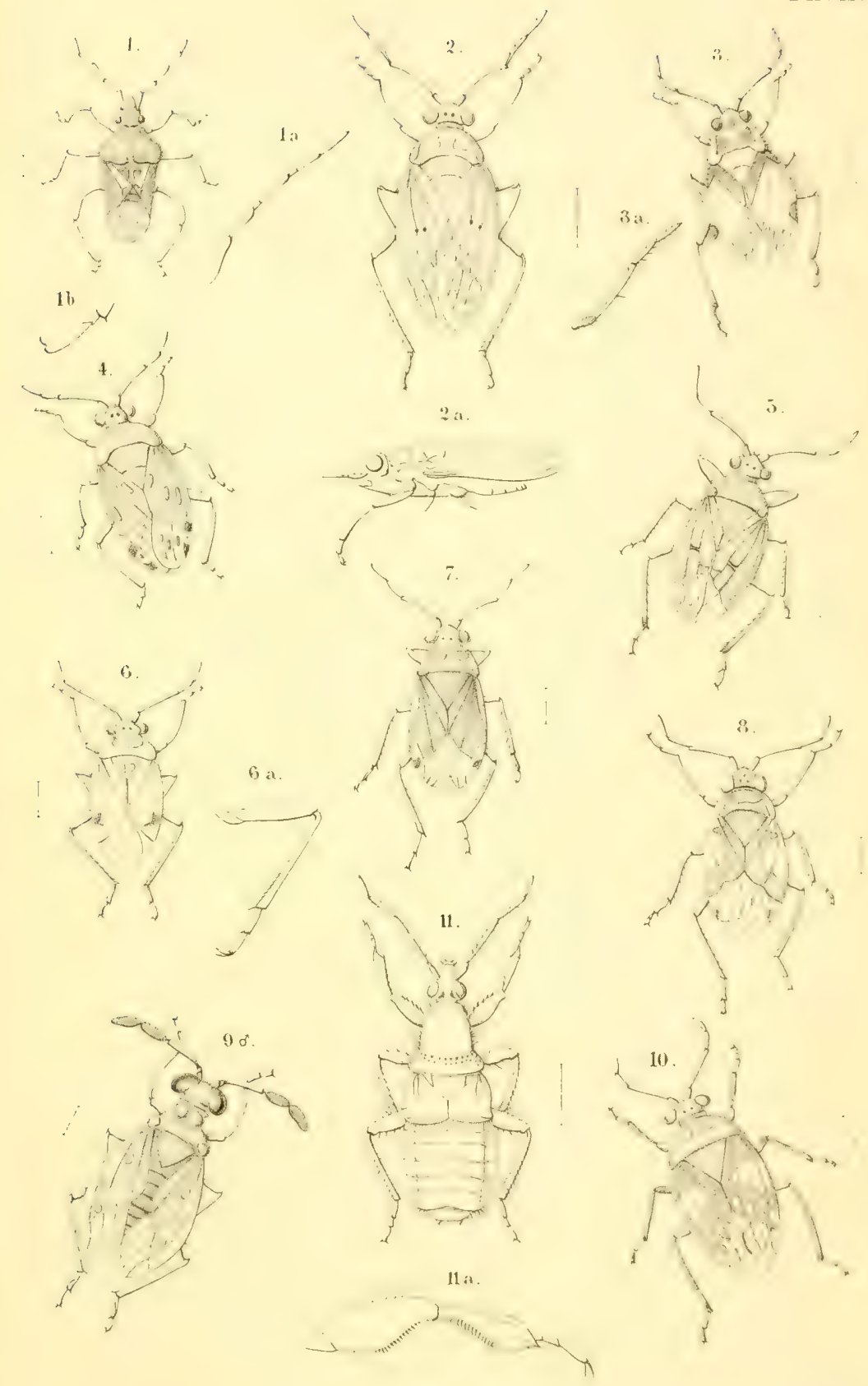

S.V.V.fec.

Inlandsche Hemiptera. 

PL. XITII
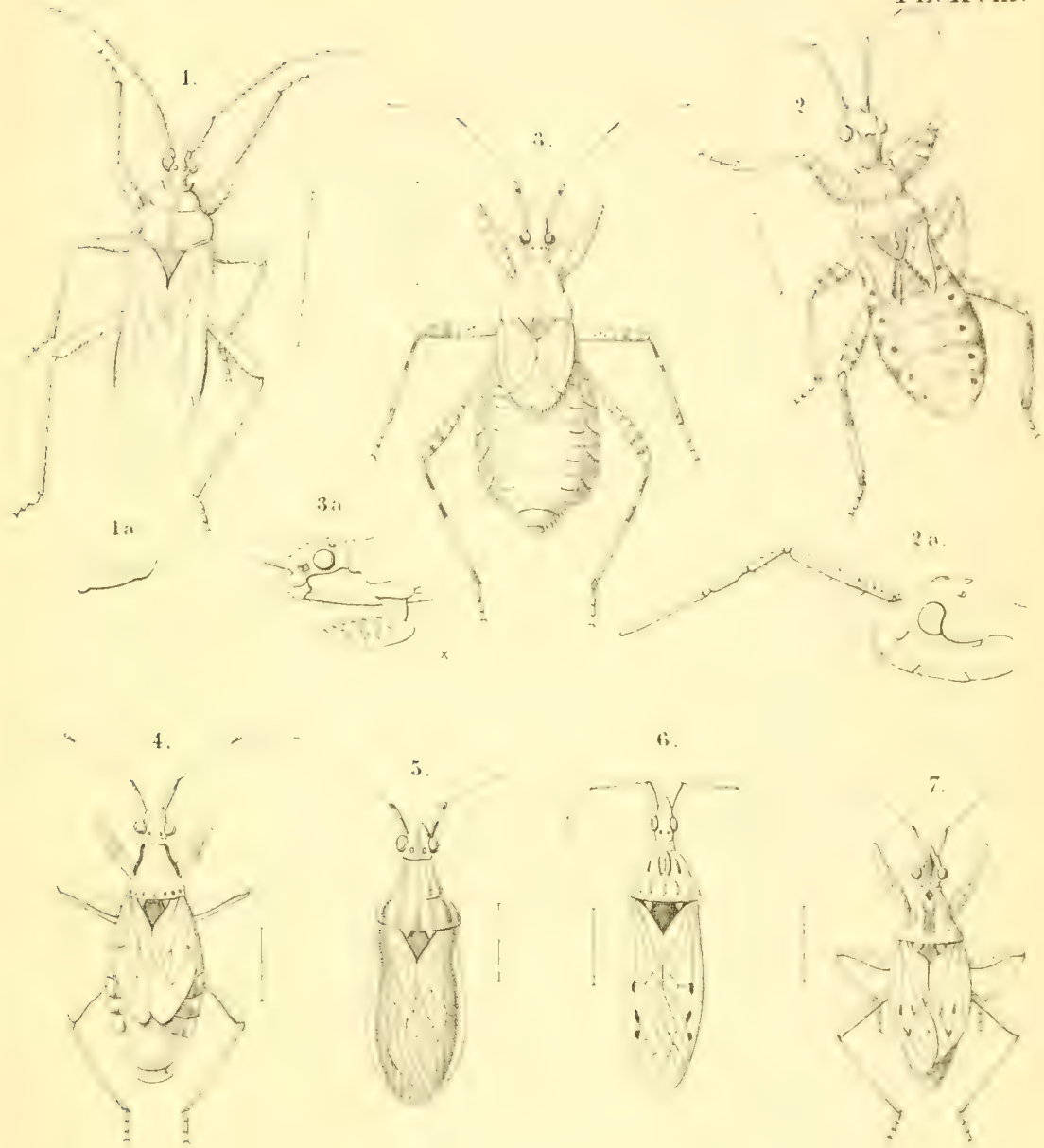

i.
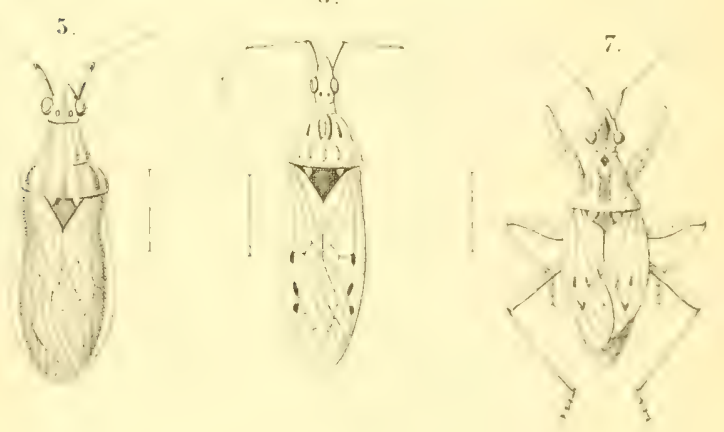

i.
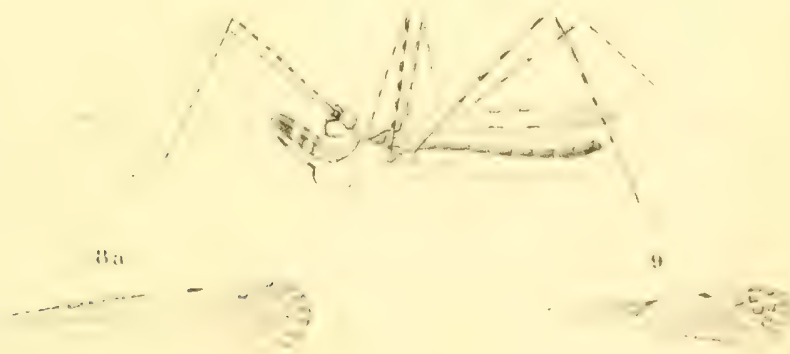

Inlandsche Hemiptera. 

PL. ITI.

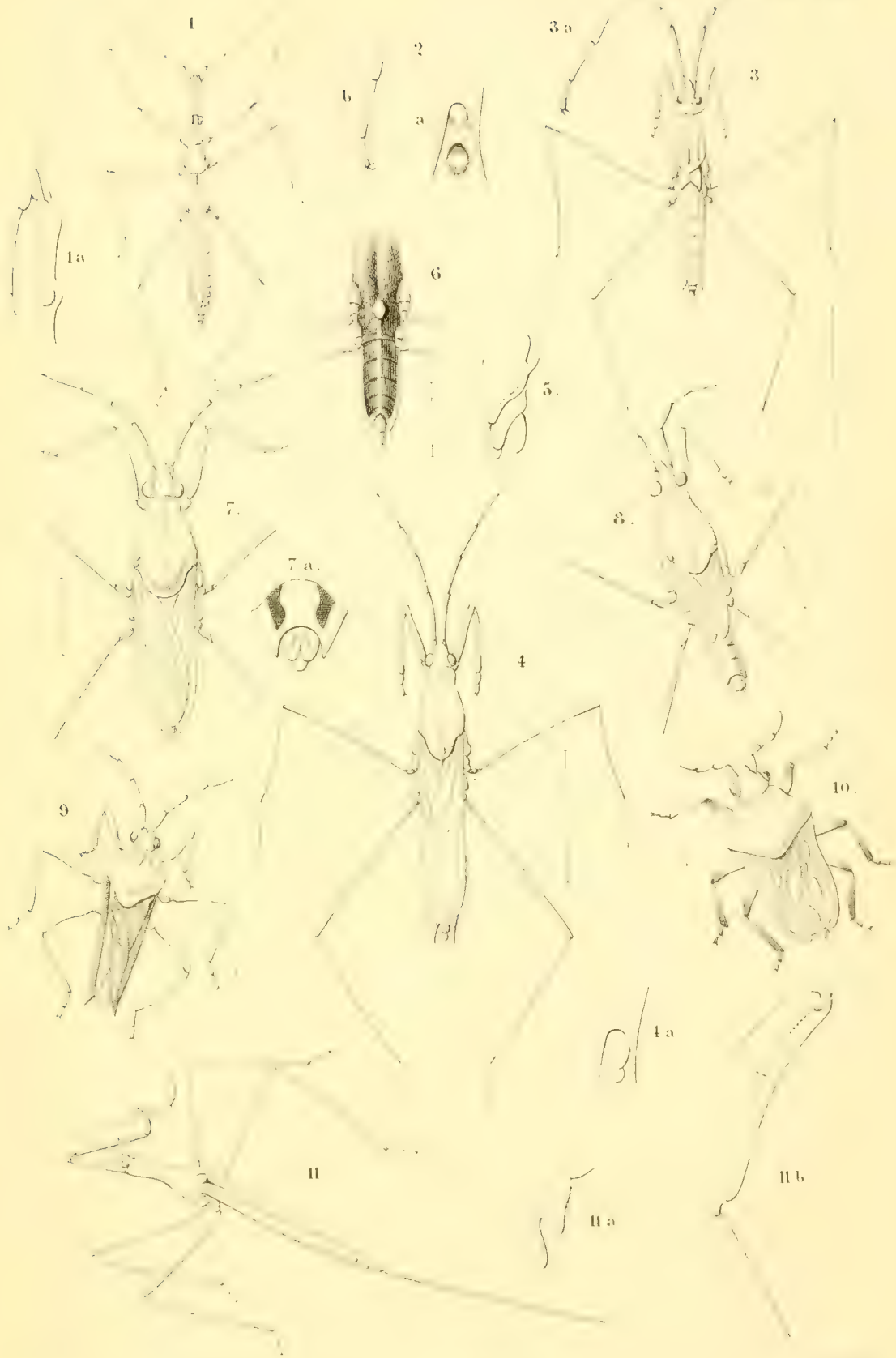

Inlandsche Itemiptera. 

I'L XX

i3
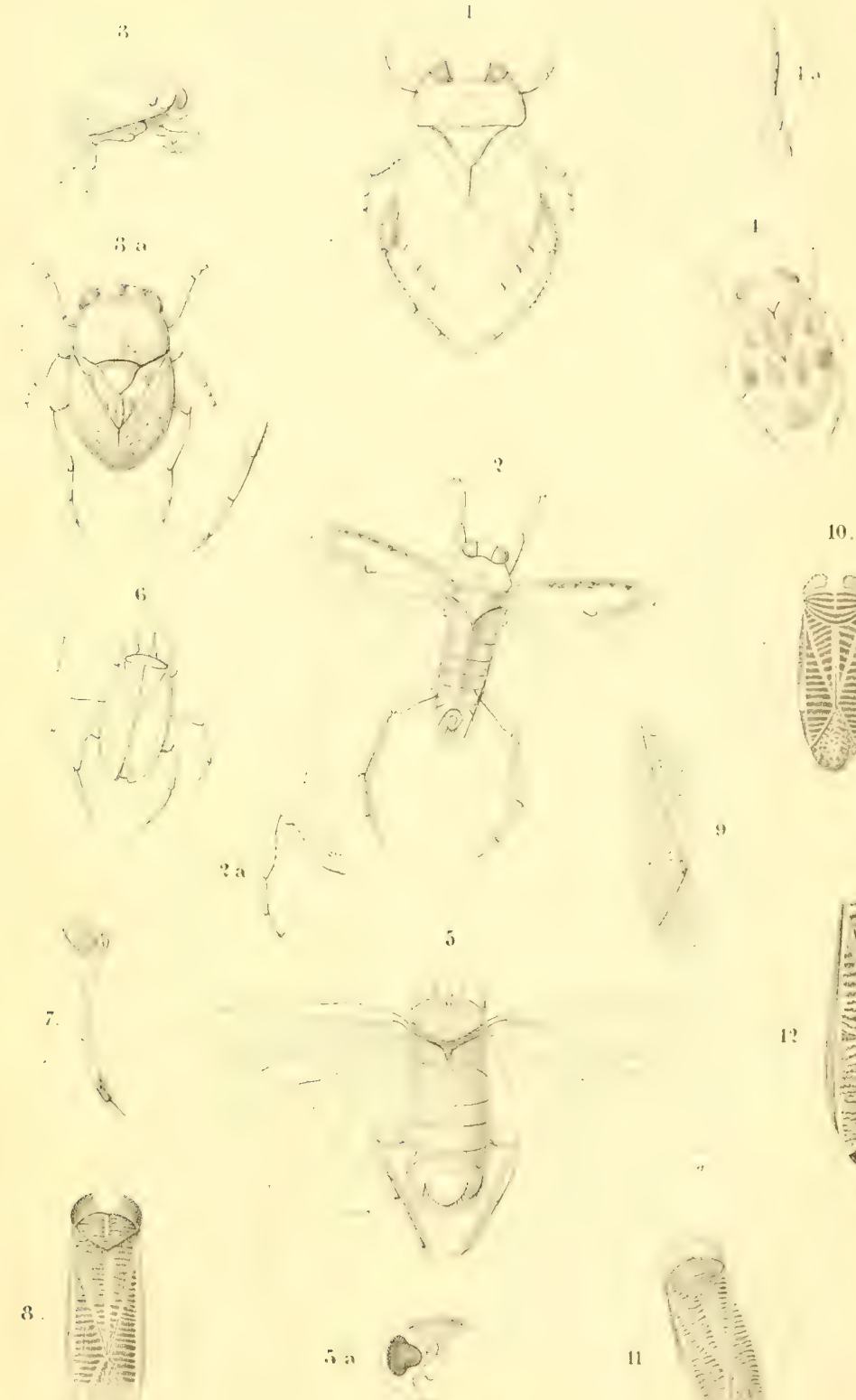

10.

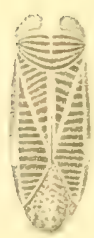

1 ?

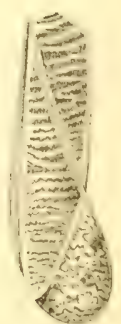

Lulaudscher II miptera 



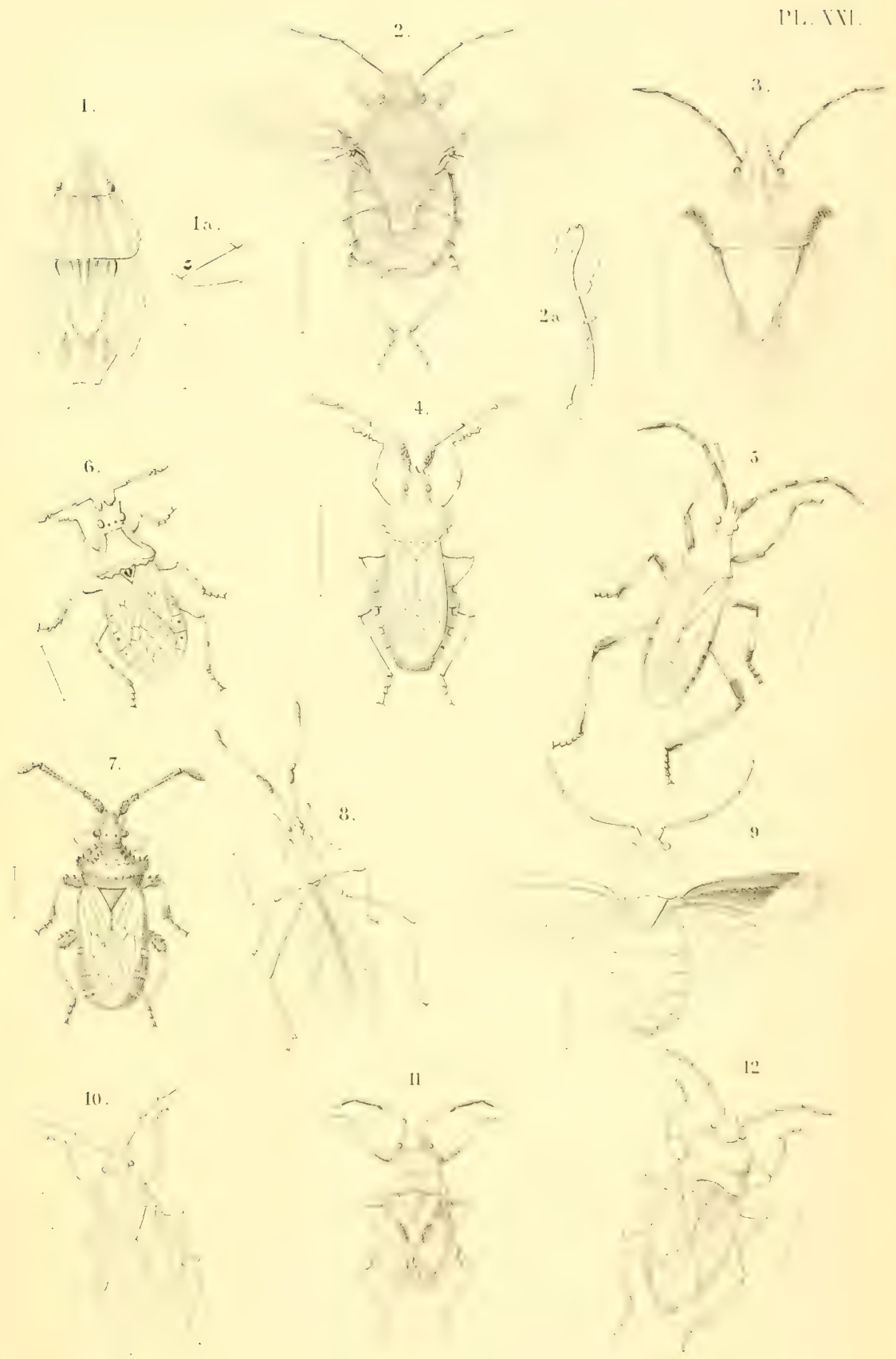




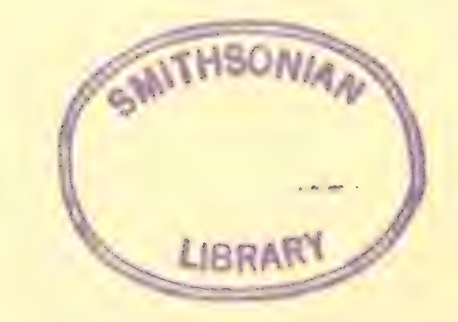



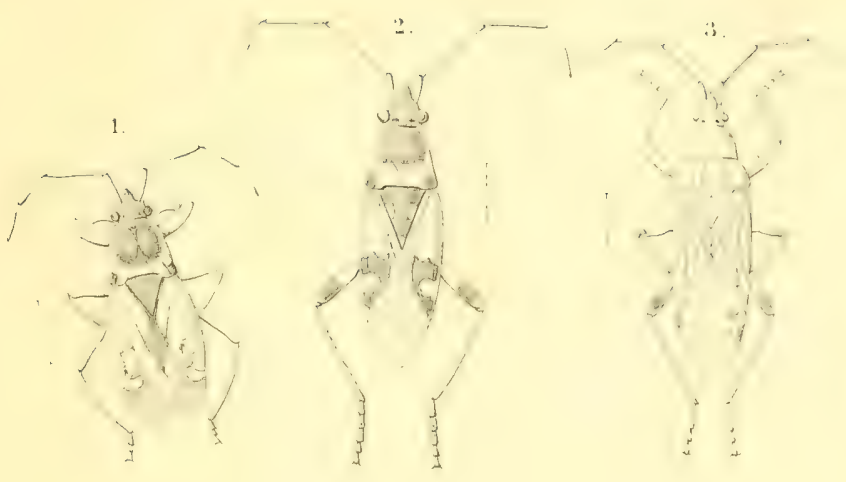

I'I XXII
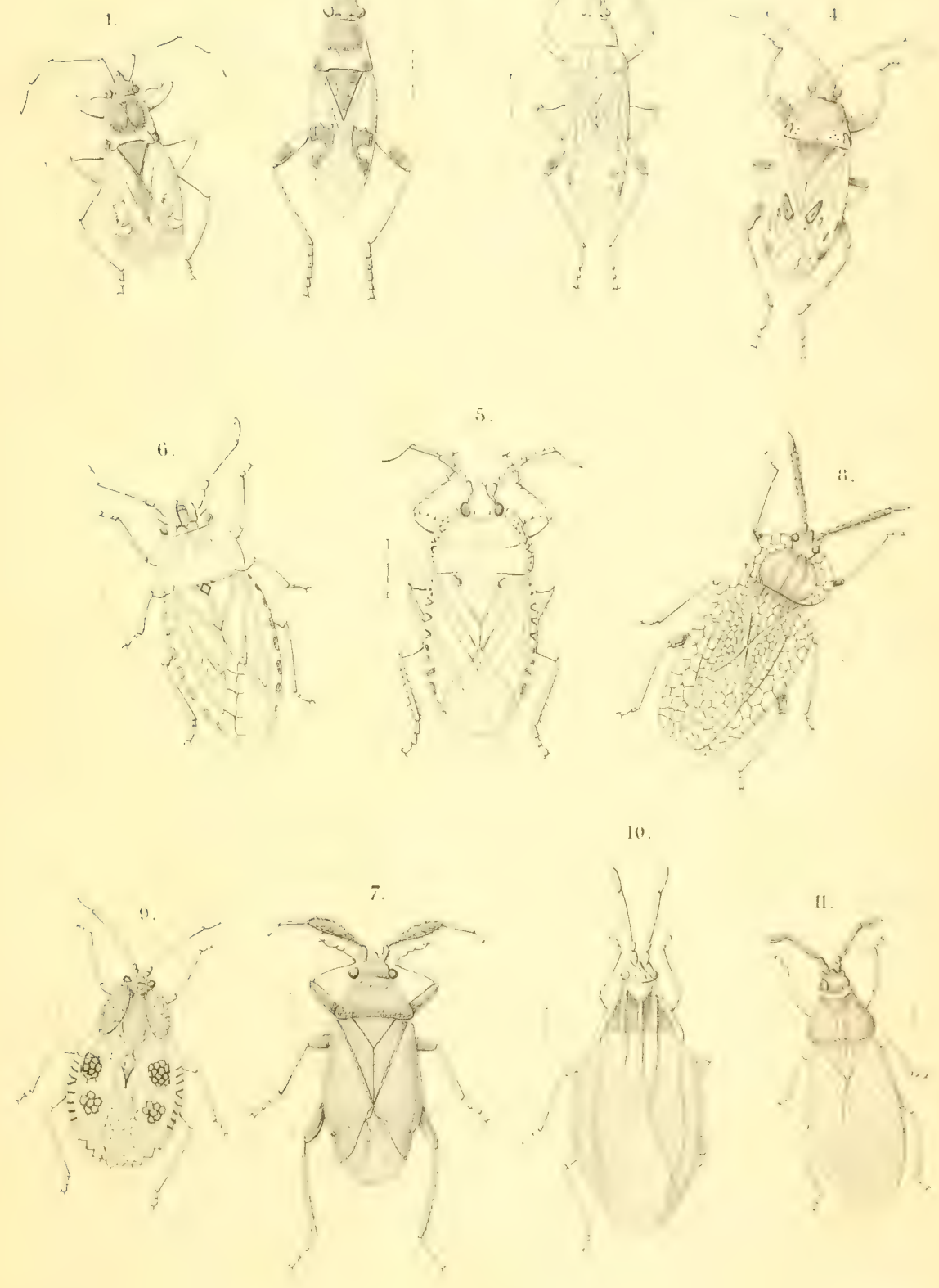

Inlandsche Ilemiptera. 



\title{
ILDIPTERA IETEROP'THL NEBRLLNDICA.
}

\section{INLANDSGIIE WARE IIEMIPTEREN}

\author{
(LAND- EN WATERIWANTSEN)
}

BESGHREVEN EN MEERENDEELS OOK AFGEBEELD

Door

S. C. SNELLEN VAN VOLLENHOVEN

$J$, U. ot $\mathrm{Ph}$, nat. Doct.

MET 22 PLATEN.

'S GR A VEN II A GE

MARTINUS NIJHOFE

1878. 


Door MARTINUS NIJHOFe te 's Gravenhage is nitgegeven:

ES AAI D'UNE FAUNE ENTOMOLOGIQUE DE LARCHIPEL INDO-NEERLANDAIS, par S. C. Stellex van VoldenHOVEN.

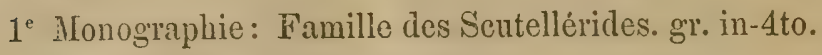
Avec 4 planches coloriées : . . . . . f 6.-

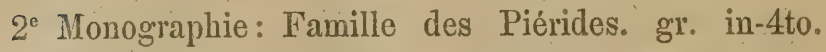
Avec 7 planches dont 6 coloriées . . . . - 8.50 3 e Monographie: Famille des Pentatomides. $1^{\mathrm{e}}$ partie. gr. in-4to. Arec 4 planches coloriées : . . . - 6.-

DE VLINDERS VAN NEDERLAND. Macrolepidoptera, systematisch beschreven door P. C. T. SNellen. Imp. 8vo. Met 4 platen . . . . . . . . . . / 9.50

DIPTERA NETRLANDICA. De Tweevleugelige Insecten van Nederland, door F. M. YAN dER WuLP. I deel, met 14 . platen. Imp. 8vo _. . . . . . . . . . . f 10.

SCHETSEN TEN GEBRIJKE BIJ DE STUDIE DER HYMENOPTERA, door Mr. S. C. Snelien vax VollenIIOVEN.

I. Ichneumoniden. Met 3 platen. gr. 4to. oblong. $f 1.50$

II. Braconiden. Met 3 platen. gr. 4to. oblong. - 1.50 III. Pteromalinen. Met 4 platen. gr. 4to. oblong - 2.IV: Proctotrupiden. Met 4 platen. gr. 4to. oblong..- 2.-

PINACOGRAPHIA. Afbeeldingen van meer dan. 1000 soorten vau Noordwest-Europeesche Sluiprespen (Ichneumones sensu Limnaeano); door Dr. S. C. Snellen van - Volienhoven. $1^{\mathrm{e}}$ - $\mathrm{C}^{\mathrm{e}}$ afl. gr. 4to. Met 30 gekleurde platen. Per aft. / 3.50

LIJST der in Nederland voorkomende Schildvlengelige Insecten (Coleoptera), opgemaakt door Jhr. Ed. Everts, Phil. Dr. gr. 8 vo . . . . . . . . . . . / 1.50

SEPP'S NEDERLANDSCHE INSECTEN. Tweede serie, bijeengebragt door Dr. S. C. SNelden van Vorlenhoten. Deel I-III. Met 150 gekleurde platen. gr. 1to. Prijs per dcel . . . . . . . . . . . . f 37.50

Van deel IV is verschenen Aflevering 1-8. Prijs per Aflevering. . . . . . . . $f$. 0.75 


